UNIVERSIDADE DE SÃO PAULO

ESCOLA DE ENGENHARIA DE SÃO CARLOS

DEPARTAMENTO DE ESTRUTURAS

\title{
ANALISE TEÓRICA E EXPERIMENTAL DO COMPORTAMENTO DE PILARES ESBELTOS DE CONCRETO DE ALTA RESISTÊNCIA, CONSIDERANDO A DUCTILIDADE.
}

FRANCISCO AGUIRRE TORRICO

Tese apresentada à Escola de Engenharia de São Carlos, da Universidade de São Paulo, como parte dos requisitos para obtenção do Título de Doutor em Engenharia de Estruturas.

Orientador: JOSÉ SAMUEL GIONGO

São Carlos

2010 
AUTORIZO A REPRODUÇÃO E DIVULGAÇÃO TOTAL OU PARCIAL DESTE TRABALHO, POR QUALQUER MEIO CONVENCIONAL OU ELETRÔNICO, PARA FINS DE ESTUDO E PESQUISA, DESDE QUE CITADA A FONTE.

Ficha catalográfica preparada pela Seção de Tratamento da Informaçāo do Serviço de Biblioteca - EESC/USP

Análise teórica e experimental do comportamento de pilares esbeltos de concreto de alta resistência, considerando a ductilidade / Francisco Aguirre Torrico ; orientador José Samuel Giongo. -- Sāo Carlos, 2010.

Tese (Doutorado-Programa de Pós-Graduação e Área de Concentraçāo em Engenharia de Estruturas) -- Escola de Engenharia de Sāo Carlos da Universidade de Sāo Paulo, 2010 .

1. Pilar. 2. Concreto de alta resistência.

3. Esbeltez. 4. Análise nāo linear. 5. Ductilidade.

6. Confinamento. I. Título. 


\section{AGRADECIMENTOS}

Meu eterno agradecimento a Deus pela sua infinita misericórdia.

À minha amada família, minha esposa Rosario pelo apoio que sempre tive em casa e durante tempo que estive fora de casa, às minhas filhas Paola, Bruna e Isabela (BF4E) as amo muito e desculpa o tempo sem vocês, vou retribuir, aos meus irmãos Ivan e Maria Fátima, à Bianca e Sebastian que tirei tempo deles para terminar este trabalho.

Ao meu orientador, Prof. José Samuel Giongo, a quem muito admiro, e considero um grande amigo. Obrigado pelo esforço, pela paciência e por ajudar a resolver os muitos problemas que tem surgido durante o desenvolvimento deste trabalho. Obrigado também pela confiança na minha pessoa e pela cuidadosa orientação, espero não ter defraudado, em alguns momentos tive fraquezas que ele soube guiar.

Ao amigo Fredy Garzón que sem sua ajuda não teria conseguido completar este trabalho, desejo para ele e sua esposa Tatiana muito êxito na vida profissional e familiar.

A todos os amigos do SET, especialmente a Eduardo Toledo de Lima Jr. e Edson Leonel, seus aportes técnicos e amizade contribuíram para a conclusão desta tese.

Um obrigado especial ao Prof. Mounir El Debs, quem facilitou o desenvolvimento do trabalho experimental.

Aos todos os professores do Departamento de Estruturas da EESC, especialmente à Prof $^{\text {a }}$. Ana Lúcia El Debs, Prof. Márcio Corrêa, Prof. Marcio Ramalho, Prof. Toshiaki Takeya, Prof. Jefferson Liborio, Prof. Wilson Venturini, Prof. Sergio Proença, e a todos os outros que direta ou indiretamente contribuíram para a elaboração deste trabalho.

Aos funcionários e amigos do laboratório de Estruturas pelo apoio durante as análises experimentais: Luiz Vareda, Amauri, Romeu, Renato, Fabiano, Mário, Mauri e Valdir.

Aos funcionários do Departamento de Engenharia de Estruturas pelo apoio durante minha curta passagem pela escola: Rosi, Nadir, Eli, Toninho, Rodrigo Paccola, Sylvia, Junior, Masaki.

In memoriam do meu pai Dr. Hector Aguirre Varela e minha mãe Maria Nieves Torrico de Aguirre, os estranho muito. 
FOLHA DE JULGAMENTO

Candidato: Engenheiro FRANCISCO AGUIRRE TORRICO.

Tese defendida e julgada em 22/02/2010 perante a Comissão Julgadora:

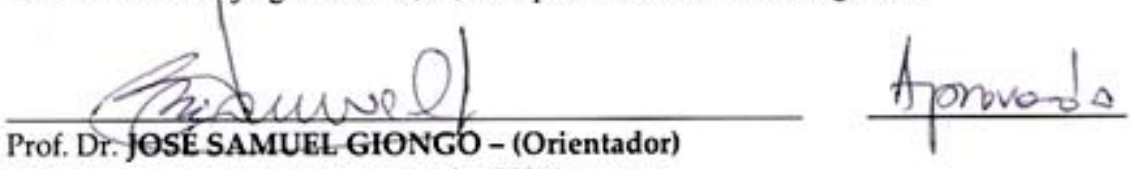

(Escola de Engenharia de São Carlos/USP)

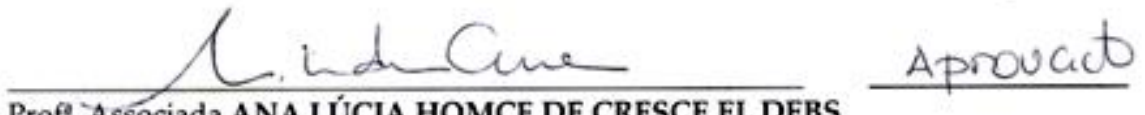

Profe. Associada ANA LÚCIA HOMCE DE CRESCE EL DEBS

(Escola de Engenharia de São Carlos/USP)

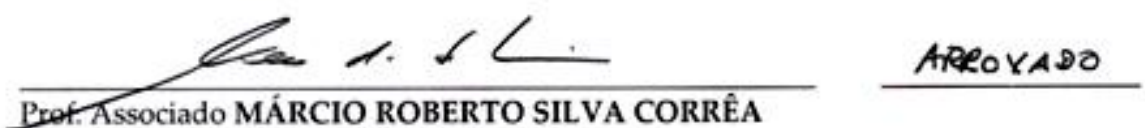
(Escola de Engenharia de São Carlos/USP)

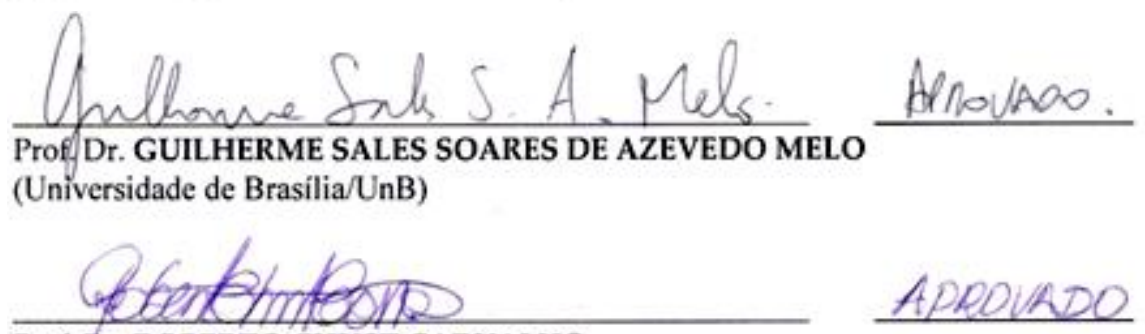

Prof. Dr. ROBERTO CHUST CARVALHO

(Universidade Federal de São Carlos/UFSCar)

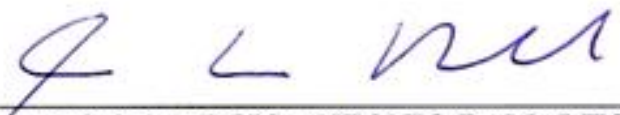

Prof.Associado MARCIO ANTONIO RAMALHO

Coordenador do Programa de Pós-Graduação em

Engenharia Civil (Engenharia de Estruturas)

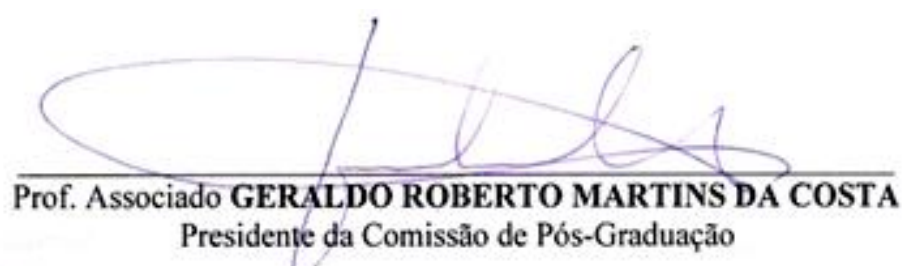




\section{SUMÁRIO}

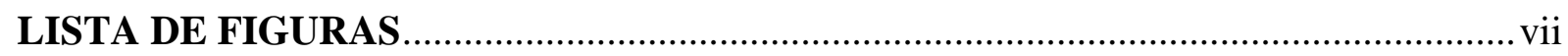

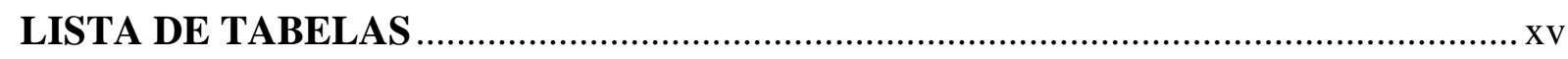

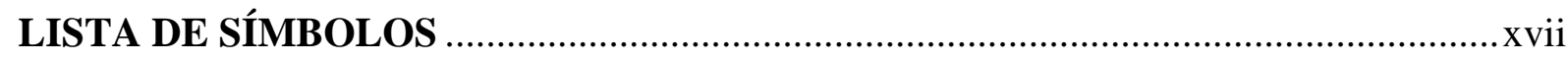

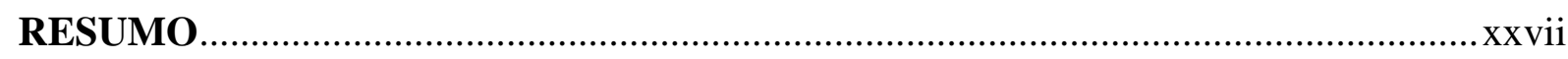

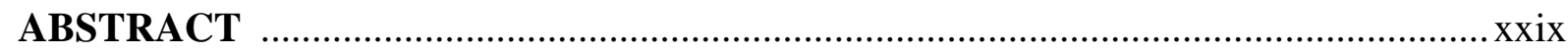

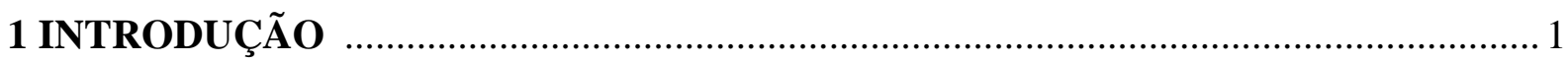

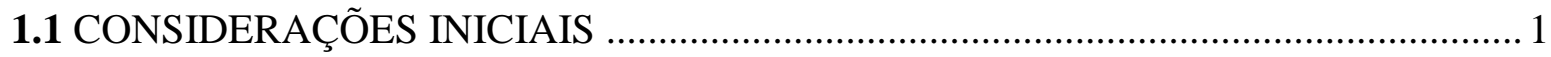

1.2 APLICAÇÕES DO CONCRETO DE ALTA RESISTÊNCIA …………………….........

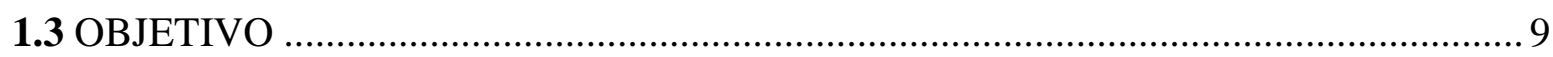

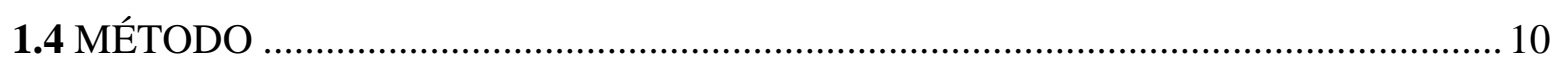

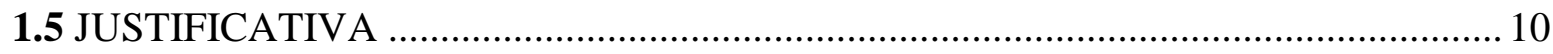

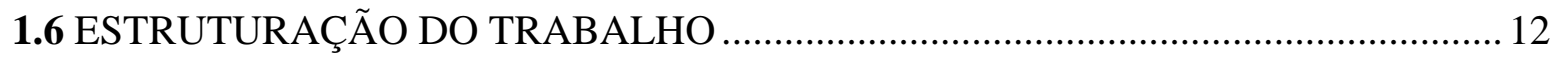

2 PROPRIEDADES DO CONCRETO DE ALTA RESISTÊNCIA …………………….... 15

2.1 HISTÓRICO E DEFINIÇÕES ............................................................................... 15

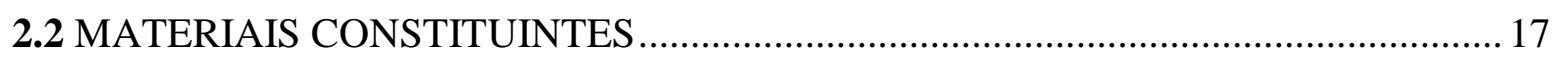

2.2.1 Cimento

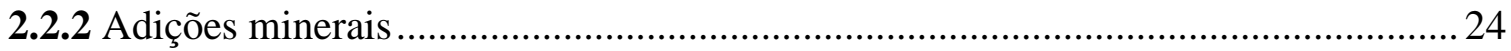

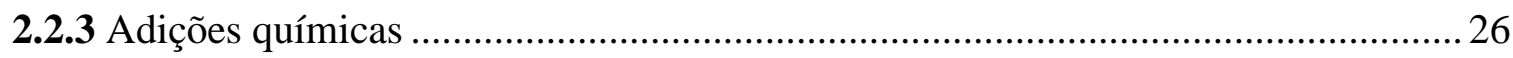

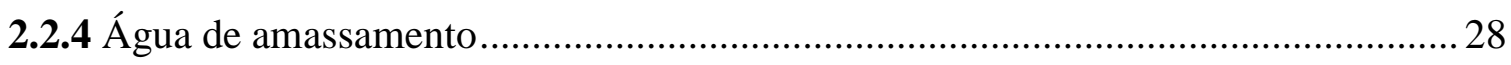

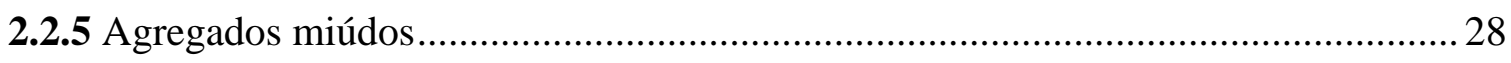

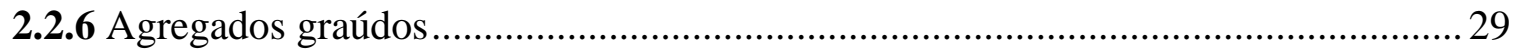




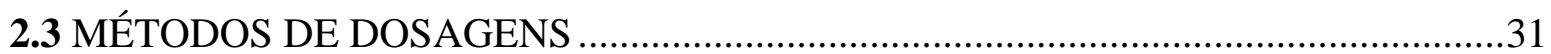

2.4 PROPRIEDADES MECÂNICAS DO CAR SEM CONFINAMENTO ........................32

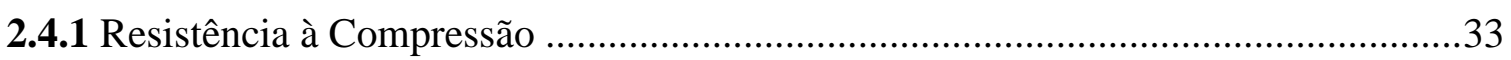

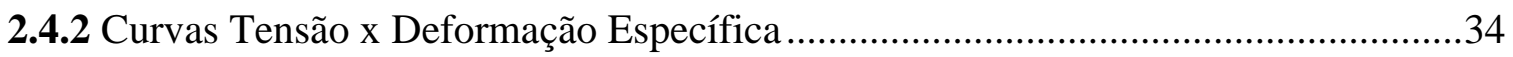

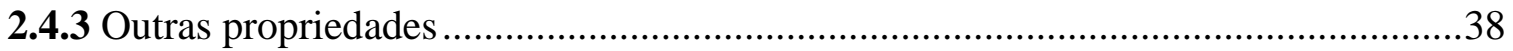

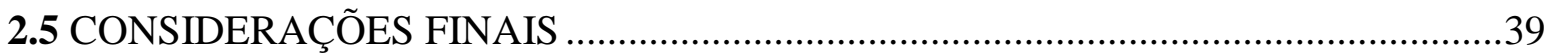

3 MODELOS DE CONCRETO DE ALTA RESISTENCIA CONFINADO .................4

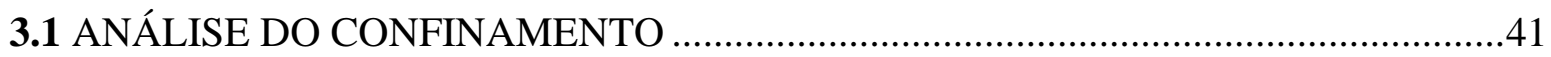

3.2 COMPORTAMENTO DO CONCRETO SOB ESTADOS MÚLTIPLOS DE

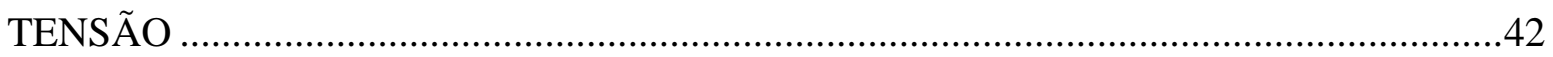

3.3 HISTÓRICO DAS INVESTIGAÇÕES ..................................................................46

3.3.1 Pilares sujeitos à compressão centrada .....................................................................46

3.3.2 Pilares sujeitos à compressão excêntrica ................................................................58

3.4 EQUAÇÕES CONSTITUTIVAS DO CONCRETO CONFINADO ............................63

3.4.1 Modelo de Cusson e Paultre (1995) ...............................................................................65

3.4.2 Modelo de Légeron e Paultre (2003) .......................................................................69

3.5 OUTROS MODOS DE QUANTIFICAR A DUCTILIDADE ….................................. 71

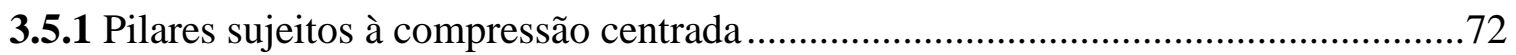

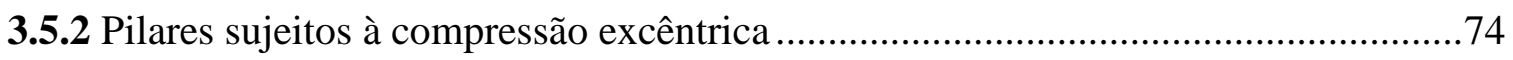

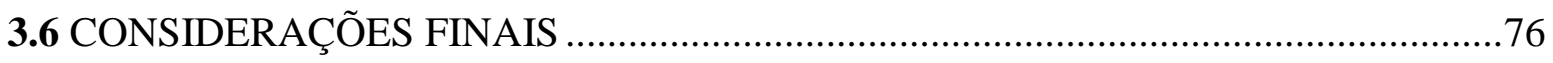

4 ANÁlise E COMPORTAMENTO DE PILARES ESBELTOS DE CONCRETO

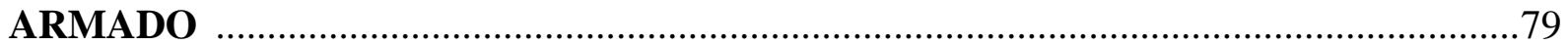

4.1 INTRODUÇÃ

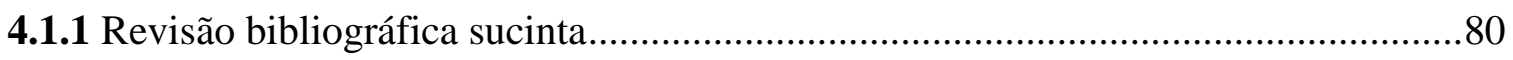

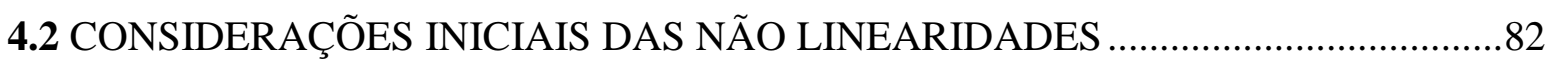

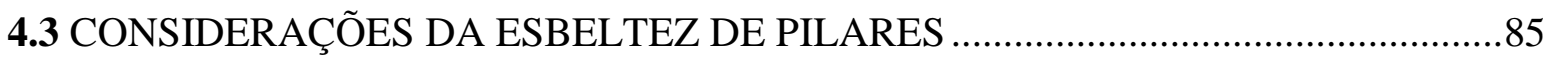

4.4 INSTABILIDADE DE BARRAS SUBMETIDAS À COMPRESSÃO CENTRADA

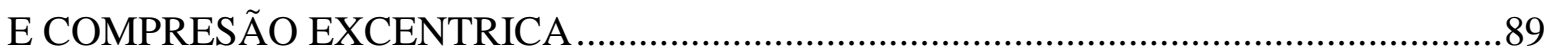

4.4.1 Relações entre deslocamento e curvatura para um pilar sujeito à

flexo-compressão. 
4.4.2 Resolução da equação diferencial de um elemento de material elástico linear sujeito à compressão excêntrica

4.5 DIAGRAMA FORÇA NORMAL-MOMENTO RESISTENTE-CURVATURA ......... 96

4.5.1 Traçado do diagrama momento-curvatura 98

4.6 ESTADO LIMITE ÚLTIMO PARA PILARES COM QUALQUER ESBELTEZ

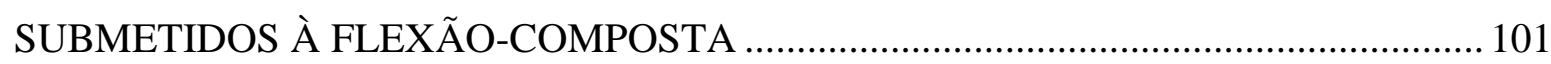

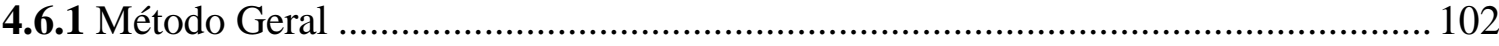

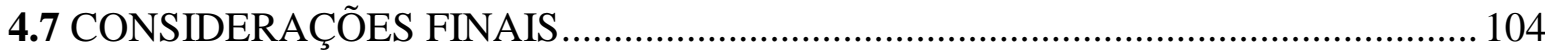

5 PROGRAMA EXPERIMENTAL: MÉTODOS E MATERIAIS ................................ 105

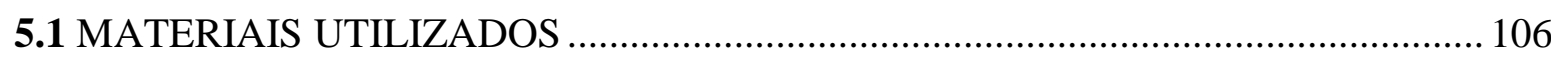

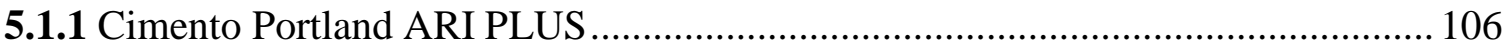

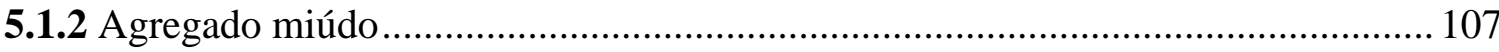

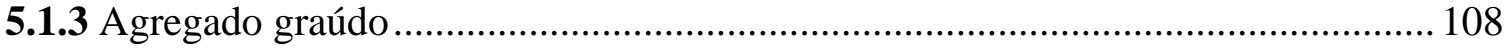

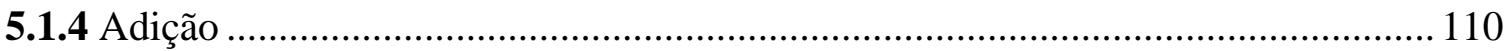

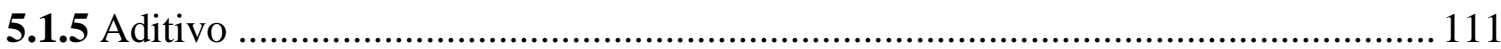

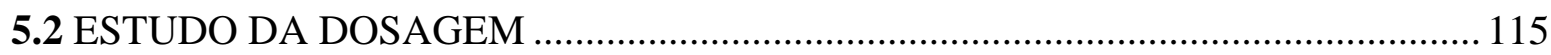

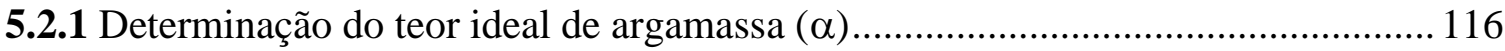

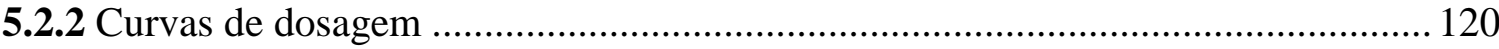

5.3 PROPRIEDADES MECÂNICAS DAS ARMADURAS ........................................... 124

5.4 DESCRIÇÃO DOS MATERIAIS E INSTRUMENTAÇÃO DOS PILARES

CURTOS E PILARES ESBELTOS ....................................................................... 126

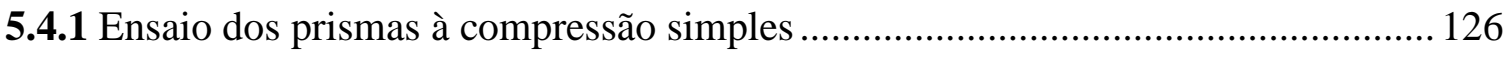

5.4.2 Ensaio dos pilares esbeltos à compressão excêntrica............................................ 129

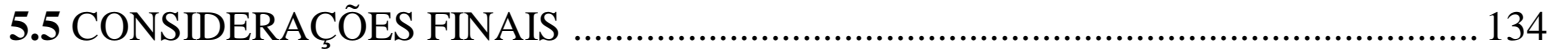

6 ANÁLISE DOS RESULTADOS EXPERIMENTAIS ................................................ 137

6.1 PILARES CURTOS SUBMETIDOS À COMPRESSÃO SIMPLES ........................ 139

6.1.1 Avaliação gráfica dos modelos propostos confinados ......................................... 139

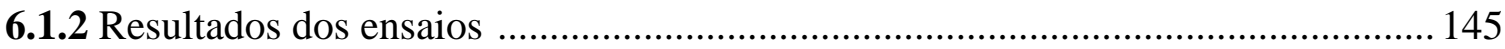

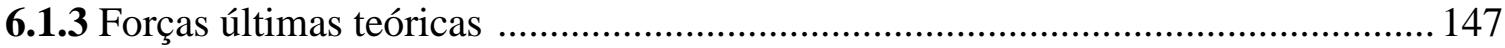

6.1.4 Diagramas de força aplicada-deformação específica dos pilares curtos ................ 150

6.1.5 Diagramas de deformação específica estribos-deformação específica pilar curto. 153 
6.1.6 Diagramas tensão-deformação específica do concreto ........................................155

6.2 PILARES ESBELTOS SUBMETIDOS À COMPRESSÃO EXCÊNTRICA..............157

6.2.1 Estudo do deslocamento vertical dos pilares .......................................................161

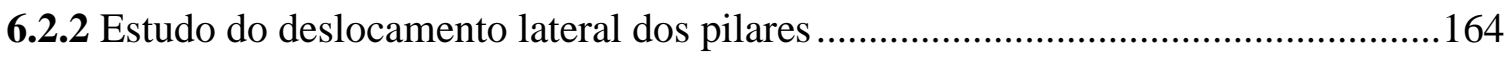

6.2.3 Estudo das deformações específicas das armaduras transversais ............................168

6.2.4 Estudo das deformações específicas das armaduras longitudinais .........................169

6.2.5 Estudo das deformações específicas do concreto na face mais comprimida...........172

6.2.6 Estudo das variações do diagrama de deformações da seção transversal................174

6.2.7 Resumo dos resultados obtidos nos ensaios ...........................................................179

6.2.8 Estudo da ductilidade dos pilares esbeltos ............................................................182

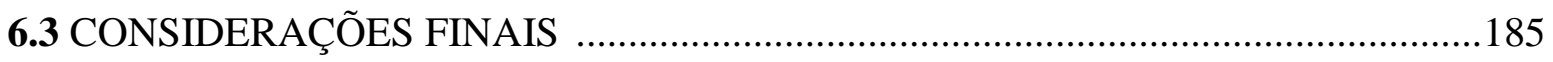

7 ANÁLISE NUMÉRICA DOS PILARES CURTOS ....................................................189

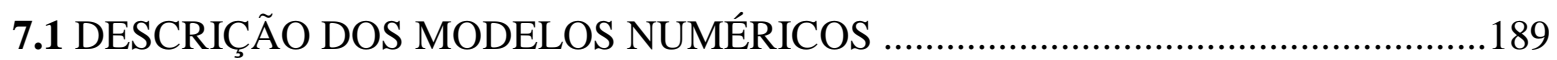

7.1.1 Modelos de ruína para o concreto e para as armaduras ..........................................190

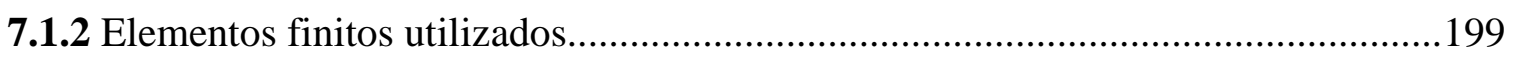

7.1.3 Critérios de ruptura empregados no ANSYS ….................................................200

7.2 IMPLEMENTAÇÃO COMPUTACIONAL DOS PILARES CURTOS......................203

7.3 COMPARAÇÃO DOS VALORES OBTIDOS NUMERICAMENTE, PELO

MODELO DE LÉGERON E PAULTRE (2003) E OS EXPERIEMENTAIS ..................212

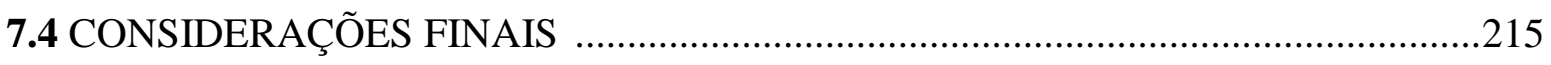

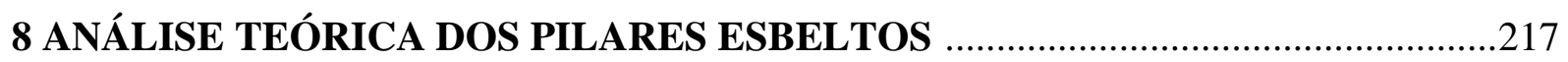

8.1 CONSIDERAÇÕES NA ELABORAÇÃO DO PROGRAMA …...............................217

8.1.1 Diagramas momento-curvatura dos pilares esbeltos ...........................................219

8.1.2 Diagramas força axial-deslocamento lateral dos pilares esbeltos ..........................224

8.2 COMPARAÇÃO DOS RESULTADOS EXPERIMENTAIS DOS PILARES POR

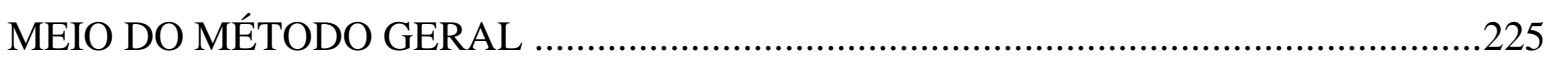

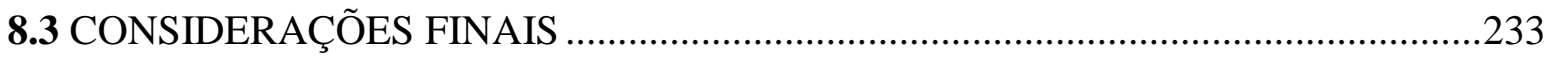

CONCLUSÃO

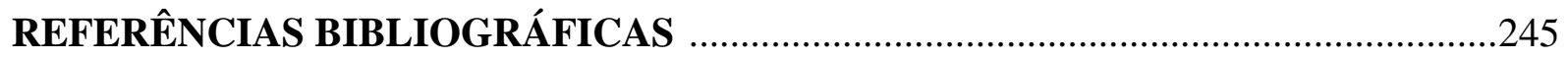

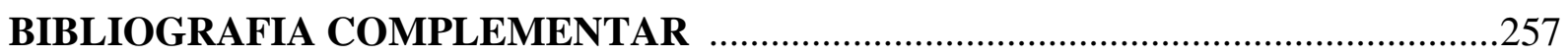


ANEXO A - ESTUDO DO TRAÇO PARA A ELABORAÇÃO DAS CURVAS DE DOSAGEM

ANEXO B - RESULTADOS DA RESISTÊNCIA À COMPRESSÃO DO CONCRETO

PARA OS PILARES (DOS TRAÇOS FINAIS OBTIDOS DAS CURVAS DE DOSAGEM)

ANEXO C - RESULTADO DA RESISTÊNCIA À COMPRESSÃO DIAMETRAL

(DOS TRAÇOS FINAIS)

ANEXO D - DIAGRAMAS AXIAL-MOMENTO PARA O ESTADO LIMITE ÚLTIMO PELO EUROCODE 2 (2004) SEM CONFINAMENTO

ANEXO E - DIAGRAMAS MOMENTO-CURVATURA PARA O

DIMENSIONAMENTO

ANEXO F - DIAGRAMAS FORÇA AXIAL-MOMENTO DE DIMENSIONAMENTO

PARA VÁRIAS ESBELTEZES COM O MÉTODO GERAL 285

ANEXO G - APLICAÇÃO DOS DIAGRAMAS MOMENTO-CURVATURA E FORÇA AXIAL-MOMENTO A UM EXEMPLO DE DIMENSIONAMENTO. ANEXO H - PROGRAMA PILCON_MG: CALCULA UM PONTO DO GRÁFICO FORÇA-DESLOCAMENTO LATERAL, ELABORADO COM O MATH-CAD V.14.. 297 


\section{LISTA DE FIGURAS}

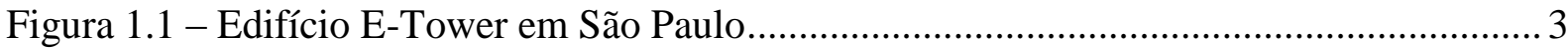

Figura 1.2 - MASP e o Centro Empresarial Nações Unidas (São Paulo - SP). ........................ 4

Figura 1.3 - Evolution Towers (Curitiba -PA) ................................................................... 5

Figura 1.4 - Centro Empresarial Previnor e Suarez Trade Center (Salvador-Bahia)................5

Figura 1.5 - Torre de Burj Dubai e Torre Taipei 101 ......................................................... 6

Figura 1.6 - Shangai Word Finance Center e as Torres Gêmeas Petronas .............................. 6

Figura 1.7 - Viaduto Millau - França ............................................................................... 7

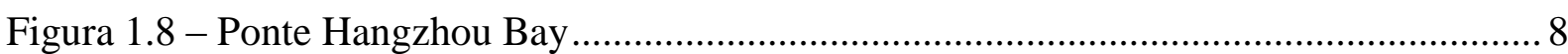

Figura 1.9 - Base da Plataforma de Hibernia - Canadá......................................................... 8

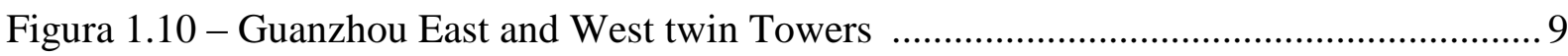

Figura 2.1 - Evolução da resistência a compressão dos distintos tipos de

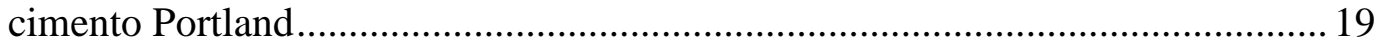

Figura 2.2 - Desenvolvimento da microestrutura do da pasta na hidratação do

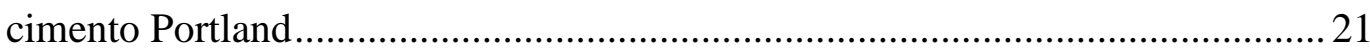

Figura 2.3 - Evolução da hidratação dos compostos do cimento........................................... 22

Figura 2.4 - Curvas de resistência à compressão dos compostos do cimento ......................... 22

Figura 2.5 - Composição do cimento, antes e depois da hidratação ....................................... 23

Figura 2.6 - Atuação da SA na zona de interfase entre a pasta e agregado. ............................ 25

Figura 2.7 - Zona de interface entre a pasta de cimento e um grão de areia .......................... 26

Figura 2.8 - Esquema da floculação das partículas de cimento ............................................. 27

Figura 2.9 - Efeito da SA melhorando o comportamento mecânico do agregado .................. 31

Figura 2.10 - Superfície de um agregado frágil, poroso com dopagem superficial ................ 30

Figura 2.11 - Diagramas $\sigma_{\mathrm{c}} \mathrm{x} \varepsilon_{\mathrm{c}}$ de concretos com várias resistências à compressão .............35 
Figura 3.1 - Superfícies de plastificação e de ruptura. .42

Figura 3.2 - Curva da resistência biaxial do concreto .43

Figura 3.3 - Resistência do concreto no estado múltiplo de tensão . .44

Figura 3.4 - Círculos de Mörh-Coulomb na iminente ruptura do material .44

Figura 3.5 - Ruptura do concreto sob combinação de tensões tangenciais e tensões normais 45

Figura 3.6 - Modelo de concreto confinado proposto por Sheikh e Uzumeri (1982) . .47

Figura 3.7 - O a) é modelo de Chan, o b) de Roy e Sozen e o c) de Sargin . .47

Figura 3.8 - Curva $\sigma_{\mathrm{c}} \mathrm{x} \varepsilon_{\mathrm{c}}$ proposta para um CAR confinado por Cusson e Paultre (1995) ...49

Figura 3.9 - Distribuição das tensões de confinamento ao longo do pilar .50

Figura 3.10 - Curva $\sigma_{\mathrm{c}}$ x $\varepsilon_{\mathrm{c}}$ proposta por Saatcioglu e Razvi (1992) .51

Figura 3.11 - Distribuição das pressões laterais .51

Figura 3.12 - Curvas $\sigma_{\mathrm{c}}$ X $\varepsilon_{\mathrm{c}}$ propostas por Cusson e Paultre, 1995 .52

Figura 3.13 - Destacamento do cobrimento da armadura, Paultre et al. 55

Figura 3.14 - Diagrama momento x curvatura para o esforço axial reduzida $\mathrm{F} /\left(\mathrm{A}_{\mathrm{c}} \times \mathrm{f}_{\mathrm{c}}\right)=0,3$ .59

Figura 3.15 - Momento-curvatura para diferentes tensões axiais reduzidas .60

Figura 3.16 - Comportamento esquemático do concreto confinado segundo a ACI-441 (1997) .65

Figura 3.17 - Outras configurações de armado (adaptada de Cusson e Paultre,1994) .............71

Figura 3.18 - Definição do fator energético ..... .73

Figura 3.19 - Metodologia para a obtenção do índice de ductilidade pós-pico .73

Figura 3.20 - Diagramas de força axial x deformação combinada para pilares sujeitos a força excêntrica .76

Figura 4.1 - Etapas do comportamento não linear de um elemento à flexão de

Concreto Armado. .84

Figura 4.2 - Diagrama $\sigma_{\mathrm{c}} \times \varepsilon_{\mathrm{c}}$ uniaxial de um material não linear e inelástico .85

Figura 4.3 - Valores de k para em pilares isolados .86

Figura 4.4 - Obtenção do k para estruturas de nós móveis (esquerda) e nós fixos (direita) ....87

Figura 4.5 - Comprimento efetivo de pilares, na esquerda para estrutura de nós

fixos e na direita para estrutura de nós móveis . .88

Figura 4.6 - Definição de esbeltez mecânica e geométrica .88

Figura 4.7 - Formas de estabilidade nas barras .90

Figura 4.8 - Diagrama de interação de força axial-momento fletor .90 


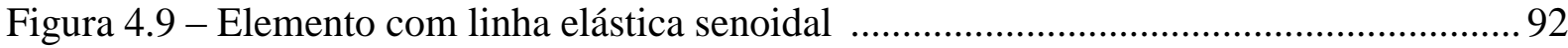

Figura 4.10 - Diagramas momento-curvatura na flexo-compresão ...................................... 94

Figura 4.11 - Esquema de um pilar sujeito à flexão-compressão uniforme............................ 94

Figura 4.12 - Pilar sujeito a excentricidades diferentes nas extremidades ........................... 95

Figura 4.13 - Elemento diferencial de barra à flexão .......................................................... 98

Figura 4.14 - Diagrama de tensões e deformações ............................................................... 99

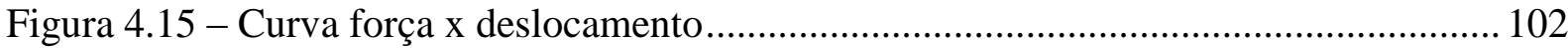

Figura 4.16 - Pilar bi-articulado com divisões ................................................................ 102

Figura 5.1 - Análise granulométrica da areia empregada no ensaio .................................... 108

Figura 5.2 - Estudo da percentagem ideal de brita 1 no estudo do empacotamento.............. 109

Figura 5.3 - Análise granulométrica do agregado graúdo empacotado ............................... 110

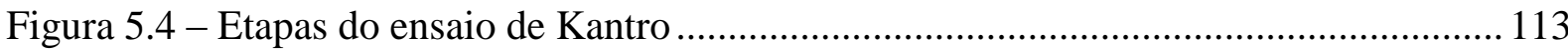

Figura 5.5 - Gráfica área espalhada-\% do aditivo sem sílica ativa na mistura .................... 114

Figura 5.6 - Gráfica área espalhada-\% do aditivo com sílica ativa na mistura .................... 115

Figura 5.7 - Curva de dosagem para a obtenção do concreto de $30 \mathrm{MPa}$............................. 121

Figura 5.8 - Curva de dosagem para a obtenção do concreto de $60 \mathrm{MPa}$.............................. 122

Figura 5.9 - Curva de dosagem para a obtenção do concreto de $100 \mathrm{MPa}$........................... 123

Figura 5.10 - Diagrama tensão-deformação específica para o CP1 …................................ 125

Figura 5.11 - Diagrama tensão-deformação específica para o CP4 ..................................... 126

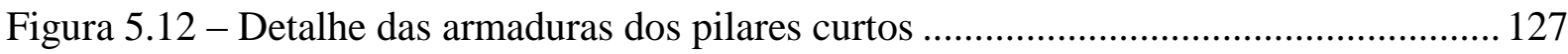

Figura 5.13 - Detalhe da forma dos pilares curtos ..................................................... 128

Figura 5.14 - Detalhe da instrumentação dos pilares curtos .............................................. 128

Figura 5.15 - Detalhe do pilar curto antes do ensaio ........................................................ 129

Figura 5.16 - Detalhe do aparelho de apoio utilizado nos ensaios dos pilares .................... 130

Figura 5.17 - Detalhe das armaduras dos pilares esbeltos .................................................. 132

Figura 5.18 - Detalhe da forma dos pilares esbeltos ........................................................ 132

Figura 5.19 - Detalhe da instrumentação dos pilares esbeltos ............................................. 133

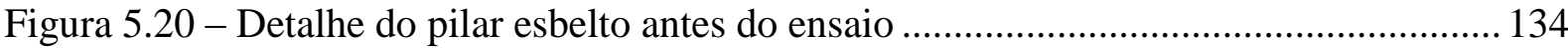

Figura 6.1 - Esquema da máquina INSTRON do LE - EESC - USP .................................... 139

Figura 6.2 - Diagramas $\sigma_{\mathrm{c}} \mathrm{x} \varepsilon_{\mathrm{c}}$ realista para concreto do pilar de varias resistências, mostrando suas deformações específicas limites para o concreto C60

Figura 6.3 - Diagramas $\sigma_{\mathrm{c}}$ x $\varepsilon_{\mathrm{c}}$ realistas para concretos C30, C60 e C90 (FIB, 1999) e do CEB Bulletin 228 (1995) para concretos C60 e C100 
Figura 6.4 - Curvas $\sigma_{\mathrm{c}} \times \varepsilon_{\mathrm{c}}$ para os modelos com confinamento e uma taxa volumétrica de $2,41 \%$ (esquerda), uma taxa volumétrica de $1,2 \%$ (direita) e para um modelo não confinado

Figura 6.5 - Modelo de Cusson e Paultre, 1995 (esquerda) e Légeron e Paultre, 2003

(direita) para as diferentes armaduras de confinamento dos modelos

Figura 6.6 - Diagramas $\sigma_{\mathrm{c}} \mathrm{x} \varepsilon_{\mathrm{c}}$ para concretos sem confinamento

Figura 6.7 - Diagramas $\sigma_{\mathrm{c}} \mathrm{x} \varepsilon_{\mathrm{c}}$ do modelo de Légeron e Paultre (2003)

Figura 6.8 - Forma da ruptura dos prismas de CAR e de concreto convencional, sem armadura 146

Figura 6.9 - Pilares curtos 100M, 50H e 50L após o ensaio 146

Figura 6.10 - Plano de cisalhamento do pilar curto 100M após a ruína 147

Figura 6.11 - Diagrama força-deformação específica vertical do pilar $50 \mathrm{H}$ 151

Figura 6.12 - Diagrama força-deformação específica vertical do pilar 50M 151

Figura 6.13 - Diagrama força-deformação específica vertical do pilar 50L 151

Figura 6.14 - Diagrama força-deformação específica vertical do pilar $100 \mathrm{H}$ 152

Figura 6.15 - Diagrama força-deformação específica vertical do pilar 100M 152

Figura 6.16 - Diagrama força-deformação específica vertical do pilar 100L

Figura 6.17 - Diagrama deformação estribo-deformação vertical dos pilares 50H e 100H...154

Figura 6.18 - Diagrama deformação estribo-deformação vertical dos pilares 50M e 100M .154

Figura 6.19 - Diagrama deformação estribo-deformação vertical dos pilares 50L e 100L....155

Figura 6.20 - Diagrama tensão-deformação específica do concreto dos pilares $50 \mathrm{H} \mathrm{e}$ $100 \mathrm{H}$

Figura 6.21 - Diagrama tensão-deformação específica do concreto dos pilares 50M e $100 \mathrm{M}$ 156

Figura 6.22 - Diagrama tensão-deformação específica do concreto dos pilares 50L e $100 \mathrm{~L}$.

Figura 6.23 - Detalhe de fixação do pilar junto aos aparelhos de apoio por meio dos colares metálicos .158

Figura 6.24 - Detalhe da fixação do pilar junto à rótula.

Figura 6.25 - Final do ensaio para o Pilar 100M12 mostrando suas fissuras e o destacamento do cobrimento do pilar 50H12 160

Figura 6.26 - Diagrama força-deslocamento vertical para os pilares 50H12, 50H30, $100 \mathrm{H} 12$ e $100 \mathrm{H} 30$ 
Figura 6.27 - Diagrama força-deslocamento vertical para os pilares 50M12, 50M30, $100 \mathrm{M} 12$ e $100 \mathrm{M} 30$

Figura 6.28 - Diagrama força-deslocamento vertical para os pilares 50L12, 50L30, $100 \mathrm{~L} 12$ e $100 \mathrm{~L} 30$

Figura 6.29 - Diagrama força-deslocamento lateral para os pilares $50 \mathrm{H} 12,50 \mathrm{H} 30$, $100 \mathrm{H} 12$ e $100 \mathrm{H} 30$. 165

Figura 6.30 - Diagrama força-deslocamento lateral para os pilares 50M12, 50M30, $100 \mathrm{M} 12$ e $100 \mathrm{M} 30$ 165

Figura 6.31 - Diagrama força-deslocamento lateral para os pilares 50L12, 50L30, $100 \mathrm{~L} 12$ e $100 \mathrm{~L} 30$ 166

Figura 6.32 - Comparação entre as deformadas obtidas nos ensaios e a forma senoide.

Figura 6.33 - Diagrama força-deformação específica dos estribos dos pilares 50H12, $50 \mathrm{H} 30,100 \mathrm{H} 12$ e $100 \mathrm{H} 30$. 168

Figura 6.34 - Diagrama força-deformação específica dos estribos dos pilares 50M12, 50M30, 100M12 e 100M30 168

Figura 6.35 - Diagrama força-deformação específica dos estribos dos pilares 50L12, 50L30, 100L12 e 100L30.

Figura 6.36 - Diagrama força-deformação específica das armaduras longitudinais dos pilares $50 \mathrm{H} 12,50 \mathrm{H} 30,100 \mathrm{H} 12$ e $100 \mathrm{H} 30$

Figura 6.37 - Diagrama força-deformação específica das armaduras longitudinais dos pilares 50M12, 50M30, 100M12 e 100M30

Figura 6.38 - Diagrama força-deformação específica das armaduras longitudinais dos pilares 50L12, 50L30, 100L12 e 100L30

Figura 6.39 - Diagrama força-deformação específica máxima do concreto dos pilares $50 \mathrm{H} 12,50 \mathrm{H} 30,100 \mathrm{H} 12$ e $100 \mathrm{H} 30$.

Figura 6.40 - Diagrama força-deformação específica máxima do concreto dos pilares 50M12, 50M30, 100M12 e 100M30

Figura 6.41 - Diagrama força-deformação específica máxima do concreto dos pilares 50L12, 50L30, 100L12 e 100L30

Figura 6.42 - Valores da deformação específica última do concreto em função da excentricidade da força.

Figura 6.43 - Diagramas de deformações da seção transversal 175 
Figura 6.44 - Diagrama força-deformação do eixo centroidal dos pilares 50H12, $50 \mathrm{H} 30,100 \mathrm{H} 12$ e $100 \mathrm{H} 30$

Figura 6.45 - Diagrama força-deformação do eixo centroidal dos pilares 50M12, 50M30, 100M12 e 100M30.

Figura 6.46 - Diagrama força-deformação do eixo centroidal dos pilares 50L12, 50L30, 100L12 e 100L30 178

Figura 6.47 - Diagrama força-deformação específica combinada dos pilares 50H12, $50 \mathrm{H} 30,100 \mathrm{H} 12$ e $100 \mathrm{H} 30$

Figura 6.48 - Diagrama força-deformação específica combinada dos pilares 50M12, 50M30, 100M12 e 100M30

Figura 6.49 - Diagrama força-deformação específica combinada dos pilares 50L12, 50L30, 100L12 e 100L30. 184

Figura 6.50 - Parâmetro de ductilidade 184

Figura 7.1 - Espaço das tensões principais 190

Figura 7.2 - Encruamento para materiais isotrópicos

Figura 7.3 - Critério de Rankine no espaço das tensões principais limitado por planos perpendiculares aos eixos 192

Figura 7.4 - Representação gráfica do critério de Rankine no plano das tensões 193

Figura 7.5 - Superfícies de ruptura dos critérios de Tresca e von-Misses

Figura 7.6 - Comportamento biaxial do concreto no modelo Rankine e von-Misses 194

Figura 7.7 - Superfície de ruptura de Mörh-Coulomb e Drucker-Prager 194

Figura 7.8 - (a) Modelo de Mörh-Coulomb e (b) modelo de Drucker-Prager 195

Figura 7.9 - Modelo biaxial e uniaxial de Drucker- Prager 195

Figura 7.10 - Resistência do concreto no critério de Mörh-Coulomb em um plano qualquer do material 196

Figura 7.11 - Seções dos meridianos e plano desviatório para o critérios de Willam-Warnke 197

Figura 7.12 - Curva de resistência biaxial do concreto 197

Figura 7.13 - Superfície de ruptura sugerida pela norma FIB, 1999 198

Figura 7.14 - Plano desviatório para uma superfície de ruptura definida por $\tau_{0}$ 198

Figura 7.15 - Elemento SOLID65 199

Figura 7.16 - Elemento LINK8 200

Figura 7.17 - Comportamento uniaxial do concreto 201 
Figura 7.18 - Superfície de ruptura em 3D

Figura 7.19 - Modelos dos pilares curtos (a) estribos a cada $10 \mathrm{~cm} \mathrm{e}$

(b) estribos a cada $5 \mathrm{~cm}$

Figura 7.20 - Incremento de tensões no núcleo devido ao confinamento para o pilar curto $50 \mathrm{H}$ 204

Figura 7.21 - Incremento de tensões no núcleo devido ao confinamento para o pilar curto $100 \mathrm{H}$.

Figura 7.22 - Incremento de tensões no núcleo devido ao confinamento para o pilar curto $50 \mathrm{M}$

Figura 7.23 - Incremento de tensões no núcleo devido ao confinamento para o pilar curto $100 \mathrm{M}$ 205

Figura 7.24 - Incremento de tensões no núcleo devido ao confinamento para o pilar curto $50 \mathrm{~L}$ 206

Figura 7.25 - Incremento de tensões no núcleo devido ao confinamento para o pilar curto $100 \mathrm{~L}$ 206

Figura 7.26 - Valor das tensões nas armaduras na força última no pilar curto $50 \mathrm{H}$ 207

Figura 7.27 - Valor das tensões nas armaduras na força última no pilar curto $100 \mathrm{H}$ 208

Figura 7.28 - Valor das tensões nas armaduras na força última no pilar curto 50M 208

Figura 7.29 - Valor das tensões nas armaduras na força última no pilar curto 100M 209

Figura 7.30 - Valor das tensões nas armaduras na força última no pilar curto 50L 209

Figura 7.31 - Valor das tensões nas armaduras na força última no pilar curto 100L 210

Figura 7.32 - Tensões laterais de confinamento do pilar 50M para um $14 \%$ da força última

Figura 7.33 - Tensões laterais de confinamento do pilar 50M para um $84 \%$ da força última

Figura 8.1 - Fluxograma para a obtenção do gráfico Momento-Curvatura e do

Método Geral com força axial incremental

Figura 8.2 - Diagrama momento-curvatura para os pilares esbeltos do ensaio para espaçamento entre estribos de $5 \mathrm{~cm}$ (esquerda) e $10 \mathrm{~cm}$ (direita)

Figura 8.3 - Diagrama momento-curvatura para os pilares esbeltos do ensaio sem confinamento

Figura 8.4 - Diagramas momento-curvatura para os pilares com concreto tipo $\mathrm{H}$ 220

Figura 8.5 - Diagramas momento-curvatura para os pilares com concreto tipo $\mathrm{M}$ 221 
Figura 8.6 - Diagrama momento-curvatura para os pilares com concreto tipo L .221

Figura 8.7 - Diagrama momento-curvatura do pilar 50H30 e a validação do resultado do ensaio com os momentos de $1^{\mathrm{a}}$ e $2^{\mathrm{a}}$ ordem

Figura 8.8 - Resultado da aplicação do Método Geral para um pilar do ensaio .224

Figura 8.9 - Diagrama força-excentricidade de $2^{\mathrm{a}}$ ordem para os pilares com concreto tipo $\mathrm{H}$

Figura 8.10 - Diagrama força-excentricidade de $2^{\mathrm{a}}$ ordem para os pilares com concreto tipo $\mathrm{M}$

Figura 8.11 - Diagrama força-excentricidade de $2^{\mathrm{a}}$ ordem para os pilares com concreto tipo L 226

Figura 8.12 - Pilares com concreto tipo $\mathrm{H}$ sem o efeito do confinamento 229

Figura 8.13 - Pilares com concreto tipo M sem o efeito do confinamento 230

Figura 8.14 - Pilares com concreto tipo L sem o efeito do confinamento 230

Figura 8.15 - Resultados obtidos experimentalmente e com o Método Geral dos pilares com concreto tipo $\mathrm{H}$

Figura 8.16 - Resultados obtidos experimentalmente e com o Método Geral dos pilares com concreto tipo $\mathrm{M}$

Figura 8.17 - Resultados obtidos experimentalmente e com o Método Geral dos pilares com concreto tipo L 


\section{LISTA DE TABELAS}

Tabela 2.1 - Propriedades dos quatro componentes principais do clinquer............................ 18

Tabela 2.2 - Tipos de cimento produzidos no Brasil ........................................................... 19

Tabela 2.3 - Grau de hidratação do cimento necessário para que ocorra a descontinuidade

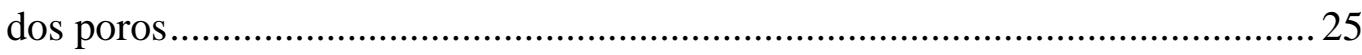

Tabela 2.4 - Limites Granulométricos do agregado miúdo ................................................ 28

Tabela 2.5 - Limites Granulométricos do agregado graúdo ................................................2 29

Tabela 2.6 - Valores do fator $\alpha_{\mathrm{a}}$ que afeta o módulo de deformação $\mathrm{E}_{\mathrm{cm}} \quad$................................ 37

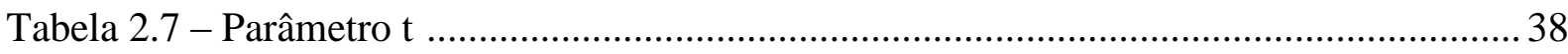

Tabela 5.1 - Resistência a compressão do CPV-ARI PLUS ............................................... 106

Tabela 5.2 - Propriedades físicas do CPV-ARI PLUS ...................................................... 107

Tabela 5.3 - Distribuição granulométrica do agregado miúdo ............................................ 107

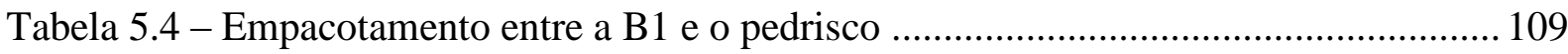

Tabela 5.5 - Distribuição do agregado graúdo da mistura empacotada ............................... 110

Tabela 5.6 - Propriedades físicas e químicas da sílica ativa ................................................ 111

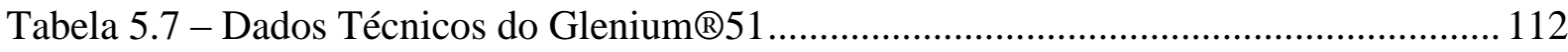

Tabela 5.8 - Resultados do ensaio de Kantro sem sílica ativa ............................................. 114

Tabela 5.9 - Resultados do ensaio de Kantro com sílica ativa............................................... 114

Tabela 5.10 - Determinação do teor de argamassa para um concreto convencional para um traço médio de 1:5,0.

Tabela 5.11 - Traço unitário em massa (1:areia:brita) para concreto convencional com teor

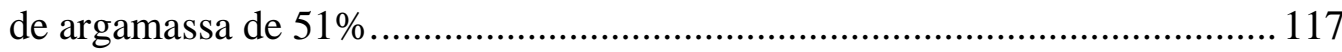

Tabela 5.12 - Quantidade de materiais por $\mathrm{m}^{3}$ de para o concreto convencional ................. 117

Tabela 5.13 - Quantidade de materiais por $\mathrm{m}^{3}$ de para o concreto com superplastificante .. 119

Tabela 5.14 - Quantidade de materiais por $\mathrm{m}^{3}$ de para o concreto com superplastificante e sílica ativa 
Tabela 5.15 - Resultados e consumo de materiais dos traços adotados para os três tipos de concreto.

Tabela 5.16 - Propriedades físicas e mecânicas das barras de aço

Tabela 5.17 - Propriedades geométricas e mecânicas dos pilares curtos

Tabela 5.18 - Propriedades geométricas e mecânicas dos pilares esbeltos

Tabela 6.1 - Cronograma de ensaios dos pilares e corpos-de-prova cilíndricos, resumo de resultados dos ensaios dos corpos-de-prova cilíndricos

Tabela 6.2 - Propriedades físicas e mecânicas dos materiais dos pilares curtos 145

Tabela 6.3 - Resultados entre a força última experimental e as forças teóricas

Tabela 6.4 - Deformação específica dos estribos e do pilar correspondente à força última .153

Tabela 6.5 - Propriedades dos materiais empregados nos pilares esbeltos 161

Tabela 6.6 - Resumo dos resultados correspondentes à força última 179

Tabela 6.7 - Resumo dos momentos máximos 181

Tabela 6.8 - Incremento na capacidade dos pilares com o incremento da resistência do concreto

Tabela 6.9 - Variação da resistência dos pilares em função da variação da excentricidade de força 182

Tabela 6.10 - Parâmetro da ductilidade $\mathrm{D}_{\mathrm{c}}$ 185

Tabela 7.1 - Respostas dos modelos da análise numérica dos pilares curtos 212

Tabela 7.2 - Resultados da análise dos pilares com o modelo de Légeron e Paultre (2003) 213

Tabela 7.3 - Resumo dos resultados dos ensaios de laboratório para os pilares curtos ........214

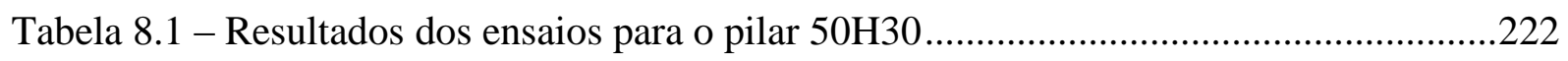

Tabela 8.2 - Comparação de valores de forças últimas e deslocamentos laterais .................228 


\section{LISTA DE SÍMBOLOS}

\section{Letras romanas minúsculas}

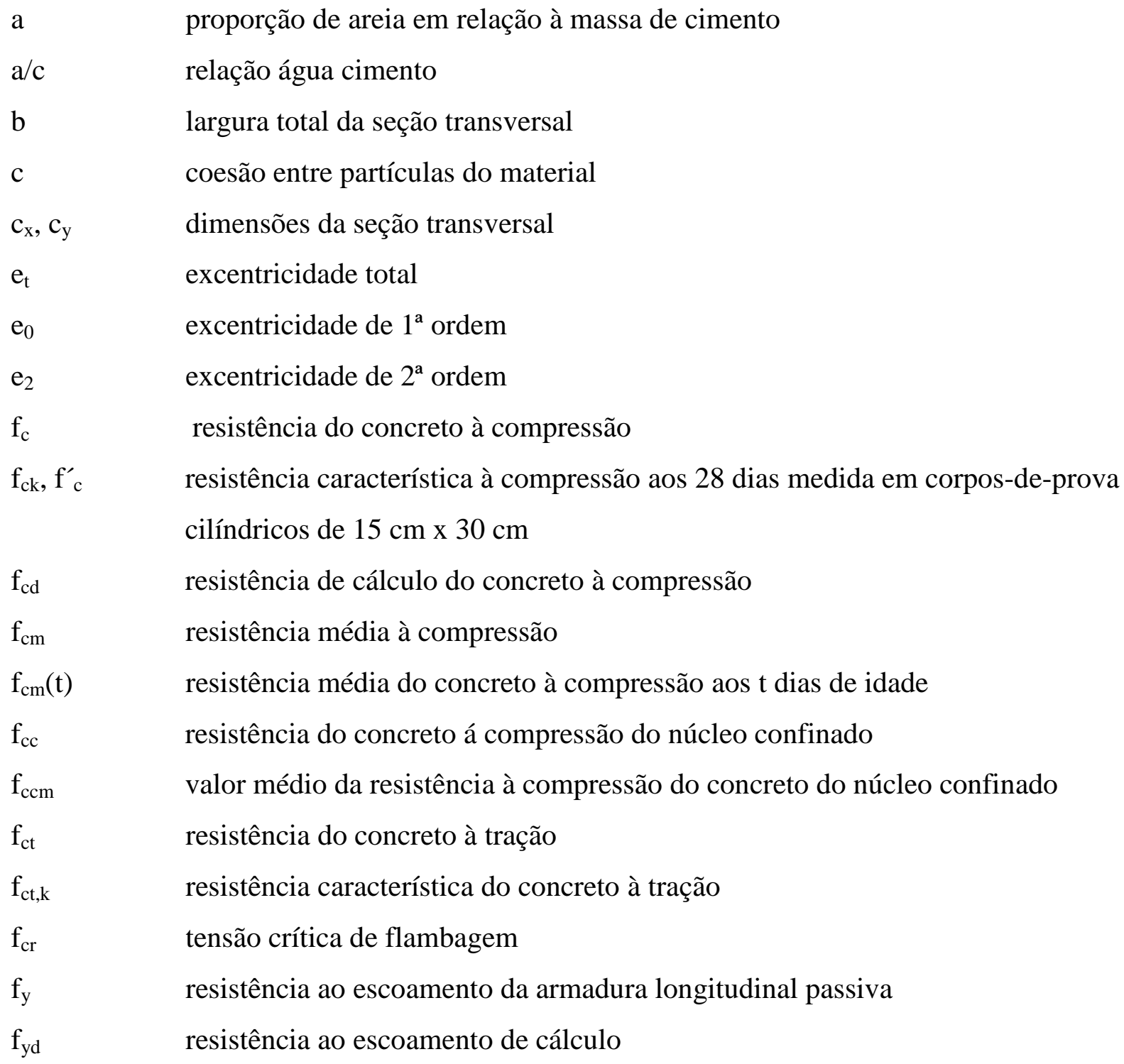


$\mathrm{f}_{\mathrm{yw}} \quad$ resistência ao escoamento da armadura transversal

h altura total da seção transversal

$\mathrm{k}$

parâmetro das normas EUROCODE 2, FIB e B228, fator que considera o comprimento efetivo do pilar, valor máximo da tensão de cisalhamento no critério de ruptura de Tresca

$\mathrm{k}^{\prime} \quad$ valor máximo da tensão de cisalhamento do critério de ruptura de von-Misses

$\mathrm{k}_{\mathrm{d}}$ parâmetro que considera o tipo de ductilidade no cálculo da área de armadura transversal

$\mathrm{k}_{\mathrm{F}}$ parâmetro que considera a força atuante no cálculo do confinamento

$\mathrm{k}_{\bmod 1}$

$\mathrm{k}_{\bmod 2}$ considera o acréscimo de resistência do concreto após os 28 dias considera que a resistência do concreto do elemento estrutural é menor ao do corpo-de-prova

$\mathrm{k}_{\bmod 3} \quad$ considera a diminuição da resistência do concreto sob cargas de longa duração $\mathrm{k}_{\mathrm{n}}$ parâmetro que considera a distribuição da armadura longitudinal no cálculo da área da armadura transversal

$\mathrm{k}_{0}, \mathrm{k}_{1}$ e $\mathrm{k}_{2} \quad$ parâmetros da curva tensão-deformação específica do concreto confinado que consideram a inclinação dos ramos da curva

$\mathrm{k}_{2}$ coeficiente de confinamento efetivo e representa a taxa de concreto menos confinada do modelo de Razvi e Saaticioglu (1996)

m traço (proporção - massa de agregados em relação à massa de cimento)

nc dimensões do núcleo de um pilar quadrado entre centros de estribos mais externos

$\mathrm{nc}_{\mathrm{x}}$ e $\mathrm{nc}_{\mathrm{y}}$ dimensões do núcleo do pilar nas direções $\mathrm{x}$ e y (distancias entre eixos dos estribos mais externos)

$\mathrm{n}_{\ell} \quad$ número de barras longitudinais na seção transversal efetivamente sujeitas pela armadura transversal

p proporção de brita em relação à massa de cimento

r raio de giro; raio de curvatura da seção fletida

s coeficiente que depende do tipo de cimento

$\mathrm{s}_{\mathrm{e}} \quad$ espaçamento entre centros de estribos

Sı distancia entre armaduras longitudinais

t idade do concreto em dias, parâmetro do concreto da norma CEB-B228, espessura do cobrimento do concreto considerada como chapa 


$\begin{array}{ll}\{\mathrm{u}\} & \text { deslocamentos dos nós da estrutura } \\ \mathrm{x} & \text { variável que considera o comprimento do pilar; posição da linha neutra em } \\ & \text { relação à borda mais comprimida } \\ \text { y } & \text { variável para considerar o deslocamento lateral do pilar; variável que considera } \\ & \text { a posição de uma fibra qualquer na seção transversal } \\ \frac{1}{r} & \text { curvatura }\end{array}$

\section{Letras romanas maiúsculas}

A parâmetro que define o tipo de superfície de ruptura do concreto (elástica ou ruptura), área da seção transversal

$\mathrm{A}_{\mathrm{c}} \quad$ área total da seção transversal do pilar

$\mathrm{A}_{\mathrm{nc}}$ área do núcleo da seção transversal medida a partir do perímetro externo do estribo

$\mathrm{A}_{\mathrm{s}} \quad$ área da armadura longitudinal

$\mathrm{A}_{\mathrm{sw}} \quad$ área da armadura transversal

$\mathrm{A}_{\mathrm{swx}}, \mathrm{A}_{\mathrm{swy}}$ áreas das armaduras transversais de confinamento nas direções x e y

$\mathrm{CV} \quad$ coeficiente volumétrico

D diâmetro de cada partícula de grava

$\mathrm{D}_{\max } \quad$ diâmetro máximo do agregado

$\mathrm{D}_{\mathrm{c}} \quad$ parâmetro para medir a ductilidade

$\mathrm{E}_{\mathrm{cm}} \quad$ módulo de deformação do concreto tangente na origem

$\mathrm{E}_{\mathrm{cs}} \quad$ módulo de deformação do concreto secante na origem

$\mathrm{E}_{\mathrm{c} 1} \quad$ módulo de deformação secante correspondente à tensão pico

$\mathrm{E}_{\mathrm{c}} \quad$ módulo de deformação do concreto

$\mathrm{E}_{\mathrm{s}} \quad$ módulo de elasticidade do aço

$\mathrm{E}_{\mathrm{e}} \quad$ energia de deformação elástica

$\mathrm{E}_{\mathrm{p}} \quad$ energia de deformação plástica

E.I rigidez a flexão do pilar

F força axial aplicada, força axial atuante

$\mathrm{F}_{\mathrm{cr}} \quad$ força axial critica de flambagem por flexão

$\mathrm{F}_{\mathrm{crL}} \quad$ força axial critica de instabilidade 
$\mathrm{F}_{\mathrm{u}} \quad$ força última que pode suportar o pilar

$\mathrm{F}_{\text {ult,exp }}$ força última experimental (força pico) obtida dos ensaios à compressão simples ou flexo-compressão força última teórica resistente considerando a área do núcleo da seção

$\mathrm{F}_{\text {ult,tot }}$ força última teórica resistente considerando a área total da seção transversal

$\mathrm{F}_{\sigma}$ função que depende dos valores do tensor de tensões principais de um ponto do corpo

$\mathrm{G}_{\mathrm{A}}, \mathrm{G}_{\mathrm{B}} \quad$ fatores de restrição dos nós A e B das extremidades do pilar

$\mathrm{I}_{\mathrm{c}}$ parâmetro para medir a ductilidade

$\mathrm{ID}_{\mathrm{pos}} \quad$ índice de ductilidade pós-pico

$\mathrm{I}_{\mathrm{e}}$ índice de confinamento efetivo

$\mathrm{I}_{\mathrm{e} \_50}$ índice de confinamento efetivo calculado na curva pós-pico para a deformação específica correspondente ao $50 \%$ da resistência do concreto confinado

$\mathrm{I}_{\mathrm{x}}$ momento de inércia em relação ao eixo $\mathrm{x}$

$\mathrm{I}_{5}, \mathrm{I}_{10}$ parâmetros para medir a tenacidade matriz de rigidez da estrutura

$\mathrm{K}$ constante

$\mathrm{K}_{\mathrm{e}}$ coeficiente de confinamento efetivo e representa a taxa de concreto menos confinada do modelo de Légeron e Paultre (2003)

$\mathrm{K}_{\mathrm{h}} \quad$ coeficiente de confinamento efetivo correspondente ao arco horizontal

$\mathrm{K}_{\mathrm{v}}$ coeficiente de confinamento efetivo correspondente ao arco vertical

$\mathrm{L}$ comprimento de uma tira do cobrimento como se for uma chapa, comprimento do pilar

$\mathrm{L}_{\mathrm{e}} \quad$ comprimento efetivo do pilar

$\mathrm{M}_{\mathrm{A}} \quad$ momento maior aplicado na extremidade do pilar

$\mathrm{M}_{\mathrm{B}} \quad$ momento menor aplicado na extremidade do pilar

$\mathrm{M}_{\mathrm{ext}}, \mathrm{M}_{\mathrm{int}}$ momento externo solicitante que provem da força aplicada, momento interno resistente

$\mathrm{M}_{\max } \quad$ momento máximo do diagrama momento-curvatura quando do destacamento do cobrimento

$\mathrm{M}_{\mathrm{Rcc}} \quad$ momento produzido pela resultante do concreto comprimido em relação à fibra comprimida mais externa

$\mathrm{M}_{\text {tot }} \quad$ momento total no pilar que inclui os efeitos de $2^{\mathrm{a}}$ ordem

$\mathrm{M}_{\mathrm{u}}$ momento de ultimo de um pilar sujeito à flexo-compresão 


$\begin{array}{ll}M_{\mathrm{yc}} & \text { momento correspondente à ruptura do concreto simples } \\ \mathrm{M}_{\mathrm{yc}} & \text { momento correspondente ao escoamento da armadura longitudinal } \\ \mathrm{M}_{0} & \text { momento de } 1^{\mathrm{a}} \text { ordem de um pilar, momentos iguais aplicados nas } \\ & \text { extremidades do pilar provocando curvatura simples } \\ \mathrm{M}_{0, \mathrm{cr}} & \text { momento crítico de } 1^{\mathrm{a}} \text { ordem correspondente força axial critica de instabilidade } \\ & \text { considerando a excentricidade de } 1^{\mathrm{a}} \text { ordem } \\ \mathrm{M}_{2, \mathrm{cr}} & \text { momento crítico de } 2^{\mathrm{a}} \text { ordem correspondente força axial critica de instabilidade } \\ & \text { considerando a excentricidade de } 2^{\mathrm{a}} \text { ordem } \\ \mathrm{R}_{\mathrm{cc}} & \text { resultante do concreto comprimido do diagrama de tensões } \\ \mathrm{R}_{\mathrm{s} 1} & \text { resultante na armadura longitudinal tracionada pelo momento fletor } \\ \mathrm{R}_{\mathrm{s} 2} & \text { resultante na armadura longitudinal comprimida pelo momento fletor } \\ \mathrm{S} & \text { superfície de ruptura } \\ \mathrm{SA} & \text { proporção de sílica ativa em relação à massa de cimento } \\ \mathrm{V} & \text { volume de uma amostra de grava } \\ \mathrm{V}_{\mathrm{sw}} & \text { volume de armadura transversal em cada nível de separação de estribos } \\ \mathrm{V}_{\mathrm{nc}} & \text { volume do núcleo da seção do concreto (centro a centro dos estribos) }\end{array}$

\section{Letras gregas minúsculas}

$\alpha$

$\alpha_{\mathrm{a}}$

$\alpha_{\mathrm{v}}$

$\alpha_{1}$

$\alpha_{2}$

$\beta_{\mathrm{cc}}(\mathrm{t})$

$\beta_{\mathrm{x}}$

$\beta_{1}$ e $\beta_{2}$ teor de argamassa (relação entre massa de finos e massa total de partículas) parâmetro que considera o tipo de agregado parâmetro que considera o tipo de ductilidade no coeficiente de confinamento efetivo no arco vertical tensão atuante reduzida na armadura longitudinal tracionada pelo momento fletor tensão atuante reduzida na armadura longitudinal comprimida pelo momento fletor

coeficiente que depende da idade do concreto

posição da linha neutra reduzida em relação à borda mais comprimida parâmetros que consideram a ductilidade na definição da tensão atuante da armadura transversal

deslocamento lateral do pilar, cobrimento mecânico da armadura longitudinal 
$\delta_{v c} \quad$ distancia reduzida da fibra extrema comprimida à posição da resultante do concreto comprimido

$\varepsilon \quad$ deformação especifica

$\varepsilon_{\mathrm{c}} \quad$ deformação especifica do concreto não confinado, deformação específica do concreto não confinado correspondente ao pico da curva

$\varepsilon_{\text {climD5 }}$ deformação específica última quando $\beta_{\mathrm{x}}>1$

$\varepsilon_{\mathrm{cmax}}$ deformação específica máxima do concreto comprimido correspondente à fibra extrema da seção transversal

$\varepsilon_{\mathrm{c} 1}, \varepsilon^{\prime}{ }_{\mathrm{c}}$ deformação específica correspondente à tensão pico do concreto não confinado (valor de norma)

$\varepsilon_{\mathrm{cul}}, \varepsilon_{\mathrm{cu}} \quad$ deformação específica última do concreto não confinado (valor de norma)

$\varepsilon_{\mathrm{c} \_50}$ deformação especifica do concreto não confinado no ramo descendente da curva correspondente ao $50 \%$ do valor da resistência pico da curva tensãodeformação específica

$\varepsilon_{c_{\_} 85}$ deformação especifica do concreto não confinado no ramo descendente da curva correspondente ao $85 \%$ do valor da resistência pico da curva tensãodeformação específica

$\varepsilon_{c_{\_} U} \quad$ deformação especifica última indicativa do concreto não confinado

$\varepsilon_{\mathrm{cc}}$

$\varepsilon_{\mathrm{cc} 1}$

$\varepsilon_{\mathrm{ccu} 1}$ deformação especifica do concreto confinado, deformação específica do concreto confinado correspondente ao pico da curva deformação específica correspondente à tensão pico do concreto confinado (valor de norma) deformação específica última do concreto confinado (valor de norma) deformação especifica do concreto confinado no ramo descendente da curva correspondente ao 50\% do valor da resistência pico da curva tensãodeformação específica deformação especifica do concreto confinado no ramo descendente da curva correspondente ao $85 \%$ do valor da resistência pico da curva tensãodeformação específica

$\varepsilon_{\mathrm{cc}_{-} \mathrm{U}}$ deformação especifica última indicativa do concreto confinado deformação específica última do concreto confinado quando o estribo rompe deformação específica no centróide da seção transversal 
deformação especifica da armadura longitudinal tracionada

deformação especifica da armadura longitudinal tracionada correspondente à ruptura do estribo deformação específica da armadura transversal de confinamento deformação especifica correspondente ao escoamento da armadura longitudinal tracionada deformação especifica da armadura transversal correspondente ao escoamento deformação específica da armadura longitudinal tracionada pelo momento fletor deformação específica da armadura longitudinal comprimida pelo momento fletor

deformação específica correspondente à fibra extrema oposta da fibra mais comprimida da seção ângulo de atrito interno das partículas do material que pode ser o concreto diâmetro da armadura transversal parâmetro para definir a deformação específica correspondente ao $50 \%$ da tensão pico no ramo descendente da curva tensão-deformação específica do concreto não confinado parâmetro do EUROCODE 2 parâmetro que considera a ração entre deformações pico da norma CEB-B228 parâmetro empregado para definir a tensão atuante na armadura transversal esbeltez do pilar parâmetro que define ductilidade momento fletor reduzido ductilidade última momento reduzido produzido pela resultante do concreto comprimido em relação à fibra comprimida mais externa coeficiente de Poisson, força axial reduzida resultante reduzido do concreto comprimido do diagrama de tensões resultante reduzida na armadura tracionada pelo momento fletor resultante reduzida na armadura comprimida pelo momento fletor curvatura adimensional, ângulo de Lode 
$\theta_{\mathrm{u}} \quad$ curvatura correspondente ao $80 \%$ do momento máximo no ramo pós-critico ou quando a armadura longitudinal rompe ou quando o concreto confinado esmaga do diagrama momento-curvatura

$\theta_{\text {ult }} \quad$ curvatura correspondente á ruína simultânea dos materiais (armadura longitudinal ou concreto)

$\theta_{\mathrm{y}} \quad$ curvatura correspondente á ruptura do concreto não confinado ou escoamento da armadura longitudinal

$\theta_{\mathrm{yc}} \quad$ curvatura quando o concreto não confinado rompe

$\theta_{\mathrm{ys}} \quad$ curvatura quando a armadura longitudinal escoa

$\rho \quad$ reta inserida num plano desviatório no espaço das tensões principais

$\rho_{\text {cim }} \quad$ massa específica do cimento

$\rho_{\mathrm{SA}} \quad$ massa específica da sílica ativa

$\rho_{\mathrm{s}} \quad$ taxa geométrica de armadura longitudinal em relação à seção transversal total do pilar

$\rho_{\mathrm{snc}} \quad$ taxa de armadura longitudinal, em relação ao núcleo do pilar

$\rho_{\mathrm{sw}} \quad$ taxa volumétrica da armadura transversal em relação ao volume núcleo do concreto

$\rho_{\text {swx }}$ e $\rho_{\text {swy }}$ taxas da área da armadura transversal em relação à seção longitudinal do núcleo do pilar entre estribos nas direções x e y

$\rho_{\mathrm{sw \_}} \quad$ taxa volumétrica efetiva da armadura transversal em relação ao núcleo da seção transversal

$\rho_{1} \quad$ quantia geométrica da armadura longitudinal tracionada pelo momento fletor

$\rho_{2} \quad$ quantia geométrica da armadura longitudinal comprimida pelo momento fletor

$\sigma \quad$ tensão normal

$\sigma_{\mathrm{asc}}\left(\varepsilon_{\mathrm{cc}}\right)$ forma da curva tensão-deformação específica do concreto confinado do ramo ascendente

$\sigma_{\text {desc }}\left(\varepsilon_{\mathrm{cc}}\right)$ forma da curva tensão-deformação específica do concreto confinado do ramo descendente

$\sigma_{\mathrm{c}} \quad$ tensão de compressão do concreto

$\sigma_{\mathrm{cd}} \quad$ tensão de compressão de cálculo que considera a resistência do elemento estrutural

$\sigma_{\mathrm{cr}} \quad$ tensão crítica de flambagem de uma chapa 


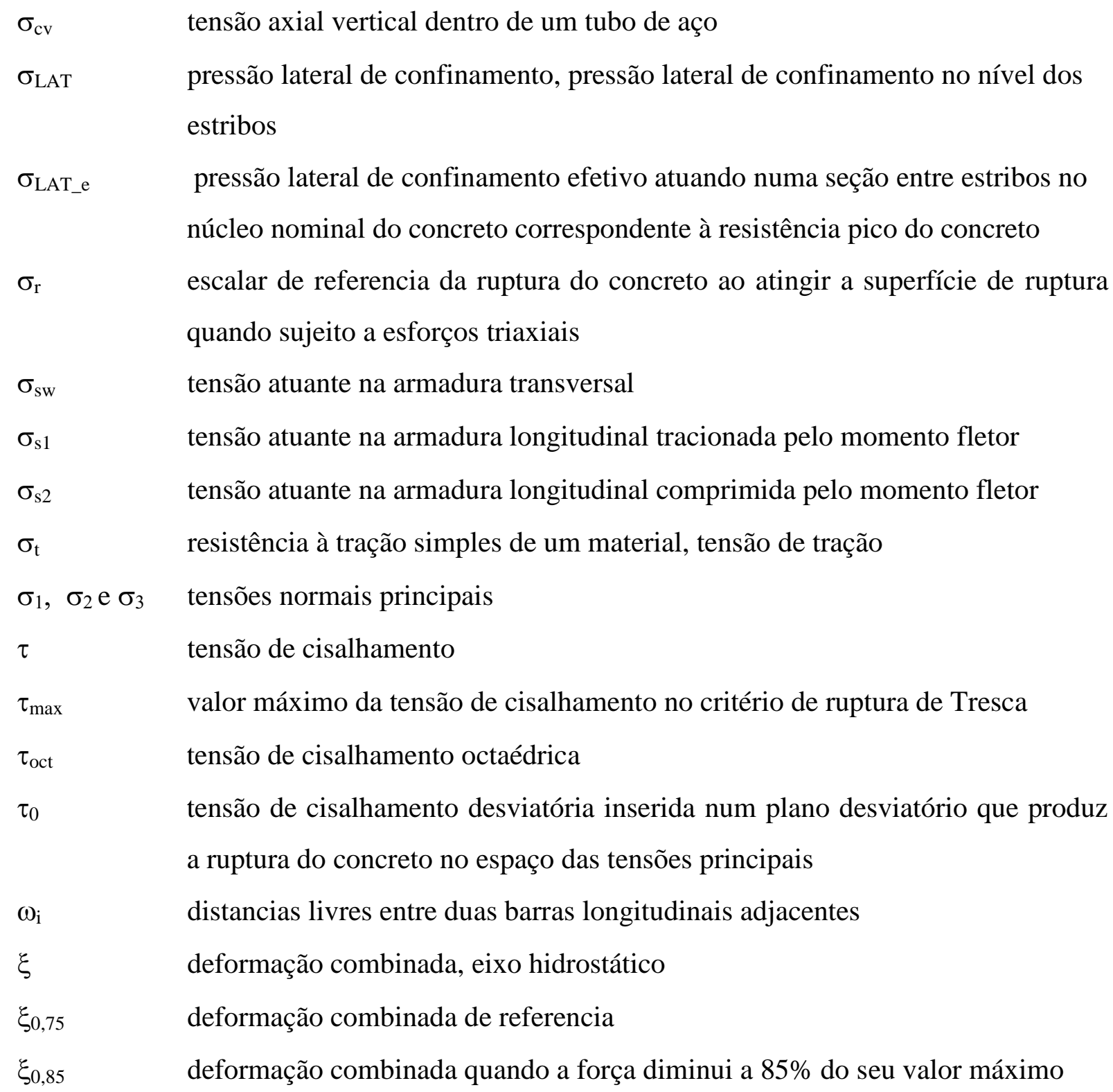

\section{Abreviaturas e siglas}

ABCP Associação Brasileira de Cimento Portland

ABNT Associação Brasileira de Normas Técnicas

ACI American Concrete Institute

ASCE American Society of Civil Engineering

CAR Concreto de Alta Resistência

CAD Concreto de Alto Desempenho

CEB-FIP Comité Euro-Internationale du Béton-Féderation Internationale de la

Précontrainte 
EESC Escola de Engenharia de São Carlos

EL Estados limites

EF Elementos finitos

FIB Fédération Internationale du Béton

GD Graus de liberdade

$\mathrm{H} \quad$ Concreto de alta resistência

L Concreto de baixa resistência (concreto convencional)

LVDT Leitores automáticos de deformação linear

M Concreto de moderada resistência

MG Método Geral

NBR Norma Brasileira Registrada

NLG Não linearidade geométrica

NLF Não linearidade física

SA Sílica Ativa

SG Extensômetros de resistência

SP Superplastificante

USP Universidade de São Paulo

AFt estringita ou sal de Candlot ou sulfoaluminato de cálcio

AFm monosulfoaluminato de cálcio hidratado

$\mathrm{Al}_{2} \mathrm{O}_{3} \quad$ alumina

$\mathrm{Fe}_{2} \mathrm{O}_{3} \quad$ óxido de ferro

$\mathrm{SiO}_{2} \quad$ sílica

$\mathrm{CaO} \quad$ cal, cal livre

$\mathrm{MgO}$ magnésia, periclásico

$\mathrm{C}_{2} \mathrm{~S} \quad$ belita

$\mathrm{C}_{3} \mathrm{~S} \quad$ alita

$\mathrm{C}_{3} \mathrm{~A} \quad$ aluminato tricálcico

$\mathrm{C}_{4} \mathrm{AF} \quad$ celita

C-S-H silicato de cálcio hidratado

$\mathrm{CH}$ portlandita ou hidróxido de cálcio 


\section{RESUMO}

Aguirre Torrico, F. (2009). Analise teórica e experimental do comportamento de pilares esbeltos de concreto de alta resistência, considerando a ductilidade. Tese (Doutorado) Escola de Engenharia de São Carlos, Universidade de São Paulo, São Carlos-SP, Brasil.

Esta tese discute as análises teórica e experimental de pilares de seção retangular, esbeltos, confinados por estribos, de concreto de alta resistência, sujeitos à flexo-compressão, considerando os estados limites últimos de ruptura do concreto ou por deformação excessiva das barras da armadura ou por instabilidade. Foram ensaiados 12 modelos de pilares com esbeltez mecânica igual a 92, compondo três séries de 4 pilares cada uma; os parâmetros estudados foram a excentricidade da força, a taxa volumétrica de armadura transversal e a resistência do concreto. Em uma segunda fase, foram analisados 9 pilares curtos de seção quadrada à compressão concêntrica com o objetivo de avaliar a ductilidade e obter as propriedades do concreto confinado. Para a realização dos ensaios foram empregadas rótulas unidirecionais, que permitiram transferir a força excêntrica ao pilar. Para a obtenção das resistências dos concretos, foram realizados ensaios para a determinação da composição dos materiais e foram traçadas curvas de dosagem. Os resultados experimentais foram comparados com os obtidos com o método exato que considera a não linearidade física e geométrica por meio de programas computacionais elaborados pelo autor. Observou-se que os resultados experimentais se aproximaram dos resultados teóricos. As ruínas dos pilares esbeltos foram por instabilidade, sendo que todos eles atingiram o ponto limite. Foi verificado que a capacidade resistente dos pilares é muito sensível para pequenas variações da excentricidade da força. Nos modelos analíticos foram incorporadas formulações de várias normas que contemplam concretos de alta resistência e o critério de confinamento indicadas pela literatura técnica com algumas modificações. Foi verificada uma pequena melhora na 
ductilidade ao incrementar a taxa de armadura transversal dos modelos ensaiados. Com os resultados obtidos e com as formulações analisadas, sugere-se uma forma alternativa de projeto de pilares esbeltos.

Palavras-chave: pilar, concreto de alta resistência, esbeltez, análise não linear, ductilidade, confinamento. 
Aguirre Torrico, F. (2009). Theoretical and experimental analysis of slender high-strength concrete columns, considering the ductility. Ph.D. Thesis - São Carlos Engineering School, São Paulo University, São Carlos, Brazil.

This thesis discusses the theoretical and experimental analyses of slender high-strength concrete rectangular columns confinement by lateral reinforcement, subjected to combined axial load and bending, considering the ultimate limit states of concrete crushing at the compressive face or the longitudinal bars excessive deformation or the column instability. Twelve column models were tested with 92 mechanical slenderness. These models included three series of four columns each; the parameters studied were axial load eccentricity, volumetric lateral reinforcement ratio and concrete strength. In a second step, nine square cross section short columns under concentric compression were tested to evaluate ductility and to obtain the confined concrete properties. A pair of unidirectional hinges was used to transfer the eccentric load to the columns. Tests were carried out for material's composition determination and dosage curves were drawn to obtain concrete strengths. The experimental results were compared with those obtained using the exact method that considers physical and geometrical nonlinearities through computational programs prepared by the author. There is not a significant difference between experimental and theoretical results. The instability failure was reach in all columns because of high slenderness, all of they reached the limit point. It was observed that the column ultimate strength is very sensitive for small axial load eccentricity variations. The formulations of several standards codes that consider the highstrength concrete and technical literature confinement criterion with some modifications have been incorporated in the analytical models. A small ductility improvement was observed 
considering the tests volumetric lateral reinforcement ratio increase. There is an alternative method suggested for slender columns design, based on the obtained results.

keywords: column, high-strength concrete, slenderness, nonlinear analysis, ductility, confinement. 


\section{Capítulo 1}

\section{INTRODUÇÃO}

\subsection{CONSIDERAÇÕES INICIAIS}

O concreto é um material muito empregado na construção civil por apresentar vantagens tais como: a facilidade na moldagem, a resistência ao fogo, a resistência à água, a resistência às influências atmosféricas, aos desgastes mecânicos, pequeno investimento em manutenção adequado à utilização da obra, entre outras. O estudo desse material é permanente e tem como objetivo aprimorar os procedimentos de projeto e os sistemas construtivos.

O comportamento do material concreto é muito complexo, pois é composto por vários outros, e, pode ser analisado como um material composto de uma fase estável (os agregados) e uma fase evolutiva (a pasta) passível de retração ou expansão na etapa de cura, isto conduz à formação de uma zona de transição. As variações volumétricas criam no material degradações iniciais de natureza irreversível, são as fissuras na zona de interface e formação de poros na argamassa. No concreto de alta resistência, a redução de água/aglomerante e o uso de aditivos minerais como a sílica ativa melhoram a resistência da zona de transição.

Entre alguns outros fatores que dificultam a compreensão do comportamento do concreto têm-se a diferença das resistências à compressão e à tração, a não linearidade física (considerada pelo seu diagrama tensão-deformação), a presença de fissuras, os fenômenos reológicos como a fluência e a retração etc.

No concreto armado têm-se as barras das armaduras formando um material composto. A correlação entre as forças e os deslocamentos nos elementos estruturais é de análise mais difícil, pois depende, entre outros fatores, da porcentagem de armadura presente na seção transversal, ainda mais, se não for considerada a perfeita aderência entre as barras de aço e o concreto que as circundam. 
Considerando que os concretos têm as suas propriedades melhoradas ao longo do tempo, para a compreensão dos fenômenos físicos e químicos e a correta utilização nas estruturas é necessário acompanhá-los por meio de modelos numéricos e, principalmente por meio de ensaios experimentais, pois o concreto é um material heterogêneo de comportamento frágil.

Durante quase um século, o concreto estrutural foi rotineiramente produzido com resistências aos 28 dias entre $15 \mathrm{MPa}$ e $30 \mathrm{MPa}$. Aproximadamente há 20 anos, começaram a ser utilizados concretos entre $40 \mathrm{MPa}$ e $60 \mathrm{MPa}$ e mais recentemente, concretos de até 150 MPa.

Ao empregar concretos de resistências convencionais (e, muito anteriormente, barras de aço da categoria CA-25), o problema de instabilidade em pilares usuais era pouco freqüente, em virtude das medidas das seções transversais adotadas nos projetos.

É inegável a evolução das resistências dos concretos nas últimas décadas, diversas técnicas vêm sendo implementadas com o intuito de produzir concretos de alta resistência associados, também, à durabilidade. Os grandes avanços provêm de estudos dos materiais constitutivos do concreto, especialmente do cimento e dos aditivos para o concreto.

O incremento no uso de concretos de altas resistências e com os modelos matemáticos cada vez mais refletindo o modelo real é possível projetar pilares com dimensões das seções transversais menores que em outras épocas obtendo-se, assim, elementos esbeltos. Com o maior desenvolvimento e inovações da engenharia e arquitetura são criadas edificações e obras de arte mais ousadas, cujos dimensionamentos com materiais convencionais resultam anti-econômicos e muitas vezes inviáveis. Assim, surgiu a necessidade de pesquisar novas tecnologias, novos materiais, e modelos matemáticos mais realistas.

Considerando essas premissas, o emprego do Concreto de Alta Resistência (CAR) é uma necessidade, permitindo elementos estruturais mais esbeltos e, portanto, projetos arquitetônicos mais arrojados.

A história da teoria de pilares começa no ano 1744, nos trabalhos do matemático Leonard Euler, que, naquela data, publicou sua famosa expressão para a análise da flambagem de elementos comprimidos de material elástico linear.

No caso de pilares construídos em concreto armado, a resistência dos pilares curtos e medianamente esbeltos é controlada pela ação da resistência dos materiais e os conceitos de segurança das seções transversais se resumem a um problema de tensões. No caso de pilares esbeltos a análise da resistência geralmente é feita considerando modelos de instabilidade. 
É conhecido que os concretos de alta resistência têm pouca porosidade e uma quantidade menor de fissuras internas iniciais, conseguida principalmente pela diminuição de água na mistura e com a escolha adequada dos agregados, isto geralmente provoca um incremento na resistência do concreto. Considerando essa diminuição quando o concreto está sujeito à compressão acumula energia antes da ruptura o que a torna repentina e frágil. Geralmente os pilares são elementos sujeitos a intensas tensões de compressão, uma das técnicas para evitar a fragilidade e obter ductilidade é aumentar a área das barras da armadura transversal, fornecendo ao concreto um confinamento lateral passivo.

\subsection{APLICAÇÕES DO CONCRETO DE ALTA RESISTÊNCIA}

No Brasil, o uso do CAR está bastante difundido, sendo que uma referencia é o edifício E-Tower em São Paulo, com mais de $160 \mathrm{~m}$ de altura, projetado pelo Engenheiro e Professor Ricardo Leopoldo e Silva França, no qual foi empregado CAR, apresentando resistências maiores do que $100 \mathrm{MPa}$ (Fig. 1.1). O edifício representa uma barreira ultrapassada pelos projetistas brasileiros.

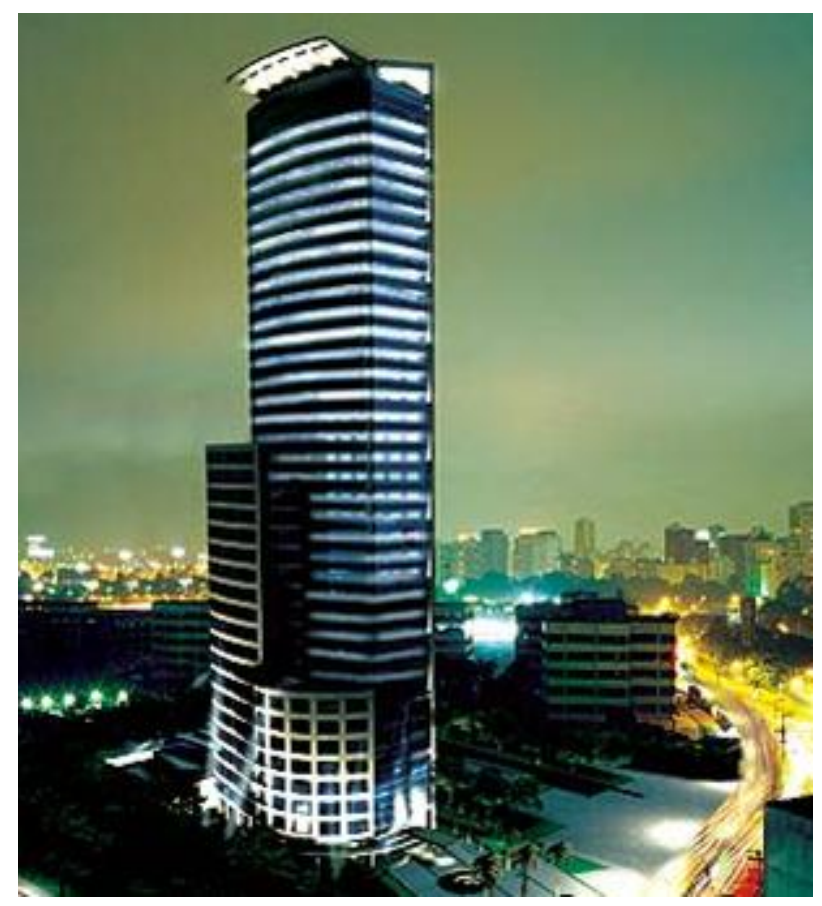

Fig. 1.1 - Edifício E-Tower em São Paulo. Disponível em:

\section{http://forum.skyscraperpage.com}

Texto da BASF (The Chemical Company) informa que os pilares, no nível das fundações, podem ser submetidos a forças de compressão de grande intensidade, que oscilam entre $13800 \mathrm{kN}$ e $18200 \mathrm{kN}$, as quais exigem seções resistentes de medidas próximas a $0,9 \mathrm{~m}$ 
x $0,9 \mathrm{~m}$, com concreto com $\mathrm{f}_{\mathrm{ck}}=40 \mathrm{MPa}$. No entanto, por especificações de projeto, considerando as vagas de estacionamento, era indispensável que as dimensões máximas dos pilares não ficassem maiores do que $0,6 \mathrm{~m} \mathrm{x} \mathrm{0,7} \mathrm{m}$. Para tal, foi estudada a viabilidade da utilização de um CAR, solução mais cara com relação aos concretos utilizados rotineiramente no Brasil. Foi considerado, no estudo de viabilidade, questões econômicas e de durabilidade, que é aumentada de modo relevante pela utilização do CAR. Consegui-se um recorde de resistência do concreto em canteiro de obras, com resistência média de $125 \mathrm{MPa}$ e máximo de $149 \mathrm{MPa}$ aos 28 dias e $155 \mathrm{MPa}$ aos 63 dias. O valor médio do módulo de elasticidade foi de 47 GPA, valor que também representa um recorde. O concreto dos pilares foi dosado com adição de corante vermelho, para valorizar o seu significado histórico e de desempenho tecnológico.

Entre outros edifícios com estrutura de CAR, ainda no Brasil, na cidade de São Paulo, têm-se o MASP que é considerado o primeiro edifício com CAR no Brasil (45 MPa) e Centro Empresarial Nações Unidas (Fig. 1.2). Em Curitiba-PA o Evolution Towers (Fig. 1.3), em Salvador-BA, o Centro Empresarial Previnor e o Suarez Trade Center (Fig. 1.4). Todos eles com parte dos seus elementos estruturais (pilares) de concreto com resistência maior do que $60 \mathrm{MPa}$.

Entre os futuros projetos com uso de CAR, na cidade de São Paulo está o Company Business Tower que terá ao redor de $200 \mathrm{~m}$ de altura.

Estas são algumas edificações com CAR das muitas existentes no Brasil, como a ponte do Rio Maranhão (80 MPa) inaugurada em 1997.
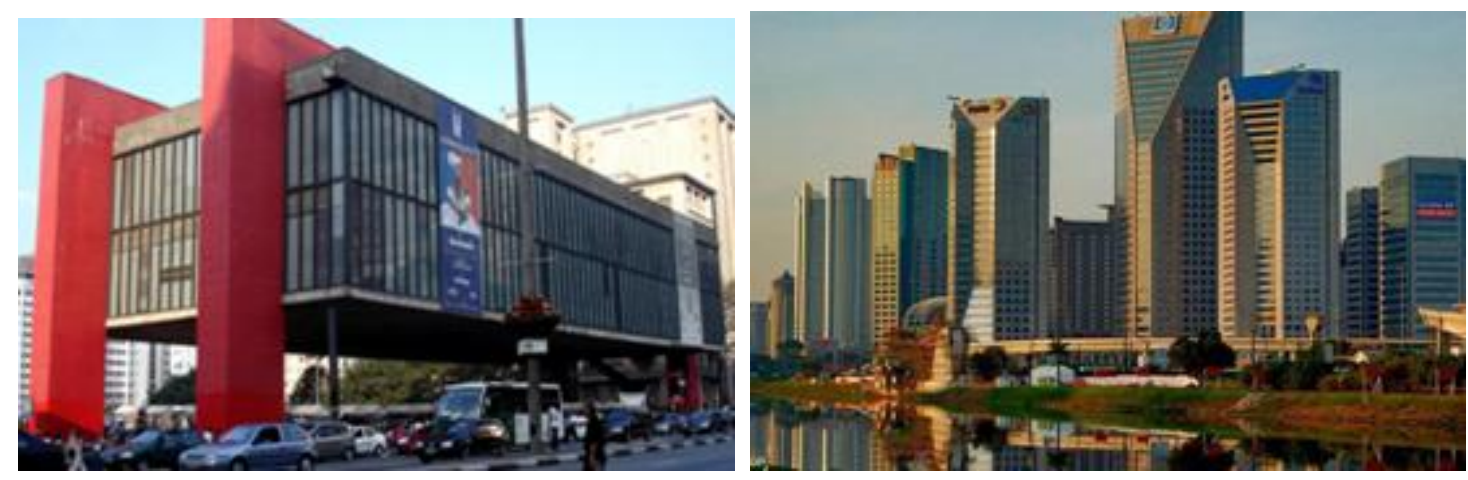

Fig. 1.2 - MASP e o Centro Empresarial Nações Unidas (São Paulo - SP). Disponível em: http://es.urbarama.com e em http://es.wikipedia.org 


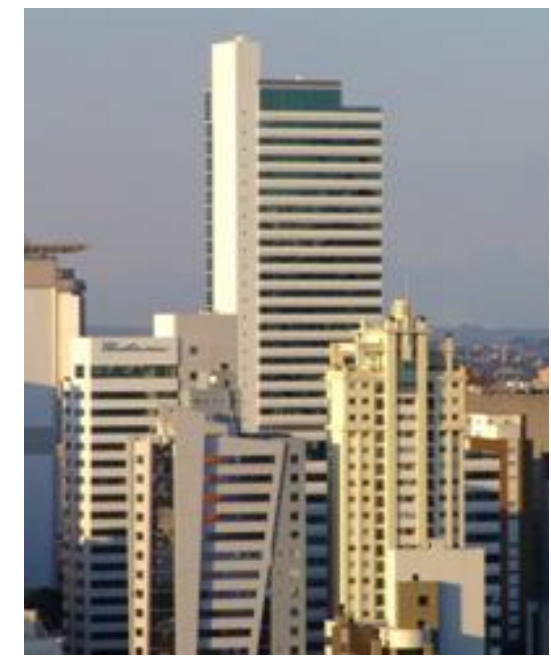

Fig. 1.3 - Evolution Towers (Curitiba - PA). Disponível em:

http://www.skyscrapercity.com
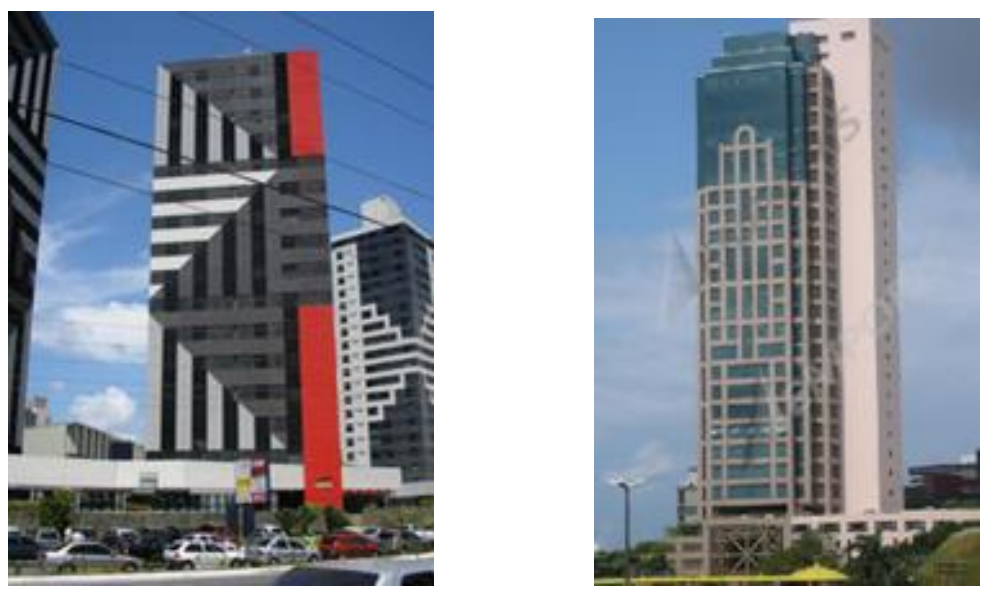

Fig. 1.4 - Centro Empresarial Previnor e Suarez Trade Center (Salvador - BA). Disponível em: http://www.skyscrapercity.com e em http://www.skyscraperlife.com

No mundo são muitas as edificações construídas com CAR que tem se tornado quase que obrigatório para obras importantes, entre os quais podem ser citados os quatro mais altos edifícios do mundo: na Fig. 1.5 a Torre de Burj Dubai (Dubai - Emirados Árabes Unidos) é o prédio mais alto, inaugurado em 5 de janeiro de 2010 com $828 \mathrm{~m}$ de altura; a Torre Taipei 101 (Taipei - Taiwan) finalizada em 2004 tem 509 m de altura; na Fig. 1.6 o Shangai Word Finance Center (Shangai - China) com 492 m, finalizada em 2008; e, as Torres Gêmeas Petronas (Kuala Lumpur - Malásia) com $452 \mathrm{~m}$ de altura, as maiores torres gêmeas do mundo na atualidade, finalizadas em 1998. Em todas elas tem-se empregado concretos com resistências à compressão maiores do que $70 \mathrm{MPa}$. 

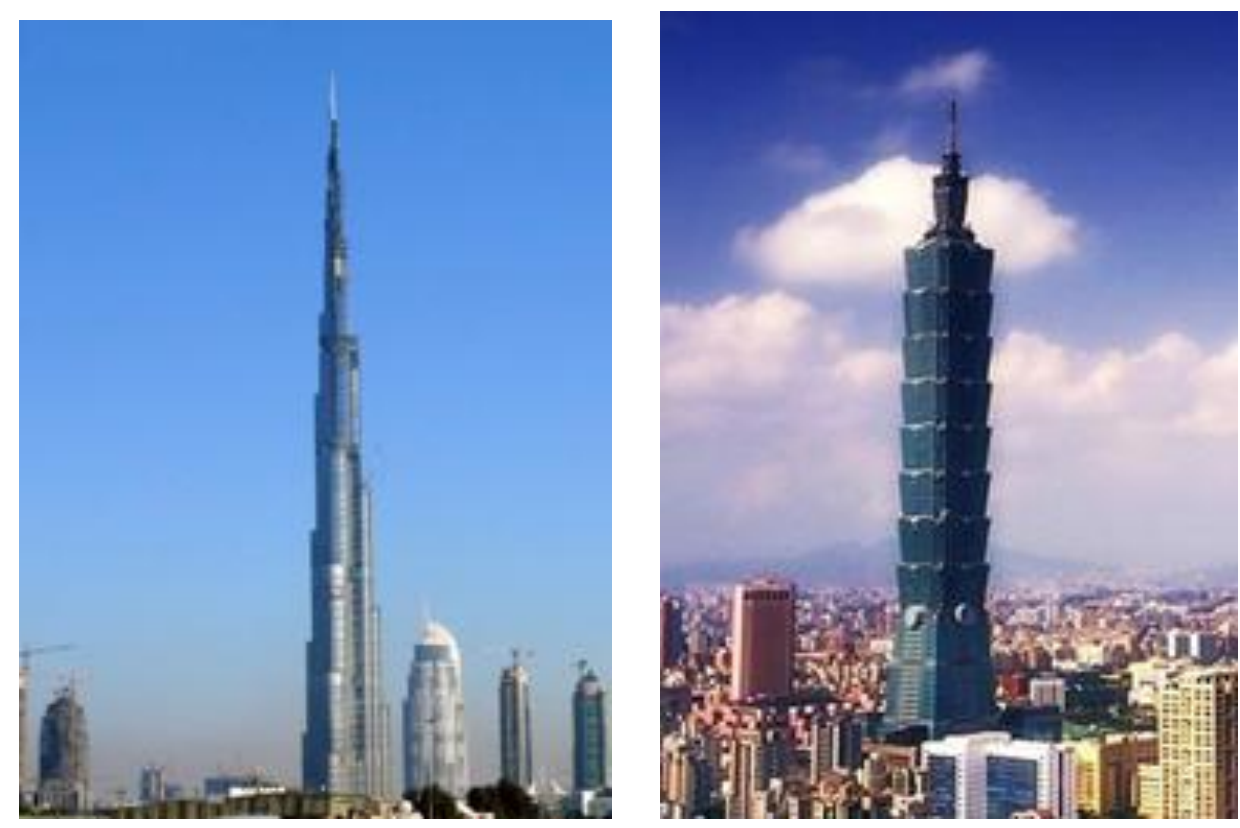

Fig. 1.5 - Torre de Burj Dubai e Torre Taipei 101. Disponível em: http://wiki.taringa.com e em http://portalplanetasedna.com.ar
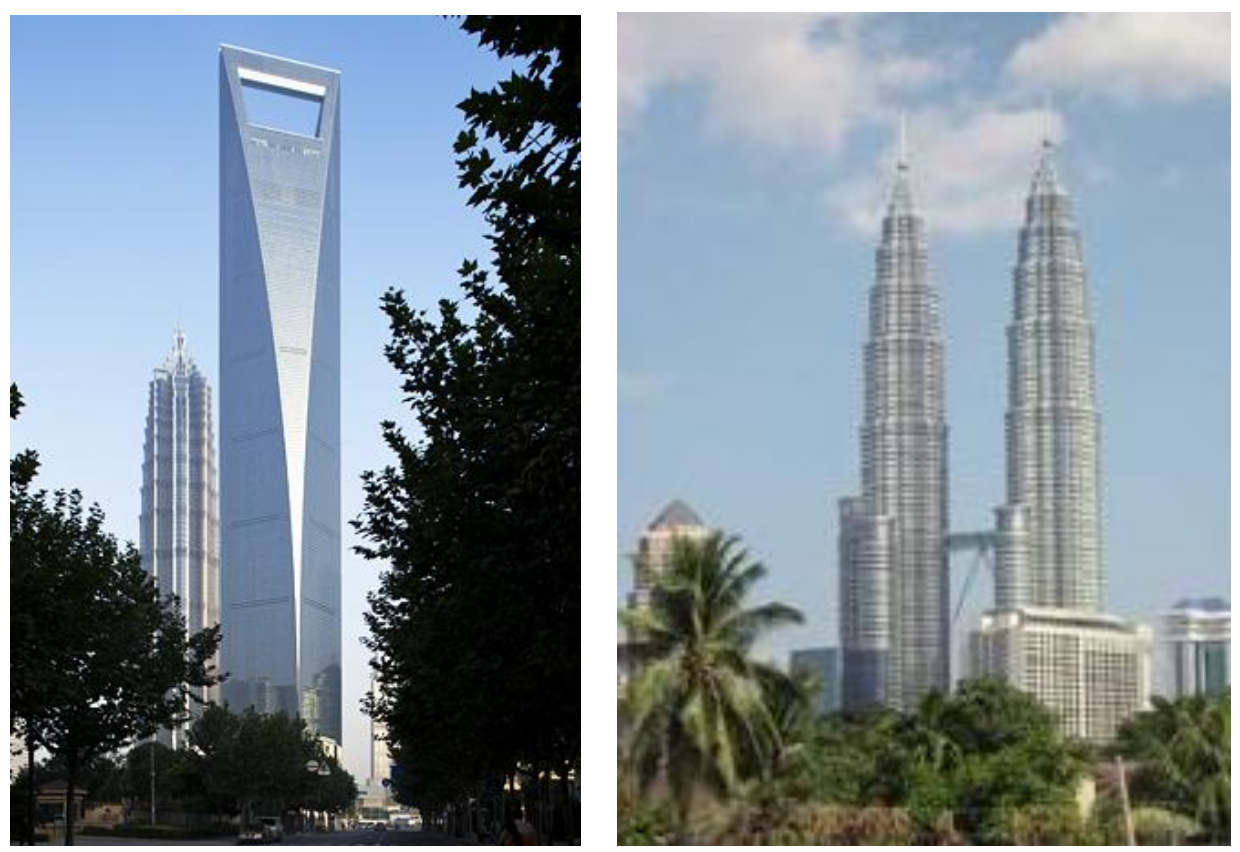

Fig. 1.6 - Shangai Word Finance Center e as Torres Gêmeas Petronas. Disponível em

\section{http://www.taringa.net}

Existem outros em construção que terão alturas maiores do que as do Taipei 101, Shangai World Center e as das Torres Gêmeas Petronas, entre eles Pentominium (Dubai Emirados Árabes Unidos, a ser finalizado em 2012, com 618 m de altura); Chicago Spire (Chicago - USA, a ser finalizado em 2010, com 610 m de altura); o Freedom Tower (Nova York - USA, a ser finalizado em 2011, que está sendo construído no espaço deixado pelas torres gêmeas do World Trade Center, esta edificação terá 541 m de altura, com um núcleo de 
CAR de $100 \mathrm{MPa}$, a maior resistência de concreto que foi empregada em prédios na cidade de Nova York até agora).

A China é o país com maior quantidade de edifícios altos em construção, entre eles o Shanghai Tower (em Shanghai, será de 632 m de altura e será finalizado em 2014), o China 117 Tower (em Tianjin TJ, será de $600 \mathrm{~m}$ de altura e será concluído em 2012) o Pingan International Finance Center (em Shenzhen GD, terá 508 m de altura e estará concluído em 2012). Alem desses, existem 7 edifícios em construção com mais de $400 \mathrm{~m}$ de altura, e muitos outros com mais de $300 \mathrm{~m}$.

Atualmente a Ásia é o continente onde mais se emprega o CAR. O Skyscraper City indica que, em todas as edificações anteriormente mencionadas que estão em construção ou que foram construídas e 5 das 7 com mais de 400 m em construção na China, foi empregado o CAR, seja no núcleo, na estruturas de barras ou como parte de uma estrutura mista.

O CAR é muito empregado em pontes e viadutos, o viaduto de Millau na França (Fig. 1.7), é uma das grandes obras deste inicio de século, têm $2460 \mathrm{~m}$ de comprimento, apoiado em 7 pilares de concreto com resistência de $60 \mathrm{MPa}$ com seção variando de um diâmetro de 24,5 $\mathrm{m}$ na base até $11 \mathrm{~m}$ no alto, foi empregada forma deslizante na execução dos pilares em tramos de $4 \mathrm{~m}$, que forma a maior pista suportada por cabos do mundo, com $343 \mathrm{~m}$ de altura sobre o rio Tarn.
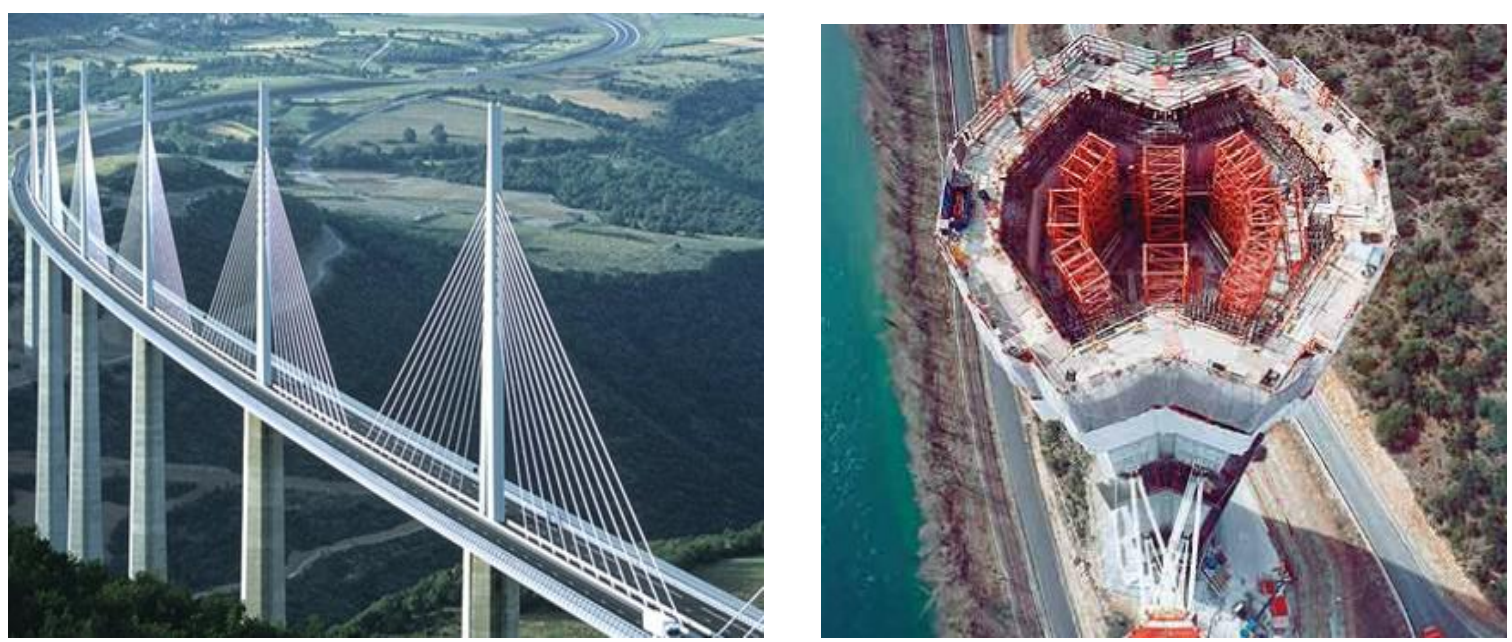

Fig. 1.7 - Viaduto Millau - França. Disponível em:

http://www.arqhys.com e em http://brifgepros.com

Em estruturas pré-moldadas, o uso do CAR é muito vantajoso, um exemplo é o da Fig. 1.8, a ponte Hangzhou Bay (Hangzhou - China), que é a ponte mais extensa que atravessa o mar com $36 \mathrm{~km}$ de comprimento, com as vigas tipo caixão perdido pré-moldadas e 
protendidas, nestas foram empregados concretos com $80 \mathrm{MPa}$, esta obra foi concluída em 2008.
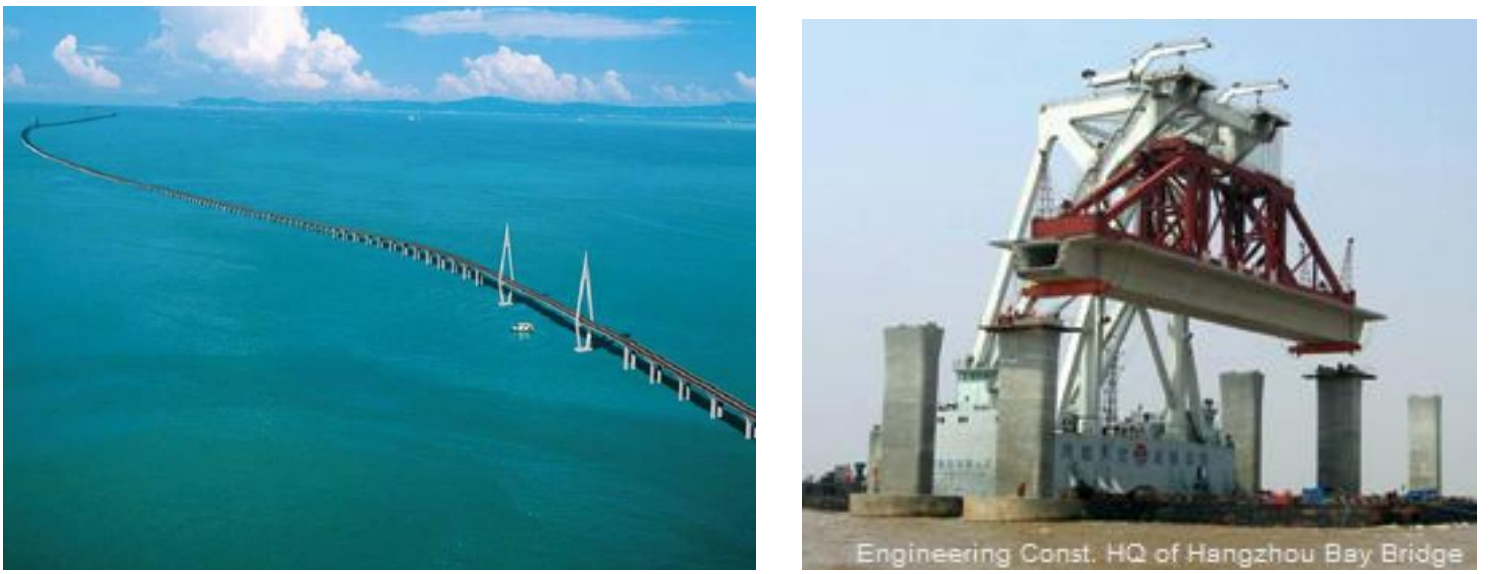

Fig. 1.8 - Ponte Hangzhou Bay. Disponível em:

http://www.arqhys.com e em http://www.bpovia.com

Pode-se pensar que o início dos trabalhos com CAR foi com as plataformas de petróleo do Mar do Norte nos anos 80 e 90 do século passado, onde as ações e ambiente muito agressivo levaram à utilização do CAR. Na Fig. 1.9 a plataforma Hibernia (Canadá) na fase construtiva, lançada ao mar em 1997, o concreto empregado na sua base foi de $80 \mathrm{MPa}$.

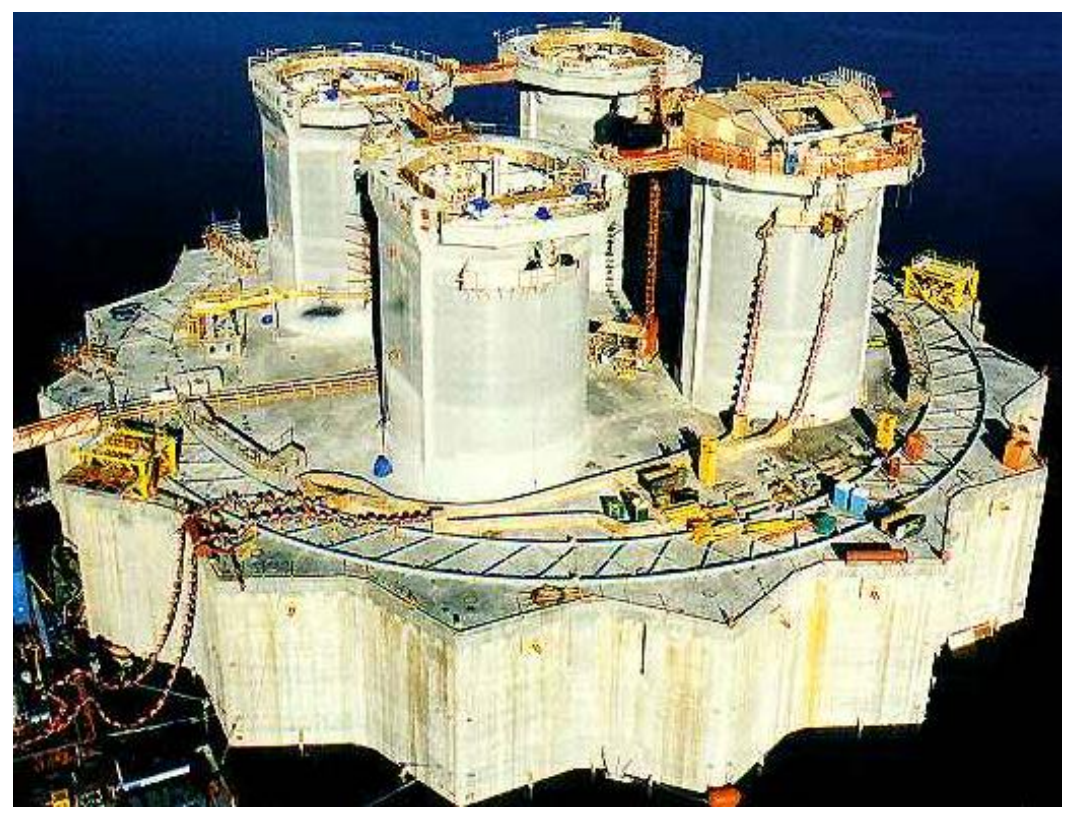

Fig. 1.9 - Base da Plataforma de Hibernia - Canadá. Disponível em: http://www.offshore-technology.com

Outra edificação de relevância é o edificio Guangzhou West Tower, o mais alto de Guanghou e o segundo mais alto da China na atualidade, com 103 andares e $440 \mathrm{~m}$ de altura (na Fig. 1.10 mostram-se as Torres Este e Oeste, sendo que a Torre Este ainda está no projeto). O recorde nesta construção, é que o concreto foi bombeado a mais de $400 \mathrm{~m}$ de 
altura, utilizando um CAR de $100 \mathrm{MPa}$, com dosagem estudada para não necessitar de compactação mecânica.

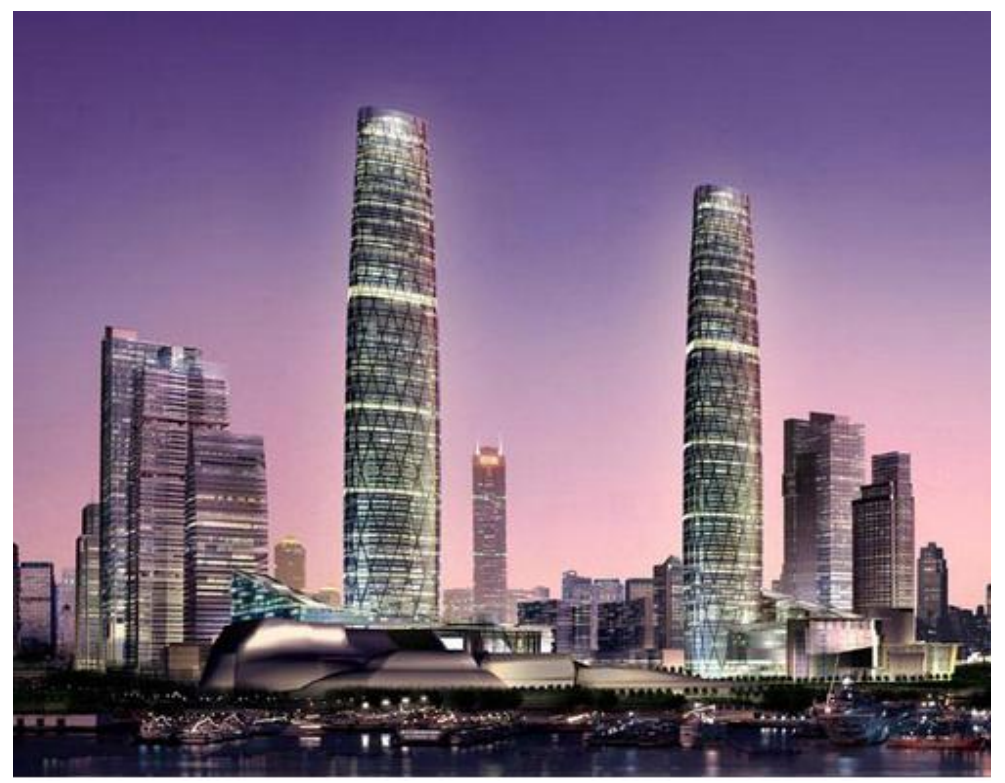

Fig. 1.10 - Guanzhou East and West twin Towers. Disponível em:

http://www.herdaily.com

\subsection{OBJETIVO}

O objetivo principal desta tese é o estudo do comportamento de pilares esbeltos de CAR sujeitos a flexo-compressão reta analisando os estados limites de ruptura do concreto ou a deformação plástica excessiva das barras das armaduras e a instabilidade do pilar, considerando a ductilidade. Entende-se que a ductilidade, que provem do confinamento por meio da armadura transversal, é a capacidade do pilar de deformar-se inelasticamente sem perder de modo brusco a capacidade resistente. O confinamento da seção transversal promove uma melhora na ductilidade da peça e incremento da resistência do núcleo da seção transversal.

Também é realizada uma análise numérica utilizando o programa comercial ANSYS (ANalyser SYStem) v. 11 que considera a não linearidade física e geométrica do pilar, incorporando no programa os elementos e critérios de ruína correspondentes aos modelos.

Com os resultados dos ensaios experimentais, das análises dos modelos numéricos, das análises dos modelos matemáticos de outros pesquisadores e de normas que consideram o CAR, foram elaborados programas computacionais empregando o software de programação algébrico e simbólico MathCad v. 14 considerando os métodos exatos de análise de pilares que incluem a não linearidade física e geométrica. 


\subsection{MÉTODO}

O método empregado nesta tese consiste na realização de ensaios, elaboração de programas e a utilização do programa ANSYS baseado no método dos Elementos Finitos.

Inicialmente, um estudo experimental foi realizado, para calibrar o efeito da ductilidade dos modelos propostos por meio de ensaios à compressão centrada de 9 pilares curtos de seção quadrada de $15 \mathrm{~cm}$ x $15 \mathrm{~cm}$, com as mesmas resistências à compressão dos modelos dos pilares esbeltos e mesmo espaçamento entre estribos. Este estudo teve como finalidade a obtenção do diagrama tensão-deformação específica do concreto confinado para sua posterior aplicação nos pilares esbeltos fletidos.

Na parte principal deste trabalho, foram realizados 12 ensaios de modelos de pilares de CAR com esbeltez mecânica igual a 92 com seção retangular de $12 \mathrm{~cm}$ x $20 \mathrm{~cm}$ e sujeitos a flexo-compressão reta, modificando a excentricidade da força, a resistência do concreto e a taxa volumétrica de armadura transversal. Considerando que a altura útil da máquina de ensaio Instron é de $350 \mathrm{~cm}$, as dimensões da seção transversal do pilar foram escolhidas para se obter uma esbeltez do pilar maior que 90 . Estes ensaios foram realizados com deformação controlada, obtendo assim comportamentos pós-críticos, que mostram o resultado da ductilidade.

Em virtude do concreto ser preparado no próprio laboratório foi necessário elaborar um procedimento de dosagem para os concretos. Para poder estudar as propriedades mecânicas do concreto endurecido foram realizados ensaios em corpos-de-prova cilíndricos de $10 \mathrm{~cm}$ x $20 \mathrm{~cm}$ para a determinação da resistência à compressão, resistência à tração e módulo de deformação longitudinal. Para o concreto fresco foi determinada a consistência.

Para a determinação das propriedades mecânicas das barras das armaduras foram realizados ensaios de tração para cada diâmetro e, em função destes resultados, obterem-se outras propriedades como os módulos de elasticidades.

\subsection{JUSTIFICATIVA}

O crescente avanço da tecnologia tem mostrado necessidades da indústria da construção civil, cujas soluções podem ser pesquisadas ou encontradas nas Universidades. Nesse contexto, insere-se a questão da análise de pilares esbeltos de concreto de alta resistência sujeitos a flexo-compressão. Uma das principais aplicações do CAR é em pilares, logo têm sido feitas diversas pesquisas que possibilitem uma utilização racional do CAR em 
pilares. No caso de elementos esbeltos confinados, não foram feitas pesquisas relevantes considerando este tipo de elemento para o concreto de alta resistência.

Os procedimentos para os projetos encontrados na norma brasileira ABNT NBR 6118:2003 entre outras, com respeito ao fenômeno restringem-se basicamente a concretos convencionais. Os métodos presentes nas normas consideram simplificações que muitas vezes estão baseados em teorias elásticas lineares e podem levar a resultados contra a segurança para o CAR. Logo se percebe a necessidade de utilização de outros métodos mais realistas e gerais. Os projetistas necessitam conhecer as propriedades mecânicas do concreto de alta resistência, e as modernas teorias de dimensionamento que se aplicam ao concreto armado.

Considerando que o CAR é um material diferente e frágil e para melhorar a ductilidade, é necessário estudar o efeito do confinamento produzido pela armadura transversal, incorporando este confinamento no dimensionamento.

Como o problema principal dos pilares de CAR é a falta de ductilidade e o estudo do confinamento requer muita atenção. Nesta pesquisa não se estudam os comportamentos dos pilares em regiões sísmicas e sob ações dinâmicas.

$\mathrm{O}$ estudo dos pilares curtos permite obter, entre outros, o modelo do diagrama $\sigma_{\mathrm{c}} \mathrm{x} \varepsilon_{\mathrm{c}}$ do concreto confinado para que este modelo seja empregado no dimensionamento dos pilares esbeltos sujeitos a flexão-composta.

O caráter inovador do assunto de pilares esbeltos de concreto de alta resistência constitui uma das principais motivações para este trabalho. Pretende-se que em futuro próximo, frente á demanda cada vez maior pelo uso de CAR em pilares, esta tese possa ser aproveitada pelo meio técnico para análise do dimensionamento de pilares esbeltos com e sem confinamento.

Com a elaboração dos programas computacionais pretende-se preparar curvas, gráficos e tabelas que podem servir, entre outras coisas, para confirmar os resultados experimentais dos pilares de CAR e concreto convencionais sujeitos a flexão composta. $\mathrm{O}$ emprego destes procedimentos, no dimensionamento, facilita em muito o cálculo de pilares esbeltos, sendo quase desnecessário utilizar métodos aproximados, obtendo assim dimensionamentos seguros e econômicos.

É necessário considerar ainda que poucos laboratórios brasileiros apresentam condições de realizar ensaios de pilares esbeltos de concreto armado sob deformação controlada, e certamente os resultados obtidos podem ajudar em futuros trabalhos com a mesma linha de ação. 
Finalmente, dentro do exposto, ressalta-se que todos os trabalhos que possam gerar subsídios para a normalização do uso do CAR adquirem importância.

\subsection{ESTRUTURAÇÃO DO TRABALHO}

O presente trabalho está dividido em 9 capítulos, a bibliografia e anexos, dos quais esta introdução é o primeiro, onde constam os comentários iniciais, o objetivo, a justificativa, o método empregado e a estruturação do trabalho.

Os capítulos 2, 3 e 4 apresentam a revisão bibliográfica, sendo que o último item de considerações finais apresenta as discussões criticas feitas pelo autor.

No capítulo 2, encontra-se uma descrição da técnica de dosagem que foi adotada para a obtenção das resistências dos concretos delineados neste trabalho e um estudo das propriedades do CAR e das propriedades físicas e mecânicas dos seus materiais componentes.

No capítulo 3, apresenta-se um breve histórico dos ensaios e dos modelos para o concreto confinado passivo submetido à compressão centrada. Apresenta-se uma discussão dos modelos matemáticos para descrever o confinamento existente na literatura, especialmente em pilares curtos de CAR confinado com armadura transversal. São estudadas as vantagens e desvantagens dos diferentes modelos e quais foram os adotados nesta pesquisa. Também será abordado um estudo do comportamento do concreto sujeito a estados múltiplos de tensão.

No capítulo 4 é apresentado um breve histórico dos ensaios e dos modelos de pilares esbeltos. É feita uma análise dos pilares baseada nos métodos exatos, um estudo da instabilidade levando em conta os efeitos de segunda ordem geométricos e físicos.

No capitulo 5 é apresentado o programa experimental, desde os materiais utilizados, a preparação dos pilares curtos (prismas) sujeitos a força de compressão centrada e pilares esbeltos sob força de compressão excêntrica até a realização dos ensaios.

No capitulo 6 mostram-se os resultados obtidos nos ensaios dos pilares curtos e pilares esbeltos e as analises desses resultados incluído análises estatísticas. São apresentados diversos gráficos, curvas e tabelas das diferentes respostas dos modelos a compressão centrada e a compressão excêntrica, como forças últimas, deformações das seções transversais, deslocamentos verticais, deslocamentos laterais, deformação das armaduras.

No capitulo 7 uma descrição dos modelos numéricos e simulação numérica dos resultados obtidos nos ensaios dos pilares curtos. 
No capítulo 8 são feitas análises, críticas e comparações entre os resultados experimentais obtidos por meio dos ensaios e os resultados obtidos pelos programas para os pilares esbeltos.

No capitulo 9 discutem-se as principais conclusões desta tese, as avaliações do estudo e sugestões de futuros trabalhos para a continuidade da pesquisa.

Finalmente, apresentam-se a bibliografia que viabilizou o aprofundamento teórico e o desenvolvido desta pesquisa e os anexos com informações importantes a respeito de assuntos abordados na tese e a impressão dos programas elaborados pelo autor. 


\section{Capítulo 2}

\section{PROPRIEDADES DO \\ CONCRETO DE ALTA RESISTÊNCIA}

\subsection{HISTÓRICO E DEFINIÇÕES}

Com o avanço da tecnologia o conceito de CAR foi se alterando. Segundo Aïtcin (2000), na década de 50, os concretos com 35 MPa eram considerados de alta resistência. Na década dos 70 os concretos atingiam os $60 \mathrm{MPa}$. Nos anos 80 e 90, com o advento dos superplastificantes e com a utilização regular da sílica ativa, os concretos chegaram a resistências de $100 \mathrm{MPa}$ e, atualmente, os concretos podem ser empregados com resistências de até $150 \mathrm{MPa}$.

Nos últimos 30 anos têm sido realizados estudos intensivos a respeito do concreto de alta resistência com o objetivo de fornecer aos empreiteiros, engenheiros e construtores informações necessárias em relação as suas propriedades, bem como para aprimorar os processos de dimensionamento das normas considerando as propriedades do material.

O CAR tornou-se uma linha prioritária de pesquisa na área de materiais e a bibliografia sobre o tema é bastante ampla. Vários congressos, simpósios, seminários têm sido promovidos em vários países para a divulgação de trabalhos sobre os diferentes procedimentos de fabricação do CAR.

A EESC - USP tem investido na pesquisa desse material, entre os últimos trabalhos podem ser citados os de Castro (2007), Silva (2007), Tiboni (2007), Lima (2008).

Atualmente tanto a resistência mecânica quanto a durabilidade vem influenciando na seleção dos materiais utilizados na construção civil. Os concretos de alto desempenho (CAD) que incorporam os CAR, foram viabilizados quando foram usados aditivos superplastificantes que diminuem a relação a/c e atuam como lubrificantes, com isto têm-se concretos mais 
fluidos, modulo de deformação maior e é mais durável entre outras vantagens. Ultimamente os concretos de alta resistência e os concretos de alto desempenho têm merecido destaque no meio técnico, estando em crescente utilização, empregados em edifícios altos proporciona estruturas esbeltas, com redução significativa da seção dos pilares, diminuição do peso próprio da estrutura e aumento da velocidade de construção. Também seu emprego tem-se tornado comum em estruturas como pontes, estruturas pré-moldadas, plataformas marítimas, pisos de tráfico intenso, reparos em estruturas danificadas etc.

No Brasil, os concretos estruturais estão classificados conforme a ABNT NBR 8953:1992 em duas classes distintas. A Classe I abrange concretos com resistência característica de até $50 \mathrm{MPa}$ e a Classe II concretos com resistência característica entre 55 MPa e $80 \mathrm{MPa}$.

Muitas definições foram sugeridas para o CAD, por exemplo:

"Elaborado com materiais apropriados e selecionados de acordo a um estudo de dosagem, que sejam misturados, transportados, lançados, adensados e curados adequadamente, resultando um concreto que forneça um excelente desempenho no local da estrutura, no meio ambiente que estará exposto e considerando a ação do carregamento durante o tempo que foi projetado"(Foster, 1994).

“As proporções de seus ingredientes foram escolhidas para que tenham propriedades apropriadas para seu uso na estrutura. Estas propriedades, normalmente, são alta resistência e pouca permeabilidade" (Neville, 1997);

"Os elementos fabricados com este material terão ótimo desempenho frente às ações e meio onde vai ser exposto, consistente com seu custo, vida útil e durabilidade; não necessariamente significa emprego de materiais caros ou tecnologia de fabricação complexa" (Swamy ${ }^{1}$ apud, Russell, 1999);

Em 1998, o Subcomitê Técnico de Concreto de Alto Desempenho do ACI (TACTHPC) definiu oficialmente o CAD como:

“Concreto que reúne combinações especiais de desempenho, que nem sempre são obtidas com os componentes convencionais ou com a mistura, colocação e curas normais.

Comentário.- O CAD é um concreto no qual certas propriedades são melhoradas para alguma aplicação especial e para o meio que será exposto. Exemplos destas propriedades que numa aplicação podem ser consideradas:

\footnotetext{
${ }^{1}$ Swamy, R. N. (1996). High Performance and Durability through Design. International Workshop on High-Performance Concrete, SP-159, ACI, Farmington Hills, Mich., p. 209-230.
} 
- fácil colocação;

- compactação sem segregação;

- resistência elevada às idades precoces;

- propriedades mecânicas a longo prazo;

- permeabilidade;

- densidade;

- dureza;

- calor de hidratação;

- estabilidade de volume;

- longa duração em ambientes severos” (ACI TAC-THPC² apud, Russell, 1999)

Liborio (2005) define o CAD como “...O concreto de alto desempenho deve ser entendido como um material, cientificamente produzido, que atende as expectativas do cliente do ponto de vista estrutural, da estética, de durabilidade frente ao meio ambiente atual e futuro, para fins pré-determinados. Deve ser econômico (custo/benefício) e propiciar vantagens frente a outras alternativas tecnológicas...”.

\subsection{MATERIAIS CONSTITUINTES}

Para Aïtcin (2000), a seleção dos materiais e a otimização dos constituintes de um CAR trata-se mais de uma arte do que de uma ciência. E a melhor forma de garantir a seleção da maioria dos materiais adequados é por meio de ensaios prévios de laboratório. Os materiais e princípios utilizados para a obtenção dos concretos convencionais não são os mesmos para serem aplicados na produção de CAR.

\subsubsection{Cimento}

A norma brasileira ABNT NBR 5732:1991 define o cimento Portland comum como um aglomerante hidráulico obtido pela moagem do clinquer Portland ao qual se adiciona, durante a operação, a quantidade necessária de uma ou mais formas de sulfato de cálcio, durante a moagem é permitido adicionar a esta mistura materiais pozolânicos, escórias granuladas de alto-forno e/ou materiais carbonáticos em quantidades limitadas. A está definição pode-se complementar que o cimento é um pó muito fino (as partículas podem se hidratar totalmente quando sua dimensão é menor a $10 \mu \mathrm{m}$ ou $0,01 \mathrm{~mm}$ ) que provem da moagem do clinquer, que é uma mistura de materiais calcários (como rocha calcária e gesso),

2 American Concrete Institute. (1998) ACI TAC-THPC. Technical Activities Committee Subcommittee on high-performance concrete, 1998. 
alumina e sílica calcinada (encontrada nas argilas) a temperaturas perto de $1450^{\circ} \mathrm{C}$, aproximadamente em proporções de um $80 \%$ e $20 \%$ respectivamente, tem propriedades aglomerantes e aglutinantes que endurece com a água. $\mathrm{O}$ cimento é um dos produtos mais consumidos na Terra (Pasquel, 1996).

Segundo Pasquel (1996), quando a mistura é submetida a elevadas temperaturas há uma dissociação das matérias primas formando os óxidos componentes do cimento $(\mathrm{CaO}-$ cal $-61 \%$ a $67 \%, \mathrm{SiO}_{2}$ - sílica - 20\% a 27\%, $\mathrm{Al}_{2} \mathrm{O}_{3}$ - alumina - 4\% a $7 \%, \mathrm{Fe}_{2} \mathrm{O}_{3}-2 \%$ a $4 \%$, $\mathrm{MgO}$ - magnésia - $1 \%$ a $5 \%, \mathrm{SO}_{3}-1 \%$ a $3 \%$, Álcalis $-0,25 \%$ a $1,5 \%$, entre outros) se interagem entre si formando elementos mais complexos no clinquer como duas fases bem cristalizadas: os silicatos tricálcico ou alita $\left(3 \mathrm{CaO} . \mathrm{SiO}_{2}-\mathrm{C}_{3} \mathrm{~S}\right)$ e silicatos dicálcicos ou belita ( $2 \mathrm{CaO} . \mathrm{SiO}_{2}-\mathrm{C}_{2} \mathrm{~S}$ ), uma fase intersticial (líquida a temperatura de clinquerização) o aluminato tricálcico $\left(3 \mathrm{CaO} \cdot \mathrm{Al}_{2} \mathrm{O}_{3}-\mathrm{C}_{3} \mathrm{~A}\right)$ e uma fase mais ou menos cristalizada o ferroaluminato tetracálcico ou celita $\left(4 \mathrm{CaO} \cdot \mathrm{Al}_{2} \mathrm{O}_{3} \cdot \mathrm{Fe}_{2} \mathrm{O}_{3}-\mathrm{C}_{4} \mathrm{AF}\right)$. Areia, e mineiro de ferro são adicionados como corretivos do $\mathrm{SiO}_{2}$ e $\mathrm{Fe}_{2} \mathrm{O}_{3}$ respectivamente quando necessário.

Podem ser encontradas algumas impurezas como o oxido de magnésio ou periclásico $(\mathrm{MgO})$, o oxido de cálcio endurecido ( $\mathrm{CaO}$ - cal livre) e sulfatos alcalinos. Depois o clinquer moído sofrerá adições como gesso, pozolanas, escoria, entre outros, formando assim os diferentes cimentos. As quantidades dos principais componentes variam entre $50 \%$ a $70 \%$ para o $\mathrm{C}_{3} \mathrm{~S}, 15 \%$ a $30 \%$ de $\mathrm{C}_{2} \mathrm{~S}, 5 \%$ a $10 \%$ para o $\mathrm{C}_{3} \mathrm{~A}$ e $\mathrm{C}_{4} \mathrm{AF}$. Usualmente calcula-se o teor dos compostos do clinquer a partir dos óxidos, empregando uma série de equações originalmente desenvolvidas por Bogue (Neville,1997).

As propriedades dos quatro componentes principais podem ser resumidas na Tabela 2.1. Com relação aos componentes do concreto pode-se acrescentar que as pastas com $\mathrm{C}_{2} \mathrm{~S}$ endurecem lentamente nos primeiros 28 dias, mas em um ano alcança a resistência do $\mathrm{C}_{3} \mathrm{~S}$ (ver Fig. 2.3), isto porque a estrutura do $\mathrm{C}_{2} \mathrm{~S}$ é mais compacta que do $\mathrm{C}_{3} \mathrm{~S}$. O $\mathrm{C}_{3} \mathrm{~A}$ tem suscetibilidade ao ataque em meios sulfatados e tem uma alta retração, o $\mathrm{C}_{4} \mathrm{AF}$ proporciona resistência a os meios sulfatados, elevados teores de cal livre causam expansão e fissuração.

Tabela 2.1 - Propriedades dos quatro componentes principais do clinquer. (Liborio, 2005).

\begin{tabular}{|c|c|c|c|c|}
\hline Propriedades & $\mathrm{C}_{3} \mathrm{~S}$ & $\mathrm{C}_{2} \mathrm{~S}$ & $\mathrm{C}_{3} \mathrm{~A}$ & $\mathrm{C}_{4} \mathrm{AF}$ \\
\hline \hline Resistência em pequenas idades & boa & fraca & fraca & fraca \\
\hline Resistência em idades posteriores & boa & boa & fraca & fraca \\
\hline Velocidade de reação com a água & rápido & lenta & muito rápida & lenta \\
\hline Quantidade de calor gerado na hidratação & grande & pequena & grande & media \\
\hline Resistência a águas agressivas & media & boa & fraca & fraca \\
\hline
\end{tabular}


Com o avanço da tecnologia na melhora dos materiais, foi possível produzir novos tipos de cimento com propriedades específicas para uma determinada utilização.

Os principais tipos de cimento Portland que existem no Brasil, que diferem entre si por sua composição, podem ser resumidos na Tabela 2.2.

Tabela 2.2 - Tipos de cimento produzidos no Brasil. (ABCP BT-106, 2002).

\begin{tabular}{|c|c|c|c|c|c|c|}
\hline \multirow[b]{2}{*}{$\begin{array}{l}\text { Tipo de } \\
\text { cimento } \\
\text { portland }\end{array}$} & \multirow[b]{2}{*}{ Sigla } & \multicolumn{4}{|c|}{ composição (\% em massa) } & \multirow[b]{2}{*}{$\begin{array}{c}\text { Norma Brasileira } \\
\text { ABNT }\end{array}$} \\
\hline & & $\begin{array}{c}\text { Clinquer } \\
+ \\
\text { gesso }\end{array}$ & $\begin{array}{c}\text { Escoria } \\
\text { granulada } \\
\text { de alto- } \\
\text { forno (E) }\end{array}$ & $\begin{array}{c}\text { Material } \\
\text { pozolânico } \\
\text { (Z) }\end{array}$ & $\begin{array}{c}\text { Material } \\
\text { Carbonático } \\
\text { (F) }\end{array}$ & \\
\hline \multirow{2}{*}{ Comum } & $\mathrm{CPI}$ & 100 & - & - & - & \multirow{2}{*}{ NBR 5732:1991 } \\
\hline & CP I-S & $99-95$ & $1-5$ & - & - & \\
\hline \multirow{3}{*}{ Composto } & CP II-E & $94-56$ & $6-34$ & - & $0-10$ & \multirow{3}{*}{ NBR 11578:1991 } \\
\hline & CP II-Z & $94-76$ & - & $6-14$ & $0-10$ & \\
\hline & CP II-F & $94-90$ & - & - & $6-10$ & \\
\hline Alto Forno & CP III & $65-25$ & $35-70$ & - & $0-5$ & NBR 5735-EB 208:1991 \\
\hline Pozolânico & CP IV & $85-45$ & - & $15-50$ & $0-5$ & NBR 5736:1991 \\
\hline $\begin{array}{c}\text { Ata } \\
\text { Resistência } \\
\text { Inicial }\end{array}$ & CP V-ARI & $100-95$ & - & - & $0-5$ & NBR 5733:1991 \\
\hline
\end{tabular}

Na Fig. 2.1 a ABCP BT-106 (2002) mostra a evolução da resistência média à compressão com o tempo dos diferentes tipos de cimento classificados no Brasil.

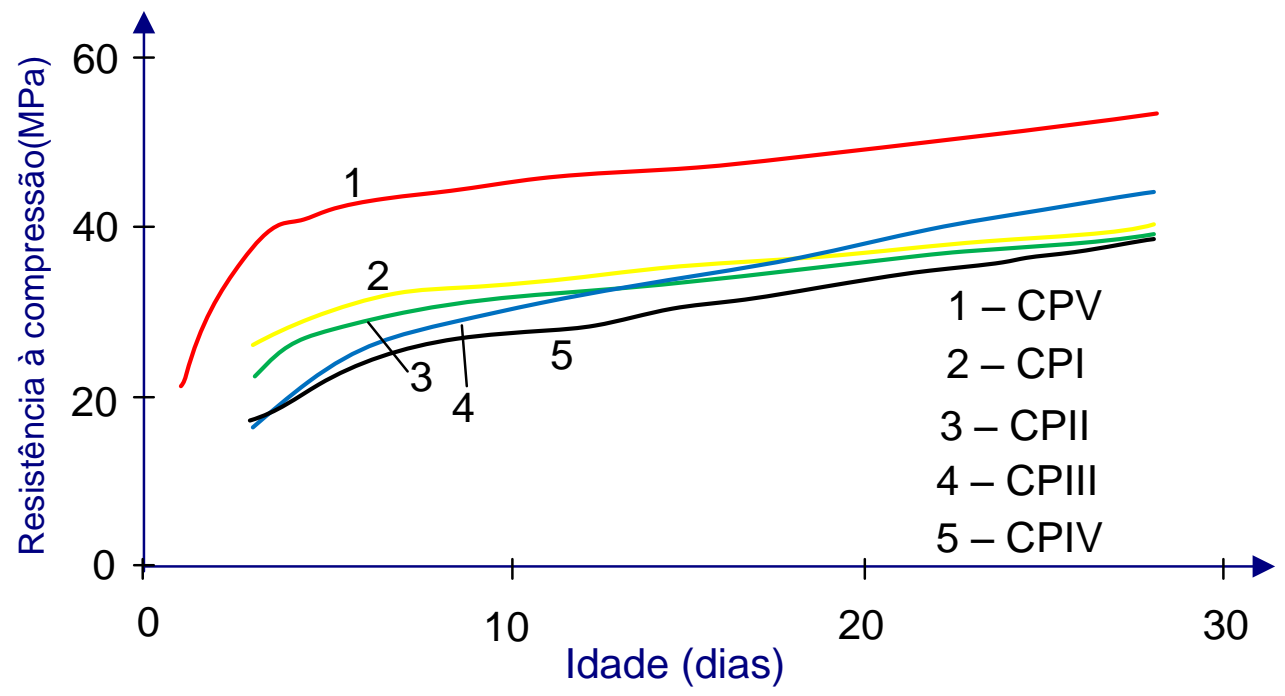

Fig. 2.1 - Evolução da resistência à compressão dos distintos tipos de cimento Portland.

(ABCP BT-106, 2002).

Na Fig. 2.1 é possível perceber que o cimento CPV é um cimento de alta resistência inicial e o que mais resistência adquire com o tempo, isto ocorre porque suas partículas são mais finamente moídas e têm maior possibilidade de hidratar-se totalmente. Em virtude dessas 
propriedades é um cimento muito empregado nos concretos de alta resistência especialmente em laboratório.

Além dos anteriores, existem os Resistentes aos Sulfatos e os de pequeno Calor de Hidratação, sendo que quaisquer dos cimentos indicados na Tabela 2.2 podem ter essas propriedades. Para o primeiro é necessário limitar o teor de $\mathrm{C}_{3} \mathrm{~A}$ a $8 \%$ no clinquer e a $5 \%$ o teor de adições carbonáticas (entre outras condições), na sua sigla deve ser incluída no final as letras RS. Para o segundo terá que ter taxas lentas de evolução de calor, são os que geram entre $280 \mathrm{~J} / \mathrm{g}$ e até $300 \mathrm{~J} / \mathrm{g}$ aos 3 dias e 7 dias de hidratação, na sua sigla devem ser incluída no final as letras BC. Nos cimentos do tipo CP I, CP II, CP III e CP IV, deve ser incluída a resistência do cimento aos 28 dias de cura obtida segundo ensaio da norma ABNT NBR 7215:1996, os valores que deverão estar indicados e ser garantidos pelo fabricante são 25 MPa, 32 MPa e 40 MPa. Um exemplo de identificação é CP II-F-32BC. O cimento CP V-ARI não tem uma resistência mínima especificada aos 28 dias, mas aos 7 dias sua resistência deve ser maior que $34 \mathrm{MPa}$, geralmente é o mais finamente moído, e tem uma dosagem diferente de calcário e argila, com teor maior de $\mathrm{C}_{3} \mathrm{~S}$ (ABCP BT-106, 2002).

Segundo Liborio et al. (2005), o novo aglomerante hidráulico pode ser constituído com partes de materiais como o clinquer, gipsita (controlador de pega), escoria de alto-forno, cinzas volantes, sílica ativa de ferro-silício ou silício metálico, cinza e sílica extraídas da casca de arroz, metacaulinitas, terra diatomáceas, argilas calcinadas, pós de concretos reciclados, cerâmica moída, vidros, microfibras, filer, calcário etc.

\section{Hidratação do cimento}

Quimicamente, a hidratação é um processo muito complexo, varias reações de hidratação ocorrem simultaneamente, quanto mais fino o cimento mais rápida a hidratação (Pasquel, 1996).

Os principais produtos da hidratação do cimento são:

- o silicato de cálcio hidratado (C-S-H), responsável pela resistência mecânica e durabilidade do concreto, constitui de $50 \%$ a $60 \%$ do volume dos sólidos da pasta, - o hidróxido de cálcio - $\mathrm{Ca}(\mathrm{OH})_{2}(\mathrm{CH}$ - portlandita) ocupa um $20 \%$ a $25 \%$ da pasta, é muito solúvel,

- o sulfoaluminato de cálcio ou etringita ou sal de Candlot (3CaO. $\left.\mathrm{Al}_{2} \mathrm{O}_{3} \cdot 3 \mathrm{CaSO}_{4} \cdot 31 \mathrm{H}_{2} \mathrm{O}-\mathrm{AF}_{\mathrm{t}}\right)$,

- o monosulfatoalumninato de cálcio hidratado $\left(\mathrm{AF}_{\mathrm{m}}\right)$, pouco estável, pode converter facilmente em outro hidrato. 
Os dois primeiros provem da hidratação do $\mathrm{C}_{2} \mathrm{~S}$ e $\mathrm{C}_{3} \mathrm{~S}$, e os últimos da reação do aluminato de cálcio hidratado (da hidratação do $\mathrm{C}_{3} \mathrm{~A}$ e $\mathrm{C}_{4} \mathrm{AF}$ ) com os sulfatos de cálcio $\left(\mathrm{CaSO}_{4}\right.$ - que pode provir das adições da gipsita), estes últimos constituem de $15 \%$ a $20 \%$ do volume da pasta. Na realidade a etringita, quando falta o gesso, reage com o $\mathrm{C}_{3} \mathrm{~A}$ formando os monosulfatos $\left(\mathrm{AF}_{\mathrm{m}}\right)$, pode ocasionar a deterioração do concreto em presença de vários tipos de sulfatos existentes no meio externo que podem reagir com o aluminato de cálcio hidratado ou com o $\mathrm{CH}$ dado lugar à etringita (formação retardada da etringita) que é expansiva, (Coutinho, 2001).

O processo de hidratação é afetado pela relação a/c e pela qualidade da cura. Se o cimento for muito fino a retração e o calor de hidratação é muito alto durante a hidratação, o que pode ser prejudicial para sua durabilidade, mas pode melhorar a resistência (novamente CAR não necessariamente é igual a CAD). A Fig. 2.2 mostra formação da microestrutura do cimento durante sua hidratação no tempo.

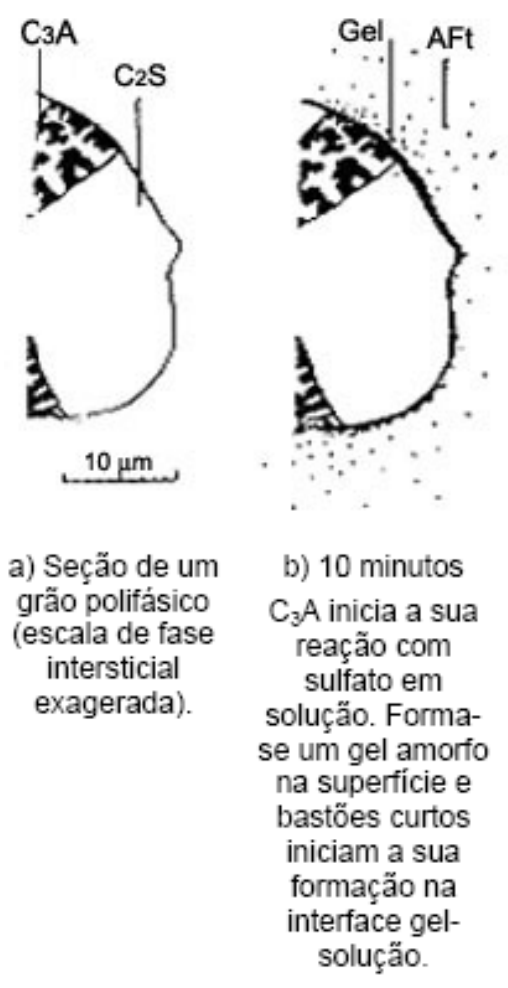

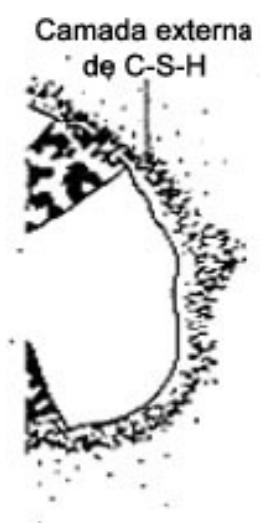

c) 10 horas

Reação do $\mathrm{C}_{3} \mathrm{~S}$ com formação da camada externa de C-S-H (outer shell) sobre os bastốes de AFt.

Forma-se um

vazio de $1,0 \mu \mathrm{m}$ entre a superficie do grão e a camada externa.
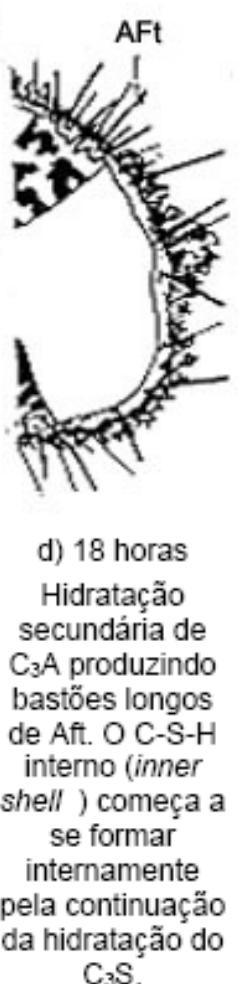

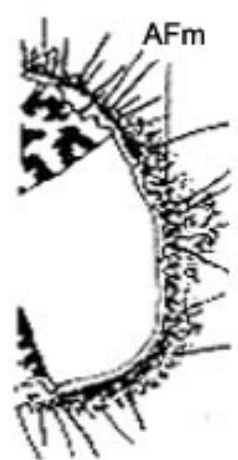

e) 1 a 3 dias $\mathrm{C}_{3} \mathrm{~A}$ reage com Aft da camada interna formando placas hexagonais de $\mathrm{AFm}$. A formação de produto interno reduz a separação entre o grão anidro e a camada externa.

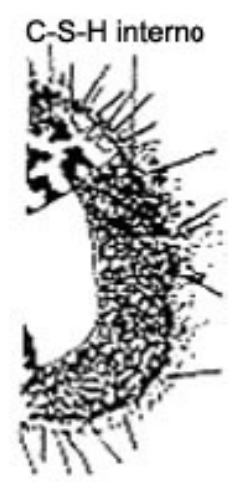

f) 14 dias

Formou-se C-S$\mathrm{H}$ suficiente para preencher 0 espaço vazio ao redor do grão. A camada externa torna-se fibrosa.

Fig. 2.2 - Desenvolvimento da microestrutura do da pasta na hidratação do cimento Portland.

(Adaptada de Castro, 2007).

A velocidade de hidratação dos elementos que compõem o cimento é diferente, seja pela velocidade que ocorrem ou pelas quantidades de compostos hidratados que delas resultam. A Fig. 2.3 mostra as velocidades dos diferentes compostos em estado puro. Até 24 horas após o início da hidratação aproximadamente o 30\% do cimento já hidratou, e todas as 
partículas menores a $5 \mu \mathrm{m}$ estarão completamente hidratadas. Neville (1997) demonstra pelas equações de hidratação do $\mathrm{C}_{3} \mathrm{~S}$ e $\mathrm{C}_{2} \mathrm{~S}$ que a quantidade de água que ambos compostos precisam é a mesma, mas o $\mathrm{C}_{3} \mathrm{~S}$ produz mais que o dobro de $\mathrm{CH}$. Existem muitos outros fatores envolvidos na hidratação, logo quantias dos produtos de hidratação serão diferentes para diferentes conteúdos dos compostos do clinquer.

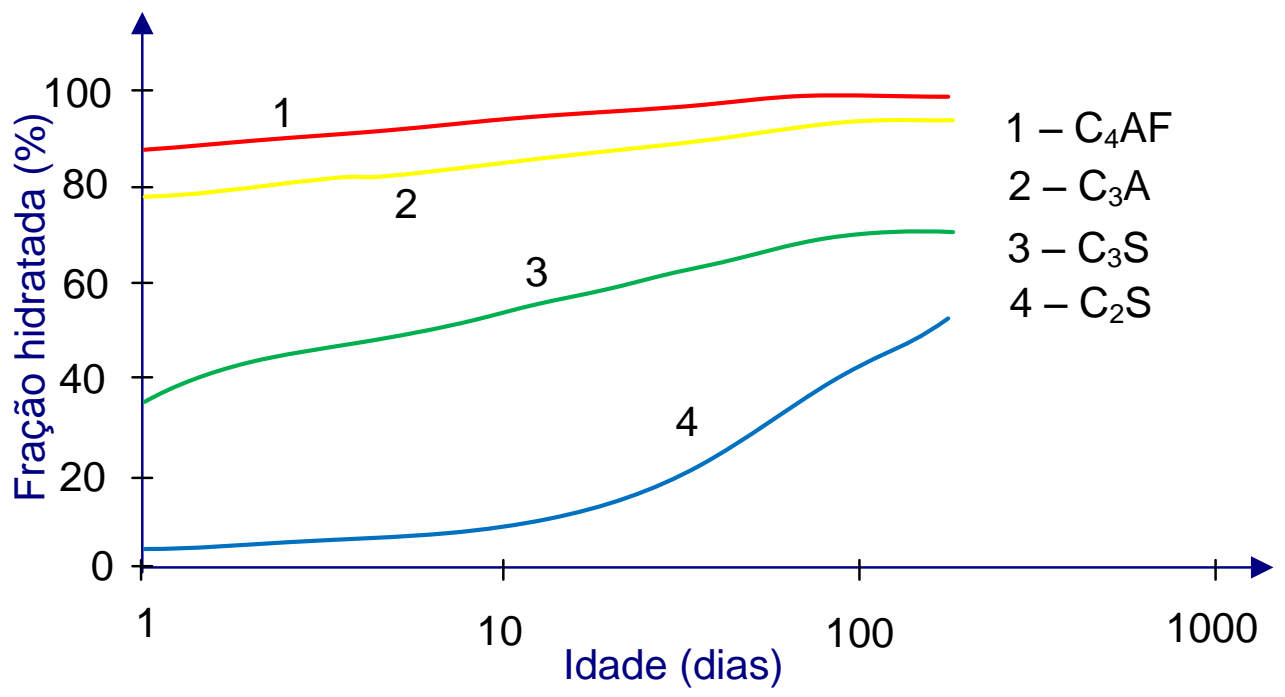

Fig. 2.3 - Evolução da hidratação dos compostos do cimento. (Neville, 1997).

Na Fig. 2.4 podem ser vistas as curvas de resistência à compressão dos componentes isolados. Considerando a resistência o $\mathrm{C}_{2} \mathrm{~S}$ e $\mathrm{C}_{3} \mathrm{~S}$ são os compostos mais importantes, o $\mathrm{C}_{3} \mathrm{~S}$ nas primeiras idades e o $\mathrm{C}_{2} \mathrm{~S}$ em idades maiores, ao ano os aportes nas resistências se igualam, e para idades maiores o aporte do $\mathrm{C}_{2} \mathrm{~S}$ é maior.

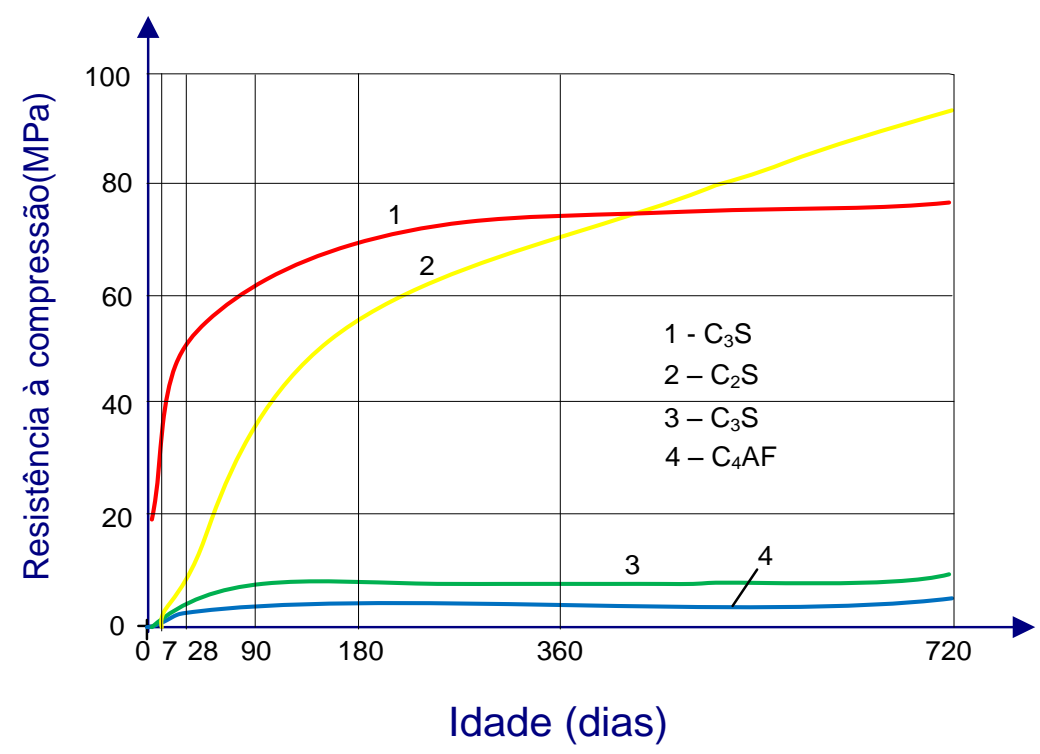

Fig. 2.4 - Curvas de resistência à compressão dos compostos do cimento.

(Adaptada de Petrucci, 1982). 
A análise em conjunto das Fig. 2.3 e Fig. 2.4 permitem observar as diferentes contribuições das fases que formam o clinquer para as resistências mecânicas do produto hidratado.

Na Fig. 2.5 pode ser observado, de maneira aproximada, o processo de formação dos diferentes compostos à medida que ocorre a hidratação do cimento. Outro fato importante é a diminuição dos poros do concreto, pois o cimento hidratado duplica seu volume (Aguirre e Montedor, 2005).
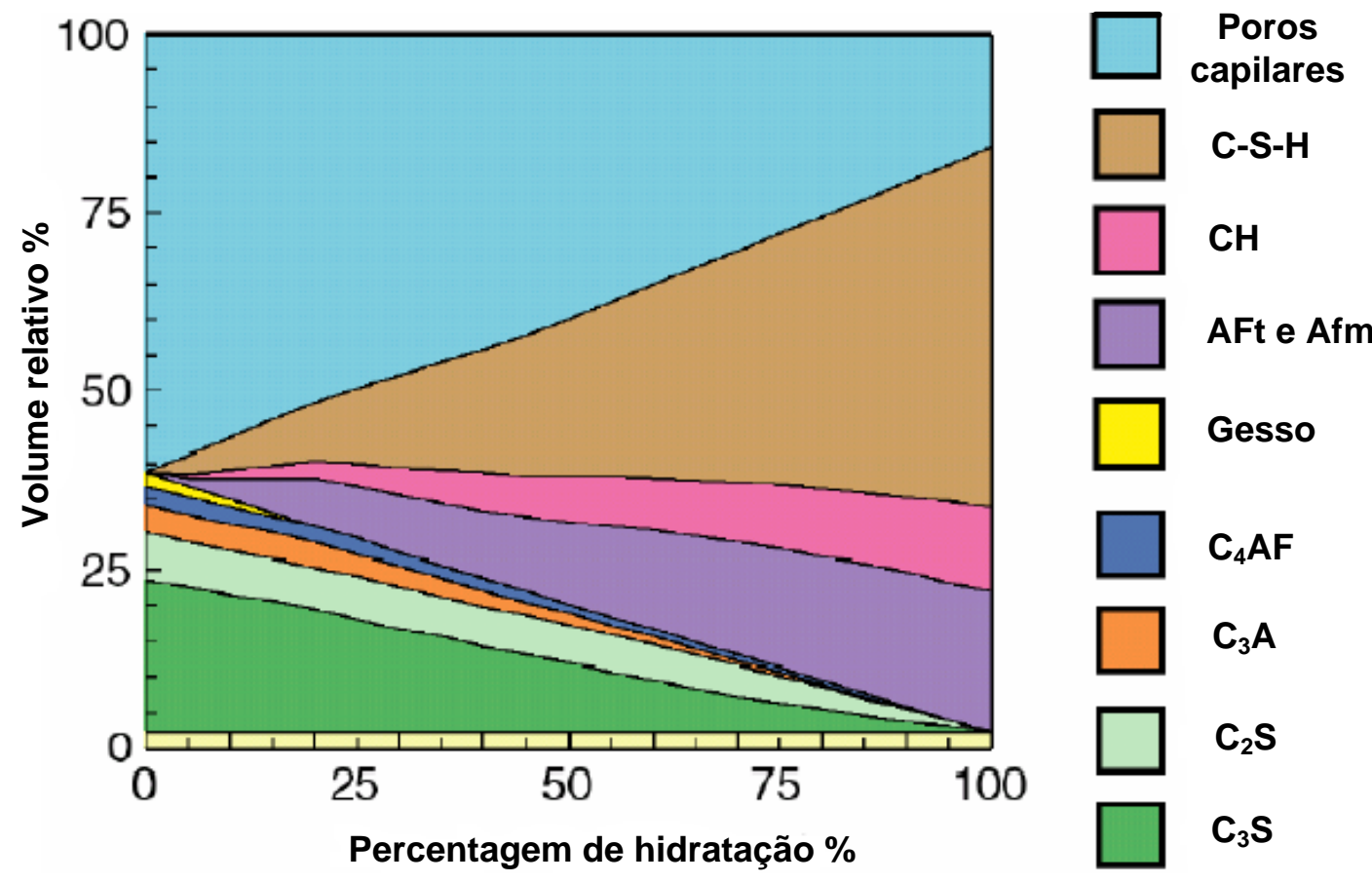

Fig. 2.5 - Composição do cimento, antes e depois da hidratação.

Disponível em: http://www.etsimo.uniovi.es/usr

Aïtcim e Neville (1993) indicam que o cimento mais adequado para a produção do $\mathrm{CAD}$ seria um que tenha pequeno teor de $\mathrm{C}_{3} \mathrm{~A}$ e não muito fino e com a reatividade da fase intersticial que pode ser controlada pelos íons sulfatos, derivados, por exemplo, das adições de gesso. Mas, a escolha do tipo de cimento provem do estudo da compatibilidade com o do aditivo superplastificante a ser empregado no concreto. Assim os teores de $\mathrm{C}_{3} \mathrm{~A}, \mathrm{C}_{4} \mathrm{AF}$, sulfatos de cálcio irão afetar as propriedades defloculantes do cimento.

A escolha do cimento precisa ser feita considerando as propriedades finais que o concreto precisa ter. Para obter concretos de alta resistência, é necessário consumos elevados de cimento, segundo Neville (1997), teores maiores a $530 \mathrm{~kg} / \mathrm{m}^{3}$ podem provocar uma perda da aderência entre pasta e agregado levando à uma diminuição da resistência. Considerando isto pode ser necessário trocar parte do cimento por aditivos minerais cimentícios, obtendo 
assim um novo material aglomerante. Logo, é um conjunto de ações que devem ser adotadas para ter um adequado desempenho do concreto e de acordo com a ACI 363 (1991) o melhor cimento é aquele que apresenta menor variabilidade em termos de suas propriedades físicas e mecânicas.

\subsubsection{Adições minerais}

O uso de adições serve para minimizar problemas ambientais, pois normalmente são resíduos industriais poluentes. Os principais benefícios alcançados com as adições minerais são ambientais, econômicos e tecnológicos, neste último podem melhorar a resistência à fissuração térmica, à expansão álcali-agregados, ao ataque por sulfatos (Metha e Monteiro, 1994).

As adições podem ser classificadas como as pouco reativas ou reativas de acordo com a sua ação no interior do concreto. As reativas como a sílica ativa, pozolanas, cinza de casca de arroz, cinza volante e metacaulinita contribuem na formação de C-H-S. Se depois de certo tempo não existe mais disponibilidade de $\mathrm{CH}$, as adições reativas atuam como um filer inerte, melhorando o conjunto fisicamente. As pouco reativas, proporcionam ao concreto uma estrutura mais compacta (são encapsuladas no interior do concreto), nestes tem-se os filers de calcário, quartzo, entre outros.

Como neste trabalho foi empregada a sílica ativa como aditivo mineral, os esclarecimentos vão ser em relação à mesma. A sílica ativa (SA) ou fumo de sílica ou "microsílica" é um subproduto da fabricação do silício metálico ou das ligas de ferro-silicio, são partículas esféricas com diâmetro médio de $0,2 \mu \mathrm{m}$ e uma massa específica de 2220 $\mathrm{kg} / \mathrm{m}^{3}$, tem um alto teor de $\mathrm{SiO}_{2}$ (maior a 90\%) no formato amorfo (não cristalino), o que proporciona uma altíssima reatividade com os produtos decorrentes da hidratação do cimento. A quantidade de sílica ativa que normalmente é adicionada ao cimento ou que substitui parte do cimento é entre 5\% a 15\% (Tecnosil - Sílica Ativa). Por causa de sua extrema fineza entre 50 a 100 vezes mais fino que o cimento, precisa de uma maior quantidade de água para uma mesma trabalhabilidade sem sílica, logo se torna necessário o uso de suplerplastificantes.

A SA gera uma ação física no concreto, no estado fresco melhora a sua coesão, reduz a exsudação, reduz a segregação e melhoram o empacotamento das partículas do concreto.

Possui uma ação química (pozolânica), reage com o $\mathrm{CH}$ (que ocupa até $25 \%$ do volume da pasta e é um cristal com pequena resistência) para formar um C-S-H incrementado a resistência, e durabilidade. 
Com a adição da SA no concreto, observa-se uma redução na quantidade de $\mathrm{CH}$ e um incremento de C-S-H obtendo-se uma zona da interface mais coesa (Fig. 2.6).

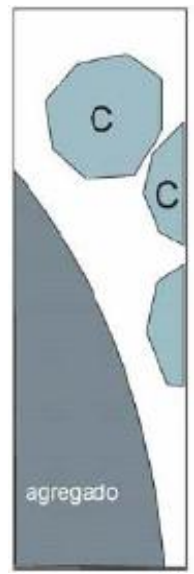

a)

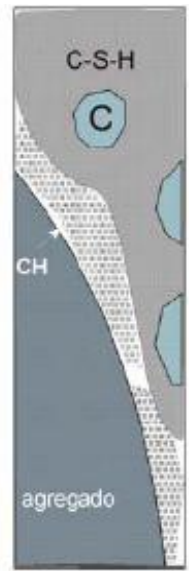

b)

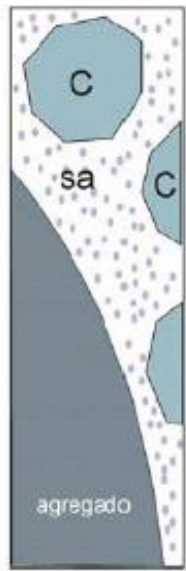

c)

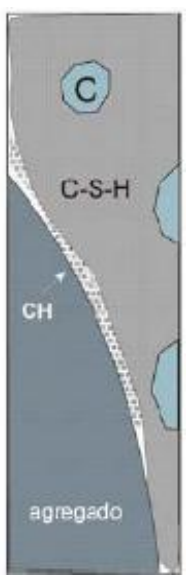

d)

Fig. 2.6 - Atuação da SA na zona de interfase entre a pasta e agregado. a) e b) concreto sem SA, antes e depois da hidratação. c) e d) concreto com SA antes e depois da hidratação.

(Adaptada de Silva, 2007).

Além disso, ocorre uma descontinuidade dos poros capilares em função da quantidade de SA adicionada ao cimento, da relação a/c e do grau e hidratação do cimento. Para uma maior quantidade de SA e menor relação a/c o grau de hidratação necessária para obter a descontinuidade é menor, ver Tabela 2.3.

Tabela 2.3 - Grau de hidratação do cimento necessário para que ocorra a descontinuidade dos poros. (Adaptada de Castro, 2007).

\begin{tabular}{|c|c|c|c|c|c|c|c|c|c|c|}
\hline \multirow{2}{*}{$\begin{array}{c}\text { Relação } \\
\text { a/c }\end{array}$} & 0 & 2,5 & 5 & 7,5 & 10 & 12,5 & 15 & 20 & 25 & 30 \\
\hline \hline 0,23 & 0,31 & 0,27 & 0,23 & 0,22 & 0,22 & 0,22 & 0,21 & 0,2 & 0,2 & 0,19 \\
\hline 0,25 & 0,36 & 0,32 & 0,27 & 0,26 & 0,26 & 0,25 & 0,25 & 0,24 & 0,24 & 0,23 \\
\hline 0,28 & 0,41 & 0,37 & 0,32 & 0,3 & 0,29 & 0,29 & 0,29 & 0,28 & 0,27 & 0,26 \\
\hline 0,3 & 0,46 & 0,42 & 0,37 & 0,33 & 0,33 & 0,32 & 0,32 & 0,32 & 0,31 & 0,3 \\
\hline 0,33 & 0,51 & 0,47 & 0,42 & 0,37 & 0,37 & 0,36 & 0,36 & 0,35 & 0,35 & 0,34 \\
\hline 0,35 & 0,56 & 0,52 & 0,47 & 0,42 & 0,41 & 0,4 & 0,4 & 0,39 & 0,38 & 0,38 \\
\hline 0,38 & 0,61 & 0,57 & 0,52 & 0,47 & 0,44 & 0,44 & 0,44 & 0,43 & 0,42 & 0,41 \\
\hline 0,4 & 0,66 & 0,62 & 0,57 & 0,52 & 0,48 & 0,47 & 0,47 & 0,47 & 0,46 & 0,45 \\
\hline 0,43 & 0,71 & 0,67 & 0,62 & 0,57 & 0,53 & 0,51 & 0,51 & 0,5 & 0,5 & 0,49 \\
\hline 0,45 & 0,76 & 0,72 & 0,67 & 0,62 & 0,58 & 0,55 & 0,55 & 0,54 & 0,53 & 0,53 \\
\hline 0,48 & 0,81 & 0,77 & 0,72 & 0,67 & 0,63 & 0,59 & 0,59 & 0,58 & 0,57 & 0,56 \\
\hline 0,5 & 0,86 & 0,82 & 0,77 & 0,72 & 0,68 & 0,63 & 0,62 & 0,62 & 0,61 & 0,6 \\
\hline 0,53 & 0,91 & 0,87 & 0,82 & 0,77 & 0,73 & 0,68 & 0,66 & 0,65 & 0,65 & 0,64 \\
\hline 0,55 & 0,96 & 0,92 & 0,87 & 0,82 & 0,78 & 0,73 & 0,7 & 0,69 & 0,68 & 0,68 \\
\hline 0,6 & - & - & 0,97 & 0,92 & 0,88 & 0,83 & 0,78 & 0,76 & 0,76 & 0,75 \\
\hline 0,65 & - & - & - & - & 0,98 & 0,93 & 0,88 & 0,84 & 0,83 & 0,82 \\
\hline 0,7 & - & - & - & - & - & - & 0,98 & 0,91 & 0,91 & 0,9 \\
\hline
\end{tabular}


A durabilidade pode estar relacionada com os poros, por falta de continuidade entre os materiais constituintes do concreto, e não diretamente com a maior resistência mecânica, por isso um CAD não necessariamente é um CAR, nem vice-versa, mas pode ser elaborado um CAR para que também seja um CAD. Por exemplo, quando é fabricado um CAR com cimento contendo elevados teores de $\mathrm{C}_{3} \mathrm{~S}$ e $\mathrm{C}_{3} \mathrm{~A}$ na hidratação pode produzir elevados teores de etringita e portlandita na presença de sulfatos, restringindo sua durabilidade.

O que foi esquematizado na Fig. 2.6 pode ser observado nas micrografias realizadas numa região da qual foi extraído um grão de areia. Na Fig. 2.7 a) tem-se uma elevada porosidade e grande quantidade de $\mathrm{CH}$ e na Fig. 2.7 b) uma região de interface compacta onde em virtude da reação pozolânica foi transformado o $\mathrm{CH}$ em C-S-H.

As outras adições apresentam outras propriedades físicas e mecânicas, proporcionando ao concreto diferentes propriedades finais.

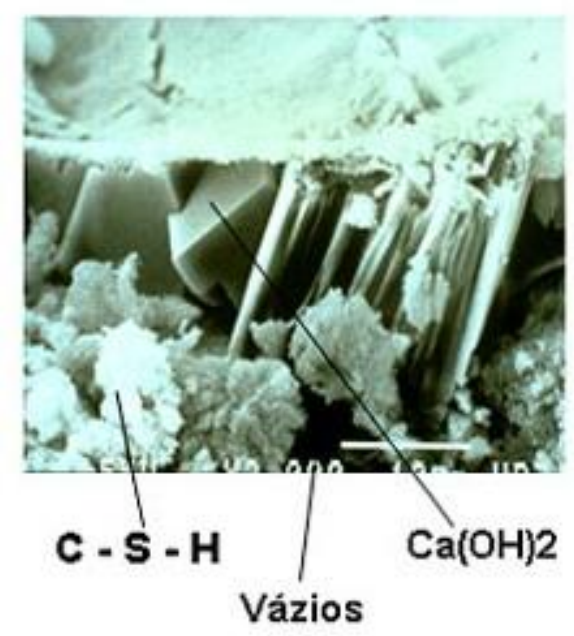

a)

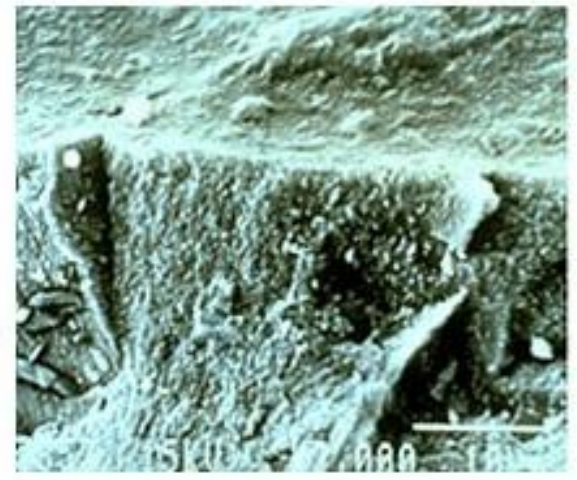

b)

Fig. 2.7 - Zona de interface entre a pasta de cimento e um grão de areia. a) argamassa sem SA, b) argamassa com SA. (Tecnosil - Sílica Ativa).

\subsubsection{Adições químicas}

Existem muitos tipos de aditivos que modificam as propriedades dos concretos, por uma ação física, química ou ambos. Entre os principais, tem-se: o superplastificante, plastificante, plastificante retardador de pega, plastificante acelerador de pega, retardadores de pega, incorporadores de ar, os controladores de hidratação, expansores entre outros (BASF, The Chemical Company).

As adições químicas normalmente utilizadas no CAR são os aditivos redutores de água plastificantes e superplastificantes (redutores de água de alta eficácia) - que permitem a redução da relação água/aglomerante e melhoram a trabalhabilidade do concreto. 
Quanto aos aditivos redutores de água a serem utilizados em CAR, podem ser encontrados aditivos de diversas composições e que contribuem para a melhoria de diversas propriedades do concreto. No entanto, faz-se necessário a sua seleção e definição dos teores a serem empregados.

Segundo U. S. Department of Transportation - FHA, entre os tipos de superplastificantes (SP) tem-se os lingosulfonados modificados (MLS), as resinas de naftaleno-formaldeido sulfonado ( $\mathrm{SNF}$ - naftaleno sulfonado), as resinas de melaminaformaldeido sulfonada (SMF - melamina sulfonada) e os derivados do éter policarboxílico, sendo que este último é de terceira geração.

Os SP de terceira geração não são absorvidos pelas partículas do cimento e sim recobrem a superfície das partículas no processo de mistura. Os sulfônicos aumentam a carga negativa da superfície das partículas e dispersam estas por repulsão elétrica, requerendo menos água para uma determinada consistência do concreto. Os derivados do éter policarboxílicos possuem largas cadeias laterais que se depositam na superfície das partículas de cimento, aumentam o espaço físico no sistema de partículas de cimento, iniciando o mecanismo de dispersão eletrostática e mesmo durante o processo de hidratação o polímero continua atuando, resultando em uma redução de água maior aos $40 \%$ que os SP sulfônicos. (BASF, The Chemical Company). A Fig. 2.8 mostra a ação do SP dentro do concreto fresco.

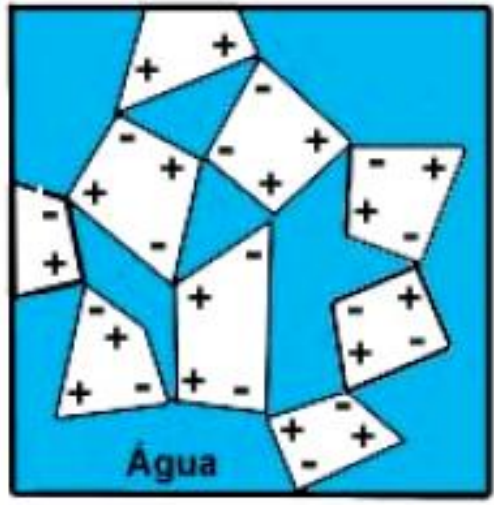

a)

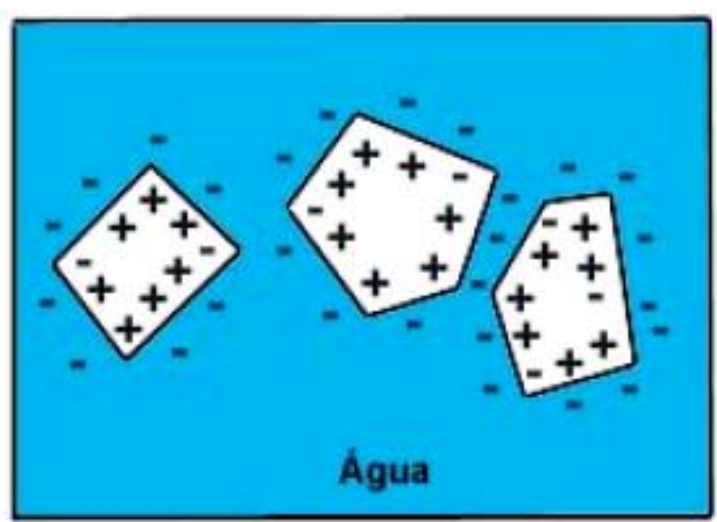

b)

Fig. 2.8 - Esquema da floculação das partículas de cimento: a) antes da adição do SP e b) dispersão dos flocos após a adição (Metha e Monteiro, 1994).

Como mencionado anteriormente é necessário fazer um estudo para verificar a compatibilidade do cimento com um determinado aditivo SP. Normalmente a dosagem de superplastificante utilizada em CAR varia entre 0,5 a 2,5 do teor de sólidos do aditivo em relação à massa de cimento (Aïtcim, 2000), uma boa indicação são os catálogos do fabricante. 
Diversos estudos têm sido realizados com o objetivo de definir métodos e ensaios para esta seleção. Dentre os métodos mais empregados, cita-se: ensaios em pasta pelo Método de Kantro (mini slump) e Cone de Marsh (Aïtcim,2000).

A utilização de quantidades adicionais de superplastificante, do que a dosagem correspondente ao ponto de saturação, não traz benefícios, quantidades excessivas podem causar segregação no concreto e retardar a pega.

No presente trabalho foram empregados o superplastificante Glenium ${ }^{\circledR} 51$ e o cimento CPV ARI PLUS, a verificação da compatibilidade de ambos foi realizada com o ensaio de Kantro que é um método rápido e que exige pouca quantidade de material para avaliar o poder superplastificante em pastas de cimento.

\subsection{4 Água de amassamento}

Segundo Aïtcin e Neville (1993) a relação água/cimento necessária para hidratar o cimento é 0,22 , mas é preciso uma quantidade adicional para adequada trabalhabilidade. A qualidade da água de amassamento e de cura precisa cumprir com os requisitos presentes na norma ABNT NBR 6118:2003. Em geral a água potável, proveniente da rede de abastecimento público, é adequada ao emprego no amassamento de concretos.

\subsubsection{Agregados miúdos}

A ABNT NBR 7211:1983, classifica o agregado miúdo de acordo com sua composição granulométrica em zonas (muito fina, fina, média e grossa), ver Tabela 2.4.

Tabela 2.4 - Limites Granulométricos do agregado miúdo (ABNT NBR 7211:1983).

\begin{tabular}{|c|c|c|c|c|c|c|c|c|}
\hline \multicolumn{8}{|c|}{ Porcentajem retida acumulada em massa } \\
\hline $\begin{array}{c}\text { Abertura } \\
\text { peneiras } \\
\text { (mm) }\end{array}$ & $\begin{array}{c}\text { Zona 1 } \\
\text { (muito } \\
\text { fina) }\end{array}$ & $\begin{array}{c}\text { Zona 2 } \\
\text { (fina) }\end{array}$ & \multicolumn{2}{c|}{$\begin{array}{c}\text { Zona 3 } \\
\text { (média) }\end{array}$} & \multicolumn{2}{|c|}{$\begin{array}{c}\text { Zona 4 } \\
\text { (grossa) }\end{array}$} \\
\hline \hline 6,3 & 0 & 3 & 0 & 7 & 0 & 7 & 0 & 7 \\
\hline 4,8 & 0 & 5 & 0 & 10 & 0 & 11 & 0 & 12 \\
\hline 2,4 & 0 & 5 & 0 & 15 & 0 & 25 & 5 & 40 \\
\hline 1,2 & 0 & 10 & 0 & 25 & 10 & 45 & 30 & 70 \\
\hline 0,6 & 0 & 20 & 21 & 40 & 41 & 65 & 66 & 85 \\
\hline 0,3 & 50 & 85 & 60 & 88 & 70 & 92 & 80 & 95 \\
\hline 0,15 & 85 & 100 & 90 & 100 & 90 & 100 & 90 & 100 \\
\hline
\end{tabular}

Segundo Amaral Filho (1992), para resistências até 170 MPa, a areia quartzosa normal bem graduada é suficiente, para resistências maiores é necessário uma areia artificial de bauxita calcinada. 
O certo é procurar uma proporção ótima de agregados miúdos de acordo com suas propriedades de granulométricas a fim de que a mistura seja a mais compacta possível.

\subsubsection{Agregados graúdos}

A norma ABNT NBR 7211:1983 divide os agregados em brita 0, brita 1, brita 2, brita 3 e brita 4 e seus limites são apresentados na Tabela 2.5 .

Tabela 2.5 - Limites Granulométricos do agregado graúdo (ABNT NBR 7211:1983).

\begin{tabular}{|c|c|c|c|c|c|c|c|c|c|c|}
\hline \multicolumn{11}{|c|}{ Porcentajem retida acumulada em massa } \\
\hline $\begin{array}{c}\text { Abertura } \\
\text { peneiras } \\
(\mathrm{mm})\end{array}$ & \multicolumn{2}{|c|}{ Brita 0} & \multicolumn{2}{|c|}{ Brita 1} & \multicolumn{2}{|c|}{ Brita 2} & \multicolumn{2}{|c|}{ Brita 3} & \multicolumn{2}{|c|}{ Brita 4} \\
\hline 76 & \multicolumn{2}{|c|}{-} & \multicolumn{2}{|c|}{-} & \multicolumn{2}{|c|}{-} & \multicolumn{2}{|c|}{-} & 0 & 0 \\
\hline 64 & \multicolumn{2}{|c|}{-} & \multicolumn{2}{|c|}{-} & \multicolumn{2}{|c|}{-} & \multicolumn{2}{|c|}{-} & 0 & 30 \\
\hline 50 & \multicolumn{2}{|c|}{-} & \multicolumn{2}{|c|}{-} & \multicolumn{2}{|c|}{-} & 0 & 0 & 75 & 100 \\
\hline 38 & \multicolumn{2}{|c|}{-} & \multicolumn{2}{|c|}{-} & \multicolumn{2}{|c|}{-} & 0 & 30 & 90 & 100 \\
\hline 32 & \multicolumn{2}{|c|}{-} & \multicolumn{2}{|c|}{ 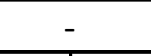 } & 0 & 0 & 75 & 100 & 95 & 100 \\
\hline 25 & \multirow{2}{*}{\multicolumn{2}{|c|}{$\frac{-}{-}$}} & 0 & 0 & 0 & 25 & 87 & 100 & \multicolumn{2}{|c|}{-} \\
\hline 19 & & & 0 & 10 & 75 & 100 & 95 & 100 & & - \\
\hline 12,5 & 0 & 0 & & 90 & 100 & \multicolumn{2}{|r|}{-} & \multicolumn{2}{|c|}{-} \\
\hline 9,5 & 0 & 10 & 80 & 100 & 95 & 100 & & - & & - \\
\hline 6,3 & \multicolumn{2}{|c|}{-} & 92 & 100 & \multicolumn{2}{|c|}{-} & \multicolumn{2}{|c|}{-} & \multicolumn{2}{|c|}{-} \\
\hline 4,8 & 80 & 100 & 95 & 100 & \multicolumn{2}{|c|}{-} & \multicolumn{2}{|c|}{-} & \multicolumn{2}{|c|}{ - } \\
\hline 2,4 & 95 & 100 & \multicolumn{2}{|c|}{ - } & \multicolumn{2}{|c|}{-} & & - & & - \\
\hline
\end{tabular}

A quantidade de agregado graúdo na mistura pode variar em função do tipo do traço a ser adotado, e pode ser maior a $50 \%$ do total da massa das partículas presentes no concreto. Em geral, os agregados graúdos são procedentes de jazidas naturais, seja na forma de pedregulhos, seixos ou pedra britada. Rochas ígneas, como granito e basalto, sedimentares como arenitos e calcários, metamórficas como o gnaisse. Poderiam também ser empregados agregados de escória de alto forno e agregados reciclados de resíduos cerâmicos entre outros.

As propriedades físicas e mineralógicas desses agregados afetam consideravelmente a obtenção das propriedades de resistência e durabilidade do concreto. Metha e Monteiro (1994) indicam que a fase agregado é predominantemente responsável pela massa unitária, modulo de elasticidade e estabilidade dimensional do concreto, estas propriedades do concreto dependem da densidade e resistência do agregado, que por sua vez, são determinadas mais por propriedades físicas do que por propriedades da estrutura do agregado.

Segundo Helland (1988), para resistências à compressão menores que $80 \mathrm{MPa}$ o concreto apresenta comportamento de um material compósito, e as fissuras ocorrem na 
interface. Entre resistências de $80 \mathrm{MPa}$ e $100 \mathrm{MPa}$ a capacidade resistente da pasta e agregado pode ser da mesma ordem de grandeza e o comportamento do concreto é homogêneo. Para resistências maiores que $100 \mathrm{MPa}$, o concreto novamente se comporta como um compósito, e neste caso o agregado pode ser o componente mais frágil do concreto e as fissuras atravessam os agregados.

O comportamento mecânico do agregado no concreto depende de sua disposição dentro da argamassa, geralmente o efeito da exsudação interna (a exsudação externa é o fenômeno cuja manifestação é o aparecimento de água na superfície do concreto após o lançamento, porém antes do inicio da pega), num concreto sem SA, faz com que a água em excesso fique depositada na parte inferior dos agregados e seu comportamento pode ser considerado similar ao de uma viga carregada e simplesmente apoiada (Fig. 2.9). Este efeito é minimizado com o emprego da SA, resultando em concretos mais coesos com um comportamento mecânico do agregado mais resistente.
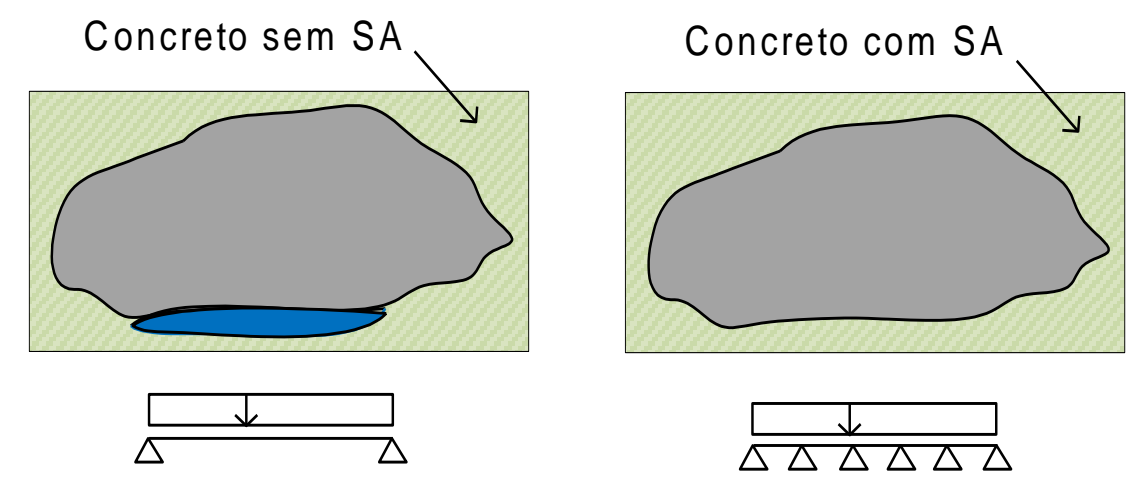

Fig. 2.9 - Efeito da SA melhorando o comportamento mecânico do agregado (Liborio, 2005).

No CAR a aderência entre o agregado e a pasta do cimento hidratado é muito forte e permite transmitir uma parte significativa de tensões por meio da interfase entre agregadopasta e a ruptura geralmente acontece cortando o agregado. Para melhorar a aderência com a pasta a forma do agregado deve ser angulosa e irregular, mas o mais equidimensional possível. Os agregados menores são geralmente mais resistentes que os maiores, isto se deve ao processo de britagem, e quanto menor o agregado menor presença de zonas fracas, para concretos com resistências maiores do que 100 MPa o diâmetro máximo deve ser menor a 10 mm ou 12 mm (Aïtcin e Neville, 1993).

O’Reilly (1990), cita que outra propriedade importante a ser avaliada é o índice de forma do agregado. Para sua determinação pode-se utilizar a norma francesa AFNOR P-18301. O método consiste em determinar um coeficiente volumétrico (CV) médio de uma amostra obtida a partir do quarteamento de um lote representativo de agregados, até obter-se 
uma massa de 250 g. O volume dos agregados é calculado pelo deslocamento de um líquido de volume previamente estabelecido, obtendo-se então o valor V, que é o volume da amostra, na seqüência medem-se os diâmetros $\mathrm{D}$ de cada partícula. Outra maneira é tirar as medidas $\mathrm{n}$ vezes de 20 grãos de uma mesma fração de agregados. A expressão 2.1 do CV médio é:

$$
C V=\frac{V}{\frac{\pi}{6} \cdot \sum D^{3}}
$$

Para uma esfera CV é um. Quanto maior o índice de angulosidade (menor CV), mais água será exigida para uma mesma trabalhabilidade. Para um CAR o CV recomendável é maior do que 0,2 .

Liborio et al. (2005) recomenda realizar uma dopagem dos agregados para melhorar a zona de interface reduzindo os vazios, preenchendo fissuras e ajudando a formar $\mathrm{C}-\mathrm{S}-\mathrm{H}$ e $\mathrm{CH}$ na superfície dos agregados. A dopagem consiste em lavar os agregados com uma solução de pequena relação a/c ou água/aglomerante.

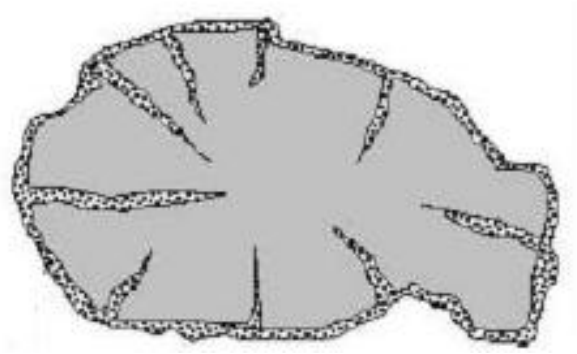

Fig. 2.10 - Superfície de um agregado frágil, poroso com dopagem superficial. (Liborio et al., 2005).

Considerando a durabilidade, alguns agregados podem sofrer, depois de algum tempo, reações químicas. Uma das mais preocupantes é a reação álcali-agregado, na qual componentes do agregado reagem com os álcalis do cimento, as adições minerais diminuem este efeito como conseqüência da reação destas com o $\mathrm{CH}$.

\subsection{MÉTODOS DE DOSAGENS}

É um processo no qual se trata de obter a melhor proporção entre cimento, agregados, água e adições. Existem muitos métodos de dosagem para concretos, especialmente para concretos convencionais.

Segundo Aïtcim (2000), iguais propriedades para o concreto fresco e endurecido podem ser alcançadas com diferentes combinações dos mesmos materiais. 
Não é nenhum segredo que para obter CAR é necessário diminuir a quantidade de água a proporções que o concreto deixa de ser trabalhável, sendo necessário incorporar na mistura adições químicas como o superplastificante para ter novamente trabalhabilidade, além disso, o consumo do cimento aumenta a valores até maiores que $500 \mathrm{~kg} / \mathrm{m}^{3}$. A incorporação de adições minerais é necessária para melhorar ainda mais a resistência e durabilidade do concreto. Entre os objetivos dos métodos o principal é obter uma economia nos materiais para as mesmas propriedades desejadas do concreto.

Entre os mais comuns, podem-se citar o de Aïtcim (2000), Helene e Terzian (1992), Jimenez et al. (2000), O’Reilly (1990). Embora existam métodos apropriados de dosagem para o CAR, os materiais e seus componentes devem ser selecionados empiricamente por meio de testes em laboratório.

A maioria dos métodos fixa quantias e relações entre os materiais com base em resultados de ensaios obtidos anteriormente e com base em condições de trabalhabilidade e resistência com a utilização de planilhas e gráficos. Consideram-se propriedades físicas e mecânicas dos materiais empregados e, normalmente, sempre é necessário fazer correções na quantidade de água considerando a umidade dos agregados.

No presente trabalho foi utilizado o método de Helene e Terzian (1992). Esse método é melhor estudado no Capítulo 5 no qual é apresentado o programa experimental.

\subsection{PROPRIEDADES MECÂNICAS DO CAR SEM CONFINAMENTO}

Neste item serão explicitadas as expressões das normas e de diversos pesquisadores que consideram o CAR, relacionadas à resistência à compressão, à tração, ao modulo de deformação e diagrama tensão-deformação específica.

Os concretos de alta resistência têm propriedades diferentes dos concretos convencionais. Entre os fatores que reforçam a diferença, que já foram mencionados anteriormente, estão as maiores coesões na região da interfase pasta-agregado, menor porosidade da pasta endurecida, a maior influência da rigidez do agregado graúdo, entre outras. É importante mencionar que o CAR tem um comportamento frágil tanto na tração como na compressão. 


\subsubsection{Resistência à Compressão}

É a propriedade mais importante do concreto e serve de referência para sua classificação e é uma medida da qualidade do concreto, porque sua resistência está relacionada com a sua estrutura interna.

Segundo Aïtcin (2000), a resistência à compressão do concreto depende de fatores como o tipo de máquina para a realização do ensaio, influência do procedimento do ensaio, influência da forma e dimensões do corpo-de-prova, influência da cura, entre outros.

Na prática é bem sabido que a resistência à compressão é inversamente proporcional à relação água/aglomerante, para o CAR esta proporcionalidade é valida somente até o limite da resistência do agregado graúdo, portanto para cada tipo de agregado existe um valor crítico da relação água/aglomerante (Aïtcin, 2000).

O valor da resistência à compressão é obtido em ensaios à compressão de corpos-deprova cilíndricos ou cúbicos com dimensões padrões de $15 \mathrm{~cm}$ x $30 \mathrm{~cm}$ ou $15 \mathrm{~cm}$ x $15 \mathrm{~cm}$ x $15 \mathrm{~cm}$, dependendo da norma. No Brasil a norma ABNT NBR 7215:1991, padroniza os corpos-de-prova cilíndricos de $15 \mathrm{~cm}$ x $30 \mathrm{~cm}$. Mas no caso do CAR empregam-se corpos-deprova de $10 \mathrm{~cm}$ x $20 \mathrm{~cm}$, os valores obtidos com estes últimos são em media $5 \%$ maiores.

Para se evitar o surgimento de concentração de tensões junto às extremidades dos corpos-de-prova em virtude as imperfeições que surgem no processo de moldagem o emprego de capeamentos de enxofre para regularizar os extremos são necessários, mas para o concreto de elevada resistência, pode ocorrer uma ruptura prematura do capeamento, neste sentido, para ensaiar os corpos-de-prova deste trabalho foram retificadas as extremidades de todos os corpos-de-prova.

A resistência à compressão é avaliada aos 28 dias de idade, para idades maiores as resistências são maiores. A ABNT NBR 6118:2003 e o EUROCODE 2 (2004), propõe as Eq. 2.2 e Eq. 2.3 para obter a evolução da resistência à compressão com o tempo.

$$
\begin{gathered}
f_{c m}(t)=\beta_{c c}(t) \times f_{c m} \\
\beta_{c c}(t)=\exp \left\{s\left[1-\left(\frac{28}{t}\right)^{1 / 2}\right]\right\}
\end{gathered}
$$

sendo que:

$\mathrm{f}_{\mathrm{cm}}(\mathrm{t})$ é resistência média do concreto à compressão a t dias de idade;

$\mathrm{f}_{\mathrm{cm}}$ é resistência média do concreto à compressão aos 28 dias de idade;

$\beta_{c c}(t)$ é um coeficiente que depende da idade do concreto;

s é um coeficiente que depende do tipo de cimento;

= 0,2 para cimentos CP V-ARI segundo a ABNT NBR 6118:2003; 
= 0,25 para cimentos CP I e CP II segundo a ABNT NBR 6118:2003;

= 0,38 para cimentos CP III e CP IV segundo a ABNT NBR 6118:2003.

\subsubsection{Curvas Tensão x Deformação Específica}

No dimensionamento podem-se empregar as curvas tensão-deformação específica $\left(\sigma_{c}\right.$ $\mathrm{x} \varepsilon_{\mathrm{c}}$ ) mais realistas que se originam dos ensaios de laboratório, para que o comportamento real se adapte ao experimental.

Nas últimas décadas, houve um número considerável de pesquisas, para se obter a parte ascendente e descendente das curvas tensão-deformação específica. Os aditivos incorporados ao concreto modificam a forma da curva, cujo aspecto final não está totalmente definido pelas normas. Há diferenças (em virtude, principalmente, aos diferentes tipos de ensaios empregados), especialmente, na parte descendente da curva (Aïtcin, 2000).

Antes da aplicação da ação, já existem micro-fissuras na zona de interface entre a pasta e o agregado graúdo do concreto. Significa que o concreto mesmo fissurado pode suportar bem as ações, mas no CAD, como o grau de fissuração é menor, o concreto tem uma ruptura frágil, sem plastificação.

Nos concretos convencionais, quando o carregamento se aproximar de $25 \%$ da resistência final, as fissuras da zona de transição aumentam de comprimento (isto significa que o gráfico $\sigma_{\mathrm{c}} \times \varepsilon_{\mathrm{c}}$ começa a se curvar). Próximo de $70 \%$ da resistência final iniciam-se as fissuras na matriz, que se interligam com as da interface, formando um padrão de fissuração contínua. Ocorre uma propagação rápida da fissuração e a curva $\sigma_{\mathrm{c}} \times \varepsilon_{\mathrm{c}}$ aumenta sua curvatura a uma razão crescente, até chegar à ruptura, que corresponde ao pico da curva.

Após atingir a tensão máxima (tensão de pico), ao reduzir a força (utilizando prensa com deformação controlada) a deformação continuará a crescer. Essa é a parte pós-pico que representa na curva $\sigma_{\mathrm{c}} \times \varepsilon_{\mathrm{c}}$ uma perda progressiva de rigidez do concreto, ou seja, a parte descendente do diagrama.

Nos concretos de alta resistência a interface tem um comprimento concentrado de fissuras menor que os concretos convencionais, e o estágio da propagação rápida de fissuras começa aproximadamente com $85 \%$ ou mais da resistência final. A ruptura que se segue pode ter lugar no agregado graúdo e na matriz. Os agregados não atuam como barreira para a fissuração, sendo rápida a ruptura. No CAR, por causa da menor quantidade de fissuras, a parte ascendente e a descendente da curva são mais inclinadas, de modo que os CAR são mais 
frágeis que os concretos comuns. Por isso, nestes primeiros podem ocorrer rupturas repentinas ao permitir o acumulo de energia.

Esta conduta pode ser observada na Fig. 2.11 para concretos convencionais e para concretos de alta resistência.

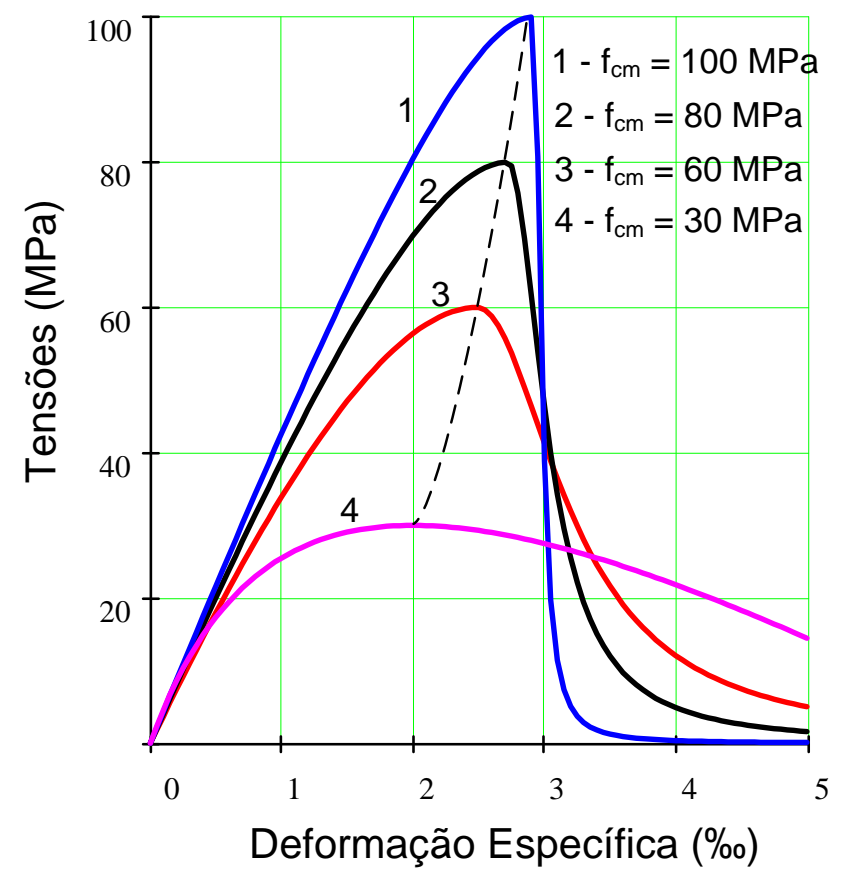

Fig. 2.11 - Diagramas $\sigma_{\mathrm{c}} \times \varepsilon_{\mathrm{c}}$ de concretos com várias resistências à compressão. (Aguirre et al., 2006).

Na Fig. 2.11 verifica-se que com o incremento da resistência do concreto existe um incremento da deformação específica correspondente ao pico da curva e uma perda de resistência mais repentina no ramo pós-pico da curva, não observada para o concreto convencional.

O diagrama tensão-deformação parábola-retângulo, muito empregado no dimensionamento de peças de concreto convencional precisa ser substituído por um diagrama que se aproxime dos resultados experimentais. O CAR apresenta curvas tensão-deformação diferentes, é um material frágil, e quanto maior a resistência maior a fragilidade, portanto cada tipo de concreto possui sua própria curva. Há uma necessidade de quantificar estes parâmetros para efetuar um dimensionamento seguro.

As normas de concreto armado fornecem expressões para a consideração das propriedades mecânicas para as resistências à compressão de concreto menores que $40 \mathrm{MPa}$ ou $50 \mathrm{MPa}$.

Algumas normas internacionais já consideram em seus textos resistências maiores como o CEB-FIP-MC90 (1993), FIB Structural Concrete (1999), CEB Bulletin 228 - 
Recommended Extensions to the CEB-FIB MC90 (1995), NS 3473-E (1992), EUROCODE 2 - EN 1992-1-1 (2004), Instrucción Española de Hormigón Armado - EHE (2008), DIN 10451 (2001), CSA CAN3-A23.3.04 (2005), outras normas como a ACI-318 (2005) permitem o seu emprego sem um limite de resistência à compressão especificada. A maioria das normas que considera o CAR permitem concretos com resistências características máximas entre 80 MPa e $115 \mathrm{MPa}$.

Entre as várias propostas do diagrama $\sigma_{\mathrm{c}} \mathrm{x} \varepsilon_{\mathrm{c}}$, serão mostras as expressões da curva pré e pós-pico das seguintes:

\section{EUROCODE 2 - EN 1992-1-1, $2004\left(20 \mathrm{MPa} \leq \mathrm{f}_{\mathrm{cm}} \leq 98 \mathrm{MPa}\right)$.}

A relação $\sigma_{\mathrm{c}} \times \varepsilon_{\mathrm{c}}$ para compressões uniaxiais de curta duração está descrita pela Eq. 2.4, válida para o ramo ascendente como descendente.

$$
\sigma_{c}=\frac{k \times \eta\left(\varepsilon_{c}\right)-\left(\eta\left(\varepsilon_{c}\right)\right)^{2}}{1+(k-2) \times \eta\left(\varepsilon_{c}\right)} \times f_{c m}
$$

Nesta: $\eta\left(\varepsilon_{c}\right)=\frac{\varepsilon_{c}}{\varepsilon_{c 1}}$ e $k=\frac{1,05 \times E_{c s}}{E_{c 1}}$

As Eq. 2.5 e a Eq. 2.6 fornecem as expressões da deformação específica correspondentes ao pico da curva:

$$
\begin{gathered}
\varepsilon_{c 1}=0,7 \times\left(f_{c m}\right)^{0,31} \text { para } \mathrm{f}_{\mathrm{cm}}<87,5 \mathrm{MPa} \\
\varepsilon_{c 1}=2,8 \text { para } \mathrm{f}_{\mathrm{cm}} \geq 87,5 \mathrm{MPa}
\end{gathered}
$$

A Eq. 2.7 e a Eq. 2.8 mostram as expressões da deformação específica última:

$$
\begin{gathered}
\varepsilon_{c u 1}=2,8+27 \times\left(\frac{98-f_{c m}}{100}\right)^{4} \text { para } 58 \mathrm{MPa} \leq \mathrm{f}_{\mathrm{cm}} \leq 98 \mathrm{MPa} \\
\varepsilon_{c u 1}=3,5 \text { para } 20 \mathrm{MPa} \leq \mathrm{f}_{\mathrm{cm}}<58 \mathrm{MPa}
\end{gathered}
$$

As deformações especificas, das Eq. 2.6 até a Eq. 2.8 estão expressas em função da resistência média do concreto aos 28 dias $\mathrm{f}_{\mathrm{cm}}$ que pode ser adotado como $f_{c m}=f_{c k}+8$ (ou outra idade considerando a Eq. 2.2).

O módulo de deformação secante corresponde ao pico é:

$$
E_{c 1}=\frac{f_{c m}}{\varepsilon_{\mathrm{c} 1} / 1000}
$$

A expressão do módulo de deformação secante na origem é: 


$$
E_{c s}=\alpha_{a} \times 22000 \times\left(\frac{f_{c m}}{10}\right)^{0,3}
$$

A Tabela 2.6 mostra o parâmetro $\alpha_{a}$ que afeta ao módulo de deformação considerando o tipo de agregado.

Tabela 2.6 - Valores do fator $\alpha_{a}$ que afeta o módulo de deformação.

\begin{tabular}{|c|c|c|c|c|}
\hline Tipo de agregado & basáltico & quartzo & pedra calcaria & arenito \\
\hline$\alpha_{a}$ & 1,2 & 1,0 & 0,9 & 0,7 \\
\hline
\end{tabular}

As unidades dos módulos de deformação e das tensões é MPa e as unidades das deformações específicas devem ser expressas em \%o.

Segundo esta norma a Eq. 2.4 é válida até a deformação específica última (Eq. 2.7 e Eq. 2.8). Considerando esta norma a Fig. 6.2 mostra a forma da curva.

\section{FIB STRUCTURAL CONCRETE $1999\left(25 \mathrm{MPa} \leq \mathrm{f}_{\mathrm{cm}} \leq 90 \mathrm{MPa}\right)$.}

A relação $\sigma_{c} \times \varepsilon_{c}$ para compressões uniaxiais de curta duração está descrita pela mesma Eq. 2.4, válida para o ramo ascendente como descendente.

Os valores e suas unidades que afetam a Eq. 2.4 são os mesmos da norma EUROCODE 2 (2004) com exceção de:

O parâmetro k:

$$
k=\frac{E_{c m}}{E_{c 1}}
$$

A deformação específica correspondentes ao pico da curva:

$$
\varepsilon_{c 1}=1,7+\frac{f_{c m}}{70}
$$

O módulo de deformação tangente na origem:

$$
E_{c m}=\alpha_{a} \times 21500 \times\left(\frac{f_{c m}}{10}\right)^{0,33}
$$

Os diagramas $\sigma_{\mathrm{c}} \times \varepsilon_{\mathrm{c}}$ são válidos, no ramo descendente, até a deformação específica correspondente aos $50 \%$ da tensão máxima. Para os concretos C90, C60 e C30 a validade corresponderia até 4,1 \%o, 3,8 \%o e 3,9\%o respectivamente (os valores de estas deformações não são últimas, é até a condição que é válida a Eq. 2.4 nesta norma). A Fig. 6.3 mostra esta situação. 


\section{CEB-BULLENTIN D'INFORMATION 228, 1995 ( $58 \mathrm{MPa} \leq \mathrm{f}_{\mathrm{cm}} \leq 108 \mathrm{MPa}$ ).}

Para o ramo ascendente da curva $\sigma_{\mathrm{c}} \times \varepsilon_{\mathrm{c}}\left(\left|\varepsilon_{\mathrm{c}}\right| \leq\left|\varepsilon_{\mathrm{c} 1}\right|\right)$ é a mesma expressão da Eq. $2.4 \mathrm{e}$ para o ramo descendente da curva $\left(\left|\varepsilon_{\mathrm{c}}\right|>\left|\varepsilon_{\mathrm{c} 1}\right|\right)$ é:

$$
\sigma_{\mathrm{c}}=\frac{1}{1+\left(\frac{\eta\left(\varepsilon_{c}\right)-1}{\eta_{2}-1}\right)^{2}} \times f_{c m}
$$

Os valores e suas unidades que afetam a Eq. 2.4 são os mesmos da norma EUROCODE 2 (2004) com exceção de:

O parâmetro k é igual ao da norma FIB (1999).

A deformação específica correspondentes ao pico da curva:

$$
\varepsilon_{\mathrm{c} 1}=0,7 \times\left(f_{c m}\right)^{0,31}
$$

O módulo de deformação tangente na origem:

$$
E_{c m}=\alpha_{a} \times 22000 \times\left(\frac{f_{c m}}{10}\right)^{0,3}
$$

Na Eq. 2.14 aparece o parâmetro $\eta_{2}$ que controla a parte da curva no ramo descendente e é igual a:

$$
\eta_{2}=\frac{\varepsilon_{\mathrm{c} 1}+t}{\varepsilon_{\mathrm{c} 1}}
$$

A Tabela 2.7 mostra o parâmetro t que afeta $\eta_{2}$.

Tabela 2.7 - Parâmetro t

\begin{tabular}{|c|c|c|c|c|c|c|}
\hline $\mathrm{f}_{\text {ck }}(\mathrm{MPa})$ & 50 & 60 & 70 & 80 & 90 & 100 \\
\hline $\mathrm{t}$ & 0,807 & 0,579 & 0,338 & 0,221 & 0,070 & 0,015 \\
\hline
\end{tabular}

A Fig. 6.3 mostra os diagramas realistas $\sigma_{\mathrm{c}} \mathrm{x} \varepsilon_{\mathrm{c}}$ de dois CAR segundo o CEB Bulletin 228 (1995), com seu comportamento pós-pico, sendo que para o concreto de maior resistência à compressão a ruptura é mais repentina.

Como o EUROCODE 2 (2004), FIB (1999) e CEB Bulletin 228 (1995) são normas de dimensionamento, em seus modelos, para o valor da resistência do concreto à compressão foi empregada a resistência média aos 28 dias, que pode ser adotada como $\mathrm{f}_{\mathrm{cm}}=\mathrm{f}_{\mathrm{ck}}+8 \mathrm{MPa}$. As suas expressões (Eq. 2.4 até Eq. 2.17) podem ser utilizadas para outras idades (ver Eq. 2.2) ou para resultados de resistência obtidos nos ensaios. 


\subsubsection{Outras propriedades}

Existem outras propriedades que poderiam ser estudadas como a resistência à tração, o módulo de deformação, o coeficiente de Poisson, a deformação lenta, a retração, entre outras, mas como não fazem parte do estudo do presente trabalho, não são analisadas. Quando necessário serão consideradas com as explicações respectivas.

Algumas outras propriedades como a ductilidade e tenacidade serão estudadas em capítulos posteriores.

\subsection{CONSIDERAÇÕES FINAIS}

Existem muitas maneiras de obter o CAR, mas este deve ser econômico (custo/benefício) e propiciar vantagens frente às alternativas tecnológicas.

Para realizar um estudo de traço considerando todos os componentes do concreto é necessária uma análise dos materiais disponíveis na região. Para a obtenção de CAR, pode-se pensar em substituir parte do cimento com aditivos minerais para melhorar suas propriedades de coesão e resistência. No caso da sílica ativa a percentagem de adição pode variar em função à relação água/aglomerante, mas o usual é entre 5\% a 15\%. A maneira correta de obter um traço é realizando estudos de prévios em laboratório.

$\mathrm{Na}$ obtenção do CAR o cimento normalmente empregado em laboratório é o cimento CP V-ARI que permite obter resistências maiores em pequenas idades, mas como é um cimento mais finamente moído é mais caro. Nos canteiros de obra, para o CAR o cimento mais empregado é o CP II. Mas para uma definição do tipo de cimento a ser empregado é necessário conhecer todos os pormenores da obra e dos materiais que serão empregados na fabricação do concreto para evitar possíveis degradações prematuras do concreto ou do concreto armado, sendo importante um conhecimento básico da química do cimento.

Para o dimensionamento de pilares é necessário o estudo da distribuição das tensões de compressão nas seções, por isso é muito importante a definição do diagrama $\sigma_{\mathrm{c}} \mathrm{x} \varepsilon_{\mathrm{c}}$. Neste trabalho são adotadas as curvas do CEB Bulletin 228 (1995), FIB (1999) e do EUROCODE 2 (2004), modificando suas expressões quando necessário. As expressões das três normas são muito similares e seus modelos são realistas que provem de estudos experimentais. Com a diferença que o EUROCODE 2 mostra as expressões para as deformações específicas últimas, mas não define o comportamento pós-critico necessário para o cálculo das tensões de confinamento. As equações do FIB (1999) são válidas até a deformação correspondente a $50 \%$ da tensão máxima no ramo descendente do diagrama $\sigma_{\mathrm{c}} \times \varepsilon_{\mathrm{c}}$ e o CEB Bulletin 228 
(1995) apresenta uma expressão que atende todo o ramo descendente da curva, sendo esta última adequada para complementar o modelo do confinamento.

Como anteriormente comentado o comportamento do CAR é frágil e uma das maneiras de melhorar este comportamento é considerar o confinamento imposto pela armadura transversal, é o tema a ser revisto no próximo capítulo. 


\section{Capítulo 3}

\section{MODELOS DE CONCRETO DE ALTA RESISTÊNCIA CONFINADO}

\subsection{ANÁLISE DO CONFINAMENTO}

O problema de estruturas construídas com CAR é sua fragilidade quando comprimida e quando é comparada com o comportamento de estruturas moldadas com concreto convencional, por causa da diferença na composição interna de ambos os concretos. A rigidez da pasta do CAR pode ser igual ou maior que a do agregado, logo, na interface entre os agregados e pasta a presença de fissuras é menor.

A formação dos planos de fissuras que contornam os agregados e ocorre desde o inicio da aplicação da força nos concretos convencionais, no CAR começa a surgir para uma força aproximadamente igual a $80 \%$ a $90 \%$ da resistência última, por isso obtém-se uma parte ascendente do diagrama tensão-deformação específica $\left(\begin{array}{llll}\sigma_{\mathrm{c}} & \mathrm{x} & \varepsilon_{\mathrm{c}}\end{array}\right)$ mais linear. No CAR a formação do plano de fissuras compreende também a ruptura dos agregados graúdos, a redistribuição de tensões após o pico quase não existe, por isso sua ruptura é repentina, e, a parte descendente do diagrama $\sigma_{\mathrm{c}} \mathrm{x} \varepsilon_{\mathrm{c}}$ é quase vertical, sendo mais acentuada para concretos de maior resistência (ver Fig. 2.11, Fig. 6.2, e Fig. 6.3).

Um dos fatores que melhora a fragilidade do concreto comprimido é o confinamento do elemento estrutural, que na prática pode ser obtido pela presença de armadura transversal, o que significa aumentar a capacidade resistente do elemento estrutural suportando maiores deformações antes da ruína. O confinamento é obtido quando os estribos estão pouco espaçados e adequadamente distribuídos e com taxas volumétricas elevadas. 
Quando a intensidade da forças axial é pequena a armadura transversal está pouco solicitada, ou quando a intensidade da força é relativamente elevada e a taxa da armadura transversal é pequena, o comportamento do concreto confinado é semelhante ao do não confinado. Para que o concreto comprimido esteja efetivamente confinado a tensão deve estar perto da resistência máxima à compressão, nesta situação as deformações laterais são muito elevadas por causa do intenso estado de fissuração e o concreto se apóia na armadura transversal a qual aplica uma reação ao concreto, retardando a ruína do elemento estrutural, por meio do controle de sua expansão lateral (Park e Paulay, 1996). No caso do CAR, perto da resistência máxima apresenta uma menor expansão lateral, por causa da menor fissuração interna, assim como a armadura transversal somente é solicitada para valores elevados de deformações, diminui a eficiência do confinamento, logo para os concretos convencionais é necessária uma taxa de armadura transversal menor para atingir um mesmo grau de ductilidade de um CAR.

\subsection{COMPORTAMENTO DO CONCRETO SOB ESTADOS MÚLTIPLOS DE TENSÃO}

Em muitas estruturas o concreto está sujeito a tensões em varias direções. De acordo com Oliveira (2001), as formas da superfície elástica e de ruptura do concreto no espaço das tensões principais estão bem definidas, Fig. 3.1, na qual considera-se um comportamento elástico linear do concreto até o início da plastificação. A partir desse limite o concreto apresenta propriedades de encruamento até que se atinja a ruptura que deve ser seguida por um ramo de amolecimento para os estados de tração e para os estados compressivos a capacidade última é estabelecida pela ruptura do concreto em virtude do estado de deformação plástica excessiva.

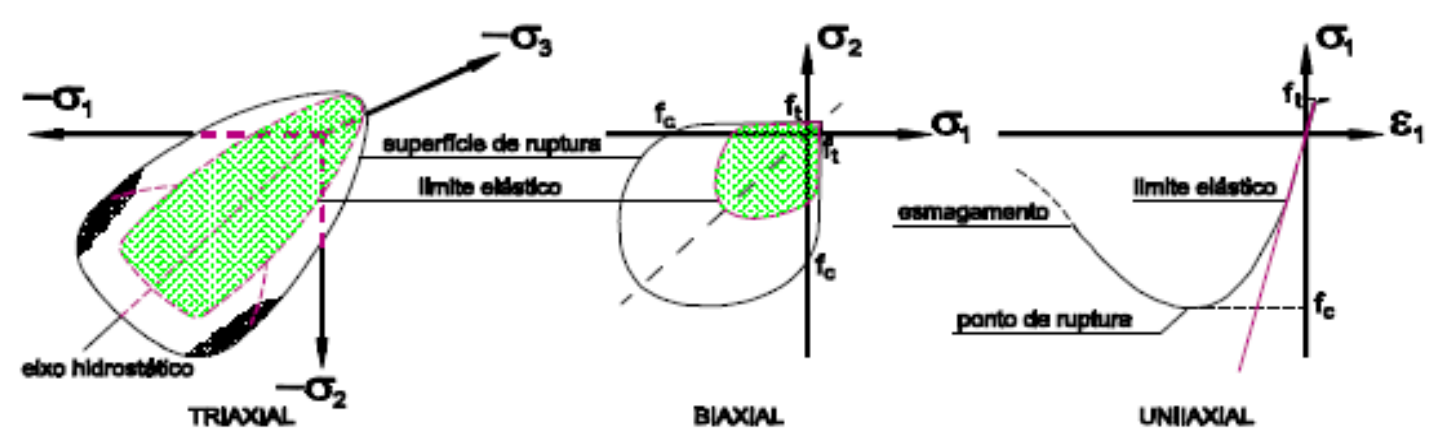

Fig. 3.1 - Superfícies de plastificação e de ruptura. (Oliveira, 2001). 
A Fig. 3.2 mostra a curva da envoltória da resistência biaxial do concreto (a linha tracejada corresponde a um eixo de simetria).

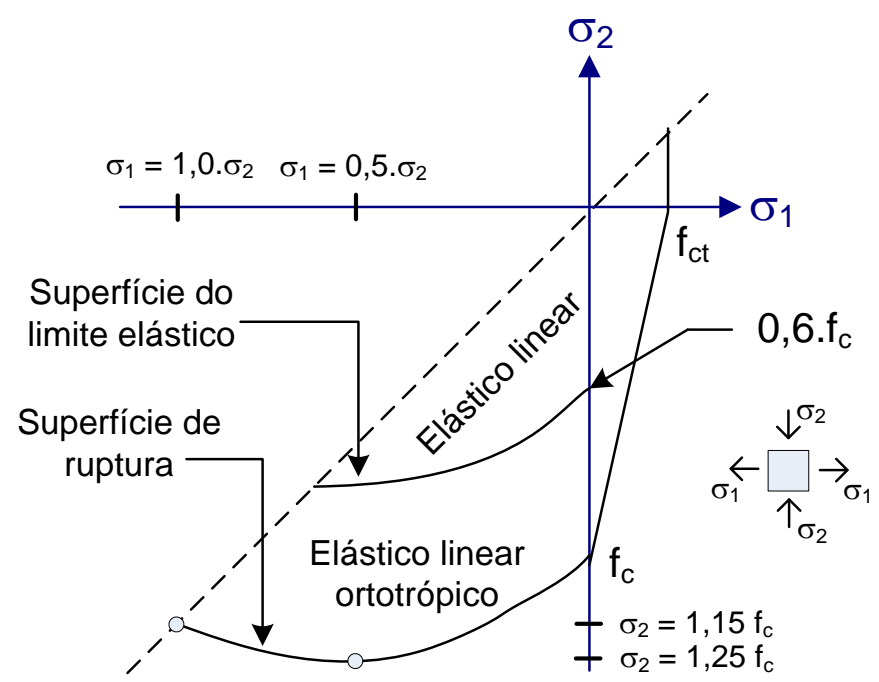

Fig. 3.2 - Curva da resistência biaxial do concreto. (adaptada de Kwak e Filippou, 1990).

Por exemplo, no estado biaxial de tensões de tensões principais, sendo que $\sigma_{1}$ e $\sigma_{2}$ são a maior e a menor tensão principal: quando $\sigma_{1} / \sigma_{2}$ está próxima de 0,5 ocorre um ganho de resistência, que pode representar um acréscimo superior a $25 \%$ em relação a resistência uniaxial do concreto à compressão $\mathrm{f}_{\mathrm{c}}\left(\right.$ Chen, 1982 e Fig. 3.2), quando $\sigma_{1} / \sigma_{2}$ está próximo de 1,0 o incremento pode ser de um $15 \%$ sobre $f_{c}$ (ver Fig. 3.2). Pela Fig. 3.2 é possível observar que para combinação de tensões de tração e compressão há uma diminuição da resistência quase linear com o incremento da tensão principal maior (de tração). Para ambas as superfícies (superfície do limite elástico e superfície de ruptura) Kupfer et al. ${ }^{3}$ apud Kwak e Filippou (1990) descrevem as expressões das superfícies pela expressão:

$$
\frac{\left(\sigma_{1}+\sigma_{2}\right)^{2}}{\sigma_{2}+3,65 \times \sigma_{1}}-A \times f_{c}=0
$$

Sendo que:

A é um parâmetro que define o tipo de superfície limite (1,0 para superfície de ruptura e 0,6 para a superfície do limite elástico).

A ABNT NBR 6118:2003 indica que quando o concreto está sujeito a um estado múltiplo de tensões principais e $\sigma_{1}>\sigma_{2}>\sigma_{3}$, para não ocorrer ruptura deve-se ter $\sigma_{1} \leq \mathrm{f}_{\mathrm{ct}, \mathrm{k}} \mathrm{e}$ $\sigma_{3} \geq-\left(f_{c k}+4 . \sigma_{1}\right)$ (ver Fig.3.3), sendo que $f_{c k}$ e $f_{c t, k}$ as resistências características do concreto aos 28 dias de compressão e tração respectivamente, ambas resistências com sinal positivo.

\footnotetext{
${ }^{3}$ Kupfer, H.; Hilsdorf, H.K. e Rüsch, H. (1969). Behavior of Concrete under Biaxial Stresses. ACl Journal, Vol. 65, No 6, PP. 656-667.
} 


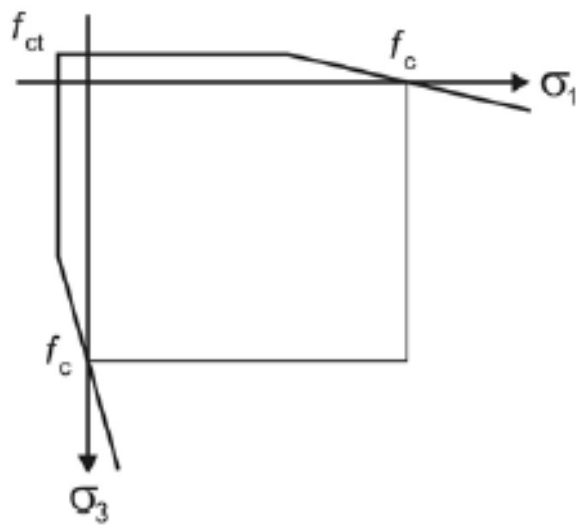

Fig. 3.3 - Resistência do concreto no estado múltiplo de tensão (ABNT NBR 6118:2003).

Algumas outras normas apresentam expressões em função da combinação de tensões.

Em planos distintos aos principais, as tensões normais $\sigma$ estão acompanhadas por tensões tangenciais $\tau$. Para materiais como o concreto a Teoria de Mörh-Coulumb tem sido empregada para este caso de tensões combinadas (ver Fig. 3.4), sendo que nesta teoria a linha de ruína corresponde à ruptura do material, e sua expressão é: $|\tau|=c-\sigma \times \tan \phi$. Logo os parâmetros procurados são a coesão do concreto c e o ângulo de atrito das partículas do material ф. A Fig. 3.4 define esses parâmetros.

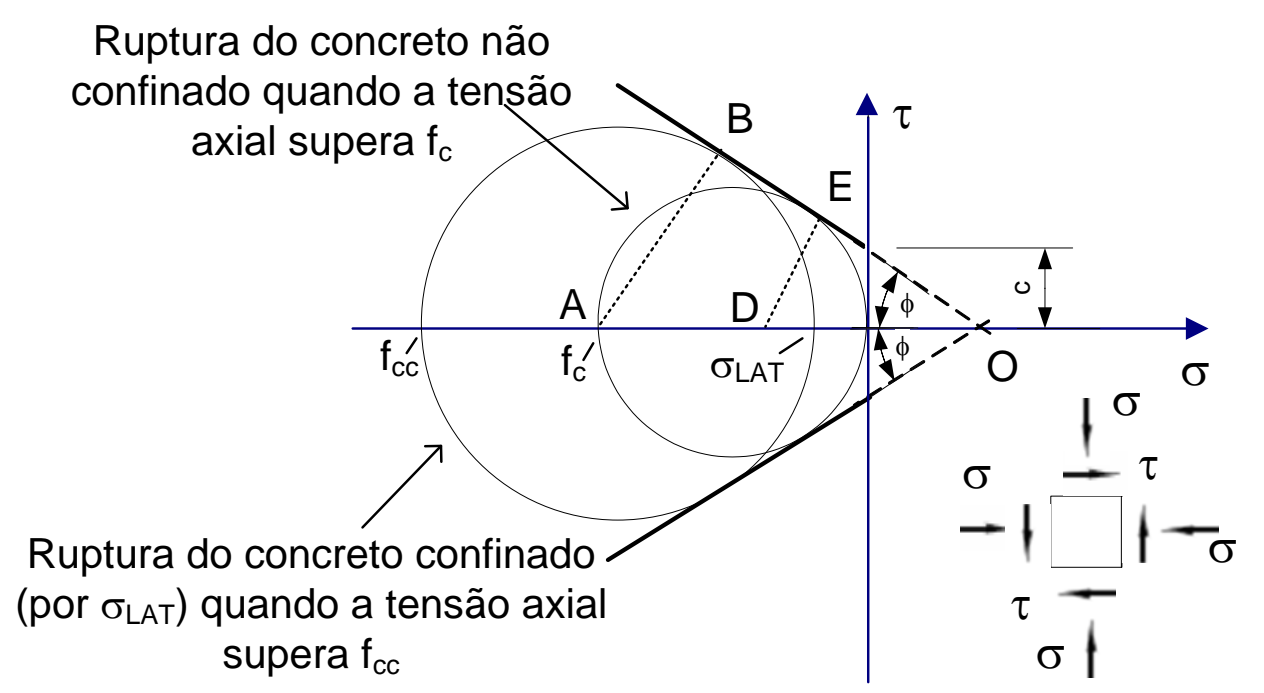

Fig. 3.4 - Círculos de Mörh-Coulomb na iminente ruptura do material (Adaptado de Carrazedo, 2002).

Equacionando a envoltória do critério de Mörh-Coulomb em termos das tensões principais, que neste caso podem ser: a pressão lateral de confinamento $\sigma_{\mathrm{LAT}}$, a resistência do concreto confiando $f_{c c}$ e a resistência do concreto não confinado $f_{c}$, obtêm-se (ver Fig. 3.4): 


$$
f_{c c}=f_{c}+\left[\frac{(1+\operatorname{sen} \phi)}{(1-\operatorname{sen} \phi)}\right] \times \sigma_{L A T}
$$

Sendo que $\phi$ é o ângulo de atrito interno do concreto que pode ser adotado como $37^{\circ}$ para o CAR (Guray, 2007). Substituindo $\phi$ na Eq. 3.2 obtêm-se a Eq. 3.3 proposta por Richard et al. ${ }^{4}$ apud, Cusson e Paultre (1995).

Na Fig. 3.5 mostra-se uma curva de ruptura para elementos com tensão normal em uma direção combinada com tensão tangencial. A resistência à compressão do concreto diminui na presença da tensão tangencial. Isto ocorre em uma região comprimida de viga ou pilar onde existe também ação de força cortante.

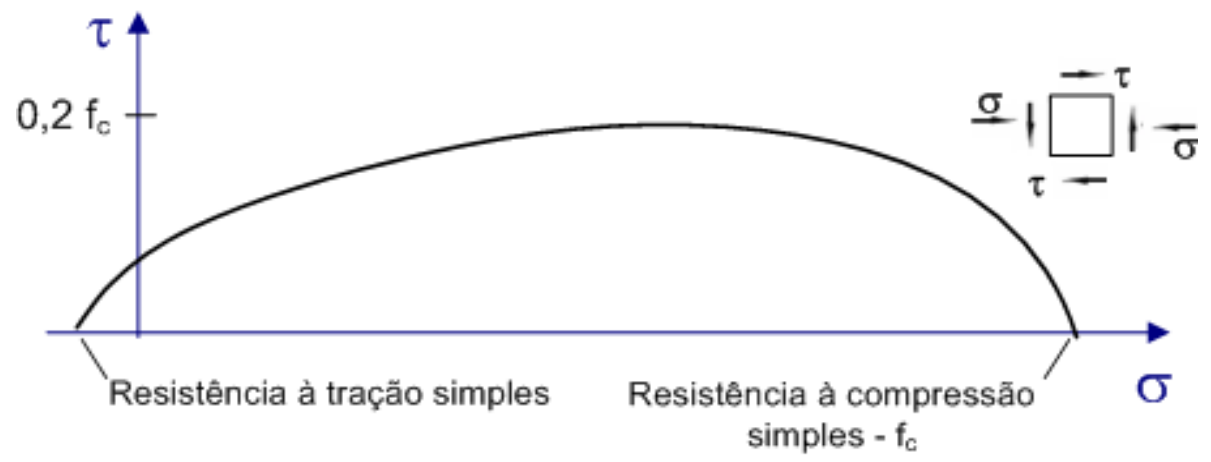

Fig. 3.5 - Ruptura do concreto sob combinação de tensões tangenciais e tensões normais (Park e Paulay, 1996).

A resistência e a ductilidade do concreto incrementam consideravelmente sob condições de compressão triaxial. Richard et al. (op. cit.), ensaiaram cilindros de concreto sob força axial até a ruptura junto com uma pressão lateral constante de confinamento provocado por um fluido, encontrando a seguinte relação (Eq. 3.3) para a resistência dos cilindros:

$$
f_{c c}=f_{c}+4,1 \times \sigma_{L A T}
$$

O conceito de confinamento é relativamente simples, ao considerar o concreto dentro de um tubo de aço e sendo solicitado por uma pressão vertical $\sigma_{\mathrm{cv}}$, este sofre um encurtamento longitudinal e um alongamento transversal que é parcial ou totalmente impedido, provocando uma reação $\sigma_{\mathrm{LAT}}$ que pode ser chamada de pressão de confinamento, que é o mesmo efeito da pressão lateral constante exercida por um fluido nos ensaios de Richard et al. (op. cit.). Em função disso aparece um estado triplo de tensões e a resistência vertical $\mathrm{f}_{\mathrm{cc}}$ pode aumentar muito além da resistência do concreto não confinado. A Eq. 3.3

\footnotetext{
${ }^{4}$ Richard, F. E.; Brandtzaeg, A. and Brown, R. L. (1928). A study of the failure of concrete under combined compressive stresses. Bull. No 185, Engineering Experimental Station, University of Illinois, Urbana, III.
} 
mostra este incremento máximo. Foi verificado que a Eq. 3.3 é válida para pressões de confinamento menores a 15\% da resistência do concreto (Attard e Setunge, 1996).

Para pressões de confinamento maiores do que $15 \%$ da resistência do concreto a relação é mais bem expressa por uma equação não linear e para confinamento passivo costuma-se utilizar a tensão de confinamento efetiva que é a atuante entre os estribos (Ansari e Li, 1998), assim tem-se a Eq. 3.4:

$$
\sigma_{L A T_{-} e}=K_{e} \times \sigma_{L A T}=K_{v} \times K_{h} \times \sigma_{L A T}
$$

Sendo que: $K_{e}$ é o coeficiente de confinamento efetivo, $K_{v}$ e $K_{h}$ representam o efeito do arco vertical e horizontal respectivamente (Fig. 3.9).

Os pilares circulares com armadura transversal formada por espirais se assemelham muito a um cilindro de concreto envolto por um tubo de aço de parede fina. Para pilares retangulares o confinamento pode ser obtido por meio de armadura transversal com pequenos espaçamentos. Outra maneira de confinar o concreto é com tubos de aço, mas se são de parede fina podem estar sujeitos a flambagem localizada além de ter coeficientes de Poisson diferentes e a probabilidade de se ter expansões diferentes dos materiais retardando o confinamento, também os tubos de aço apresentam um alto custo de manutenção. Outros materiais que poderiam ser empregados como confinantes são as mantas de fibras de carbono ou fibras de vidro (materiais compósitos formados pela combinação de fibras de alta resistência com uma matriz de resina polimérica), mas, são mais empregados em reforço de estruturas (Machado, 2002).

Para elementos uniaxiais como vigas e pilares, é suficiente o emprego das relações constitutivas uniaxiais para representação do comportamento mecânico dos materiais, considerando o efeito do confinamento.

\subsection{HISTÓRICO DAS INVESTIGAÇÕES}

Em diferentes países muitas investigações foram realizadas nas últimas décadas com pilares de concreto de alta resistência, que propiciaram melhor entendimento do comportamento do diagrama $\sigma_{\mathrm{c}} \times \varepsilon_{\mathrm{c}}$ do CAR confinado, visando principalmente aumentar a capacidade de deformação.

\subsubsection{Pilares sujeitos à compressão centrada}

Os primeiros estudos do confinamento no concreto foram realizados por Richart et al. (op. cit.). Sheikh e Uzumeri (1982) citam que em pesquisas anteriores não foram consideradas 
a distribuição, quantidade e as propriedades mecânicas das armaduras longitudinais e transversais. Estes mesmos autores construíram um modelo no qual o confinamento era incorporado por meio de um coeficiente $\left(\mathrm{k}_{\mathrm{s}}\right.$ da Fig. 3.6) que modifica a tensão máxima e incorpora à relação $\sigma_{c} \times \varepsilon_{c}$ do concreto não confinado, a relação proposta mostra-se graficamente na Fig. 3.6.

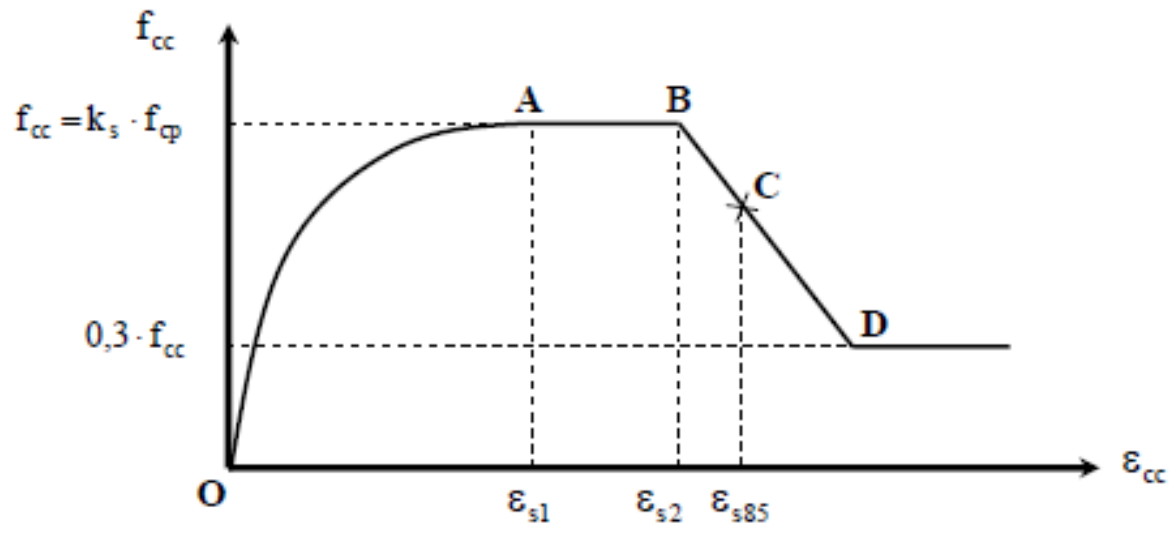

Fig. 3.6 - Modelo de concreto confinado proposto por Sheikh e Uzumeri (1982).

A Fig. 3.7 mostra outros modelos anteriores ao de Sheikh e Uzumeri (1982).

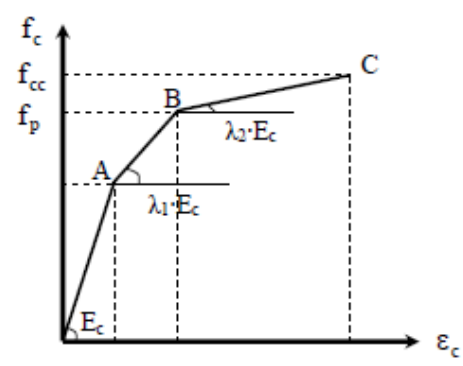

a)

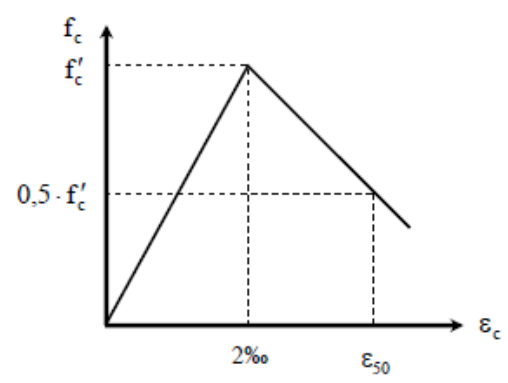

b)

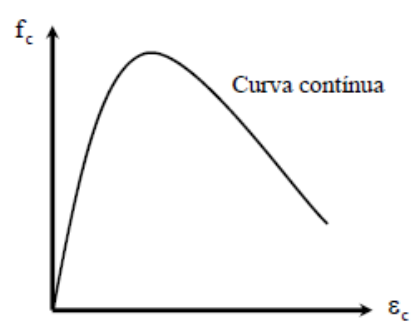

c)

Fig. 3.7 - O a) é modelo de Chan, o b) de Roy e Sozen e o c) de Sargin. (Adaptada de Lima Jr., 2003).

Todos os modelos anteriores têm diferentes características, mas, em todos eles o trecho ascendente corresponde ao concreto não confinado. A Fig. 3.7 a) é um modelo tri linear (ano 1955), na Fig. 3.7 b) o autor sugere a substituição da parte descendente por uma reta que passa pela deformação correspondente a $0,5 f_{c}$ (proposta no ano de 1964) e o modelo da Fig. 3.7 c) adota uma curva contínua (proposta no ano de 1971). Todas elas consideram a quantia da armadura transversal e sua tensão de escoamento (Park e Paulay, 1996).

$\mathrm{Na}$ década de 90 começaram a ser realizados ensaios de pilares com CAR, considerando, entre outros problemas, a perda prematura do cobrimento, mas, os modelos de concreto convencional serviram de base para as novas formulações dos modelos de CAR. Das 
muitas pesquisas serão citadas algumas e detalhados os modelos a serem incorporados no presente trabalho.

Yong et al. (1989) ensaiaram 24 pilares curtos quadrados de concreto com resistências entre $84 \mathrm{MPa}$ a $94 \mathrm{MPa}$, confinados por estribos de tensão de escoamento de $496 \mathrm{MPa}$ e em função a seus resultados propuseram uma curva $\sigma_{\mathrm{c}} \times \varepsilon_{\mathrm{c}}$ formada por três partes, em sua pesquisa obtiveram parâmetros da taxa volumétrica de armadura transversal, cobrimento da armadura e distribuição da armadura longitudinal ao longo do seu perímetro.

Cusson e Paultre (1994) ensaiaram 30 pilares curtos de 23,5 cm x 23,5 cm e uma altura de $140 \mathrm{~cm}$. A resistência do concreto à compressão estava entre $60 \mathrm{MPa}$ e $120 \mathrm{MPa}$ e a resistência de escoamento da armadura transversal entre $400 \mathrm{MPa}$ a $800 \mathrm{MPa}$. Os parâmetros estudados eram o cobrimento, forma dos ganchos, taxa volumétrica de armadura transversal, taxa e distribuição da armadura longitudinal. Para a obtenção da resistência do concreto foram ensaiados cilindros e prismas, sendo que os últimos apresentavam uma resistência, em média $12 \%$ menor. Em algumas amostras ensaiadas os estribos escoaram. Os pesquisadores observaram um destacamento súbito do cobrimento, mas depois do destacamento o núcleo apresentou importantes ganhos de resistência e ductilidade em amostras bem confinadas.

Verificaram que o incremento na resistência do núcleo do concreto de aproximadamente $70 \%$ resultou num incremento da tensão lateral de confinamento em aproximadamente $25 \%$. O aumento da resistência de escoamento da armadura transversal não resultou em ganhos de resistência relativa de confinamento.

Cusson e Paultre (1995) apresentaram um estudo bastante detalhado do confinamento com os resultados que obtiveram nos ensaios apresentados em Cusson e Paultre (1994). Entre as conclusões a que chegaram classificaram o confinamento em função de um índice efetivo de confinamento (Eq. 3.5).

$$
I_{e}=\frac{\sigma_{L A T_{-} e}}{f_{c}}
$$

Sendo que:

$\sigma_{\text {LAT_e }}$ é a pressão lateral de confinamento efetivo atuando numa seção entre estribos no núcleo nominal do concreto.

Em função do valor de $I_{e}$, tem-se:

Pequeno grau de confinamento para $\mathrm{I}_{\mathrm{e}}<5 \%$, mediano grau de confinamento para $5 \%$ $<\mathrm{I}_{\mathrm{e}}<20 \%$ e alto grau de confinamento para $\mathrm{I}_{\mathrm{e}}>20 \%$. Segundo estes pesquisadores para um pequeno grau de confinamento o núcleo do concreto não incrementa a resistência e têm um 
pequeno ganho na ductilidade e sugerem que este tipo de confinamento deve ser somente empregado em regiões não sísmicas. O pilar com armaduras longitudinais nos 4 cantos recai neste tipo de confinamento.

$\mathrm{O} \mathrm{I}_{\mathrm{e}}$ é função da tensão de trabalho da armadura transversal, que é obtida mediante interações (não é em função da tensão de escoamento).

A Fig. 3.8, ilustra graficamente o modelo proposto por Cusson e Paultre (1995) com duas curvas, uma do CAR não confinado, e a outra do CAR confinado, o ramo descendente foi ajustado para que passe pelo ponto $\left(\varepsilon_{\mathrm{cc} \_50}, 0,5 \mathrm{f}_{\mathrm{cc}}\right)$, sendo $\varepsilon_{\mathrm{cc} \_50}$ a deformação específica no ramo descendente da curva correspondente a $50 \%$ do valor da resistência máxima confinada. $\mathrm{O}$ valor de $\varepsilon_{\mathrm{cc} \_50}$ depende da deformação específica do concreto não confinado $\varepsilon_{\mathrm{c} \_50}$, com o mesmo significado.

Em concretos com armadura longitudinal e transversal, adequadamente dispostas, o ganho de resistência pode incrementar em até $100 \%$ e a ductilidade pode ficar em até 20 vezes maior que em elementos de concreto não confinado (Cusson e Paultre, 1995).

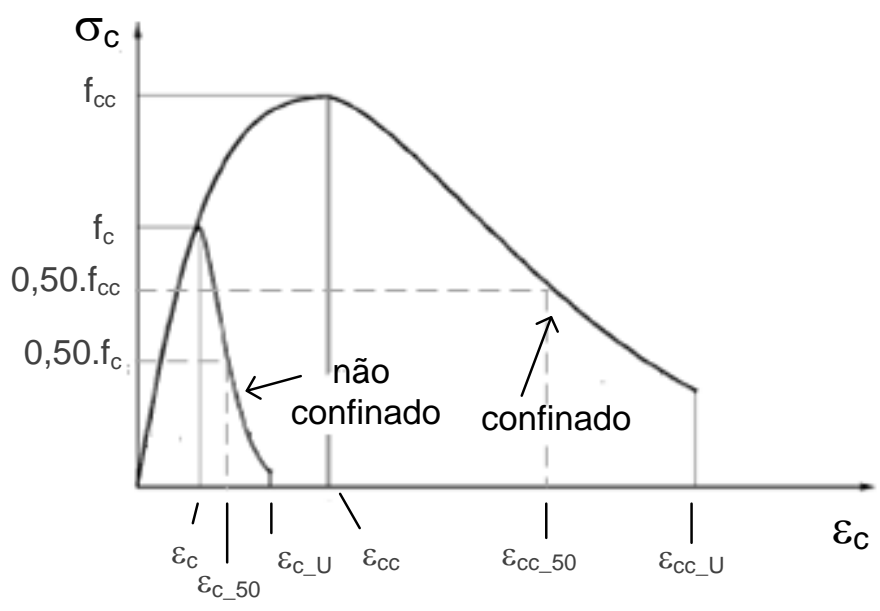

Fig. 3.8 - Curva $\sigma_{\mathrm{c}} \mathrm{x} \varepsilon_{\mathrm{c}}$ proposta para um CAR confinado por Cusson e Paultre (1995).

Na Fig. 3.9 a) pode-se observar uma armadura transversal pouco eficiente e na Fig. 3.9 b) muito mais efetiva. Nessa mesma figura observa-se a ação de arco, e como a pressão lateral nominal desenvolve completamente na região dos estribos. 


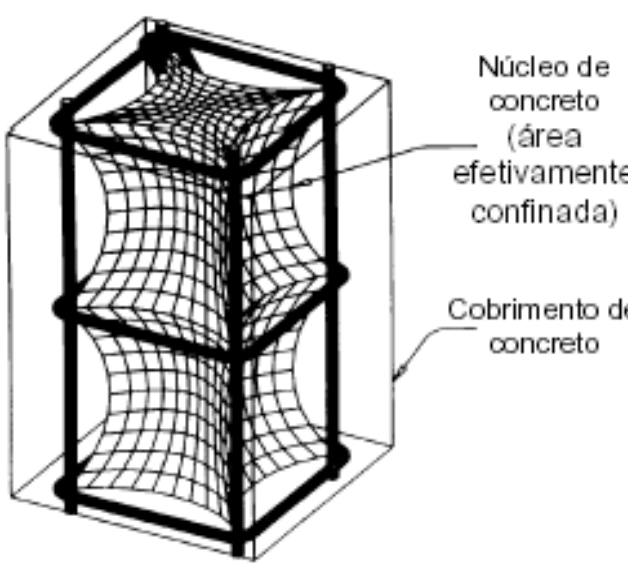

(a)

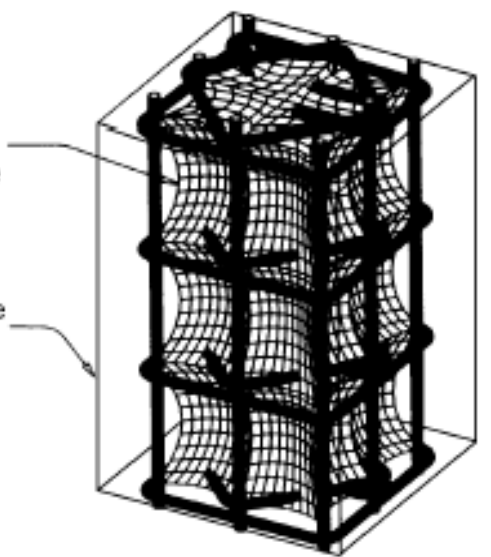

(b)

Fig. 3.9 - Distribuição das tensões de confinamento ao longo do pilar, (Cusson e Paultre, 1994).

Razvi e Saaticioglu ${ }^{5}$ (1996) apud, Yalcin e Saatcioglu (2000) demonstraram que para considerar o CAR certas modificações seriam necessárias no modelo de confinamento proposto anteriormente pelos mesmos autores em 1992. Nesse trabalho Saaticioglu e Razvi (1992) construíram uma curva para concretos convencionais confinados e o ramo descendente linear e foi ajustado para que passe pelo ponto $\left(\varepsilon_{\mathrm{cc} \_85}, 0,85 f_{\mathrm{cc}}\right)$, a Fig. 3.10 mostra esta curva. A Fig. 3.11 mostra o esquema espacial da pressão lateral confinante, também o espaçamento entre estribos $\mathrm{s}_{\mathrm{e}} \mathrm{e}$ as distancias entre as barras da armadura longitudinal efetivamente contidas por estribos $\mathrm{s}_{b}$, estes são os dados necessários para avaliar a eficiência do confinamento por meio do parâmetro k2. Razvi e Saaticioglu, 1996 (op. cit.) obtiveram para pilares de seção quadrada um novo valor simplificado (Eq. 3.6) para o $\mathrm{k}_{2}$.

$$
k_{2}=0,15 \times \sqrt{\frac{(n c)^{2}}{s_{e} \times s_{l}}} \leq 1
$$

Sendo que:

nc é a dimensão do núcleo da seção medida entre centros de estribos mais externos.

Para considerar a tensão lateral confinante efetiva $\sigma_{L_{A A T} e}=k_{2} \times \sigma_{\text {LAT }}$ em pilares de seção retangular é necessário ponderar o confinamento em ambas as direções, assim:

$$
\sigma_{L A T_{-} e}=\frac{\sigma_{L A T_{-} e x} \times n c_{x}+\sigma_{L A T_{-} e y} \times n c_{y}}{n c_{x}+n c_{y}}
$$

Na Eq. 3.7:

\footnotetext{
${ }^{5}$ Razvi, S. and Saaticioglu, M. (1996). Design of RC columns for confinement based on lateral drift. Department of Civil Engineering. University of Ottawa, Report No OCEERC 96-02, 1996. 92 p.
} 
$\mathrm{nc}_{\mathrm{x}}$ e $\mathrm{nc}_{\mathrm{y}}$ são as dimensões do núcleo do pilar nas direções $\mathrm{x}$ e y (entre eixos dos estribos mais externos);

$\sigma_{\text {LAT_ex }}$ e $\sigma_{\text {LAT_ey }}$ são as tensões laterais confinantes efetivas nas direções x e y, obtidas por meio dos parâmetros $\mathrm{k}_{2 \mathrm{x}}$ e $\mathrm{k}_{2 \mathrm{y}}$ da Eq. 3.6, substituindo $\mathrm{nc}$ por $\mathrm{nc}_{\mathrm{x}}$ e $\mathrm{nc}_{\mathrm{y}}$ para cada direção e considerando as áreas das armaduras transversais nas direções x e y no cálculo de $\sigma_{\text {LAT_x }}$ e $\sigma_{L_{A A}}$ (ver Fig. 3.11).

A resistência $f_{c c}$ foi obtida considerando a pressão lateral de confinamento equivalente e não com a distribuição variável (Fig. 3.11).

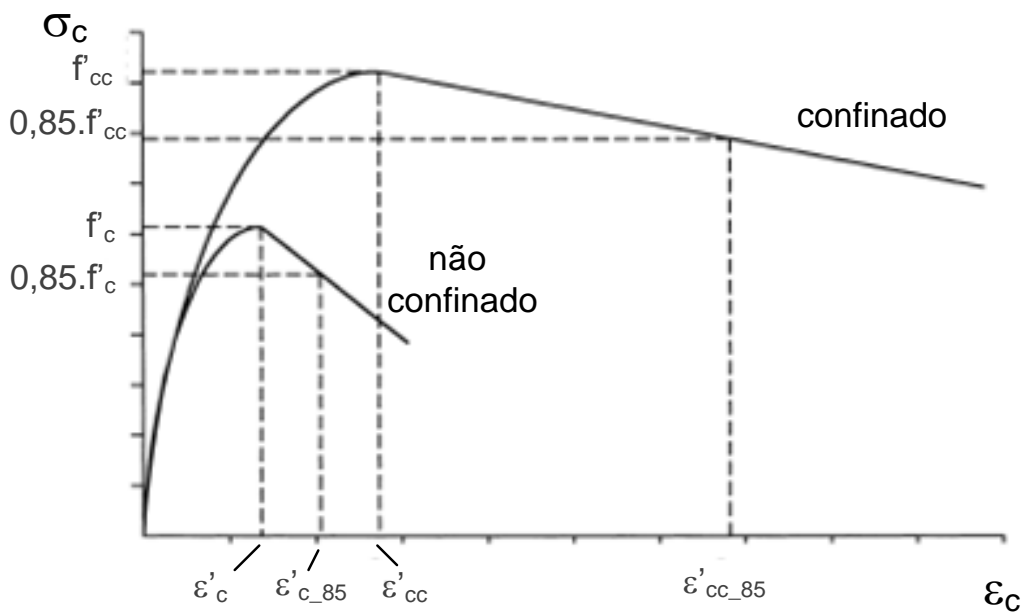

Fig. 3.10 - Curva $\sigma_{\mathrm{c}}$ x $\varepsilon_{\mathrm{c}}$ proposta por Saatcioglu e Razvi (1992).
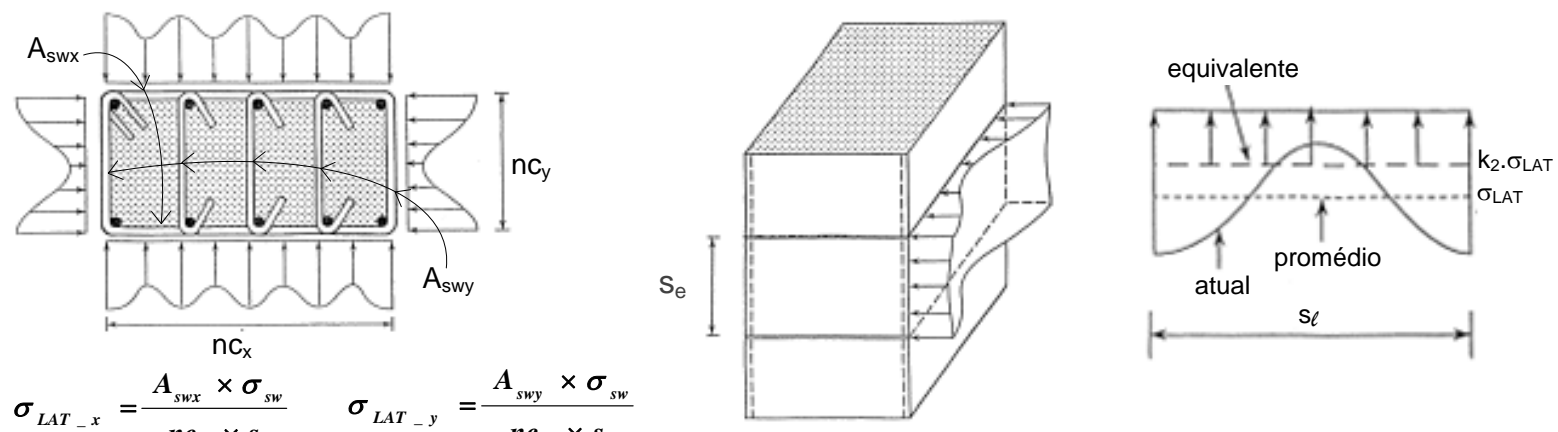

$\sigma_{L A T_{-} x}=\frac{\boldsymbol{A}_{s w x} \times \sigma_{s w}}{n c_{y} \times s_{e}} \quad \sigma_{L A T_{-} y}=\frac{\boldsymbol{A}_{s w y} \times \sigma_{s w}}{n c_{x} \times s_{e}}$

Fig. 3.11 - Distribuição das pressões laterais (Saatcioglu e Razvi, 1992).

Posteriormente, Saatcioglu e Razvi (1998), durante a pesquisa de pós-doutorado de Saatcioglu, fizeram ensaios em pilares de CAR e observaram que quanto maior a resistência do concreto maior é a necessidade do confinamento para melhorar a ductilidade, que poderia ser obtida aumentando-se a taxa de armadura transversal ou a resistência de escoamento do aço. Obtiveram uma relação adequada para dimensionamento de pilares confinados de CAR (Eq. 3.8). 


$$
\left(\frac{k_{2} \times \rho_{s w} \times f_{y w}}{f_{c}^{\prime}}\right)_{\min } \geq 0,07 \quad\left(\frac{k_{2} \times \rho_{s w} \times f_{y w}}{f_{c}^{\prime}}\right)_{\text {tipico }} \geq 0,1
$$

Sendo que:

$\mathrm{k}_{2}$ é coeficiente efetivo de confinamento (mesmo significado do $\mathrm{K}_{\mathrm{e}}$ da Eq. 3.4 do modelo de Cusson e Paultre, 1995);

$\rho_{\text {sw }}$ é a relação entre a taxa volumétrica da armadura transversal em relação ao volume do núcleo do concreto;

$\mathrm{f}_{\mathrm{yw}}$ é a resistência de escoamento da armadura transversal;

$\mathrm{f}^{\prime}{ }_{\mathrm{c}}$ é a resistência característica do concreto à compressão simples.

Razvi e Saatcioglu (1998) observaram inconsistências no modelo de Cusson e Paultre (1995) como: pequenas variações nos parâmetros de confinamento, parâmetros da armadura transversal (como seu módulo de elasticidade, Fig. 3.12) e do concreto simples, provocam grandes variações da tensão de trabalho da armadura transversal, variações na forma do diagrama $\sigma_{\mathrm{c}} \mathrm{x} \varepsilon_{\mathrm{c}}$ (Fig. 3.12), e outros. Estes autores verificaram que, quando a tensão de serviço da armadura transversal inicialmente adotada estava distante da tensão real, a convergência do processo interativo para o cálculo da tensão na armadura não produzia valores de tensão de serviço reais.

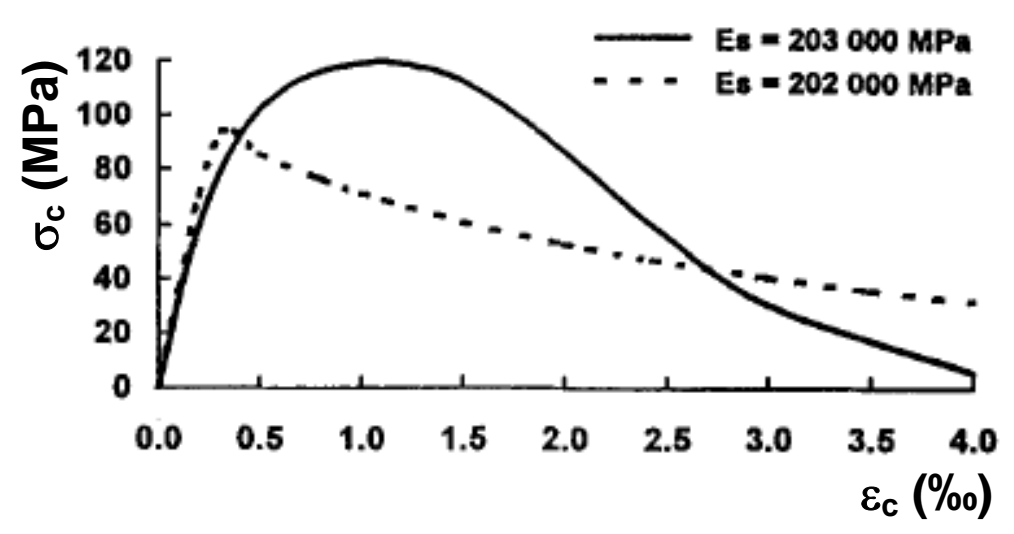

Fig. 3.12 - Curvas $\sigma_{\mathrm{c}} \mathrm{x} \varepsilon_{\mathrm{c}}$ propostas por Cusson e Paultre, 1995. (Razvi e Saatcioglu, 1998).

Yalin e Saatcioglu (2000) estudaram o modelo constitutivo para as armaduras longitudinais à compressão com o fenômeno da instabilidade e incorporaram no programa COLum Analysis (COLA) de sua autoria que considera além do fenômeno da instabilidade das armaduras comprimidas, os efeitos de $2^{\mathrm{a}}$ ordem físicos e geométricos, confinamento do concreto e a aderência entre concreto e armadura.

Foster (2001) demonstra que a fissuração na interface entre o núcleo e o cobrimento, que provoca o destacamento do cobrimento em pilares de CAR, é resultado do 
comportamento triaxial do núcleo do concreto. O fenômeno do destacamento prematuro do concreto provoca uma ruína antecipada do concreto do pilar (com tensões inferiores à resistência do concreto simples). Collins et al. (1993) consideram que o destacamento prematuro é em virtude da pequena permeabilidade do CAR, a retração do cobrimento em primeiro e depois a do núcleo produz um gradiente de tensões que provoca planos de ruptura responsáveis pelo fenômeno. Cusson e Paultre (1994) atribuem a um plano de preferencial de ruptura provocado pela densa quantidade de armadura transversal e longitudinal. Paultre et al. $(1996)^{6}$ apud, Aguiar e Pinheiro (2000) consideram o destacamento prematuro pode ser uma perda de instabilidade de uma chapa quando atuam forças elevadas que provocam diminuição na capacidade resistente do pilar comprimido, Fig. 3.13.
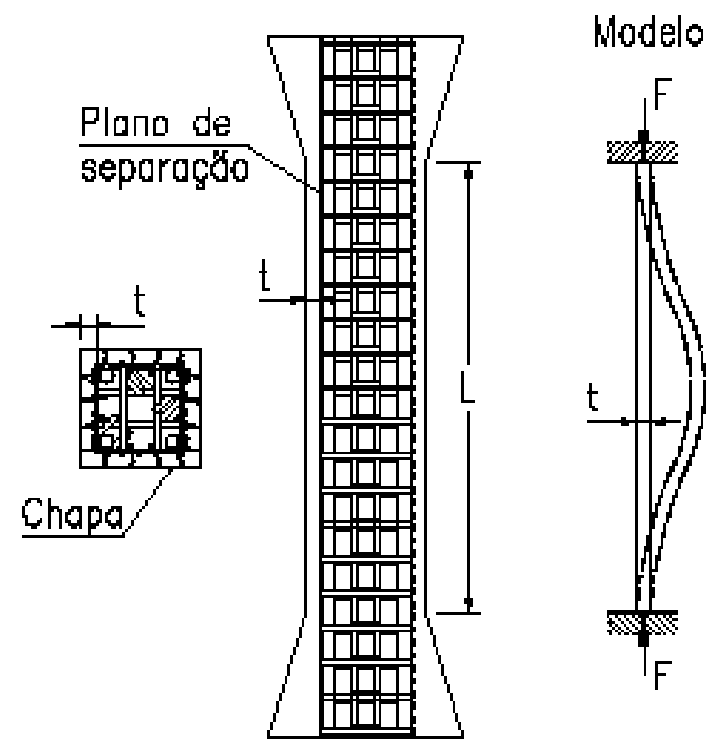

Fig. 3.13 - Destacamento do cobrimento da armadura, Paultre et al. (op. cit.).

A tensão crítica que provoca a instabilidade provem da equação de flambagem de chapas:

$$
\sigma_{c r}=\frac{\pi \times E_{c}}{3 \times\left(1-v^{2}\right)} \times\left(\frac{t}{L}\right)^{2}
$$

Sendo que:

$\mathrm{E}_{\mathrm{c}}$ é o modulo de deformação do concreto;

$v$ é o coeficiente de Poisson do concreto igual a 0,2 ;

t é a espessura do cobrimento;

\footnotetext{
${ }^{6}$ Paultre, P. et al. (1996). Structural Performance of Some Special Concretes. In: 4th International Symposium on the Utilization of High Performance Concrete, 1996. Proceedings...France.
} 
L é o comprimento da chapa e segundo Claeson ${ }^{7}$ apud, Aguiar e Pinheiro (2000) pode ser adotado como quatro vezes a menor dimensão do pilar.

Analisando a Eq. 3.9 observa-se que quanto maior a espessura do cobrimento maior será a força que provoca o destacamento do cobrimento, isto não foi observado por, Foster (2001) que analisou resultados de pilares retangulares sujeitos a forças centradas com variações da espessura do cobrimento.

Foster e Attard (2001) demonstram que com a adição de fibras ao concreto, este efeito pode ser minorado.

Li et al. (2001) ensaiaram pilares de concreto convencional e CAR de seções circulares e quadradas confinados com várias taxas de armaduras transversais, aplicaram forças axiais quase-estáticas e a resistência de escoamento da armadura transversal era de 430 $\mathrm{MPa}$ e $1300 \mathrm{MPa}$. Propuseram uma curva $\sigma_{\mathrm{c}}$ x $\varepsilon_{\mathrm{c}}$ para o concreto convencional e outra para o CAR, os resultados dos ensaios se aproximaram mais ao modelo que propuseram para armadura transversal com resistência de escoamento $\mathrm{f}_{\mathrm{yw}}<500 \mathrm{MPa}$. Entre suas propostas a deformação específica última do concreto confinado pode ser considerada como a correspondente à ruptura da armadura de confinamento. Em relação a espaçamentos mínimos entre armaduras, considerando o CAR, para evitar a flambagem da armadura longitudinal e um pequeno efeito de arco vertical no núcleo do concreto confinado propuseram como espaçamento máximo entre estribos: 4 vezes o diâmetro do estribo para resistências de escoamento de estribos menores a $430 \mathrm{MPa}$ e 5 vezes o diâmetro do estribo para maiores resistências, alem disso recomendaram uma quantidade mínima de 8 barras longitudinais distribuídas em todo o perímetro do núcleo.

Légeron e Paultre (2003) modificaram a curva $\sigma_{c} \times \varepsilon_{c}$ proposta inicialmente por Cusson e Paultre (1995), fundamentados na compatibilidade de deformações e o equilíbrio de forças transversais e pode ser empregado sem restrição em concretos de alta resistência confinados e armaduras transversais com uma elevada resistência de escoamento. O modelo pode ser empregado para situações de carregamentos cíclicos e pode ser adaptado para ocorrências sísmicas. O modelo de Cusson e Paultre (1995) foi considerado muito complexo, porque era necessário um procedimento iterativo para calcular a tensão atuante da armadura transversal, que podia provocar inconsistências nos seus resultados. No modelo de Légeron e Paultre (2003) foi eliminado o procedimento iterativo para o cálculo da tensão atuante da

\footnotetext{
${ }^{7}$ Claeson, C. (1998). Structural behavior of reinforced high-strength concrete columns. Göteborg. Thesis (PhD) - Chalmers University of Technology, 1998.
} 
armadura transversal. Seus resultados foram baseados em mais de 210 ensaios de pilares circulares e quadrados sob compressão centrada e 50 ensaios sob carregamento cíclico.

No Brasil várias universidades têm realizado pesquisas considerando o confinamento de pilares em concreto, entre os muitos se tem os de Paiva (1994) que pesquisou pilares de CAR à compressão simples confinados por armadura transversal com seção retangular de 8 $\mathrm{cm} \times 10 \mathrm{~cm}$ e de $8 \mathrm{~cm} \times 12$, todos os pilares com $48 \mathrm{~cm}$ de altura e espaçamento entre estribos de entre $2,5 \mathrm{~cm}$ a $4,7 \mathrm{~cm}$ que correspondiam a taxas volumétricas de $1,5 \%$ até $2,75 \%$, e observa que para concretos convencionais toda a seção participa como resistente e para o CAR verifica que o cobrimento não participa da seção resistente, conclui que o comportamento dos pilares de seção quadrada e retangular é o mesmo, e que o confinamento começa a ser eficiente para taxas de armadura transversal a partir de $2 \%$ e longitudinal de $3,2 \%$.

Rigazzo (2003) analisou incrementos de resistência de 8 pilares de concreto confinados por vários arranjos de polímeros de fibras de carbono, e verificou que existe um incremento significativo da capacidade resistente em seções circulares, mas os acréscimos de deformações longitudinais são grandes (da ordem de $1 \%$ a $2 \%$ ) e não poderia ser empregado este tipo de reforço em projetos e verifica outros arranjos de reforço como em laços; estes 2 últimos pesquisadores da Universidade Estadual de Campinas.

Moreira (2002) fez uma analise teórica do confinamento passivo em pilares circulares, quadrados e retangulares com armaduras transversais, tubos e polímeros com fibras de carbono e vidro, demonstra que a seção circular é a mais eficiente em relação ao incremento da resistência e ductilidade, aborda algumas expressões para seu cálculo e cita que não existem muitos estudos dos outros tipos de confinamento passivo; esta última da COPPE Universidade Federal de Rio de Janeiro.

A Escola de Engenharia de São Carlos - USP vem desenvolvendo pesquisas com pilares, considerando o efeito do confinamento passivo por armaduras transversais, com trabalhos realizados por Lima (1997) que ensaiou pilares de CAR à compressão centrada, de seção transversal quadrada de $20 \mathrm{~cm}$ x $20 \mathrm{~cm}$ e altura de $124 \mathrm{~cm}$ com estribos espaçados a cada $5 \mathrm{~cm}$ e $10 \mathrm{~cm}$ e retangulares de $15 \mathrm{~cm}$ x $30 \mathrm{~cm}$ e altura de $94 \mathrm{~cm}$ com estribos a cada 2,5 $\mathrm{cm}$ e $5 \mathrm{~cm}$, tendo concluído que a seção resistente era do núcleo e não a seção total, também observou que para melhorar a ductilidade é necessário incrementar a armadura longitudinal e que as taxas de armadura longitudinal e transversal podem ser menores que os sugeridos por Paiva(1994). 
Guimarães (1999) ensaiou pilares de CAR com fibras metálicas à compressão centrada, com seção transversal quadrada de $20 \mathrm{~cm}$ x $20 \mathrm{~cm}$ e altura de $120 \mathrm{~cm}$; verificou que existe um incremento na ductilidade ao incrementar a taxa de fibras e que as fibras contiveram o destacamento do cobrimento até antes da ruína dos pilares, a seção resistente do pilar correspondia ao núcleo.

Queiroga (1999) ensaiou à compressão simples pilares quadrados de $20 \mathrm{~cm}$ de lado e altura de $120 \mathrm{~cm}$ e retangulares de $15 \mathrm{~cm}$ x $30 \mathrm{~cm}$ e altura de $90 \mathrm{~cm}$ com estribos espaçados a cada $15 \mathrm{~cm}$, cada $10 \mathrm{~cm}$ e cada $5 \mathrm{~cm}$ e um concreto com resistência à compressão de $60 \mathrm{MPa}$ e obteve comportamentos dúcteis já para taxas de estribos de $0,51 \%$, mas considera que poderia melhorar com adequada distribuição da armadura transversal.

Ramos (2001) analisou pilares de seção quadrada de $20 \mathrm{~cm}$ x $20 \mathrm{~cm}$ e altura de $120 \mathrm{~cm}$ variando o espaçamento dos estribos entre $10 \mathrm{~cm}$ e $15 \mathrm{~cm}$ e retangulares de $15 \mathrm{~cm}$ x $30 \mathrm{~cm}$ e altura de $90 \mathrm{~cm}$ variando o espaçamento de estribos entre $7,5 \mathrm{~cm}$ até $15 \mathrm{~cm}$, indica que foi muito difícil obter a solicitação de compressão simples, verificou que não ocorre a formação do núcleo resistente porque este confinamento não excluiu o cobrimento da seção, mas os com maior taxa de estribos apresentam maior ductilidade, verificou também que os pilares de seção quadrada apresentaram maior ductilidade que os pilares de seção retangular

Lima Junior (2003) investigou pilares de CAR confinados com e sem adição de fibras metálicas sujeitos à compressão simples de $15 \mathrm{~cm} \mathrm{x} 15 \mathrm{~cm}$ e altura de $50 \mathrm{~cm}$ com espaçamento entre estribos a cada $5 \mathrm{~cm}$ e a cada $10 \mathrm{~cm}$, modificou o modelo de Cusson e Paultre (1995) para o emprego de fibras, verificou que houve influencia na ductilidade ao adicionar fibras no concreto.

Oliveira (2004-b) analisou a ductilidade de pilares de concreto de $40 \mathrm{MPa}$ sob compressão centrada, com seção transversal quadrada de $20 \mathrm{~cm}$ x $20 \mathrm{~cm}$ e altura de $120 \mathrm{~cm}$ e retangular de $15 \mathrm{~cm}$ x $30 \mathrm{~cm}$ e altura de $90 \mathrm{~cm}$, o espaçamento entre estribos entre 7,5 cm até $20 \mathrm{~cm}$ com diversas configurações de estribos. O pesquisador observou que não é possível obter uma situação de compressão centrada, e, apresenta um fator que modifica a resistência dos corpos-de-prova cilíndricos de $10 \mathrm{~cm}$ x $20 \mathrm{~cm}$ para transformar nos corpos-de-prova padrões de norma, variando com a resistência do concreto, houve uma melhora no índice de ductilidade com o incremento da taxa de armadura transversal e verificou que é necessário um incremento na taxa para concretos de maior resistência para uma mesma ductilidade.

Empregando outros mecanismos de confinamento como tubos metálicos ou mediante polímeros de fibras de carbono e vidro a Escola de Engenharia de São Carlos também têm realizando pesquisas com Nardin (1999) que ensaiou pilares mistos de aço sob compressão 
centrado preenchidos com concreto de $60 \mathrm{MPa}$, os tubos com seções circulares de $12,7 \mathrm{~cm} \mathrm{x}$ $12,7 \mathrm{~cm}$, quadradas de $15 \times 15 \mathrm{~cm}$ e retangulares de $10 \mathrm{~cm}$ x $20 \mathrm{~cm}$, a espessura das chapas dos tubos entre $3,0 \mathrm{~mm}$ e $6,3 \mathrm{~mm}$, todos os pilares com $120 \mathrm{~cm}$ de altura, mostra que para pilares sob flexo-compressão é necessário melhorar a aderência e não sendo preciso para o caso de pilares sob compressão simples, os pilares circulares apresentaram comportamento elasto-plástico perfeito, em relação à ductilidade verificou-se melhora ao incrementar a espessura da chapa dos tubos, para a seção retangular verificou-se menor ductilidade, em relação ao incremento da resistência do concreto confinado indica que não é necessário considerar este incremento por ser relativamente pequeno

Takeuti (1999) estudou reforço de pilares sujeitos à compressão centrada empregando CAR com fibras e confinando com armadura transversal, a seção dos pilares de referência de $15 \mathrm{~cm}$ x $15 \mathrm{~cm}$ e altura de $120 \mathrm{~cm}$ e espaçamento entre estribos de $10 \mathrm{~cm}$ e o reforço com tela eletrosoldada e estribos abertos, observou que o uso de maiores taxas de armadura transversal, proporciona melhor confinamento da parte interna da seção.

Carrazedo (2002) abordou o confinamento desenvolvido em pilares circulares e quadrados de concreto armado reforçado com polímeros de fibras de carbono, verificou que com uma camada de reforço da ordem de $0,5 \mathrm{~mm}$ de espessura obteve acréscimos da capacidade resistente de ao redor de 50\%, mesmo para os pilares com elevada taxa de armadura transversal obteve melhoras na resistência, os efeitos do confinamento podem ser avaliados por vários modelos, inclusive por Mörh-Coulomb, para os pilares de seção quadrada é necessário um raio de curvatura para arredondar as arestas e não ocorrer a ruptura do tecido.

Sudano (2005) estudou o efeito do confinamento em pilares sem armadura, com seções circulares de $20 \mathrm{~cm}$ de diâmetro, quadrada de $18 \mathrm{~cm}$ x $18 \mathrm{~cm}$, retangular de $13 \mathrm{~cm}$ x 13 $\mathrm{cm}$, elíptica e outra composta, todas elas com $60 \mathrm{~cm}$ de altura e sujeitas à compressão simples empregando para o confinamento polímeros de fibras de carbono e fibra de vidro, verificou que o reforço com fibra de vidro não produz resultados satisfatórios e que o diagrama tensão $x$ deformação específica do concreto com reforço de fibra de carbono é diferente e está composto por 4 trechos, também conclui que a forma da seção transversal influi na distribuição das pressões de confinamento.

Oliveira (2008) ensaiou 64 pilares mistos aço-concreto sob compressão centrada para seção circular com diâmetro de $11,4 \mathrm{~cm}$, diferentes resistências do concreto entre $30 \mathrm{MPa}$ e $100 \mathrm{MPa}$, diferentes esbeltezes do pilar e espessura da chapa do tubo, verificou que a ruina dependeu da esbeltez global e local dos pilares, sendo a ruina por instabilidade global para os 
pilares com maior esbeltez e por esmagamento do núcleo de concreto e flambagem local do tubo com um alto grau de ductilidade para os menos esbeltos.

\subsubsection{Pilares sujeitos à compressão excêntrica}

Sheikh e Uzumeri (1982), considerando um gradiente no diagrama de deformações específicas em virtude da flexo-compressão reta, observaram um incremento na ductilidade em pilares de concreto convencional e propuseram um modelo com resultados de ensaios a compressão simples e com esse modelo obtiveram o diagrama momento-curvatura com boas aproximações entre os resultados teóricos e experimentais.

Saatacioglu et al. (1995) ensaiaram pilares de concreto convencional e mostraram que o erro é pequeno quando é adotado o modelo de confinamento de compressão centrada para o maior gradiente de tensões de compressão simples no estudo do confinamento.

Lloyd e Rangan (1996) ensaiaram pilares esbeltos de CAR à flexo-compressão com armadura de confinamento com varias excentricidades e verificaram que os pilares com pouca excentricidade atingiam a ruína com pequena ductilidade e com perda repentina do cobrimento, o efeito do confinamento foi desprezível.

Paultre e Légeron (2008), apresentam novas equações para o cálculo das armaduras de confinamento em elementos estruturais de concreto que podem ter resistências acima de 120 MPa e armaduras com resistência de escoamento acima de $1400 \mathrm{MPa}$, para situações sísmicas em pilares circulares e retangulares considerando a ductilidade. Os resultados apresentados são em função de simulações numéricas muito parecidas aos ensaios de laboratório. Apresentam parâmetros de ductilidade em função do diagrama momento-curvatura. Proporcionam modelos simplificados que consideram situações de confinamento para o emprego nas normas. Os resultados estão baseados em um número elevado de ensaios de laboratório e em resultados de simulações numéricas empregando o programa MNPhi. Este programa divide a seção em faixas, as faixas correspondentes ao cobrimento como não confinado, as faixas do núcleo como confinado e as faixas das armaduras com suas respectivas propriedades mecânicas, conforme Fig. 3.14. O programa calcula o diagrama momento-curvatura considerando o destacamento do cobrimento. 


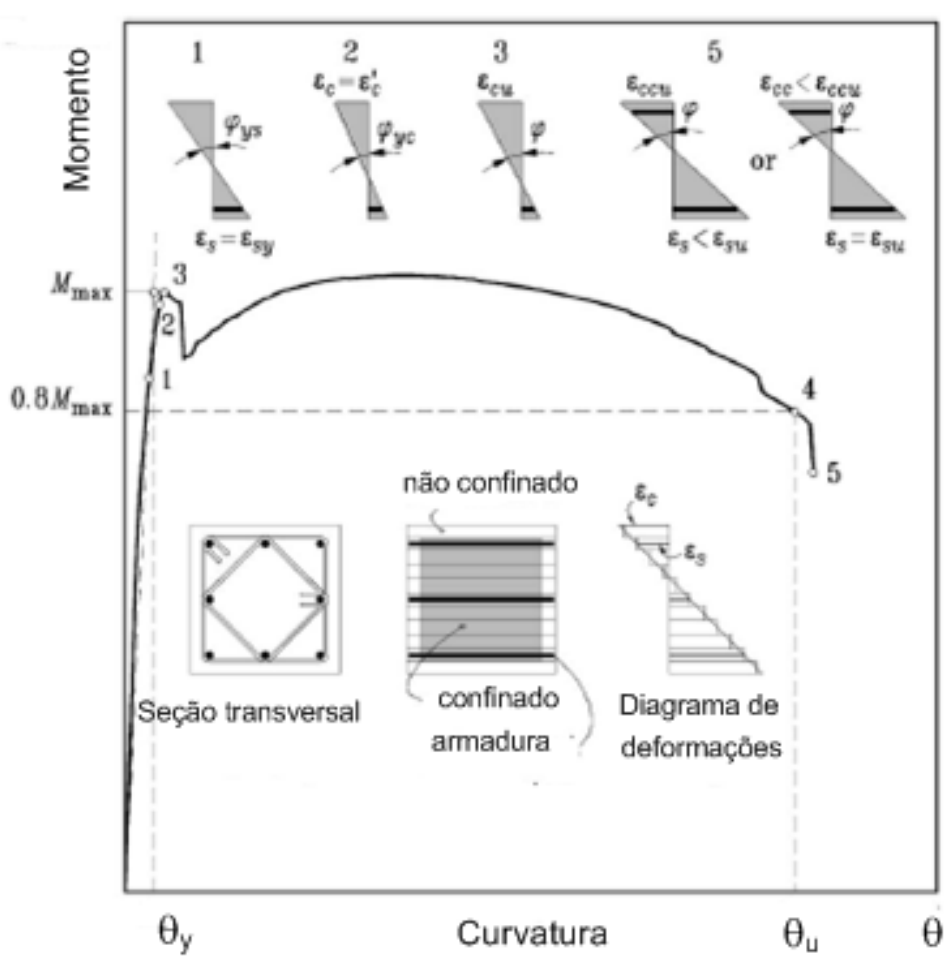

Fig. 3.14 - Diagrama momento $x$ curvatura para a força axial reduzida $F /\left(A_{c} \times f_{c}\right)=0,3$.

(Paultre e Légeron, 2008).

Na Fig. 3.14 a deformação específica no concreto confinado $\varepsilon_{\mathrm{ccu}}$ corresponde à tensão na qual a armadura transversal rompe. Como exemplo, para um concreto não confinado $\left(\mathrm{I}_{\mathrm{e}}=\right.$ 0) $\varepsilon_{\text {ccu }}=4 \%$ e para um concreto bem confinado $\left(\mathrm{I}_{\mathrm{e}}=20 \%\right) \varepsilon_{\mathrm{ccu}}=51 \%$. A definição de ductilidade última corresponde a:

$$
\mu_{\theta}=\frac{\theta_{u}}{\theta_{y}}
$$

Sendo que:

$\theta_{\mathrm{u}}$ é a curvatura correspondente a $80 \%$ (75\% para Diniz e Frangopol, 1997) do momento máximo no ramo pós-critico ou quando a armadura longitudinal rompe ou quando o concreto confinado esmaga;

$$
\theta_{y}=\min \left(\theta_{y c} \times \frac{M_{\max }}{M_{y c}} ; \theta_{y s} \times \frac{M_{\max }}{M_{y s}}\right)
$$

$\theta_{\mathrm{yc}}$ é a curvatura quando o concreto simples atinge sua resistência máxima e $\mathbf{M}_{\mathrm{yc}}$ seu correspondente momento máximo;

$\theta_{\mathrm{ys}}$ é a curvatura quando a armadura longitudinal atinge a resistência de escoamento e $\mathrm{M}_{\mathrm{ys}}$ seu correspondente momento máximo. 
$\mathrm{Na}$ Fig. 3.15 mostra-se a resposta momento-curvatura para tensões axiais correspondentes a 0,1 até 0,6 de $A_{c} \times f_{c}$, considerando a quantia de armadura longitudinal em relação à seção total como: $\rho_{\mathrm{s}}=1,5 \%$, o índice efetivo de confinamento $\mathrm{I}_{\mathrm{e}}=10 \%$, a resistência à compressão do concreto $\mathrm{f}_{\mathrm{c}}=80 \mathrm{MPa}$ e a resistência de escoamento da armadura longitudinal e transversal como $\mathrm{f}_{\mathrm{y}}=\mathrm{f}_{\mathrm{yw}}=400 \mathrm{MPa}$.

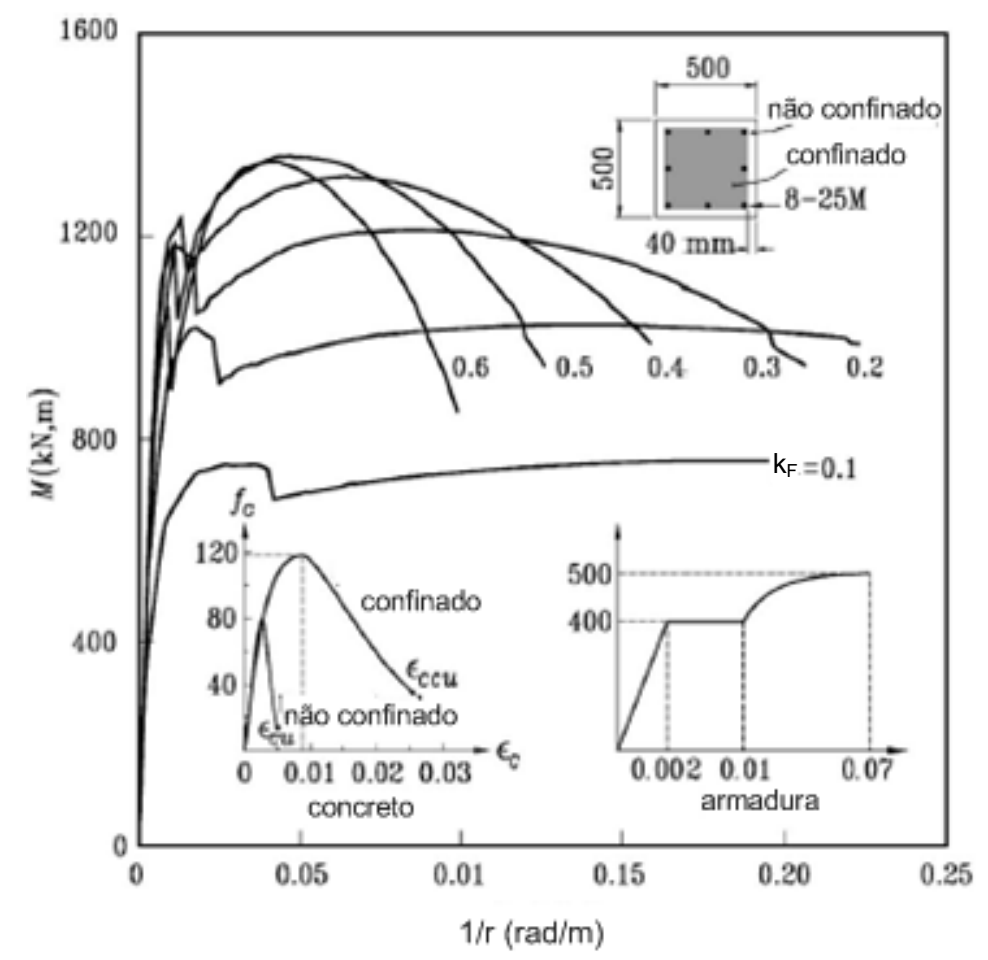

Fig. 3.15 - Momento-curvatura para diferentes tensões axiais reduzidas (Paultre e Légeron, 2008).

Para as diferentes variáveis (resistência do concreto simples, a taxa de armadura transversal e longitudinal e sua resistência de escoamento e as dimensões da seção transversal) foi realizado um estudo do $I_{e}$ considerando a ductilidade por meio do parâmetro de curvatura $\mu_{\theta}$ (todas as variáveis estão consideradas em $\mu_{\theta}$ )

$$
I_{e}=0,0111 \times k_{F} \times \mu_{\theta}
$$

Sendo que: $k_{F}=\frac{F}{0,85 \times\left(A_{c}-A_{s}\right) \times f_{c}+A_{s} \times f_{y}}$

$\mathrm{A}_{\mathrm{c}}$ é a área da seção transversal;

$\mathrm{A}_{\mathrm{s}}$ é a área da armadura longitudinal;

$\mathrm{f}_{\mathrm{y}}$ é a tensão de escoamento da armadura longitudinal;

$\mathrm{f}_{\mathrm{c}}$ é a resistência do concreto à compressão axial (que pode ser a característica);

F é a força axial. 
Foram adotados 2 intensidades de ductilidade, moderada ductilidade para $\mu_{\theta}=10 \mathrm{e}$ elevada ductilidade para $\mu_{\theta}=16$.

Paultre e Légeron (2008) obtiveram com base em modelo proposto por eles mesmos (Légeron e Paultre, 2003) expressões simplificadas para ser incluídas nas normas, estudaram o efeito da ductilidade em termos do diagrama momento-curvatura. Obtiveram uma expressão para o índice efetivo de confinamento em função da força axial atuante na seção e em função do parâmetro da ductilidade em termos do diagrama momento-curvatura (Eq. 3.12).

As simplificações provêm do desmembramento do coeficiente de confinamento efetivo $\mathrm{K}_{\mathrm{e}}$ em:

$$
K_{e}=K_{V} \times K_{h}
$$

$\mathrm{Na}$ Eq. $3.14 \mathrm{~K}_{\mathrm{h}}$ é a parte correspondente ao efeito de arco horizontal e $\mathrm{K}_{\mathrm{v}}$ ao efeito de arco vertical (Eq. 3.15 e Eq. 3.16), assim:

$$
\begin{gathered}
K_{v}=\alpha_{v} \times\left(\frac{A_{n c}}{A_{c}}\right) \\
K_{h}=1-\frac{2}{n_{l}}
\end{gathered}
$$

Sendo que:

$\alpha_{v}$ é o coeficiente que considera moderada ductilidade $(=0,95)$ ou elevada ductilidade $(=1,05)$;

$\mathrm{A}_{\mathrm{nc}}$ é a área do núcleo, de eixo a eixo dos estribos mais externos;

$\mathrm{A}_{\mathrm{c}}$ é a área total da seção transversal;

$\mathrm{n}_{1}$ é o número de barras longitudinais efetivamente contidas pela armadura transversal.

Conhecendo as dimensões da seção transversal e a distribuição das armaduras na seção é possível obter diretamente o coeficiente de confinamento efetivo $K_{e}$, sem necessidade de conhecer o espaçamento entre estribos. Neste caso é necessário adotar o tipo de ductilidade para a seção.

Outra simplificação foi a definição da tensão de trabalho da armadura transversal, por meio da equação 3.17 .

$$
\sigma_{s w}=\beta_{1} \times\left(10 \times k_{F}+\beta_{2}\right) \times\left(f_{c}\right)^{0,4} \geq 43 \times\left(f_{c}\right)^{0,4} \leq f_{y w}
$$

Sendo que:

$\beta_{1}$ e $\beta_{2}$ são parâmetros que consideram a ductilidade $\left(\beta_{1}=17,8\right.$ e $\beta_{2}=1,41$ para elevada ductilidade e $\beta_{1}=11,1$ e $\beta_{2}=2,82$ para moderada ductilidade) e $\mathrm{k}_{\mathrm{F}}$ é fornecida pela Eq. 3.13. 
O objetivo destas simplificações é obter a área de armadura transversal, por exemplo na direção y (Eq. 3.18), em função da ductilidade requerida, dos materiais empregados, da força axial atuante, das dimensões e distribuição das armaduras da seção transversal, assim:

$$
A_{s w y}=k_{d} \times n c_{y} \times s_{e} \times \frac{k_{F}}{K_{e}} \times \frac{f_{c}}{\sigma_{s w}}
$$

Sendo que:

$\mathrm{nc}_{\mathrm{y}}$ dimensão do núcleo da seção transversal medida de centro a centro do estribo mais externo na direção y;

$\mathrm{S}_{\mathrm{e}}$ é o espaçamento entre estribos;

$\mathrm{A}_{\mathrm{sw}}$ é a área da armadura transversal, neste caso na direção y;

$\mathrm{k}_{\mathrm{d}}$ é um parâmetro que considera a moderada ductilidade $\left(\mathrm{k}_{\mathrm{d}}=0,111\right)$ ou elevada ductilidade $\left(\mathrm{k}_{\mathrm{d}}=0,178\right)$. Os outros parâmetros da Eq. 3.18 foram definidos anteriormente (Eq. 3.13 até Eq.3.17).

Adotando para a tensão atuante nas armaduras transversais de confinamento os valores de $0,83 \mathrm{x} \mathrm{f}_{\mathrm{yw}}$ para elevada ductilidade e $0,68 \mathrm{x}_{\mathrm{yw}}$ para moderada ductilidade foram obtidas expressões simplificadas da área de armadura transversal. Para a resistência de escoamento da armadura transversal $\mathrm{f}_{\mathrm{yw}}=400 \mathrm{MPa}$, a Eq. 3.19 corresponde a elevada ductilidade e a Eq. 3.20 a moderada ductilidade.

$$
\begin{aligned}
& A_{s w y}=0,2 \times k_{F} \times k_{n} \times n c_{y} \times s_{e} \times \frac{f_{c}}{f_{y w}} \times \frac{A_{c}}{A_{n c}} \\
& A_{s w}=0,17 \times k_{F} \times k_{n} \times n c_{y} \times s_{e} \times \frac{f_{c}}{f_{y w}} \times \frac{A_{c}}{A_{n c}}
\end{aligned}
$$

Sendo que:

$$
k_{n}=\frac{n_{l}}{\left(n_{l}-2\right)}
$$

Os autores Paultre e Légeron (op. cit.) mostraram que o efeito da ductilidade poderia ser obtido analisando o diagrama momento-curvatura. No item 3.5 outras propostas de ductilidade serão avaliadas.

Entre as pesquisas realizadas nas Universidades Brasileiras encontra-se a Escola de Engenharia de São Carlos com trabalhos como o de Lima (1997) que também ensaiou pilares de CAR à compressão excêntrica com seção retangular de $15 \mathrm{~cm}$ x $30 \mathrm{~cm}$ e altura de $174 \mathrm{~cm}$, confinados por estribos duplos a cada $5 \mathrm{~cm}$ e 7,5 cm, comparou seu modelo com o de Collins et al. (1993), mas com seu modelo os valores dos momentos últimos eram mas do dobro dos experimentais, para o cálculo do momento fletor experimental não considerou efeitos de 
segunda ordem, alem disso informa que teve muita dificuldade em transmitir o momento planejado ao pilar e as condições de contorno reais não correspondiam à situação em estudo, e não houve incremento na ductilidade ao dobrar a taxa de armadura transversal.

Vanderlei (1999) estudou o comportamento de pilares de CAR com seção retangular de $15 \mathrm{~cm}$ x $30 \mathrm{~cm}$ e altura de $150 \mathrm{~cm}$ com duas taxas de estribos com espaçamento de $5 \mathrm{~cm} \mathrm{e}$ $10 \mathrm{~cm}$, aplicou compressão excêntrica em pilares por meio de consolos, considerou que até o $80 \%$ da força última a estrutura estava em serviço, não houve conclusões em relação à ductilidade.

Delalibera (2002) analisou a utilização de armadura de confinamento em vigas superarmadas de concreto armado com concreto de resistência de $25 \mathrm{MPa}$, com seção retangular de $15 \mathrm{~cm}$ x $30 \mathrm{~cm}$ e comprimento de $305 \mathrm{~cm}$. Verificou que os estribos não escoaram no instante da ruptura do concreto, verificou que com o aumento da taxa de armadura transversal a ductilidade aumentou e a resistência do núcleo também.

Lima Junior (2003) investigou pilares de CAR confinados com e sem adição de fibras metálicas sujeitos à compressão excêntrica, com dimensões de $15 \mathrm{~cm}$ x $15 \mathrm{~cm}$ e altura de 170 $\mathrm{cm}$ e espaçamento entre estribos de $5 \mathrm{~cm}$ e $15 \mathrm{~cm}$, modificou o modelo de Cusson e Paultre (1995) para o emprego de fibras, verificou que houve influencia na ductilidade ao adicionar fibras no concreto, verificou também que o ramo do estribo paralelo à face mais comprimida atingiu o escoamento e mesmo com a excentricidade de força dentro do núcleo houve inversão de sinal nas deformações.

Carrazedo (2005) avaliou a forma da seção transversal e a excentricidade da força sobre o efeito do confinamento em pilares de concreto de seção circular com $15 \mathrm{~cm}$ de diâmetro, quadrada de $15 \mathrm{~cm}$ x $15 \mathrm{~cm}$ e retangular de $15 \mathrm{~cm}$ x 22,5 cm todos com altura de 45 $\mathrm{cm}$, encamisados com polímeros reforçados com fibras de carbono, introduziu um coeficiente de efetividade em função à forma de seção transversal, este coeficiente de efetividade é maior para concretos de menor resistência, os pilares de seção quadrada tiveram um maior ganho de resistência em função à excentricidade da força em relação ao de compressão centrada, o contrario aconteceu com o pilar de seção circular.

\subsection{EQUAÇÕES CONSTITUTIVAS DO CONCRETO CONFINADO}

Muitos foram os investigadores que estudaram o comportamento do CAR confinado e fizeram suas propostas para modelar tanto a parte ascendente como a parte descendente do diagrama $\sigma_{\mathrm{c}} \mathrm{x} \varepsilon_{\mathrm{c}}$. Han et al. (2003) cita que o primeiro modelo foi proposto por Richart et al. 
(op. cit.) em 1928. Muitos modelos são compostos por vários trechos, alguns são retos ou pode ser uma curva única. A partir de 1980 diversos modelos vêm sendo propostos para modelar o comportamento à compressão do CAR e do CAR confinado (Lima Jr. 2003).

Dentre os muitos são citados alguns de maior destaque como Sheikh e Uzumeri (1982), Colins et al. (1993), Cusson e Paultre (1995), Ibrahim e MacGregor (1996-b), Diniz e Frangopol (1997), Saatcioglu e Razvi (1998), Yalcin e Saatcioclu (2000), Li et al. (2001), Légeron e Paultre (2003), Han et al. (2003), Tasnimi (2004), Hong et al. (2006), Montoya et al. (2006), Lu e Hsu (2007), Paultre e Légeron (2008). Alguns já tiveram seus modelos estudados, dos que não foram detalhados as modificações incorporadas correspondem a pequenos parâmetros que modificam um pouco a forma da curva $\sigma_{\mathrm{c}} \mathrm{X} \varepsilon_{\mathrm{c}}$.

Sharma et al. (2005), fizeram um estudo considerando as equações constitutivas de vários modelos, verificaram suas similitudes as suas diferenças e concluíram, depois de comparar com resultados de 22 pilares selecionados dos muitos existentes nas literatura, que o modelo de Légeron e Paultre (2003) é o que melhor aproxima dos resultados de laboratório para seções circulares e retangulares, outro modelo que também forneceu resultados próximos dos experimentais foi o de Razvi e Saatcioglu, 1999 (ambos modelos cobrem resistências entre $60 \mathrm{MPa}$ e $120 \mathrm{MPa}$ ), outro modelo que teve resultados apropriados foi o de Cusson e Paultre (1995). O modelo de Paultre e Légeron (2008) traz expressões simplificadas do modelo de Légeron e Paultre (op. cit.) que foram incorporadas na norma CAN3-A23.3.04.

Outra curva que apresenta destaque é a do Comitê 441 da ACI (ACI-441, 1997) que pode ser observada na Fig. 3.16, nota-se um trecho linear até um $80 \%$ a $90 \%$ da força última, nesse trecho o confinamento tem pouco ou nenhum efeito e a armadura transversal trabalha com tensões bem menores que a de escoamento. Após o ponto B a expansão lateral do concreto atinge seu valor máximo e o comportamento do pilar depende do confinamento. Essa figura mostra esquematicamente a forma da curva em função da taxa de armadura presente na seção. 


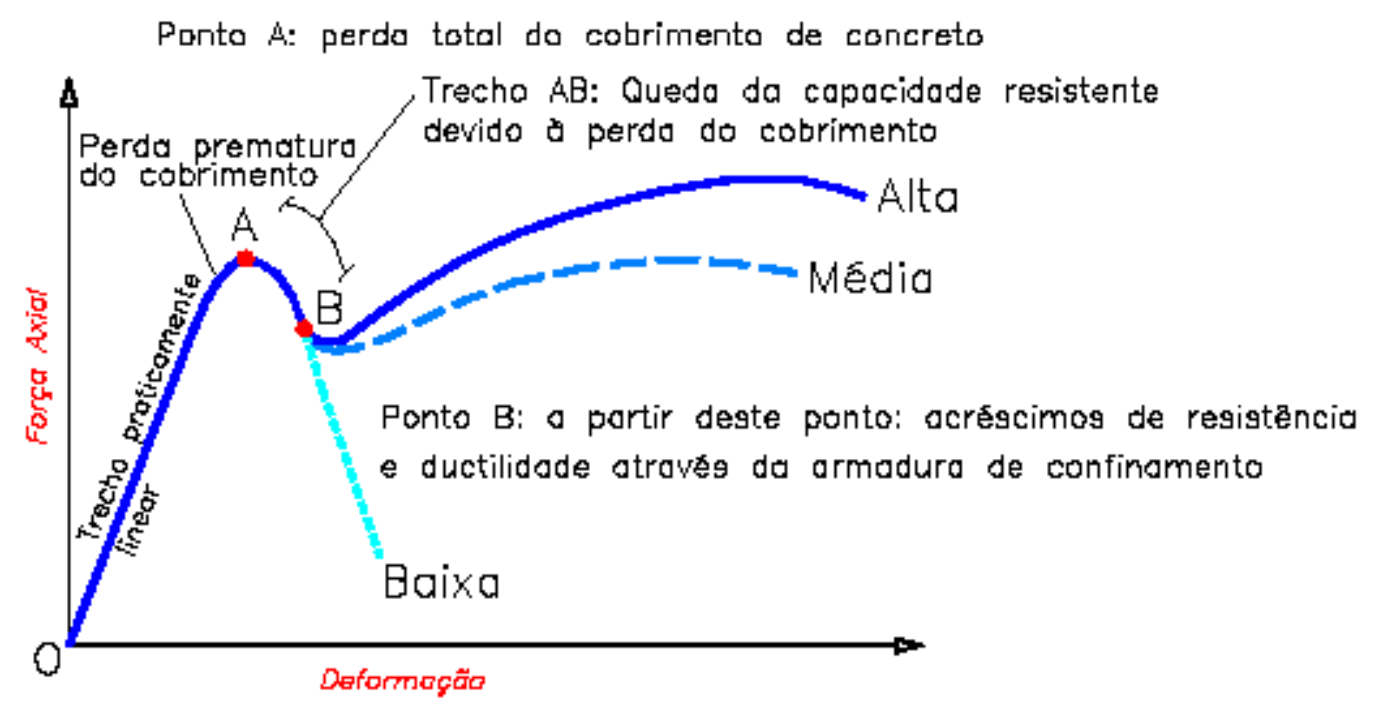

Fig. 3.16 - Comportamento esquemático do concreto confinado segundo a ACI-441 (1997).

Neste trabalho foram analisados os modelos de Cusson e Paultre (1995) e Légeron e Paultre (2003) e adotado este último por ter-se aproximado mais aos resultados de laboratório.

\subsubsection{Modelo de Cusson e Paultre (1995)}

O modelo é baseado em resultados experimentais de 50 pilares ensaiados à compressão centrada.

As expressões do modelo do Cusson e Paultre (1995) são expostas a continuação. A Eq. 3.22 determina a forma da curva $\sigma_{\mathrm{c}} \mathrm{x} \varepsilon_{\mathrm{c}}$ do concreto confinado.

$$
\sigma\left(\varepsilon_{c c}\right)=\sigma_{R}\left(\varepsilon_{c c}\right) \times f_{c c}
$$

Nesta: $\mathrm{f}_{\mathrm{cc}}$ é a resistência do concreto do núcleo sujeito a um estado triaxial de tensões (resistência do concreto confinado) e $\sigma\left(\varepsilon_{\mathrm{cc}}\right)$ é a expressão da forma do diagrama (Eq. $3.23 \mathrm{e}$ Eq. 3.24).

A Eq. 3.23 corresponde ao ramo ascendente e a Eq. 3.24 ao ramo descendente da curva $\sigma_{\mathrm{c}} \times \varepsilon_{\mathrm{c}}$ do concreto confinado (Fig. 3.8).

$$
\begin{gathered}
\sigma_{a s c}\left(\varepsilon_{c c}\right)=\frac{k_{0} \times \frac{\varepsilon_{c c}}{\varepsilon_{c c 1}}}{k_{0}-1+\left(\frac{\varepsilon_{c c}}{\varepsilon_{c c 1}}\right)^{k_{0}}} \\
\sigma_{d e s c}\left(\varepsilon_{c c}\right)=\exp \left(k_{1} \times\left(\varepsilon_{c c}-\varepsilon_{c c 1}\right)^{k_{2}}\right)
\end{gathered}
$$

$\mathrm{Na}$ Eq. 3.23, $\mathrm{k}_{0}$ controla a inclinação do ramo ascendente da curva $\sigma_{\mathrm{c}} \times \varepsilon_{\mathrm{c}}$ e está dada por: 


$$
k_{0}=\frac{E_{c}}{E_{c}-\frac{f_{c c}}{\varepsilon_{c c 1}}}
$$

$\mathrm{Na}$ Eq. 3.24, $\mathrm{k}_{1}$ controla a inclinação do ramo descendente e foi ajustado para que neste ramo a curva $\sigma_{\mathrm{c}} \times \varepsilon_{\mathrm{c}}$ passe pelo ponto $\left(\varepsilon_{\mathrm{cc} \_50}, 0,5 \mathrm{f}_{\mathrm{cc}}\right)$. A Fig. 3.8 mostra este detalhe. $\mathrm{O}$ parâmetro $\mathrm{k}_{2}$ dá uma idéia do confinamento do concreto, quanto maior é $\mathrm{k}_{2}$ melhor é o confinamento e produz uma curvatura convexa, para pilares pouco confinados uma curvatura côncava. Os valores de $\mathrm{k}_{1}$ e $\mathrm{k}_{2}$ estão dados por:

$$
\begin{gathered}
k_{1}=\frac{\ln (0,5)}{\left(\varepsilon_{c c_{-} 50}-\varepsilon_{c c 1}\right)^{k_{2}}} \\
k_{2}=0,58+16 \times\left(I_{e}\right)^{1,4}
\end{gathered}
$$

Para obter o valor de $\mathrm{k}_{1}$ é necessário calcular $\varepsilon_{\text {cc_50 }}$ que é a deformação específica correspondente a $50 \%$ da tensão máxima no ramo descendente da curva do concreto confinado que depende da $\varepsilon_{\mathrm{c}_{-} 50}$ que é a deformação específica do concreto não confinado com o mesmo significado (são os comportamentos pós-críticos do modelo confinado e não confinado respectivamente). Para Cusson e Paultre (1995) o $\varepsilon_{\mathrm{c}_{\mathrm{c}} 50}$ do modelo não confinado poderia ser adotado como 0,004, mas foi obtido do CEB-Bulletin 228, 1995 (Eq. 2.14) e foi incorporado no modelo do CAR confinado, este valor é mais realista que o 0,004 (para concretos convencionais $\varepsilon_{\mathrm{c}_{-} 50}$ foi adotado da norma FIB 1999). As expressões de $\varepsilon_{\mathrm{c}_{-}} 50 \mathrm{e}$ $\varepsilon_{\text {cc_}} 50$ são as da Eq. 3.28 e Eq. 3.29.

$$
\begin{gathered}
\varepsilon_{c_{-} 50}=\eta \times \varepsilon_{c 1} \\
\varepsilon_{c c_{-} 50}=\varepsilon_{c_{-} 50}+0,15 \times I_{e}
\end{gathered}
$$

Na Eq. $3.28 \eta$ é um parâmetro obtido da Eq. 2.14 para o CAR ou da Eq. 2.4 para o concreto convencional e $\varepsilon_{\mathrm{c} 1}$ é a deformação específica correspondente ao pico da curva $\sigma_{\mathrm{c}} \mathrm{x} \varepsilon_{\mathrm{c}}$ do concreto não confinado obtida da Eq. 2.15 para o CAR ou Eq. 2.12 para o concreto convencional. Estes parâmetros são diferentes porque o B228 somente considera o CAR (com resistências médias entre $58 \mathrm{MPa}$ até $108 \mathrm{MPa}$ ) e a norma FIB considera o concreto convencional e CAR até $90 \mathrm{MPa}, \log$ o para o CAR foi adotado o B228 e para o concreto convencional a FIB, ver item 2.4.2. Estas normas foram empregadas somente para obter o parâmetro pós-crítico $\varepsilon_{\text {cc_55 }}$ porque o EUROCODE 2 não apresenta comportamentos póscríticos após a deformação última, mas para efeitos de verificação e dimensionamento, $\varepsilon_{\mathrm{c} 1}$ provem do EUROCODE 2 (Eq. 2.5 e Eq. 2.6). 
Nas Eq. 3.23 até Eq. $3.26 \varepsilon_{\mathrm{cc} 1}$ é a deformação específica correspondente ao pico da curva $\sigma_{\mathrm{c}}$ x $\varepsilon_{\mathrm{c}}$ do concreto confinado (mostrada como $\varepsilon_{\mathrm{cc}}$ na Fig. 3.8) e dada pela Eq. 3.34. Na Eq. 3.25 $\mathrm{E}_{\mathrm{c}}$ é o módulo de deformação secante na origem do diagrama $\sigma_{\mathrm{c}} \mathrm{x} \varepsilon_{\mathrm{c}}$ do concreto não confinado (adotado da Eq. 2.10). Na Eq. $3.27 \mathrm{I}_{\mathrm{e}}$ é o índice de confinamento dado pela Eq. 3.35 .

Para obter a pressão lateral de confinamento efetiva na região entre estribos $\sigma_{\text {LAT_e }}$ é necessário aplicar o coeficiente de confinamento efetivo $K_{e}$ na pressão lateral nominal na região dos estribos $\sigma_{\mathrm{LAT}}$, assim:

$$
\sigma_{L A T_{-} e}=K_{e} \times \sigma_{L A T}
$$

O coeficiente de confinamento efetivo (Eq. 3.31) representa a relação entre a menor área da seção efetivamente confinada (área localizada entre os estribos) e a área do núcleo da seção, e é obtido com:

$$
K_{e}=\frac{\left(1-\frac{\sum \omega_{i}^{2}}{6 \times n c_{x} \times n c_{y}}\right) \times\left[1-\frac{\left(s_{e}-\phi_{e}\right)}{2 \times n c_{x}}\right] \times\left[1-\frac{\left(s_{e}-\phi_{e}\right)}{2 \times n c_{y}}\right]}{1-\rho_{s n c}}
$$

Para seções retangulares, considerando o equilíbrio das pressões laterais no núcleo do concreto e as forças nas armaduras transversais de confinamento em ambas as direções, a pressão nominal de confinamento pode ser obtida com a Eq. 3.32.

$$
\sigma_{L A T}=\frac{\sigma_{s w}}{s_{e}} \times\left(\frac{A_{s w x}+A_{s w y}}{n c_{x}+n c_{y}}\right)
$$

Sendo que, nas Eq. 3.31 e Eq. 3.32:

$\omega_{\mathrm{i}}$ são as distancias livres entre duas barras longitudinais adjacentes;

$\phi_{\mathrm{e}}$ é o diâmetro da armadura transversal;

$\mathrm{S}_{\mathrm{e}}$ é o espaçamento entre centro de estribos;

$\rho_{\text {snc }}$ é a taxa de armadura longitudinal efetivamente contida pelos estribos, em relação ao núcleo do pilar;

$\mathrm{nc}_{\mathrm{x}}$ e $\mathrm{nc}_{\mathrm{y}}$ são as dimensões do núcleo do pilar nas direções $\mathrm{x}$ e y (entre eixos dos estribos mais externos);

$\mathrm{A}_{\text {swx }}$ e $\mathrm{A}_{\text {swy }}$ são as áreas da seção transversal das armaduras de confinamento nas direções x e y;

$\sigma_{\mathrm{sw}}$ é a tensão atuante na armadura transversal, dada pela Eq. 3.37. 
Foram realizadas analises de regressão por Cusson e Paultre (1995) em resultados obtidos de ensaios de laboratório para se obter o valor da resistência do núcleo confiando $\mathrm{f}_{\mathrm{cc}}$ e foi aferida a Eq. 3.33.

$$
f_{c c}=\left[1+\left[2,1 \times\left(I_{e}\right)\right]^{0,7}\right] \times f_{c}
$$

A deformação específica correspondente à resistência do núcleo confinado $\varepsilon_{\mathrm{cc} 1}$ (pico da curva $\sigma_{\mathrm{c}} \mathrm{x} \varepsilon_{\mathrm{c}}$ confinada) foi obtida analisando o ganho nas deformações específicas (diferença entre a deformação específica $\varepsilon_{\mathrm{cc} 1}$ do concreto confinado e a deformação específica $\varepsilon_{\mathrm{c} 1}$ do concreto não confinado) em relação à variação do índice de confinamento $\mathrm{I}_{\mathrm{e}}$.

$$
\varepsilon_{c c 1}=\varepsilon_{c 1}+0,21 \times\left(I_{e}\right)^{1,7}
$$

Para o valor de $\varepsilon_{\mathrm{c} 1}$ (mostrada como $\varepsilon_{\mathrm{c}}$ na Fig. 3.8) foi adotado o do EUROCODE 2 (2004), Eq. 2.5 ou Eq. 2.6.

Foi proposto um novo índice de confinamento $\mathrm{I}_{\mathrm{e}}$ que considera o efeito do arco no núcleo do concreto (Fig. 3.9), como:

$$
I_{e}=\frac{\sigma_{L A T_{-} e}}{f_{c}}
$$

A deformação específica da armadura transversal confinante, considerando a presença das tensões laterais de confinamento efetivo do concreto $\sigma_{\mathrm{LAT}_{-} \mathrm{e}} \mathrm{em}$ ambas direções, é definida como:

$$
\varepsilon_{s w}=0,5 \times \varepsilon_{c c 1} \times\left[1-\left(\frac{\sigma_{L A T_{-} e}}{f_{c c}}\right)\right]
$$

Em função do valor da deformação específica da armadura transversal obtêm-se sua tensão de serviço (seu limite é a resistência de escoamento):

$$
\sigma_{s w}=\varepsilon_{s w} \times E_{s}
$$

Sendo que $\mathrm{E}_{\mathrm{s}}$ é o modulo de elasticidade do aço.

Para calcular $\sigma_{\mathrm{sw}}$ é necessário obter o valor da deformação específica da armadura (Eq. 3.36), mas é necessário realizar uma serie de interações para obter seu valor, pois as Eq. 3.32 até Eq. 3.37 estão inter-relacionadas. Para obter os diagramas das Fig. 6.4 e Fig. 6.5 foram realizadas estas interações.

As Eq. 3.22 até Eq. 3.37 definem a curva do CAR confinado do modelo de Cusson e Paultre (1995) e as Eq. 2.4 e Eq. 2.14 do CAR não confinado. Estas curvas realistas são as empregadas na verificação e no dimensionamento das seções considerando o concreto confinado ou não confinado, sendo necessário realizar uma integração numérica desses 
diagramas para obter a resultante das tensões nas fibras do concreto comprimido. Com esses diagramas vão ser obtidas resultados mais realistas que com os diagramas parábola-retângulo ou o bloco retangular de tensões empregado no dimensionamento de concretos convencionais.

\subsubsection{Modelo de Légeron e Paultre (2003)}

Neste modelo foi eliminado o processo interativo que existia para calcular a tensão de serviço da armadura transversal. Suas principais variáveis são a taxa de armadura transversal, a distribuição espacial da armadura longitudinal e transversal, a resistência do concreto e a resistência de escoamento da armadura transversal, sendo bastante efetivo para aços com elevada resistência de escoamento.

Foram feitas algumas modificações nas expressões de Cusson e Paultre (1995), no caso, somente serão explicitadas as modificações feitas.

As Eq. 3.22, Eq. 3.23 e Eq. 3.24 são as mesmas, e são as que definem a forma tramo da curva ascendente e descendente do diagrama $\sigma_{\mathrm{c}} \times \varepsilon_{\mathrm{c}}$. Entre os parâmetros das expressões anteriores a o $\mathrm{k}_{0}$ e o $\mathrm{k}_{1}$ são iguais (Eq. 3.25 e Eq. 3.26). Os parâmetros necessários para obter a forma das curvas do modelo de Légeron e Paultre (2003) estão definidos nas Eq. 3.38 até Eq. 3.48.

$\mathrm{O}$ parâmetro $\mathrm{k}_{2}$ que controla a forma do ramo descendente da curva $\sigma_{\mathrm{c}} \mathrm{x} \varepsilon_{\mathrm{c}}$ foi definido como:

$$
k_{2}=1+25 \times\left(I_{e_{-} 50}\right)^{2}
$$

$\mathrm{Na}$ Eq. 3.38 o índice de confinamento efetivo calculado na curva pós-pico para a deformação específica correspondente ao $50 \%$ da resistência do concreto confinado $\left(\mathrm{I}_{\mathrm{e}_{-} 50}\right)$ está dado por:

$$
I_{e_{-} 50}=\rho_{s w_{-} e} \times \frac{f_{y w}}{f_{c}}
$$

Nesta $\rho_{\text {sw_e }}$ é a taxa volumétrica efetiva da armadura transversal em relação ao núcleo do pilar e pode ser obtida de:

$$
\rho_{s w_{-} e}=K_{e} \times\left(\rho_{w x}+\rho_{w y}\right)
$$

As taxas da armadura transversal em relação à seção longitudinal do núcleo do pilar entre estribos nas direções x e y são:

$$
\rho_{s w x}=\frac{A_{s w x}}{s_{e} \times n c_{y}} \quad \rho_{s w y}=\frac{A_{s w y}}{s_{e} \times n c_{x}}
$$


O valor da deformação específica na curva pós-pico correspondente ao $50 \%$ da resistência do concreto confinado foi proposta como:

$$
\varepsilon_{c c_{-} 50}=\varepsilon_{c_{-} 50} \times\left(1+60 \times I_{e_{-} 50}\right)
$$

Em função aos resultados dos ensaios de Cusson e Paultre (1995), os valores da resistência do concreto confiando e sua correspondente deformação específica foram novamente avaliados e adotadas novas expressões (Eq. 3.43 e Eq. 3.44).

$$
\begin{aligned}
& \varepsilon_{c c 1}=\varepsilon_{c 1}\left(1+35 \times\left(I_{e}\right)^{1,2}\right) \\
& f_{c c}=f_{c} \times\left(1+2,4 \times\left(I_{e}\right)^{0,7}\right)
\end{aligned}
$$

Para obter os valores das deformações específicas $\varepsilon_{\text {cc_5 } 50}, \varepsilon_{\mathrm{c} \_50}$ e $\varepsilon_{\mathrm{c} 1}$ permanecem as mesmas considerações do modelo de Cusson e Paultre (1995) e com os mesmos significados. A tensão lateral de confinamento efetiva $\sigma_{\text {LAT_e }}$ varia de zero quando a tensão na armadura de confinamento é nula e vai até seu valor máximo quando a tensão da armadura de confinamento é a resistência de escoamento. Sua expressão está dada por:

$$
\sigma_{L A T_{-} e}=\rho_{s w_{-} e} \times \sigma_{s w}
$$

A tensão da armadura transversal de confinamento pode ser obtida das Eq. 3.46 até Eq. 3.48.

$$
\begin{array}{cc}
\sigma_{s w}=f_{y w} & \text { se } \kappa \leq 10 \\
\sigma_{s w}=\frac{0,25 \times f_{c}}{\rho_{s w_{-} e} \times(\kappa-10)} & \text { se } \kappa>10 \\
\kappa=\frac{f_{c}}{\rho_{s w_{-} e} \times E_{s} \times \varepsilon_{c 1}} &
\end{array}
$$

Todos os outros parâmetros não definidos têm o mesmo significado do modelo de Cusson e Paultre (1995).

Foi realizada uma série de analises com as propostas apresentadas por Cusson e Paultre (1995) e Légeron e Paultre (2003) considerando os pilares que foram ensaiados à compressão centrada, comparando com o modelo do CEB Bulletin 228 (1995) do concreto não confinado. Seus resultados se encontram no Capitulo 6.

\section{Taxa volumétrica de armadura transversal}

De forma geral a taxa volumétrica da armadura transversal é definida como:

$$
\rho_{s W}=\frac{V_{s W}}{V_{n c}}
$$


Sendo que:

$\mathrm{V}_{\mathrm{sw}}$ é o volume de armadura transversal em cada nível de espaçamento de estribos;

$\mathrm{V}_{\mathrm{nc}}$ é o volume do núcleo da seção do concreto (centro a centro dos estribos).

Outra maneira de melhorar o confinamento é adotar um detalhe mais efetivo com outras configurações de armadura transversal, Fig. 3.17. A configuração dos ensaios, estribo de 2 ramos, é a menos eficiente e não deveria ser utilizada quando é procurada a ductilidade.

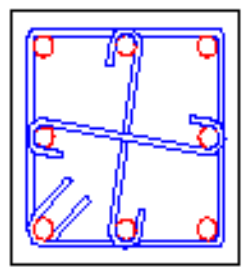

A

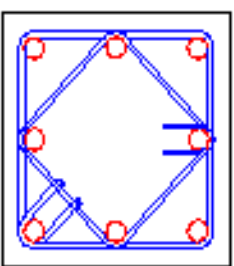

B

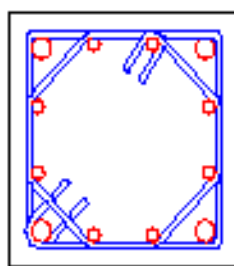

$\mathrm{C}$

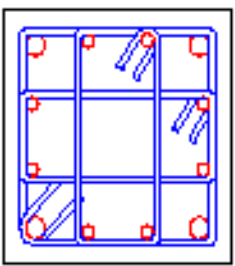

$\mathrm{D}$

Fig. 3.17 - Outras configurações de armado (adaptada de Cusson e Paultre, 1994).

Com o objetivo de facilitar o cálculo das armaduras $\mathrm{A}_{\mathrm{swx}}$ ou $\mathrm{A}_{\mathrm{swy}}$ nas expressões dos modelos de Cusson e Paultre (1995) e Légeron e Paultre (2003), sem necessidade de calcular a taxa volumétrica, será feita uma relação com a área de uma perna do estribo para as configurações de armado da Fig. 3.17.

Para estribos fechados de 2 pernas: $\mathrm{A}_{\mathrm{sw}}=2 \mathrm{x}$ área de uma perna.

Para o caso $\mathrm{A}: \mathrm{A}_{\mathrm{sw}}=3 \mathrm{x}$ área de uma perna.

Para o caso $\mathrm{B}: \mathrm{A}_{\mathrm{sw}}=3,42 \mathrm{x}$ área de uma perna.

Para o caso $\mathrm{C}: \mathrm{A}_{\mathrm{sw}}=3,6 \mathrm{x}$ área de uma perna.

Para o caso D: $\mathrm{A}_{\mathrm{sw}}=4,66 \mathrm{x}$ área de uma perna.

\subsection{OUTROS MODOS DE QUANTIFICAR A DUCTILIDADE}

O confinamento pode ser definido como a capacidade de impedir a deformação transversal perpendicular à direção da aplicação da força. Segundo Van Vlack ${ }^{8}$ apud, Lima Jr (2003) ductilidade é uma medida de deformação que indica a capacidade de um corpo deformar-se inelasticamente, sem perder de forma brusca a sua capacidade resistente, e, tenacidade é a medida de energia que quantifica a capacidade de um corpo absorver energia elástica ou inelástica até chegar à ruptura. A tenacidade pode ser obtida medindo a área sob da curva $\sigma_{\mathrm{c}} \mathrm{x} \varepsilon_{\mathrm{c}}$. Assim um material pode ser tenaz e frágil ou dúctil e pouco tenaz. Mas as duas propriedades estão relacionadas.

\footnotetext{
${ }^{8}$ Van Vlack, L. H. (1982). Materials engineering. Edited by Addison Wesley Pub,. 256 p..
} 
A ductilidade é de muita importância em concretos de alta resistência e especialmente em países sujeitos a movimentos sísmicos. Neste último caso o estudo da ductilidade teria que ser considerada na estrutura também.

\subsubsection{Pilares sujeitos à compressão centrada}

É comum avaliar a ductilidade de um pilar considerando o diagrama $\sigma_{\mathrm{c}} \mathrm{x} \quad \varepsilon_{\mathrm{c}}$ do concreto retirando a parcela correspondente às armaduras longitudinais e observando o comportamento pós-crítico da curva. Segundo Cusson e Pautre (1995); Légeron e Paultre (2003) o ponto ideal para verificar a ductilidade é a deformação correspondente a $50 \%$ da tensão de pico na curva descente. Outros como Saatcioglu e Razvi (1992) definem como a correspondente ao $85 \%$ da tensão de pico na curva descendente. No caso de pilares sujeitos a flexão pode ser utilizado o diagrama de momento fletor-giro. A verificação da ductilidade do material concreto é feita analisando o diagrama tensão-deformação específica obtida em ensaios de corpos-de-prova submetidos à compressão simples.

Segundo Lima Jr. e Giongo (2000) quando se realizam ensaios à compressão simples, mesmo com uma prensa de ensaios com controle de deslocamentos, é difícil obter deformações confiáveis depois de 4 vezes a deformação correspondente ao pico, por esta razão sugerem adotar um limite de 3 vezes a deformação pico como limite para verificar a ductilidade. Sugerem o parâmetro da Eq. 3.50, para definir a ductilidade (fator energético):

$$
\begin{gathered}
\lambda_{e}=\frac{E_{t}}{E_{e}} \\
E_{t}=E_{e}+E_{p} \\
E_{e}=\int_{0}^{\varepsilon_{c c 1}} \frac{F\left(\varepsilon_{c c}\right)}{F_{u}} d \varepsilon_{c c} \\
E_{p}=\int_{\varepsilon_{c c 1}}^{\varepsilon_{c c u l}} \frac{F\left(\varepsilon_{c c}\right)}{F_{u}} d \varepsilon_{c c}
\end{gathered}
$$

Sendo que:

$\mathrm{E}_{\mathrm{e}}$ é uma energia de deformação elástica;

$\mathrm{E}_{\mathrm{p}}$ é uma energia de deformação plástica;

$\varepsilon_{\mathrm{cc} 1}$ é a deformação correspondente ao pico da curva;

$\varepsilon_{\mathrm{ccu} 1}$ é a deformação última que pode ser adotada como 3 x $\varepsilon_{\mathrm{cc} 1}$;

$\mathrm{F}_{\mathrm{u}}$ é a força máxima que pode suportar o pilar. 
A Fig. 3.18 mostra graficamente que as Eq. 3.52 e Eq. 3.53 representam a área sob a curva.

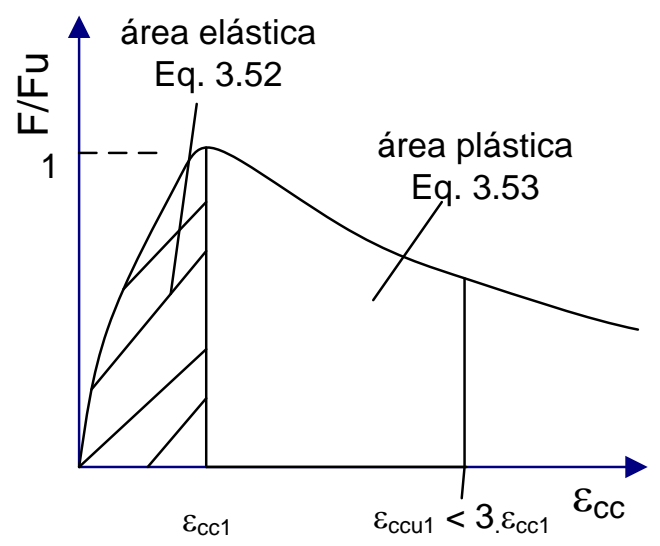

Fig. 3.18 - Definição do fator energético (Lima Jr. e Giongo, 2000).

Segundo os autores para valores de $\lambda_{\mathrm{e}}$ (Eq. 3.50) entre 1 e 3 o comportamento do pilar é frágil e para valores de $\lambda_{\mathrm{e}}$ entre 5 e 7 o comportamento do pilar é dúctil.

Lima Jr. (2003) propõe um índice de ductilidade pós-pico para avaliar a ductilidade dos pilares analisando o diagrama $\sigma_{\mathrm{c}} \mathrm{x} \varepsilon_{\mathrm{c}}$ do pilar (Eq. 3.54).

$$
I D_{p o s}=\int_{\varepsilon_{c c 1}}^{\varepsilon_{c c u l}} \frac{\sigma\left(\varepsilon_{c c}\right)}{\varepsilon_{c c 1} \times f_{c c}} d \varepsilon_{c c}
$$

$\mathrm{O} \mathrm{ID}_{\text {pos }}$ da Eq. 3.54 é o comprimento da base de um retângulo de altura unitária e área igual à área sob o ramo descendente do diagrama reduzido (Fig. 3.19).
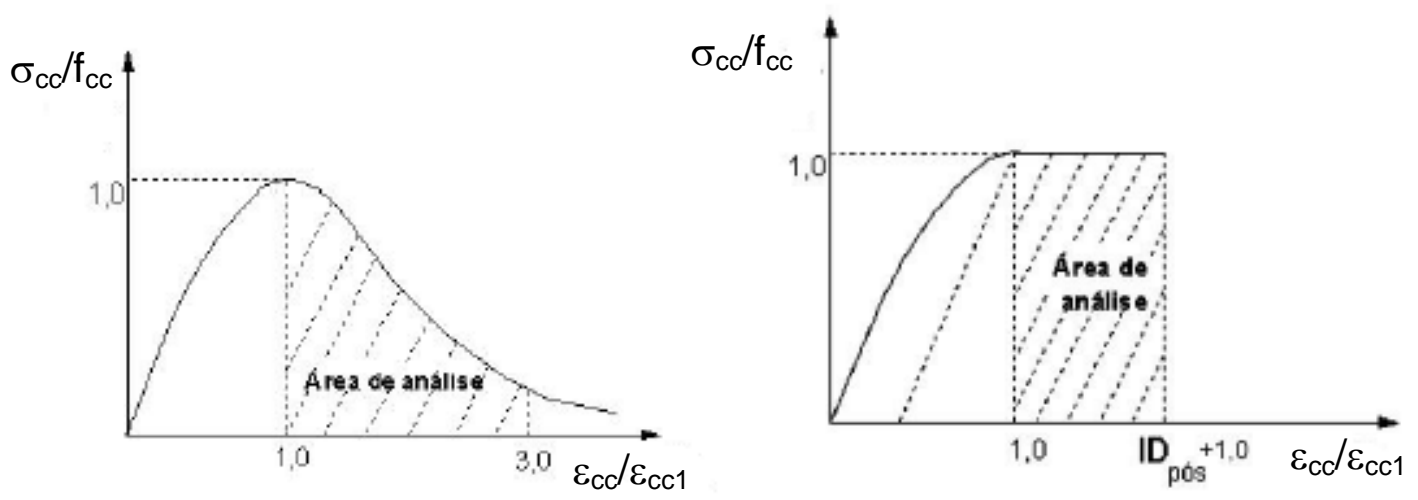

Fig. 3.19 - Metodologia para a obtenção do índice de ductilidade pós pico (adaptada de Lima

$$
\text { Jr.,2003). }
$$

Segundo Cámara et al. (2002), o índice de ductilidade mínimo aceitável para o CAR deve estar entre os índices dos pilares de concretos com resistência média a compressão de 40 MPa (sem considerar o efeito favorável das armaduras na ductilidade), e obtiveram os seguintes resultados médios $\varepsilon_{\mathrm{cc} \_50} / \varepsilon_{\mathrm{cc}}=1,775$ e $\mathrm{ID}_{\mathrm{pos}}=0,958$. 
Lima Jr. obteve, depois de uma análise de regressão polinomial das curvas do modelo de Cusson e Paultre (1995), as seguintes expressões algébricas (para concretos de $60 \mathrm{MPa}, 80$ $\mathrm{MPa}$ e $100 \mathrm{MPa}$ com seção quadrada de $20 \mathrm{~cm}$ x $20 \mathrm{~cm}$ e diferentes taxas de armadura transversal e longitudinal):

$$
\begin{gathered}
\varepsilon_{c c-50} / \varepsilon_{c c}=3,151-0,024 \times f_{c}+1,427 \times \rho_{s w}+0,208 \times \rho_{s} \\
I D_{p o s}=1,359-0,007 \times f_{c}+0,406 \times \rho_{s w}+0,060 \times \rho_{s}
\end{gathered}
$$

Com as Eq. 3.55 e Eq. 3.56, em função das relações de ductilidade (por exemplo, de Cámara et al., 2002), é possível obter as taxas da armadura transversal numa determinada direção $\rho_{\mathrm{sw}}$ (Eq. 3.41), conhecendo a resistência do concreto à compressão uniaxial e a taxa de armadura longitudinal em relação à seção total do pilar $\rho_{\mathrm{s}}$.

\subsubsection{Pilares sujeitos à compressão excêntrica}

No item 3.3.2 Paultre e Légeron (2008) mostra a proposta de verificar a ductilidade considerando o diagrama momento-curvatura, o modelo divide a seção em faixas. Após a obtenção do diagrama momento-curvatura calcula o parâmetro de ductilidade dado pela Eq. 3.10, mas para definir este parâmetro é necessário obter o valor do momento correspondente ao $80 \%$ do momento máximo ou o correspondente quando a armadura transversal confinante rompe ou o concreto do núcleo confinado rompe. Considerando este modelo foram adotados dois valores de ductilidade: para moderada ductilidade $\mu_{\theta}=10$ e para elevada ductilidade $\mu_{\theta}=$ 16.

Galeano e Vignoli (2008) definem a ductilidade para o caso de uma força F aplicada excentricamente. Normalmente é analisada a região de formação de uma rótula plástica na qual são definidas as relações força axial $(F)$ x deformação específica média no centróide da seção transversal $\left(\varepsilon_{\mathrm{m}}\right)$ e o momento $(\mathrm{M})$ provocado por $\mathrm{F}$ x curvatura $(\theta)$. É possível analisar a ductilidade da região para diferentes excentricidades de força examinando o trabalho realizado pela força $\mathrm{F}$.

Considerando os efeitos de segunda ordem local, a excentricidade total é: $e_{t}=e_{0}+e_{2} e$ o trabalho realizado pela força axial F na região de plastificação R, é (Foster e Attard, 1997 e Galeano e Vignoli, 2008):

$$
\int_{R}\left(F \times \varepsilon_{m}+F \times\left(e_{t}\right) \times \theta\right) \times d x=\int_{R} F \times\left(\varepsilon_{m}+\left(e_{t}\right) \times \theta\right) \times d x=\int_{R} F \times \xi \times d x
$$

Sendo que: 
$\xi$ é como uma combinação de deformação (deformação média $\varepsilon_{\mathrm{m}}+$ a curvatura multiplicada pela excentricidade total $\mathrm{e}_{\mathrm{t}}$ ).

O parâmetro $\xi$ pode ser empregado para medir a ductilidade por meio de:

$$
D_{c}=\frac{\xi_{0,85}}{\xi_{0,75}}
$$

O parâmetro $\xi_{0,75}$ é definido na Fig. 3.20 e $\xi_{0,85}$ é a deformação combinada quando a força diminui a $85 \%$ do seu valor máximo $\mathrm{F}_{\mathrm{u}}$ (ou último). $\mathrm{O}$ valor marcado com asterisco (*) corresponde ao início da "deformação de ruptura incontrolada" (ocorre quando o concreto do lado comprimido rompe e acontece o destacamento do cobrimento para o CAR). Se a deformação axial correspondente a $\left(^{*}\right)$ é maior à 0,85 da força última $F_{u}$, o parâmetro de ductilidade é definido como:

$$
D_{c}=\frac{\xi_{*}}{\xi_{0,75}}
$$

Foster e Attard (1997) sugerem considerar como parâmetro de ductilidade a área sob a curva força-deformação combinada $(\xi)$ que na realidade é a tenacidade. Os parâmetros de tenacidade são $\mathrm{I}_{5}$ e $\mathrm{I}_{10}$, sendo que $\mathrm{I}_{5}$ é a área $\mathrm{OCD}$ dividido pela área $\mathrm{OAB}$ e $\mathrm{I}_{10}$ é a área $\mathrm{OEF}$ dividido pela área OAB (Fig. 3.20). Para um material perfeitamente elasto-plástico (material com elevada tenacidade) $\mathrm{I}_{5}=5$ e $\mathrm{I}_{10}=10$ e para um material frágil (com tenacidade insignificante) $I_{5}=I_{10}=1$. Como mencionado anteriormente a tenacidade é um indicador energético e serve, neste caso, para medir a tenacidade à flexão.

Galeano e Vignoli (2008) sugerem empregar um outro parâmetro de ductilidade o $I_{c}$ como a área $\mathrm{OHG}$ dividido pela área $\mathrm{OAB}$ (Fig. 3.20). Estes investigadores obtiveram em seus ensaios valores de $D_{c}$ entre 2 e 9 e de $I_{c}$ entre 3 e 25 em função da excentricidade de força e do tipo do concreto.

Para o CAR, Foster e Attard (1997) obtiveram valores de $\mathrm{I}_{10}$ entre 6 e 9 e com $\mathrm{D}_{\mathrm{c}}$ entre 1 e 4 em função do tipo de concreto, da taxa e tensão de escoamento da armadura transversal. 


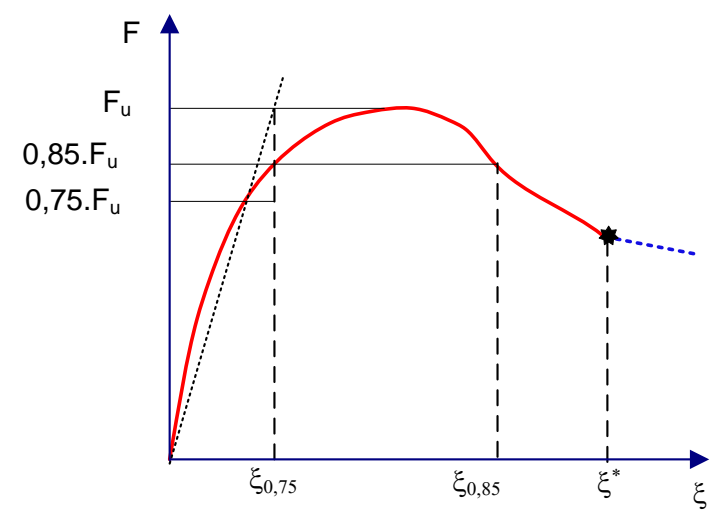

(a)

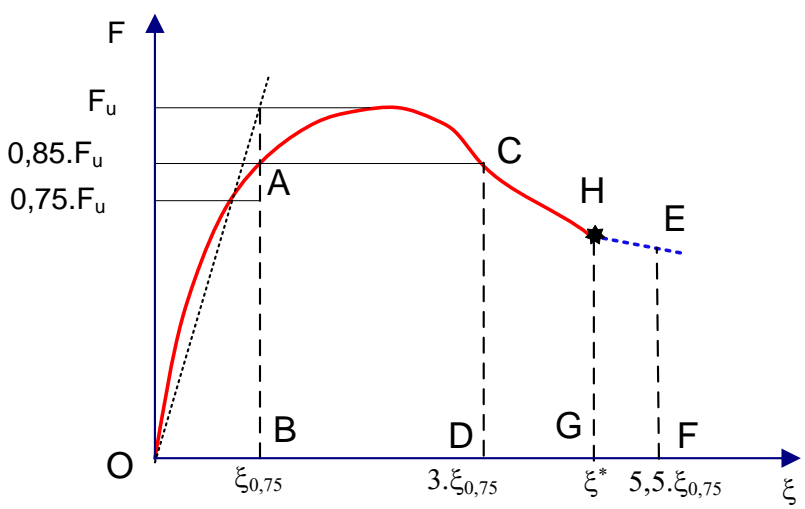

(b)

Fig. 3.20 - Diagramas de força axial x deformação combinada para pilares sujeitos a força excêntrica (a) ductilidade combinada e (b) ductilidade energética (Galeano e Vignoli, 2008).

Para os pilares esbeltos dos ensaios será calculado o parâmetro de ductilidade $\mathrm{D}_{\mathrm{c}}$.

\subsection{CONSIDERAÇÕES FINAIS}

Entre todos os fatores que influenciam o comportamento do confinamento dos pilares de concreto por estribos está a resistência do concreto, o destacamento do cobrimento, geometria e taxa volumétrica da armadura transversal, diâmetro e taxa da armadura longitudinal, resistência de escoamento da armadura transversal e longitudinal. Todos estes fatores influenciam na forma do diagrama $\sigma_{\mathrm{c}} \mathrm{x} \varepsilon_{\mathrm{c}}$ do concreto confinado.

Para pilares com quantias de armadura transversal e longitudinal densa a perda do cobrimento, especialmente se repentino, pode ser maior, podendo formar um plano natural de separação do cobrimento.

Os pilares, especialmente em CAR, quando perdem o cobrimento tem sua seção transversal diminuída, e se este pilar estiver efetivamente confinado, a sua seção transversal passa a ser a do núcleo, ou a área do núcleo efetivamente confinada considerada por meio do coeficiente de confinamento.

O CAR apresenta uma menor expansão lateral que o concreto convencional, quando submetida à compressão simples, isto corresponde a uma menor eficiência ao considerar o confinamento.

Não há influencia no confinamento ao incrementar a resistência de escoamento da armadura transversal, sempre que o limite de resistência dos estribos não seja atingido. Cusson e Paultre (1995), Légeron e Paultre (2003), concluíram que quanto maior é a tensão na armadura de confinamento $\sigma_{\mathrm{sw}}$, o confinamento é mais efetivo. 
O arranjo da armadura transversal é importante quando se quer melhorar o grau de confinamento. A Fig. 3.17 mostra melhores arranjos de armadura longitudinal e transversal. Diminuir o espaçamento entre estribos é outra maneira de melhorar a ductilidade e incrementar a resistência da peça.

Incrementar a taxa de armadura longitudinal melhora o confinamento, desde que esta armadura esteja contida pela armadura transversal, a Eq. 3.29 mostra esta relação, taxas mínimas recomendas estão por volta de 3\% (Lima, 1997 e Queiroga, 1999).

Não foi empregado o modelo Pautre e Legeron (2008) para avaliar a ductilidade porque durante os ensaios não foi possível chegar até a ruptura dos estribos ou até a ruptura do concreto confinado.

Pela Fig. 3.16 o efeito do confinamento, que é principalmente a ductilidade, começa a ter importância após a perda do cobrimento.

O efeito do confinamento adquire muita importância em regiões com abalos sísmicos, onde é necessário considerar o efeito da redistribuição de esforços sendo que os elementos estruturais devem apresentar ductilidade. Nestas regiões o índice efetivo de confinamento $I_{e}$ (Eq. 3.5) deve ser pelo menos 5\%.

Não foram feitos muitas pesquisas experimentais de pilares esbeltos (esbeltez maior a 90) sob compressão excêntrica e considerando o confinamento, sendo que no Brasil este é o primeiro. 


\section{Capítulo 4}

\section{ANÁLISE E COMPORTAMENTO DE PILARES ESBELTOS DE CONCRETO ARMADO}

\subsection{INTRODUÇÃO}

Um pilar de concreto armado pode atingir a ruína de duas maneiras: por esgotamento da capacidade resistente ou perda de estabilidade. Se a ruína for por instabilidade, quando da ocorrência de um pequeno acréscimo de força normal, resulta um deslocamento adicional de modo que o pilar não é capaz de mobilizar esforços resistentes suficientes para absorver os esforços solicitantes, é quando a força axial atinge valor crítico e o equilíbrio torna-se instável.

A ABNT NBR 6118:2003 indica que é necessário o cálculo dos esforços solicitantes na estrutura deformada quando estes se alteram de maneira significativa. Isto pode acontecer, entre outros fatores, quando o comprimento da peça comprimida é muito maior (mais que 10 vezes) a menor dimensão da seção transversal. Normalmente o parâmetro para considerar a estrutura na posição deformada é quando o incremento dos esforços, quando comparadas com a situação não deformada, é maior do que $5 \%$ ou $10 \%$.

Os efeitos locais de $2^{\mathrm{a}}$ ordem são aqueles que se somam aos obtidos na análise global (seja de $1^{\mathrm{a}}$ ordem ou de $2^{\mathrm{a}}$ ordem, pois esta fornece apenas os esforços solicitantes nas extremidades das barras) quando a análise do equilíbrio passa a ser considerada na posição deformada do pilar. Uma análise global de $2^{\mathrm{a}}$ ordem refere-se às mudanças de geometria por causa dos deslocamentos, neste caso a matriz de rigidez $[\mathrm{K}]$ da estrutura é função dos seus deslocamentos $\{\mathrm{u}\}$, isto é, ela se altera simultaneamente às alterações da forma da estrutura, a relação força-deslocamento deixa de ser linear. 
A ABNT NBR 6118:2003 apresenta métodos para a determinação dos efeitos de $2^{\mathrm{a}}$ ordem local. Até esbeltezes de elementos estruturais menores que 140 permite métodos simplificados; com esbeltezes maiores que 140, somente com o método geral, que é considerado um método exato. Outras normas utilizam outros limites.

\subsubsection{Revisão bibliográfica sucinta}

$\mathrm{Na}$ USP foram realizadas várias pesquisas teóricas a respeito do comportamento de pilares esbeltos. Aufiero (1977) e Buchaim (1979) foram os primeiros a abordar a instabilidade de pilares sujeitos a flexão normal composta, ambos utilizam o método do pilar padrão. França (1984) fez um estudo detalhado das relações momento-curvatura e força normal-deformação longitudinal em barras sujeitas a flexão oblíqua composta e elaborou um programa computacional de dimensionamento e tabelas para as relações momento-curvatura. Paula (1988), em base ao método geral, abordou o tema de pilares submetidos à flexão normal composta. França (1991) estudou problemas reológicos e propõe o emprego de relações momento-rigidez secante como uma maneira de linearizar as relações momento-curvatura e construiu ábacos acoplados a valores de rigidez secante, estas sugestões foram adotadas na atual norma ABNT NBR 6118:2003. Cadamuro Jr. (1997) elaborou um programa computacional (FLEXOR) de pilares esbeltos solicitados a flexão obliqua composta considerando o efeito da fluência do concreto. Borges (1999) analisou o programa computacional FLEXOR em vários exemplos práticos comparando o método do pilar padrão com o método geral. Aguiar (2000) abordou o tema do dimensionamento de pilares (com esbeltez mecânica de até 90) de concreto de alto desempenho com o emprego de diagramas momento-curvatura. Scadelai (2004) apresentou um dimensionamento de pilares de acordo com a norma ABNT NBR 6118:2003 para peças sob solicitações normais, aborda os processos aproximados. Oliveira (2004) fez um estudo da rigidez de pilares em função das relações momento-rigidez secante por meio da linearização das relações momento-curvatura. Ceccon (2008) estudou pilares sujeitos a flexão oblíqua composta comparando dois processos de cálculo, desacoplando as flexões nas direções principais e sem desacoplar considerando a curvatura obtida de diagramas momento-curvatura ponto a ponto incluindo os efeitos de $2^{\text {a }}$ ordem e concluiu que a simplificação de desacoplar as flexões e incluir os efeitos de $2^{\mathrm{a}}$ ordem em forma independente em cada direção e logo somar considerando um ELU de flexão oblíqua composta pode ser empregado com segurança.

Todos os trabalhos anteriormente relacionados tiveram uma abordagem analítica, outros estudos também foram realizados sob abordagem numérica. No laboratório foram 
realizadas várias pesquisas com pilares curtos ou de mediana esbeltez, estes trabalhos já foram expostos no item 3.3.

Em outras Universidades brasileiras também o assunto é abordado e já foram mencionados alguns trabalhos no item 3.3 no estudo do confinamento, e podemos citar outros como o de Araujo (1984) que estudou teoricamente o dimensionamento de pilares esbeltos com ajuda das relações momento-curvatura, considerou efeitos reológicos. Dantas (2006) ensaiou pilares esbeltos submetidos à flexão normal composta de concreto com resistência à compressão de $40 \mathrm{MPa}$ e verifica resultados com um programa computacional que considera a Teoria do Campo de Compressão Diagonal.

Esta tese faz o estudo teórico-experimental de pilares esbeltos de CAR considerando a ductilidade e o método geral como método de análise de resultados experimentais.

Fora do Brasil o tema de pilares foi e é um assunto bastante abordado. Os primeiros estudos foram realizados por volta de 1960 com as pesquisas de Broms e Viest ${ }^{9}$ apud, Kim e Yang (1995) nestes primeiros trabalhos foram adotadas as deformadas do pilar como funções de senos e cossenos, e com isto foi possível resolver a equação diferencial do pilar. Nesta mesma década iniciaram os ensaios de laboratório para o estudo de pilares esbeltos com Chang e Fergusson ${ }^{10}$ apud, Kim e Yang (1995).

Entre os trabalhos mais destacados e recentes o de Rangan (1990) apresentou uma rotina tentando simplificar o dimensionamento de pilares esbeltos considerando as relações momento-curvatura e compara resultados com a ACI-318. Bazant et al. (1991) introduz um conceito de projeto de pilares esbeltos com as curvas de interação força axial-momento com diagramas $\sigma_{\mathrm{c}} \mathrm{x} \varepsilon_{\mathrm{c}}$ realistas, faz uma comparação com resultados obtidos com ao ACI $318 \mathrm{e}$ com o CEB MC-90. MacGregor (1993) propõe uma revisão dos itens 10.10 e 10.11 da norma ACI 318, entre as mudanças está a nova rigidez à flexão para ser utilizada em conjunto com os efeitos de $2^{\mathrm{a}}$ ordem. Kim e Yang (1995) ensaiaram pilares esbeltos de CAR e modelaram numericamente diagramas de interação axial-momento para pilares esbeltos para validar os resultados dos seus ensaios. Bazant e Kwon (1994); Nemecek e Bittnar (2004) pesquisaram os efeitos dos ensaios em escala reduzida com os mesmos materiais e concluíram que não existe variação da resistência nominal pico, mas o comportamento pós-critico é mais dúctil para ensaios em escala reduzida.

\footnotetext{
${ }^{9}$ Broms, B. and Viest, I. M. (1958). Ultimate strength analysis of long restrained reinforced concrete columns. Proc. ASCE, 84(ST3), 1635-1-1635-30.

${ }^{10}$ Chang, W. F. and Fergusson, P. M. (1963). Long reinforced concrete columns, Proc. ACI. 60(1), 126.
} 
Claeson e Gylltoft (2000) realizam ensaios em pilares de CAR sujeitos a forças de longa duração. Mendis (2000) considera concretos com resistências maiores a $100 \mathrm{MPa}$, verifica a validade das expressões da norma ACI 318. Lloyd e Rangan (1996); Chuang e Konk (1997); Chuang et al. (2000); Germain e Espion (2005); Claeson e Gylltoft (1998); ensaiaram pilares esbeltos de CAR, os primeiros validaram resultados com a relação $\sigma_{\mathrm{c}} \times \varepsilon_{\mathrm{c}}$ proposta por Collins et al. (1993) e adotaram para a curvatura uma função seno; os segundos até os quartos validaram seus resultados com as normas e os últimos com o programa comercial ABAQUS v. 5.5. Mostafei et al. (2009) incorporam na obtenção da curvatura e da capacidade máxima do pilar o efeito da força cortante considerando o modelo simplificado da Teoria do Campo de Compressão Diagonal Modificado.

Outros pesquisadores analisaram resultados de ensaios numericamente, entre eles Chuang e Kong (1998) que transformaram o aço e o concreto num material equivalente homogêneo e elástico linear. Kwak e Kim (2004), Kwak e Kim (2006), Kwak e Kim (2006-b) introduzem no primeiro trabalho a presença das fissuras na NLF, constroem gráficos axialmomento e propõem uma expressão $F$ que diminui a resistência da seção no ELU considerando elementos esbeltos, no segundo e terceiro trabalhos introduzem a fluência do concreto e melhoram e simplificam a expressão F. Majewski et al. (2008) validam resultados de ensaios de laboratório de diversos pesquisadores através de um programa comercial de EF considerando elementos em 2D e 3D.

Outros pesquisadores trabalharam na obtenção da rigidez a flexão mais realista, entre eles Mirza (1990); Tikka e Mirza (1999); Tikka e Mirza (2005); Khuntia e Ghosh (2004); Kuntia e Ghosh (2004-b).

\subsection{CONSIDERAÇÕES INICIAIS DAS NÃO LINEARIDADES}

O comportamento da estrutura está baseado em modelos mecânicos e sua representação por modelos matemáticos. No comportamento da estrutura contribuem os efeitos da resposta do material e as mudanças de geometria, entre outros.

Quando o equilíbrio é descrito na posição deslocada, ou seja, na configuração atual, o deslocamento influencia no equilíbrio, não são necessários grandes deslocamentos, esta é a não linearidade geométrica (NLG), comumente chamada de $2^{\mathrm{a}}$ ordem. Na teoria de $2^{\mathrm{a}}$ ordem não se aplica o principio da superposição dos efeitos. 
Fazendo referência à posição deslocada permite analisar a estabilidade do equilíbrio identificando-se o aparecimento de ponto limite (para estruturas reais) ou ponto de bifurcação (para estruturas ideais) na resposta em deslocamento para diferentes intensidades de força.

Para pequenos deslocamentos se confundem as posições deformadas com as não deformadas, e se podem empregar as teorias lineares, e o equilíbrio é na posição não deformada. Nestas há proporcionalidade entre causas e efeitos.

É aceitável considerar NLG de forma simplificada, por exemplo, para pequenos giros é possível adotar as configurações em funções de senos e cosenos, ou adotar sen $\theta=\theta$, ou cos $\theta=1$ etc., a isto se chama de não linearidade geometricamente aproximada. Se não são adotadas hipóteses simplificadas em relação aos giros, realiza-se uma descrição geometricamente exata. Logo é possível adotar um modelo geometricamente aproximado ou um modelo geometricamente exato, geralmente é necessário um procedimento computacional para resolver um problema mecânico no modelo exato. O objetivo é descrever a relação forçadeslocamento, que poderia ser com uma expressão matemática dos deslocamentos, as relações deformações x deslocamentos incluem termos não lineares (Proença 1988).

Para determinar as respostas de qualquer problema de pilar é necessário resolver a condição de equilíbrio na posição deformada, junto com condições de compatibilidade e relações constitutivas. Surgem muitas complicações como, por exemplo, no campo das deformações intervirem termos de ordem superior, no final obtêm-se um sistema de equações diferenciais do problema, aplicando condições de contorno obtêm-se expressões matemáticas dos deslocamentos.

Este problema pode ter solução exata em estruturas muito simples, normalmente é necessário um procedimento computacional que considera uma solução incremental e interativa para obter a relação força-deslocamento (Proença, 2004). Na determinação desses efeitos de $2^{\mathrm{a}}$ ordem deve ser considerado o comportamento não linear do material.

O concreto armado é um compósito formado por dois materiais com diferentes propriedades, o aço pode ser considerado homogêneo e suas propriedades bem definidas e o concreto material heterogêneo composto por cimento, agregados e outros, suas propriedades são de difícil definição. Um diagrama típico força $\mathrm{x}$ deslocamento de um elemento de concreto armado submetida à flexão pode ser observado na Fig. 4.1. 


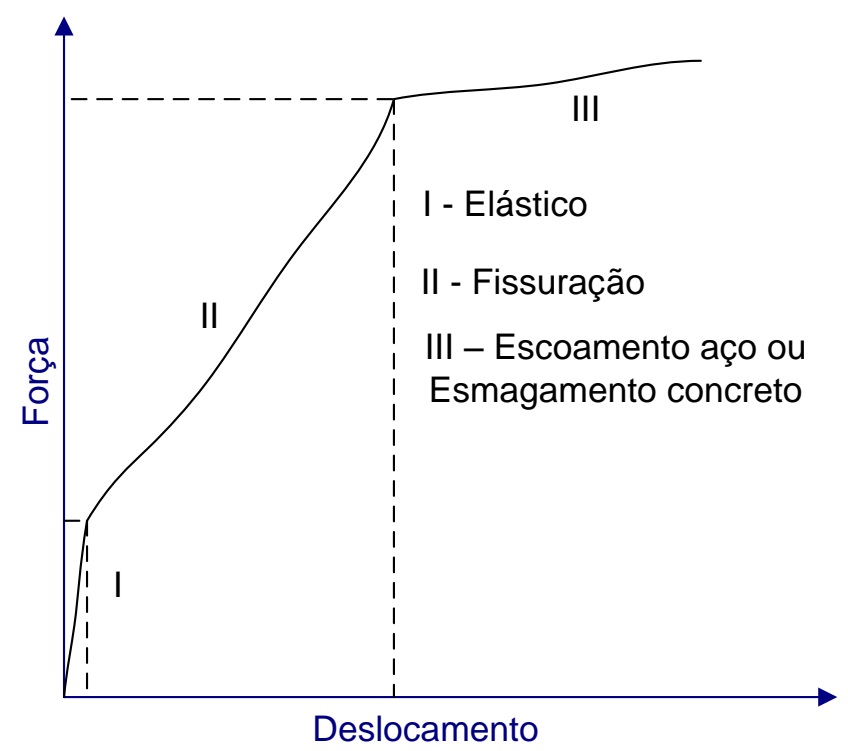

Fig. 4.1 - Etapas do comportamento não linear de um elemento à flexão de Concreto Armado (Kwak e Filippou, 1990).

A resposta não linear na Fig. 4.1 é em virtude da fissuração do concreto e escoamento da armadura ou ruptura do concreto. Entre outros fatores que influenciam o comportamento não linear tem-se o diagrama $\sigma_{\mathrm{c}} \times \varepsilon_{\mathrm{c}}$ do concreto e aço, a aderência entre aço-concreto, o engrenamento dos agregados nas fissuras diagonais, os efeitos reológicos, propagação das fissuras existentes na interfase, entre outros (Kwak e Filippou, 1990).

Quando o material não é linear (usualmente considerado pela forma do diagrama $\sigma_{\mathrm{c}} \mathrm{X}$ $\left.\varepsilon_{c}\right)$ o modelo se complica. Um material é linear quando obedece a lei de Hooke e não necessariamente é elástico, um material é elástico quando cessada a aplicação da força volta à sua posição inicial. O concreto não é nem elástico nem linear, é anelástico e não linear (Fusco, 1981). A Fig. 4.2 mostra o diagrama $\sigma_{c} \times \varepsilon_{c}$ de um material não linear e não elástico, no caso pode ser o diagrama do concreto. Esse comportamento do concreto é provocado pela perda de rigidez durante a fissuração do concreto, mas também intervém a plasticidade do concreto comprimido. 


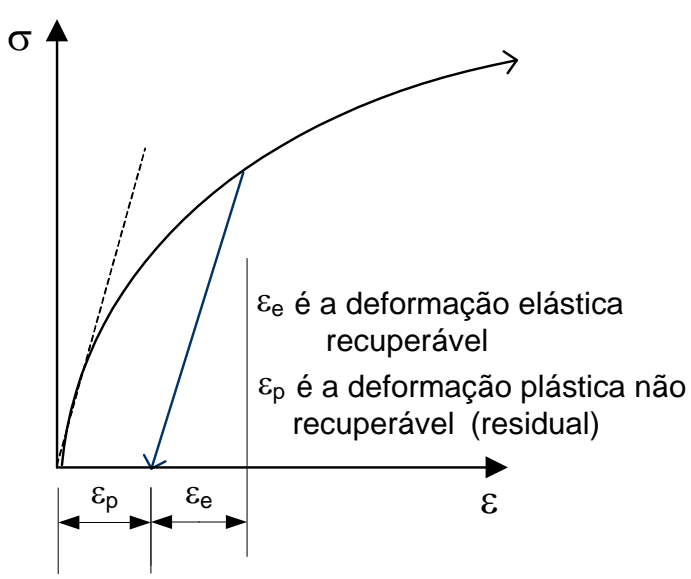

Fig. 4.2 - Diagrama $\sigma_{\mathrm{c}} \times \varepsilon_{\mathrm{c}}$ uniaxial de um material não linear e inelástico.

A utilização do concreto como material estrutural está muito difundido, mas o conhecimento de suas propriedades físicas e seu comportamento frente a combinações de esforços é muito precário. $\mathrm{O}$ comportamento do concreto sujeito a forças uniaxiais, biaxiais e triaxiais é diferente. É necessário formular um critério de ruptura quando o concreto está sujeito a vários estados de tensões. A resistência do concreto sujeito a diversos tipos e direções de tensões depende do estado de tensões e não pode ser avaliado por resistências uniaxiais de tração ou compressão de forma independente.

Neste trabalho, na elaboração dos programas computacionais, são empregados algoritmos para elementos lineares e a consideração da não linearidade física e geométrica é realizada com base ao diagrama momento-curvatura, que é obtido a partir de equações de equilíbrio, das equações de compatibilidade de deformações, das propriedades dos materiais incluindo o confinamento, da geometria da seção transversal, da armadura longitudinal conhecida e para a intensidade da força. Um objetivo é validar os resultados dos ensaios de laboratório, outro objetivo será a elaboração de curvas de dimensionamento.

\subsection{CONSIDERAÇÕES DA ESBELTEZ DE PILARES}

A esbeltez é um parâmetro necessário para verificar a necessidade de incorporar na análise os efeitos de segunda ordem, está baseado no comprimento efetivo do pilar (k.L), normalmente é aplicável somente nos casos de seção e armadura constante ao longo do pilar.

Pode-se pensar que o k corrige o comprimento do pilar em função da forma de sua linha elástico que depende de sua condição de contorno. O comprimento efetivo $\left(\mathrm{L}_{\mathrm{e}}=\mathrm{k}\right.$.L) é a distância entre os pontos de inflexão. A Fig. 4.3 mostra os valores de k para pilares isolados. 


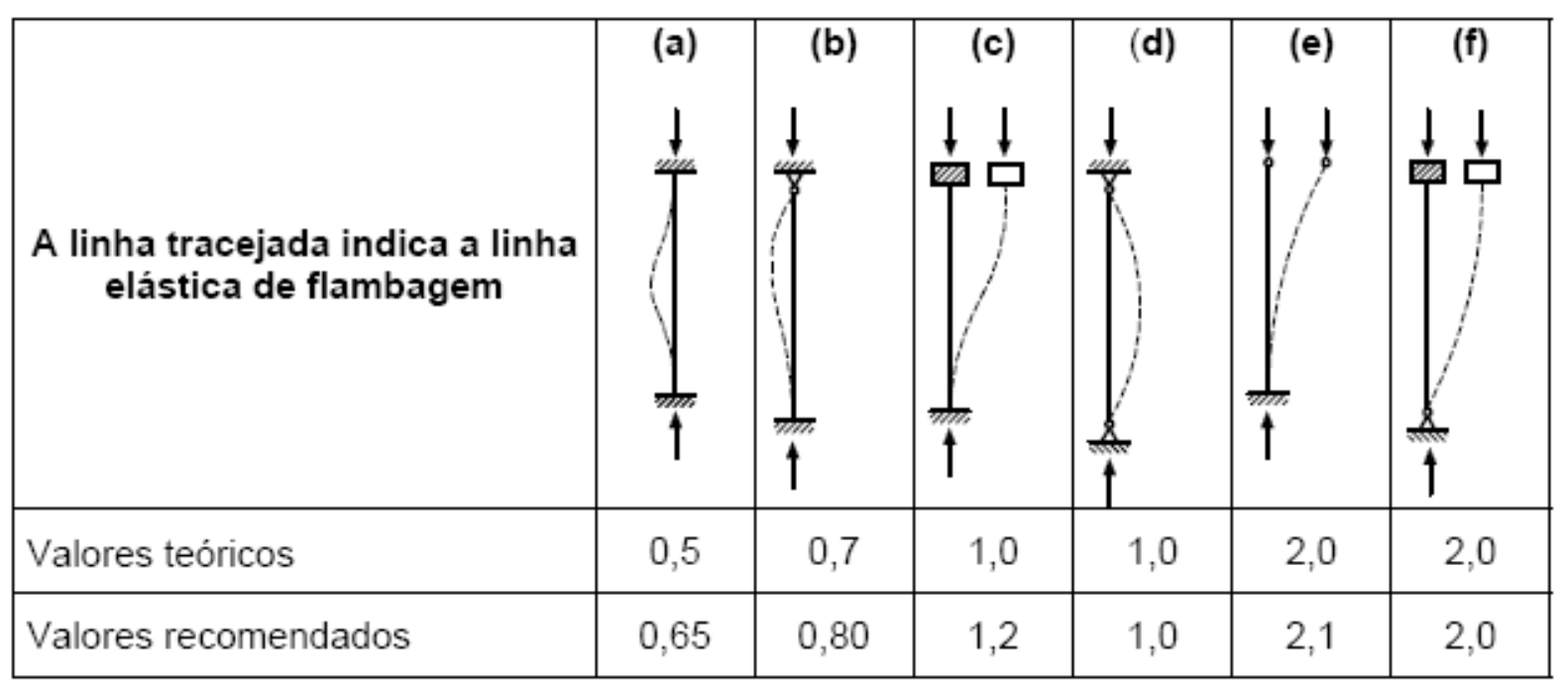

Fig. 4.3 - Valores de k para em pilares isolados (ABNT NBR 8800:2008).

A determinação do valor de $\mathrm{k}$ para pilares de pórticos depende da rotação e translação nas extremidades do pilar e pode variar em função da combinação de esforços solicitantes. Uma simplificação consiste em remover o pilar do pórtico e ser representado por um pilar simplesmente apoiado equivalente com comprimento efetivo k.L, com uma força axial no pilar real. Para a obtenção de k é necessário conhecer a rigidez à flexão das vigas fissuradas que chegam ao pilar, que normalmente é obtido no seu estado não fissurado. Quando é realizada um análise global de $2^{\mathrm{a}}$ ordem e não são considerados adequadamente as rigidezes dos elementos fissurados pode gerar, no cálculo dos esforços, uma diminuição do momento que chega ao pilar. Algumas normas fornecem valores aproximados das rigidezes das seções das vigas e pilares fissurados.

As normas ACI-318 (2005), AISC 2005, EHE 2008, DIN 1045 (2001) entre outras permitem a utilização de ábacos sugeridos pelo Structural Stability Research Council Guide (ASCE, 1997) para a obtenção do k em função de dois fatores de restrição de extremidade $G_{A}$ e $\mathrm{G}_{\mathrm{B}}$ (Fig. 4.5), onde o sub-índice A e B correspondem aos nós do topo e da base do pilar e $\mathrm{G}$ é definido como:

$$
G=\frac{\sum\left(\frac{E \times I}{L}\right)_{P}}{\sum\left(\frac{E \times I}{L}\right)_{V}}
$$

Sendo que:

$\left(\frac{E \times I}{L}\right)_{P} \mathrm{e}\left(\frac{E \times I}{L}\right)_{V}$ são a rigidez do elemento a flexão dos pilares e vigas respectivamente (no plano de flexão); 
$\sum$ significa que são todos os elementos que concorrem ao nó.

O valor de k é necessário para as duas direções principais do pilar.

Se um dos nós é engastado $G=0$ e se for articulado $G=\infty$. É comum simular a flexibilidade da fundação pelo valor de $G$. MacGregor (1997) recomenda $G=0,2$ e $G=10$, respectivamente, assim se considera pequenos giros na base dos pilares.

Conhecidos os valores da rigidez relativa dos nós $(\mathrm{G})$ é possível obter o k, de gráficos ou com expressões, a Fig. 4.4 mostras os gráficos para estruturas de nós móveis e fixos respectivamente.

Algumas condições restritivas ao uso dos nomogramas da Fig. 4.4: vigas sem carregamento, todos os pilares atingem suas cargas críticas ao mesmo tempo e as vigas são consideradas sem compressão, isto pode subestimar o valor de $\mathrm{k}$ em $15 \%$. Logo valores mínimos de k recomendados pela DIN 1045 (2001), para nós fixos 0,66 e para nós móveis 1,1; MacGregor (1997) recomenda 0,6 e 1,2 respectivamente.
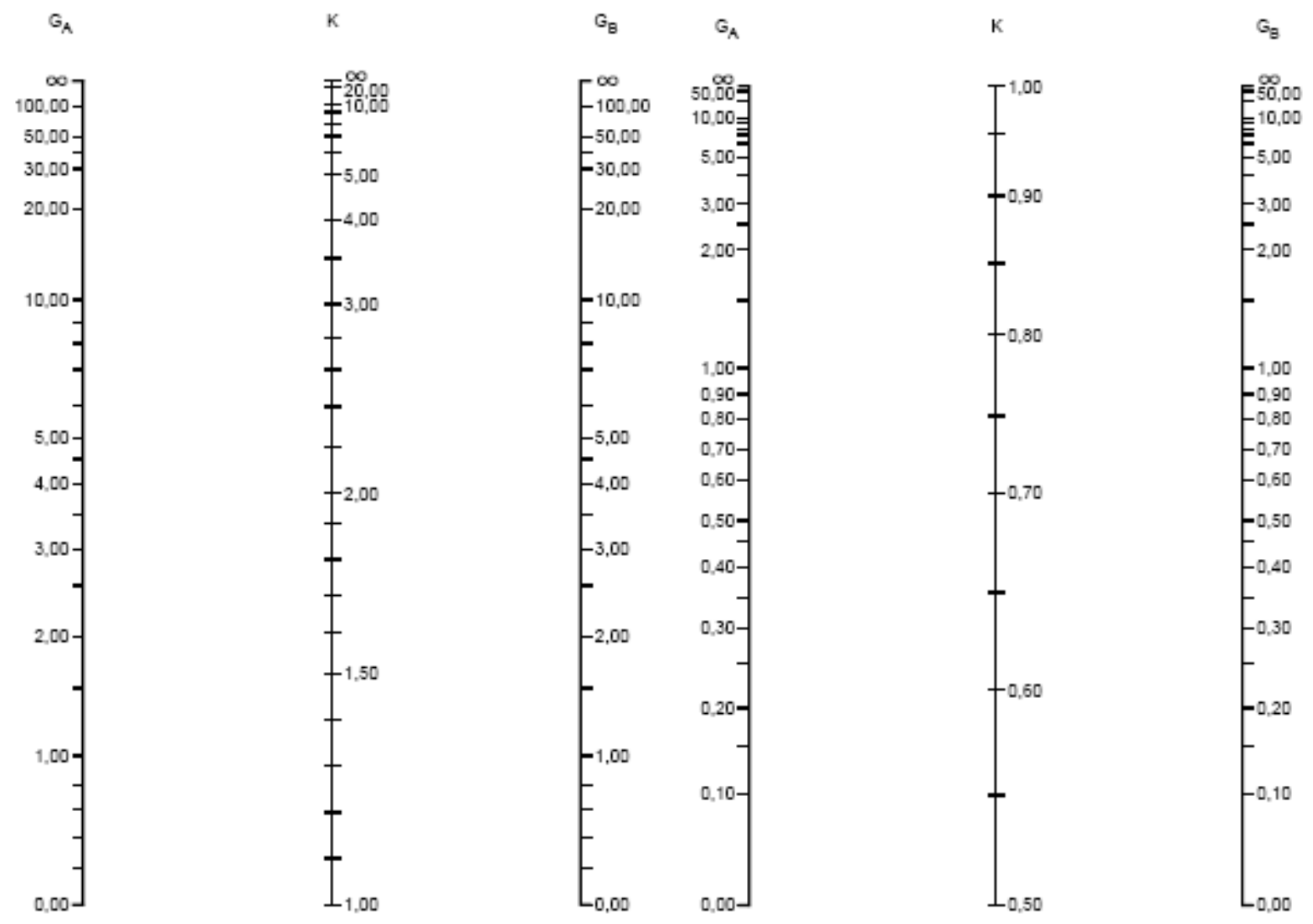

Fig. 4.4 - Obtenção do k para estruturas de nós móveis (esquerda) e nós fixos (direita), (adotado de Comentários AISC, 2005).

É necessário notar que existe um incremento no comprimento efetivo por causa do deslocamento lateral relativo entre os extremos do pilar, ou seja para estruturas de nós móveis 
os valores de k são maiores. A Fig. 4.5 mostra um pilar pertencente a um pórtico de nós fixos e a um pórtico de nós móveis.

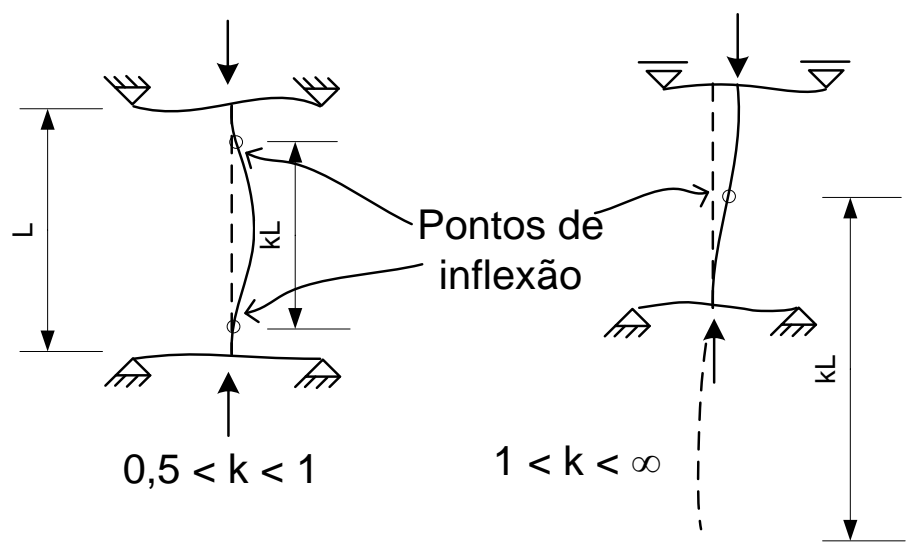

Fig. 4.5 - Comprimento efetivo de pilares, na esquerda para estrutura de nós fixos e na direita para estrutura de nós móveis (Park e Paulay, 1996).

Conhecido o comprimento efetivo do pilar (k.L) numa determinada direção é possível calcular a esbeltez do pilar que pode ser chamada de esbeltez geométrica quando o comprimento efetivo divide-se pela dimensão da seção do pilar na direção da flexão ou a esbeltez mecânica quando o comprimento efetivo divide-se pelo raio de giro da seção do pilar correspondente ao eixo perpendicular ao plano de flexão (Fig. 4.6). Neste estudo, se não for dito o contrário, quando mencionada a palavra esbeltez ela corresponderá à esbeltez mecânica.

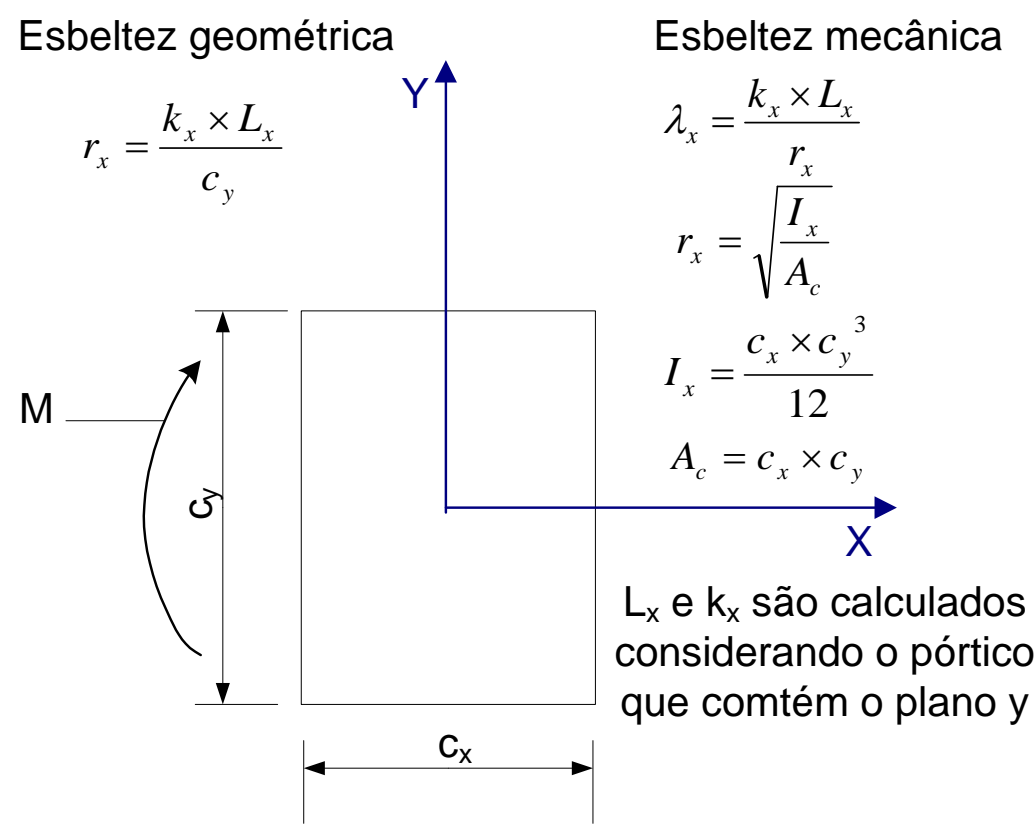

Fig. 4.6 - Definição de esbeltez mecânica e geométrica. 


\subsection{INSTABILIDADE DE BARRAS SUBMETIDAS À COMPRESSÃO CENTRADA E COMPRESSÃO EXCÊNTRICA.}

Para considerar um pilar esbelto compara-se a esbeltez do elemento com uma esbeltez limite, sendo que o limite foi adotado para que a redução da capacidade do pilar, em virtude dos efeitos de $2^{\mathrm{a}}$ ordem local provocados por deslocamentos laterais, seja menor do que $5 \%$ (ACI-318 2005) e 10\% (ABNT NBR 6118:2003) quando comparada com a capacidade resistente obtida de acordo com a teoria de $1^{\mathrm{a}}$ ordem.

Para o caso de pilares esbeltos (esbeltez da peça maior à esbeltez limite) sujeitos a flexo-compressão, as condições de equilíbrio devem ser realizadas no elemento deformado, ou seja, é obrigatória a consideração da NLG e NLF do elemento.

Na Fig. 4.7 são agrupados comportamentos de diferentes fenômenos que poderiam ocorrer em elementos sujeitos à compressão simples (à esquerda) e na compressão excêntrica (à direita). Verifica-se que somente para o caso de compressão simples tem-se um problema de estabilidade com bifurcação de equilíbrio (fenômeno de flambagem). Os deslocamentos para forças maiores a $F_{c r}$ deverão ser obtidas com a expressão exata da curvatura (Eq. 4.4).

Para barras esbeltas sujeitas a compressão excêntrica, e comportamento elástico linear (traço azul da direita), a barra deforma desde o inicio, e enquanto o material permanecer na situação elástica não existirá problemas de estabilidade (sempre haverá uma configuração de equilíbrio estável), a ruína ocorrerá por ruptura do material, é um problema de tensões. Neste caso, o cálculo dos deslocamentos precisaria ser realizado considerando a expressão exata da curvatura (Eq. 4.4); é possível obter deslocamentos empregando a equação simplificada, mas estes não são os verdadeiros. Este mesmo comportamento pode ocorrer em barras curtas de material não linear sujeitas à flexo-compressão.

Em elementos moderadamente esbeltos sujeitos ao fenômeno de instabilidade inelástica, ou elementos esbeltos com material de comportamento anelástico (traço vermelho da direita na Fig. 4.7), o deslocamento no topo $e_{2}$ e a força $F$ crescerão até que $F$ atinja um valor limite $\mathrm{F}_{\text {crI }}$, além do qual o momento interno cresce menos que o momento externo, tratase de um problema de ponto limite ou problema de estabilidade sem bifurcação de equilíbrio. Este é o caso de pilares esbeltos de concreto armado. 

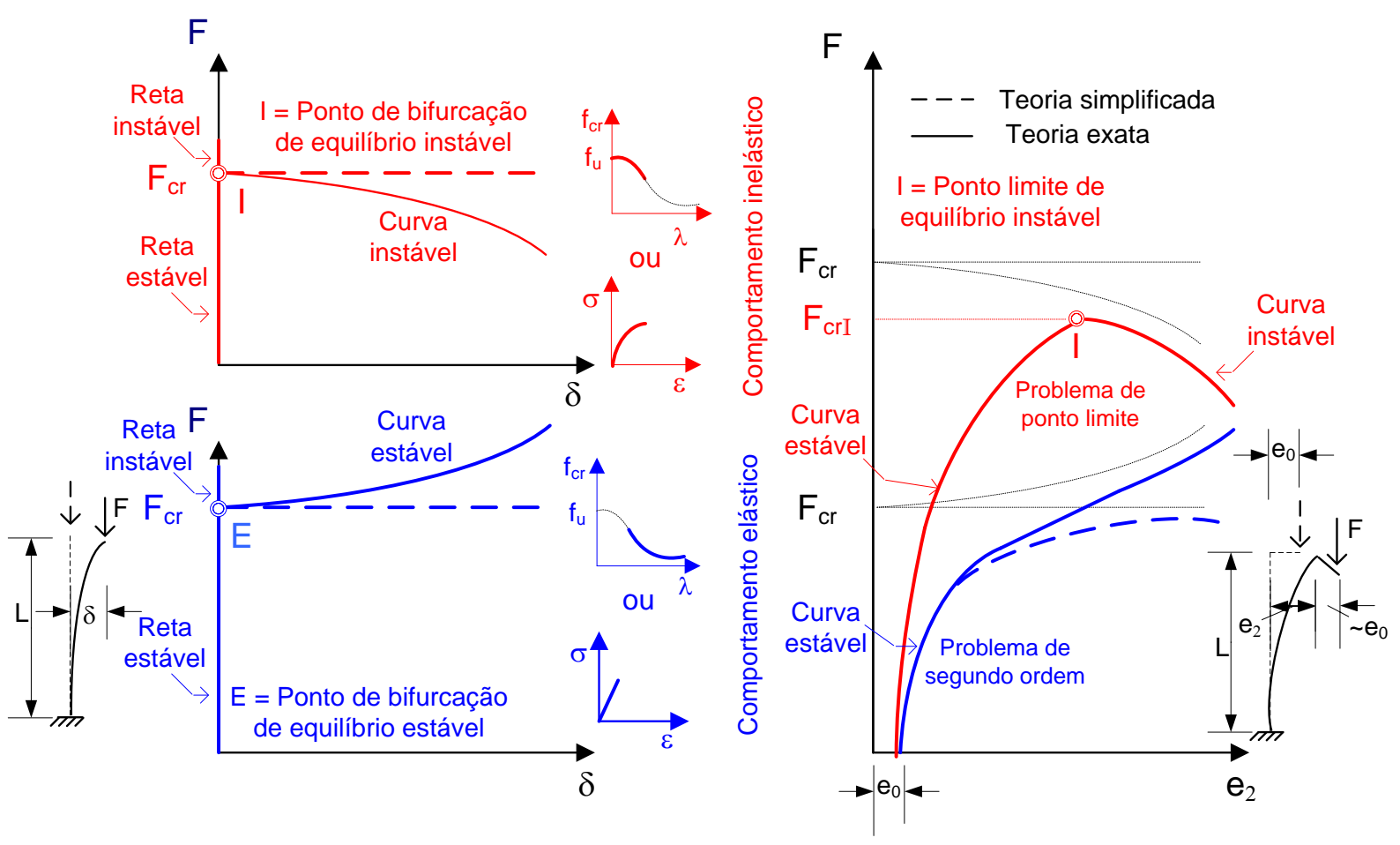

Fig. 4.7 - Formas de estabilidade nas barras (adaptada de Galambos, 1998).

Considerando os pilares de concreto armado, se não houver ruptura do concreto ou deformação excessiva da armadura (usualmente nos pilares curtos e moderadamente esbeltos), poderá ocorrer o estado limite último por instabilidade à flexo-compressão, isto pode ser melhor apreciado na Fig. 4.8.
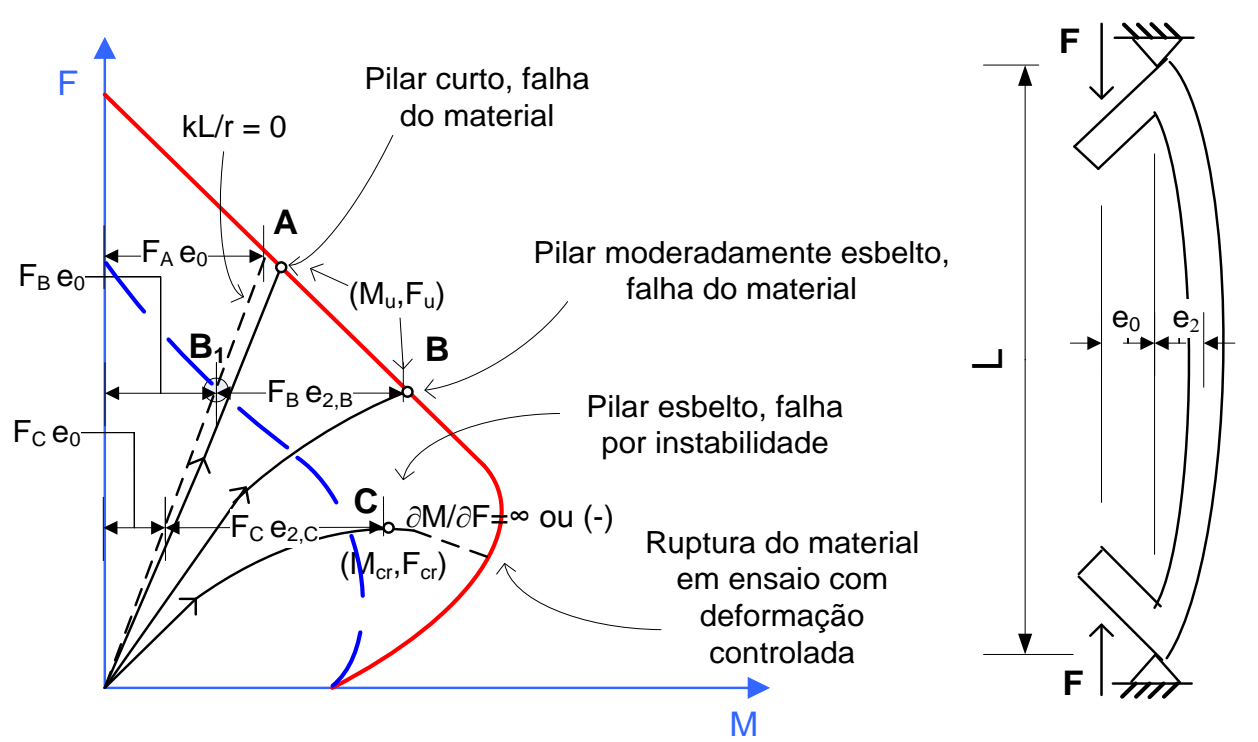

Fig. 4.8 - Diagrama de interação de força axial-momento fletor (adaptado de MacGregor, 1997). 
A curva de interação axial-momento (em vermelho) da Fig.4.8 corresponde ao estado limite dos materiais. A linha reta segmentada preta corresponde a incrementos de força axial mantendo constante a excentricidade inicial $\mathrm{e}_{0}$. Para um pilar do caso A, na Fig. 4.8, como seu deslocamento final é pequeno, os efeitos de $2^{\mathrm{a}}$ ordem podem ser desconsiderados, o momento final pode ser avaliada como $M_{u}=M_{0}=F_{A} \times e_{0}$.

No caso B, a flecha já é apreciável e o equilíbrio precisa ser considerado na situação deformada, surge um momento de segunda ordem $\mathrm{M}_{2}$, sendo que o momento último é $M_{u}=F_{B} \times e_{0}+F_{B} \times e_{2, B}$. Este caso corresponde a um problema de tensões, é o caso mais usual nos elementos moderadamente esbeltos, é o caso da maioria dos pilares medianamente esbeltos ou alguns esbeltos pertencentes a pórticos contraventados. Há uma diminuição na capacidade resistente do pilar à força axial por efeito da esbeltez. Unindo pontos que conduzem à ruína da seção [ponto $\mathrm{B}$ trasladado ao $\mathrm{B}_{1}$, por cima da reta preta segmentada, que corresponde a uma posição de esbeltez nula (não considera o incremento do deslocamento de segunda ordem)] para uma determinada esbeltez, é possível ser desenhada uma curva que forneça o valor da força e o momento de $1^{\mathrm{a}}$ ordem máximos que poderiam ser aplicados ao pilar, sendo que a curva corresponde à linha azul segmentada. A diferença, na direção da abscissa, entre a curva vermelha e a curva azul é o efeito de segunda ordem, o diagrama azul segmentado corresponde à curva força axial-momento de $1^{\mathrm{a}}$ ordem para a esbeltez do pilar $\mathrm{B}$.

Finalmente no caso $\mathrm{C}$, o diagrama de interação não foi alcançado, significa ruína por instabilidade à flexo-compressão, neste caso a força axial máxima que o pilar esbelto pode suportar é $\mathrm{F}_{\mathrm{crI}}$, que é a força crítica de instabilidade por flexo-compressão, ou em termos do momento de $1^{\mathrm{a}}$ ordem $M_{0, c r}=F_{c r I} \times e_{0}$, é o momento máximo de $1^{\mathrm{a}}$ ordem que o elemento pode suportar. Este último caso corresponde a um problema de ponto limite e pode ocorrer em elementos muito esbeltos. São justamente os pilares do caso B e C que interessam neste trabalho.

\subsubsection{Relações entre deslocamento e curvatura para um pilar sujeito a flexo- compressão.}

Em problemas de verificação ou de dimensionamento de elementos de concreto armado, existem vários procedimentos que consideram estados limites de carga crítica de instabilidade ou ruína do material. Muitos deles são simplificados e para incorporar a não linearidade geométrica fornecem expressões aproximadas para a linha elástica da 
configuração deformada, como por exemplo, uma senóide (Fig. 4.9), podendo ter sinal positivo ou negativo (Eq. 4.2).

$$
y=-e_{2} \times \operatorname{sen}\left(\frac{\pi}{L_{e}} \times x\right)
$$

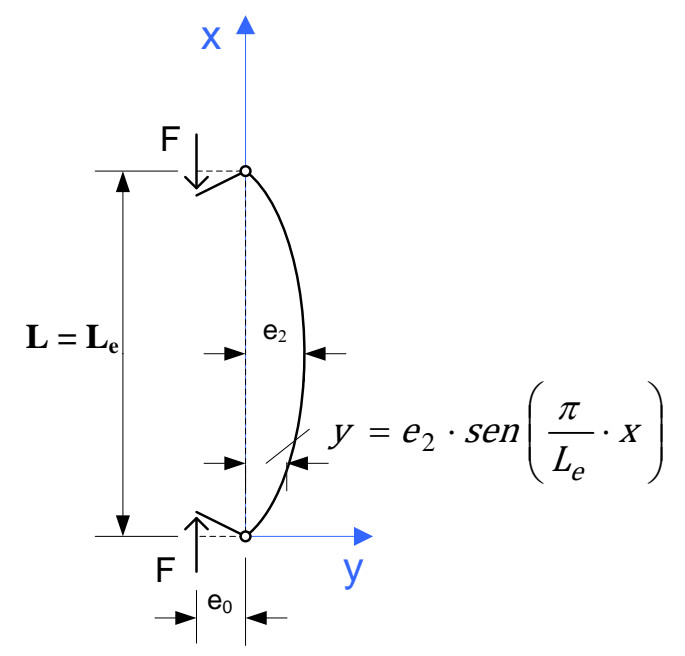

Fig. 4.9 - Elemento com linha elástica senoidal.

Considerando a flexo-compressão em materiais elásticos lineares, as expressões dos momentos externos atuantes e resistentes são:

$$
M_{e x t}=F\left(e_{0}+y\right) \quad \text { e } \quad M_{\mathrm{int}}=-\frac{1}{r} \times(E . I)
$$

Sendo que:

$\mathrm{L}_{\mathrm{e}}=\mathrm{k} . \mathrm{L}$ é o comprimento efetivo da barra (comprimento de uma semi-onda com forma de senoide, que é a configuração na qual se admite que a barra se deforma ou distância entre os pontos de inflexão);

$\frac{1}{r}$ é a curvatura da barra na situação fletida;

$\mathrm{e}_{0}$ é a excentricidade inicial da força;

$\mathrm{e}_{2}$ é a excentricidade de $2^{\mathrm{a}}$ ordem;

E.I é a rigidez a flexão da barra.

Para se verificar a existência do equilíbrio estável, é necessário que seja considerada a continuidade do equilíbrio (dado pela condição $\mathrm{M}_{\mathrm{ext}}=\mathrm{M}_{\text {int }}$ ), quando é produzido um pequeno acréscimo de $\mathrm{M}_{\mathrm{ext}}$. É justamente aí que se verifica o estado limite último de instabilidade, ou seja, quando a força atinge certo valor que produza um equilíbrio instável (Fig. 4.10).

Num regime elástico linear, demonstra-se que a expressão exata da curvatura é (Fusco, 1981): 


$$
\frac{1}{r}=\frac{\frac{d^{2} y}{d x^{2}}}{\left[1+\left(\frac{d y}{d x}\right)^{2}\right]^{\frac{3}{2}}}
$$

Nas estruturas usuais, para pequenos giros $\frac{d y}{d x}<<1$, a expressão da curvatura pode ser aproximada para:

$$
\frac{1}{r} \approx \frac{d^{2} y}{d x^{2}}
$$

Substituindo a Eq. 4.2 na Eq. 4.5, resulta a Eq. 4.6

$$
\frac{1}{r} \approx\left(\frac{\pi}{L_{e}}\right)^{2} \times y \quad \text { ou seja } \quad y \approx c t t e \times \frac{1}{r}
$$

Segundo Fusco (1981), considerando a expressão exata da curvatura e junto com a Eq. 4.2 obtêm-se a expressão algébrica exata da curvatura (Eq. 4.7):

$$
\frac{1}{r}=\frac{\left(\frac{\pi}{L_{e}}\right)^{2}}{\left[1+\left(\frac{\pi}{L_{e}}\right)^{2} \times\left(e_{2}{ }^{2}-y^{2}\right)\right]^{\frac{3}{2}}} \times y
$$

A Eq. 4.6 mostra que, num determinado trecho da barra, existe linearidade entre o deslocamento e a curvatura. No caso da Eq. 4.7 não há linearidade entre o deslocamento e a curvatura, mas o momento resistente, em função da curvatura permanece linear (Eq. 4.3). Agora num comportamento inelástico ou um material não linear, não existe linearidade entre o momento resistente e a curvatura, pois a rigidez a flexão não é constante.

No caso do concreto armado (material anelástico e não linear) o momento interno é obtido da resultante do diagrama das tensões correspondentes à curvatura em consideração, o que acarreta um diagrama curvo do momento resistente-curvatura.

Para o caso do momento solicitante, como nas estruturas reais as rotações são pequenas, usualmente considera-se a expressão aproximada da curvatura (Eq. 4.6), neste sentido existe linearidade entre o momento externo e a curvatura.

$\mathrm{Na}$ Fig. 4.10 são apresentadas as curvas momento-curvatura reunindo todas as explicações sobre os diferentes fenômenos que podem ocorrer com as barras a flexocompressão. O caso que mais interessa é quando a reta correspondente ao momento externo 
tangencia a curva do momento interno resistente, é quando a carga $F=F_{2}$ atinge a carga crítica de instabilidade por flexo-compressão $F_{\text {crl }}$ (ver Fig. 4.7 e Fig. 4.8).

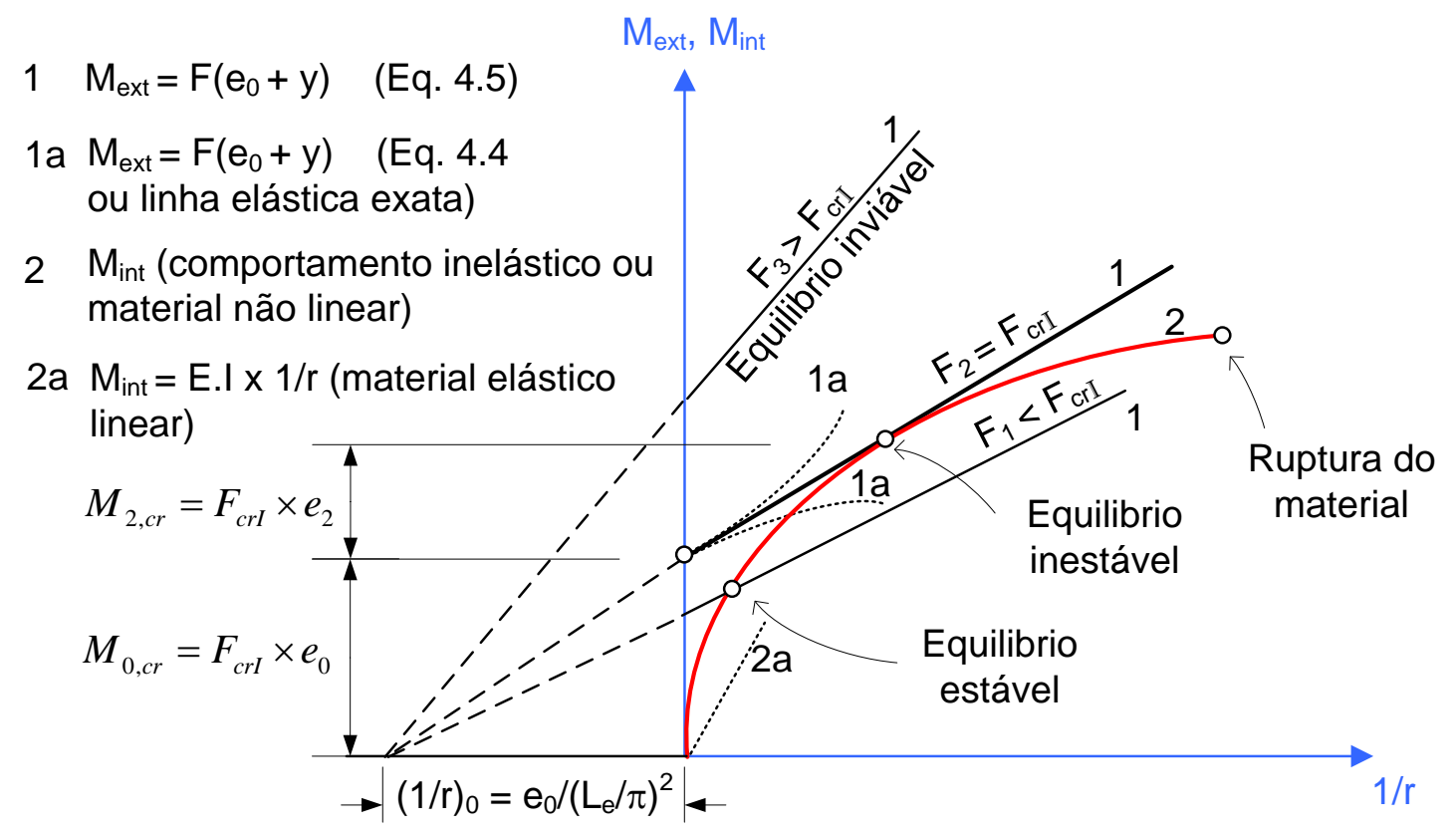

Fig. 4.10 - Diagramas momento-curvatura na flexo-compresão (adaptada de Fusco, 1981).

\subsubsection{Resolução da equação diferencial de um elemento de material elástico linear sujeito à compressão excêntrica.}

Para o caso de um pilar com excentricidades iguais nas extremidades (Fig. 4.11), considerando a rigidez E.I constante em toda a barra e igualando o momento solicitante com o resistente (Eq. 4.3) e utilizando a expressão simplificada da curvatura, Eq. 4.5 obtêm-se:

$$
\frac{d^{2} y}{d x^{2}}+\frac{F \times y}{E \times I}=-\frac{M_{0}}{E \times I}
$$

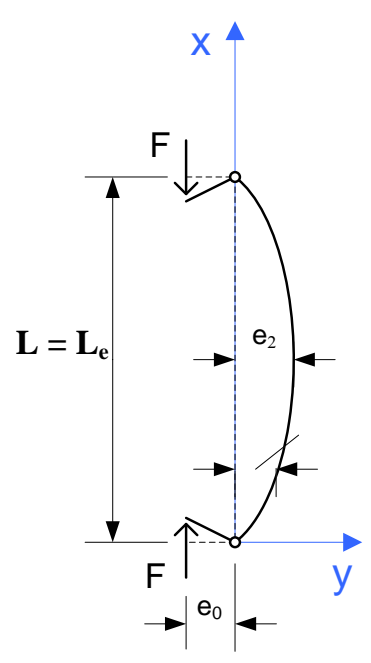

Fig. 4.11 - Esquema de um pilar sujeito à flexão-compressão uniforme. 
Operando a Eq. 4.8 (diferenciando duas vezes) junto com a expressão do momento resistente da Eq. 4.3 e simplificando, obtêm-se a equação diferencial:

$$
-\frac{1}{E \times I} \times \frac{d^{2} M(x)}{d x^{2}}-\frac{F}{E \times I} \times \frac{M(x)}{E \times I}=-\frac{1}{E \times I} \times \frac{d^{2} M_{0}}{d x^{2}}
$$

Substituindo $\frac{F}{E \times I}=K^{2}$ e simplificando, têm-se:

$$
\frac{d^{2} M(x)}{d x^{2}}+K^{2} \times M(x)=\frac{d^{2} M_{0}}{d x^{2}}
$$

As equações 4.9 e 4.10 também são válidas para pilares com qualquer tipo de ações (ao longo do seu comprimento) e excentricidades nas extremidades.

A Eq. 4.10 é uma equação diferencial de segunda ordem, não homogênea, e sua solução é a soma de uma equação homogênea e uma solução particular p(x), assim:

$$
M(x)=C_{1} \times \operatorname{sen}(K \times x)+C_{2} \times \cos (K \times x)+p(x)
$$

A solução desta equação para o caso de momentos desiguais aplicados nas extremidades (Fig. 4.12) foi apresentada por Salmon e Johnson (1996) e corresponde à Eq. 4.12 .

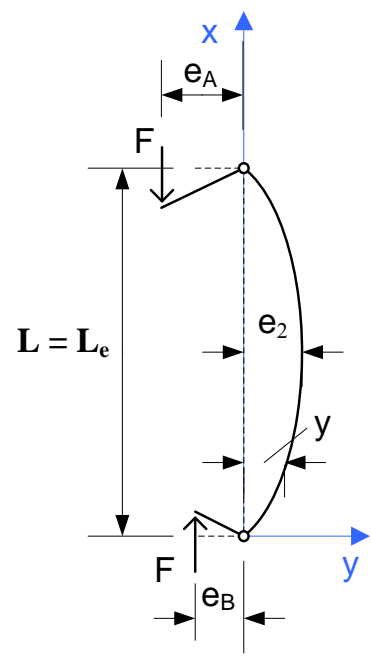

Fig. 4.12 - Pilar sujeito a excentricidades diferentes nas extremidades.

$$
M_{\max \text { imo }}=M_{A} \times \sqrt{\frac{1-2 \times \frac{M_{B}}{M_{A}} \times \cos (K \times L) \times\left(\frac{M_{B}}{M_{A}}\right)^{2}}{\operatorname{sen}^{2}(K \times L)}}
$$

Para o caso de excentricidades iguais nas extremidades (Fig. 4.11):

$$
M_{\max \text { imo }}=M_{0} \times \sec \left(\frac{K \times L}{2}\right)
$$


Sendo:

$\mathrm{M}_{0}$ o momento de $1^{\mathrm{a}}$ ordem (para excentricidades iguais nas extremidades, $\mathrm{F} \times \mathrm{e}_{0}$ );

$\mathrm{M}_{\mathrm{A}}$ o momento maior aplicado na extremidade;

$\mathrm{M}_{\mathrm{B}}$ o momento menor aplicado na extremidade;

$$
K=\sqrt{\frac{F}{E \times I}} .
$$

Para considerar os efeitos de $2^{\mathrm{a}}$ ordem, é necessário conhecer a linha elástica ou como mínimo a flecha na seção crítica; as expressões da Mecânica de Materiais não são válidas para o concreto armado, usualmente se aplicam à materiais elásticos lineares e não consideram as forças axiais no cálculo do deslocamento (as Eq. 4.12 e Eq. 4.13 consideram a flexãocomposta).

As Eq. 4.12 e Eq. 4.13 poderiam ser consideradas no dimensionamento do concreto armado se a rigidez à flexão (E.I) fosse a adequada. A norma ACI-318 (2005) adota uma expressão para (E.I) a ser utilizada indiretamente na obtenção do momento último.

Logo é necessária uma expressão do "momento resistente-curvatura" (simplificadamente momento-curvatura) ou curvas de interação momento-força axialcurvatura como uma forma adequada no cálculo dos momentos últimos em pilares de concreto armado considerando os efeitos de $2^{\mathrm{a}}$ ordem.

\subsection{DIAGRAMA FORÇA NORMAL-MOMENTO RESISTENTE- CURVATURA}

Os diagramas de interação normalmente denominados de momento-curvatura são fundamentais quando as peças de concreto armado apresentam as não linearidades físicas e geométricas e são básicos para o cálculo do dimensionamento e estudo da estabilidade.

Sua construção é para poder conhecer a curvatura provocada por um determinado momento fletor atuante, para uma dada seção transversal com armadura conhecida, e para uma intensidade de força normal preestabelecida, considerando as equações de equilíbrio, equações de compatibilidade, equações constitutivas dos materiais e geometria dos componentes do conjunto. No lugar de diagramas podem ser elaboradas tabelas.

Para sua construção considera-se que as seções transversais permanecem planas e normais ao eixo deformado até o ELU e que existe uma perfeita aderência entre o concreto e a armadura longitudinal com isto o diagrama de deformação para uma seção qualquer serve 
para o aço e concreto. Também são excluidos os deslocamentos em virtude das forças cortantes e consideram-se deslocamentos e rotações moderados (Ceccon, 2008).

Para que exista uma forma fletida estável, basta encontrar uma deformada tal que a curvatura em qualquer seção corresponda a um momento resistente igual ao momento externo total (incluindo os efeitos de $2^{\mathrm{a}}$ ordem) calculado com a deformada. O valor limite da curvatura está na falha do material, ou seja, a ruptura do concreto ou na deformação excessiva da armadura longitudinal.

As expressões das curvaturas do item anterior (Eq. 4.5 e Eq. 4.7) não são válidas para o concreto armado. Para ter uma expressão da curvatura válida para qualquer tipo de material, inclusive para o concreto armado, é necessário considerar um elemento de barra de comprimento elementar dx sujeito a flexão e que esteja em equilíbrio após a deformação (Fig. 4.13). Da Fig. 4.13 pode-se obter a expressão da curvatura considerando relações de triângulos.

$$
\frac{1}{r}=\frac{\varepsilon_{c \max }-\varepsilon_{1}}{h}
$$

Sendo que:

$\varepsilon_{\mathrm{cmax}}$ é a deformação máxima do concreto comprimido;

$\varepsilon_{1}$ é a deformação correspondente à fibra extrema oposta da fibra mais comprimida da seção;

h é a altura total da seção.

$\mathrm{Na}$ expressão anterior e nas seguintes que envolvem a determinação das relações momento-curvatura foi considerado o alongamento com sinal negativo e o encurtamento com sinal positivo.

Como vai se empregar grandezas adimensionais, no caso da curvatura:

$$
\theta=\frac{h}{r} \times 1000=\varepsilon_{c \max }-\varepsilon_{1}
$$

Sendo que:

$\theta$ é a curvatura adimensional (ou simplesmente curvatura e juntamente com as deformações específicas em \%o). A Fig. 4.13 corresponde a um elemento diferencial de barra à flexão por meio desta é possível obter relações entre as deformações específicas. 


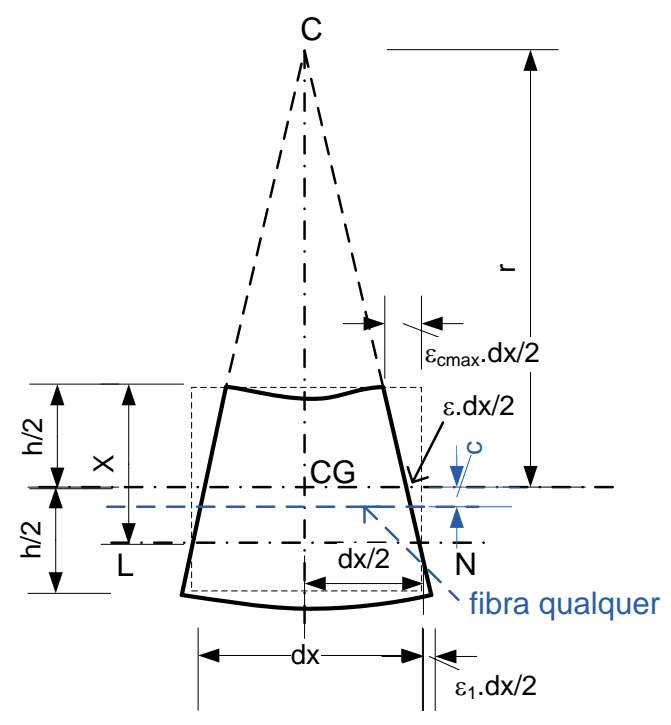

Fig. 4.13 - Elemento diferencial de barra à flexão.

Da Fig. 4.13 obtém-se:

$$
\beta_{x}=\frac{x}{h}=\frac{\varepsilon_{c \max }}{\varepsilon_{c \max }-\varepsilon_{1}}=\frac{\varepsilon_{c \max }}{\theta}
$$

Sendo que: $\beta x$ é a posição da LN reduzida em relação à borda mais comprimida.

\subsubsection{Traçado do diagrama momento-curvatura}

A sua construção é por tentativas sendo necessário um procedimento computacional e interativo para a obtenção dos diferentes pontos da curva. Não são empregadas as expressões dos Estados Limites (EL), porque as solicitações correspondentes a uma determinada curvatura são menores do que os relativos aos EL, isto significa que os diagramas de deformações específicas não podem pertencer aos domínios de deformação, mas corresponder a uma situação qualquer de serviço (Santos, 1987). Com os valores das deformações específicas são obtidas as forças resultantes nas armaduras e no concreto comprimido, para tal foram empregados os diagramas tensão-deformação específica realistas tanto do aço como do concreto. Para a obtenção da resultante do concreto comprimido foi realizada uma integração numérica da área sob a curva $\sigma_{\mathrm{c}} \times \varepsilon_{\mathrm{c}}$ realista, quando necessário foi incorporado o efeito do confinamento nos diagramas realistas do concreto (ver Capítulo 2 e Capítulo 3).

Toda a abordagem foi adimensional, e o objetivo era poder desenhar os diagramas e empregar as rotinas para serem utilizadas na verificação das seções sujeitas a flexocompressão como o método geral. Para a verificação dos valores obtidos nos ensaios dos pilares esbeltos por meio dos programas elaborados pelo autor, foram empregados os modelos 
realistas da norma EUROCODE 2 (2004) para o concreto comprimido não confinado e o modelo de Légeron e Paultre (2003) para o concreto comprimido parcialmente confinado.

As grandezas foram desenvolvidas analiticamente com expressões adimensionais, reduzidas em relação à h (altura da seção transversal), b (largura da seção) e à resistência média do concreto $\mathrm{f}_{\mathrm{cm}}$ (ou para projeto $0,85 \mathrm{f}_{\mathrm{cd}}$ ).

A Fig. 4.14 mostra o diagrama de tensões e de deformações e seus diferentes parâmetros de cálculo (quando entre parênteses, junto com seus correspondentes reduzidos).

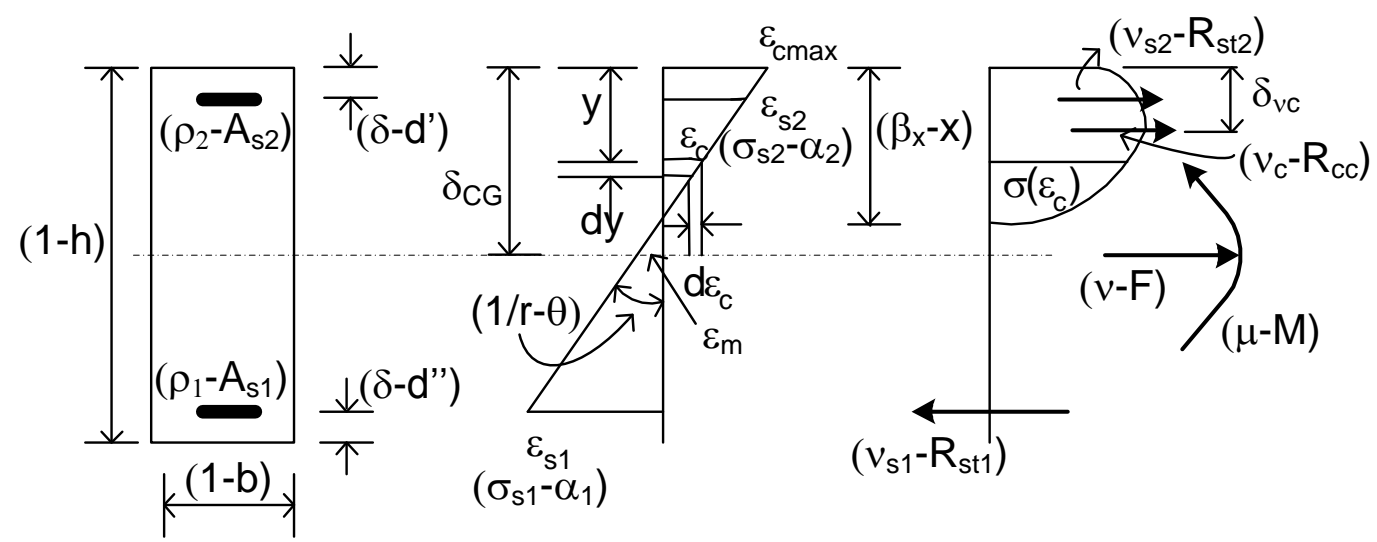

Fig. 4.14 - Diagrama de tensões e deformações (Aguirre et al., 2006).

Os parâmetros da Fig. 4.14 são:

Áreas das armaduras ( $\rho_{1}$ é a quantia geométrica reduzida da armadura tracionada pelo momento fletor $\mu, \rho_{2}$ é a quantia geométrica reduzida da armadura comprimida pelo momento fletor $\mu)$ :

$$
\rho_{1}=\frac{A_{s 1}}{b \times h} \quad \text { e } \quad \rho_{2}=\frac{A_{s 2}}{b \times h}
$$

Tensões nas armaduras:

$$
\alpha_{1}=\frac{\sigma_{s 1}}{f_{c m}} \quad \text { e } \quad \alpha_{2}=\frac{\sigma_{s 2}}{f_{c m}}
$$

Resultantes nas armaduras:

$$
v_{s 1}=\frac{R_{s t 1}}{f_{c m} \times b \times h} \quad \text { e } \quad v_{s 2}=\frac{R_{s t 2}}{f_{c m} \times b \times h}
$$

Em relação aos esforços solicitantes e resistentes, tem-se:

Momento fletor e força normal atuantes:

$$
\mu=\frac{M}{f_{c m} \times b \times h^{2}} \quad \text { e } \quad v=\frac{F}{f_{c m} \times b \times h}
$$

A resultante do concreto comprimido e o momento produzido pela mesma em relação à fibra comprimida mais externa, são: 


$$
\begin{gathered}
R_{c c}=\int_{0}^{x} b \times \sigma\left(\varepsilon_{c}\right) \times d y \\
M_{R c c}=\int_{0}^{x} b \times \sigma\left(\varepsilon_{c}\right) \times y \times d y
\end{gathered}
$$

São relacionadas as grandezas "y" com " $\theta$ " da Fig. 4.14, com o objetivo de modificar as variáveis de integração das Eq. 4.21 e Eq. 4.22:

$$
y=\frac{h}{\theta} \times\left(\varepsilon_{c \max }-\varepsilon_{c}\right) \quad d y=-\frac{h}{\theta} \times d \varepsilon_{c}
$$

Substituindo as Eq. 4.23 nas Eq. 4.21 e Eq. 4.22, obtêm-se as equações paramétricas da resultante do concreto e do seu momento em relação à fibra comprimida mais externa:

$$
\begin{gathered}
\nu_{c}=\frac{1}{\theta} \times \int_{0}^{\varepsilon_{c} \max } \sigma_{R}\left(\varepsilon_{c}\right) \times d \varepsilon_{c} \\
\mu_{c}=\frac{1}{\theta^{2}} \times \int_{0}^{\varepsilon_{c} \max } \sigma_{R}\left(\varepsilon_{c}\right) \times\left(\varepsilon_{c \max }-\varepsilon_{c}\right) \times d \varepsilon_{c}
\end{gathered}
$$

Considerando a ruptura simultânea dos materiais é possível calcular o valor da curvatura última.

$$
\theta_{u l t}=\frac{\varepsilon_{c u 1}+0,01}{1-\delta}
$$

Sendo que: $\varepsilon_{\mathrm{cu} 1}$ é a deformação limite do concreto comprimido (Fig. 6.2).

Da Fig. 4.14, obtém-se as deformações das armaduras (Eq. 4.27) e com estas suas tensões de serviço:

$$
\varepsilon_{s 1}=\varepsilon_{c \max } \times \frac{\beta_{x}-(1-\delta)}{\beta_{x}} \quad \text { e } \quad \varepsilon_{s 2}=\varepsilon_{c \max } \times \frac{\beta_{x}-\delta}{\beta_{x}}
$$

A obtenção dos diferentes pares do diagrama momento-curvatura foi adotando um valor de curvatura $(\theta)$, para este valor foram tomados diferentes valores da deformação máxima do concreto $\left(\varepsilon_{\mathrm{cmax}}\right)$ e com a Eq. 4.16 obtida a posição da linha neutra $\left(\beta_{\mathrm{x}}\right)$. Os valores de $\varepsilon_{\mathrm{cmax}}$ foram incrementado até a deformação de ruptura do concreto $\varepsilon_{\mathrm{cu} 1}$ ou $\varepsilon_{\mathrm{climD5}}$ (este último para $\beta_{\mathrm{x}}>1$ ). A Eq. 4.28 mostra o limite da deformação específica última quando $\beta_{\mathrm{x}}>$ 1.

$$
\varepsilon_{c \lim D 5}=\frac{\beta_{x} \times \varepsilon_{c 1} \times \varepsilon_{c u 1}}{\beta_{x} \times \varepsilon_{c u 1}+\varepsilon_{c 1}-\varepsilon_{c u 1}}
$$

Sendo que: $\varepsilon_{\mathrm{c} 1}$ é a deformação específica correspondente ao pico da curva $\sigma_{\mathrm{c}} \mathrm{x} \varepsilon_{\mathrm{c}}$ (Fig. $6.2)$.

Atingir o valor limite significa atingir o valor da curvatura última para a força axial aplicada e para a seção transversal em estudo. 
Em cada incremento de $\varepsilon_{\text {cmax }}$ foram calculadas as resultantes nas armaduras e no concreto considerando o diagrama realista do concreto seja confinado ou não confinado, para isso foram adotadas as expressões correspondentes ao diagrama $\sigma_{\mathrm{c}} \times \varepsilon_{\mathrm{c}}$ do item 2.4.2 ou do item 3.4.2 (para o concreto confinado no lugar de $\varepsilon_{\mathrm{c} 1}$ e $\varepsilon_{\mathrm{cu} 1}$, foram empregados $\varepsilon_{\mathrm{cc} 1}$ e $\varepsilon_{\mathrm{ccu} 1}$ ). Para o cálculo da resultante no concreto foi empregada a Eq. 4.24.

A soma das duas resultantes (concreto e aço) é a força resultante resistente. Quando esta resultante igual à força externa (Eq. 4.20) significa que foi satisfeita a equação das forças normais e a posição da linha neutra para esta interação é a correta. Com o valor correto da posição da linha neutra calcula-se o momento resistente correspondente a fibra extrema comprimida com a Eq. 4.25. O momento serve para obter a posição da força resultante do concreto $\left(\delta_{v c}\right.$ - Fig. 4.14) e com a posição conhecida é obtido o momento correspondente ao centróide da seção transversal incluindo os aportes das resultantes das armaduras $\rho_{1}$ e $\rho_{2}$ (Fig. 4.14). Este é um ponto da curva que corresponde a uma curvatura adotada e um momento interno correspondente. Continua-se para outra curvatura até atingir os valores limites dos materiais ou até o valor último da curvatura.

\subsection{ESTADO LIMITE ÚlTIMO PARA PILARES COM QUALQUER ESBELTEZ SUBMETIDOS À FLEXÃO-COMPOSTA}

Como mencionado anteriormente, existem várias maneiras de analisar o problema de instabilidade de elementos a flexo-compressão, mas o método mais rigoroso é obrigatório pelas normas para elementos com esbeltezes mecânicas elevadas [100 segundo o ACI-318 (2005), e 140 como indica a ABNT NBR-6118:2003] é o método geral, que estuda o comportamento da peça à medida que ocorre o incremento de força; na realidade é um método de verificação e aplicável às peças com seção e armadura variáveis ou constantes ao longo do comprimento, é indispensável considerar a não linearidade física e geométrica reais, assim como a retração e deformação lenta.

Logo, a determinação do estado limite último de instabilidade pode ser feita utilizando o Método Geral (é o método considerado exato), mas existem outros métodos importantes e simplificados que são adotados por algumas normas até certa esbeltez, estes métodos são os métodos do pilar padrão e o método da amplificação de momentos. O primeiro adotado por normas de concreto européias e também pela ABNT NBR 6118:2003 e o outro pelas normas de concreto americanas. 


\subsubsection{Método Geral}

Todas as normas em geral sugerem este método para aplicar para qualquer esbeltez. Para a consideração da NLF tem-se a história das tensões, a curvatura das seções e o diagrama não elástico $\sigma_{\mathrm{c}} \mathrm{x} \quad \varepsilon_{\mathrm{c}}$ dos materiais componentes. É necessário obter a curva força $\mathrm{x}$ deslocamento do pilar (Fig. 4.15) e verificar se é atingida a força limite ou as rupturas dos materiais. A curva é obtida ponto a ponto.
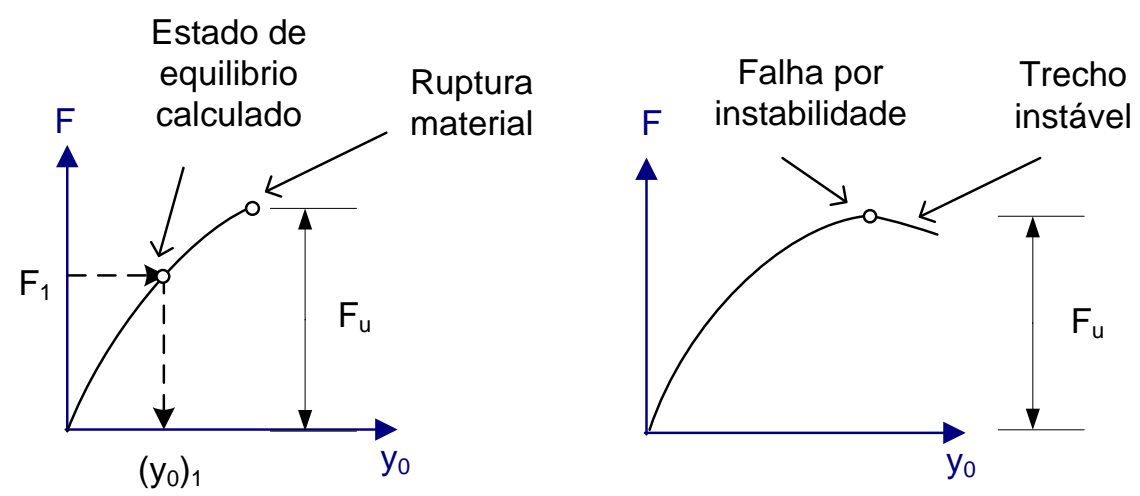

Fig. 4.15 - Curva força-deslocamento.

Existem dois processos numéricos conhecidos, o das diferenças finitas e o processo da analogia de Mörh. Neste trabalho vai se empregar o método das diferenças finitas. A determinação da deformada é por tentativas sendo necessário dividir o elemento em subelementos. É fixada a excentricidade de $2^{\mathrm{a}}$ ordem, normalmente na seção mais crítica, e empregando os critérios de diferenças finitas, ao chegar ao extremo do pilar, deve-se obter como flecha zero, se der diferente de zero se recomeça as tentativas com um novo valor da excentricidade de $2^{\mathrm{a}}$ ordem. A Fig. 4.16 mostra um pilar bi-articulado dividido em subelementos.
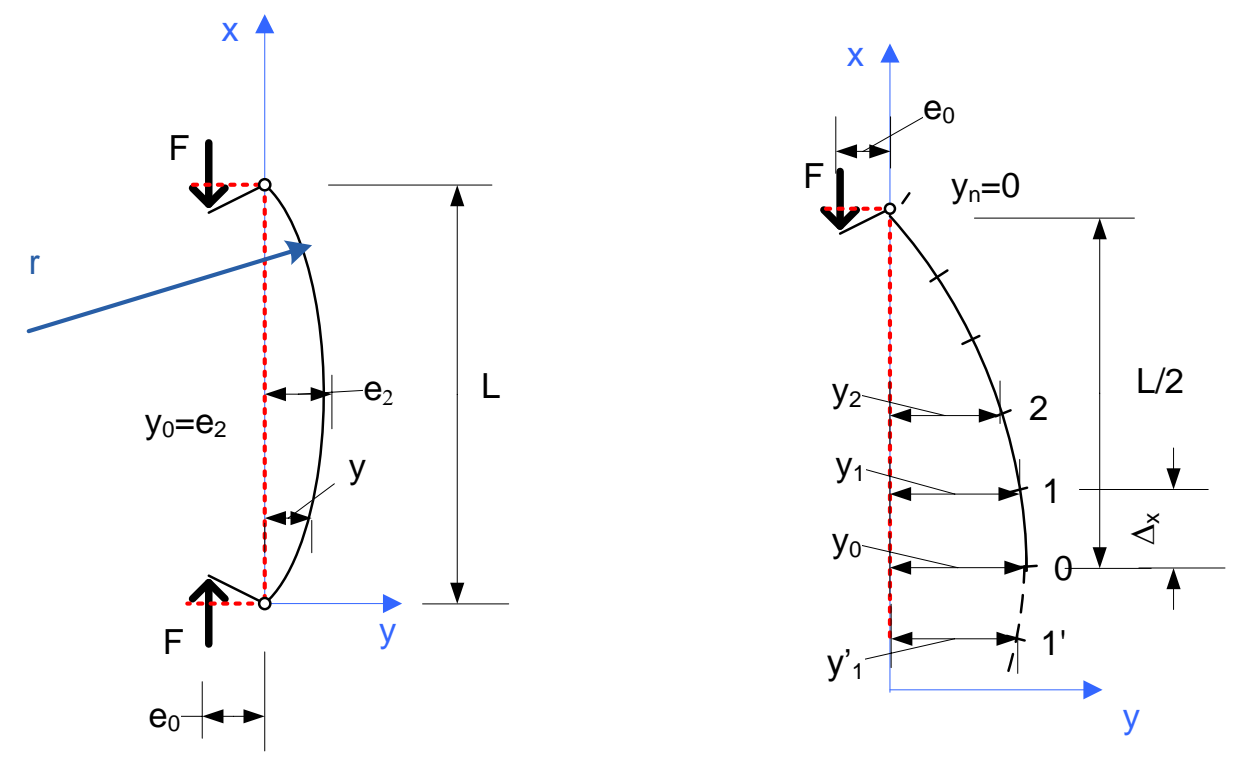

Fig. 4.16 - Pilar bi-articulado com divisões. 
A construção da curva será feita ponto a ponto, os pontos são definidos por equilíbrio de forças e compatibilidade de deformações entre 2 etapas. As etapas estão resumidas num fluxograma (ver Fig. 8.1).

Da Fig. 4.16 adota-se um valor para $\mathrm{y}_{0} \mathrm{em} \mathrm{x}=\mathrm{L} / 2$, calcula-se o momento total nessa seção e nas outras seções (Eq.4.29).

$$
M_{t o t, 0}=F \times\left(e_{0}+y_{0}\right) \quad M_{t o t, i}=F \times\left(e_{0}+y_{i}\right)
$$

Empregando o diagrama momento-curvatura construído para $\mathrm{F}$ obtém-se os valores da curvatura para as diferentes seções, por interpolação (Eq. 4.30).

$$
M_{t o t, 0} \rightarrow\left(\frac{1}{r}\right)_{0} \quad M_{t o t, i} \rightarrow\left(\frac{1}{r}\right)_{i}
$$

Empregando o método das diferenças finitas calcula-se as excentricidades $\mathrm{y}_{1}, \mathrm{y}_{2}, \ldots \mathrm{y}_{\mathrm{n}}$, por meio da Eq. 4.31.

$$
y_{1}=y_{0}-\frac{\Delta x^{2}}{2} \times\left(\frac{1}{r}\right)_{0} \quad y_{i+1}=2 \times y_{i}-y_{i-1}-\Delta x^{2} \times\left(\frac{1}{r}\right)_{i}
$$

$\mathrm{Na}$ seção $\mathrm{n}$ é necessário obter $\mathrm{y}_{\mathrm{n}}=0$, se não ocorre isto é preciso recomeçar as tentativas; se ocorre a configuração fletida é estável.

Para cada valor de F deve-se traçar um novo diagrama momento-curvatura. Quando é encontrado uma configuração de equilíbrio estável (ponto da curva axial-deslocamento lateral), significa que a seção pode estar com resistência além do necessário, logo pode ser incrementado a força axial até que o pilar atinja a ruína.

No presente trabalho foram obtidos os gráficos força axial-deslocamento lateral para validar os ensaios de laboratório, a obtenção dos gráficos foi ponto a ponto, nestas validações foram considerados os efeitos do confinamento proposto por Légeron e Paultre (2003).

Existem algumas variações do método, entre elas a que considera a força atuante constante, modificando as excentricidades de $1^{\text {a }}$ ordem de modo incremental, elaborando um diagrama excentricidade $1^{\mathrm{a}}$ ordem x excentricidade total e o valor crítico da excentricidade é obtido como o valor assintótico do diagrama. A vantagem de este método é que não são necessárias tentativas e somente precisa de um diagrama momento-curvatura.

Com esta variante foram elaborados diagramas de força axial-momento para diferentes esbeltezes considerando o Método Geral. O objetivo da elaboração de estes diagramas foi a análise dos resultados de laboratório e ter um procedimento de projeto de fácil emprego e de resultados mais confiáveis, pois considera os diagramas realistas do concreto, sendo que é 
possível incluir o efeito do confinamento e tem como base de cálculo o Método Geral que é o método analítico reconhecido por todas as normas como exato.

Alguns programas comerciais já incorporam em seus cálculos o método geral no cálculo de pilares. Usualmente as normas permitem também o emprego de métodos aproximados para o cálculo dos efeitos locais de $2^{\mathrm{a}}$ ordem. Os dois principais são o método do pilar padrão indicado pelo CEB-FIB MC(90), as normas européias e a norma brasileira ABNT NBR 6118:2003 e o método da amplificação dos momentos que é adotado pelas normas que seguem o modelo da norma ACI-318 (2005).

\subsection{CONSIDERAÇÕES FINAIS}

O estudo de pilares esbeltos deve considerar necessariamente a NLF e NLG, estes estão dentro do modelo do Método Geral.

O emprego do CAR em pilares com $\lambda<90$ poderia ser considerada como uma prática prudente, tendo em vista a fragilidade que este material apresenta. Caso seja necessário a utilização do CAR em pilares com $\lambda>90$, métodos adequados da verificação da estabilidade devem ser utilizados, sendo o Método Geral (MG) o mais adequado, que é considerado exato.

Neste trabalho, ao modelo do MG foram incorporadas as hipóteses de comportamento de estruturas em CAR por meio de diagramas $\sigma_{\mathrm{c}} \times \varepsilon_{\mathrm{c}}$ realistas e, alem disto, o efeito do confinamento.

O MG é um método de verificação, mas com a elaboração das curvas (que levam em conta o modelo do MG) de força axial-momento fletor que considera a força e o momento fletor máximo de $1^{\mathrm{a}}$ ordem que se está aplicando ao pilar incluindo a esbeltez do mesmo, tornou-se um método de dimensionamento, porque estas curvas já incluem os efeitos de $2^{\mathrm{a}}$ ordem. 


\section{Capítulo 5}

\section{PROGRAMA EXPERIMENTAL: MÉTODOS E MATERIAIS}

O estudo experimental desenvolvido neste trabalho foi baseado em uma programação dividida em duas fases: a primeira se constituiu na análise dos parâmetros de ductilidade de pilares curtos submetidos à compressão centrada considerando o confinamento da armadura transversal, e, na segunda foi analisado o comportamento dos pilares esbeltos considerando os parâmetros de confinamento.

A seção dos pilares foi escolhida para que a esbeltez mecânica fosse superior a 90 e em função da altura útil disponível na máquina de ensaio foi adotada uma seção de $12 \mathrm{~cm} x$ $20 \mathrm{~cm}$, com um comprimento de $300 \mathrm{~cm}$, considerando o comprimento até as rótulas o pilar, para efeitos de cálculo, tinha $320 \mathrm{~cm}$. Para os pilares curtos a seção adotada foi de $15 \mathrm{~cm}$ x 15 cm porque com esta seção e considerando o mesmo espaçamento entre estribos, a taxa volumétrica da armadura transversal era quase a mesma dos pilares (variação de 10\%); os comprimentos dos pilares curtos foram de $60 \mathrm{~cm}$ e de $70 \mathrm{~cm}$.

Foram estudados 3 fatores: a resistência do concreto, a taxa volumétrica de armadura transversal e a excentricidade da força (para o caso dos pilares esbeltos). Foram selecionadas 3 resistências: $30 \mathrm{MPa}, 60 \mathrm{MPa}$ e $100 \mathrm{MPa}$; duas taxas volumétricas de armadura transversal: $1,27 \%$ ( $\phi 6,3$ c. 10) e 2,54\% ( $\phi 6,3$ c. 5); duas excentricidades de força $1,2 \mathrm{~cm} \mathrm{e} \mathrm{3,0} \mathrm{cm.} \mathrm{As}$ mesmas resistências do concreto à compressão e as mesmas taxas volumétricas de armadura transversal foram empregadas para os ensaios dos pilares curtos.

O objetivo de ensaiar os pilares com resistência de $30 \mathrm{MPa}$ foi para ter um parâmetro de avaliação dos resultados das duas fases do estudo experimental. 
Para cada tipo de concreto foram necessárias duas concretagens, porque a capacidade da betoneira do Laboratório de Estruturas - EESC - USP, que é de eixo vertical, é de 300 litros e o número de fôrmas era insuficiente para o preparo de todos os pilares de um mesmo concreto de uma só vez.

Para cada combinação de variáveis foi empregada somente uma réplica, no total, foram ensaiados 12 pilares de $12 \mathrm{~cm}$ x $20 \mathrm{~cm}$ x $300 \mathrm{~cm}, 6$ pilares curtos de $15 \mathrm{~cm}$ x $15 \mathrm{~cm}$ x $60 \mathrm{~cm}$ e 3 pilares curtos de $15 \mathrm{~cm}$ x $15 \mathrm{~cm}$ x $70 \mathrm{~cm}$.

\subsection{MATERIAIS UTILIZADOS}

Com o objetivo de se obterem parâmetros que permitissem descrever o comportamento dos pilares esbeltos, se fez necessário um estudo dos materiais utilizados neste trabalho.

\subsubsection{Cimento Portland ARI PLUS}

O cimento Portland escolhido para compor todas as misturas executadas neste trabalho era o CPV-ARI PLUS, Cimento Portland de Alta Resistência Inicial, fabricado pela Holcim do Brasil S.A. Este é um cimento de alta resistência inicial em função do grau de moagem a que é submetido. O clinquer é o mesmo utilizado para a fabricação de um cimento convencional, mas permanece no moinho por um tempo mais prolongado. Foi escolhido por causa da sua finura e por não conter adições pozolânicas ou escoria, mas produz alto calor de hidratação, logo não é indicado para grandes volumes de concreto.

A Tabela 5.1 mostra a resistência à compressão do cimento com as varias idades.

Tabela 5.1 - Resistência à compressão do CPV-ARI PLUS (Cimentos Holcim S.A.).

\begin{tabular}{|c|c|}
\hline Idade (dias) & $\begin{array}{c}\text { Resistência à } \\
\text { compressão (MPa) }\end{array}$ \\
\hline \hline 1 & 26 \\
\hline 3 & 41 \\
\hline 7 & 46 \\
\hline 28 & 53 \\
\hline
\end{tabular}

Outros parâmetros físicos estão apresentados na Tabela 5.2. 
Tabela 5.2 - Propriedades físicas do CPV-ARI PLUS (Cimentos Holcim S.A.).

\begin{tabular}{|c|c|c|}
\hline Ensaio & Resultados & $\begin{array}{c}\text { Limites da } \\
\text { ABNT NBR 5733:1991 }\end{array}$ \\
\hline $\begin{array}{c}\text { Finura [Resíduo na peneira de 75 } \\
\mu \mathrm{m}(\%)]\end{array}$ & 0,1 & $\leq 6,0 \%$ \\
\hline Massa específica $\left(\mathrm{g} / \mathrm{cm}^{3}\right)$ & 3,1 & - \\
\hline Área específica $\left(\mathrm{m}^{2} / \mathrm{kg}\right)$ & 492 & $\geq 300 \mathrm{~m}^{2} / \mathrm{kg}$ \\
\hline Início de pega $(\mathrm{h}: \mathrm{min})$ & $02: 50$ & $\geq 1 \mathrm{~h}$ \\
\hline Fim de pega $(\mathrm{h}: \mathrm{min})$ & $03: 45$ & $\leq 10 \mathrm{~h}$ \\
\hline
\end{tabular}

\subsubsection{Agregado miúdo}

A areia utilizada neste trabalho foi de rio e de material quartzoso, tinha uma aparência de estar limpa, e também foi lavada pela água da chuva. Não foi necessário fazer correções da umidade, porque antes das concretagens foi seca ao ar.

Os limites granulométricos das areias estão na Tabela 2.4 (ABNT NBR 7211:1983). Para realizar o ensaio da análise granulométrica o material foi seco em estufa a aproximadamente $100^{\circ} \mathrm{C}$ durante $24 \mathrm{~h}$. Segundo o ensaio preconizado pela ABNT NBR 7217:1987 o resultado da análise granulométrica dos agregados miúdos está apresentada na Tabela 5.3.

Tabela 5.3 - Distribuição granulométrica do agregado miúdo.

\begin{tabular}{|l|c|c|c|c|c|}
\hline $\begin{array}{c}\text { peneira } \\
\text { No }\end{array}$ & $\begin{array}{c}\text { Peneira } \\
(\mathrm{mm})\end{array}$ & $\begin{array}{c}\text { massa } \\
\text { retida } \\
(\mathrm{g})\end{array}$ & $\begin{array}{c}\text { massa } \\
\text { acumulada } \\
(\mathrm{g})\end{array}$ & $\begin{array}{c}\% \text { retida } \\
(\%)\end{array}$ & $\begin{array}{c}\% \text { retida } \\
\text { acumulada } \\
(\%)\end{array}$ \\
\hline \hline $1 / 4 "$ & 6,300 & 4,5 & 4,5 & 0,42 & 0,42 \\
\hline 4 & 4,760 & 3,5 & 8,0 & 0,33 & 0,75 \\
\hline 8 & 2,362 & 36,3 & 44,3 & 3,42 & 4,17 \\
\hline 16 & 1,190 & 137,2 & 181,5 & 12,93 & 17,10 \\
\hline 30 & 0,590 & 344,0 & 525,5 & 32,41 & 49,51 \\
\hline 50 & 0,297 & 317,1 & 842,6 & 29,88 & 79,39 \\
\hline 100 & 0,149 & 191,4 & 1034,0 & 18,03 & 97,42 \\
\hline resíduo & 0 & 27,4 & 1061,4 & 2,58 & 100,00 \\
\hline total & & 1061,4 & & & \\
\hline
\end{tabular}

Em função dos resultados da análise granulométrica foram obtidas as seguintes propriedades do agregado miúdo: a dimensão máxima característica do agregado miúdo igual a 2,4 mm e o Módulo de Finura 2,48, este último é um pouco inferior a 2,7 que é o mínimo que recomenda Aïtcim (2000) para o CAR, mas este foi empregado porque era o único material disponível. A massa específica da areia para efeitos de cálculo da dosagem foi adotada, com base em trabalhos anteriores, como $2630 \mathrm{~kg} / \mathrm{m}^{3}$. 
A Fig. 5.1 mostra a curva granulométrica da areia e segundo a ABNT NBR 7211:1983 a areia corresponde à do tipo média que se encontra na zona 3.

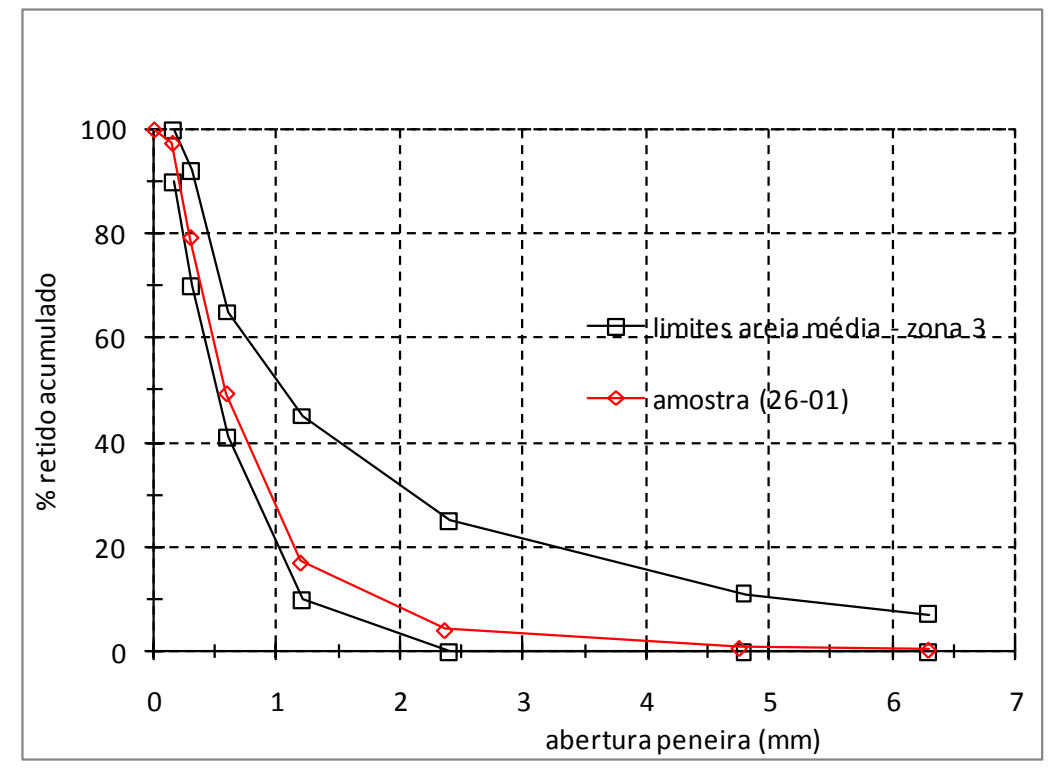

Fig. 5.1 - Análise granulométrica da areia empregada no ensaio.

\subsubsection{Agregado graúdo}

A composição granulométrica tem influência sobre a qualidade dos concretos, agindo na compacidade e na resistência. A melhor composição é a que apresenta a menor quantidade de vazios. No concreto foram empregados dois tipos de agregados graúdos: brita $1\left(D_{\text {máx }}=19\right.$ $\mathrm{mm})$ e pedrisco $\left(\mathrm{D}_{\text {máx }}=6,3 \mathrm{~mm}\right)$.

Para a determinação da proporção adequada de cada tipo de agregado foi feito o estudo de empacotamento recomendado por Helene e Terzian (1992). A Tabela 5.4 mostra os resultados deste trabalho. 
Tabela 5.4 - Empacotamento entre a B1 e o pedrisco.

\begin{tabular}{|c|c|c|c|c|c|}
\hline $\begin{array}{c}\text { Composição } \\
\text { entre os } \\
\begin{array}{c}\text { agregados B1 } \\
\text { e pedrisco \% }\end{array}\end{array}$ & $\begin{array}{c}\text { Massa de } \\
\text { Brita 1 (fixa) } \\
(\mathrm{kg})\end{array}$ & $\begin{array}{c}\text { Massa de } \\
\text { pedrisco } \\
\text { necessaria para } \\
\text { composição (kg) }\end{array}$ & $\begin{array}{c}\text { Acrécimo de } \\
\text { pedrisco } \\
\text { considerando a } \\
\text { anterior }(\mathrm{kg})\end{array}$ & $\begin{array}{c}\text { Massa total } \\
\text { agregados no } \\
\text { recipiente } \\
(\mathrm{kg})\end{array}$ & $\begin{array}{c}\text { Massa } \\
\text { unitária } \\
\text { compactada } \\
(\mathrm{kg} / \mathrm{m} 3)\end{array}$ \\
\hline \hline $100 / 0$ & 23 & 0,000 & 0,000 & 22,30 & 1548,6 \\
\hline $90 / 10$ & 23 & 2,556 & 2,556 & 22,85 & 1586,8 \\
\hline $80 / 20$ & 23 & 5,750 & 3,194 & 23,05 & 1600,7 \\
\hline $70 / 30$ & 23 & 9,857 & 4,107 & 23,25 & 1614,6 \\
\hline $60 / 40$ & 23 & 15,333 & 5,476 & 23,40 & 1625,0 \\
\hline $50 / 50$ & 23 & 23,000 & 7,667 & 23,55 & 1635,4 \\
\hline $40 / 60$ & 23 & 34,500 & 11,500 & 23,60 & 1638,9 \\
\hline $30 / 70$ & 23 & 53,667 & 19,167 & 23,50 & 1631,9 \\
\hline $20 / 80$ & 23 & 92,000 & 38,333 & 0 & 0,0 \\
\hline $10 / 90$ & 23 & 207,000 & 115,000 & 0 & 0,0 \\
\hline
\end{tabular}

A Fig. 5.2 mostra que a melhor composição entre a brita 1 e o pedrisco está na proporção de $40 \%$ e $60 \%$ respectivamente. O volume do recipiente metálico utilizado para o estudo foi de $14,4 \ell$.

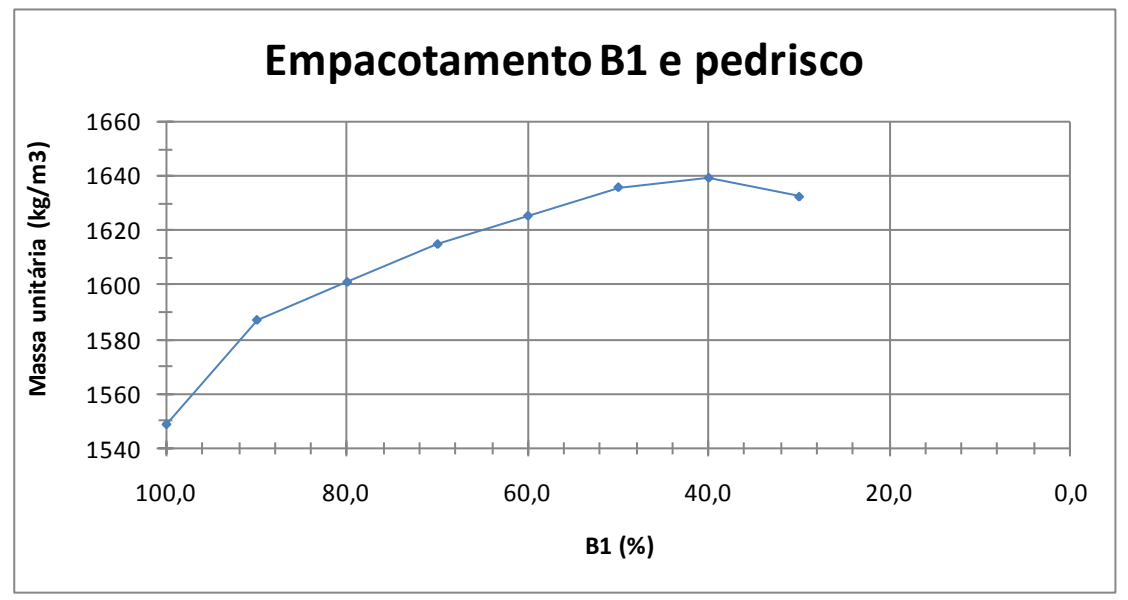

Fig. 5.2 - Estudo da percentagem ideal de brita 1 no estudo do empacotamento.

Foi feita análise granulométrica da composição de acordo com a ABNT NBR 7217:1987, e os resultados se encontram na Tabela 5.5. 
Tabela 5.5 - Distribuição do agregado graúdo da mistura empacotada.

\begin{tabular}{|l|c|c|c|c|c|}
\hline $\begin{array}{c}\text { peneira } \\
\text { No }\end{array}$ & $\begin{array}{c}\text { Peneira } \\
(\mathrm{mm})\end{array}$ & $\begin{array}{c}\text { massa } \\
\text { retida } \\
(\mathrm{g})\end{array}$ & $\begin{array}{c}\text { massa } \\
\text { acumulada } \\
(\mathrm{g})\end{array}$ & $\begin{array}{c}\% \text { retida } \\
(\%)\end{array}$ & $\begin{array}{c}\% \text { retida } \\
\text { acumulada } \\
(\%)\end{array}$ \\
\hline \hline $3 / 4^{\prime \prime}$ & 19,10 & 14,8 & 14,8 & 0,29 & 0,29 \\
\hline $1 / 2^{\prime \prime}$ & 12,50 & 1114,1 & 1128,9 & 21,47 & 21,76 \\
\hline $3 / 8^{\prime \prime}$ & 9,52 & 720,9 & 1849,8 & 13,90 & 35,66 \\
\hline $1 / 4 "$ & 6,30 & 2382,4 & 4232,2 & 45,92 & 81,58 \\
\hline 4 & 4,76 & 780,3 & 5012,5 & 15,04 & 96,62 \\
\hline 8 & 2,36 & 119,6 & 5132,1 & 2,31 & 98,92 \\
\hline resíduo & 0 & 55,9 & 5188,0 & 1,08 & 100,00 \\
\hline total & & 5188,0 & & & \\
\hline
\end{tabular}

A Fig. 5.3 mostra a curva granulométrica do agregado graúdo empacotado segundo a ABNT NBR 7211:1983, a composição não corresponde a nenhuma das regiões estabelecidas pela norma, pois já é uma mistura.

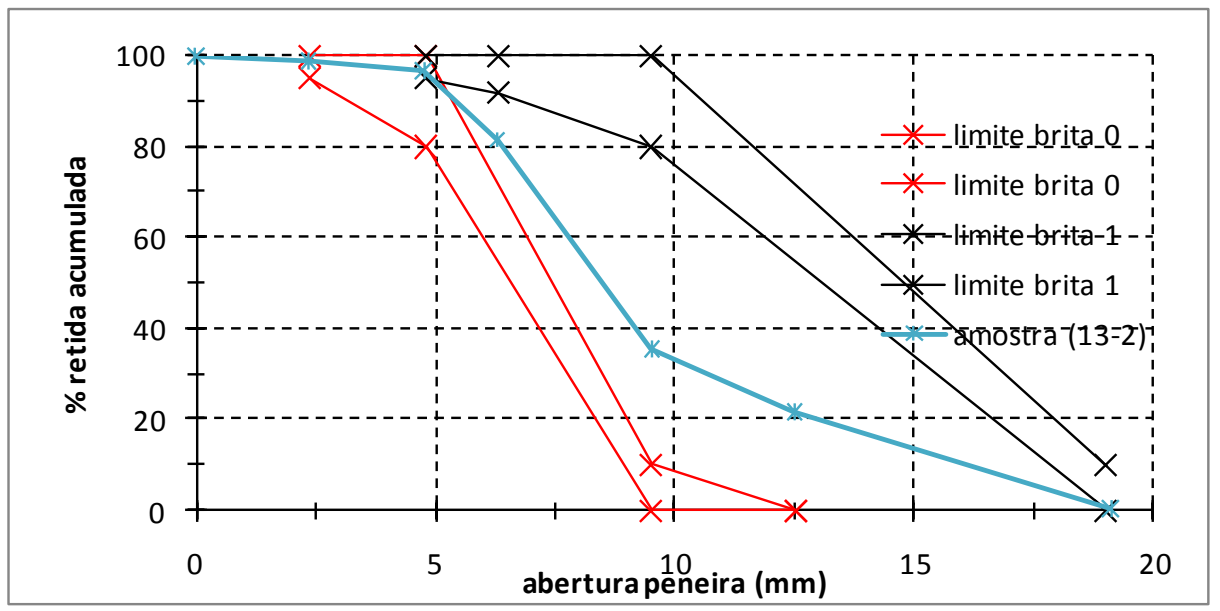

Fig. 5.3 - Análise granulométrica do agregado graúdo empacotado.

Em função dos resultados da análise granulométrica foram obtidas as seguintes propriedades do agregado graúdo: a dimensão máxima característica do agregado graúdo empacotado é 19 mm e o Módulo de Finura 6,27.

Não foram feitos outros estudos como o ensaio de abrasão de "Los Angeles" porque a brita era de origem basáltica que é de uma qualidade reconhecida para seu emprego em concretos de alta resistência. A massa especifica da brita empregada nos cálculos de dosagem foi adotada, em base a trabalhos anteriores, como $2860 \mathrm{~kg} / \mathrm{m}^{3}$.

\subsubsection{Adição}

$\mathrm{O}$ aditivo mineral que foi escolhido é a sílica ativa. Para a escolha do aditivo mineral, levou-se em conta que este melhora a formação do C-H-S, incrementado a resistência do 
concreto e melhorando a coesão da zona de interface entre a pasta e o agregado e entre a pasta e a armadura. O produto foi doado pela empresa Tecnosil-Sílica Ativa. Foi inicialmente feito um estudo adicionando um teor de $10 \%$ em substituição volumétrica ao cimento, mas foram obtidas resistências um pouco menores as adotadas nas premissas e para melhorar este resultado foi diminuída a quantidade de sílica ativa a $8 \%$, diminuindo assim a quantidade de água da mistura e obtendo uma melhora na resistência do concreto. Não foi feito nenhum ensaio para caracterizar este produto, mas a Tabela 5.6 mostra algumas propriedades do produto utilizado.

Tabela 5.6 - Propriedades físicas e químicas da sílica ativa (Tecnosil - Sílica Ativa)

\begin{tabular}{|l|c|}
\hline \multicolumn{2}{|c|}{ Características Físicas e Químicas } \\
\hline \hline Massa específica & $2.220 \mathrm{~kg} / \mathrm{m} 3$ \\
\hline Teor de SiO2 & $>90 \%$ \\
\hline Superfície específica (B.E.T.) & $\sim 19.000 \mathrm{~m} 2 / \mathrm{kg}$ \\
\hline Formato da partícula & Esférico \\
\hline Diâmetro médio da párticula & $0,20 \mu \mathrm{m}$ \\
\hline \multicolumn{2}{|c|}{ Massa unitária } \\
\hline Não densificado & $<350 \mathrm{~kg} / \mathrm{m3}$ \\
\hline Densificada & $>350 \mathrm{~kg} / \mathrm{m3}$ \\
\hline \multicolumn{2}{|c|}{ Comparativo de finura de alguns materiais } \\
\hline Sílica Ativa & $\sim 19.000 \mathrm{~m} 2 / \mathrm{kg}$ \\
\hline Fumaça do cigarro & $\sim 10.000 \mathrm{~m} 2 / \mathrm{kg}$ \\
\hline Fly Ash (Pozolana) & $400 \mathrm{a} 700 \mathrm{~m} 2 / \mathrm{kg}$ \\
\hline Cimento Portland & 300 a $500 \mathrm{~m} 2 / \mathrm{kg}$ \\
\hline
\end{tabular}

\subsubsection{Aditivo}

Para a redução da água de amassamento, escolheu-se um aditivo superplastificante à base de éster carboxílico, que produz o feito da dispersão das partículas de cimento pela repulsão eletrostática. Entre os aditivos existentes no mercado foi escolhido o Glenium®51 por ser um aditivo muito conhecido e que tem boa compatibilidade com os cimentos de alta resistência inicial. Este aditivo é comercializado pela BASF (The Chemical Company) e seus dados técnicos estão na Tabela 5.7. 
Tabela 5.7- Dados Técnicos do Glenium ${ }^{\circ} 51$ (BASF, The Chemical Company).

\begin{tabular}{|c|c|c|c|}
\hline Função & \multicolumn{3}{|c|}{ Aditivo super plastificante de terceira geração para concreto. } \\
\hline Base Químic & \multicolumn{3}{|c|}{ Éter policarboxílico. } \\
\hline Aspecto & \multicolumn{3}{|l|}{ Líquido } \\
\hline Cor & \multicolumn{3}{|l|}{ Branco turvo } \\
\hline \multicolumn{4}{|c|}{ Ação secundária: Redutor de água } \\
\hline \multicolumn{4}{|c|}{ Solubilidade em água: Total } \\
\hline \multicolumn{4}{|c|}{$\begin{array}{l}\text { Não contém cloreto de cálcio, intencionalmente adicionado, ou } \\
\text { ingredientes a base de cloreto. }\end{array}$} \\
\hline Teste & Método BASF & Especificação & Unidade \\
\hline Aparência & TM 761B & Líquido branco turvo & Visual \\
\hline $\mathrm{pH}$ & TM $112 \mathrm{~B}$ & 5-7 & - \\
\hline Densidade & TM 103 B & $1,067-1,107$ & $\mathrm{~g} / \mathrm{cm} 3$ \\
\hline Sólidos & TM 613 B & $28,5-31,5$ & $\%$ \\
\hline Viscosidade & TM 117 & $<150$ & cps \\
\hline
\end{tabular}

A empresa BASF (The Chemical Company) indica que a dosagem deve estar entre $0,2 \%$ a $1 \%$ do peso do cimento, mas foi feito um estudo para verificar a melhor eficiência do aditivo Glenium ${ }^{\circledR 51}$ com o cimento CPV-ARI PLUS, este estudo consistiu em avaliar a eficiência de teores diversos de aditivo usando o minitronco de cone, ou mais conhecido como ensaio de Kantro.

\section{Ensaio de Kantro}

O ensaio de Kantro consiste em avaliar a eficiência de teores diversos de aditivo, na plastificação de uma pasta de cimento Portland, ou cimento com adição.

Para se obter a eficiência de um aditivo sobre um determinado cimento ou uma mistura de aglomerantes, tem-se adotado relações água/cimento ou água/aglomerante entre 0,30 até 0,35 . A essas misturas vai se adicionando o aditivo que se escolheu, em doses que variam com o tipo de aditivo:

- naftalenos, melaminas: $0 \%, 0,5 \%, 1,0 \%, 1,5 \%$ e $2,0 \%$

- éster-carboxílicos: $0 \%, 0,3 \%, 0,6 \%, 0,9 \%, 1,2 \%$.

Para a realização deste ensaio utilizou-se uma massa de $700 \mathrm{~g}$ de cimento, foram feitos 2 grupos de ensaios um sem sílica ativa e outro com sílica ativa em uma quantidade correspondente a $10 \%$ em substituição da massa de cimento, a relação água/aglomerante era 0,35 . O ensaio foi realizado com vários teores de aditivo superplastificante (teores relativos à massa de cimento) para se analisar a variação de plasticidade em virtude da variação do teor de aditivo, até chegar a um ponto de saturação, este ponto de saturação pode ser definido 
como a percentagem de aditivo acima da qual o incremento do aditivo não melhora a plasticidade da pasta.

$\mathrm{O}$ procedimento de mistura consiste em pesar os materiais proporcionalmente à quantidade de cimento, colocar na argamassadeira cimento e sílica ativa com quase toda a água, misturar bem até obter uma massa consistente sem grumos, logo adicionar o superplastificante e o resto da água, misturar bem até obter uma pasta homogênea. Verter a pasta sobre um mini-tronco de cone metálico e levantar, deixando derramar livremente a mistura sobre um vidro previamente untado com óleo. Calcular a média de pelo menos 3 medidas do diâmetro da pasta espalhada. O tempo de cada etapa do ensaio é cronometrado a partir do instante que se adiciona água ao cimento até ser vertido no mini-tronco, nesta primeira etapa se considera 10 minutos, depois, novamente, se introduz a pasta na argamassaderia para nova mistura e é feita uma segunda medida aos 30 minutos contados a partir do inicio do ensaio. A Fig. 5.4 mostra algumas das diferentes etapas do ensaio.

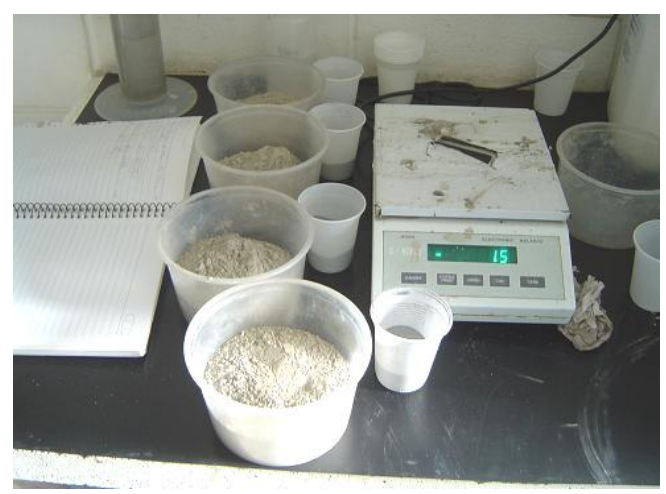

(a) pesagem dos materiais para o ensaio

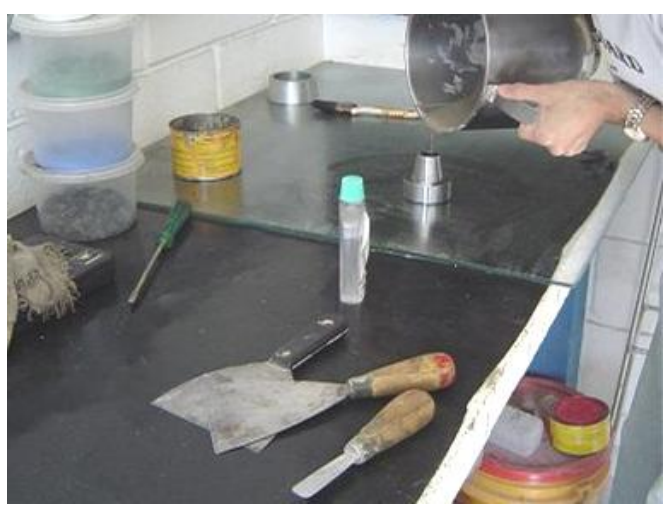

(c) colocação da mistura no cone

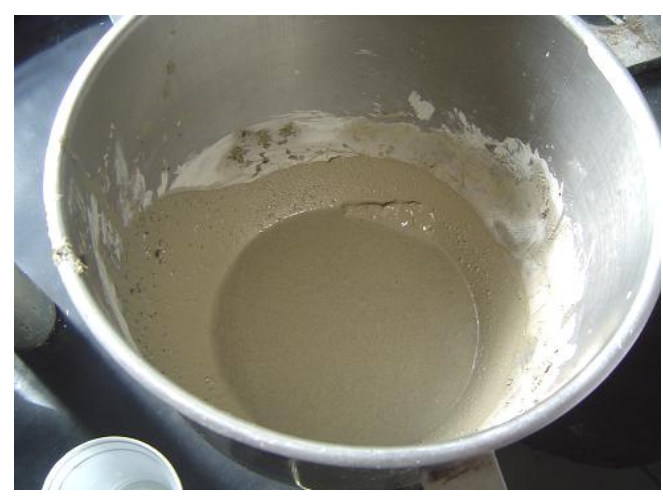

(b) mistura final

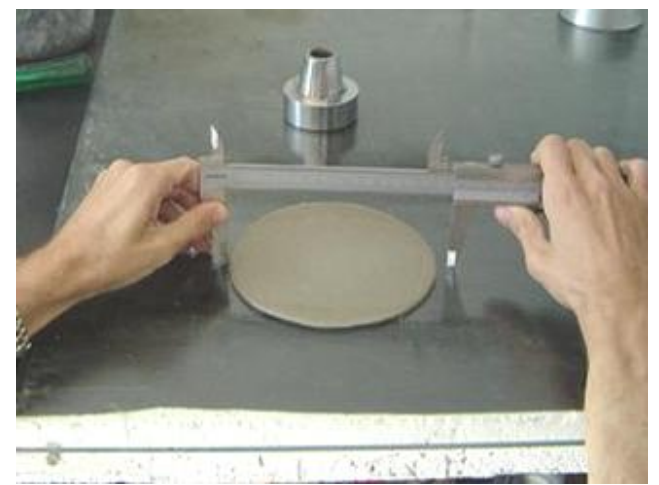

(d) medição dos diâmetros após espalhamento para cálculo da área de espalhamento

Fig. 5.4 - Etapas do ensaio de Kantro.

A Tabela 5.8 mostra os resultados do ensaio sem sílica ativa. 
Tabela 5.8 - Resultados do ensaio de Kantro sem sílica ativa.

\begin{tabular}{|c|c|c|c|c|c|}
\hline \multicolumn{6}{|c|}{ RESUMO DO ENSAIO DE KANTRO (SEM SA) } \\
\hline \multicolumn{2}{|c|}{ Relação de materiais } & \multicolumn{2}{|c|}{$\begin{array}{c}\text { Glenium } 51 \text { em relação à } \\
\text { massa de cimento }\end{array}$} & \multirow{2}{*}{$\begin{array}{l}\text { Área espalhada } \\
\text { para } 10^{\prime}(\mathrm{cm} 2)\end{array}$} & \multirow{2}{*}{$\begin{array}{l}\text { Área espalhada } \\
\text { para } 30^{\prime}(\mathrm{cm} 2)\end{array}$} \\
\hline & & $\%$ & massa (g) & & \\
\hline relação a/c & 0,35 & $0,50 \%$ & 3,50 & 199,31 & 130,04 \\
\hline massa $90 \%$ da agua $(\mathrm{g})$ & 220,5 & $0,60 \%$ & 4,20 & 230,20 & 157,25 \\
\hline massa cimento ARI (g) & 700,0 & $0,70 \%$ & 4,90 & 248,92 & 186,39 \\
\hline massa $10 \%$ da agua $(\mathrm{g})$ & 24,5 & $0,80 \%$ & 5,60 & 263,24 & 210,40 \\
\hline massa total da agua $(\mathrm{g})$ & 245 & $0,90 \%$ & 6,30 & 273,47 & 223,85 \\
\hline & & $1,00 \%$ & 7,00 & 291,42 & 235,54 \\
\hline
\end{tabular}

A Fig. 5.5 mostra o comportamento da pasta sem sílica ativa com o incremento do aditivo. É o resultado das medidas obtidas no ensaio e que estão resumidas na Tabela 5.8.

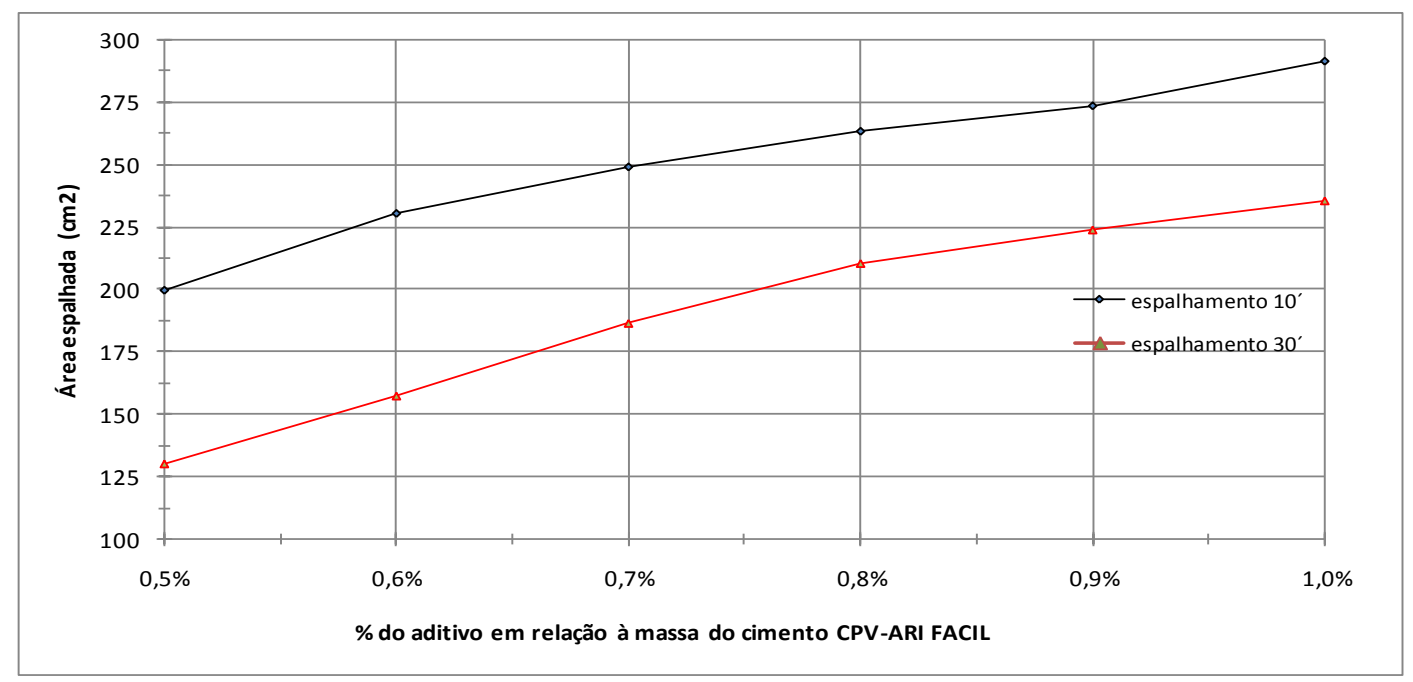

Fig. 5.5 - Gráfico área espalhada - \% do aditivo sem sílica ativa na mistura.

A Tabela 5.9 mostra os resultados do ensaio com sílica ativa.

Tabela 5.9 - Resultados do ensaio de Kantro com sílica ativa.

\begin{tabular}{|l|c|c|c|c|c|}
\hline \multicolumn{7}{|c|}{ RESUMO DO ENSAIO DE KANTRO (COM SA) } \\
\hline \multicolumn{2}{|c|}{ Relação de materiais } & $\begin{array}{c}\text { Glenium 51 em relação à } \\
\text { massa de cimento }\end{array}$ & $\begin{array}{c}\text { Área espalhada } \\
\text { para 10' (cm2) }\end{array}$ & $\begin{array}{c}\text { Área espalhada } \\
\text { para 30' (cm2) }\end{array}$ \\
\hline \hline relação a/agl & 0,35 & $\%$ & massa (g) & & 65,22 \\
\hline massa 90\% da agua (g) & 220,5 & $0,50 \%$ & 3,24 & 86,80 & 94,56 \\
\hline massa cimento ARI (g) & 648,5 & $0,60 \%$ & 3,89 & 113,43 & 131,26 \\
\hline massa 10\% da agua (g) & 24,5 & $0,70 \%$ & 4,54 & 171,39 & 168,97 \\
\hline massa total da agua (g) & 245 & $0,80 \%$ & 5,19 & 206,69 & 165,53 \\
\hline \%de SA em subst.vol.cim. & $10 \%$ & $0,90 \%$ & 5,84 & 210,92 & 177,30 \\
\hline massa de silica ativa (g) & 51,5 & $1,00 \%$ & 6,49 & 210,34 & 13 \\
\hline
\end{tabular}

A Fig. 5.6 mostra o comportamento da pasta com sílica ativa com o incremento do aditivo. É o resultado das medidas obtidas no ensaio e que estão resumidas na Tabela 5.9. 


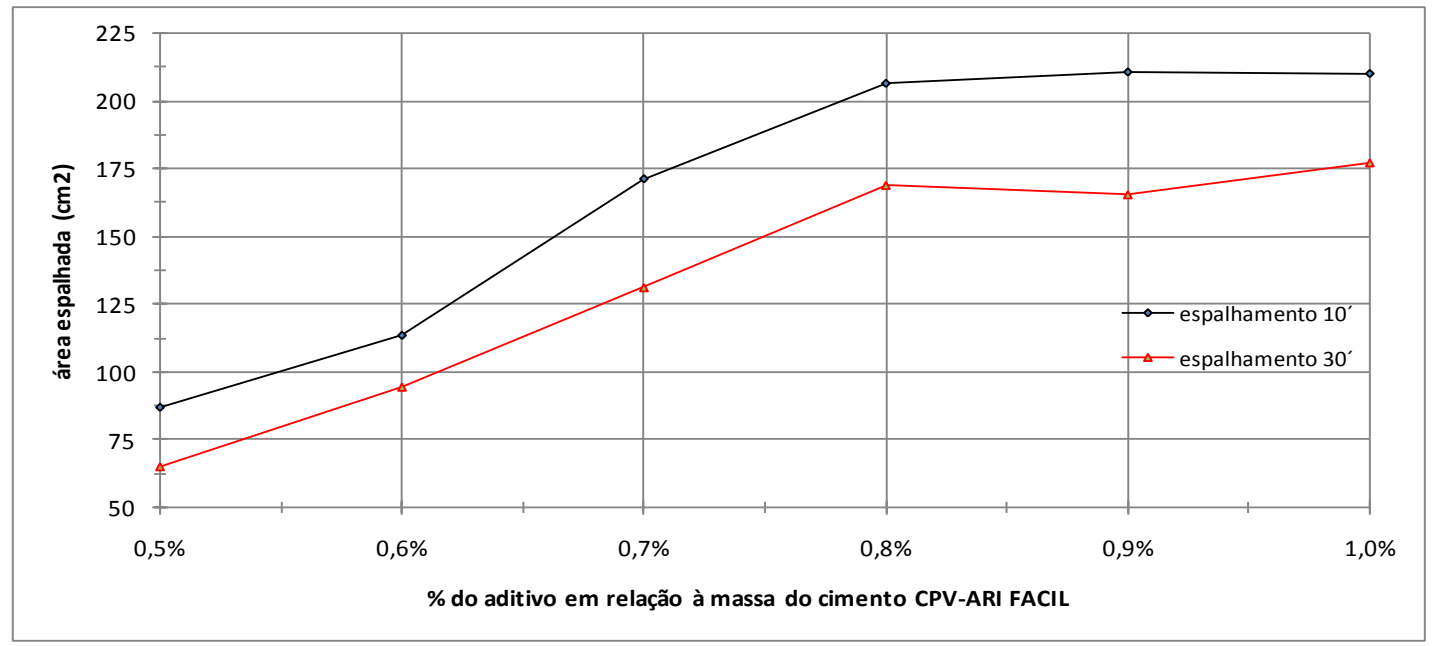

Fig. 5.6 - Gráfica área espalhada - \% do aditivo com sílica ativa na mistura.

Resumindo: na mistura sem sílica ativa foi empregado o teor máximo de superplastificante recomendado pelo fabricante de Glenium ${ }^{\circledR}$ 51. Na mistura com sílica ativa, o da Fig. 5.6 pode ser verificado que a percentagem ideal de superplastificante foi de $0,8 \%$ em relação à massa do cimento. Pode-se verificar que houve perda de plasticidade da mistura até os 30 minutos, mas a perda, que se encontra entre $15 \%$ a $20 \%$, não prejudica a trabalhabilidade da pasta, e 30’ seria o tempo razoável para o lançamento do concreto nas formas.

\subsection{ESTUDO DA DOSAGEM}

O objetivo foi o de gerar curvas de dosagem para obter concretos com as resistências de $30 \mathrm{MPa}, 60 \mathrm{MPa}$ e $90 \mathrm{MPa}$. Foram geradas 3 curvas de dosagem, uma para o concreto convencional, outra para os concretos de alta resistência e a terceira para concreto de muita elevada resistência.

As propriedades físicas e mecânicas dos materiais utilizados no concreto já foram estudados no item anterior.

O estudo de dosagem de Helene e Terzian (1992) parte do principio de que são necessários três pontos para montar o diagrama de dosagem que correlaciona a resistência à compressão com a relação água/cimento, traço e consumo de cimento.

Partiu-se da avaliação preliminar, com uma mistura do traço 1:5,0 (cimento:agregados secos totais, em massa) chamado de traço normal. Baseado nas informações obtidas elaboraram-se outros traços, chamados de rico e pobre. 


\subsubsection{Determinação do teor ideal de argamassa $(\alpha)$}

Esta é uma das fases mais importantes do estudo de dosagem, pois é a que determina a trabalhabilidade e a coesão adequada do concreto quando lançado nas fôrmas.

Helene e Terzian (1992) afirmam que a falta de argamassa na mistura acarreta porosidade ou falhas de concretagem. Um excesso proporciona um concreto de melhor aparência, mas aumenta o custo do concreto, aumenta o risco de fissuração por retração e por calor de hidratação.

O objetivo é determinar o teor de argamassa no concreto. Para tal efeito, foram consideradas variações no teor da argamassa da mistura por tentativas para que com observações práticas seja adotado o traço ideal. Na Tabela 5.10 estão as quantidades necessárias dos diferentes materiais com seus respectivos acréscimos, esta tabela foi elaborada para a obtenção da quantidade ideal de argamassa para um concreto convencional e um traço médio de 1:5,0. A quantidade mínima de concreto para a obtenção do traço foi de 20 litros, conforme mostra a Tabela 5.10 (quantidades menores não fornecem uma amostra representativa). Para a elaboração dos traços do concreto convencional foi empregado somente um tipo de brita: a brita 1.

Para este tipo de concreto o teor de argamassa ideal foi de 51\%. Depois de obter o teor ideal de argamassa foi feita uma nova mistura com o traço obtido para a moldagem dos corpos-de-prova. Foram empregados corpos-de-prova cilíndricos de $10 \mathrm{~cm}$ x $20 \mathrm{~cm}$. Para cada idade foram ensaiados 3 corpos-de-prova e para seu adensamento foi empregada a mesa vibratória. A desmoldagem foi feita 24 horas após a moldagem, e os corpos-de-prova transportados à câmara úmida para serem curados. Todo o preparo e cura dos corpos-de-prova foi segundo as recomendações da ABNT NBR 5738:1994.

Tabela 5.10 - Determinação do teor de argamassa para um concreto convencional para um traço médio de 1:5,0.

\begin{tabular}{|c|c|c|c|c|c|c|c|c|c|}
\hline \multicolumn{10}{|c|}{ QUANTIDADE DE ARGAMASSA PARA CONCRETO SEM ADITIVOS - PARA UM TRAÇO MÉDIO (CONCRETAGEM EM 20-1-09) } \\
\hline \multirow{2}{*}{$\begin{array}{c}\text { Teor de } \\
\text { argamassa } \\
\%\end{array}$} & \multirow{2}{*}{$\begin{array}{l}\text { Traço unitário } \\
\text { individual em } \\
\text { massa (1:a:p) }\end{array}$} & \multicolumn{2}{|c|}{ Qtdade de areia (kg) } & \multicolumn{2}{|c|}{ Qtdade de cimento $(\mathrm{kg})$} & \multicolumn{2}{|c|}{ Qtdade de agua (kg) } & \multirow{2}{*}{$\begin{array}{l}\text { Relação } \\
\text { a/c final }\end{array}$} & \multirow{2}{*}{$\begin{array}{c}\text { Volume de } \\
\text { concreto } \\
\text { final (I) }\end{array}$} \\
\hline & & Massa total & $\begin{array}{c}\text { Acrécimo na } \\
\text { mistura }\end{array}$ & Massa total & $\begin{array}{l}\text { Acréscimo } \\
\text { na mistura }\end{array}$ & Massa total & $\begin{array}{l}\text { Acréscimo } \\
\text { na mistura }\end{array}$ & & \\
\hline $49 \%$ & $1: 1,94: 3,06$ & 15,850 & \multirow[t]{2}{*}{0,817} & 8,170 & \multirow[t]{2}{*}{0,163} & 4,493 & \multirow[t]{2}{*}{0,150} & 0,550 & 21,91 \\
\hline $50 \%$ & $1: 2,00: 3,00$ & 16,667 & & 8,333 & & 4,643 & & 0,557 & 22,43 \\
\hline $51 \%$ & $1: 2,06: 2,94$ & 17,517 & 0,850 & 8,503 & 0,170 & 4,793 & \multirow{2}{*}{0,150} & 0,564 & 22,96 \\
\hline $52 \%$ & $1: 2,12: 2,88$ & 18,403 & 0,886 & 8,681 & 0,177 & 4,793 & & 0,552 & 23,35 \\
\hline
\end{tabular}

Considerando o mesmo teor de argamassa foram obtidos os outros traços para o concreto convencional com traço rico 1:3,5 e com traço pobre 1:6,5. 
Considerando o teor de argamassa $\alpha$ (no caso $\alpha=51 \%$ ), a obtenção da proporção de areia $\left(\mathrm{a}=\mathrm{m}_{\text {areira }} / \mathrm{m}_{\text {cimento }}\right)$ e brita $\left(\mathrm{p}=\mathrm{m}_{\text {brita }} / \mathrm{m}_{\text {cimento }}\right)$ do traço $\mathrm{m}(\mathrm{m}=5,0$ para o médio, $\mathrm{m}=3,5$ para o rico e $m=6,5$ para o pobre) provem da expressão:

$$
\alpha=\frac{1+a}{1+m}=0,51 \quad m=a+p
$$

Considerando $\mathrm{m}=3,5$, da Eq. 5.1 obtém-se $\mathrm{a}=1,3$ e $\mathrm{p}=2,21$. A Tabela 5.11 mostra os traços finais para o concreto convencional.

Tabela 5.11 - Traço unitário em massa (1:areia:brita) para concreto convencional com teor de argamassa de $51 \%$.

\begin{tabular}{|c|c|c|c|c|c|c|c|c|c|c|c|c|c|}
\hline \multicolumn{4}{|c|}{ TRAÇO FORTE 1:3,5 } & \multicolumn{5}{|c|}{ TRAÇO MÉDIO 1:5,0 } & \multicolumn{5}{|c|}{ TRAÇO FRACO 1:6,5 } \\
\hline & 1 & \begin{tabular}{l|l|l|}
$:$ & 1,3 \\
\end{tabular} & \begin{tabular}{l|l|}
$:$ & 2,21 \\
\end{tabular} & & 1 & & \begin{tabular}{l|l|}
06 & $:$ \\
\end{tabular} & 2,94 & & 1 & \begin{tabular}{l|l}
$:$ & 2,8 \\
\end{tabular} & & 3,68 \\
\hline$a / c$ & \multicolumn{3}{|c|}{0,45} & $a / c$ & \multicolumn{4}{|c|}{0,56} & $a / c$ & \multicolumn{4}{|c|}{0,71} \\
\hline
\end{tabular}

A Tabela 5.12 mostra a quantidade de materiais por $\mathrm{m}^{3}$ de concreto para o concreto convencional para os três traços, incluindo a data do preparo dos corpos-de-prova os resultados do abatimento do tronco de cone, a massa específica do concreto fresco que foi obtida de cada traço, a data dos ensaios e a média dos resultados obtidos.

Tabela 5.12 - Quantidade de materiais por $\mathrm{m}^{3}$ de para o concreto convencional.

\begin{tabular}{|c|c|c|c|c|}
\hline \multicolumn{5}{|c|}{ MATERIAIS POR M3 - NO ESTUDO DE DOSAGEM - CONCRETO SEM ADITIVOS } \\
\hline traço unitário total & $1: \mathrm{m}$ & $1: 3,50$ & $1: 5,00$ & $1: 6,50$ \\
\hline traço unitário individual & 1:a:p & $1: 1,30: 2,21$ & $1: 2,06: 2,94$ & $1: 2,83: 3,68$ \\
\hline \multicolumn{2}{|l|}{ teor de armamassa seca $(\alpha)-\%$} & $51 \%$ & $51 \%$ & $51 \%$ \\
\hline \multicolumn{2}{|l|}{ relação a/c } & 0,45 & 0,56 & 0,71 \\
\hline \multicolumn{2}{|c|}{ relação agua/materiais secos (\%) } & $10,0 \%$ & $9,3 \%$ & $9,5 \%$ \\
\hline \multicolumn{2}{|c|}{ massa específica concreto fresco $(\mathrm{kg} / \mathrm{m} 3)$} & 2444 & 2424 & 2413 \\
\hline \multicolumn{2}{|c|}{ abatimento do tronco de cone $(\mathrm{mm})$} & $120 \pm 10$ & $125 \pm 10$ & $120 \pm 5$ \\
\hline \multirow{4}{*}{$\begin{array}{l}\text { Consumo de materiais por } \\
\text { m3 de concreto }(\mathrm{kg})\end{array}$} & cimento & 490,7 & 370,9 & 294,7 \\
\hline & areia & 635,4 & 764,1 & 832,4 \\
\hline & pedra & 1081,9 & 1090,5 & 1082,9 \\
\hline & água & 220,8 & 207,7 & 209,2 \\
\hline \multirow{4}{*}{$\begin{array}{c}\text { Resistência à compressão } \\
\text { axial (MPa) }\end{array}$} & $3 d(26-1-09)$ & 38,7 & 31,1 & 16,3 \\
\hline & $7 d(30-1-09)$ & 46,5 & 34,9 & 20,0 \\
\hline & $14 d(6-2-09)$ & 49,9 & 37,2 & 21,4 \\
\hline & $28 \mathrm{~d}(20-2-09)$ & 54,5 & 41,4 & 24,0 \\
\hline & & mas & sa específica $(\mathrm{kg} / \mathrm{l}$ & m3) \\
\hline Data da moldagem & $23 / 1 / 2009$ & cimento & areia & pedra \\
\hline & & 3080 & 2630 & 2860 \\
\hline
\end{tabular}

Todos os corpos-de-prova cilíndricos foram retificados, em razão de suas imperfeições nas bases, antes de serem ensaiados à compressão simples. O procedimento dos ensaios à 
compressão simples dos corpos-de-prova cilíndricos de $10 \mathrm{~cm}$ x $20 \mathrm{~cm}$ seguiu as recomendações da ABNT NBR 5739:1994. Com os resultados dos ensaios foi elaborada a curva de dosagem (Fig.5.7), com estas curvas é possível obter qualquer traço dentro dos limites de resistências obtidos e com as propriedades dos materiais empregados

Da mesma maneira foram realizados outros estudos de teores de argamassa ideais para concretos com aditivos superplastificantes e para concretos com superplastificantes e sílica ativa (os resultados se encontram no Anexo A). Toda a seqüência para a elaboração dos traços foi a mesma que para o concreto convencional, com a diferença da incorporação da sílica ativa no cálculo do traço.

A Eq. 5.2 mostra o cálculo do teor de argamassa em função à massa de cimento considerando a presença da sílica ativa.

$$
\alpha=\frac{1+a+S A}{1+m+S A}
$$

O cuidado a se ter no cálculo do traço é que pode ser feito em relação à massa do aglomerante, e não em relação à massa do cimento (Tabela 5.13 e Tabela 5.14).

A Eq. 5.3 mostra a maneira como foi obtido o traço considerando a presença da sílica ativa.

$$
\frac{\left(1-\% T_{S A}\right)}{\left(1-\% T_{S A}\right)+S A}: 1-\frac{\left(1-\% T_{S A}\right)}{\left(1-\% T_{S A}\right)+S A}: a: p
$$

Sendo que:

$\% \mathrm{~T}_{\mathrm{SA}}$ é o teor de sílica ativa (\% de substituição volumétrica do cimento);

SA é a massa de sílica ativa em relação à massa de cimento ( $\left.S A=\frac{m_{S A}}{m_{c i m}}=\frac{\% T_{S A} \times \rho_{S A}}{\rho_{c i m}}\right)$; a e p estão em relação à massa do aglomerante.

Com os traços obtidos nos estudos foram elaborados tabelas dos materiais por $\mathrm{m}^{3} \mathrm{de}$ concreto incluindo todos os resultados do concreto fresco e endurecido. Com os resultados das resistências do concreto à compressão nas diferentes idades foram desenhadas as curvas de dosagem. Para estes concretos foram empregados 2 tipos de brita conforme o estudo do empacotamento. O teor de superplastificante em relação à massa do cimento foi aquele obtido no ensaio de Kantro para pasta sem sílica ativa.

A Tabela 5.13 mostra a quantidade de materiais por $\mathrm{m}^{3}$ de concreto para o concreto com aditivo superplastificante para os três traços. 
Tabela 5.13 - Quantidade de materiais por $\mathrm{m}^{3}$ de para o concreto com superplastificante.

\begin{tabular}{|c|c|c|c|c|c|c|c|c|c|}
\hline \multicolumn{10}{|c|}{ MATERIAIS POR M3 - NO ESTUDO DE DOSAGEM - CONCRETO COM ADITIVO SUPERPLASTIFICANTE } \\
\hline \multirow{2}{*}{$\begin{array}{c}\text { traço unitário em } \\
\text { massa }\end{array}$} & 1:m & $1: 3,00$ & & $1: 4,50$ & & & $1: 6,00$ & & \\
\hline & 1:a:p1:p2 & $1: 1,12: 0,75$ & : 1,13 & $1: 1,92$ & : 1,03 & $: 1,55$ & $1: 2,71$ & $: 1,32$ & : 1,97 \\
\hline \multicolumn{2}{|c|}{ teor de armamassa seca - $\alpha(\%)$} & \multicolumn{2}{|c|}{$53 \%$} & \multicolumn{3}{|c|}{$53 \%$} & \multicolumn{3}{|c|}{$53 \%$} \\
\hline \multicolumn{2}{|c|}{ relação a/c } & \multicolumn{2}{|l|}{0,24} & \multicolumn{3}{|c|}{0,36} & \multicolumn{3}{|c|}{0,5} \\
\hline \multicolumn{2}{|c|}{ relação agua/materiais secos (\%) } & \multicolumn{2}{|l|}{$6,0 \%$} & \multicolumn{3}{|c|}{$6,5 \%$} & \multicolumn{3}{|c|}{$7,1 \%$} \\
\hline \multicolumn{2}{|c|}{ teor superplastificante (\%massa de cim.) } & \multicolumn{2}{|l|}{$1,0 \%$} & \multicolumn{3}{|c|}{$1,0 \%$} & \multicolumn{3}{|c|}{$1,0 \%$} \\
\hline \multicolumn{2}{|c|}{ massa específica concreto fresco } & \multicolumn{2}{|l|}{2472} & \multicolumn{3}{|c|}{2458} & \multicolumn{3}{|c|}{2438} \\
\hline \multicolumn{2}{|c|}{ abatimento do tronco de cone (mm) } & \multicolumn{2}{|l|}{$220 \pm 30$} & \multicolumn{3}{|c|}{$215 \pm 25$} & \multicolumn{3}{|c|}{$210 \pm 10$} \\
\hline \multirow{6}{*}{$\begin{array}{l}\text { Consumo de } \\
\text { materiais por m3 de } \\
\text { concreto }(\mathrm{kg})\end{array}$} & cimento & \multicolumn{2}{|l|}{606,8} & \multicolumn{3}{|c|}{431,7} & \multicolumn{3}{|c|}{332,7} \\
\hline & areia & \multicolumn{2}{|l|}{679,7} & \multicolumn{3}{|c|}{826,6} & \multicolumn{3}{|c|}{901,7} \\
\hline & brita 1 & 456,3 & & & 446,3 & & & 437,9 & \\
\hline & pedrisco & 684,5 & & & 669,5 & & & 656,8 & \\
\hline & superplastificante & 6,1 & & & 4,3 & & & 3,3 & \\
\hline & água & 145,6 & & & 155,4 & & & 166,4 & \\
\hline & $3 d()$ & - & & & - & & & - & \\
\hline compressão axial & $8 d(26-2-09)$ & 80,4 & & & 68,9 & & & 48,2 & \\
\hline (MPa) & 14d (4-3-09) & 87,9 & & & 70,7 & & & 53,6 & \\
\hline & $28 d(18-3-09)$ & 96,8 & & & 76,6 & & & 57,4 & \\
\hline relação entre agregad & os graudos & brita 1 & & $40 \%$ & & edrisco & & $60 \%$ & \\
\hline & & & & massa esp & ecífica ( & $(\mathrm{kg} / \mathrm{m} 3)$ & & & \\
\hline Data da moldagem & $18 / 2 / 2009$ & cimento & & & areia & & & pedra & \\
\hline & & 3080 & & & 2630 & & & 2860 & \\
\hline
\end{tabular}

A Tabela 5.14 mostra a quantidade de materiais por $\mathrm{m}^{3}$ de concreto para o concreto com aditivo superplastificante e sílica ativa para os três traços, nesta são incluídos todos os resultados do concreto fresco e endurecido. O teor de superplastificante foi aquele obtido no ensaio de Kantro. 
Tabela 5.14 - Quantidade de materiais por $\mathrm{m}^{3}$ de para o concreto com superplastificante e sílica ativa.

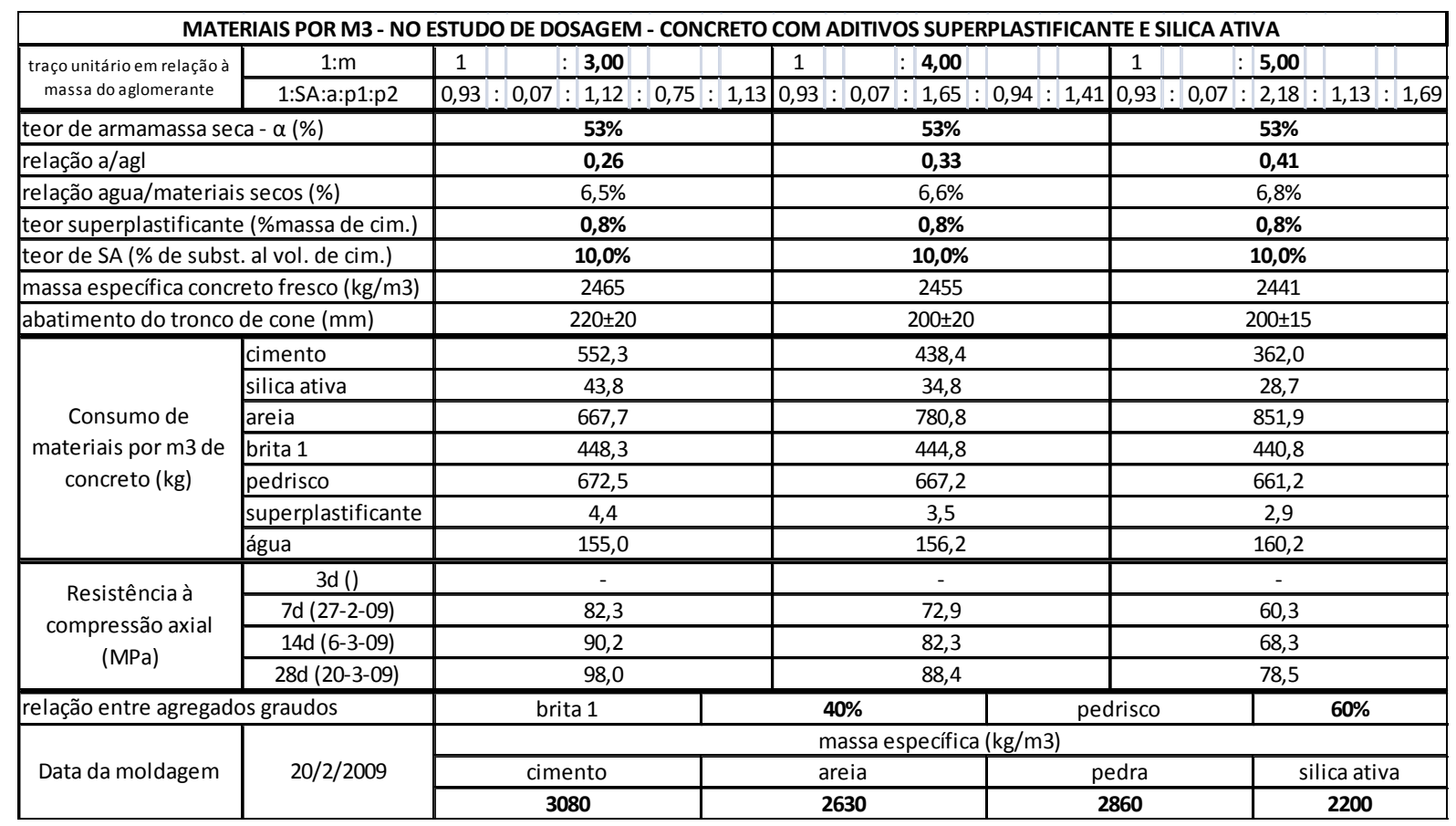

Para os três tipos de concreto se tratou de manter constante a relação água/materiais secos (nos três traços) e o abatimento do tronco de cone.

\subsubsection{Curvas de dosagem}

Com os resultados obtidos foram traçadas curvas de dosagem (Fig. 5.7 até a Fig. 5.9) relacionando alguns parâmetros observados em cada um dos tipos de concretos estudados. De cada uma das curvas de dosagem foi interpolada a resistência do concreto planificada. 


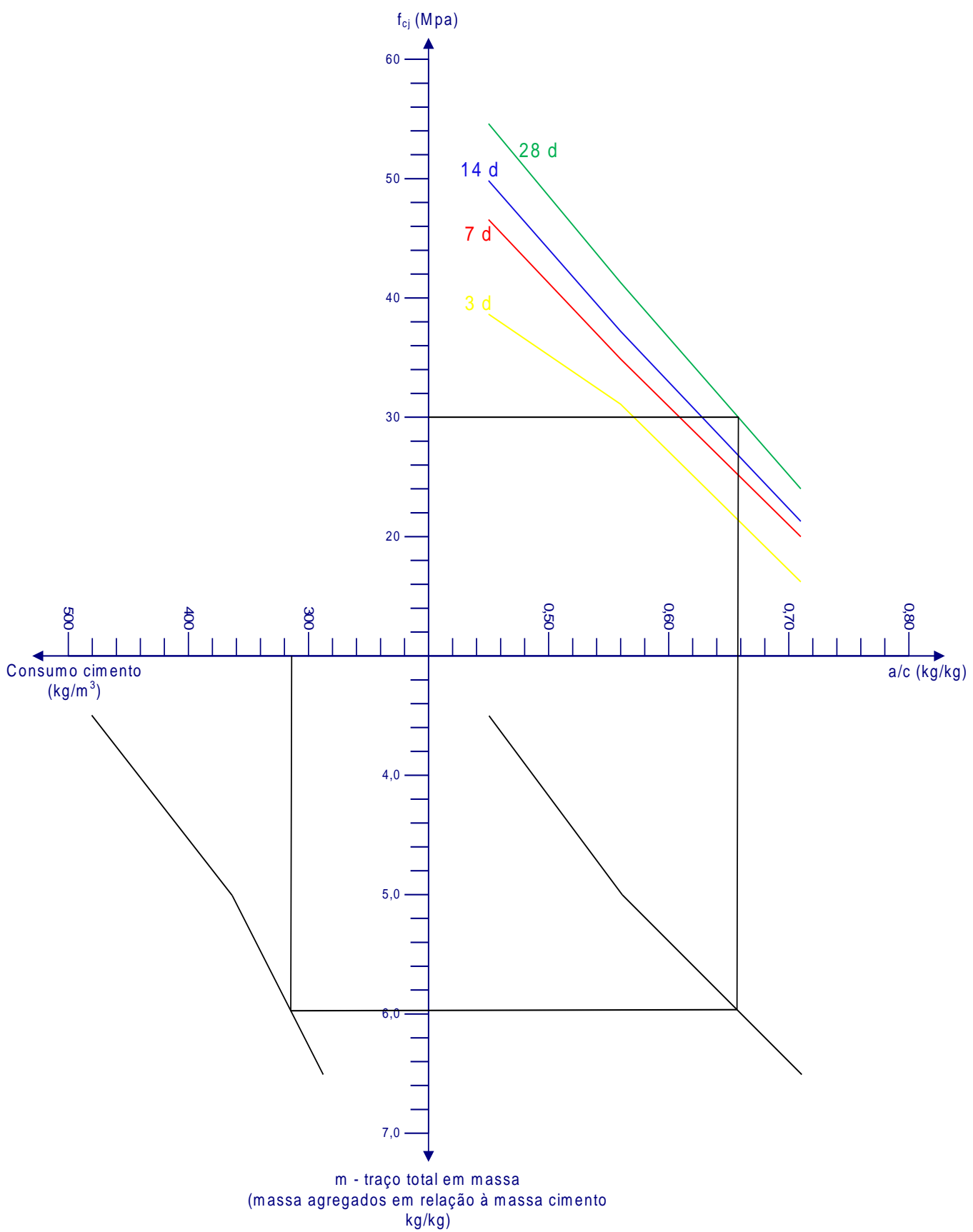

Fig. 5.7 - Curva de dosagem para a obtenção do concreto de $30 \mathrm{MPa}$.

Os resultados nas curvas de dosagem demonstram que, independente do traço empregado e a idade do ensaio, na medida em que se incrementa a relação a/c a resistência à compressão do concreto tem redução significativa. $\mathrm{O}$ excesso de água, além de provocar uma diminuição na resistência fragiliza a zona de transição, incrementa o surgimento de poros afetando a sua durabilidade. 


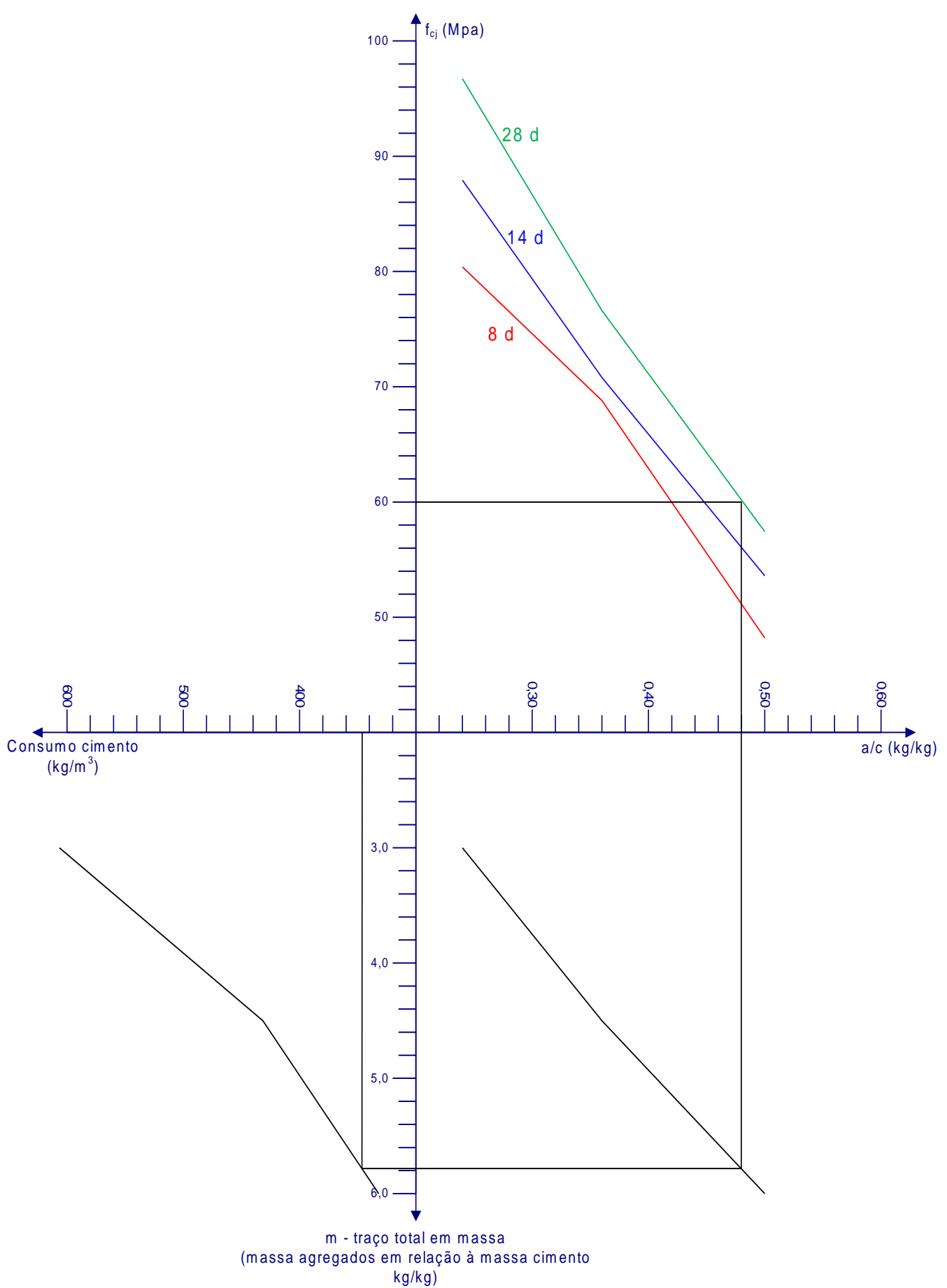

Fig. 5.8 - Curva de dosagem para a obtenção do concreto de $60 \mathrm{MPa}$. 


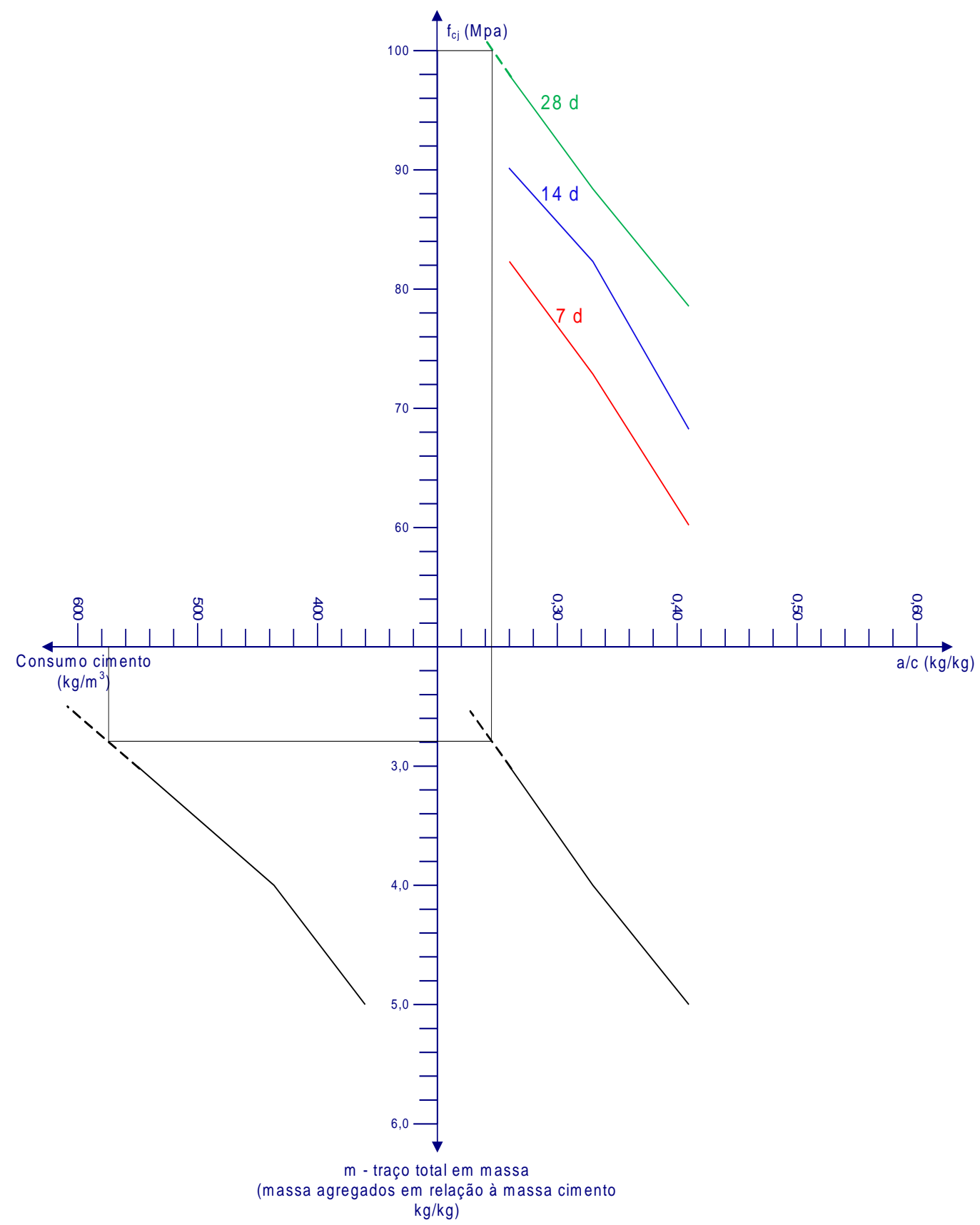

Fig. 5.9 - Curva de dosagem para a obtenção do concreto de $100 \mathrm{MPa}$.

Das curvas de dosagem foram determinados os traços finais para os três tipos de concreto. A Tabela 5.15 mostra os materiais empregados nos três traços por $\mathrm{m}^{3}$ de concreto com todos os resultados obtidos do concreto fresco e do concreto endurecido. Como mencionado anteriormente para o concreto com resistência à compressão simples estimada de $100 \mathrm{MPa}$ foi feita uma correção do teor de sílica ativa, modificando de $10 \%$ para $8 \%$. Com estes traços foram moldados os pilares e pilares curtos; a moldagem foi feita em duas etapas porque a betoneira tinha capacidade de $300 \ell$, insuficiente para moldar, de uma vez só, todos os pilares e pilares curtos. 
Tabela 5.15 - Resultados e consumo de materiais dos traços adotados para os três tipos de concreto.

\begin{tabular}{|c|c|c|c|c|c|c|c|c|c|c|c|c|c|c|c|c|}
\hline \multicolumn{17}{|c|}{ MATERIAIS POR M3 - COM TRAÇOS OBTIDOS DAS CURVAS DE DOSAGEM } \\
\hline & & \multicolumn{5}{|c|}{ TRAÇO PARA $30 \mathrm{MPa}$} & \multicolumn{5}{|c|}{ TRAÇO PARA $60 \mathrm{MPa}$} & \multicolumn{5}{|c|}{ TRAÇO PARA $100 \mathrm{MPa}$} \\
\hline \multirow{2}{*}{$\begin{array}{c}\text { traço unitário em relação à } \\
\text { massa do aglomerante }\end{array}$} & 1:m & 1 & & 6,00 & & & 1 & : & 5,80 & & & 1 & . & 3,00 & & \\
\hline & 1:SA:a:p1:p2 & 1 & 0,00 & 2,57 & 3,43 & 0,00 & 1 & $0,00:$ & 2,60 & $: 1,28$ & $: 1,92$ & 0,94 & $0,06:$ & 1,12 & 0,75 & 1,13 \\
\hline \multicolumn{2}{|c|}{ teor de armamassa seca - $\alpha(\%)$} & \multicolumn{5}{|c|}{$51 \%$} & \multicolumn{5}{|c|}{$53 \%$} & \multicolumn{5}{|c|}{$53 \%$} \\
\hline \multicolumn{2}{|c|}{ relação a/agl } & \multicolumn{5}{|c|}{0,65} & \multicolumn{5}{|c|}{0,48} & \multicolumn{5}{|c|}{0,26} \\
\hline \multicolumn{2}{|c|}{ relação agua/materiais secos (\%) } & \multicolumn{5}{|c|}{$9,3 \%$} & \multicolumn{5}{|c|}{$7,1 \%$} & \multicolumn{5}{|c|}{$6,5 \%$} \\
\hline \multicolumn{2}{|c|}{ teor superplastificante (\%massa de cim.) } & \multicolumn{5}{|c|}{$0,0 \%$} & \multicolumn{5}{|c|}{$1,0 \%$} & \multicolumn{5}{|c|}{$0,8 \%$} \\
\hline \multicolumn{2}{|c|}{ teor de SA (\% de subst. al vol. de cim.) } & \multicolumn{5}{|c|}{$0,0 \%$} & \multicolumn{5}{|c|}{$0,0 \%$} & \multicolumn{5}{|c|}{$8,0 \%$} \\
\hline \multicolumn{2}{|c|}{ massa específica concreto fresco $(\mathrm{kg} / \mathrm{m} 3)$} & \multicolumn{2}{|c|}{2420} & & 24 & & 24 & 38 & & 243 & & & 479 & & & 462 \\
\hline abatimento do tronco & cone $(\mathrm{mm})$ & 100 & \pm 5 & & $130=$ & \pm 15 & 205 & $5 \pm 5$ & & 235 & & & $5 \pm 15$ & & & $5 \pm 5$ \\
\hline & cimento & & & 317,3 & & & & & 343,4 & & & & & 561,9 & & \\
\hline & sílica ativa & & & 0,0 & & & & & 0,0 & & & & & 34,9 & & \\
\hline Consumo de & areia & & & 815,6 & & & & & 894,1 & & & & & 668,5 & & \\
\hline materiais por $\mathrm{m} 3 \mathrm{de}$ & brita 1 & & & 1088, & & & & & 439,0 & & & & & 448,8 & & \\
\hline concreto $(\mathrm{kg})$ & pedrisco & & & 0,0 & & & & & 658,5 & & & & & 673,2 & & \\
\hline & superplastificante & & & 0,0 & & & & & 3,4 & & & & & 4,5 & & \\
\hline & água & & & 206,3 & & & & & 164,8 & & & & & 155,2 & & \\
\hline & PRIMEIRA & $9 d-$ & 32,2 & & $30 \mathrm{~d}-$ & 35,9 & $14 \mathrm{~d}-$ & 53,7 & & $36 \mathrm{~d}-$ & 62,5 & $10 \mathrm{~d}-$ & 92,7 & & $33 d-$ & 103,8 \\
\hline Resistencia a & CONCRETAGEM & $15 d-$ & 33,8 & & $30 d-j-$ & 34,4 & $25 d-$ & 56,5 & & $32 d-j-$ & 63,9 & $27 d-$ & 104,5 & & $28 d-j-$ & 99,2 \\
\hline Compressdo dxidl & SEGUNDA & $7 d-$ & 24,5 & & $36 \mathrm{~d}-$ & 29,3 & $15 d-$ & 48,4 & & $34 \mathrm{~d}-$ & 55,7 & $8 d-$ & 84,2 & & $28 \mathrm{~d}-$ & 104,3 \\
\hline & CONCRETAGEM & $14 d-$ & 26,0 & & $36 d-j-$ & 30,1 & $24 d-$ & 51,9 & & $31 \mathrm{~d}-\mathrm{j}-$ & 56,8 & $24 d-$ & 102,2 & & $28 d-j-$ & 101,8 \\
\hline Resitência à tração & 1a CONCRETAGEM & $9 d-$ & 2,6 & & $30 \mathrm{~d}-$ & 2,9 & $9 d-$ & 3,2 & & $30 \mathrm{~d}-$ & 4,1 & $10 d-$ & 4,9 & & $26 d-$ & 6,2 \\
\hline (MPa) & 2a CONCRETAGEM & $9 d-$ & 2,3 & & $30 \mathrm{~d}-$ & 2,8 & $9 d-$ & 2,6 & & $34 \mathrm{~d}-$ & 3,6 & & & & $23 \mathrm{~d}-$ & 6,0 \\
\hline relação entre agregad & os graudos & & brit & ta 1 & & & 40 & & & & ped & drisco & & & $60 \%$ & \\
\hline & & & & & & & & ssa esp & pecífic & $\mathrm{ca}(\mathrm{kg} / \mathrm{m}$ & & & & & & \\
\hline Data da moldagem & & & cime & ento & & & are & & & & & edra & & & silica ati & \\
\hline & & & 30 & 80 & & & 26 & & & & & 8660 & & & 2200 & \\
\hline
\end{tabular}

Todos os resultados do estudo de dosagem estão apresentados no Anexo A. No total foram ensaiados 200 corpos-de-prova, todos eles foram retificados, foram medidos e pesados para obterem-se resultados mais realistas.

Em função do critério de ruptura a ser adotado na análise numérica em 3D dos pilares é necessário conhecer a resistência à tração do concreto. Para conhecer estes valores foram realizados ensaios à compressão diametral para os três tipos de concreto nos corpos-de-prova cilíndricos de $10 \mathrm{~cm}$ x $20 \mathrm{~cm}$ segundo a norma ABNT NBR 7222:1994. A Tabela 5.15 mostra um resumo das médias destes resultados e no Anexo $\mathrm{C}$ se encontram seus resultados individuais.

\subsection{PROPRIEDADES MECÂNICAS DAS ARMADURAS}

Foram utilizadas barras de aço com diâmetro de 12,5 $\mathrm{mm}$ para as armaduras longitudinais e de 6,3 mm para os estribos. Duas amostras de cada diâmetro foram cortadas para o ensaio de tração. As barras foram pesadas e tiveram seu comprimento medido para serem calculadas as suas áreas transversais e os respectivos diâmetros, considerando a massa específica do aço igual a $7850 \mathrm{~kg} / \mathrm{m} 3$. 
Logo foram realizados os ensaios na máquina INSTRON do Laboratório de Estruturas da Escola de Engenharia de São Carlos - USP, os corpos-de-prova foram instrumentados com “clip gage” e os resultados estão na Tabela 5.16.

Tabela 5.16 - Propriedades físicas e mecânicas das barras de aço.

\begin{tabular}{|c|c|c|c|c|c|c|c|c|c|}
\hline \multirow{2}{*}{$\begin{array}{l}\text { Corpo-de- } \\
\text { prova }\end{array}$} & \multirow{2}{*}{$\begin{array}{l}\text { diámetro } \\
\text { nominal } \\
(\mathrm{mm})\end{array}$} & \multirow{2}{*}{$\begin{array}{c}\text { área } \\
\text { nominal } \\
\text { (cm2) }\end{array}$} & \multirow{2}{*}{$\begin{array}{l}\text { comprimento } \\
\text { barra }(\mathrm{cm})\end{array}$} & \multirow[t]{2}{*}{ massa $(\mathrm{g})$} & \multirow{2}{*}{$\begin{array}{l}\text { área } \\
(\mathrm{cm} 2)\end{array}$} & \multicolumn{2}{|c|}{$\begin{array}{l}\text { Distancia entre pratos } \\
\text { mâquina ensaio }(\mathrm{cm})\end{array}$} & \multirow{2}{*}{$\begin{array}{l}\text { Resistência } \\
(\mathrm{MPa})\end{array}$} & \multirow{2}{*}{$\begin{array}{l}\text { Módulo de } \\
\text { elasticidade } \\
\text { (GPa) }\end{array}$} \\
\hline & & & & & & inicial & final & & \\
\hline CP 1 & 12,5 & 1,23 & 89,90 & 865,30 & 1,23 & 60,70 & 65,50 & 590,00 & 203,40 \\
\hline CP 2 & 12,5 & 1,23 & 90,10 & 868,30 & 1,23 & 60,70 & 66,00 & 580,00 & 195,60 \\
\hline CP 3 & 6,3 & 0,31 & 90,40 & 220,60 & 0,31 & 62,20 & 67,20 & 620,00 & 215,60 \\
\hline CP 4 & 6,3 & 0,31 & 90,40 & 220,50 & 0,31 & 62,70 & 68,80 & 620,00 & 223,10 \\
\hline MÉDIA & 12,5 & 1,23 & - & - & 1,23 & - & - & 585,00 & 199,50 \\
\hline MÉDIA & 6,3 & 0,31 & - & - & 0,31 & - & - & 620,00 & 219,35 \\
\hline
\end{tabular}

As Fig. 5.10 e Fig. 5.11 mostram os diagramas $\sigma \times \varepsilon$ das barras de aço para os diâmetros de $12,5 \mathrm{~mm}$ e $6,3 \mathrm{~mm}$ respectivamente.

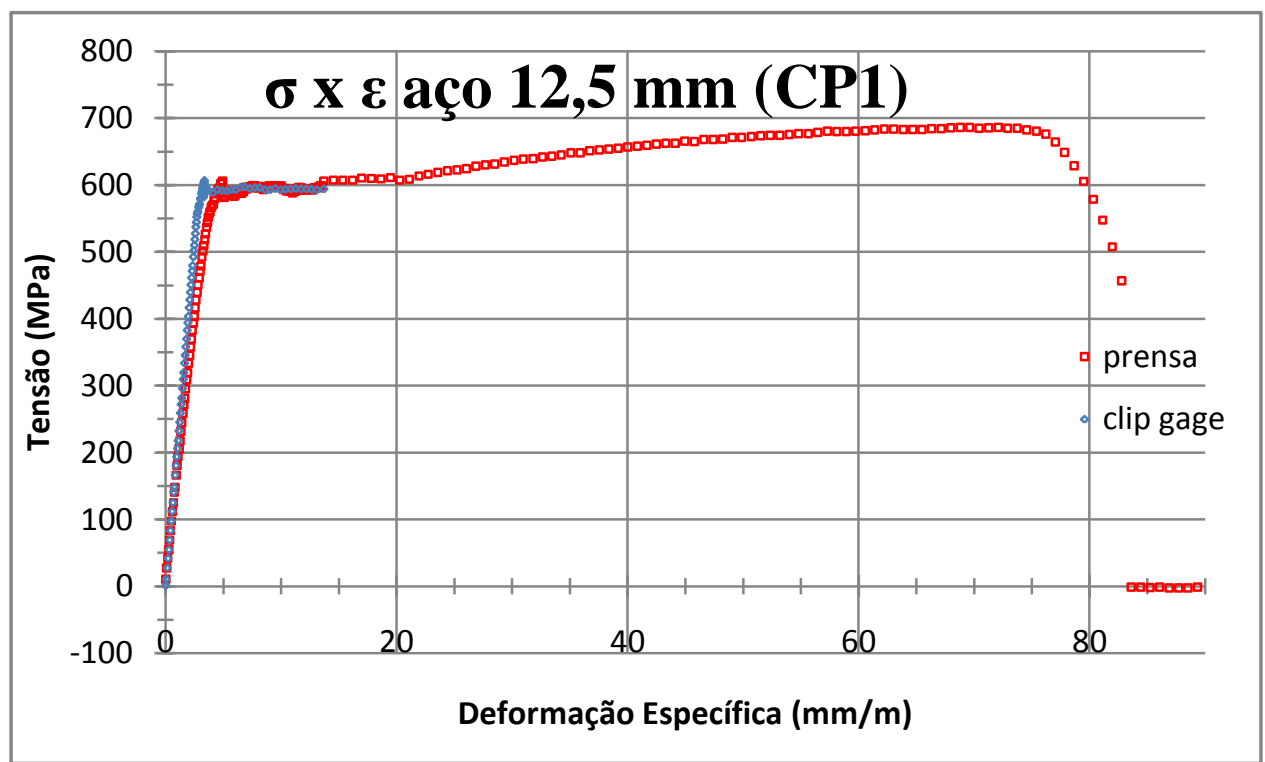

Fig. 5.10 - Diagrama tensão-deformação específica para o CP1.

Nas Fig. 5.10 e Fig. 5.11 é possível observar o patamar de escoamento e como acontece o encruamento do aço após a deformação específica de $2 \%$. 


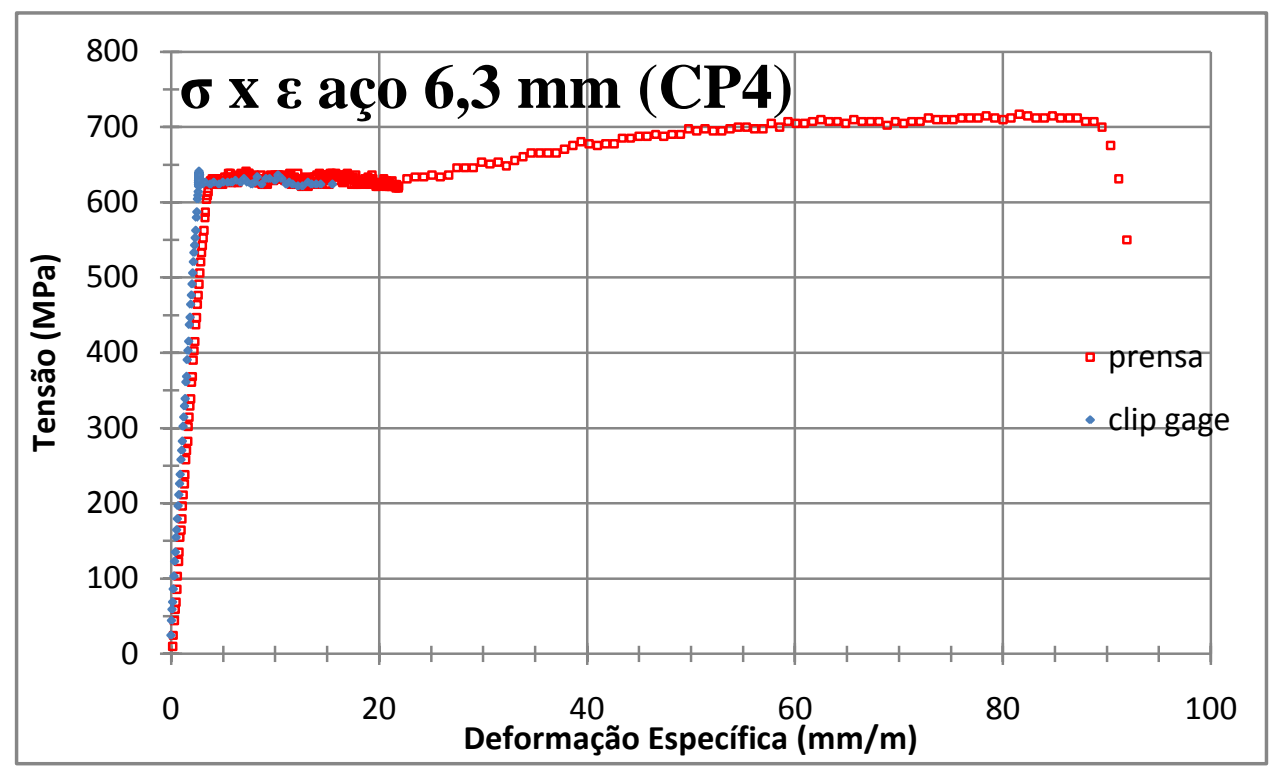

Fig. 5.11 - Diagrama tensão-deformação específica para o CP4.

\subsection{DESCRIÇÃO DOS MATERIAIS E INSTRUMENTAÇÃO DOS PILARES CURTOS E PILARES ESBELTOS}

\subsubsection{Ensaio dos pilares curtos à compressão simples}

Nesta primeira fase se fizeram os ensaios dos pilares curtos à compressão centrada, sendo que foi estudada experimentalmente a variação da ductilidade do concreto em relação à taxa de armadura transversal. Foram ensaiados 9 pilares curtos com seção transversal de 15 $\mathrm{cm} \times 15 \mathrm{~cm}, 3$ tiveram estribos a cada $5 \mathrm{~cm}, 3$ a cada $10 \mathrm{~cm}$ e $3 \mathrm{sem}$ armadura. Os concretos que foram empregados foram os mesmos dos pilares esbeltos, de resistências $30 \mathrm{MPa}, 60$ MPa e $100 \mathrm{MPa}$. A esbeltez mecânica dos pilares curtos estava entre 13 e 16. A armadura longitudinal era composta por 4 barras de 12,5 mm de diâmetro. De cada tipo ensaiado fez-se somente uma réplica.

Os pilares curtos foram nomeados segundo suas propriedades, considerando o tipo de concreto ( $\mathrm{H}$ de elevada resistência, $\mathrm{M}$ de moderada resistência e $\mathrm{L}$ de pequena resistência) e o espaçamento entre estribos. Por exemplo, $50 \mathrm{H}$ corresponde a um pilar curto com espaçamento entre estribos de $5 \mathrm{~cm}$ e com uma resistência à compressão estimada de $100 \mathrm{MPa}$. A Tabela 5.17 mostra as propriedades dos pilares curtos ensaiados. 
Tabela 5.17 - Propriedades geométricas e mecânicas dos pilares curtos.

\begin{tabular}{|c|c|c|c|c|c|c|c|}
\hline \multirow{2}{*}{ Serie } & \multirow{2}{*}{$\begin{array}{c}\text { número de } \\
\text { modelos }\end{array}$} & \multirow{2}{*}{$\begin{array}{l}\mathrm{b} \times \mathrm{h} \\
(\mathrm{cm})\end{array}$} & \multirow{2}{*}{$\begin{array}{c}\text { Altura } \\
(\mathrm{cm})\end{array}$} & \multirow{2}{*}{ Esbeltez } & \multirow{2}{*}{$\begin{array}{c}\mathrm{f}_{\mathrm{c}} \text { estimado } \\
(\mathrm{MPa})\end{array}$} & Estribos & \multirow{2}{*}{$\begin{array}{c}\text { Armadura } \\
\text { longitudinal }\end{array}$} \\
\hline & & & & & & taxa volum. & \\
\hline $100 \mathrm{H}$ & \multirow{9}{*}{$1 \mathrm{x}$} & \multirow{9}{*}{$15 \times 15$} & \multirow{3}{*}{70} & \multirow{3}{*}{16} & 100 & \multirow{3}{*}{$\begin{array}{c}\varnothing 6,3 \text { c } 10 \mathrm{~cm} \\
1,2 \%\end{array}$} & \multirow{6}{*}{$\begin{array}{c}4 \emptyset 12,5 \mathrm{~mm} \\
4,92 \mathrm{~cm} 2\end{array}$} \\
\hline $100 \mathrm{M}$ & & & & & 60 & & \\
\hline $100 \mathrm{~L}$ & & & & & 30 & & \\
\hline $50 \mathrm{H}$ & & & \multirow{6}{*}{60} & \multirow{6}{*}{14} & 100 & \multirow{3}{*}{$\begin{array}{c}\varnothing 6,3 \text { c } 5 \mathrm{~cm} \\
2,4 \%\end{array}$} & \\
\hline $50 \mathrm{M}$ & & & & & 60 & & \\
\hline $50 \mathrm{~L}$ & & & & & 30 & & \\
\hline $\mathrm{H}$ & & & & & 100 & - & - \\
\hline $\mathrm{M}$ & & & & & 60 & - & - \\
\hline $\mathrm{L}$ & & & & & 30 & - & - \\
\hline
\end{tabular}

Como mencionado anteriormente foram necessárias duas concretagens para cada tipo de concreto, os pilares curtos eram preparados junto com os pilares esbeltos sempre na primeira concretagem de cada traço.

As fôrmas eram de madeira compensada e o concreto era lançado com os pilares curtos deitados (lançamento lateral) e o adensamento era com vibrador de agulha. De cada concretagem e de cada traço foram moldados 15 corpos-de-prova cilíndricos, 9 para os ensaios à compressão simples e 6 para os ensaios à compressão diametral. Junto às extremidades dos pilares foi disposta uma armadura de fretagem, composta por estribos de vários ramos de 6,3 mm de diâmetro, espaçados a cada $3 \mathrm{~cm}$. A Fig. 5.12 mostra os detalhes das armaduras.
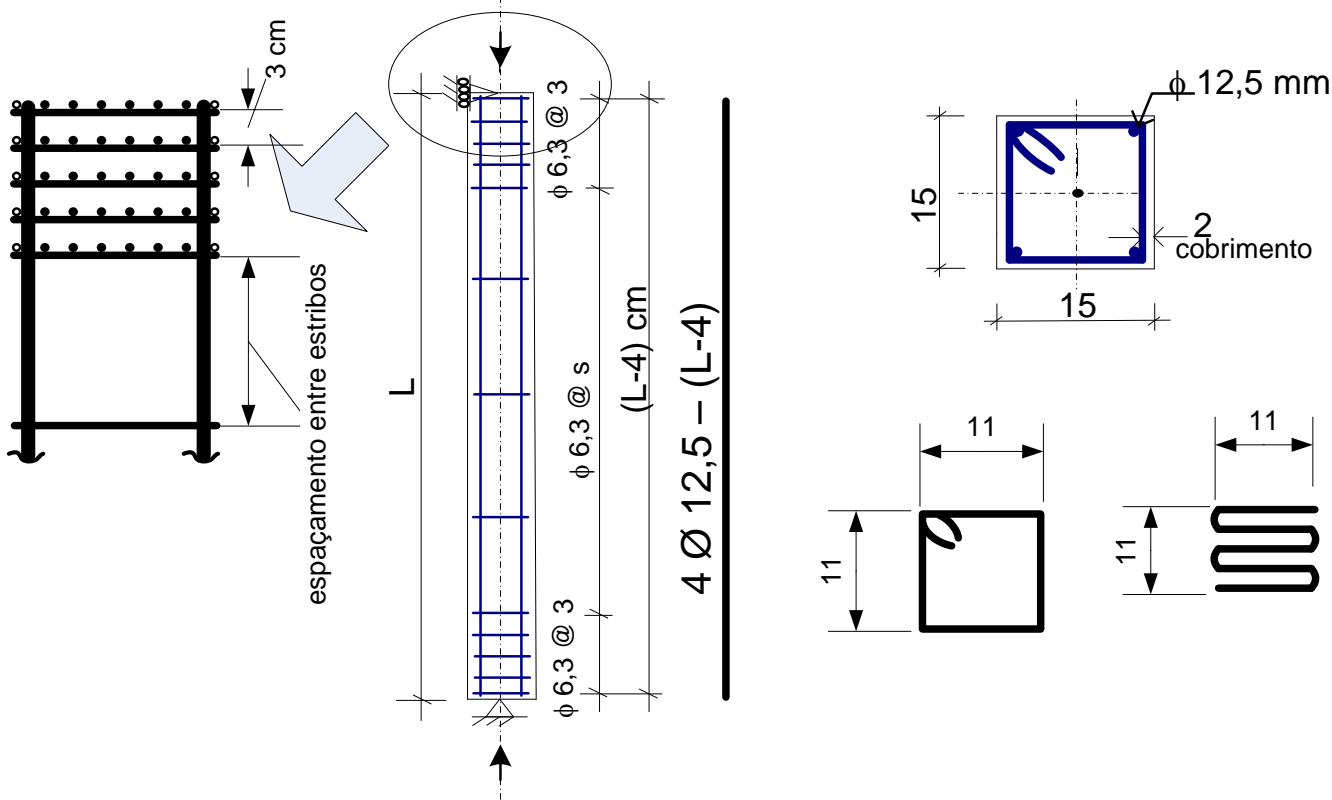

Fig. 5.12 - Detalhe das armaduras dos pilares curtos.

Na Fig. 5.13, são apresentadas as dimensões das fôrmas, estas foram reaproveitadas 3 vezes. Após a concretagem, os pilares curtos permaneceram nas fôrmas por um período de 24 
h. Durante este período foi realizada cura com espumas umidificadas. Depois das $24 \mathrm{~h}$ se procedia à desforma e os pilares curtos eram envoltos com espuma umidificada e com lonas de plástico e permaneceram assim até 2 dias antes dos ensaios.

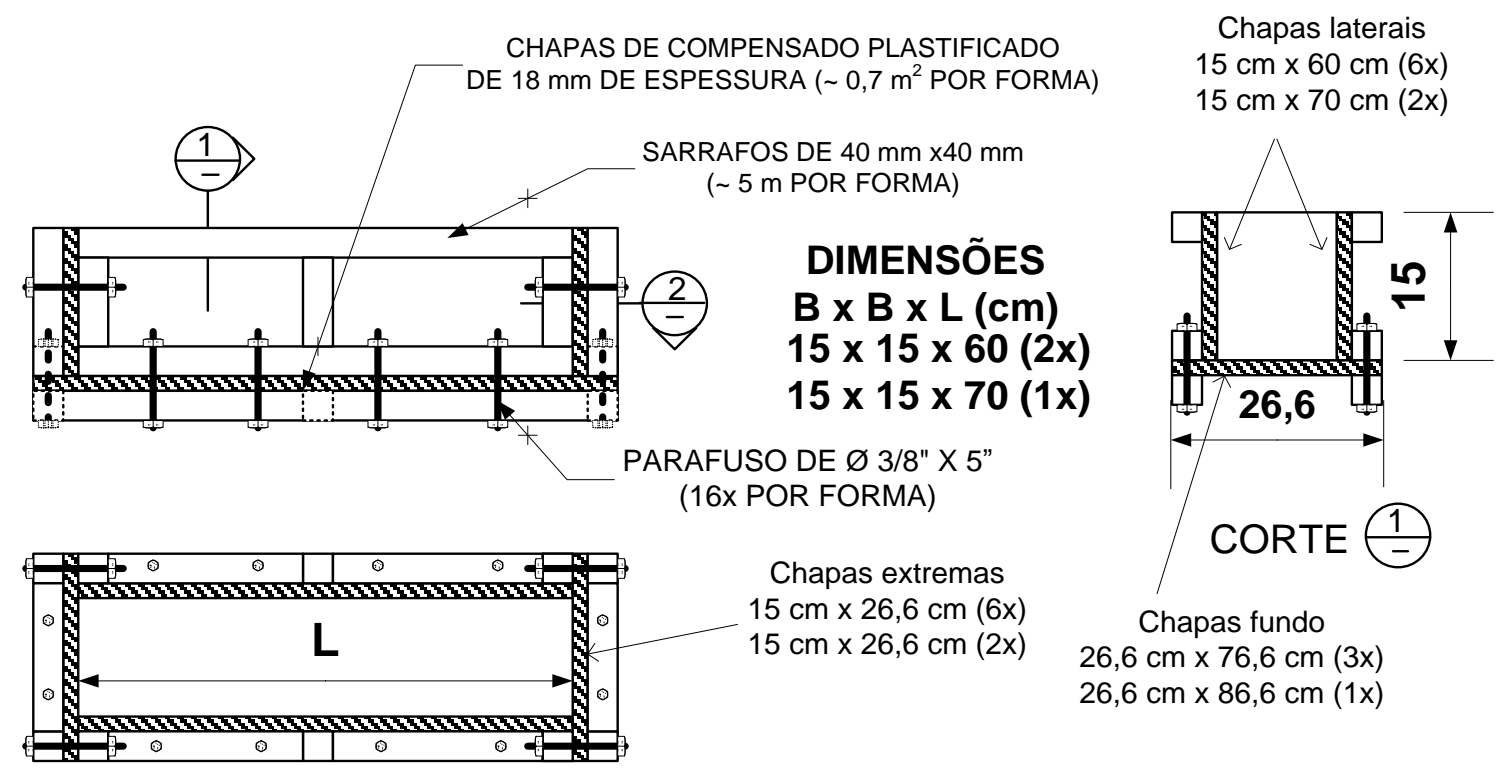

\section{CORTE}

Fig. 5.13 - Detalhe da fôrma dos pilares curtos.

A instrumentação dos pilares curtos foi composta por dois extensômetros de resistência, dispostos em dois ramos do estribo no meio do pilar curto e dois extensômetros de resistência localizados nas armaduras longitudinais perto da altura média do pilar curto. Foram também utilizados 4 leitores automáticos de deformação linear (LVDT) posicionados em cada uma das faces dos pilares curtos. Para melhorar o confinamento junto às cabeças do pilares curtos foram posicionados colares metálicos fixados com parafusos. A Fig. 5.14 mostra um esquema dos modelos instrumentados dos pilares curtos.

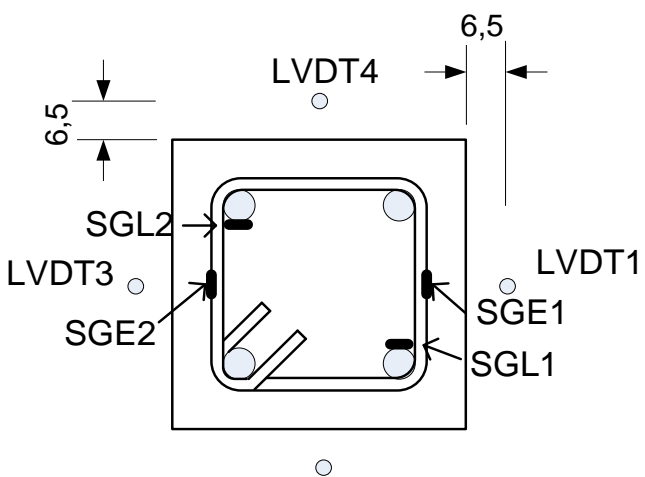

LVDT2

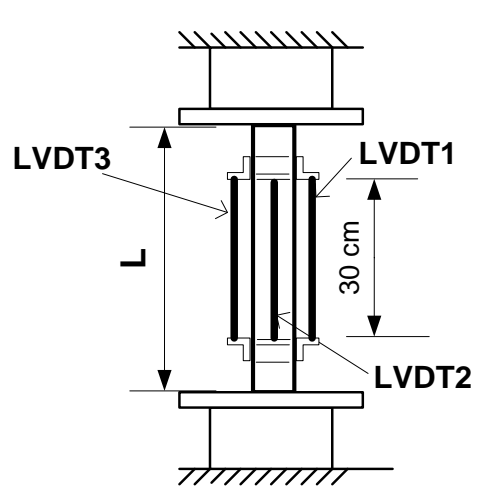

Fig. 5.14 - Detalhe da instrumentação dos pilares curtos. 
Os pilares curtos foram ensaiados na máquina INSTRON que possui controle de deslocamentos, a velocidade de aplicação da força foi controlada por meio da deformação imposta ao pilar e foi empregada a correspondente a $0,005 \mathrm{~mm} / \mathrm{m}$.s até atingir o $80 \%$ da força última no ramo pós-pico do diagrama força-deslocamento e logo a velocidade foi incrementada para $0,01 \mathrm{~mm} / \mathrm{m} . \mathrm{s}$ e mantida até o final do ensaio. A Fig. 5.15 mostra um pilar curto pouco antes do ensaio.

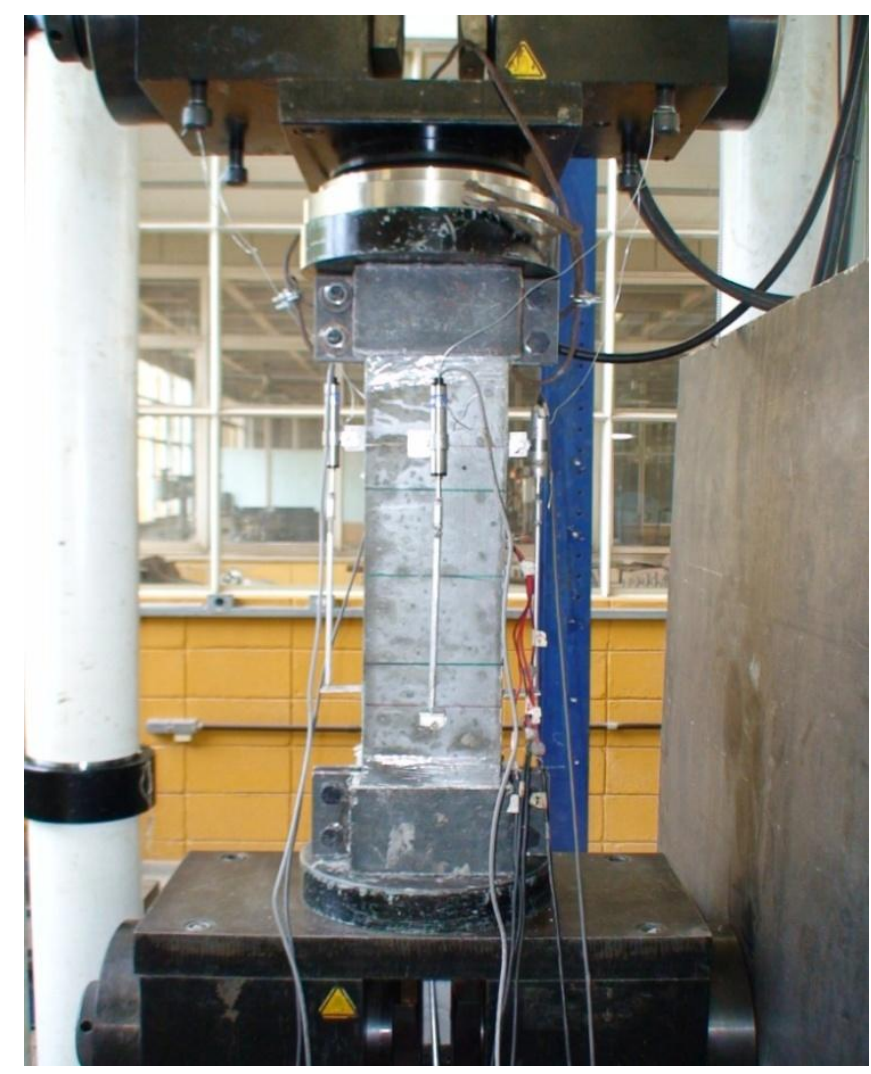

Fig. 5.15 - Detalhe do pilar curto antes do ensaio.

\subsubsection{Ensaio dos pilares esbeltos à compressão excêntrica}

Para o ensaio dos pilares esbeltos foi adotado o aparelho de apoio que foi utilizado por Lima Jr. (2003), o qual permite rotações livres nas extremidades dos pilares e a aplicação precisa de forças excêntricas. Este sistema de apoio foi desenvolvido por Lloyd e Rangan (1996), os quais desenvolveram um sistema de rótula uniaxial, denominado sistema de faca. O sistema é composto de 5 partes, três placas de aço e duas peças responsáveis pela rotação, moldadas com aços especiais com alto teor de carbono e dureza mínima de 60 na escala Rockwell (Lima Jr. e Giongo, 2005). A Fig. 5.16 mostra os detalhes do aparelho de apoio. 

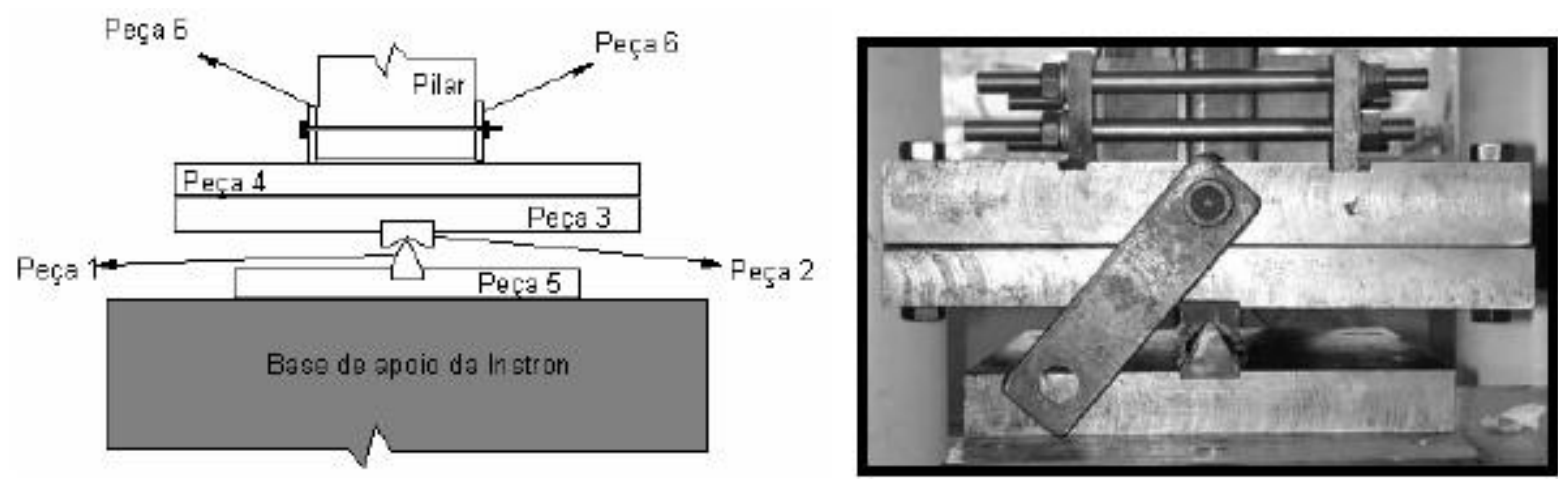

Fig. 5.16 - Detalhe do aparelho de apoio utilizado nos ensaios dos pilares (Lima Jr. e Giongo, 2005).

Foram ensaiados 12 pilares com esbeltez mecânica de 92, em que procurou-se avaliar a variação da ductilidade dos pilares de CAR em função da excentricidade de força, da resistência do concreto e da taxa volumétrica de armadura transversal. As resistências à compressão estimadas dos concretos são os mesmos dos pilares curtos $30 \mathrm{MPa}, 60 \mathrm{MPa}$ e 100 MPa.

Os pilares apresentavam seção retangular de $12 \mathrm{~cm}$ x $20 \mathrm{~cm}$ e uma altura de $300 \mathrm{~cm}$, quando posicionados no sistema de apoio apresentavam uma esbeltez mecânica de 92. A armadura transversal estava composta por estribos de $6,3 \mathrm{~mm}$ e seus espaçamentos de $5 \mathrm{~cm}$ e $10 \mathrm{~cm}$. A armadura longitudinal estava composta de 4 barras de 12,5 mm de diâmetro. Os pilares foram submetidos a excentricidades de $12 \mathrm{~mm}$ e $30 \mathrm{~mm}$. As excentricidades foram escolhidas de modo a que a força permanecesse dentro do núcleo central, e com a outra fora do núcleo. Assim como no caso dos pilares curtos foi disposta, nas extremidades do pilar, armadura de fretagem. De cada tipo ensaiado tinha-se somente um modelo.

Os pilares foram nomeados segundo suas propriedades, considerando o tipo de concreto ( $\mathrm{H}$ de elevada resistência, $\mathrm{M}$ de moderada resistência e $\mathrm{L}$ de baixa resistência), $\mathrm{o}$ espaçamento entre estribos e a excentricidade da força. Por exemplo, $50 \mathrm{H} 12$ corresponde a um pilar com espaçamento entre estribos de $5 \mathrm{~cm}$, com uma resistência à compressão estimada de $100 \mathrm{MPa}$ e uma excentricidade da força de $12 \mathrm{~mm}$. A Tabela 5.18 mostra as propriedades dos pilares ensaiados. 
Tabela 5.18 - Propriedades geométricas e mecânicas dos pilares esbeltos.

\begin{tabular}{|c|c|c|c|c|c|c|c|c|}
\hline \multirow{2}{*}{ Serie } & \multirow{2}{*}{$\begin{array}{l}\mathrm{b} \times \mathrm{h} \\
(\mathrm{cm})\end{array}$} & \multirow{2}{*}{$\begin{array}{l}\text { Altura } \\
(\mathrm{cm})\end{array}$} & \multirow{2}{*}{$\begin{array}{c}\text { Esbeltez até } \\
\text { a rótula }\end{array}$} & \multirow{2}{*}{$\begin{array}{l}\text { número de } \\
\text { modelos }\end{array}$} & \multirow{2}{*}{$\begin{array}{c}\mathrm{f}_{\mathrm{c}} \text { estimado } \\
(\mathrm{MPa})\end{array}$} & \multirow{2}{*}{$\begin{array}{l}\text { Exc. inicial } \\
(\mathrm{mm})\end{array}$} & Estribos & \multirow{2}{*}{$\begin{array}{l}\text { Armadura } \\
\text { longitudinal }\end{array}$} \\
\hline & & & & & & & Taxa volum. & \\
\hline $50 \mathrm{H} 12$ & \multirow{12}{*}{$12 \times 20$} & \multirow{12}{*}{300} & \multirow{12}{*}{92} & \multirow{12}{*}{$1 x$} & 100 & 12 & \multirow{6}{*}{$\begin{array}{c}\varnothing 6,3 \text { с } 5 \mathrm{~cm} \\
2,5 \%\end{array}$} & \multirow{12}{*}{$\begin{array}{c}4 \varnothing 12,5 \mathrm{~mm} \\
4,92 \mathrm{~cm} 2 \\
\rho_{\mathrm{s}}=2,05 \%\end{array}$} \\
\hline $50 \mathrm{H} 30$ & & & & & 100 & 30 & & \\
\hline $50 \mathrm{M} 12$ & & & & & 60 & 12 & & \\
\hline $50 \mathrm{M} 30$ & & & & & 60 & 30 & & \\
\hline 50L12 & & & & & 30 & 12 & & \\
\hline $50 \mathrm{L30}$ & & & & & 30 & 30 & & \\
\hline $100 \mathrm{H} 12$ & & & & & 100 & 12 & \multirow{6}{*}{$\begin{array}{c}\varnothing 6,3 \text { c } 10 \mathrm{~cm} \\
1,25 \%\end{array}$} & \\
\hline $100 \mathrm{H} 30$ & & & & & 100 & 30 & & \\
\hline $100 \mathrm{M} 12$ & & & & & 60 & 12 & & \\
\hline $100 \mathrm{M} 30$ & & & & & 60 & 30 & & \\
\hline $100 \mathrm{~L} 12$ & & & & & 30 & 12 & & \\
\hline 100L30 & & & & & 30 & 30 & & \\
\hline
\end{tabular}

Os pilares foram preparados em duas concretagens porque a betoneira tinha uma capacidade inferior ao volume total dos pilares, as fôrmas eram de madeira compensada e o concreto era lançado com os pilares deitados (lançamento vertical) e o adensamento era com vibrador de agulha. Para cada concretagem e cada traço foram moldados 15 corpos-de-prova, 9 para os ensaios a compressão simples e 6 para os ensaios à compressão diametral. A Fig. 5.17 mostra os detalhes das armaduras.

Na Fig. 5.18, são apresentadas as dimensões das fôrmas, estas foram reaproveitadas 3 vezes. Após a concretagem, os pilares permaneceram nas fôrmas por um período de $24 \mathrm{~h}$. Durante este período foi realizada cura com espumas umidificadas. Depois das $24 \mathrm{~h}$ se procedia com a desforma e os pilares eram envoltos com espuma umidificada e com lonas de plástico e permaneceram assim até 2 dias antes dos ensaios. 


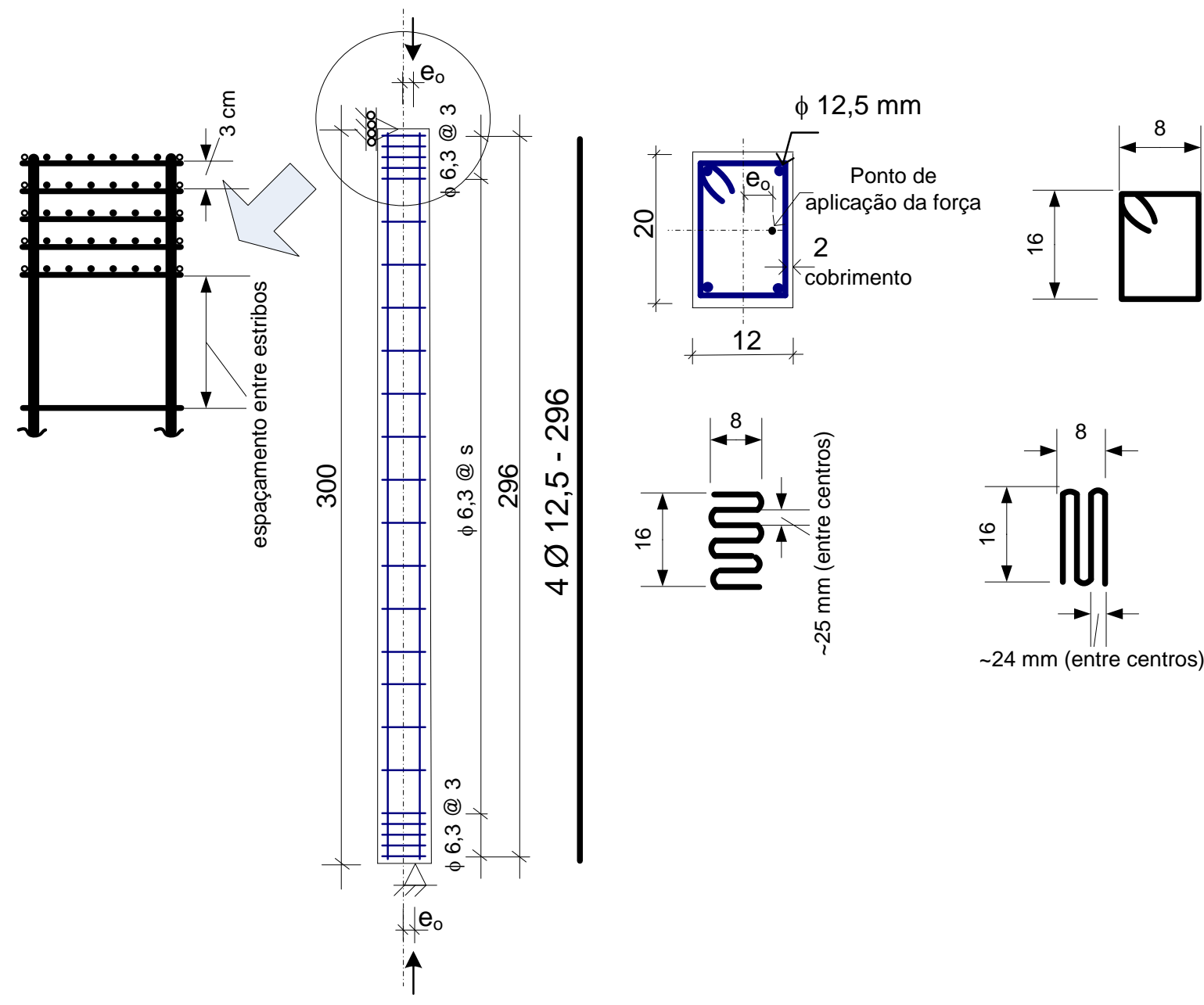

Fig. 5.17 - Detalhe das armaduras dos pilares esbeltos.

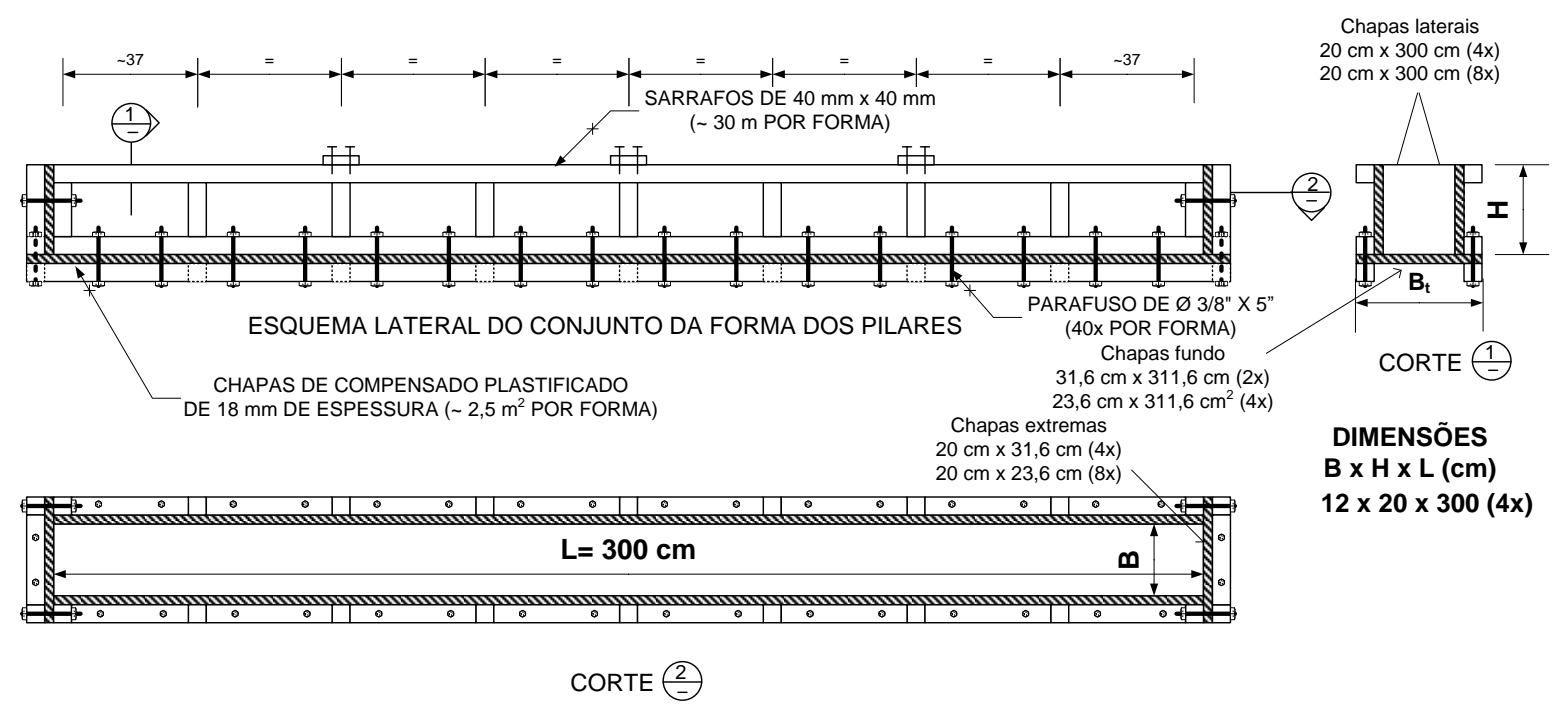

Fig. 5.18 - Detalhe da forma dos pilares esbeltos.

A instrumentação dos pilares foi composta por quatro extensômetros de resistência, dispostos nos quatro lados do estribo no meio do pilar e quatro extensômetros de resistência localizados nas armaduras longitudinais perto da altura média do pilar. Foram também 
utilizados 7 leitores automáticos de deformação linear (LVDT) posicionados: dois posicionados nas faces tracionada e comprimida e 5 posicionados horizontalmente. Para melhorar o confinamento junto as seções de base e topo do pilar foram fabricados colares metálicos fixados com parafusos. A Fig. 5.19 mostra um esquema dos modelos dos pilares instrumentados.
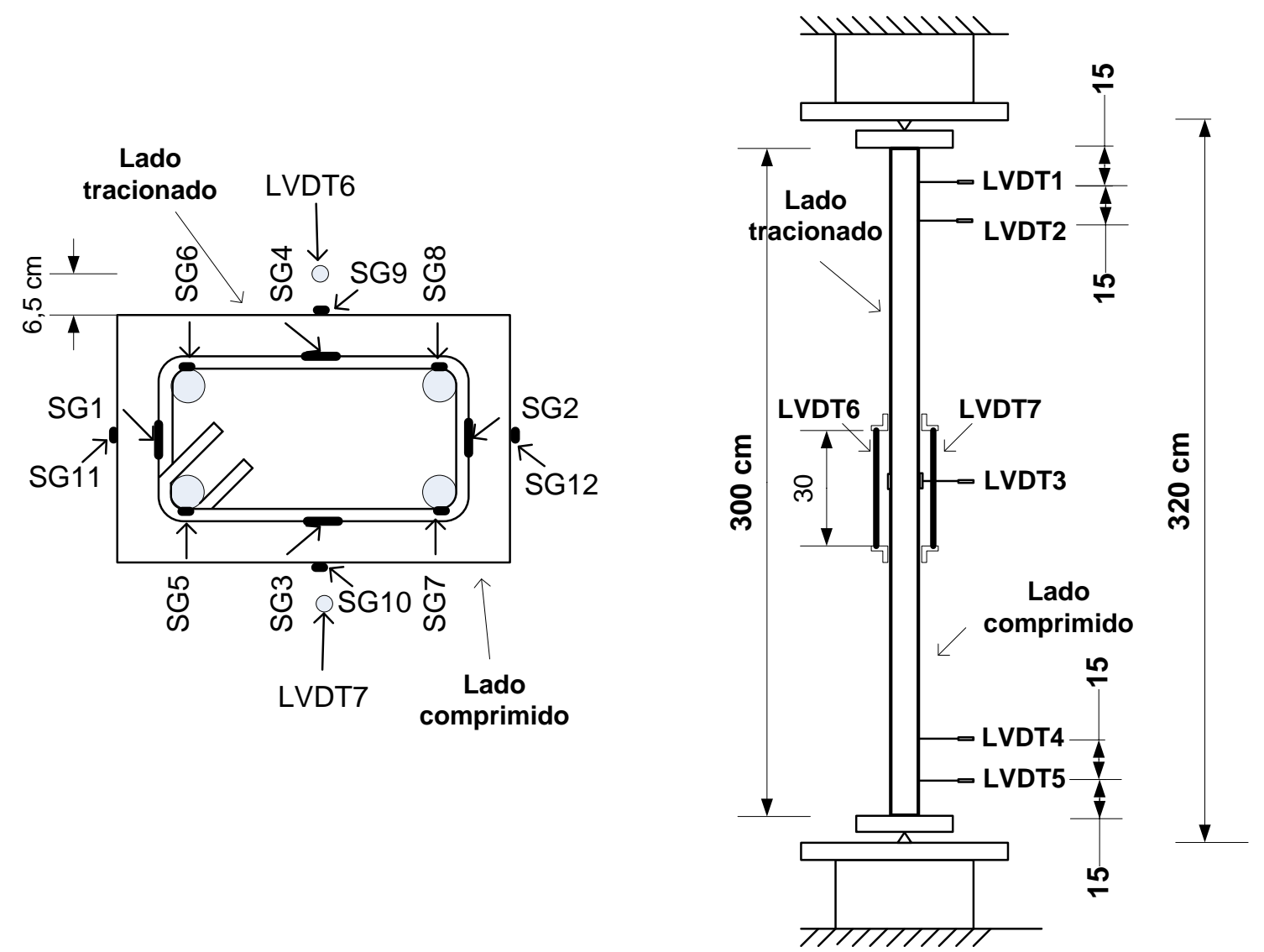

Fig. 5.19 - Detalhe da instrumentação dos pilares esbeltos.

Os pilares esbeltos foram ensaiados na máquina INSTRON que possui controle de deslocamentos e a velocidade de aplicação da força foi controlada por meio da deformação imposta ao pilar e foi empregada a correspondente a $0,005 \mathrm{~mm} / \mathrm{m} . \mathrm{s}$ até atingir o $80 \%$ da força última no ramo pós-pico do diagrama força-deslocamento e logo a velocidade foi incrementada para $0,01 \mathrm{~mm} / \mathrm{m}$.s e mantida até o final do ensaio. A Fig. 5.20 mostra um pilar um pouco antes do ensaio. 


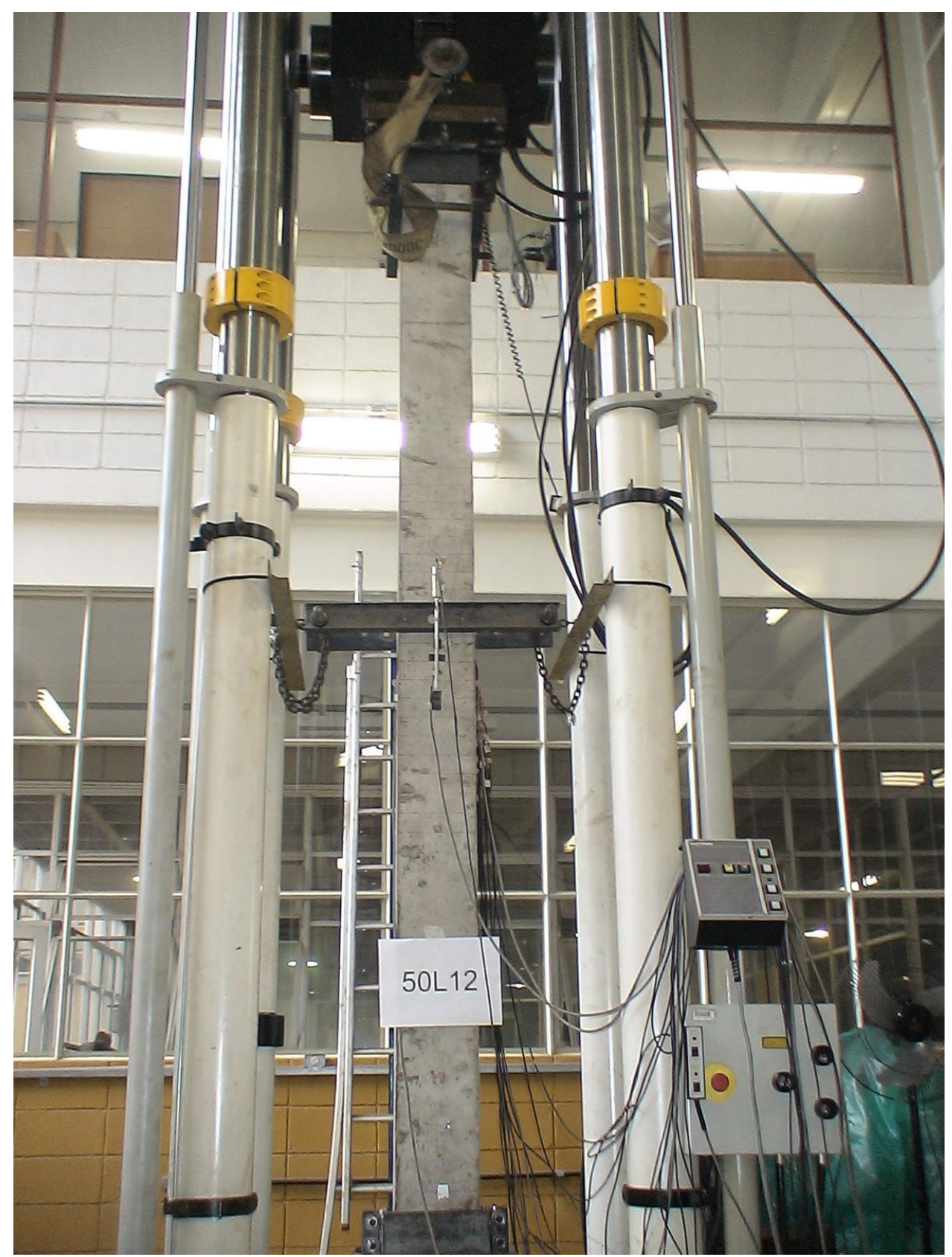

Fig. 5.20 - Detalhe do pilar esbelto antes do ensaio.

\subsection{CONSIDERAÇÕES FINAIS}

Neste capítulo foram apresentados os resultados da análise das propriedades dos materiais que dos pilares, para isto foi realizado um estudo detalhado de dosagem e ensaios de tração nas barras das armaduras transversais e longitudinais dos pilares.

É necessário um rigoroso estudo para implementação do CAR visando otimizar sua composição, por meio de um projeto de dosagem, para que a potencialidade do material esteja integralmente aproveitada. 
O CAR apresenta-se mais coeso que o concreto convencional, sendo necessário o conhecimento do tempo de manipulação que envolve a mistura, transporte, vertido e adensamento.

O método de dosagem de Helene e Terzian (1992) mostrou-se muito valioso e adequado para este tipo de estudo, principalmente pela sua simplicidade, estando ao alcance de qualquer pesquisador.

Neste capítulo estão as informações do número de pilares curtos e pilares esbeltos que foram ensaiados, quais os parâmetros que serão estudados, assim como sua denominação.

Foram ensaiados 6 pilares curtos considerando resistências estimadas do concreto de $30 \mathrm{MPa}, 60 \mathrm{MPa}$ e $100 \mathrm{MPa}$ com espaçamento entre estribos de $5 \mathrm{~cm}$ e $10 \mathrm{~cm}$, alem disto foram ensaiados prismas de concreto simples com as mesmas resistências. O objetivo destes ensaios foi verificar qual o modelo de confinamento que será adotado nas validações dos pilares esbeltos, ou seja, qual o modelo a ser adotado como diagrama $\sigma_{\mathrm{c}} \mathrm{x} \varepsilon_{\mathrm{c}}$ para a verificação dos resultados dos pilares esbeltos.

A etapa principal dos ensaios consiste em ensaiar 12 pilares esbeltos (esbeltez de 92) com as mesmas resistências do concreto dos pilares curtos, com o mesmo espaçamento entre estribos e considerando duas excentricidades de força de $12 \mathrm{~mm}$ e $30 \mathrm{~mm}$.

Tanto os pilares curtos como os pilares esbeltos foram instrumentados com extensômetros de resistência e com transdutores de deformação linear. 


\section{Capítulo 6}

\section{ANÁLISE DOS RESULTADOS EXPERIMENTAIS}

Neste capítulo são apresentados os resultados dos ensaios obtidos a partir de dados coletados por meio do sistema de aquisição de dados. Os resultados são relativos aos pilares curtos submetidos à compressão centrada e aos pilares esbeltos ensaiados com compressão excêntrica. Os ensaios se iniciaram em fevereiro de 2009 e terminaram em abril de 2009.

Como mencionado anteriormente, foram feitas duas concretagens para cada um dos tipos de traços adotados, e os ensaios foram realizados em diferentes idades. Os ensaios na máquina INSTRON começaram no dia 7 de abril até 30 de abril de 2009. A Tabela 6.1 mostra as datas dos ensaios dos pilares curtos e pilares esbeltos, data da concretagem e a idade do concreto no dia dos ensaios.

Todos os corpos-de-prova cilíndricos de $10 \mathrm{~cm}$ x $20 \mathrm{~cm}$ usados para a obtenção da resistência do concreto à compressão e à tração e os ensaiados, tanto quanto possível, no dia dos ensaios dos modelos dos pilares. A resistência adotada foi calculada pela média das resistências de dois ou três corpos-de-prova conforme mostram as tabelas no Anexo B.

Para alguns pilares não foi possível realizar os ensaios dos corpos-de-prova no mesmo dia, porque houve um defeito na máquina de ensaio que era utilizada para realizar os ensaios dos corpos-de-prova. Na Tabela 5.15 e na Tabela 6.1 encontra-se um resumo dos resultados dos ensaios dos corpos-de-prova e as idades em que foram obtidos (todos os resultados individuais dos corpos-de-prova estão no Anexo B). Para a análise teórica dos resultados dos pilares com os programas elaborados pelo autor e com o ANSYS v. 11 foram empregados os valores médios dos resultados dos corpos-de-prova, considerando a idade dos ensaios dos corpos-de-prova e dos pilares. A Tabela 6.1 mostra estes valores. 
Tabela 6.1 - Cronograma de ensaios dos pilares e corpos-de-prova cilíndricos, resumo de resultados dos ensaios dos corpos-de-prova cilíndricos.

\begin{tabular}{|c|c|c|c|c|c|c|}
\hline Serie & data ensaio & $\begin{array}{c}\text { data } \\
\text { concretagem }\end{array}$ & $\begin{array}{l}\text { idade ensaio dos } \\
\text { pilares (dias) }\end{array}$ & $\begin{array}{c}\mathrm{f}_{\mathrm{c}, \text { médio }}(\mathrm{MPa}) \\
\mathrm{CP} 10 \times 20\end{array}$ & $\begin{array}{l}\text { idade ensaio } \\
\text { dos CP (dias) }\end{array}$ & $\begin{array}{c}\mathrm{f}_{\mathrm{c}, \text { adotado }}(\mathrm{MPa}) \\
\mathrm{CP} 10 \times 20\end{array}$ \\
\hline $100 \mathrm{H}$ & $30-A b r$ & 27-Mar & 34 & 104 & 33 & 103 \\
\hline $50 \mathrm{H}$ & $29-A b r$ & 27-Mar & 33 & 104 & 33 & 103 \\
\hline $\mathrm{H}$ & $29-A b r$ & 27-Mar & 33 & 104 & 33 & 103 \\
\hline $100 \mathrm{M}$ & $28-A b r$ & 23-Mar & 36 & 63 & 36 & 59 \\
\hline $50 \mathrm{M}$ & $29-A b r$ & 23-Mar & 37 & 63 & 36 & 59 \\
\hline $\mathrm{M}$ & $28-A b r$ & 23-Mar & 36 & 63 & 36 & 59 \\
\hline $100 \mathrm{~L}$ & $08-A b r$ & 09-Mar & 30 & 36 & 30 & 34 \\
\hline $50 \mathrm{~L}$ & $08-A b r$ & 09-Mar & 30 & 36 & 30 & 34 \\
\hline $\mathrm{L}$ & $07-A b r$ & 09-Mar & 29 & 36 & 30 & 34 \\
\hline $100 \mathrm{H} 12$ & $22-A b r$ & 27-Mar & 26 & 104 & 33 & 103 \\
\hline $50 \mathrm{H} 12$ & $22-A b r$ & 27-Mar & 26 & 104 & 33 & 103 \\
\hline $100 \mathrm{H} 30$ & 23-Abr & 31-Mar & 23 & 102 & 28 & 103 \\
\hline $50 \mathrm{H} 30$ & 23-Abr & 31-Mar & 23 & 102 & 28 & 103 \\
\hline $100 \mathrm{M} 12$ & $16-\mathrm{Abr}$ & 23-Mar & 24 & 57 & 36 & 59 \\
\hline $50 \mathrm{M} 12$ & 16-Abr & 23-Mar & 24 & 57 & 36 & 59 \\
\hline $100 \mathrm{M} 30$ & $24-A b r$ & 24-Mar & 31 & 55 & 34 & 59 \\
\hline $50 \mathrm{M} 30$ & $24-A b r$ & 24-Mar & 31 & 55 & 34 & 59 \\
\hline 100L12 & $14-A b r$ & 09-Mar & 36 & 37 & 30 & 34 \\
\hline 50L12 & $13-A b r$ & 09-Mar & 35 & 37 & 30 & 34 \\
\hline 100L30 & 15-Abr & 12-Mar & 34 & 29 & 36 & 34 \\
\hline $50 \mathrm{~L} 30$ & $15-\mathrm{Abr}$ & 12-Mar & 34 & 29 & 36 & 34 \\
\hline
\end{tabular}

A Fig. 6.1 mostra o detalhe do equipamento utilizado nos ensaios à compressão simples e também à compressão excêntrica. A máquina INSTRON permitiu a aplicação de deslocamentos com velocidade controlada. Possui capacidade de $2500 \mathrm{kN}$ e uma altura útil de ensaio de 3,5 m. Como os ensaios foram sob deformação controlada foi possível obter o comportamento pós-pico dos pilares curtos e dos pilares esbeltos. 


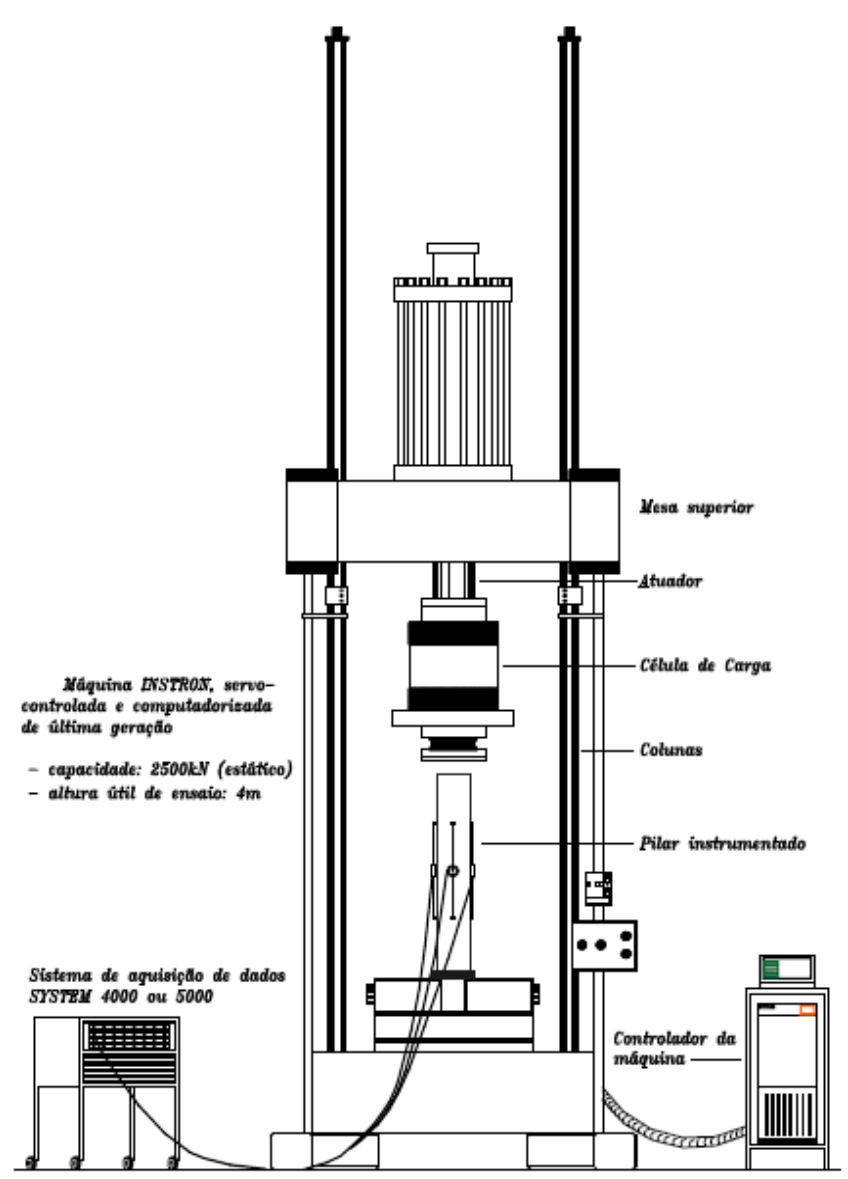

Fig. 6.1 Esquema da máquina INSTRON do LE - EESC - USP (adaptada de Queiroga 1999).

\subsection{PILARES CURTOS SUBMETIDOS À COMPRESSÃO SIMPLES}

Inicialmente vai ser feita uma comparação gráfica dos modelos de confinamento de Cusson e Paultre (1995) e de Légeron e Paultre (2003), considerando um dos pilares curtos. Depois serão apresentados os resultados dos ensaios.

\subsubsection{Avaliação gráfica dos modelos propostos confinados}

Como já foi dito no item 3.4, para obter os modelos de pilares curtos com confinamento são necessários modelos de pilares curtos não confinados, que no caso foram adotados os das normas EUROCODE 2 (2004), FIB (1999) e CEB Bulletin 228 (1995). Estes modelos encontram-se detalhados no item 2.4.2.

Foram feitas comparações entre os diferentes modelos sem confinamento para ver as diferenças entre os mesmos. A Fig. 6.2 mostra os diagramas indicados no EUROCODE 2 (2004), considerando o concreto do pilar com várias resistências médias à compressão $\left(\mathrm{f}_{\mathrm{cm}}\right)$. 

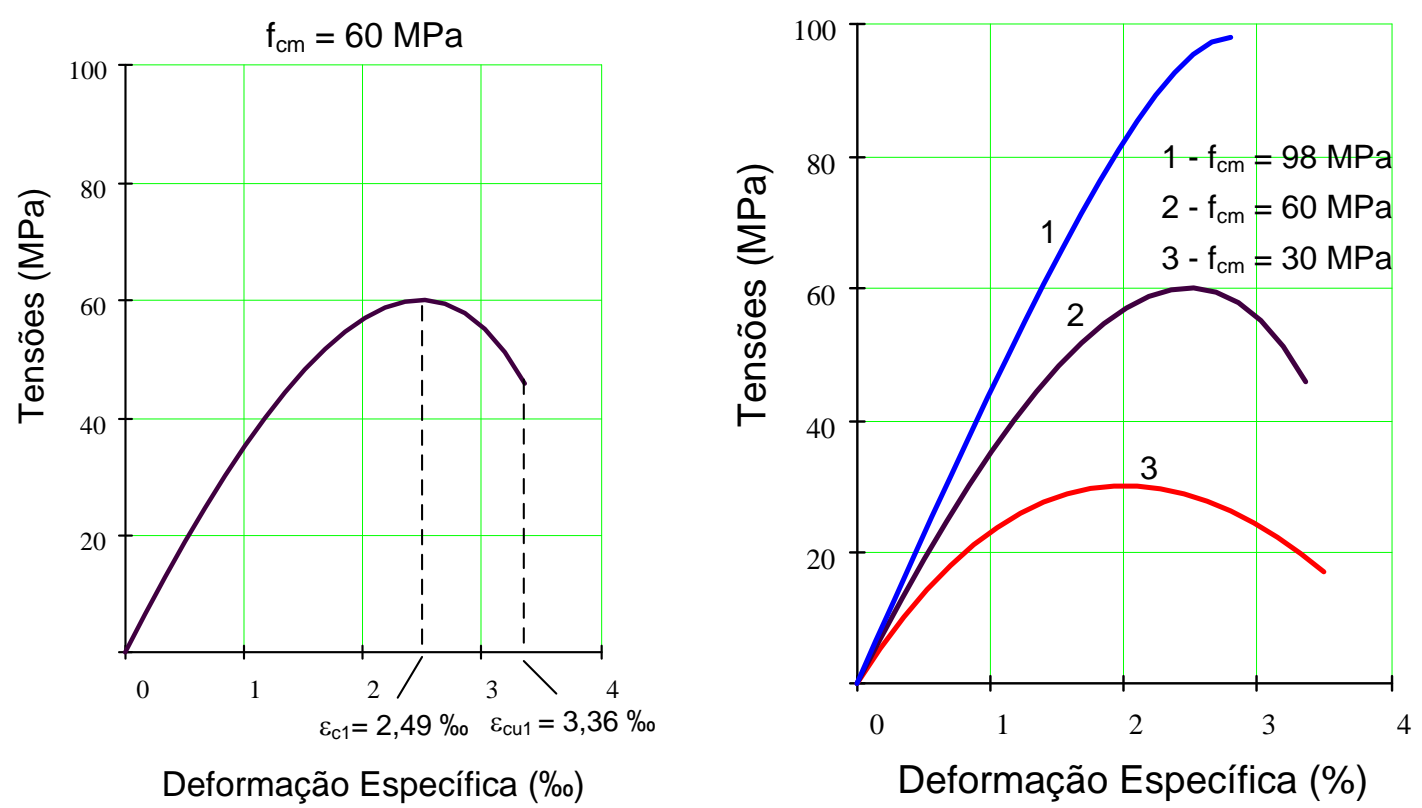

Fig. 6.2 - Diagramas $\sigma_{\mathrm{c}} \times \varepsilon_{\mathrm{c}}$ realista para concretos de varias resistências, mostrando suas deformações específicas limites para o concreto C60 (EUROCODE 2 - EN 1992-1-1 2004).

Como já mencionado anteriormente o CAR tem seus limites de deformação específica diferentes aos dos concretos convencionais e na Fig. 6.2 são mostrados os limites correspondentes ao concreto C60, sendo que para a deformação específica correspondente ao pico da curva 2,49\%o (diferente do concreto convencional, usualmente adotado como $2 \%$ ) e para a deformação específica última 3,36\%o (diferente à do concreto convencional de 3,5\%o).

A Fig. 6.3 mostra os diagramas $\sigma_{c} \times \varepsilon_{c}$ indicado nas recomendações da FIB (1995) e do boletim CEB Bulletin 228 (1995). 

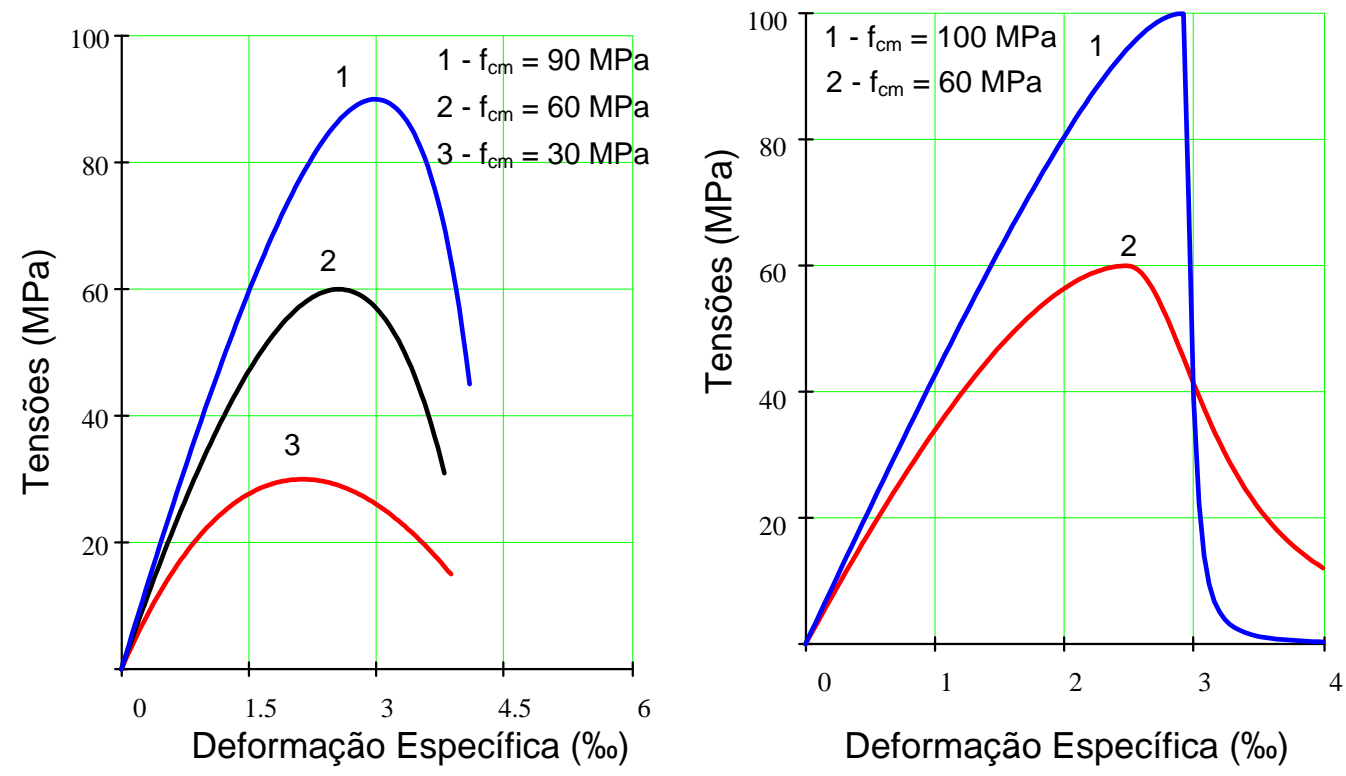

Fig. 6.3 - Diagramas $\sigma_{\mathrm{c}} \mathrm{x} \varepsilon_{\mathrm{c}}$ realistas para concretos C30, C60 e C90 (FIB, 1999) e do CEB Bulletin 228 (1995) para concretos C60 e C100.

O modelo do EUROCODE 2 (op. cit.) aceita o emprego da curva até a deformação específica última, o modelo da FIB (op. cit.) até a deformação específica correspondente aos $50 \%$ da sua resistência (no ramo pós-pico), e o CEB-Bulletin 228 (op. cit.) apresenta uma expressão do ramo pós-pico sem um limite estabelecido. Essas curvas realistas foram elaboradas com base nas expressões dos modelos do item 2.4.2. O EUROCODE 2 (2004) foi empregado para obter a resultante do concreto comprimido da região não confinada da seção e todas as três servem como base para poder elaborar os modelos de confinamento de Cusson e Paultre (1995) e de Légeron e Paultre (2003).

A Fig. 6.4 mostra as curvas $\sigma_{\mathrm{c}} \mathrm{x} \varepsilon_{\mathrm{c}}$ para um espaçamento entre estribos de $5 \mathrm{~cm}$ e sua correspondente taxa volumétrica de estribos de $2,41 \%$, e a curva da direita para um espaçamento entre estribos de $10 \mathrm{~cm}$ e uma taxa volumétrica $1,2 \%$. 

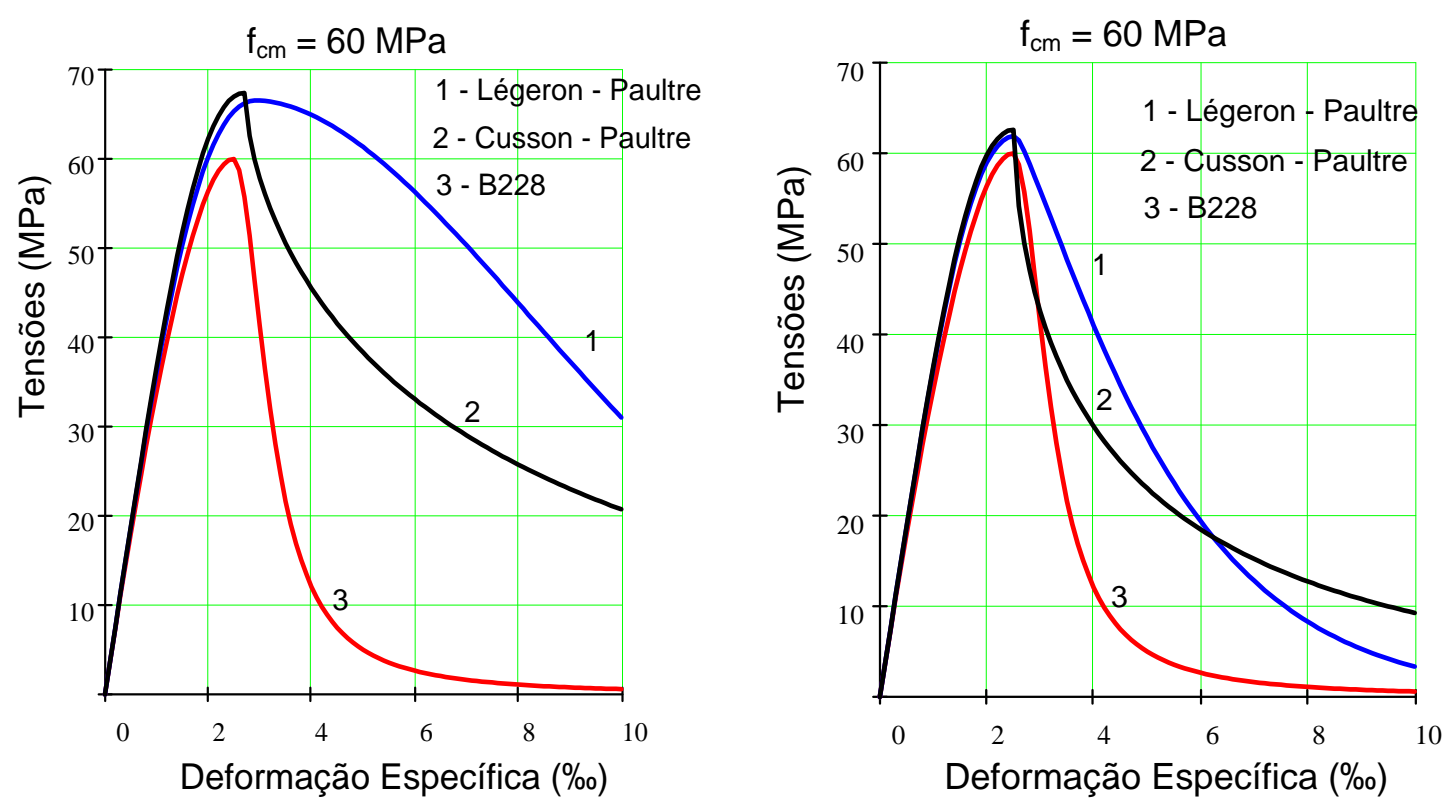

Fig. 6.4 - Curvas $\sigma_{\mathrm{c}} \times \varepsilon_{\mathrm{c}}$ para os modelos com confinamento e uma taxa volumétrica de $2,41 \%$ (esquerda), uma taxa volumétrica de $1,2 \%$ (direita) e para um modelo não confinado.

Para os modelos de pilares curtos confinados, os materiais que foram empregados para realizar a comparação entre o modelo de Cusson e Paultre (1995) e de Légeron e Paultre (2003) são os seguintes: a resistência de escoamento da armadura longitudinal igual a 585 $\mathrm{MPa}$ e dos estribos igual a $620 \mathrm{MPa}$, o módulo de elasticidade do aço foi de $210 \mathrm{GPa}$ e um concreto com resistência à compressão de $60 \mathrm{MPa}$.

Os gráficos dos modelos foram obtidos em função aos parâmetros definidos nos itens 3.4.1 e 3.4.2. Como comentado nesses itens, foi necessário incorporar o modelo do CAR não confinado do CEB Bulletin 228 (1995) para complementar seus parâmetros.

Na Fig. 6.4 da esquerda, observa-se um pequeno ganho de resistência ( 10\%) e uma melhora na ductilidade quando é considerada a presença da armadura transversal de confinamento. O modelo de Légeron e Paultre (2003) apresenta um comportamento mais dúctil. Na figura da direita, considerando ambos os modelos o ganho de resistência e ductilidade foi muito pequeno para espaçamentos de estribos de $10 \mathrm{~cm}$, poderiam ser considerados como não confinados.

O ramo ascendente de todas as curvas são quase coincidentes e a diferença se encontra no ramo descendente.

Na Fig. 6.5 foi realizada uma comparação utilizando um modelo de cada vez com as armaduras transversais empregadas nos ensaios. À esquerda o modelo de Cusson e Paultre (1995) e à direita o modelo de Légeron e Paultre (2003). 

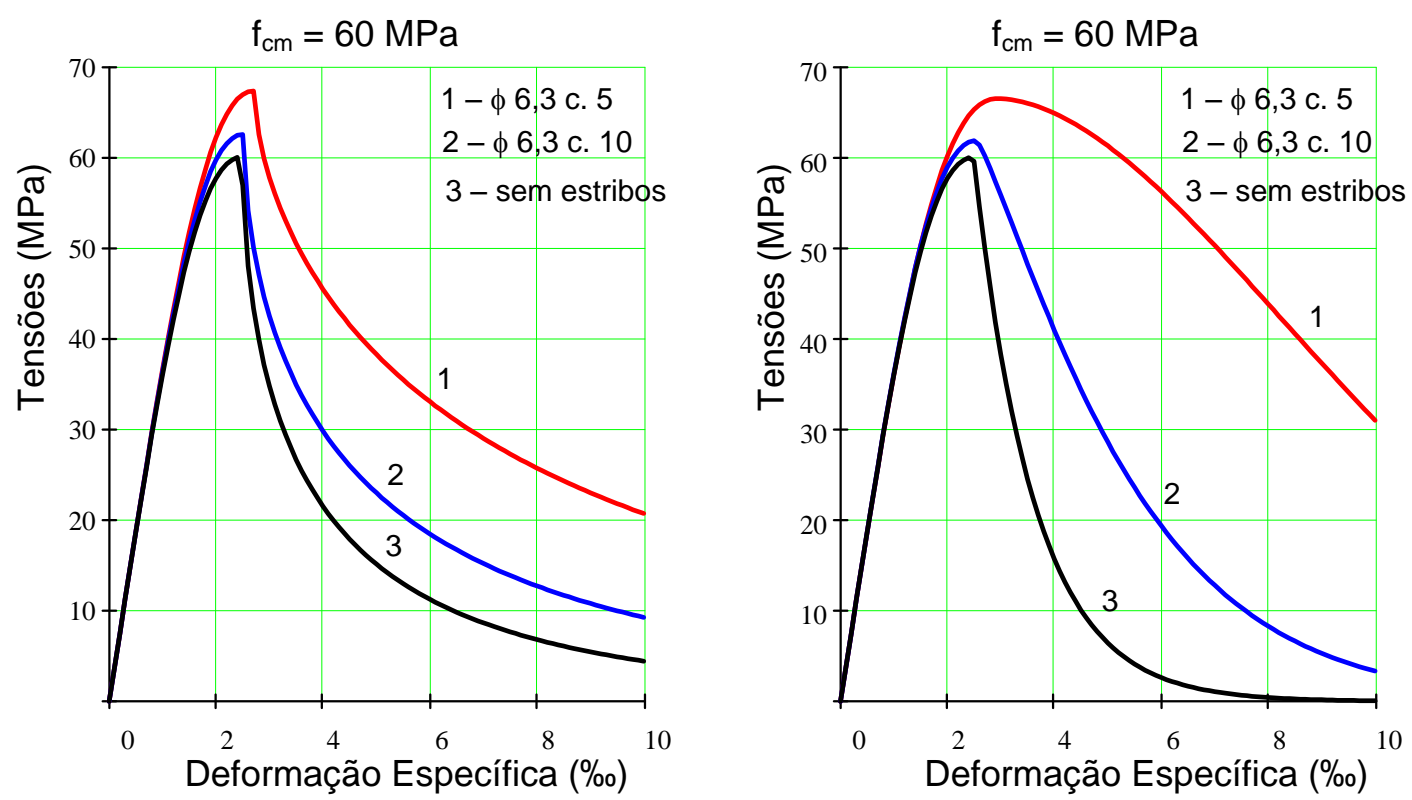

Fig. 6.5 - Modelo de Cusson e Paultre, 1995 (esquerda) e Légeron e Paultre, 2003 (direita) para as diferentes armaduras de confinamento dos modelos.

O objetivo de apresentar os dois modelos da Fig. 6.5 é mostrar que existem diferenças, especialmente para confinamentos maiores, na parte descendente da curva. Para ver qual é o modelo que será empregado nas validações dos resultados de laboratório vão ser comparadas estas curvas com as obtidas nos ensaios. As curvas serão novamente projetadas com as resistências dos materiais que foram obtidas nos ensaios.

Para o caso dos pilares curtos do concreto com a resistência média à compressão de 60 MPa e de $98 \mathrm{MPa}$, correspondentes às Fig. 6.4 e 6.5, todos eles estão com um pequeno índice de confinamento. O modelo de Légeron e Paultre (2003), para o C60, resultou $\mathrm{I}_{\mathrm{e}}=1,21 \%$ $\left(\right.$ para $\left.\mathrm{s}_{\mathrm{e}}=5 \mathrm{~cm}\right)$ e $\mathrm{I}_{\mathrm{e}}=0,21 \%$ (para $\left.\mathrm{s}_{\mathrm{e}}=10 \mathrm{~cm}\right)$. Para o concreto de resistência à compressão de $98 \mathrm{MPa}$, resultou $\mathrm{I}_{\mathrm{e}}=0,76 \%\left(\right.$ para $\left.\mathrm{s}_{\mathrm{e}}=5 \mathrm{~cm}\right)$ e $\mathrm{I}_{\mathrm{e}}=0,15 \%\left(\right.$ para $\left.\mathrm{s}_{\mathrm{e}}=10 \mathrm{~cm}\right)$. Todos estes valores são menores que o limite de $5 \%$ que corresponde a um pequeno grau de confinamento. Para o concreto de $60 \mathrm{MPa}$, as tensões de trabalho das armaduras transversais estão com $225 \mathrm{MPa}$ e $135 \mathrm{MPa}$ para um espaçamento entre armaduras transversais de $5 \mathrm{~cm}$ e $10 \mathrm{~cm}$, respectivamente. Queiroga (1999) afirma que para as taxas de armadura transversal $\rho_{\mathrm{sw}}=0,51 \%$ os pilares ensaiados já apresentavam certa ductilidade na ruína.

As curvas dos modelos confinados poderiam ser utilizadas para analisar casos sem confinamento (Fig. 6.6). 


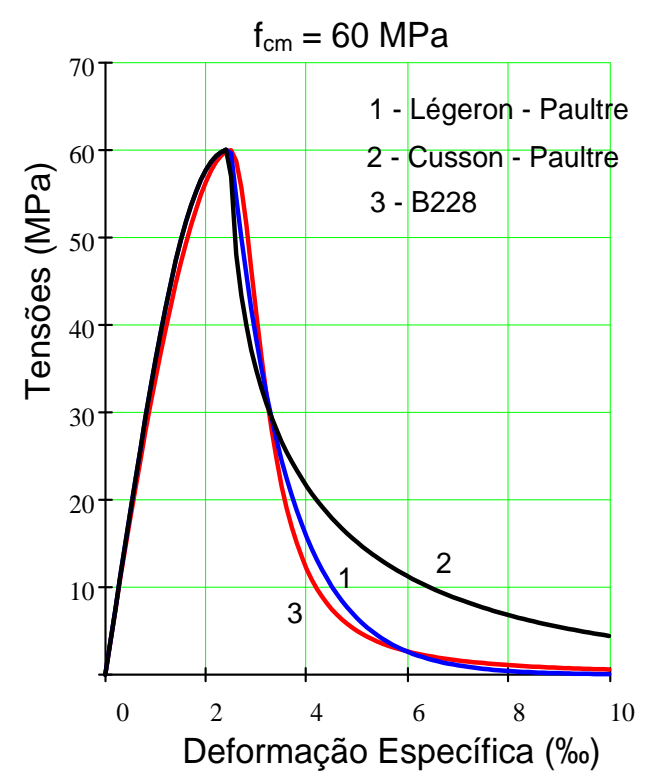

Fig. 6.6 - Diagramas $\sigma_{\mathrm{c}} \mathrm{x} \varepsilon_{\mathrm{c}}$ para concretos sem confinamento.

A Fig. 6.6 mostra a curva $\sigma_{c} \times \varepsilon_{c}$ realista do CEB Bulletin 228 (1995) é bastante coincidente no ramo ascendente como no descendente ao do Légeron e Paultre (2003) é por isso que foi adotada como base para obter alguns parâmetros de projeto dos modelos confinados.

Para os concretos com maior resistência à compressão os ganhos de resistência e ductilidade são bem menores e precisam uma quantidade maior de armadura de confinamento para melhorar a ductilidade (ver Fig. 6.5 e Fig. 6.7).

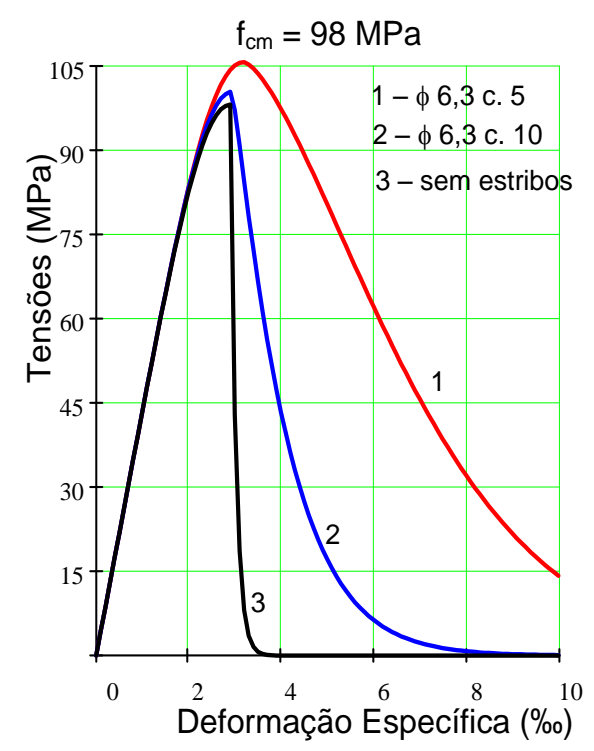

Fig. 6.7 - Diagramas $\sigma_{\mathrm{c}}$ x $\varepsilon_{\mathrm{c}}$ do modelo de Légeron e Paultre (2003).

Em todos os diagramas anteriores, para as diferentes taxas de armadura transversal, os trechos ascendentes das curvas são coincidentes, por isso é possível adotar sempre o mesmo 
módulo de deformação, isto mostra que o confinamento do concreto somente começa a agir quando a tensão está perto da resistência última.

Para considerar o efeito de confinamento da armadura transversal no dimensionamento, é necessário incluir esses modelos com suas expressões realistas incluindo os coeficientes de ponderação do CAR que minoram as resistências e modificam outros parâmetros do modelo.

\subsubsection{Resultados dos ensaios}

Os pilares curtos foram ensaiados colocando suas extremidades diretamente junto aos pratos de máquina INSTRON, não foram capeados porque como o lançamento foi lateral, suas extremidades estavam em contato com as fôrmas lisas e apresentavam um bom acabamento, sem rugosidades, mesmo considerando que em ensaios com CAR o capeamento com enxofre não é adequado por sua pouca resistência. Melhor teria sido colocar junto às extremidades elementos de teflon ou de neoprene, diminuindo o efeito provocado pelo atrito entre os extremos dos pilares e os pratos da máquina.

Na Tabela 6.2 podem ser observadas as propriedades físicas e mecânicas dos modelos ensaiados à compressão centrada, todos os valores foram obtidos experimentalmente.

Tabela 6.2 Propriedades físicas e mecânicas dos materiais dos pilares curtos.

\begin{tabular}{|c|c|c|c|c|c|c|c|c|c|}
\hline \multirow{2}{*}{ Serie } & \multirow{2}{*}{$\begin{array}{c}\mathrm{f}_{\mathrm{c}, \text { médio }}(\mathrm{MPa}) \\
\mathrm{CP} 10 \times 20\end{array}$} & \multirow{2}{*}{$\begin{array}{c}\mathrm{E}_{\mathrm{cs}} \\
(\mathrm{GPa})\end{array}$} & \multirow{2}{*}{$\begin{array}{l}\mathrm{f}_{\mathrm{ct} \text {,médio }} \\
\text { (MPa) } \\
\end{array}$} & \multicolumn{3}{|c|}{ Armadura transversal } & \multicolumn{3}{|c|}{ Armadura longitudinal } \\
\hline & & & & taxa volum. & $\mathrm{f}_{\mathrm{yw}}(\mathrm{MPa})$ & $\mathrm{E}_{\mathrm{s}}(\mathrm{GPa})$ & area $(\mathrm{cm} 2)$ & $\mathrm{f}_{\mathrm{y}}(\mathrm{MPa})$ & $\mathrm{E}_{\mathrm{s}}(\mathrm{GPa})$ \\
\hline $100 \mathrm{H}$ & 104 & 48 & 6,5 & \multirow{3}{*}{$\begin{array}{c}\varnothing 6,3 \text { c } 10 \mathrm{~cm} \\
1,2 \%\end{array}$} & \multirow{6}{*}{620} & \multirow{6}{*}{219,4} & \multirow{6}{*}{$\begin{array}{c}4 \varnothing 12,5 \\
\mathrm{~mm} \\
4,92 \mathrm{~cm} 2\end{array}$} & \multirow{6}{*}{585} & \multirow{6}{*}{199,5} \\
\hline $100 \mathrm{M}$ & 63 & 43 & 4,2 & & & & & & \\
\hline $100 \mathrm{~L}$ & 36 & 39 & 2,9 & & & & & & \\
\hline $50 \mathrm{H}$ & 104 & 48 & 6,5 & \multirow{3}{*}{$\begin{array}{c}\varnothing 6,3 \text { c } 5 \mathrm{~cm} \\
2,4 \%\end{array}$} & & & & & \\
\hline $50 \mathrm{M}$ & 63 & 43 & 4,2 & & & & & & \\
\hline $50 \mathrm{~L}$ & 36 & 39 & 2,9 & & & & & & \\
\hline $\mathrm{H}$ & 104 & 48 & 6,5 & - & - & - & - & - & - \\
\hline$M$ & 63 & 43 & 4,2 & - & - & - & - & - & - \\
\hline L & 36 & 39 & 2,9 & - & - & - & - & - & - \\
\hline
\end{tabular}

Na Tabela $6.2 \mathrm{E}_{\mathrm{cs}}$ é o módulo de deformação secante correspondente a $40 \%$ da tensão pico, obtido nos ensaios à compressão dos corpos-de-prova cilíndricos de $10 \mathrm{~cm}$ x $20 \mathrm{~cm}$ quando ensaiados na máquina INSTRON, $\mathrm{f}_{\mathrm{ct} \text {,médio }}$ é a resistência média à tração do concreto obtida com os resultados dos ensaios dos corpos-de-prova à compressão diametral (esses valores encontram-se no anexo $\mathrm{B}), \mathrm{E}_{\mathrm{s}}$ é o módulo de elasticidade das barras das armaduras obtido com os resultados dos ensaios à tração.

Na Fig. 6.8 mostra a forma da ruína por ruptura dos pilares curtos sem armadura. 

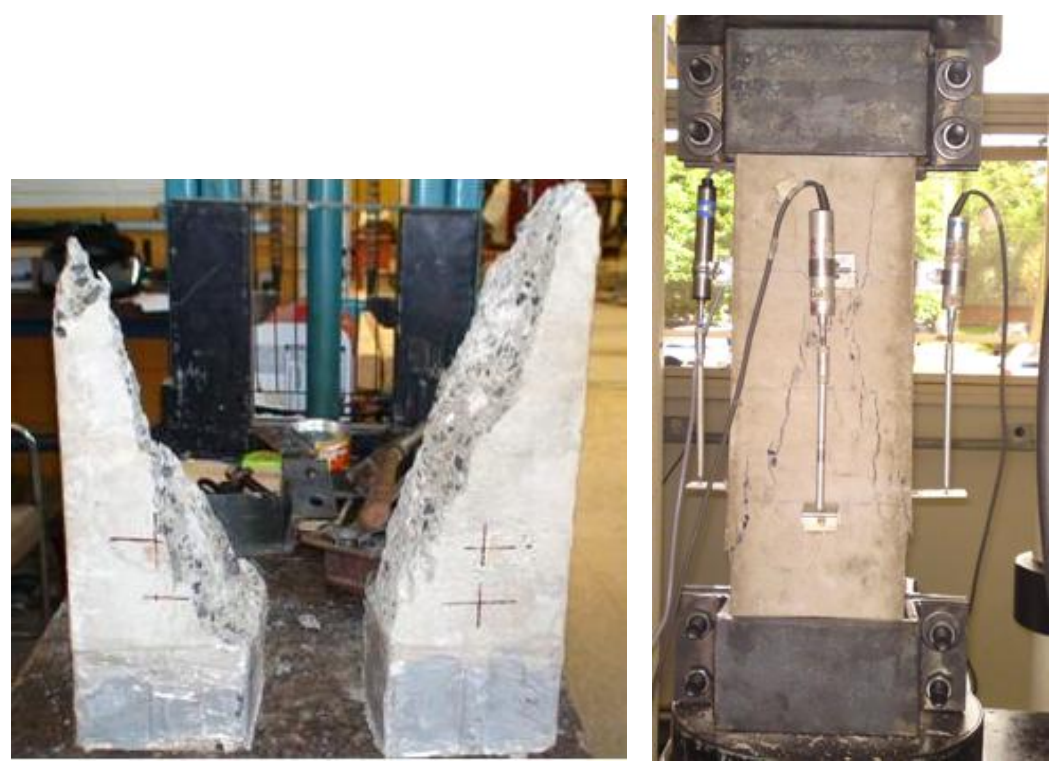

Fig. 6.8 - Forma da ruptura dos prismas de CAR e de concreto convencional, sem armadura.

O comportamento dos pilares foi muito similar aos dos corpos-de-prova cilíndricos, os de CAR apresentaram uma ruína frágil e repentina.

Na Fig. 6.9 apresentam-se os detalhes dos pilares curtos de CAR e de concreto convencional com armadura longitudinal e transversal após os ensaios.
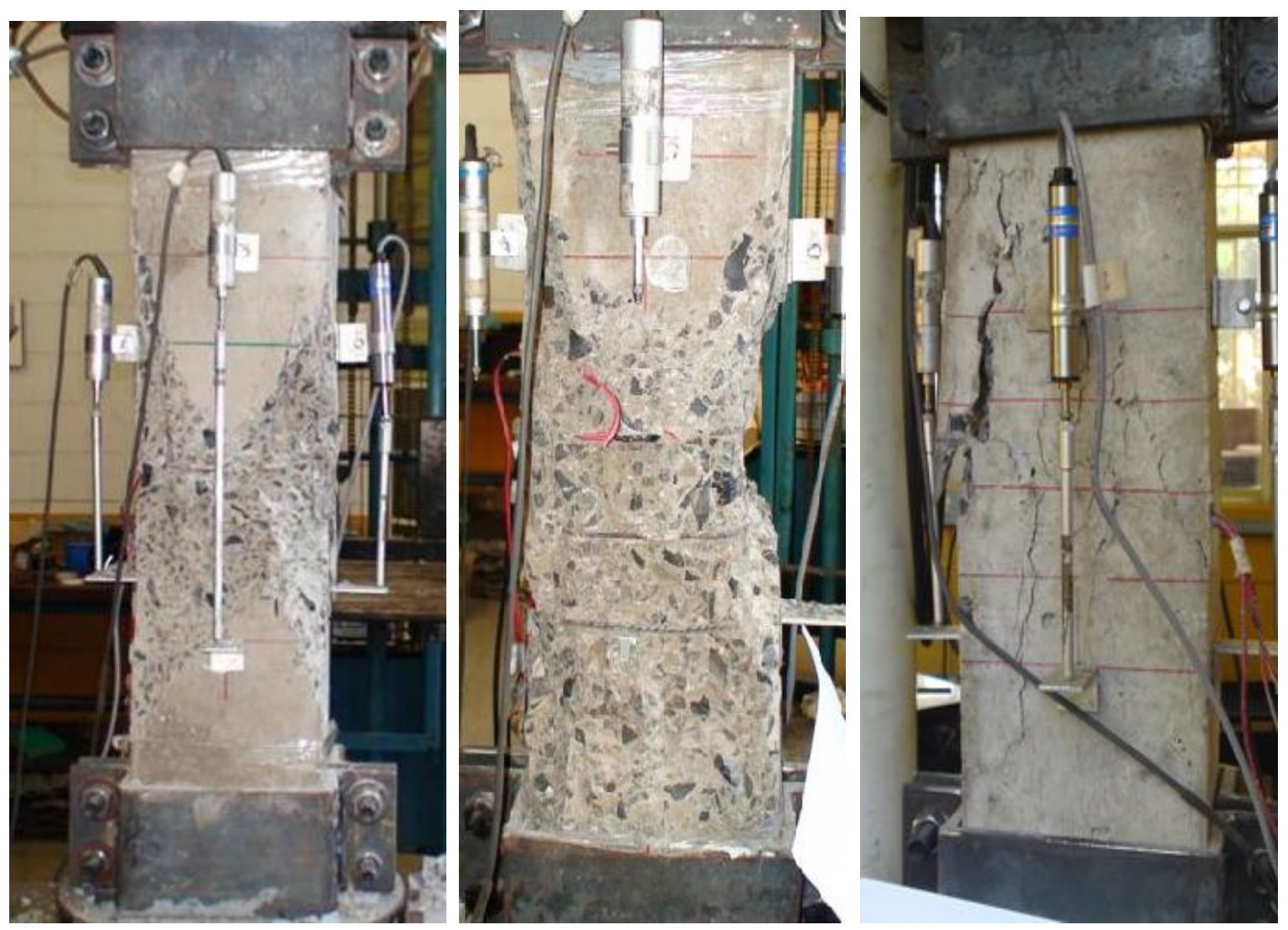

Fig. 6.9 - Pilares curtos 100M, 50H e 50L após o ensaio. 
Nos pilares curtos de CAR houve um desprendimento repentino do cobrimento, a parte do núcleo apresentava-se mais íntegra para os concretos mais confinados. A ruína dos pilares curtos aconteceu fora da região das extremidades. Foi observada flambagen das barras das armaduras longitudinais nos pilares curtos $100 \mathrm{M}$ e $100 \mathrm{~L}$ depois de terem atingido as forças máximas (Fig. 6.9).

Foram observados planos de cisalhamento bem definidos (a Fig. 6.10 mostra este detalhe), possivelmente a ruptura teria sido diferente se tivesse sido colocado teflon ou neoprene junto às faces dos pilares em contato com os pratos da máquina de ensaios.

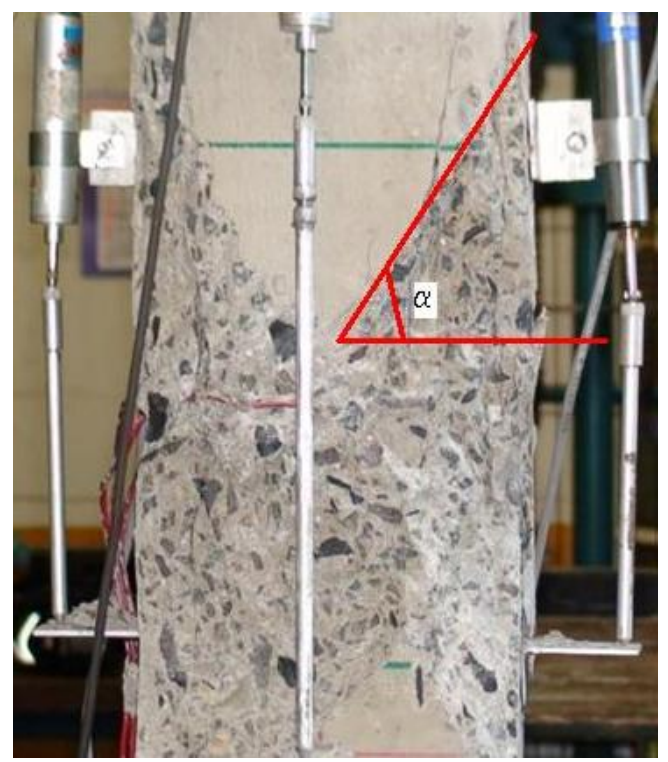

Fig. 6.10 - Plano de cisalhamento do pilar curto 100M após a ruína.

\subsubsection{Forças últimas teóricas}

Para elevadas taxas de armadura transversal acontece o destacamento do concreto do cobrimento dos pilares e a seção transversal resistente pode ser reduzida para apenas a área formada pelos estribos (item 3.3).

Considerando a seção do núcleo como a seção resistente do concreto, a Eq. 6.1 corresponde à força máxima teórica resistente $\left(\mathrm{F}_{\mathrm{ult}, \mathrm{nuc}}\right)$.

$$
F_{u t l, n u c}=A_{c n} \times f_{c}+A_{s} \times f_{y}
$$

Sendo que:

$\mathrm{A}_{\mathrm{cn}}$ é a área do núcleo do concreto;

$\mathrm{A}_{\mathrm{s}}$ é a área da armadura longitudinal;

$\mathrm{f}_{\mathrm{c}}$ é a resistência do concreto do elemento estrutural, dada pela Eq. 6.2.

$$
f_{c}=f_{c m} \times k_{\bmod 1} \times k_{\bmod 2} \times k_{\bmod 3}
$$




\section{Na Eq. 6.2:}

$\mathrm{f}_{\mathrm{cm}}$ é a resistência média à compressão do corpo-de-prova cilíndrico de $15 \mathrm{~cm}$ x $30 \mathrm{~cm}$; $\mathrm{k}_{\text {mod1 }}, \mathrm{k}_{\bmod 2}$ e $\mathrm{k}_{\bmod 3}$ são parâmetros que consideram: o acréscimo de resistência após os 28 dias; a resistência do concreto das estruturas é menor que as dos corpos-de-prova de $15 \mathrm{~cm}$ x $30 \mathrm{~cm}$ e a diminuição da resistência do concreto sob ações de longa duração respectivamente (segundo Fusco, 2008, para estruturas reais a tensão de referencia de cálculo $\sigma_{\mathrm{cd}}=1,2 \times 0,95 \times 0,75 \times \mathrm{f}_{\mathrm{cd}}$, sendo $\mathrm{f}_{\mathrm{cd}}$ a resistência de cálculo do concreto que inclui os fatores de seguridade para os 28 dias).

Para os modelos do ensaio $\mathrm{k}_{\bmod 1}=\mathrm{k}_{\bmod 3}=1$, mas os valores da resistência dos modelos é afetada por $k_{\bmod 2}$. Segundo Fusco (1995) $\mathrm{k}_{\bmod 2}=0,95$ considerando corpos-deprova de $15 \mathrm{~cm}$ x $30 \mathrm{~cm}$, mas como, para avaliar a resistência do concreto, foram empregados corpos-de-prova de $10 \mathrm{~cm}$ x $20 \mathrm{~cm}$ é necessário considerar uma diminuição adicional na resistência, pois os resultados dos ensaios com cilindros de $10 \mathrm{~cm}$ x $20 \mathrm{~cm}$ são $3 \%$ maiores do que os de $15 \mathrm{~cm}$ x $30 \mathrm{~cm}$ (EHE-2008). Logo o valor adequado para $\mathrm{k}_{\bmod 2}$ para calcular a resistência última teórica dos modelos é $0,92(0,97$ x 0,95), então para os pilares ensaiados a resistência do concreto é o produto de 0,92 pela resistência média obtida nos ensaios dos corpos-de-prova de $10 \mathrm{~cm}$ x $20 \mathrm{~cm}$.

Para taxas de armaduras transversais usuais a seção transversal resistente pode ser considerada como a total, a Eq. 6.3 mostra a força última teórica considerando a área total $\left(\mathrm{F}_{\text {ult,tot }}\right)$.

$$
F_{u t l, t o t}=\left(A_{c}-A_{s}\right) \times f_{c}+A_{s} \times f_{y}
$$

Sendo que: $\mathrm{A}_{\mathrm{c}}$ é a área total da seção transversal.

Considerando a Eq. 6.1 até a Eq. 6.3, Tabela 6.1 e Tabela 6.2, é possível calcular a força última teórica dos modelos dos pilares curtos. A Tabela 6.3 mostra estes resultados (para os prismas sem armadura está-se empregando a seção total). 
Tabela 6.3 - Resultados entre a força última experimental e as forças teóricas.

\begin{tabular}{|c|c|c|c|c|c|c|}
\hline Serie & $\begin{array}{c}0,92 \mathrm{f}_{\mathrm{c}, \text { adot }}(\mathrm{MPa}) \\
\mathrm{CP} 10 \times 20\end{array}$ & $\begin{array}{c}\mathrm{F}_{\text {ult,exp }} \\
(\mathrm{kN})\end{array}$ & $\begin{array}{c}\mathrm{F}_{\text {ult,nuc }} \\
(\mathrm{kN})\end{array}$ & $\begin{array}{c}\mathrm{F}_{\text {ult,tot }} \\
(\mathrm{kN})\end{array}$ & $F_{\text {ult,exp }} / F_{\text {ult,nuc }}$ & $\mathrm{F}_{\text {ult,exp }} / \mathrm{F}_{\text {ult,tot }}$ \\
\hline \hline $10 \mathrm{H}$ & 94,8 & 2156 & 1293,1 & 2373,3 & 1,67 & 0,91 \\
\hline $100 \mathrm{M}$ & 54,3 & 1334 & 863,7 & 1482,4 & 1,54 & 0,90 \\
\hline $100 \mathrm{~L}$ & 31,3 & 952 & 619,7 & 976,2 & 1,54 & 0,98 \\
\hline $50 \mathrm{H}$ & 94,8 & 2142 & 1293,1 & 2373,3 & 1,66 & 0,90 \\
\hline $50 \mathrm{M}$ & 54,3 & 1422 & 863,7 & 1482,4 & 1,65 & 0,96 \\
\hline $50 \mathrm{~L}$ & 31,3 & 958 & 619,7 & 976,2 & 1,55 & 0,98 \\
\hline $\mathrm{H}$ & 94,8 & 1944 & - & 2132,1 & - & 0,91 \\
\hline $\mathrm{M}$ & 54,3 & 1181 & - & 1221,3 & - & 0,97 \\
\hline $\mathrm{L}$ & 31,3 & 868 & - & 703,8 & - & 1,23 \\
\hline
\end{tabular}

Verificam-se nos resultados experimentais que há um pequeno incremento na resistência dos pilares curtos quando os espaçamentos dos estribos são de $5 \mathrm{~cm}$ (exceto nos pilares com concreto tipo $\mathrm{H}$, nos quais há uma pequena diferença contraria) e pelas Fig. 6.11 até Fig. 6.16 existe uma melhora na ductilidade para os pilares com espaçamento entre estribos de $5 \mathrm{~cm}$.

Houve muita dificuldade para aplicar a força centrada, o parâmetro para verificar esta situação foram as deformações específicas que o sistema de aquisição de dados foi registrando das leituras dos extensômetros de resistência colados nas armaduras longitudinais, seus valores tinham que ficar muito próximos; por tentativas foram-se posicionando os pilares para ter esta situação mas, a partir da etapa relativa a metade da força máxima (aproximadamente) um dos extensômetros marcava valores maiores, indicando flexão, que pode ter sido o motivo na obtenção de resultados contrários aos esperados (pilar tipo H).

Analisando os resultados da Tabela 6.3, observam-se que os valores da força teórica calculada considerando toda a seção transversal correspondem a valores mais realistas que os calculados considerando somente o núcleo, isto pode significar que toda a seção transversal resiste às forças normais incluindo os pilares com estribos espaçados de $5 \mathrm{~cm}$ (a mesma conclusão foi obtida por Lima Jr., 2003), para melhorar esta situação poderia ser necessário incrementar a taxa volumétrica de estribos. O confinamento começa a ser efetivo para a força próxima da força última e, normalmente, a importância do confinamento provem da ductilidade após a força última mais do que a vantagem do incremento da resistência do pilar.

Como a relação entre a força última experimental e a força última teórica considerando a seção total é sempre menor do que a unidade (os pilares curtos L, M e H não contam), isto provem de erros que podem ter-se cometido nas leituras dos instrumentos, em alguns modelos os valores da resistência do concreto dos corpos-de-prova não correspondem ao dia do ensaio 
dos pilares (defeito da máquina de ensaio dos corpos-de-prova), o concreto dos corpos-deprova não correspondem ao dos pilares (concretagens em etapas), excentricidades acidentais que provocaram flexões, erro ao posicionar as armaduras dentro da forma, erro no paralelismo das faces do pilar, imperfeições nas faces extremas do pilar em contato com os pratos da máquina de ensaios.

O certo, para essas taxas de armadura, seria que o valor experimental fosse maior que o teórico com a seção total porque mesmo que as taxas de armadura correspondam a pequeno grau de confinamento, parte do núcleo da seção apresenta maior resistência do concreto, isto forneceria sempre resultados experimentais um pouco maiores que os teóricos que estão considerando uma mesma resistência do concreto em toda a seção. Para que a área do núcleo seja a seção resistente, o núcleo do concreto teria que estar muito bem confinado para que ocorra compensação por causa da perda de resistência na hora da ruptura do cobrimento. Considerando o exposto neste parágrafo, é importante que sejam feitos ensaios prévios e assim detectar e evitar erros nos ensaios definitivos.

Considerar a seção resistente como aquela correspondente ao núcleo da seção transversal ficaria muito a favor da segurança. É uma observação diferente da indicada por Queiroga (1999).

Nesta situação considera-se que para estas taxas e disposição das armaduras transversais, na prática, a seção transversal total é a resistente. Sempre será necessário considerar excentricidades acidentais, e que por mais cuidado que se tenha, como no caso dos ensaios, estas vão estar presentes.

Analisando a mesma Tabela 6.3, os resultados obtidos com os ensaios dos pilares curtos sem armadura indicam que a relação média (dos três pilares) entre a força experimental e a força de ruptura é 1,03 .

\subsubsection{Diagramas de força aplicada-deformação específica dos pilares curtos}

Estão apresentados, nas Fig. 6.11 até a Fig. 6.16, os diagramas força-deformação vertical do pilar, força-deformação do concreto e força-deformação na armadura longitudinal, obtidos a partir da média das deformações medidas dos ensaios de compressão centrada. 


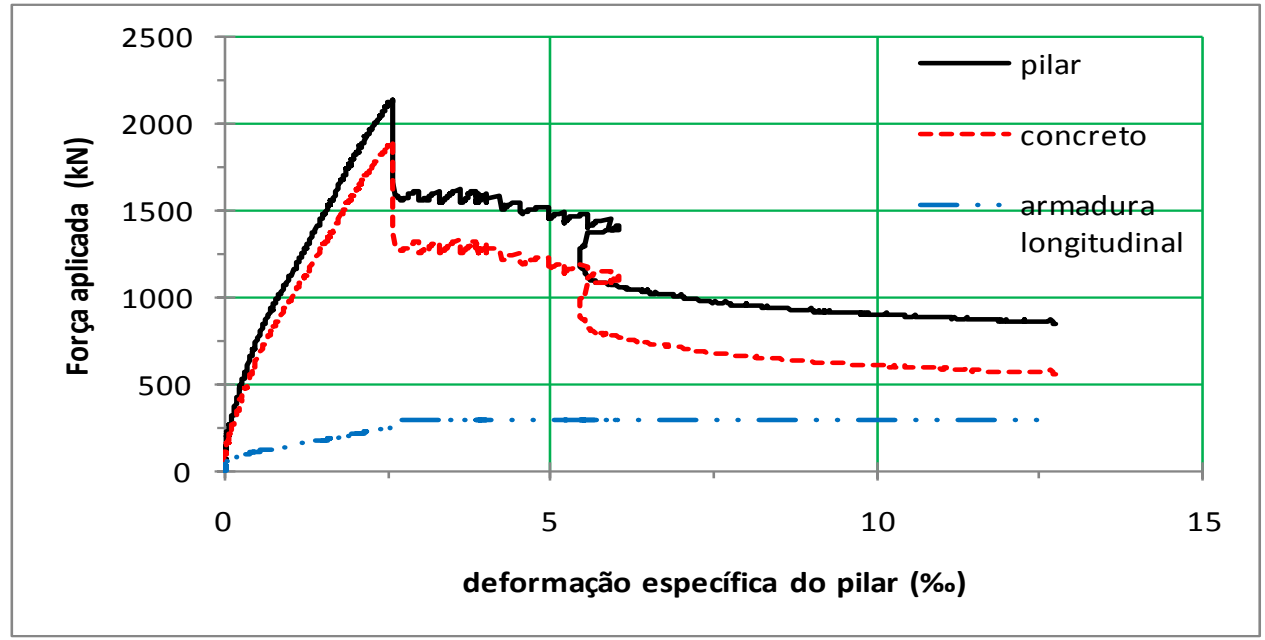

6.11 - Diagrama força-deformação específica vertical do pilar $50 \mathrm{H}$.

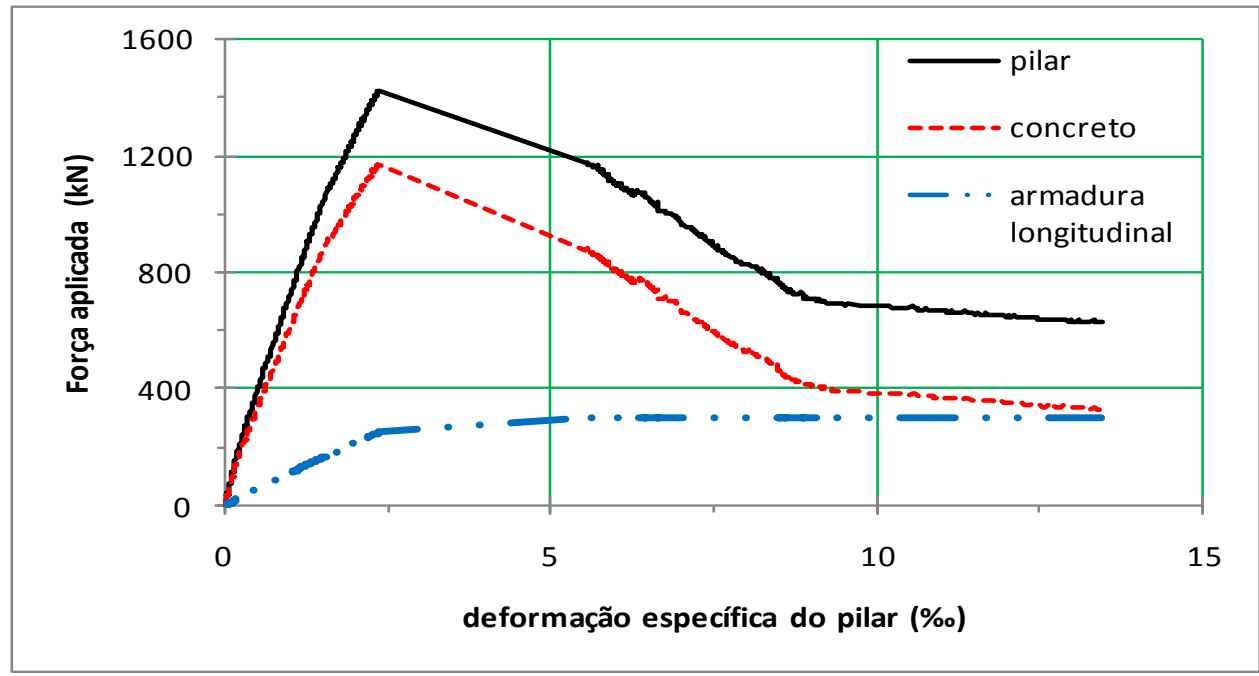

6.12 - Diagrama força-deformação específica vertical do pilar 50M.

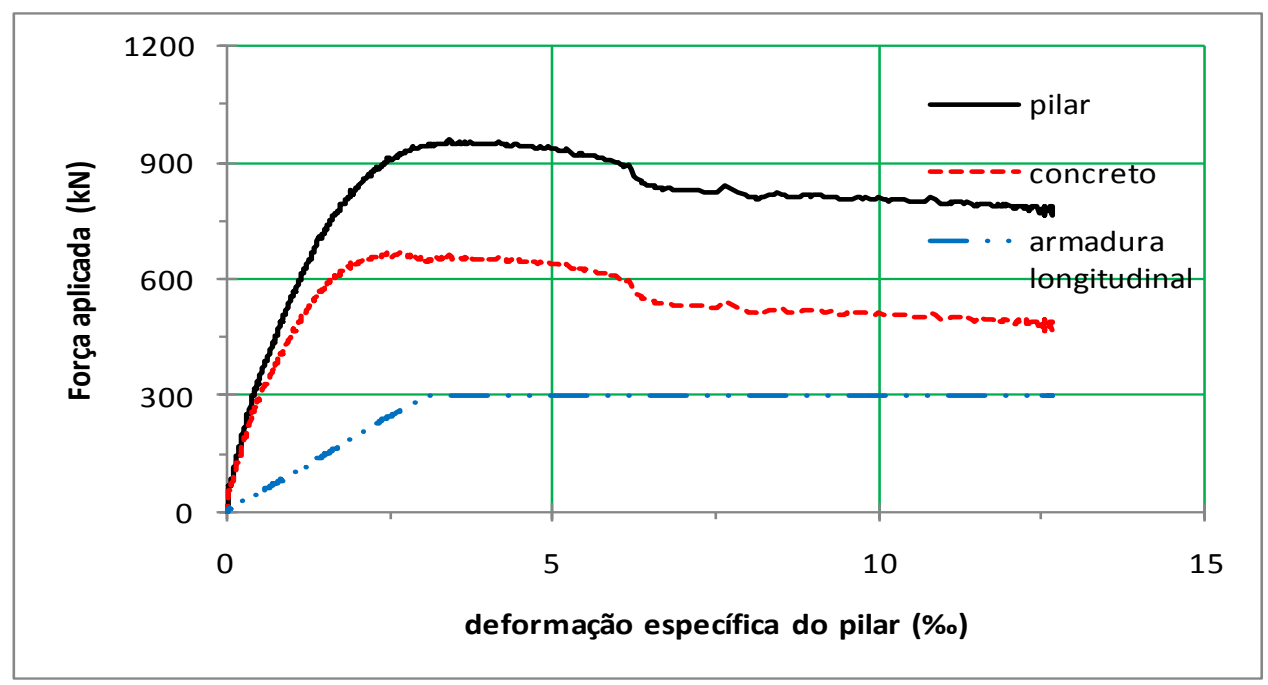

6.13 - Diagrama força-deformação específica vertical do pilar 50L. 


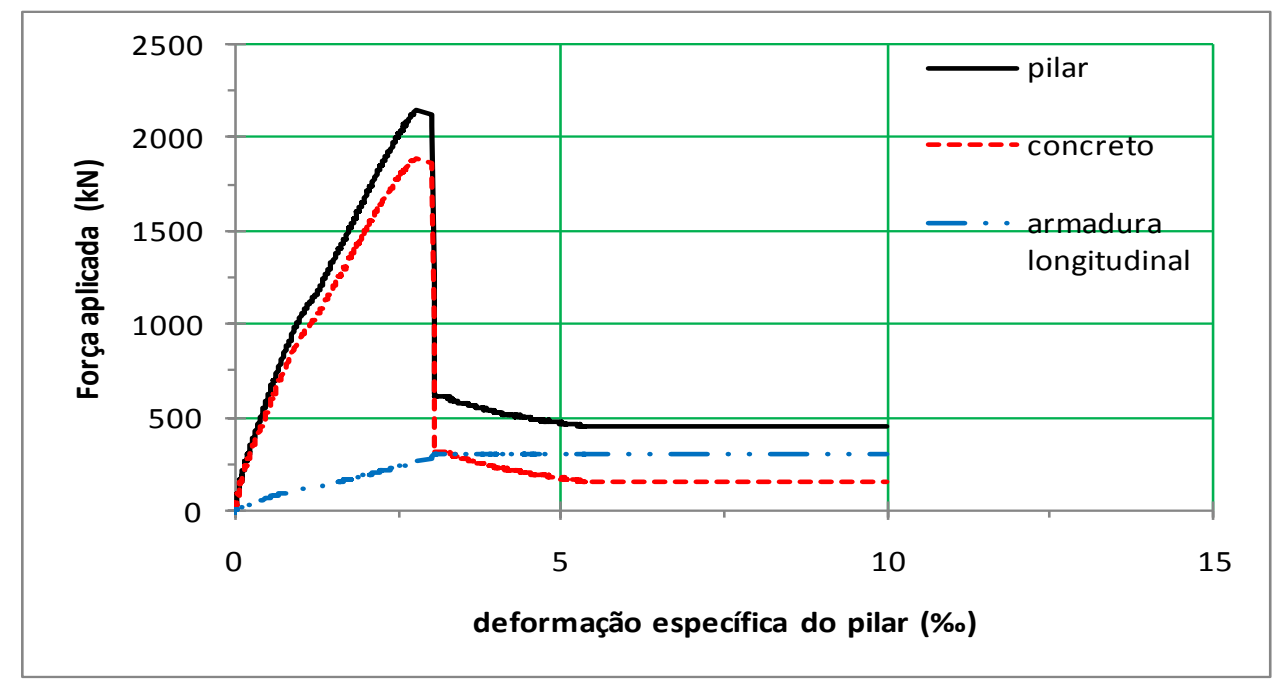

6.14 - Diagrama força-deformação específica vertical do pilar $100 \mathrm{H}$.

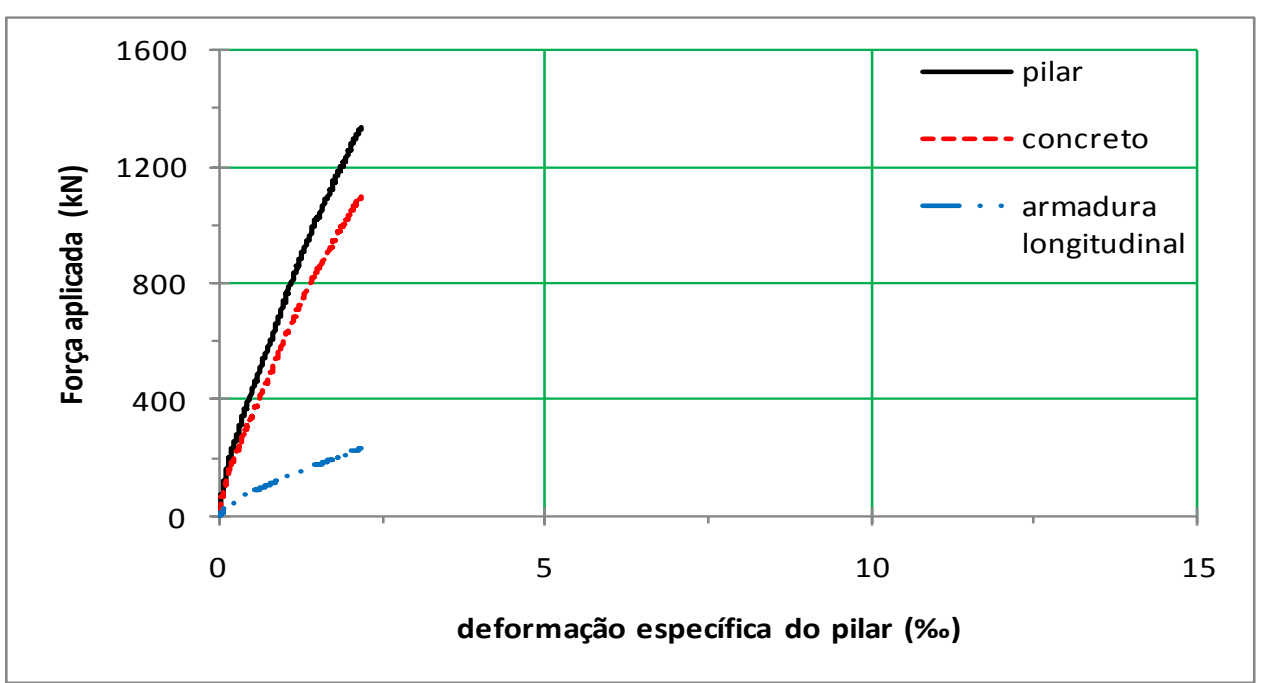

6.15 - Diagrama força-deformação específica vertical do pilar 100M.

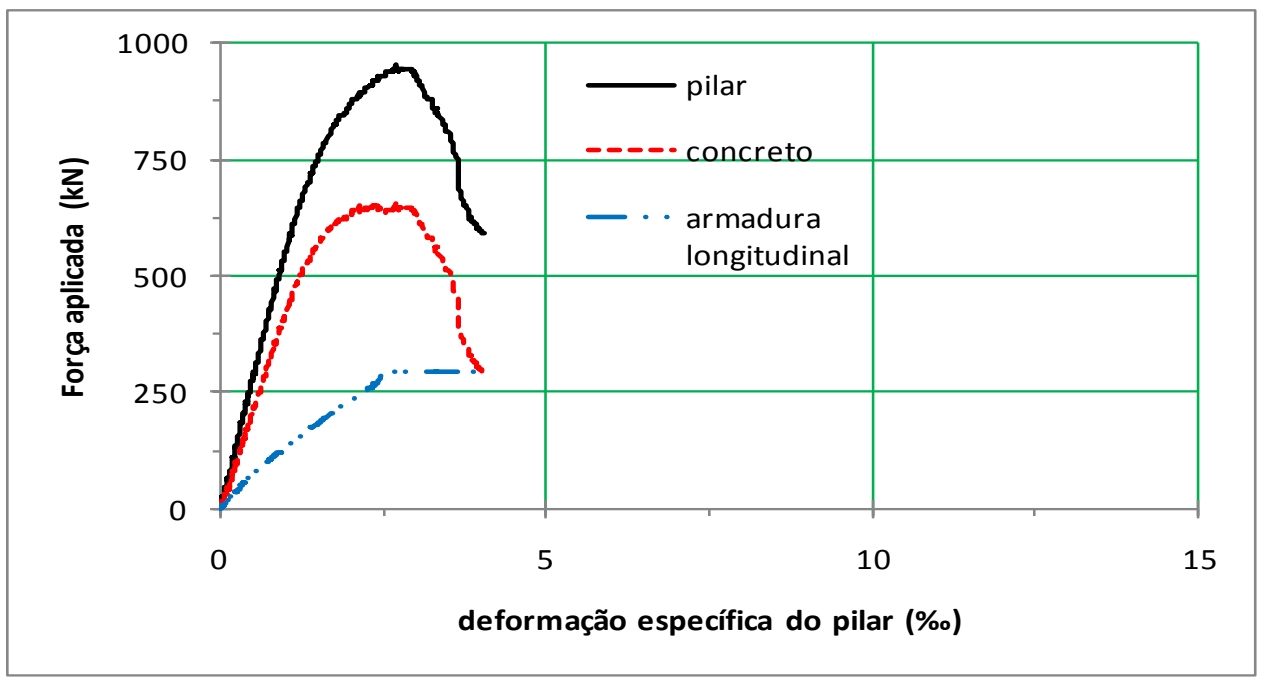

6.16 - Diagrama força-deformação específica vertical do pilar 100L. 
Nas Fig. 6.11 até a Fig. 6.16, se pode verificar o efeito da ductilidade pós-pico em todos os tipos de concreto para o espaçamento entre estribos de $5 \mathrm{~cm}$, sendo que para o concreto convencional o ganho da ductilidade foi maior, é possível verificar que houve uma queda da resistência do pilar $50 \mathrm{H}$ após a perda repentina do cobrimento, mas um processo de ductilização após o mesmo.

Com exceção do pilar curto 100M, todas as armaduras longitudinais escoaram quando foi atingida a força última. A flambagem da armadura longitudinal provocou uma perda repentina da capacidade resistente dos pilares curtos 100M e 100L.

\subsubsection{Diagramas de deformação específica estribos-deformação específica pilar curto}

Foi verificada a influência nas deformações das armaduras transversais na ductilidade dos pilares curtos, para avaliar as deformações foram utilizadas as médias das deformações específicas das leituras dos extensômetros de resistência nos dois ramos dos estribos. A Fig. 6.17 mostra os diagramas deformação específica da armadura transversal-deformação específica vertical do pilar curto. Nestas figuras a linha segmentada azul corresponde à deformação específica da resistência de escoamento da armadura transversal.

Foram verificadas as deformações específicas dos estribos correspondentes às forças últimas.

A Tabela 6.4 mostra um resumo destes valores, nesta é possível verificar que em nenhum caso foi atingida a deformação específica do escoamento da armadura transversal $\left(\varepsilon_{\text {swy }}=2,83 \%\right)$, seus valores ficaram entre $15 \%$ até $31 \%$ desta.

Tabela 6.4 - Deformação específica dos estribos e do pilar correspondente à força última

\begin{tabular}{|c|c|c|c|c|c|}
\hline Serie & $\begin{array}{c}\mathrm{F}_{\text {ult,exp }} \\
(\mathrm{kN})\end{array}$ & $\begin{array}{c}\varepsilon_{\mathrm{p}} \\
(\%)\end{array}$ & $\begin{array}{c}\varepsilon_{\mathrm{sw}} \\
(\%)\end{array}$ & $\begin{array}{c}\sigma_{\mathrm{sw}} \\
(\mathrm{MPa})\end{array}$ & $\begin{array}{c}\sigma_{\mathrm{sw}, \mathrm{LP}} \\
(\mathrm{MPa})\end{array}$ \\
\hline \hline $100 \mathrm{H}$ & 2156 & 2,79 & 0,89 & 177,56 & 155,5 \\
\hline $100 \mathrm{M}$ & 1334 & 2,16 & 0,61 & 121,70 & 140,0 \\
\hline $100 \mathrm{~L}$ & 952 & 1,82 & 0,44 & 87,78 & 130,0 \\
\hline $50 \mathrm{H}$ & 2142 & 2,89 & 0,92 & 183,54 & 210,7 \\
\hline $50 \mathrm{M}$ & 1422 & 3,37 & 1,03 & 205,49 & 238,1 \\
\hline $50 \mathrm{~L}$ & 958 & 3,73 & 0,98 & 195,51 & 386,6 \\
\hline
\end{tabular}

$\mathrm{Na}$ tabela anterior $\varepsilon_{\mathrm{p}}$ a deformação específica dos pilares curtos (corresponde ao $\varepsilon_{\mathrm{cc} 1}$ ), $\varepsilon_{\mathrm{sw}}$ é a deformação específica da armadura trasnsversal, $\sigma_{\mathrm{sw}}$ a tensão de serviço da armadura transversal, todos estes correspondentes aos resultados dos ensaios e para suas forças últimas e $\sigma_{\text {sw,LP }}$ a tensão de trabalho da armadura transversal obtida com o modelo de Légeron e Paultre (2003). Em todos os pilares a tensão de serviço considerando o modelo de Legerón e 
Paultre (op. cit.) foi maior que a dos resultados de laboratório, exceto no pilar $100 \mathrm{H}$, é possível verificar que em ambos casos (modelo teórico e resultados de laboratório) a tensão de trabalho dos pilares com espaçamento entre estribos de $5 \mathrm{~cm}$ foram maiores que os de 10 $\mathrm{cm}$.

As Fig. 6.17 até 6.19 mostram as deformações específicas dos pilares x deformações específicas dos estribos.

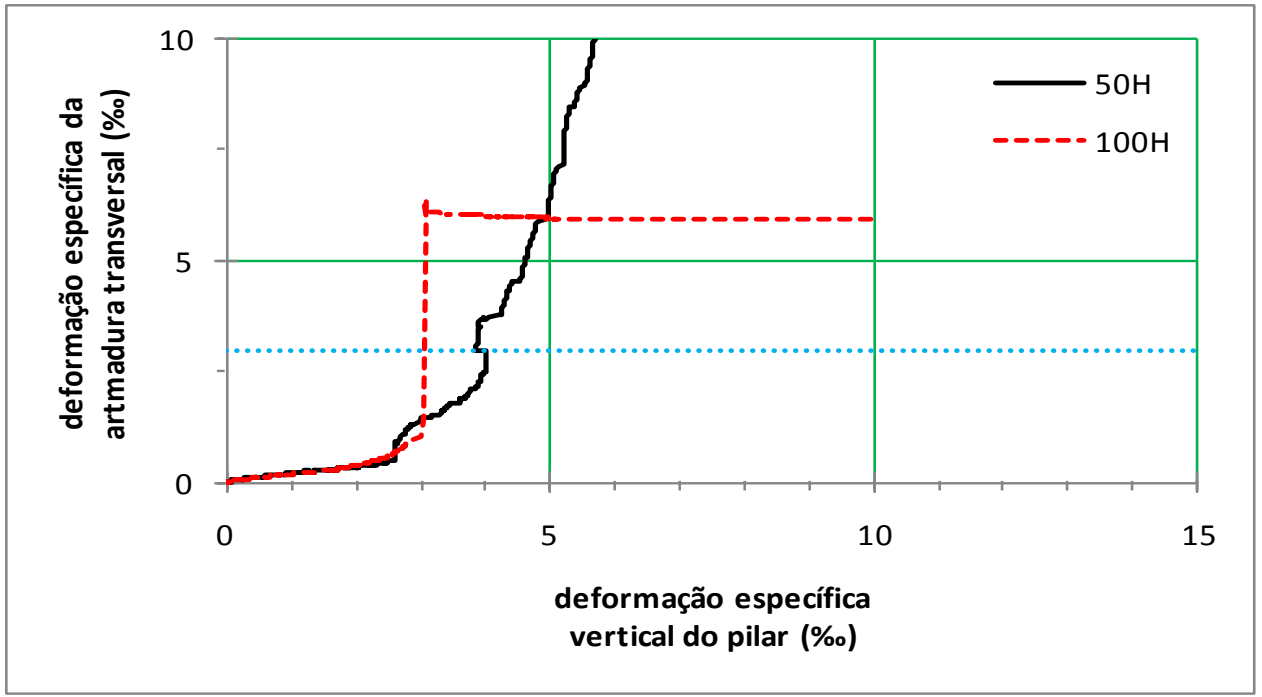

6.17 - Diagrama deformação estribo-deformação vertical dos pilares $50 \mathrm{H}$ e $100 \mathrm{H}$.

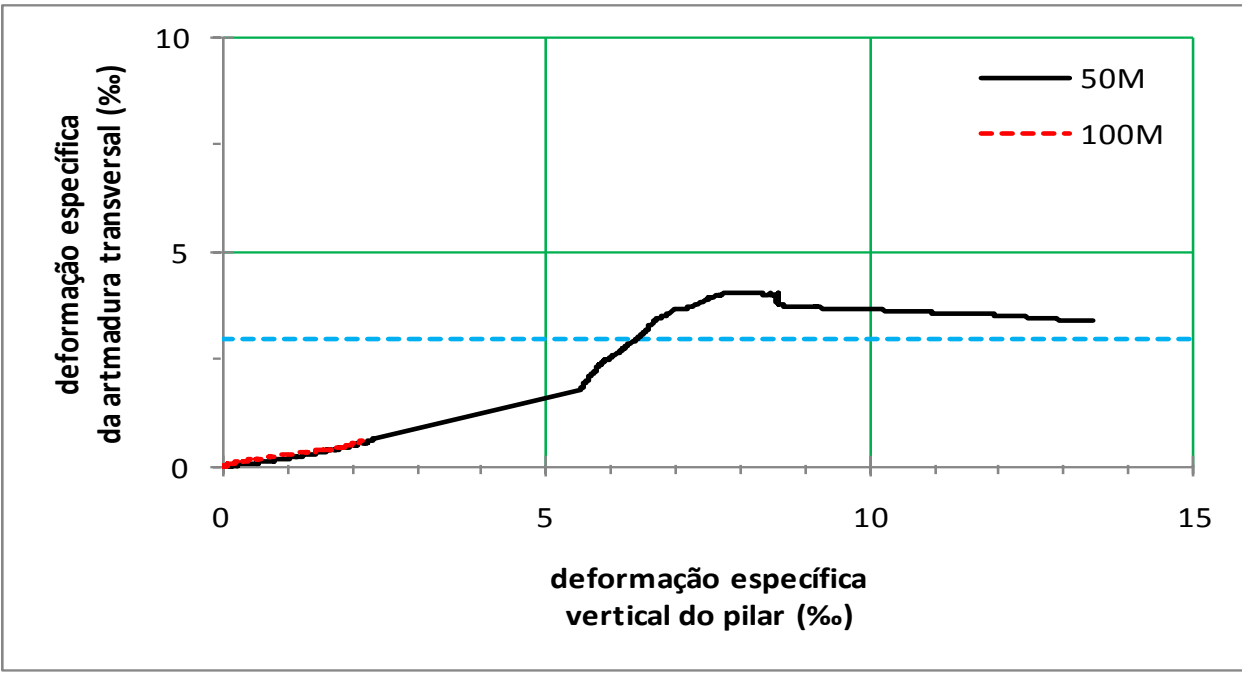

6.18 - Diagrama deformação estribo-deformação vertical dos pilares 50M e 100M. 


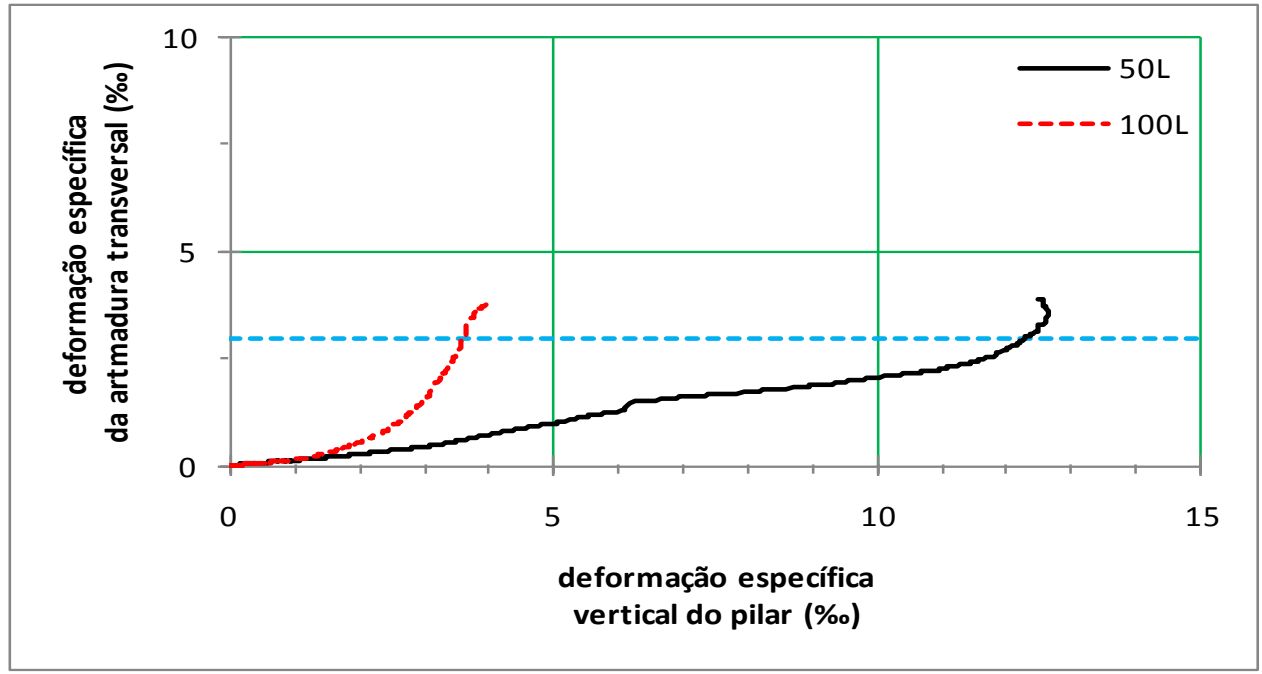

6.19 - Diagrama deformação estribo-deformação vertical dos pilares 50L e 100L.

Pelas Fig. 6.17 e Fig. 6.19, é possível observar que em nenhum caso as barras das armaduras atingiram o escoamento na etapa relativa à força última, estes dados podem ser verificados considerando o valor da deformação específica dos pilares da Tabela 6.4. Seus trechos iniciais das curvas coincidem para os pilares com as mesmas resistências do concreto, sendo que não existe influencia do espaçamento entre estribos. Contudo somente no pilar 100M não foi atingido o escoamento após a força última porque as barras da armadura longitudinal flambaram e o sistema parou de registrar as leituras. Nos pilares $50 \mathrm{H}$ e $100 \mathrm{H}$ foi atingido o escoamento quando a deformação vertical dos pilares estava ao redor de $4 \%$ e $3 \%$ o respectivamente, para o pilar $50 \mathrm{M}$ quando a deformação específica do pilar correspondia a aproximadamente $6 \%$ e para os pilares $50 \mathrm{~L}$ e $100 \mathrm{~L}$ entre aproximadamente $12 \%$ e $4 \%$ o respectivamente. Observa-se um padrão nestes valores: para os pilares com concreto de menor resistência houve uma maior deformação especifica do pilar ao atingir os estribos o escoamento.

\subsubsection{Diagramas tensão-deformação específica do concreto}

Para adotar um modelo de confinamento é necessário conhecer o gráfico tensãodeformação específica do concreto do pilar curto. Para isto nos modelos experimentais, foi retirada a parcela correspondente do aporte das armaduras longitudinais em resistir a força em cada etapa de ensaio. As Fig. 6.20 até Fig. 6.22 mostram estes diagramas para todos os pilares curtos.

Junto com os resultados dos modelos experimentais foram traçados os diagramas tensão-deformação específica do concreto confinado do modelo teórico proposto por Légeron-Paultre (2003), estes diagramas foram desenhados para efeito de comparação. Este 
trabalho não tinha como objetivo obter um modelo de pilares curtos sob compressão centrada, e sim verificar a qual modelo existente se aproximava melhor os resultados dos ensaios, e foi adotado o modelo proposto por Légeron e Paultre (2003) porque foi o que mais se aproximou, tanto nos seus valores de resistência como nos ramos pré e pós-pico da curva $\sigma_{\mathrm{c}} \mathrm{x} \varepsilon_{\mathrm{c}}$, e foi este modelo o empregado na elaboração dos programas dos pilares esbeltos.

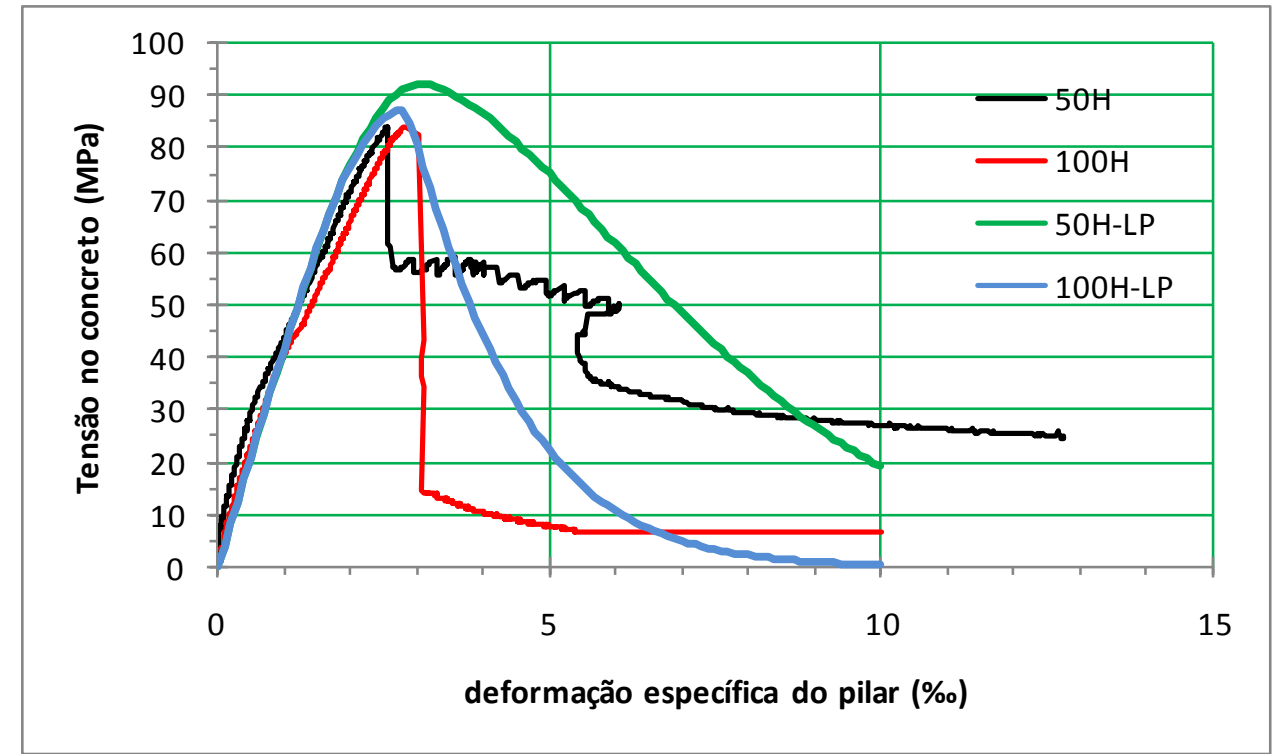

Fig. 6.20 - Diagrama tensão-deformação específica do concreto dos pilares $50 \mathrm{H}$ e $100 \mathrm{H}$.

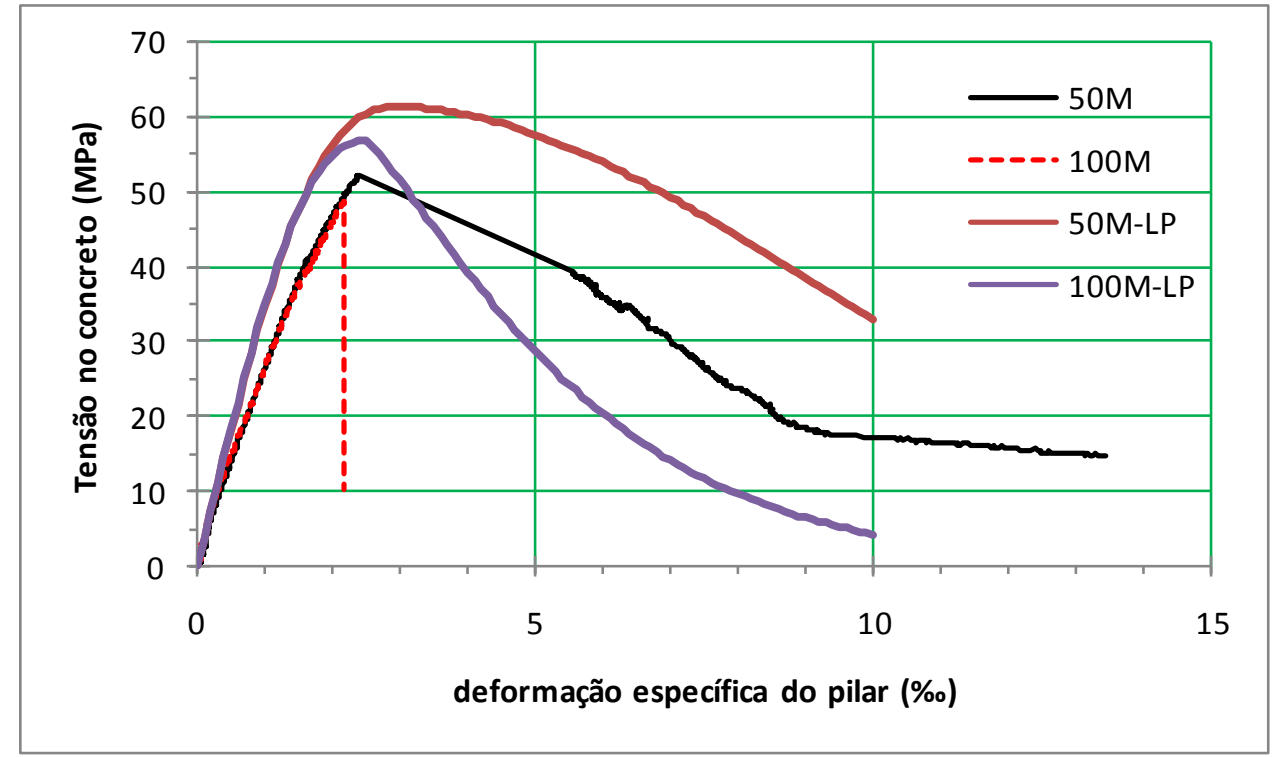

Fig. 6.21 - Diagrama tensão-deformação específica do concreto dos pilares 50M e 100M. 


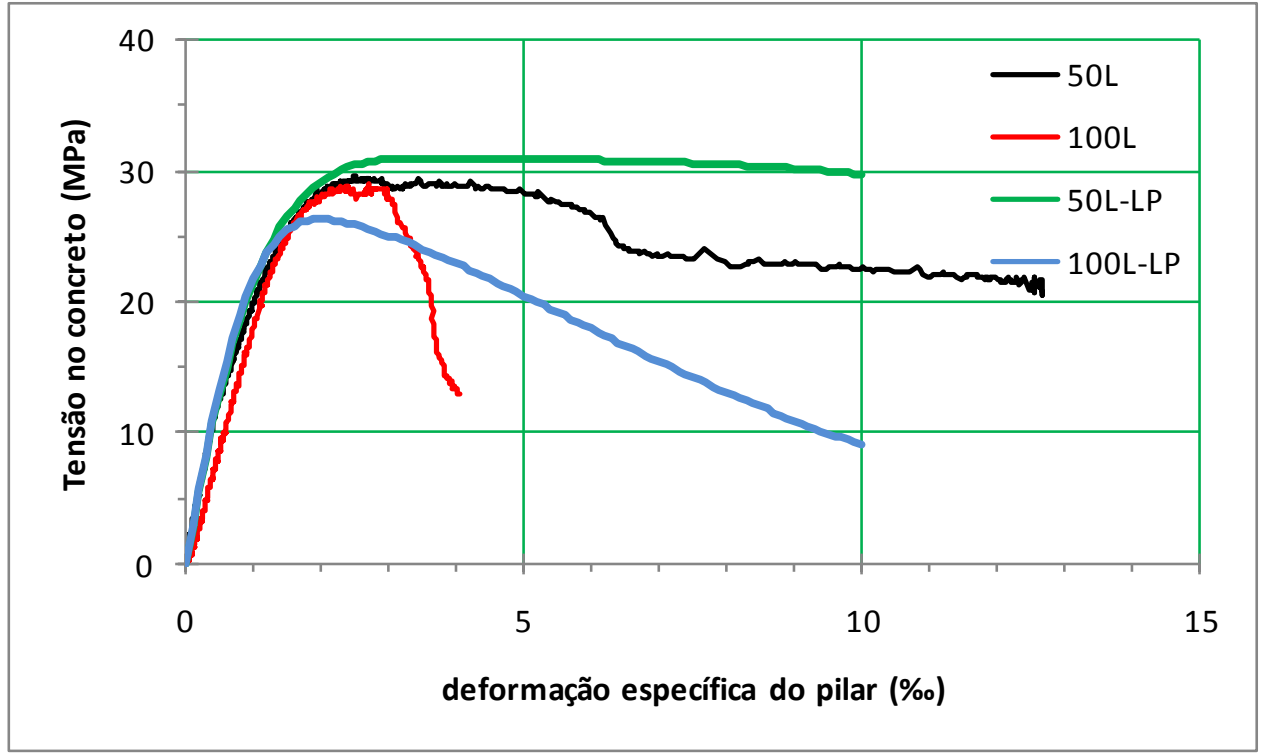

Fig. 6.22 - Diagrama tensão-deformação específica do concreto dos pilares 50L e 100L.

Das Fig. 6.20 até a Fig. 6.22, a tensão de pico no concreto corresponde aproximadamente a $0,92 \mathrm{f}_{\mathrm{cm}}$, é possível observar o efeito do confinamento do concreto para os pilares curtos com espaçamento de estribos de $5 \mathrm{~cm}$. Nos pilares 100L e 100M houve flambagem das armaduras longitudinais e o comportamento pós-pico não apresentaram ductilidade, mas em geral os modelos experimentais apresentaram menor efeito de ductilidade que os teóricos. O modelo de Légeron e Paultre não considera a descontinuidade do diagrama tensão-deformação específica quando o pilar perde repentinamente o cobrimento (ver Fig. 3.16), no seu lugar apresentam diagramas contínuos como os das Fig. 6.20 até a Fig. 6.22.

\subsection{PILARES ESBELTOS SUBMETIDOS À COMPRESSÃO EXCÊNTRICA}

Neste item são apresentados e discutidos os resultados experimentais dos 12 pilares esbeltos ensaiados à flexo-compressão.

A Tabela 6.1 mostra as idades em que foram ensaiados os pilares e as resistências dos concretos correspondentes aos resultados dos ensaios dos corpos-de-prova cilíndricos de 10 $\mathrm{cm} \times 20 \mathrm{~cm}$.

Os procedimentos dos ensaios permitiram observar as situações dos pilares depois das forças de pico. Em todos os pilares, não houve perda nas leituras dos extensômetros de resistência, não houve flambagem das armaduras longitudinais, as armaduras transversais não atingiram o escoamento em nenhuma das etapas do ensaio e em todos os 12 pilares o estado limite último (ELU) ocorreu por perda da estabilidade do pilar, ou seja, foi atingido o ponto 
limite (ver Fig. 4.7 e Fig. 4.8). Para todos os pilares, são estudadas as diferentes situações que ocorreram durante o ensaio até atingir o ELU. O método a ser utilizado na verificação dos resultados experimentais é com base no Método Geral incorporando o confinamento por meio de programas elaborados pelo autor no software de programação algébrico e simbólico MathCad v. 14.

Os colares metálicos, colocados nas extremidades dos pilares, apresentaram bom desempenho (não foi observada nenhuma fissura nas extremidades) e ajudaram a posicionar os pilares nos aparelhos de apoio, pois envolviam as chapas guia que foram soldadas sobre a peça $\mathrm{N}^{\mathrm{o}} 4$ (Fig. 5.16) do aparelho do apoio. O detalhe desta fixação se encontra na Fig. 6.23. O calço de madeira era retirado para a fixação dos colares metálicos após prender o pilar na máquina de ensaio.

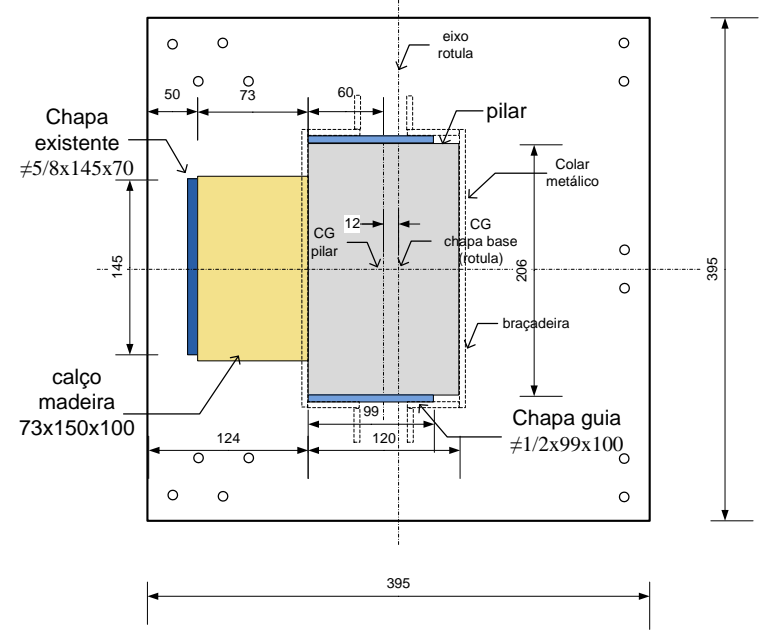

(a) para excentricidade de $12 \mathrm{~mm}$

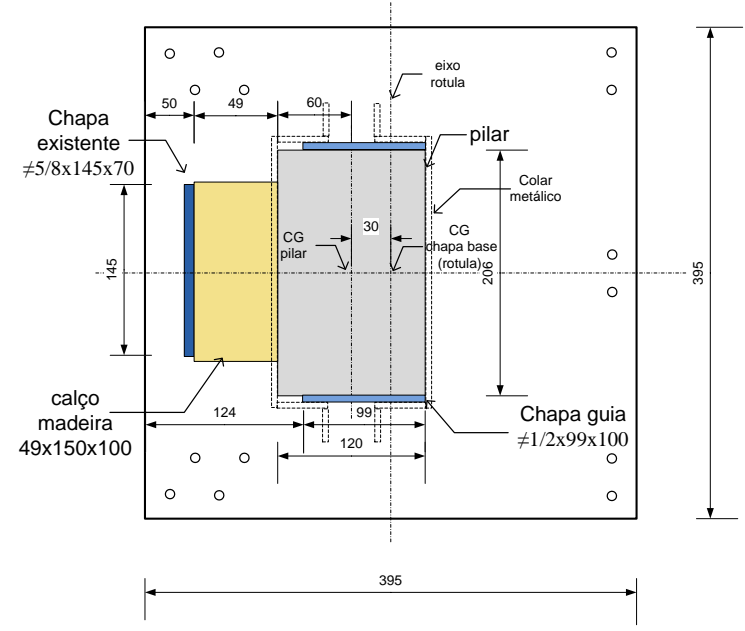

(b) para excentricidade de $30 \mathrm{~mm}$

Fig. 6.23 - Detalhe de fixação do pilar junto aos aparelhos de apoio por meio dos colares metálicos.

Para que um ensaio à compressão excêntrica forneça bons resultados é importante que o sistema de apoio permita transferir o momento externo ao pilar e que funcione como uma rótula perfeita. Lima Jr. (2003) demonstrou que o momento externo era transmitido integralmente ao pilar. A Fig. 6.24 mostra o detalhe da fixação do pilar junto ao aparelho de apoio um pouco antes do início do ensaio, nesta é possível perceber que o pilar esta sob uma força excêntrica. 


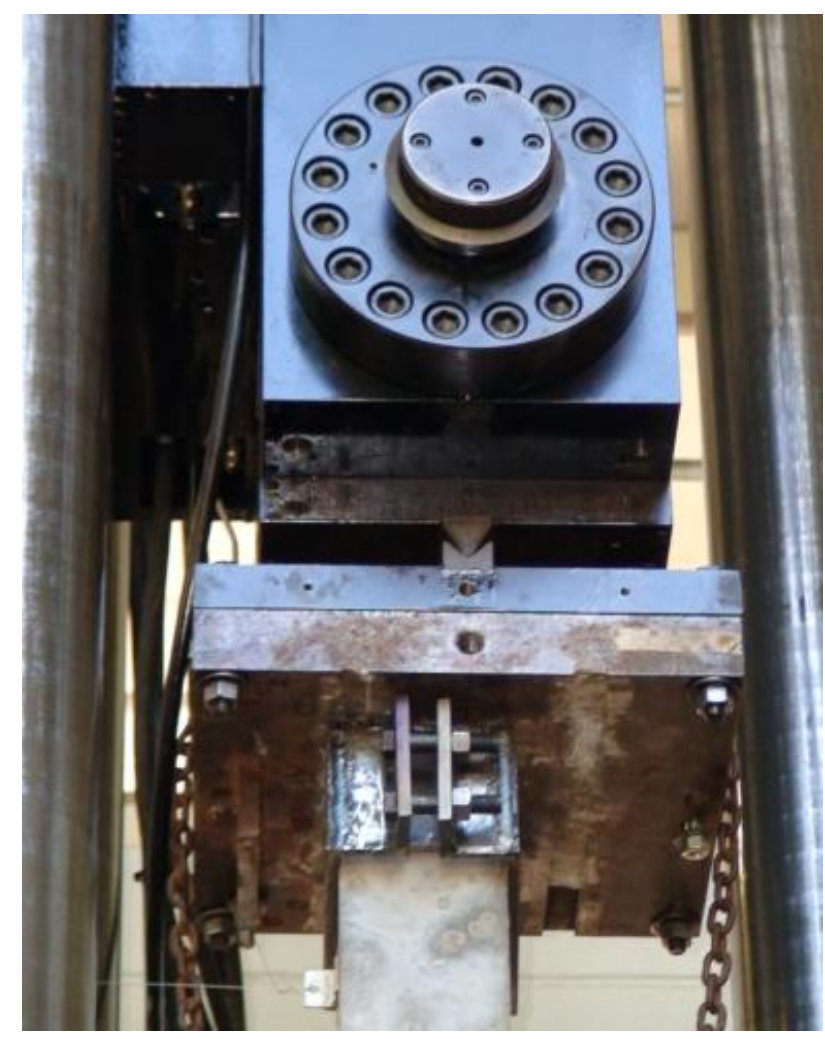

Fig. 6.24 - Detalhe da fixação do pilar junto à rótula.

Após atingir o ELU de instabilidade, em todos os pilares continuaram-se aplicando força até a ruptura dos materiais; o ensaio finalizava pouco tempo depois do concreto na face comprimida romper. $\mathrm{Na}$ face inicialmente menos comprimida o padrão de fissuração era paralelo aos estribos. Para os pilares de CAR houve um destacamento repentino do cobrimento na região comprimida. A Fig. 6.25 mostra um pilar após o ELU e o mapeamento das fissuras realizado durante o ensaio. 

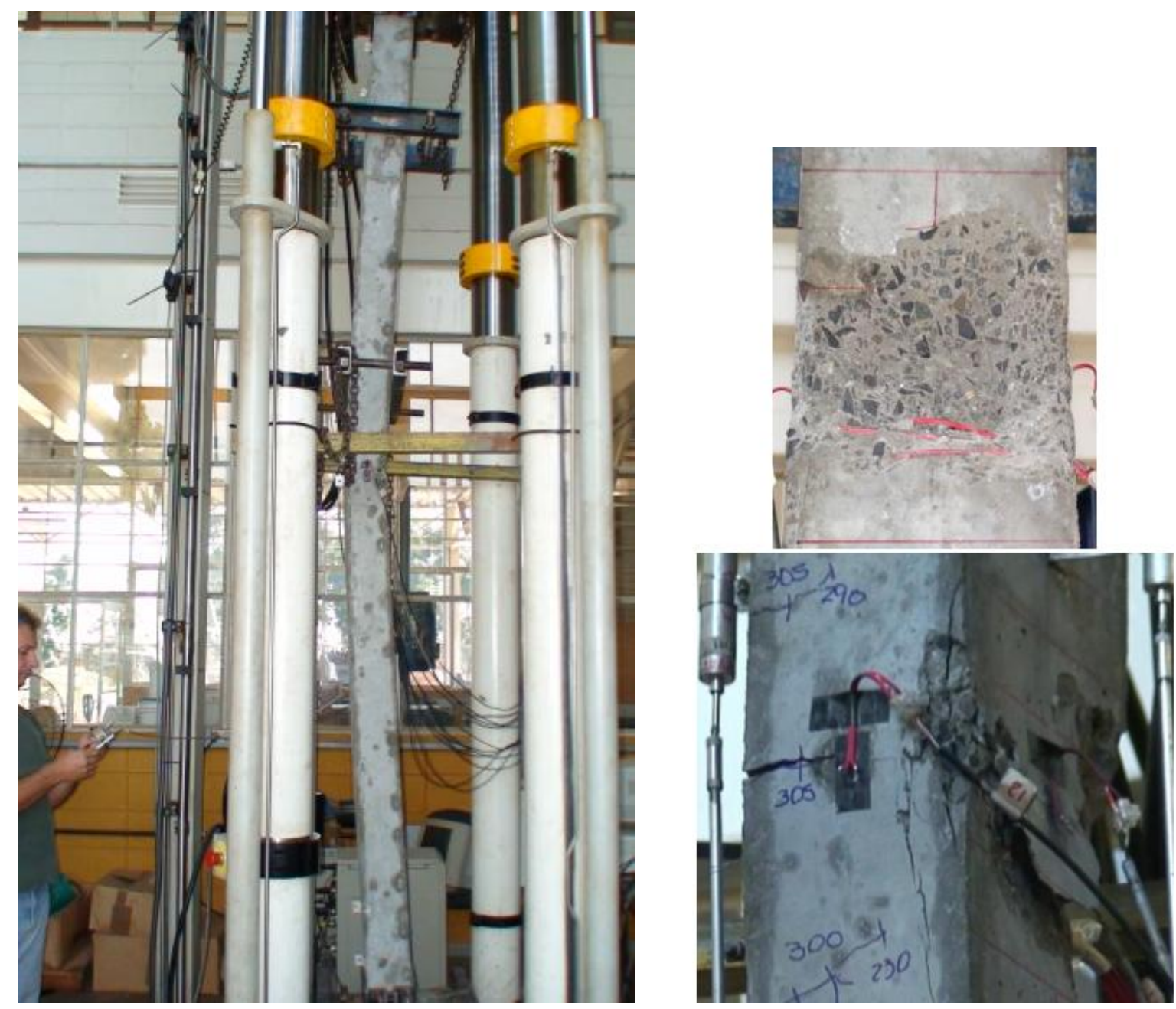

Fig. 6.25 - Final do ensaio para o Pilar 100M12 mostrando suas fissuras e o destacamento do cobrimento do pilar 50H12.

No decorrer do ensaio efetuou-se o registro das deformações das armaduras longitudinais e transversais do concreto e dos deslocamentos e as marcações das fissuras. A excentricidade final foi calculada a partir da excentricidade inicial, considerando-se as leituras de deslocamentos apresentadas.

A partir dos resultados obtidos, foram analisadas as evoluções das deformações no concreto e nas armaduras, evolução dos deslocamentos vertical e horizontal dos modelos, evolução das fissuras por meio dos diagramas de deformações, esforços solicitantes últimos e modos de ruína.

Posteriormente foram obtidas as forças e momentos experimentais por meio das medidas das deformações no aço e no concreto com a curva tensão-deformação especifica obtida dos modelos propostos.

Embora a força fosse aplicada ao plano médio paralelo à menor dimensão da seção transversal do pilar, o comportamento dos extensômetros instalados nas armaduras não 
refletiu esta condição. Houve um pequeno desvio, possivelmente em virtude da falta de paralelismo das faces da seção transversal e a um erro de posicionamento dos modelos, pois se observou flexão na outra direção. Decidiu-se, então, calcular as médias das deformações em cada face de modo a levar em conta o efeito da excentricidade acidental.

A Tabela 6.5 mostra as características dos pilares ensaiados que provem dos ensaios de laboratório.

Tabela 6.5 - Propriedades dos materiais empregados nos pilares esbeltos.

\begin{tabular}{|c|c|c|c|c|c|}
\hline \multirow{2}{*}{ Serie } & \multirow{2}{*}{$\begin{array}{c}0,92 \mathrm{f}_{\mathrm{c}, \text { adot }}(\mathrm{MPa}) \\
\mathrm{CP} 10 \times 20\end{array}$} & \multicolumn{2}{|c|}{ Armadura transversal } & \multicolumn{2}{|c|}{ Armadura longitudinal } \\
\hline & & Taxa volum. & $\mathrm{f}_{\mathrm{yw}}(\mathrm{MPa})$ & área, taxa & $\mathrm{f}_{\mathrm{y}}(\mathrm{MPa})$ \\
\hline $50 \mathrm{H} 12$ & 94,8 & \multirow{6}{*}{$\begin{array}{c}\varnothing 6,3 \text { c } 5 \mathrm{~cm} \\
2,5 \%\end{array}$} & \multirow{12}{*}{620} & \multirow{12}{*}{$\begin{array}{c}4 \varnothing 12,5 \mathrm{~mm} \\
4,92 \mathrm{~cm}^{2} \\
\rho=2,05 \%\end{array}$} & \multirow{12}{*}{585} \\
\hline $50 \mathrm{H} 30$ & 94,8 & & & & \\
\hline $50 \mathrm{M} 12$ & 54,3 & & & & \\
\hline $50 \mathrm{M} 30$ & 54,3 & & & & \\
\hline $50 \mathrm{~L} 12$ & 31,3 & & & & \\
\hline $50 \mathrm{~L} 30$ & 31,3 & & & & \\
\hline $100 \mathrm{H} 12$ & 94,8 & \multirow{6}{*}{$\begin{array}{c}\varnothing 6,3 \text { c } 10 \mathrm{~cm} \\
1,25 \%\end{array}$} & & & \\
\hline $100 \mathrm{H} 30$ & 94,8 & & & & \\
\hline $100 \mathrm{M} 12$ & 54,3 & & & & \\
\hline $100 \mathrm{M} 30$ & 54,3 & & & & \\
\hline 100L12 & 31,3 & & & & \\
\hline 100L30 & 31,3 & & & & \\
\hline
\end{tabular}

\subsubsection{Estudo do deslocamento vertical dos pilares}

Os deslocamentos verticais dos pilares foram obtidos do registro dos deslocamentos dos pratos da máquina INSTRON. As Fig. 6.26 até Fig. 6.28 mostra os diagramas obtidos para os 12 pilares. 


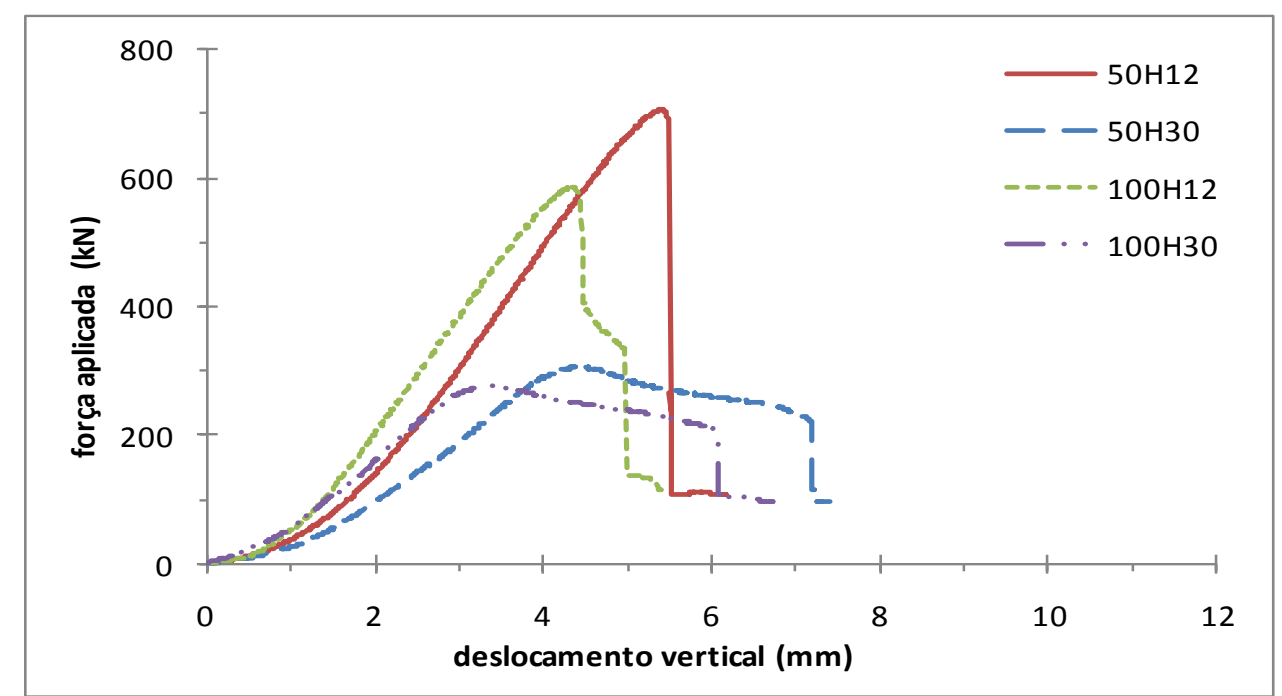

Fig. 6.26 - Diagrama força-deslocamento vertical para os pilares 50H12, 50H30, $100 \mathrm{H} 12$ e $100 \mathrm{H} 30$.

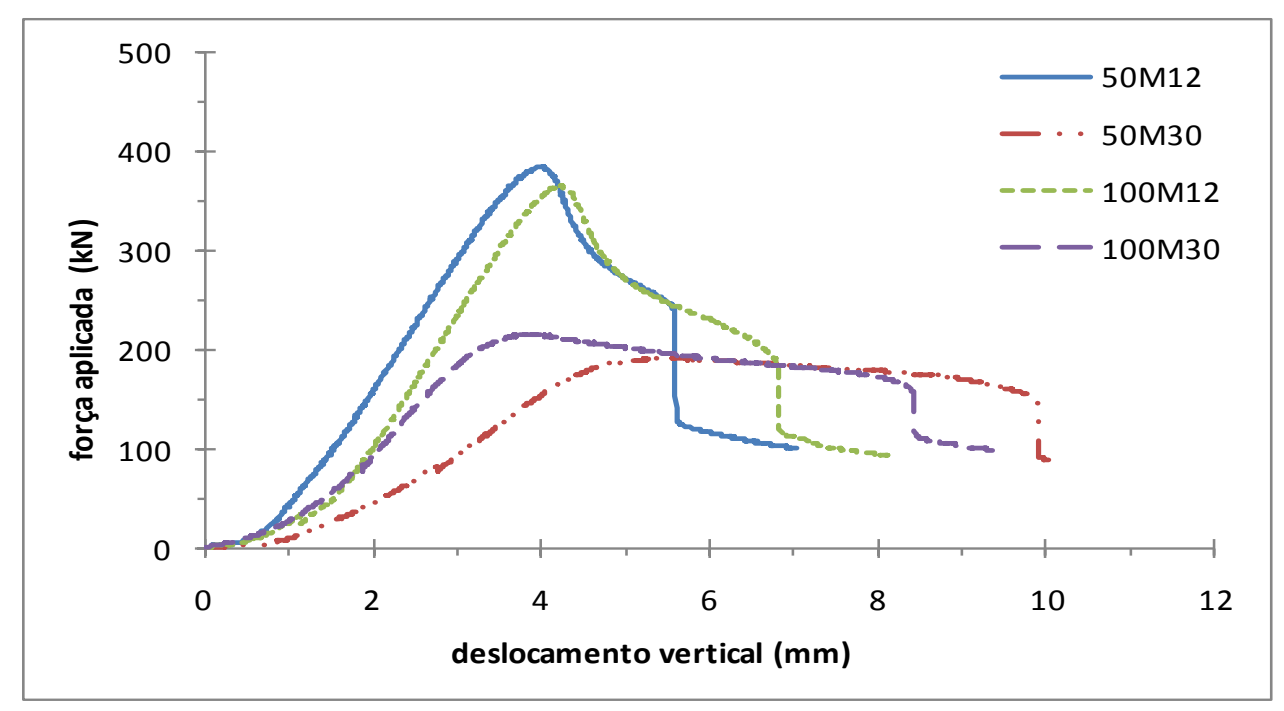

Fig. 6.27 - Diagrama força-deslocamento vertical para os pilares 50M12, 50M30, 100M12 e 100M30. 


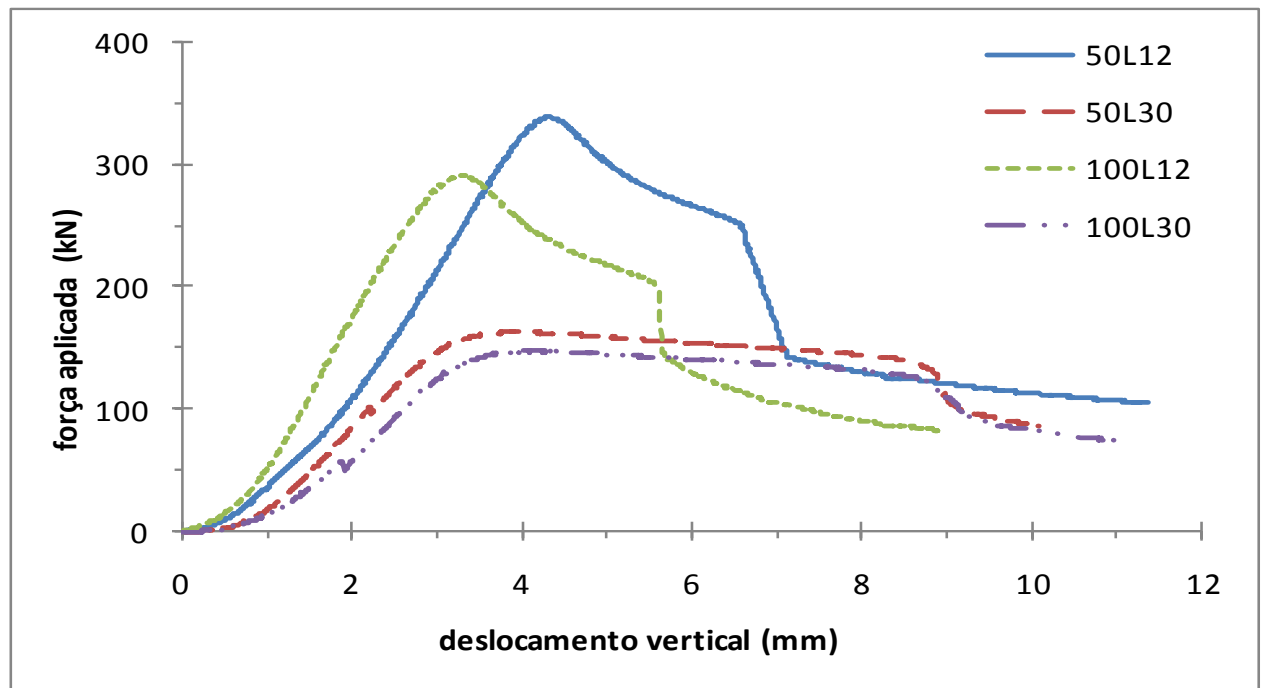

Fig. 6.28 - Diagrama força-deslocamento vertical para os pilares 50L12, 50L30, 100L12 e $100 \mathrm{~L} 30$.

Nos diagramas é possível identificar o fenômeno da ductilidade pós-pico dos pilares, ou os que não apresentam ductilidade. Uma análise visual dos resultados mostra que os pilares tipo $\mathrm{H}$ foram os que apresentam menos ductilidade pós-pico especialmente para os de excentricidade de força de $12 \mathrm{~mm}$, nestes ocorreu perda repentina do cobrimento induzindo à uma queda repentina da força, que pode ser observado nos diagramas força-deslocamento vertical dos pilares 50H12, 100H12 (o confinamento do concreto não foi suficiente para compensar a perda do cobrimento). Estes diagramas mostram melhor a perda de capacidade resistente do pilar que os diagramas força-deslocamento lateral.

Todos os pilares (exceto o pilar 50H12) mostram uma segunda queda na resistência quando aconteceu a ruptura do concreto na face mais comprimida, ou para os pilares com espaçamento de estribos de $5 \mathrm{~cm}$ o destacamento do cobrimento; subitamente perdem resistência, mais abrupto para os pilares de CAR.

Para o pilar 50H12 a força última que corresponde à instabilidade coincide com a força que provocou o destacamento do cobrimento, por este motivo este pilar não apresenta uma segunda queda na resistência, a ductilidade pós-pico que provem do efeito do confinamento é inexistente, existe um acúmulo de energia que provoca um incremento na capacidade resistente do pilar, mas a ruptura é repentina. Durante o ensaio nesta etapa final, a ruptura foi repentina, o concreto na face mais comprimida não rompeu (ver Tabela 6.6) e na face inicialmente menos comprimida (agora tracionada) estava com deformações muito pequenas (ver Fig. 6.43), para esta etapa de carga, na fibra extrema tracionada o concreto 
estava pouco fissurado. Possivelmente o fenômeno de instabilidade tenha sido antecipado por causa da ruptura do cobrimento.

Todos os pilares de concreto com excentricidade de força de $30 \mathrm{~mm}$ apresentam comportamentos de ductilidade pós-pico, mesmo aqueles com espaçamento entre estribos de $10 \mathrm{~cm}$. Os pilares de menor resistência têm maior ductilidade, considerando a segunda queda da resistência. A melhora na ductilidade pós-pico, considerando o espaçamento de estribos está mais bem mostrada nos diagramas força-deslocamento lateral.

Para os pilares com concreto convencional a segunda queda na resistência, provocado pelo destacamento do cobrimento ou ruptura do concreto, ocorre de forma gradual (ramo descendente na curva força-deslocamento vertical).

Para os pilares com concreto tipo M e L com pequena excentricidade, há uma perda de rigidez após a força última provocada pelo fenômeno de instabilidade, mas a perda não é súbita, a perda é súbita após o destacamento do cobrimento que acontece na segunda queda de resistência.

Em todos os pilares com espaçamento de estribos de $5 \mathrm{~cm}$ a força última é maior que os pilares com estribos espaçados a cada $10 \mathrm{~cm}$, mas a regra não é valida para a ductilidade.

É possível verificar como os pilares modificam seu comportamento considerado a mudança na excentricidade de força e seu confinamento devido à armadura transversal.

\subsubsection{Estudo do deslocamento lateral dos pilares}

Os deslocamentos laterais foram obtidos com os LVDT1 até o LVDT5 (Fig. 5.19). Os deslocamentos laterais correspondem às excentricidades de $2^{\mathrm{a}}$ ordem, e normalmente o valor que interessa é o correspondente ao valor do meio do pilar.

As excentricidades totais provem da soma das excentricidades de $1^{\text {a }}$ ordem com as excentricidades de $2^{\mathrm{a}}$ ordem; com a excentricidade total obtêm-se o momento total que provocou a ruína do pilar. As Fig. 6.29 até a Fig. 6.31 mostram os resultados dos ensaios considerando o deslocamento no meio do pilar (obtido com o LVDT1). 


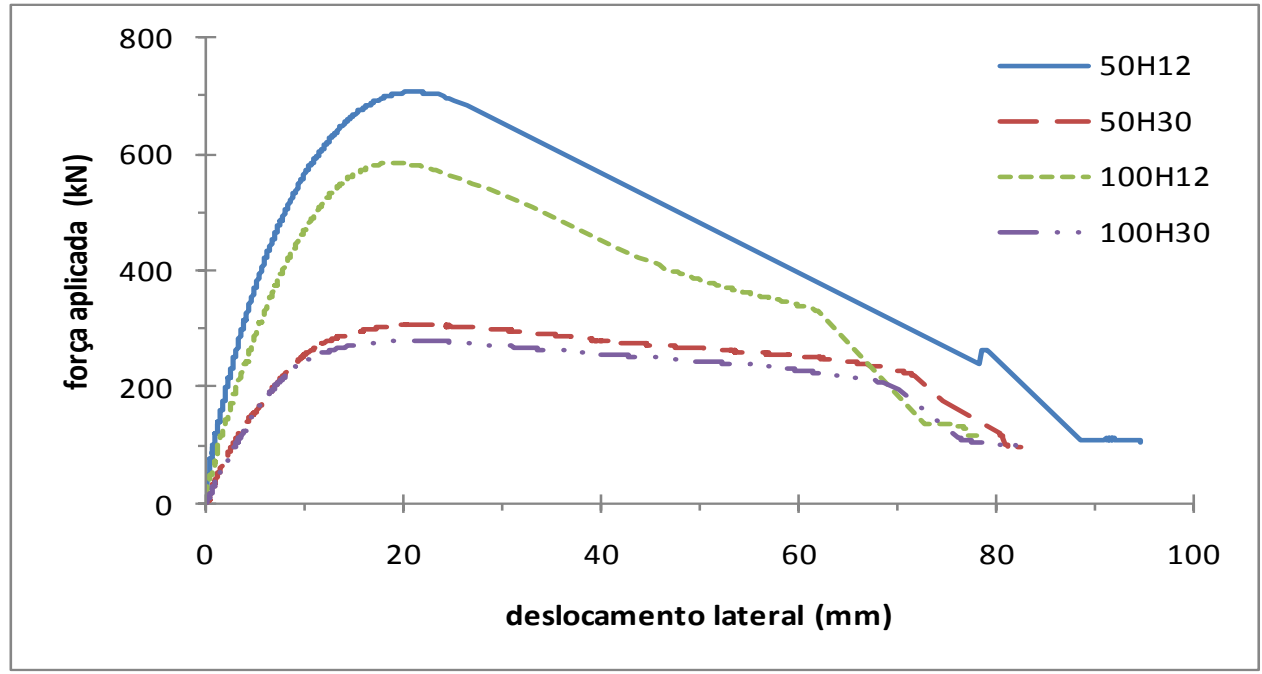

Fig. 6.29 - Diagrama força-deslocamento lateral para os pilares 50H12, 50H30, $100 \mathrm{H} 12 \mathrm{e}$ $100 \mathrm{H} 30$.

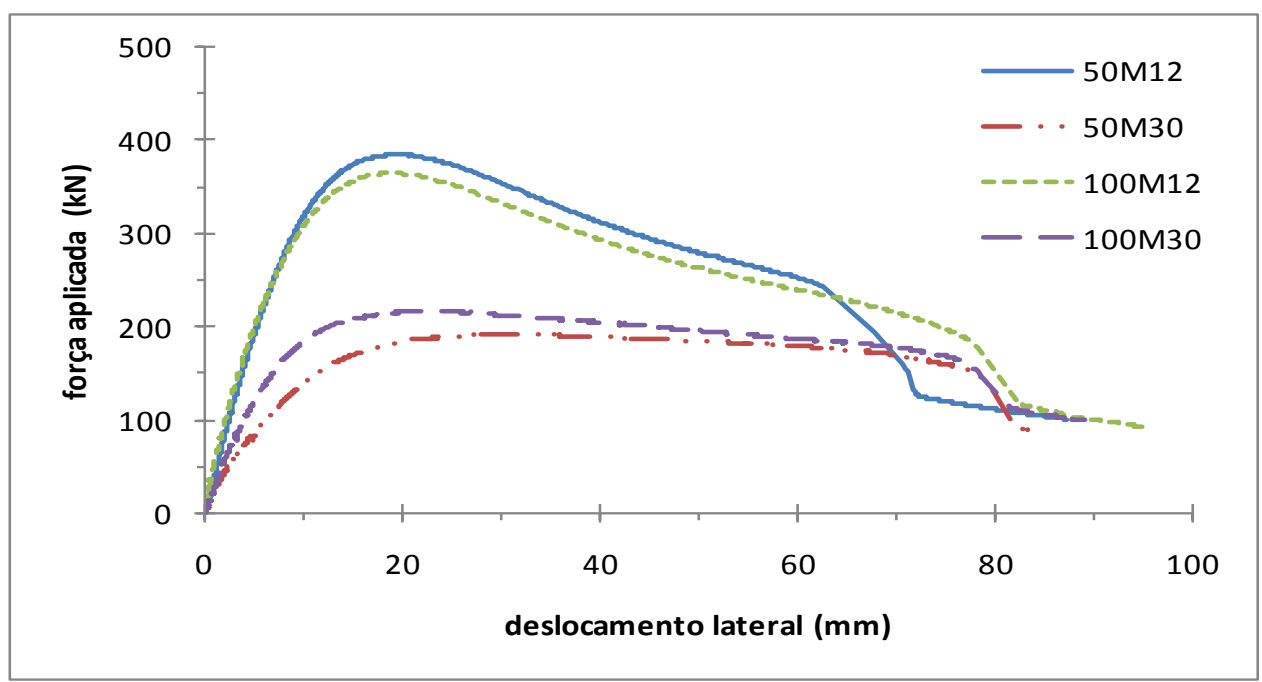

Fig. 6.30 - Diagrama força-deslocamento lateral para os pilares 50M12, 50M30, 100M12 e 100M30. 


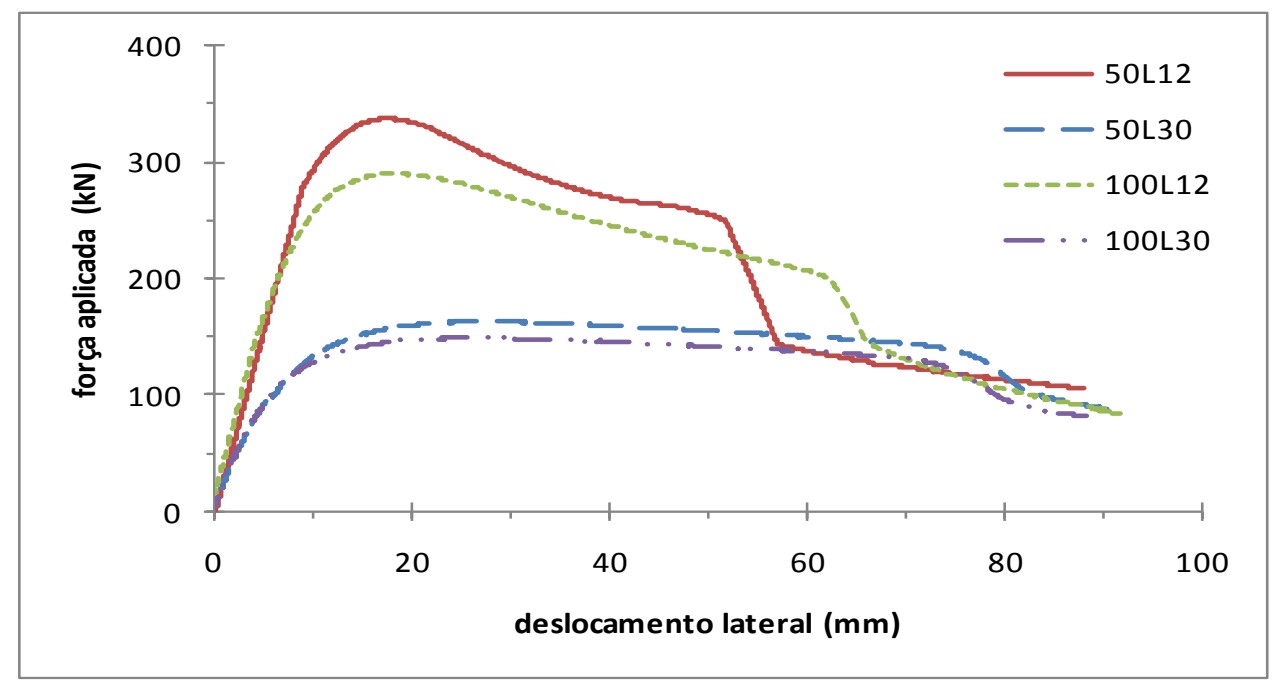

Fig. 6.31 - Diagrama força-deslocamento lateral para os pilares 50L12, 50L30, 100L12 e $100 \mathrm{~L} 30$.

Os valores dos deslocamentos laterais nas seções de meia altura dos pilares, que correspondem às forças últimas, não tiveram um padrão de comportamento em relação aos espaçamentos entre os estribos (ver Tabela 6.6), mas apresentaram valores muito próximos considerando o mesmo tipo de concreto e mesma excentricidade de força, exceto para os pilares 50M30 e 100M30, que pode ter ocorrido em virtude de excentricidade acidental. Este fato mostra que até a força última o efeito da ductilidade que proveniente do confinamento, sem poder quantificá-la, pelo menos para esta quantia de armadura transversal.

Para os pilares com excentricidade de força de $30 \mathrm{~mm}$, o incremento do deslocamento lateral após a força última foi vagaroso, demonstrando ductilidade, nestes pilares o deslocamento foi maior para os que tinham estribos a cada $5 \mathrm{~cm}$ até atingir a segunda diminuição de resistência.

Para os pilares com excentricidade de força de $12 \mathrm{~mm}$, o incremento do deslocamento lateral foi mais rápido (para o pilar 50H12 o incremento foi súbito), mas em todos os casos o deslocamento lateral pós-pico até atingir a segunda queda de resistência foi maior para os pilares com espaçamento de estribos de $10 \mathrm{~cm}$, mostrando maior ductilidade destes pilares até a ruptura do concreto.

Da mesma maneira que no item anterior, é possível observar que todos os pilares tiveram uma segunda queda na resistência (exceto o pilar 50H12, que teve um descolamento do cobrimento quase junto com a ruína do pilar). Também nas Fig. 6.29 até a Fig. 6.31, é possível notar que todos os pilares do mesmo tipo de concreto e mesma excentricidade, mas com espaçamento de estribos de $5 \mathrm{~cm}$, atingem forças últimas maiores que os pilares com estribos a cada $10 \mathrm{~cm}$ (exceto o pilar 50M30 que mostra uma força última menor que o pilar 
100M30, que como na exceção anterior, dos mesmos pilares, pode ser por causa de excentricidade acidental).

Outra verificação feita foi aproximar a deformação lateral dos pilares a uma curva representada por uma senoide, que é a deformada usualmente adotada. A Fig. 6.32 mostra esta verificação.

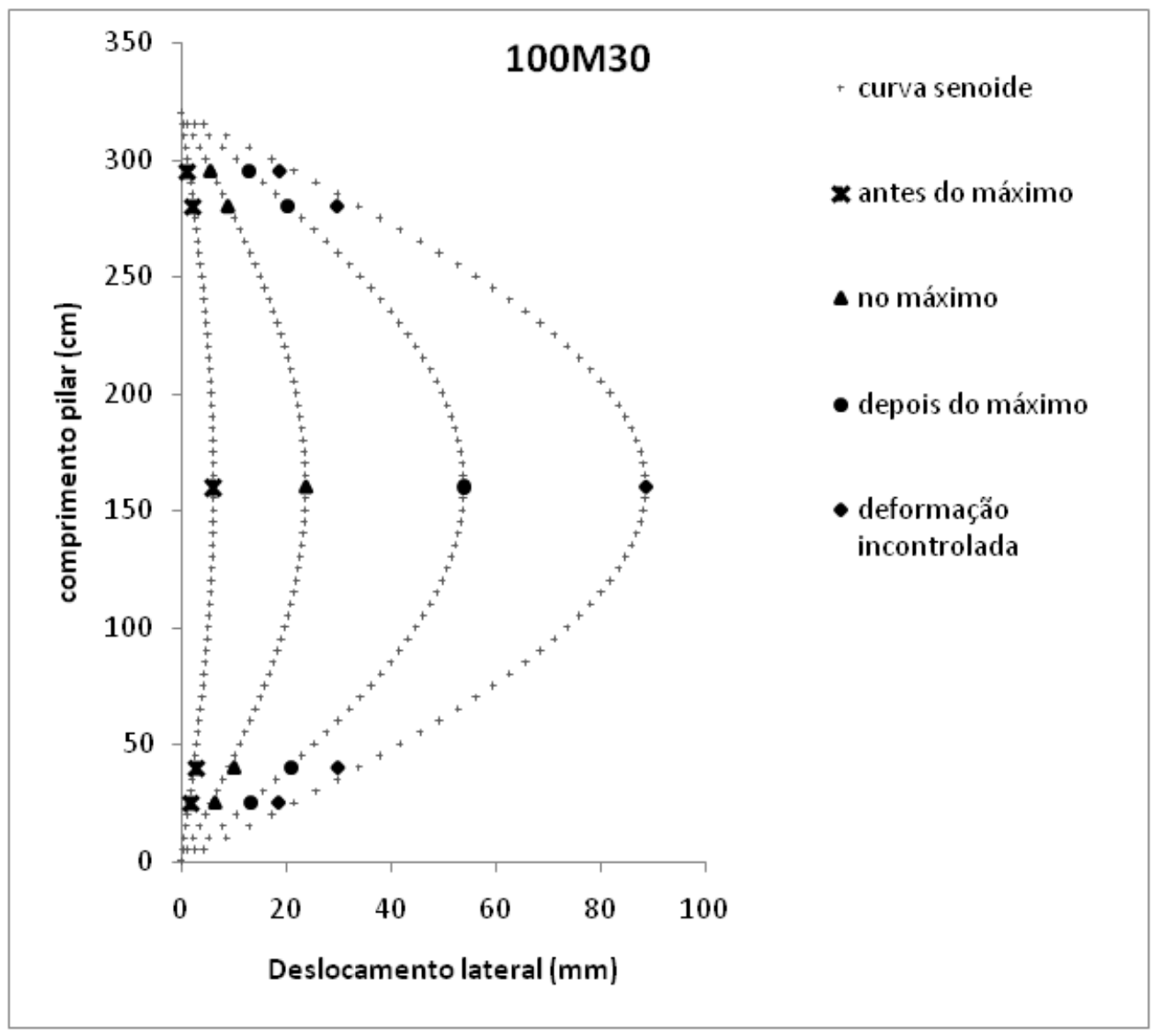

Fig. 6.32 - Comparação entre as deformadas obtidas nos ensaios e a forma senoide.

Para avaliar a NLG é necessário conhecer a elástica, que pode ser aproximada por diversas curvas $y=f(x)$, a mais empregada é a senoide. Se for admitida que a deformada do pilar tenha forma senoidal, sua expressão é $y=e_{2} \cdot \operatorname{sen}\left(\pi \cdot x / L_{e}\right)$, nesta: e é a flecha máxima obtida do ensaio nas suas diferentes etapas, $\mathrm{x}$ uma determinada posição do pilar (neste caso posição dos LVDTs 1 até 5) e y o valor do deslocamento do pilar nestas posições.

Pode-se constatar que existe uma boa aproximação entre a forma senoidal da deformada e os valores obtidos nos ensaios. Somente depois da ruptura do concreto é que não acontece esta correspondência. Para os outros pilares a aproximação é a mesma. 


\subsubsection{Estudo das deformações específicas das armaduras transversais}

Foi verificado que o único lado do estribo que apresentava uma regularidade em seu comportamento era o lado de maior comprimento situado junto à face mais comprimida do pilar, aquele que tinha colado o SG3 (extensômetro de resistência No 3 - Fig. 5.19). As Fig. 6.33 até a Fig. 6.35 mostram o diagrama força-deformação específica dos mesmos. Os lados curtos dos estribos e os lados longos do estribo junto à face inicialmente menos comprimida estavam muito pouco solicitados.

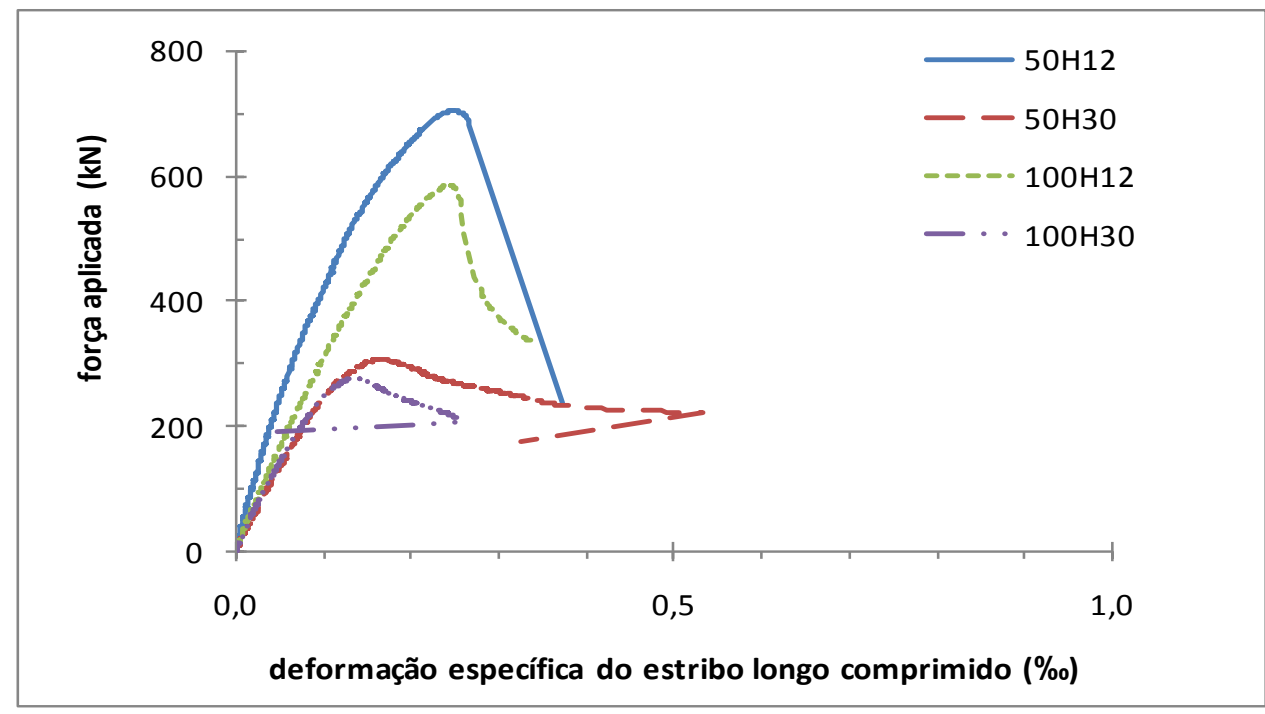

Fig. 6.33 - Diagrama força-deformação específica dos estribos dos pilares 50H12, 50H30, $100 \mathrm{H} 12$ e $100 \mathrm{H} 30$.

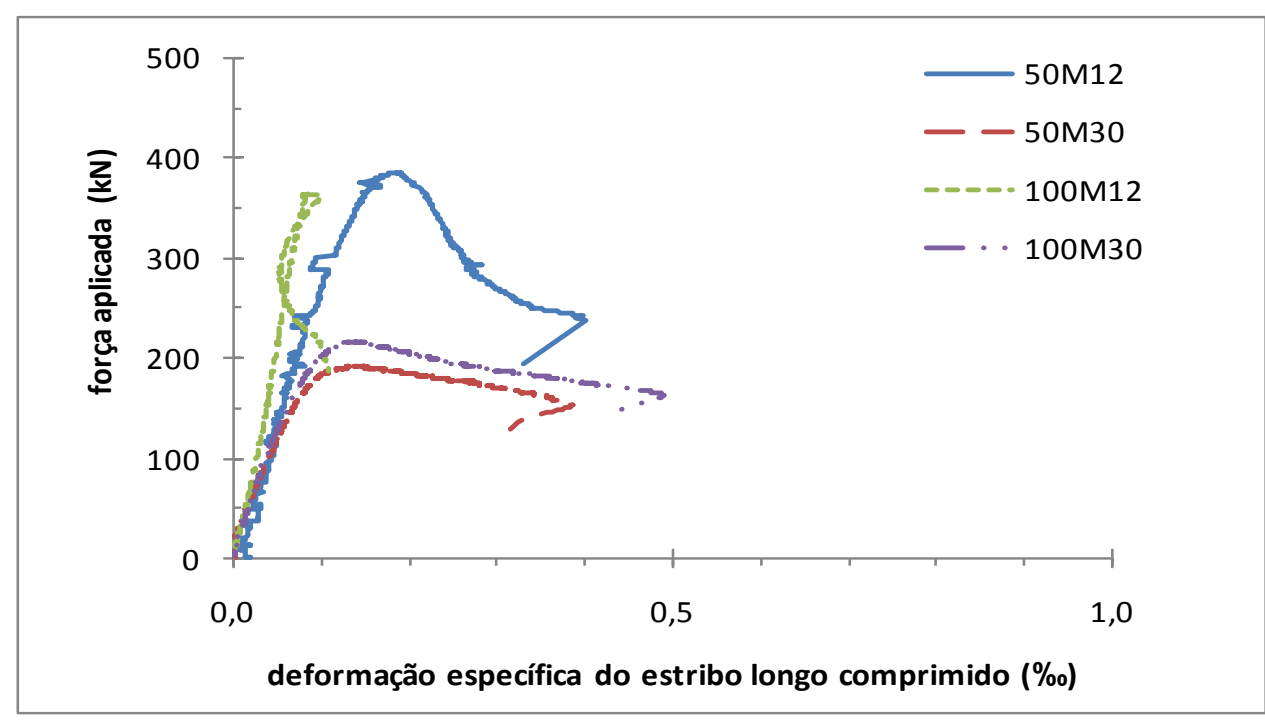

Fig. 6.34 - Diagrama força-deformação específica dos estribos dos pilares 50M12, 50M30, $100 \mathrm{M} 12$ e 100M30. 


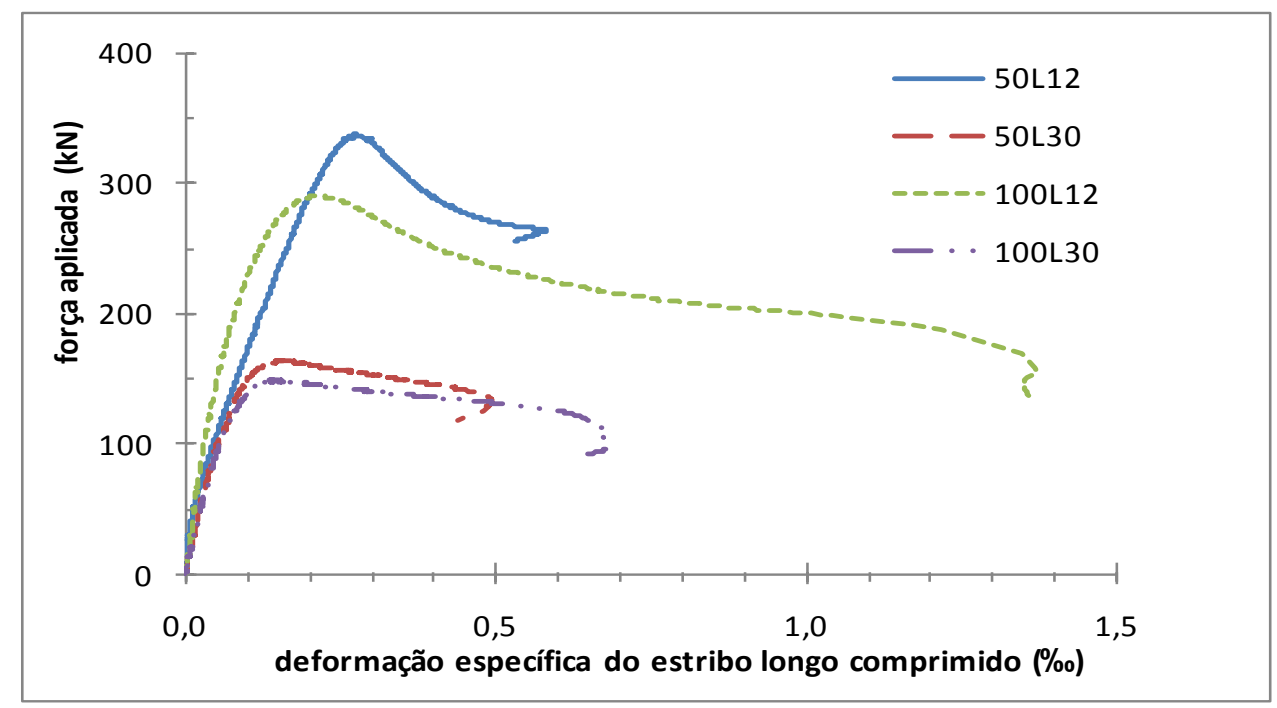

Fig. 6.35 - Diagrama força-deformação específica dos estribos dos pilares 50L12, 50L30, $100 \mathrm{~L} 12$ e $100 \mathrm{~L} 30$.

Analisando as Fig. 6.33 até a Fig. 6.35 é possível verificar que, quando atingida a força última, os lados longos comprimidos dos estribos estavam muito pouco solicitados, em todos os casos as deformações específicas eram menor do que 0,3\%, mas é possível verificar que os pilares com estribos menos espaçados apresentam estes lados dos estribos um pouco mais deformados. Após a força última, houve um pequeno incremento na deformação.

Para os pilares com concreto convencional os estribos possibilitaram maior deformação pós-pico (estes concretos permitem uma maior expansão lateral), mas tampouco conduziram ao escoamento dos estribos. Como o confinamento é função da tensão de trabalho dos estribos, pode-se concluir que o confinamento era quase inexistente e após a deformação de ruptura do concreto mais comprimido houve uma perda da deformação específica do estribo.

Possivelmente para pilares, sujeitos a forças de compressão relativamente maiores, os estribos podem funcionar como elemento confinante, o que aconteceria com pilares de menor esbeltez e pequena excentriciade de força.

\subsubsection{Estudo das deformações específicas das armaduras longitudinais}

As Fig. 6.36 até a Fig. 6.38 mostram os diagramas das deformações específicas das armaduras longitudinais. 


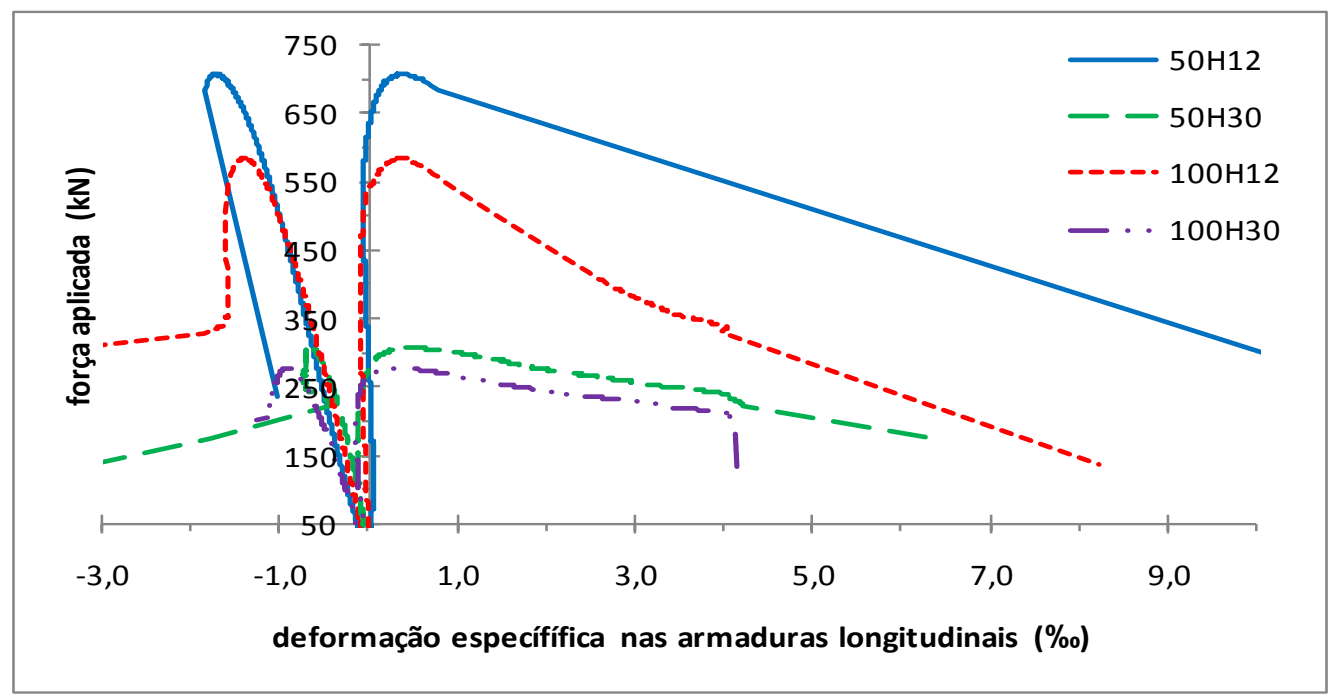

Fig. 6.36 - Diagrama força-deformação específica das armaduras longitudinais dos pilares $50 \mathrm{H} 12,50 \mathrm{H} 30,100 \mathrm{H} 12$ e $100 \mathrm{H} 30$.

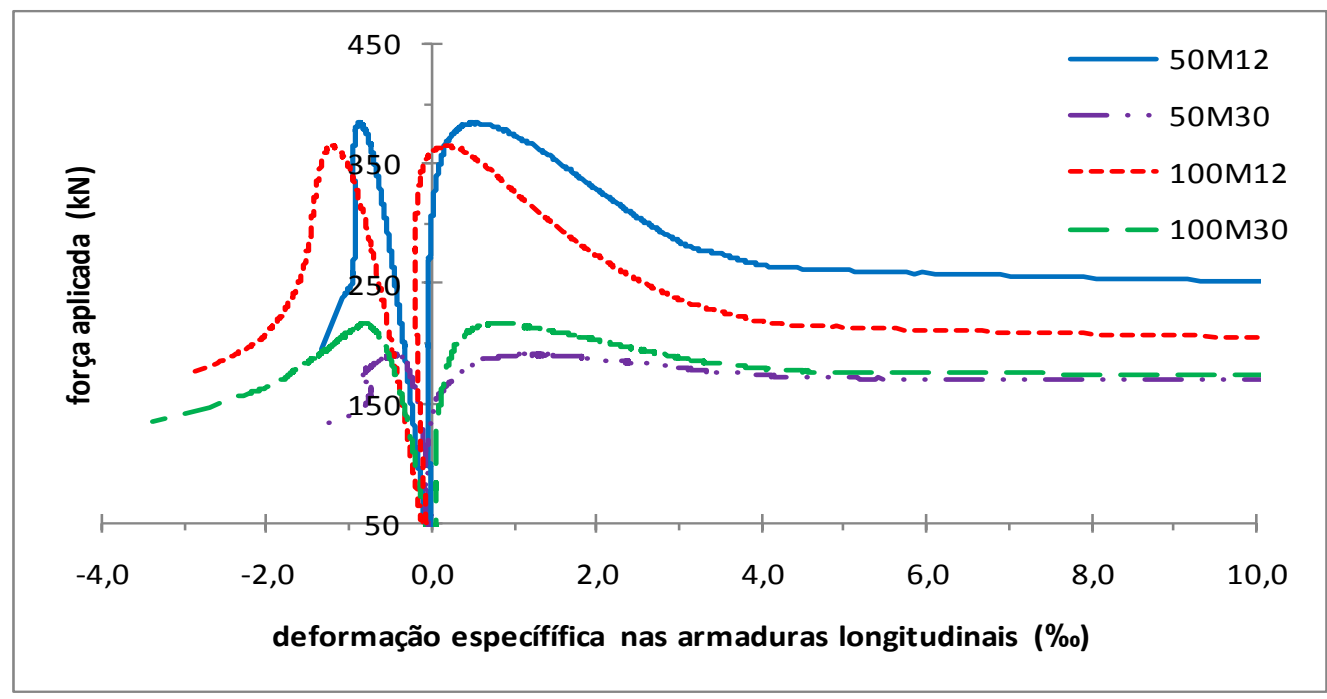

Fig. 6.37 - Diagrama força-deformação específica das armaduras longitudinais dos pilares 50M12, 50M30, 100M12 e 100M30. 


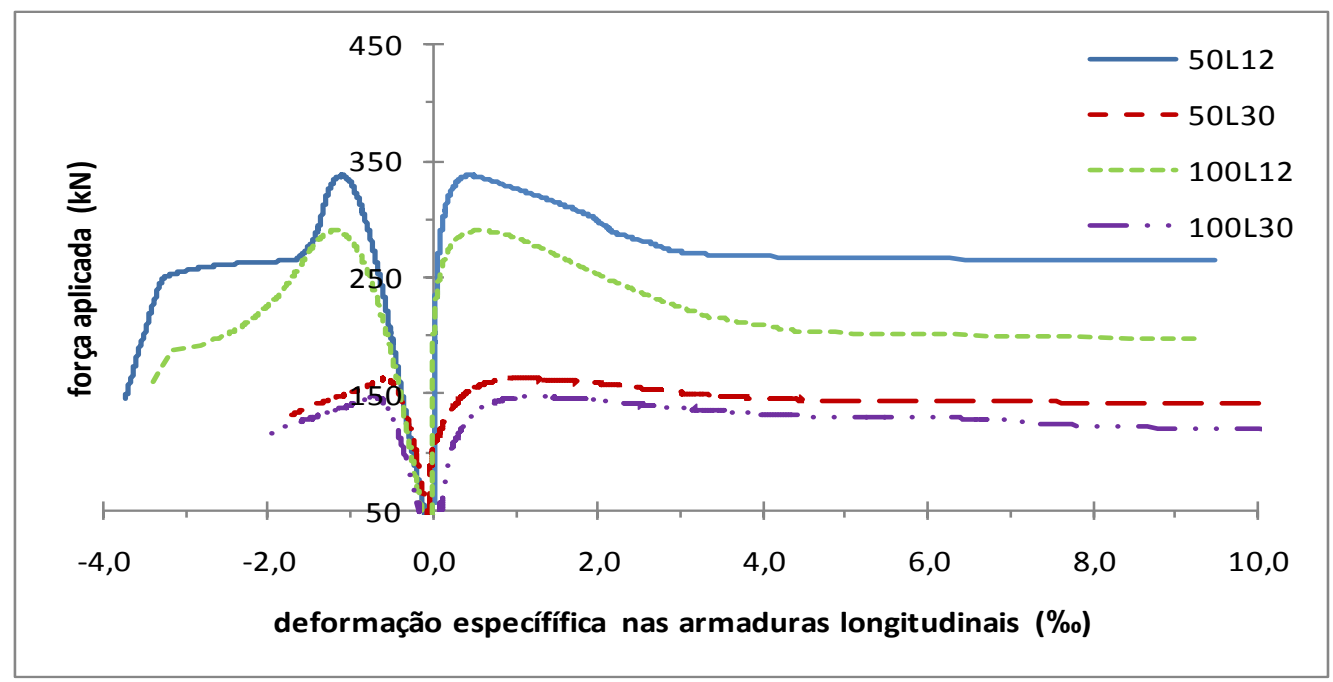

Fig. 6.38 - Diagrama força-deformação específica das armaduras longitudinais dos pilares 50L12, 50L30, 100L12 e 100L30.

É possível verificar que inicialmente, todas as barras dos pilares encontravam-se comprimidas. Perto da força máxima, as barras dos pilares com excentricidade de força de 12 mm que se encontram junto à face inicialmente menos comprimida passaram a ficar tracionadas. Para os pilares com $30 \mathrm{~mm}$ de excentricidade, as barras junto à face inicialmente menos comprimida passaram a ficar tracionadas, a partir de aproximadamente da metade da força última.

$\mathrm{Na}$ força última nenhuma das armaduras longitudinais atingiu o escoamento. Após a força última todas as barras atingirem o escoamento, aquelas junto à face inicialmente mais comprimida escoaram à compressão e aquelas junto à face inicialmente menos comprimida escoaram à tração, isto acontece porque após a força última (após a ruína por instabilidade), os deslocamentos laterais aumentaram.

Para os pilares com excentricidade de força de $12 \mathrm{~mm}$, perto de aproximadamente $70 \%$ da força última se deu inicio ao processo de fissuração na face inicialmente menos comprimida, e para os pilares com excentricidade de $30 \mathrm{~mm}$, a fissuração começou quando a força aplicada estava por volta de aproximadamente $40 \%$ (exceto para os pilares com concreto do tipo $\mathrm{H}$ que tiveram o mesmo comportamento dos pilares com pequena excentricidade). A ruptura do concreto correspondeu à formação de uma rótula plástica à meia altura do pilar.

Os pilares com excentricidade de força de $30 \mathrm{~mm}$ e com concreto do tipo $\mathrm{H}$ tiveram suas armaduras longitudinais, junto à face inicialmente menos comprimida, comprimidas até perto da força última, o motivo é porque estes pilares têm sua rigidez à flexão incrementada, em face do aumento significativo do modulo de deformação do concreto igual a $48 \mathrm{GPa}$ (ver Tabela 6.2 para os pilares do tipo H), tornando-se menos deformáveis. 


\subsubsection{Estudo das deformações específicas do concreto na face mais comprimida}

As deformações específicas do concreto foram medidas com o extensômetro de resistência $\mathrm{N}^{\mathrm{o}} 10$ (Fig. 5.19). As Fig. 6.39 até a Fig. 6.41 mostram os resultados dos ensaios.

$\mathrm{Na}$ força última, todos os pilares tiveram a deformação específica do concreto junto à face mais comprimida, menor que a deformação específica máxima $\left(\varepsilon_{\mathrm{c} 1}\right)$ correspondente ao valor máximo do diagrama tensão-deformação específica do corpo-de-prova, após a força última a deformação do concreto continuou aumentando até atingir o valor máximo e, depois, romper. O pilar 50H12 não chegou a atingir a deformação específica limite porque ocorreu o destacamento do cobrimento quase ao mesmo tempo em que ocorreu a ruína do pilar, foi o único pilar que teve uma ruína repentina.

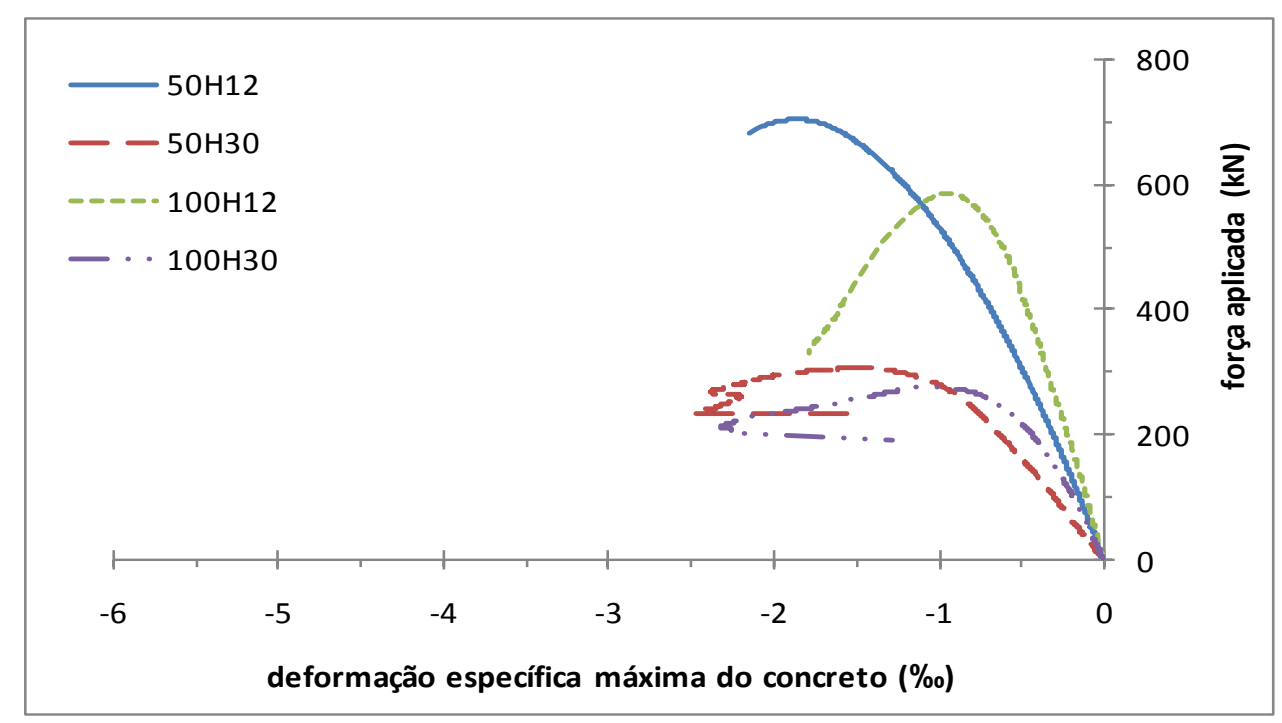

Fig. 6.39 - Diagrama força-deformação específica máxima do concreto dos pilares 50H12, $50 \mathrm{H} 30,100 \mathrm{H} 12$ e $100 \mathrm{H} 30$. 


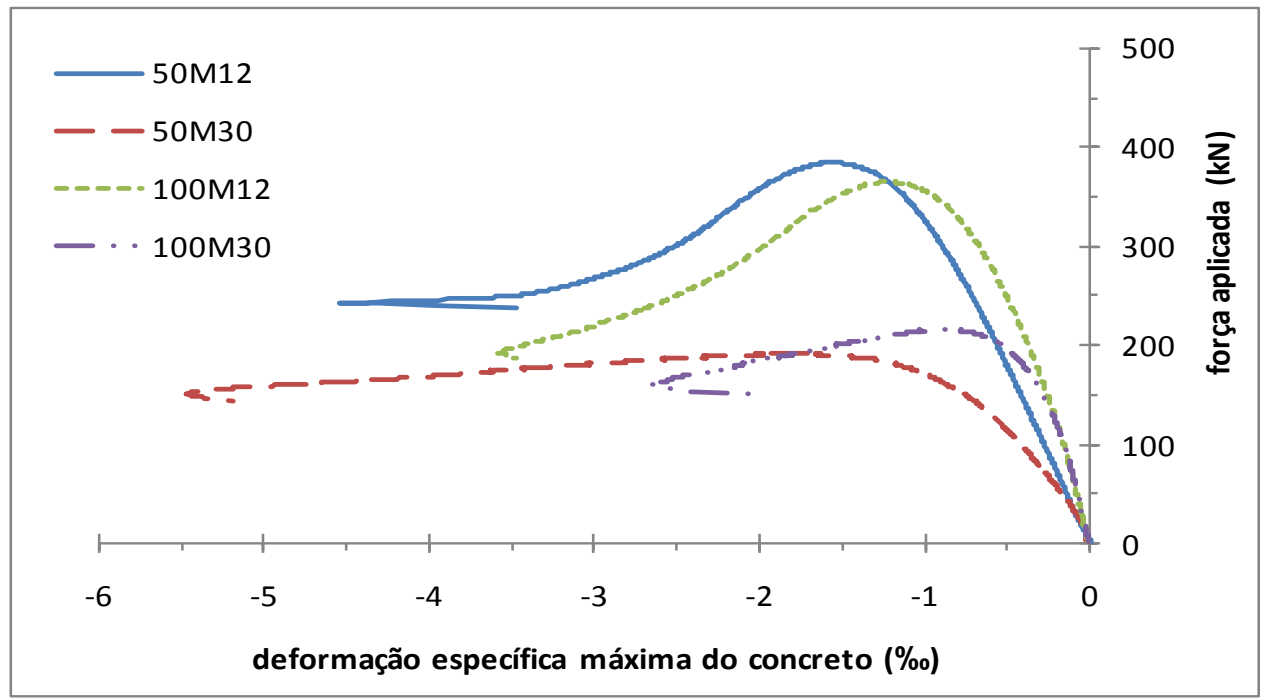

Fig. 6.40 - Diagrama força-deformação específica máxima do concreto dos pilares 50M12, 50M30, 100M12 e 100M30.

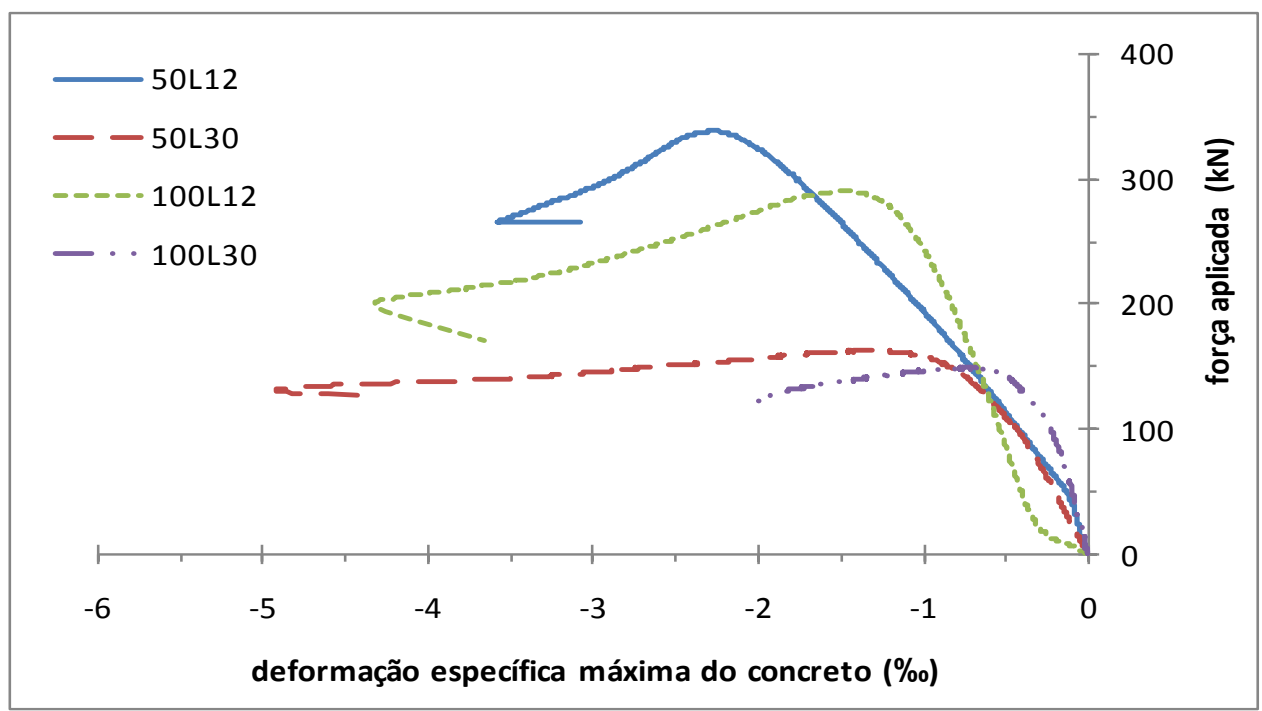

Fig. 6.41 - Diagrama força-deformação específica máxima do concreto dos pilares 50L12, 50L30, 100L12 e 100L30.

Analisando os gráficos das Fig. 6.39 até a Fig. 6.41 é possível verificar quais os pilares que tiveram um destacamento repentino do cobrimento ou a ruptura do concreto. Aqueles pilares em que o concreto não atingiu o limite de resistência, mesmo no ramo pós-pico do diagrama é que podem ter tido o destacamento do cobrimento.

Observando a Fig. 6.39 notam-se que todos os pilares com concreto do tipo $\mathrm{H}$ aparentemente tiveram um destacamento do cobrimento, mesmo aqueles com excentricidade de força de $30 \mathrm{~mm}$ (isto não foi observado durante o ensaio no pilar 100H30). Depreende-se que nas Fig. 6.40 e Fig. 6.41 os pilares 100M30 e 100L30 aparentemente também tiveram destacamento do cobrimento, mas como estes pilares não possuem um plano natural de 
separação do cobrimento, o resultado mostrado no gráfico pode ter sido provocado por algum erro de leitura ou de excentricidade acidental.

O valor da deformação específica última do concreto é o valor quando o concreto rompe na face mais comprimida ou que teve um descolamento do cobrimento. A Fig. 6.42 apresenta os valores da deformação específica última do concreto dos pilares em função do tipo de concreto e da excentricidade da força.

Pela Fig. 6.42 é possível verificar que existe certa regularidade no incremento na deformação específica última para os pilares com menor espaçamento entre estribos e com excentricidade de força maior (50L30 e 50M30). Para os pilares com concreto do tipo H não houve incremento na deformação específica última com o menor espaçamento entre estribos. Os pilares com excentricidade de força de $12 \mathrm{~mm}$ não apresentaram um padrão no incremento da deformação específica última.

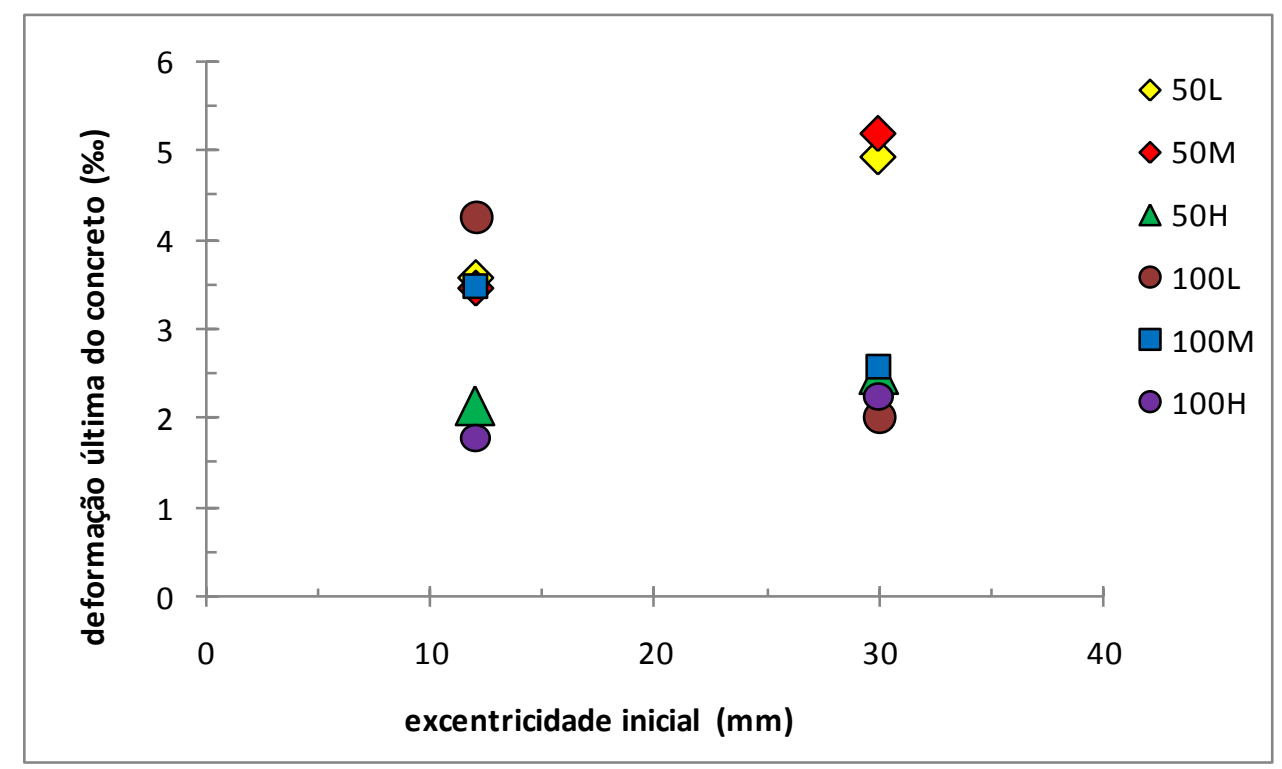

Fig. 6.42 - Valores da deformação específica última do concreto em função da excentricidade da força.

Na Fig. 6.42 mostram-se os valores das deformações específicas que atingiram os concretos dos pilares quando estes romperam à compressão, e no caso dos pilares com concreto tipo $\mathrm{H}$ e pequena excentricidade de força o descolamento do cobrimento.

\subsubsection{Estudo das variações do diagrama de deformações da seção transversal}

É possível verificar como o diagrama de deformações foi modificando durante o transcurso dos ensaios para os diferentes pilares. A Fig. 6.43 mostra estas variações. 


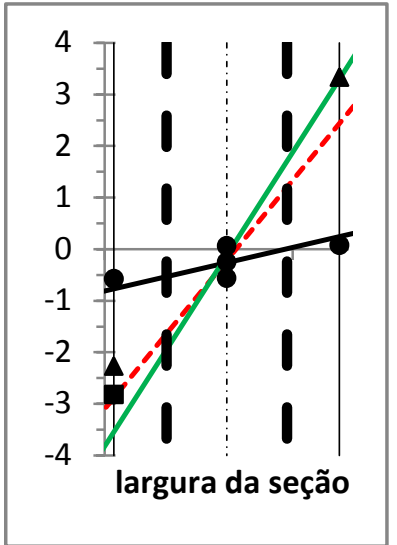

Pilar 50L12

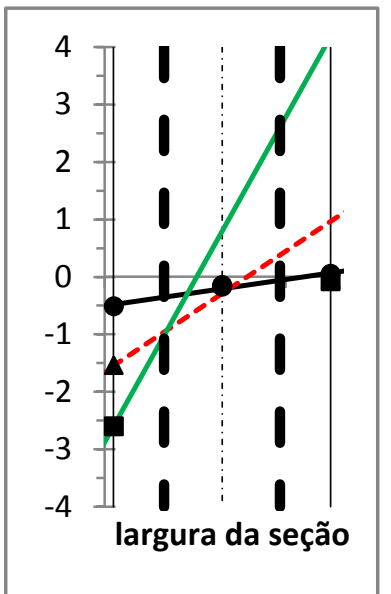

Pilar 50M12

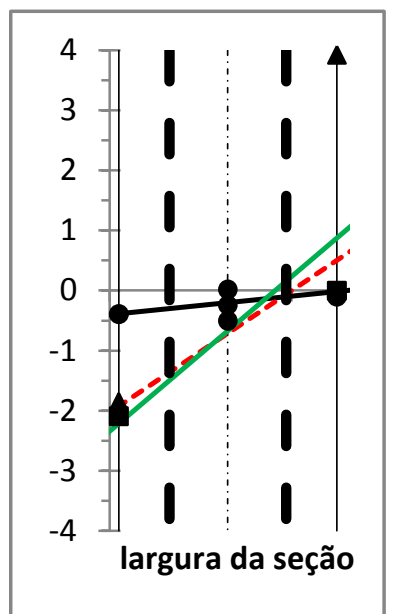

Pilar 50H12

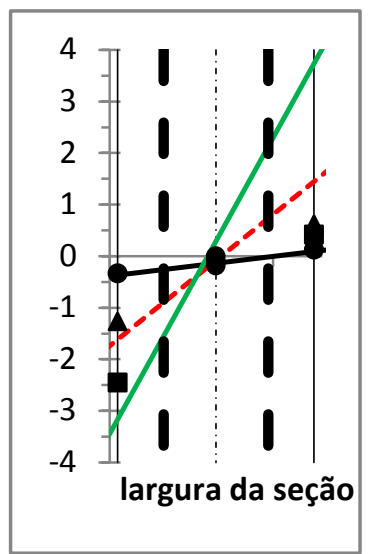

Pilar 50L30

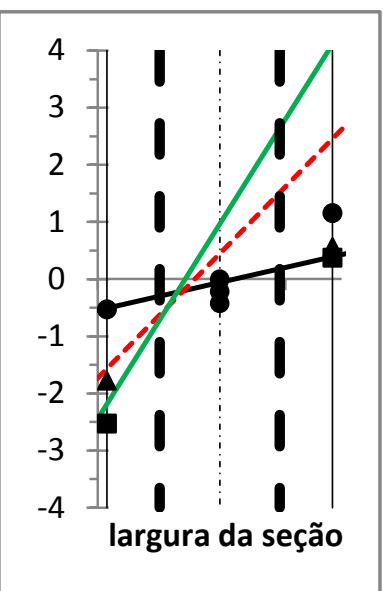

Pilar 50M30

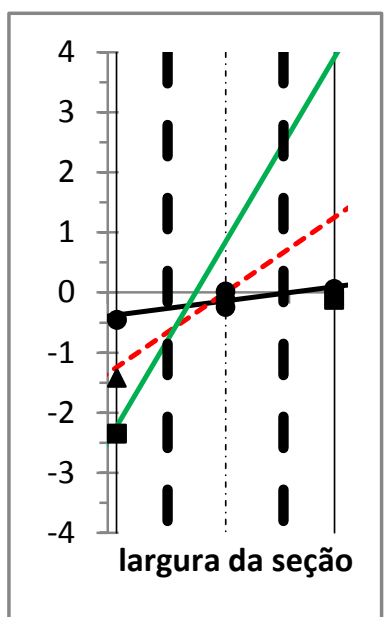

Pilar 50H30

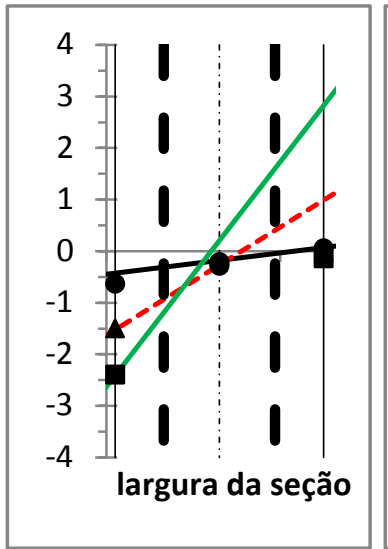

Pilar 100L12

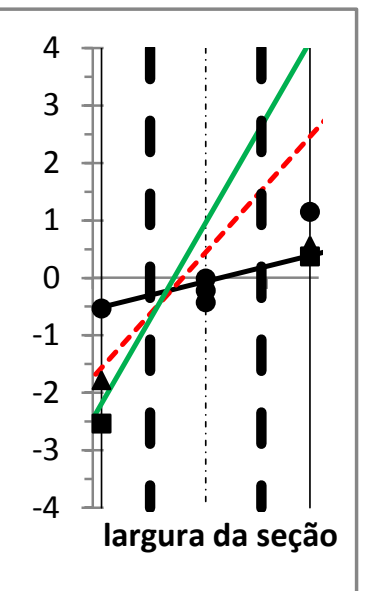

Pilar 100M12

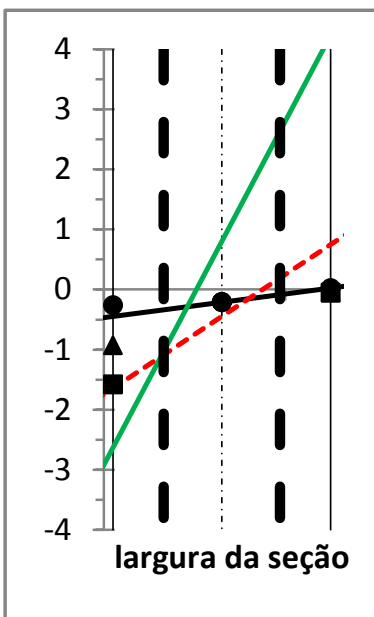

Pilar 100H12

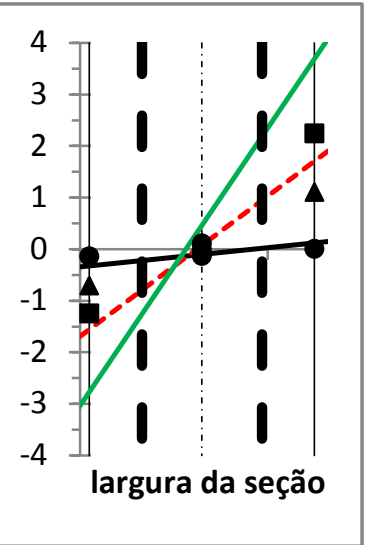

Pilar 100L30

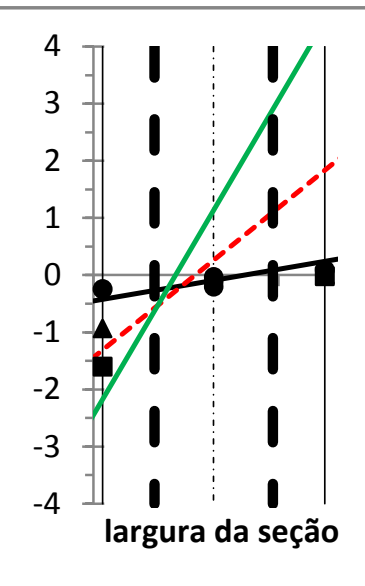

Pilar 100M30

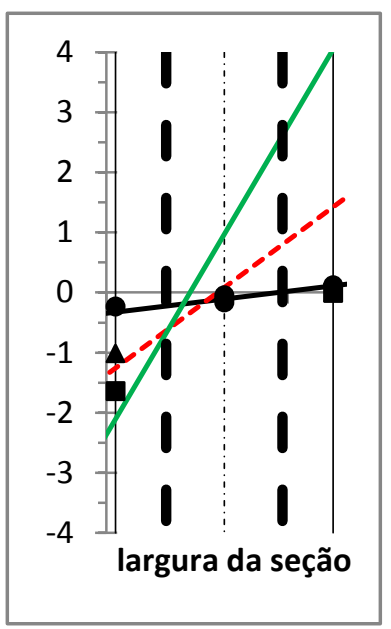

Pilar $100 \mathrm{H} 30$

Fig. 6.43 - Diagramas de deformações da seção transversal (linha preta contínua antes da força máxima, linha vermelha na força máxima e linha verde após a força máxima; a linha preta segmentada corresponde à posição das armaduras).

Os diagramas mostrados com as linhas foram obtidos com as leituras dos LVDT6 e LVDT7 (Fig. 5.19) e as marcações dos pontos (o círculo corresponde à medição antes da 
força última, o triângulo na força última e o quadrado após a força última) com as leituras dos extensômetros SG9 e SG10, posicionados nas faces inicialmente menos comprimida e mais comprimida respectivamente e os do eixo da seção transversal com a média das leituras do SG11 e SG12. Existe uma pequena diferença entre estes resultados, que pode ter acontecido em virtude das imprecisões naturais ao posicionar os extensômetros e LVDTs, este último com maior variabilidade (fora do prumo, erro ao colocar nas cantoneiras de sustentação, Fig. 5.19).

Observa-se na Fig. 6.43 que os extensômetros posicionados na face inicialmente menos comprimida e nas faces laterais foram perdidos antes da força máxima, possivelmente porque uma fissura atravessou a sua base de medição.

Quando a linha neutra passou dentro da seção foram geradas tensões de tração e posteriormente fissuras na face inicialmente menos comprimida (depois tracionada). Em todos os pilares, a face inicialmente menos comprimida ficou tracionada mesmo antes de atingida a força última, isto porque a flexão já era relevante mesmo antes da força última que foi acompanhada pela formação de fissuras.

Após o início das fissuras o comportamento dos pilares com excentricidade de força de $12 \mathrm{~mm}$ passou a ser igual a dos pilares com excentricidade de força de $30 \mathrm{~mm}$. Houve um progressivo incremento das fissuras na direção da face mais comprimida e ao longo do pilar, com suas fissuras junto à seção transversal que continha o estribo ou perto destes.

$\mathrm{Na}$ figura anterior pode ser observado que para os pilares com pequena excentricidade de força a linha neutra se encontrava fora de seção até perto da força última, é possível também observar como a linha neutra se desloca na direção da face comprimida, diminuindo a região comprimida e, com isto, provocando a ruptura do concreto. Nos pilares com excentricidades iniciais de força maiores, a diminuição da região comprimida é mais rápida, provocando uma força de ruptura menor no concreto (ver Fig. 6.39 até 6.41).

As Fig. 6.44 até Fig. 6.46 mostram como modifica a deformação específica do eixo centroidal durante o ensaio. 


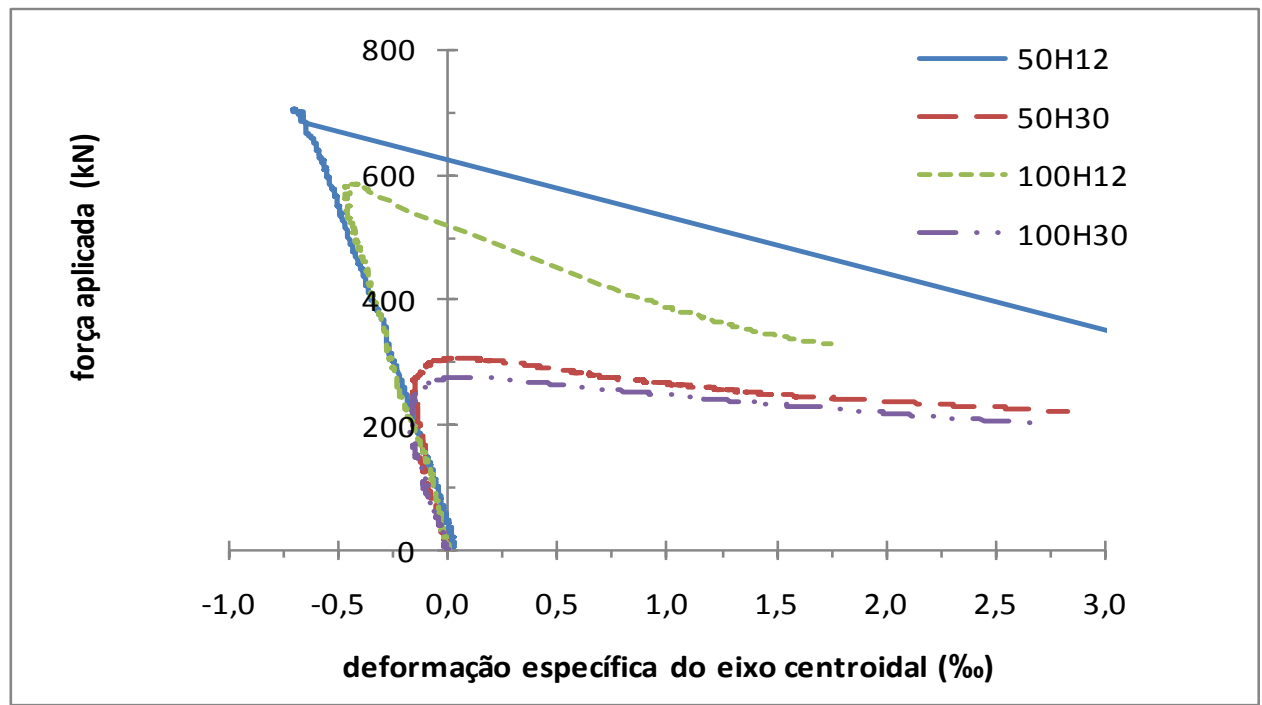

Fig. 6.44 - Diagrama força-deformação do eixo centroidal dos pilares 50H12, 50H30, $100 \mathrm{H} 12$ e $100 \mathrm{H} 30$.

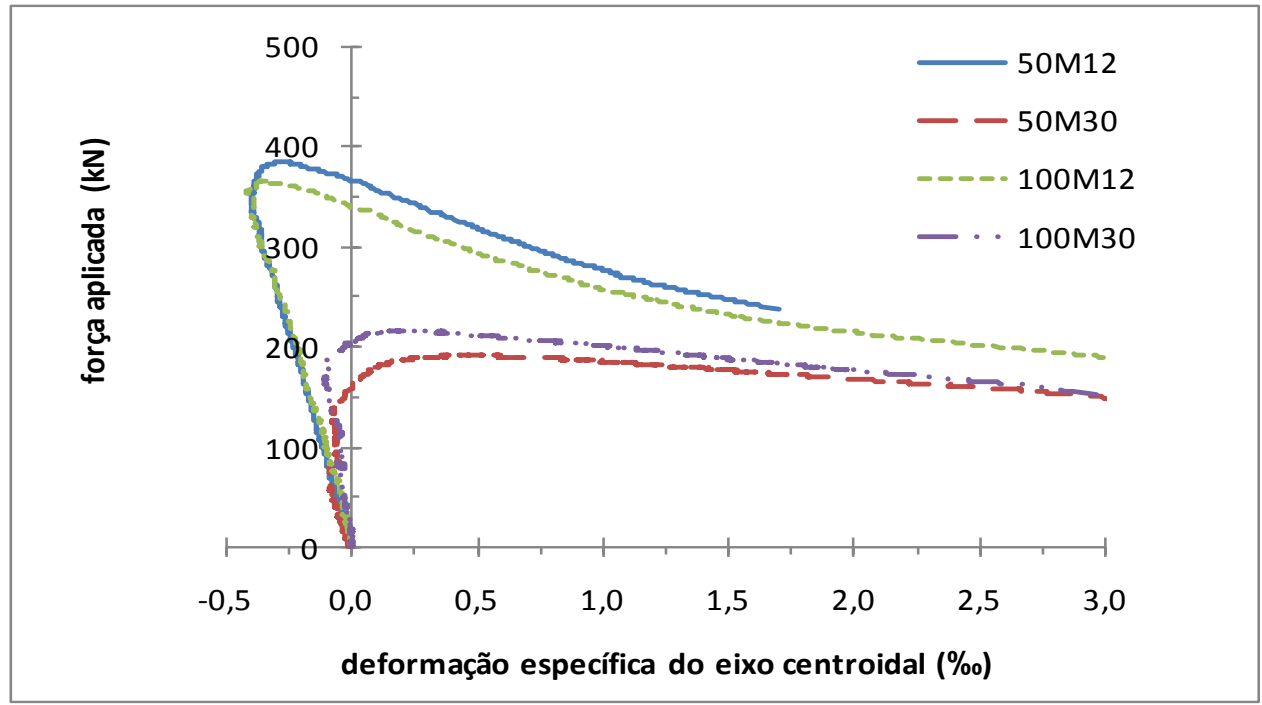

Fig. 6.45 - Diagrama força-deformação do eixo centroidal dos pilares 50M12, 50M30, $100 \mathrm{M} 12$ e $100 \mathrm{M} 30$. 


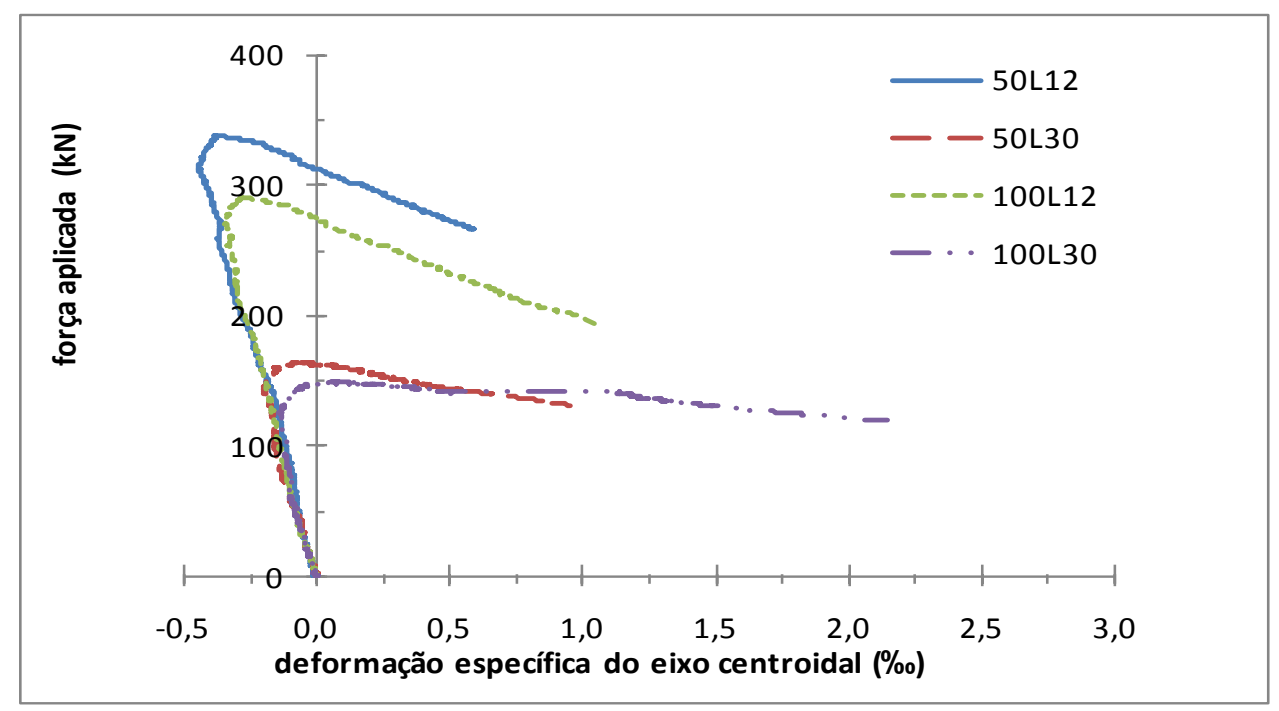

Fig. 6.46 - Diagrama força-deformação do eixo centroidal dos pilares 50L12, 50L30 e 100L12 e 100L30.

Nestas figuras é possível notar que a deformação específica do concreto no eixo centroidal foi incrementando cada vez mais em forma linear, ao chegar perto da força última houve uma diminuição do incremento, possivelmente isto tenha acontecido porque houve uma diminuição da rigidez do pilar em face da presença das fissuras. Para a força última o valor da deformação específica do concreto ficou menor (exceto no pilar 50H12, no qual sua deformação específica não diminui, porque a sua formação de fissuras aconteceu perto da força última), após a ruína dos pilares o efeito da flexão começou a prevalecer, isto provocou uma inversão do sinal da deformação específica do concreto do eixo centroidal, que no ramo pós-pico ficou tracionado.

O concreto da região do eixo centroidal ficou sempre comprimido até a força última, exceto para os pilares 50M30 e 100M30, nos quais para a força máxima o eixo centroidal se encontrava já tracionado. A perda de rigidez à flexão destes pilares foi prematura, possivelmente por defeitos do material. Considerando que apresentavam um maior módulo de deformação que os pilares com concreto do tipo L não deveriam ter perda de rigidez, sendo que o pilar 50M30 foi o que apresentou maior perda de rigidez, possivelmente por excentricidade acidental.

Estas observações coincidem com os diagramas de deformação específica mostrados na Fig. 6.43. 


\subsubsection{Resumo dos resultados obtidos nos ensaios}

Para efeitos de comparação de resultados entre os diferentes pilares, foram tabelados os valores das principais respostas obtidos nos ensaios correspondentes à força última. A Tabela 6.6 mostra estes valores.

Tabela 6.6 - Resumo dos resultados correspondentes à força última.

\begin{tabular}{|c|c|c|c|c|c|c|}
\hline Serie & $\begin{array}{l}\text { Força última } \\
F_{\text {ult,exp }}(k N)\end{array}$ & $\varepsilon_{\mathrm{s} 1}(\% 0)$ & $\varepsilon_{\mathrm{s} 2}(\% 0)$ & $\varepsilon_{c}(\% 0)$ & $\begin{array}{c}\text { deslocamento } \\
\text { lateral }(\mathrm{mm})\end{array}$ & $\begin{array}{l}\text { deslocamento } \\
\text { vertical }(\mathrm{mm})\end{array}$ \\
\hline $50 \mathrm{H} 12$ & 706,94 & $-0,05$ & $-1,35$ & $-1,85$ & 20,69 & 5,38 \\
\hline $50 \mathrm{H} 30$ & 306,73 & 0,45 & $-0,69$ & $-1,42$ & 19,88 & 4,33 \\
\hline $50 \mathrm{M} 12$ & 385,56 & 0,30 & $-1,04$ & $-1,53$ & 18,88 & 3,96 \\
\hline $50 \mathrm{M} 30$ & 191,13 & 1,55 & $-0,72$ & $-1,78$ & 30,78 & 5,46 \\
\hline 50L12 & 338,93 & 0,28 & $-1,15$ & $-2,27$ & 17,21 & 4,32 \\
\hline 50L30 & 163,89 & 1,04 & $-0,58$ & $-1,26$ & 25,98 & 3,84 \\
\hline $100 \mathrm{H} 12$ & 586,54 & 0,10 & $-1,16$ & $-1,32$ & 18,60 & 4,31 \\
\hline $100 \mathrm{H} 30$ & 277,59 & 0,66 & $-0,82$ & $-1,01$ & 20,11 & 3,35 \\
\hline $100 \mathrm{M} 12$ & 364,88 & 0,37 & $-1,21$ & $-1,23$ & 19,13 & 4,24 \\
\hline $100 \mathrm{M} 30$ & 216,39 & 0,91 & $-0,79$ & $-0,93$ & 23,75 & 3,94 \\
\hline 100L12 & 290,56 & 0,54 & $-1,20$ & $-1,49$ & 18,44 & 3,29 \\
\hline 100L30 & 148,86 & 1,17 & $-0,71$ & $-0,71$ & 25,29 & 4,07 \\
\hline
\end{tabular}

$\mathrm{Na}$ Tabela $6.6 \varepsilon_{\mathrm{sc}}$ e $\varepsilon_{\mathrm{st}}$ são as deformações específicas das armaduras longitudinais comprimidas e tracionadas quando os pilares atingiram as forças últimas, $\varepsilon_{\mathrm{c}}$ é a deformação específica do concreto na face mais comprimida. Como indicado anteriormente, pela Tabela 6.6 é possível observar que nenhuma das armaduras longitudinais (junto à face inicialmente mais comprimida ou menos comprimida) atingiu o escoamento na etapa relativa a força última.

Verificando os valores da deformação específica do concreto na face mais comprimida $\varepsilon_{\mathrm{c}}$, em todos os pilares os valores menores que as deformações limites correspondente ao pico da curva tensão-deformação específica, com exceção do pilar 50L12, que está com um valor maior, mas menor que o valor da deformação específica última. Em face do exposto e considerando os comentários do parágrafo anterior é possível afirmar que as peças ensaiadas não atingiram seu limite por ruptura dos materiais (nem por deformação específica excessiva das armaduras longitudinais ou ruptura do concreto) e, sim, houve a ruína por instabilidade das peças.

Analisando a Tabela 6.6 a armadura do pilar 50H12 junto à face menos comprimida estava ainda comprimida para a força última, isto mostra que na etapa relativa à ruína do pilar a compressão prevalecia, e como a ruína foi repentina, o confinamento não contribuiu na ductilidade. 
Em relação à ductilidade, para alguns pilares com menor espaçamento entre estribos, existe um maior deslocamento lateral, indicando maior ductilidade, mas, outros pilares mostram o contrario, logo, é possível concluir que não é possível medir a ductilidade de pilares com distintas configurações considerando os resultados de deslocamentos.

Todos os pilares com as mesmas armaduras e mesmo concreto, mas excentricidade de força de $30 \mathrm{~mm}$ tiveram maior deslocamento lateral que os que tinham $12 \mathrm{~mm}$ (exceto para os pilares 50H12 e 50H30 nos quais aconteceu o contrario, mas seus valores estão próximos, possivelmente pela elevada rigidez à flexão prevaleceu a compressão e a presença de excentricidades acidentais influiu nos valores).

Em relação aos deslocamentos verticais não foi possível verificar um padrão no incremento nos deslocamentos, não podendo concluir-se nada em relação à ductilidade por estas respostas. No item 6.2.8 serão calculados os parâmetros de ductilidade para os diferentes pilares.

Em relação ao valor da força última, foi verificado um incremento do valor da força última para os pilares que tinham as mesmas características, mas menor espaçamento entre estribos. Este padrão não mostra o pilar do tipo M com excentricidade de força de $30 \mathrm{~mm}$, pois seus valores indicam o contrário, talvez por causa de excentricidade acidental, pois os resultados teóricos mostraram que os pilares eram muito sensíveis a pequenas variações de excentricidade.

Considerando os resultados dos ensaios, a Tabela 6.7 mostra que o momento máximo não corresponde necessariamente à força última, isto em virtude dos efeitos de segunda ordem, mesmo com forças no ramo pós-pico menores, há um incremento considerável dos deslocamentos laterais. 
Tabela 6.7 - Resumo dos momentos máximos

\begin{tabular}{|c|c|c|c|c|c|}
\hline Serie & $\begin{array}{c}\text { Força última } \\
F_{\text {ult,exp }}(\mathrm{kN})\end{array}$ & $\begin{array}{c}\text { Momento para } \\
F_{\text {ult,exp }}(\mathrm{kN} . \mathrm{m})\end{array}$ & $\begin{array}{c}\text { Momento } \\
\text { máximo }(\mathrm{kN} . \mathrm{m})\end{array}$ & $\begin{array}{c}\text { Força corresp. ao } \\
\text { momento máximo }(\mathrm{kN})\end{array}$ & $\begin{array}{c}\text { Relação entre } \\
\text { momentos }\end{array}$ \\
\hline \hline $50 \mathrm{H} 12$ & 706,94 & 23,11 & 26,31 & 684,44 & 1,14 \\
\hline $50 \mathrm{H} 30$ & 306,73 & 15,30 & 23,15 & 244,62 & 1,51 \\
\hline $50 \mathrm{M} 12$ & 385,56 & 11,90 & 18,26 & 251,49 & 1,53 \\
\hline $50 \mathrm{M} 30$ & 191,13 & 11,62 & 16,93 & 169,01 & 1,46 \\
\hline $50 \mathrm{~L} 12$ & 338,93 & 9,90 & 15,96 & 248,21 & 1,61 \\
\hline $50 \mathrm{~L} 30$ & 163,89 & 9,17 & 14,63 & 142,80 & 1,60 \\
\hline $10 \mathrm{HH} 12$ & 586,54 & 17,95 & 24,57 & 339,24 & 1,37 \\
\hline $10 \mathrm{H} 30$ & 277,59 & 13,91 & 20,55 & 218,45 & 1,48 \\
\hline $100 \mathrm{M} 12$ & 364,88 & 11,36 & 17,60 & 222,95 & 1,55 \\
\hline $100 \mathrm{M} 30$ & 216,39 & 11,63 & 17,81 & 172,29 & 1,53 \\
\hline $10 \mathrm{~L} 12$ & 290,56 & 8,85 & 14,96 & 204,11 & 1,69 \\
\hline $10 \mathrm{~L} 30$ & 148,86 & 8,23 & 13,11 & 129,94 & 1,59 \\
\hline
\end{tabular}

O momento máximo obtido nos ensaios são aproximadamente $50 \%$ maiores que os momentos correspondentes á força última, exceto para o pilar 50H12, neste não existiu um comportamento pós-pico, houve um deslocamento lateral repentino logo após a força última. Este comportamento poderia ser interpretado como um indicador de ductilidade, porque houve um incremento gradual dos deslocamentos laterais após a instabilidade do pilar. Considerando que a máquina INSTRON aplicava forças com controle de deslocamentos e no ramo pós-pico a força é função da rigidez à flexão do pilar, esta rigidez, estaria de alguma maneira, considerando a ductilidade. Os pilares com concreto do tipo L apresentam maiores relações momento máximo-momento correspondente à força última, e os pilares com concreto do tipo $\mathrm{H}$ as menores (Tabela 6.7), que poderia ser um indicador da ductilidade própria destes tipos de concreto. Não há um padrão em relação ao espaçamento entre estribos.

Com base nos resultados dos ensaios outro estudo comparativo foi feito para verificar qual é o incremento da força última dos pilares ao empregar CAR no lugar de concretos convencionais, para o mesmo espaçamento entre estribos e a mesma excentricidade. A Tabela 6.8 mostra esta comparação.

Tabela 6.8 - Incremento na capacidade dos pilares com o incremento da resistência do concreto.

\begin{tabular}{|c|c|c|c|c|c|}
\hline \multirow{4}{*}{$\begin{array}{l}\text { Relação } \\
\text { entre } \\
\text { resistências } \\
\text { de concreto }\end{array}$} & \multicolumn{4}{|c|}{ Espaçamento entre estribos } & \multirow{4}{*}{$\begin{array}{l}\text { Incremento na } \\
\text { resistência do } \\
\text { concreto }\end{array}$} \\
\hline & \multirow{2}{*}{\multicolumn{2}{|c|}{$\begin{array}{c}5 \mathrm{~cm} \\
\text { excentricidade }(\mathrm{mm})\end{array}$}} & \multirow{2}{*}{\multicolumn{2}{|c|}{$\begin{array}{c}10 \mathrm{~cm} \\
\text { excentricidade }(\mathrm{mm})\end{array}$}} & \\
\hline & & & & & \\
\hline & 12 & 30 & 12 & 30 & \\
\hline$\overline{\mathrm{H} / \mathrm{L}}$ & 2,09 & 1,87 & 2,02 & 1,86 & 3,33 \\
\hline $\mathrm{H} / \mathrm{M}$ & 1,83 & 1,60 & 1,61 & 1,28 & 1,67 \\
\hline $\mathrm{M} / \mathrm{L}$ & 1,14 & 1,17 & 1,25 & 1,45 & 2,00 \\
\hline
\end{tabular}


A Tabela 6.8 mostra que o aumento da capacidade resistente dos pilares é menor, proporcionalmente ao aumento da resistência do concreto para os pilares de CAR em relação ao concreto convencional, o que mostra a pouca vantagem ao empregar CAR em pilares esbeltos. Pela mesma tabela verifica-se que pode existir vantagem, ao empregar concretos de elevada resistência (tipo $\mathrm{H}$ ) em relação a concretos de elevada resistência (tipo M). Estes valores são para as esbeltezes dos pilares que foram ensaiados, para maiores esbeltezes a relação ficaria menor e para menores esbeltezes o contrario. Como não foram realizados ensaios com pilares de outras esbeltezes, não é possível determinar uma regra analítica.

Foi realizada outra comparação entre os diferentes tipos de concretos verificando sua diminuição de resistência com o incremento na excentricidade de força. A Tabela 6.9 mostra estas variações.

Tabela 6.9 - Variação da resistência dos pilares em função da variação da excentricidade de força.

\begin{tabular}{|c|c|c|c|c|c|c|}
\hline \multirow{3}{*}{$\begin{array}{c}\text { Relação entre } \\
\text { excentricidades }\end{array}$} & \multicolumn{4}{|c|}{ Espaçamento entre estribos } \\
\cline { 2 - 7 } & \multicolumn{3}{|c|}{$5 \mathrm{~cm}$} & \multicolumn{3}{c|}{$10 \mathrm{~cm}$} \\
\cline { 2 - 7 } & $\mathrm{H}$ & $\mathrm{M}$ & $\mathrm{L}$ & $\mathrm{H}$ & $\mathrm{M}$ & $\mathrm{L}$ \\
\cline { 2 - 7 } & 0,50 de concreto & 0,48 & 0,47 & 0,59 & 0,51 \\
\hline \hline $\mathrm{e}$
\end{tabular}

A Tabela 6.9 mostra que para todos os tipos de concreto a capacidade do pilar diminui em $50 \%$ quando a excentricidade da força aumenta em $150 \%$, considerando um mesmo tipo de concreto e um mesmo espaçamento entre estribos. Os resultados obtidos com estas duas excentricidades indicam que o espaçamento entre estribos não influi no incremento da capacidade de força dos pilares quando o confinamento aumenta (para as taxas volumétricas da armadura transversal dos ensaios).

\subsubsection{Estudo da ductilidade dos pilares esbeltos}

Para a avaliação da ductilidade dos pilares à compressão excêntrica foi empregado o método descrito por Galeano e Vignoli (2008) que definem a ductilidade para o caso de uma força $\mathrm{F}$ aplicada excentricamente. Normalmente é analisada a região de formação de uma rótula plástica na qual são definidas as relações força axial $(\mathrm{F})$ x deformação específica média no centróide da seção transversal $\left(\varepsilon_{\mathrm{m}}\right)$ e o momento $(\mathrm{M})$ provocado por $\mathrm{F}$ x curvatura $(\theta)$. É possível analisar a ductilidade da região para diferentes excentricidades de força examinando o trabalho realizado pela força $F$ (ver item 3.5.2). As Fig. 6.47 até Fig. 6.49 mostra os 
diagramas força axial-deformação específica combinada obtida dos resultados dos ensaios e que é definida pela Eq. 3.57.

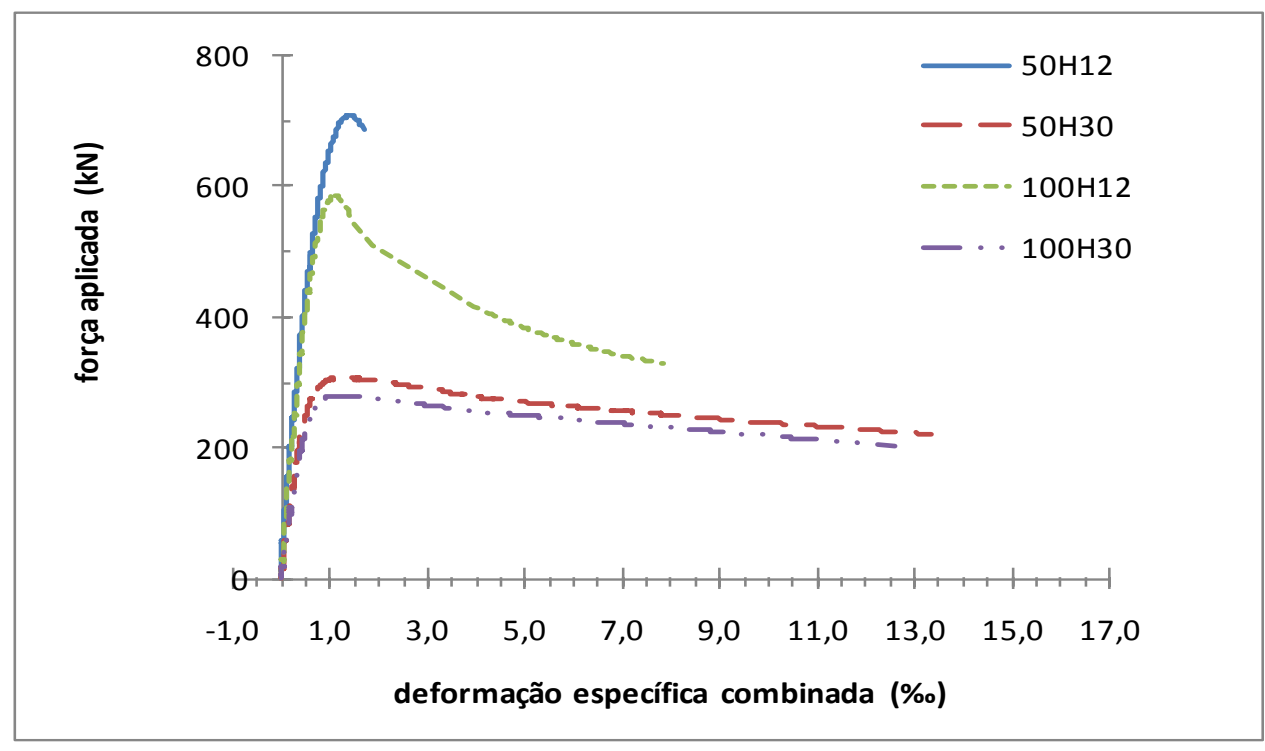

Fig. 6.47 - Diagrama força-deformação específica combinada dos pilares 50H12, 50H30, $100 \mathrm{H} 12$ e $100 \mathrm{H} 30$.

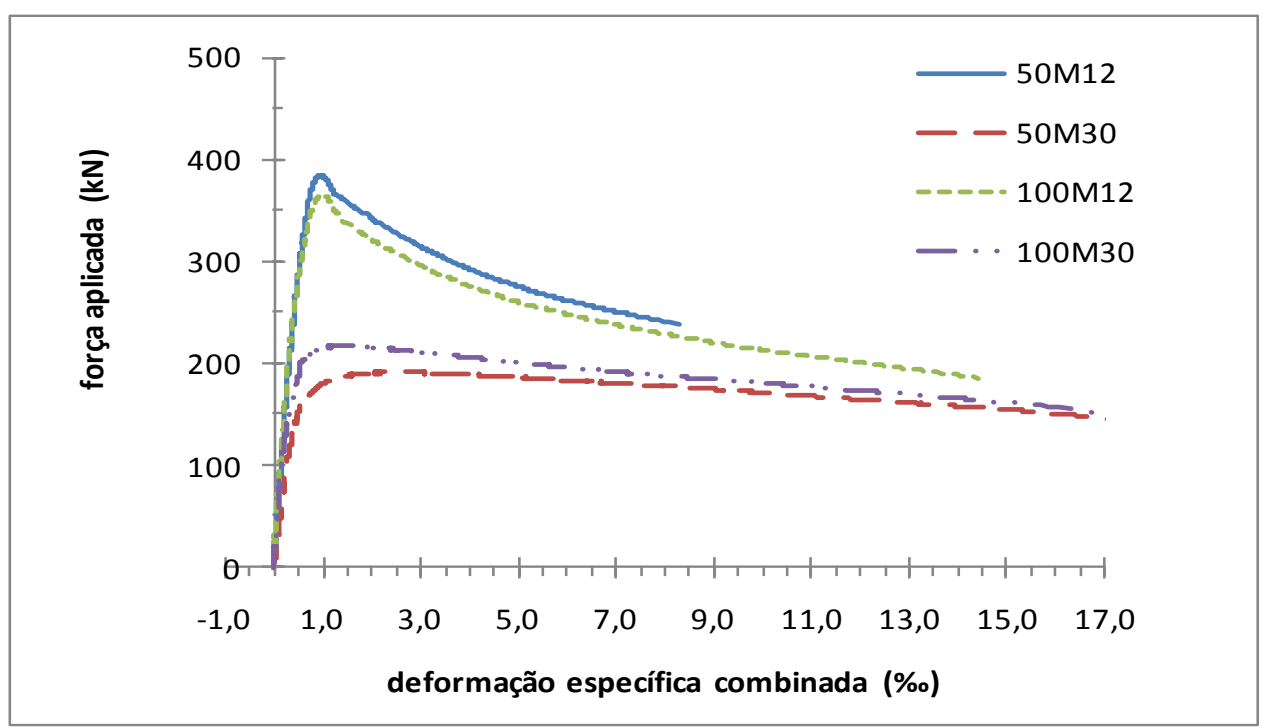

Fig. 6.48 - Diagrama força-deformação específica combinada dos pilares 50M12, 50M30, $100 \mathrm{M} 12$ e 100M30. 


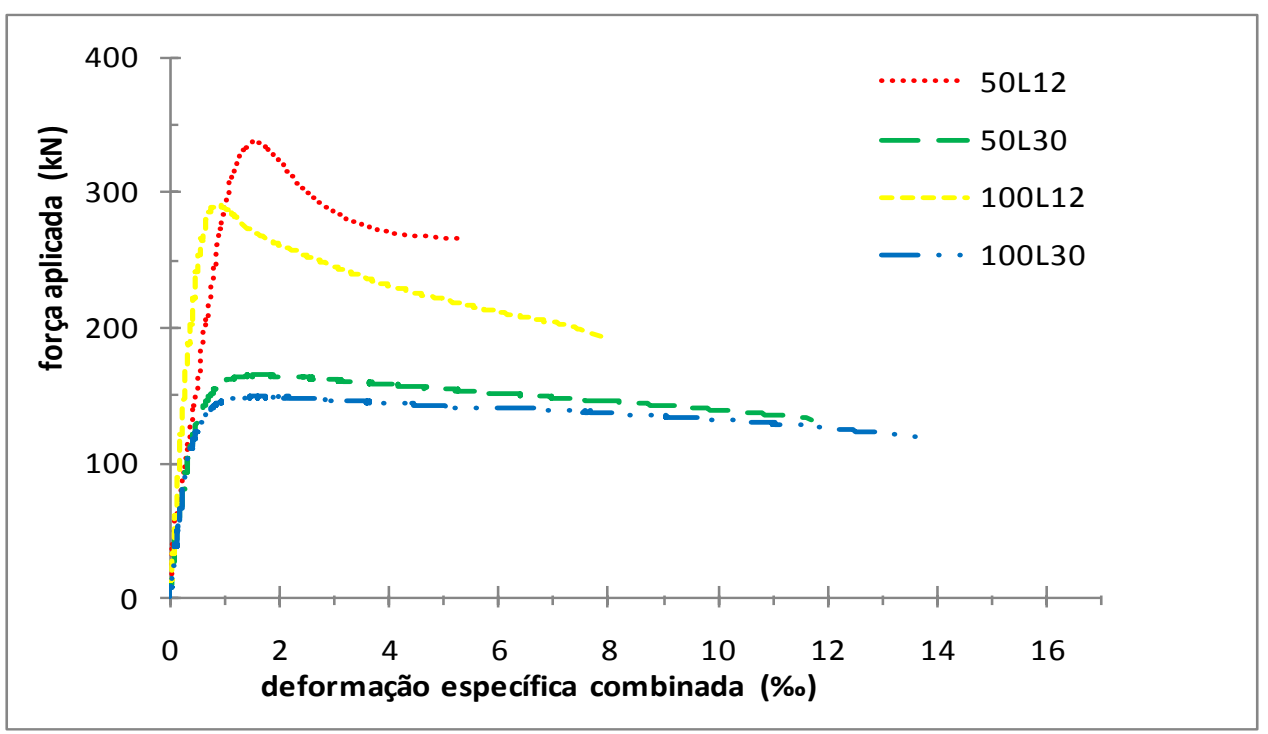

Fig. 6.49 - Diagrama força-deformação específica combinada dos pilares 50L12, 50L30,

$$
100 \mathrm{~L} 12 \text { e } 100 \mathrm{~L} 30 .
$$

O parâmetro de ductilidade empregado é obtido da geometria dos gráficos e é definido pela Eq. 3.58 (para o significado das expressões ver item 3.5.2). A Fig. 6.50 mostra a variação dos parâmetros de ductilidade em função da excentricidade inicial, do tipo de concreto e do espaçamento entre estribos.

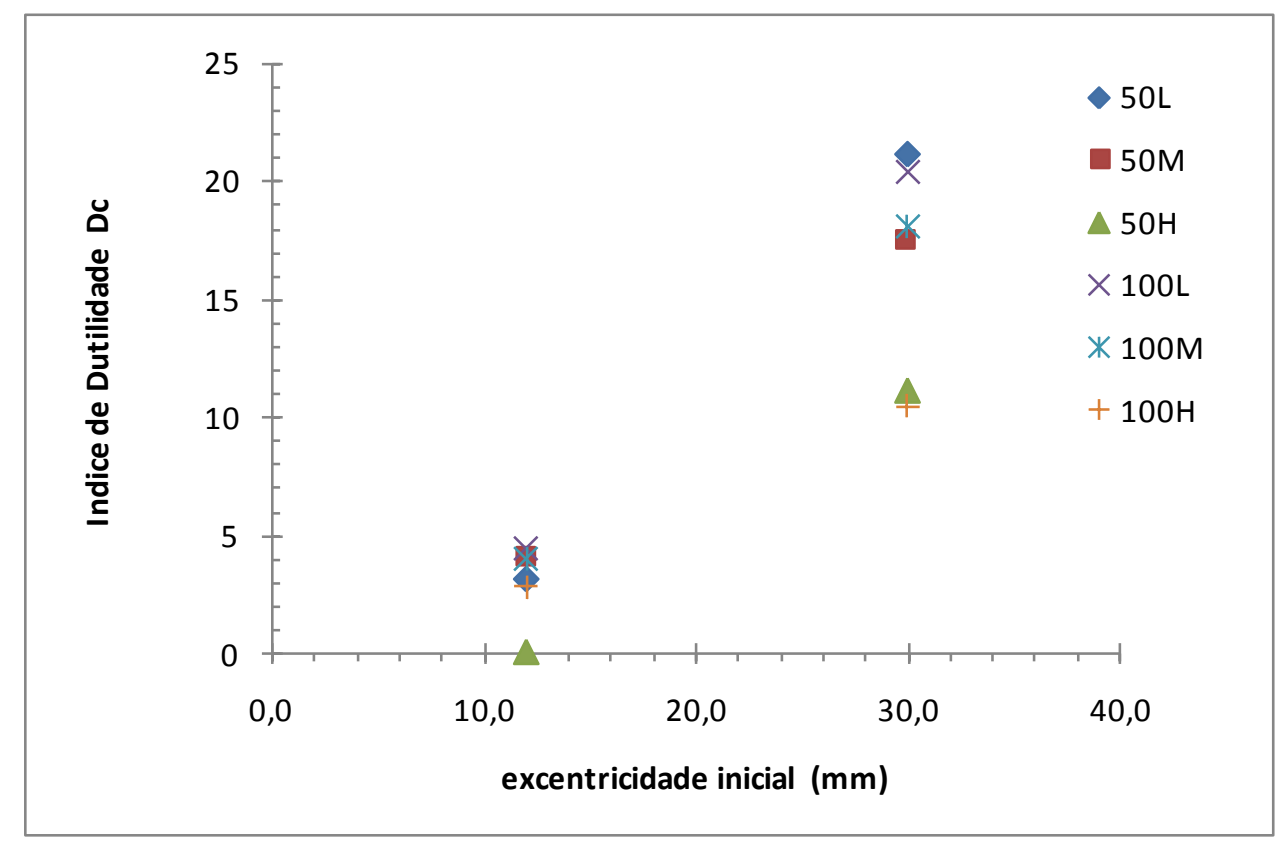

Fig. 6.50 - Parâmetro de ductilidade.

A Tabela 6.10 mostra os cálculos intermédios na obtenção do parâmetro de ductilidade D. 
Tabela 6.10 - Parâmetro da ductilidade $\mathrm{D}_{\mathrm{c}}$ (ver item 3.5.2).

\begin{tabular}{|c|c|c|c|c|c|c|}
\hline Serie & $\begin{array}{c}\text { Força última } \\
F_{\text {ult,exp }}(\mathrm{kN})\end{array}$ & $0,75 \times \mathrm{F}_{\text {ult,exp }}$ & $\xi_{0,75}(\%)$ & $0,85 \times \mathrm{F}_{\text {ult,exp }}$ & $\begin{array}{c}\left(\xi_{0,85}\right) \text { pos- } \\
\text { pico }(\%)\end{array}$ & Dc \\
\hline \hline $50 \mathrm{H} 12$ & 706,94 & 530,21 & 0,85 & 600,90 & 0,00 & 0,00 \\
\hline $50 \mathrm{H} 30$ & 306,73 & 230,05 & 0,56 & 260,72 & 6,21 & 11,09 \\
\hline $50 \mathrm{M} 12$ & 385,56 & 289,17 & 0,63 & 327,73 & 2,55 & 4,05 \\
\hline $50 \mathrm{M} 30$ & 191,13 & 143,35 & 0,71 & 162,46 & 12,46 & 17,55 \\
\hline $50 \mathrm{~L} 12$ & 338,9 & 254,2 & 0,93 & 288,1 & 2,92 & 3,14 \\
\hline $50 \mathrm{~L} 30$ & 163,9 & 122,9 & 0,45 & 139,3 & 9,49 & 21,09 \\
\hline $10 \mathrm{H} 12$ & 586,54 & 439,91 & 0,75 & 498,56 & 2,10 & 2,80 \\
\hline $10 \mathrm{H} 30$ & 277,59 & 208,19 & 0,68 & 235,95 & 7,08 & 10,41 \\
\hline $100 \mathrm{M} 12$ & 364,88 & 273,66 & 0,63 & 310,15 & 2,38 & 3,78 \\
\hline $100 \mathrm{M} 30$ & 216,39 & 162,29 & 0,49 & 183,93 & 8,85 & 18,06 \\
\hline $100 \mathrm{~L} 12$ & 290,9 & 218,1 & 0,65 & 247,2 & 2,86 & 4,40 \\
\hline 10OL30 & 148,9 & 111,6 & 0,57 & 126,5 & 11,61 & 20,37 \\
\hline
\end{tabular}

Valores obtidos do parâmetro de ductilidade estão mostrados na Fig. 6.50, a qual indica que o parâmetro de ductilidade dos pilares com pequena excentricidade é menor que os de maior excentricidade (para o pilar 50H12 é inexistente, sem ductilidade), e que a influência é pequena ao considerar a resistência do concreto e o espaçamento entre estribos. Para a excentricidade de $30 \mathrm{~mm}$ há uma maior ductilidade para os concretos de menor resistência à compressão e os pilares com menores espaçamentos entre estribos incrementam um pouco o valor da ductilidade (exceto para os pilares 50M30 e 100M30 que ocorreu o contrario), existe um padrão de ductilidade.

Com relação aos pilares com pequena excentricidade de força o padrão permanece exceto para os pilares 50L12 e 100L12 que ocorreu o contrario, como anteriormente comentado estes pilares foram muito sensíveis a pequenas variações nas suas excentricidades, e qualquer excentricidade acidental poderia produzir resultados não esperados.

No próximo capítulo serão avaliados os resultados e serão apresentadas propostas para o estudo dos pilares esbeltos considerando propostas de confinamento de modelos de Légeron e Paultre (2003), mesmo tendo sido concluído que o confinamento é muito pequeno para estas taxas volumétricas de estribos, possivelmente quando o efeito da compressão seja mais importante que o da flexão os resultados seriam mais conclusivos (que não é o caso de pilares esbeltos).

\subsection{CONSIDERAÇÕES FINAIS}

Foi realizado um pequeno estudo da forma do diagrama $\sigma_{\mathrm{c}} \times \varepsilon_{\mathrm{c}}$ do concreto sob compressão simples considerando o arranjo de armaduras dos pilares que foram ensaiados 
comparando os modelos de Cusson e Paultre (1995) e Légeron e Paultre (2003) com modelos sem confinamento, os modelos destas curvas serão implementados nas rotinas para a análise dos resultados dos pilares esbeltos empregando o Método Geral.

A velocidade de aplicação da força foi controlada por meio da deformação imposta aos pilares (curtos e esbeltos) e foi empregada a correspondente a $0,005 \mathrm{~mm} / \mathrm{m} . \mathrm{s}$ até o atingir o $80 \%$ da força última no ramo pós-pico do diagrama força-deslocamento e logo a velocidade foi incrementada para $0,01 \mathrm{~mm} / \mathrm{m}$.s e mantida até o final do ensaio.

Com o procedimento empregado no ensaio, foi possível obter o comportamento póspico, tanto dos pilares curtos como dos pilares esbeltos.

Os colares metálicos apresentaram excelente desempenho (nos pilares curtos sob compressão centrada e pilares esbeltos sob compressão excêntrica), ajudaram a fixar os pilares ao aparelho de apoio e contribuíram a melhorar o confinamento das extremidades dos pilares (estes já possuíam armadura de fretagem). Suas extremidades permaneceram íntegras após os ensaios, sendo que a ruptura aconteceu fora da região das extremidades.

No caso dos pilares curtos sob compressão centrada foi verificada que a força última corresponde à seção total do pilar, possivelmente para taxas volumétricas maiores de armadura transversal ou espaçamento entre estribos menores o cobrimento não faça parte da seção transversal do pilar. Os resultados dos ensaios de laboratório para a força última foram um pouco menores aos resultados analíticos, foi feita uma explicação desta variação considerando importante a realização dos ensaios prévios para que sejam detectados e evitados erros nos ensaios definitivos.

As armaduras transversais dos pilares curtos não atingiram o escoamento quando ocorreu a força última e sim após a força última, verificando-se ductilidade nos pilares com espaçamento entre estribos de $5 \mathrm{~cm}$, a tensão de serviço dos estribos para estes pilares na força última foi maior que para os pilares com espaçamento de estribos de $10 \mathrm{~cm}$. Houve flambagem das armaduras longitudinais para os pilares com espaçamento de estribos de 10 cm provocando queda da resistência nestes pilares.

Considera-se que para estas taxas de armadura transversal e seus arranjos é preferível não considerar o confinamento nestes pilares.

A perda do cobrimento constitui um fenômeno que não é exclusivo do CAR, acontecem também em concretos convencionais, sendo que a perda para o CAR pode ser repentina especialmente em pilares sob compressão excêntrica e pequena excentricidade ou em pilares sob compressão simples. Quando há uma perda repentina do cobrimento há uma queda repentina da força, que pode ser observado nos diagramas força-deslocamento vertical 
dos pilares $50 \mathrm{H} 12,100 \mathrm{H} 12,50 \mathrm{H}$ e $100 \mathrm{H}$, significando que o confinamento do concreto não foi suficiente para compensar a perda do cobrimento. Para os pilares com concreto de menor resistência à ruptura do cobrimento ocorre de forma gradual provocando um ramo descendente na curva força-deslocamento vertical, mas de forma gradual, isto pode ser observado nos pilares de concreto convencional e de mediana resistência e aqueles pilares com excentricidades de força maior.

As leituras dos extensômetros de resistência e dos transdutores foram obtidas adequadamente, não houve danificação de nenhum instrumento e as leituras dos extesômetros foram perdidas após a deformação específica das armaduras ter atingido valores superiores a 15\% ou no concreto, quando alguma fissura atravessou a base de medição do extensômetro (nos pilares esbeltos).

Para o caso de pilares esbeltos sob compressão excêntrica há um incremento da capacidade de força do pilar ao considerar menor espaçamento entre estribos, porem discreta, pois a possibilidade de ruína por instabilidade do pilar aumenta, sendo verificado, neste caso (para pilares com esbeltez de 92), que o incremento na capacidade do pilar é bem menos que o incremento na resistência do concreto. Para os pilares com esbeltezes maiores o incremento na capacidade do pilar será menor ainda. Em pilares robustos (pequena esbeltez) à medida que cresce a resistência do concreto à compressão, há um incremento significativo no valor da capacidade de força do pilar, o que significa uma economia considerando a diminuição das dimensões do pilar e um ganho do espaço útil, assim como uma economia na diminuição da quantidade do material concreto.

Nos diagramas força-deslocamento é possível verificar a perda de capacidade de força após a o fenômeno de instabilidade e também é possível observar uma segunda queda da força quando ocorre a ruptura do concreto na face mais comprimida, exceto no pilar 50H12 no qual o fenômeno de instabilidade aconteceu ao mesmo tempo em que o destacamento do cobrimento, para este pilar a ductilidade que provem do confinamento foi nulo.

Os lados dos estribos tiveram deformações específicas diferentes, não existiu regularidade dos seus valores, o único ramo do estribo que manteve regularidade foi o ramo junto à face mais comprimida do pilar, este ficou tracionado e sua deformação específica foi aumentado, mais não atingiu o escoamento, mesmo no comportamento pós-pico, mostrando ineficiência com relação ao confinamento.

Em relação à ductilidade houve uma pequena melhora na ductilidade para menores espaçamentos entre estribos ao analisar o parâmetro de ductilidade $D_{c}$, visualmente pelos gráficos força-deslocamento lateral a melhoria é observada. 


\section{Capítulo 7}

\section{ANÁLISE NUMÉRICA DOS PILARES CURTOS}

A metodologia aplicada para verificação dos resultados dos ensaios dos pilares curtos à compressão simples foi por meio de uma análise teórica que mostrou, para as taxas de estribos dos ensaios, que as forças últimas correspondem à seção total. Neste capítulo os resultados obtidos dos ensaios são comparados com os resultados do modelo proposto por Légeron e Paultre (2003) e também com modelos numéricos.

Os resultados dos pilares esbeltos são analisados com base no Método Geral incluindo o modelo de confinamento dos pilares curtos. Este modelo (Légeron e Paultre, 2003) é aplicado no cálculo das resultantes do concreto comprimido na região confinada, para isso é necessário conhecer o diagrama $\sigma_{\mathrm{c}} \mathrm{x} \varepsilon_{\mathrm{c}}$ do concreto confinado à compressão simples, para que seja empregado nas verificações de peças sujeitas à flexão ou flexão-composta que é o caso dos pilares esbeltos ensaiados.

A análise numérica foi feita com o programa ANSYS v. 11 e teve como objetivo somente constatar a distribuição de tensões e a ordem de grandeza dos esforços solicitantes que surgem na seção transversal quando submetidas a solicitações iguais às estudadas na análise experimental.

\subsection{DESCRIÇÃO DOS MODELOS NUMÉRICOS}

A seguir, apresentam-se alguns dados gerais sobre os recursos utilizados na análise numérica. Inicialmente vai ser realizada uma pequena descrição dos modelos de ruína que podem ser adotados para considerar a não linearidade física (NLF). 


\subsubsection{Modelos de ruína para o concreto e para as armaduras}

Com o avanço das técnicas de análise não linear, implementando algoritmos incrementais interativos associados a critérios de plasticidade e dano é possível conhecer o comportamento da estrutura sob forças crescentes. A representação das tensões para pontos no interior de corpos no espaço se escreve para o tensor de tensões que podem ser em função das tensões principais. É necessário verificar se as tensões de um ponto no interior do corpo são admissíveis, mas se localmente não satisfaz, não significa que todo o corpo apresente ruína. É necessário adotar um critério de ruína, existem muitos.

A Fig. 7.1 mostra um estado de tensões de um ponto (chamado de P) do corpo representado no espaço das tensões principais. Esse espaço contem o eixo hidrostático $\xi\left(\sigma_{1}=\right.$ $\sigma_{2}=\sigma_{3}$ ), neste eixo as tensões principais são iguais (um plano que contem o eixo hidrostático chama-se de plano meridional); os planos perpendiculares ao eixo hidrostático são planos desviatórios ou octaédricos, na figura $\rho$ é a componente inserida num plano desviatório que passa por $\mathrm{P}$ que representa o tensor de tensões principais de um ponto de um corpo. O plano desviatório que passa pela origem denomina-se plano de Nadai.

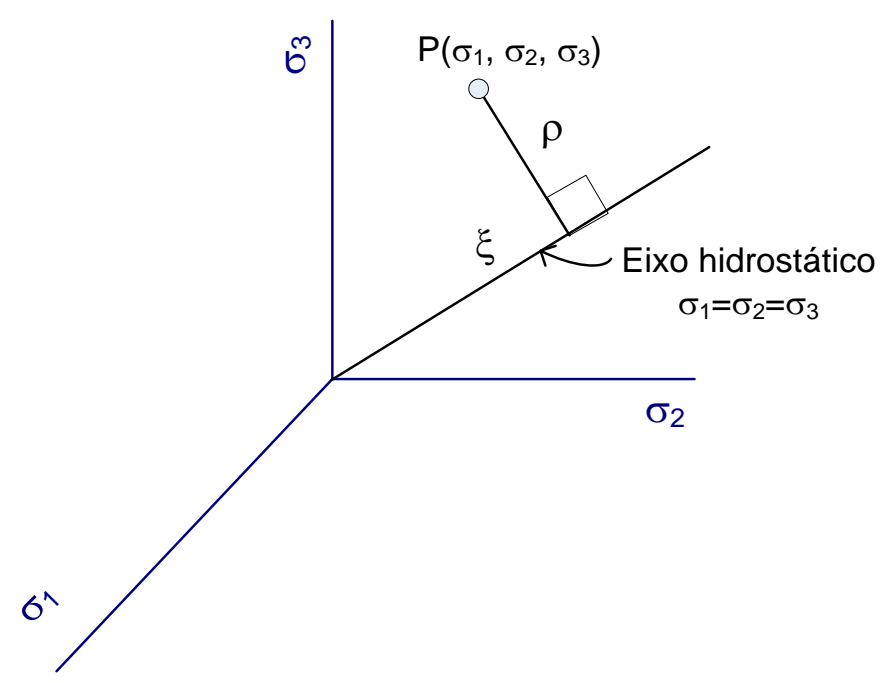

Fig. 7.1 - Espaço das tensões principais (Adaptada de Chen e Saleeb, 1994).

Assim para um ponto no espaço, matematicamente a ruptura não ocorre se:

$$
f\left(\sigma_{1}, \sigma_{2}, \sigma_{3}\right) \leq \sigma_{r}
$$

Sendo $\sigma_{\mathrm{r}}$ um valor escalar de referencia da ruptura e $\sigma_{1}, \sigma_{2}$ e $\sigma_{3}$ as tensões principais de um ponto do corpo.

Os critérios são divididos em 2 grupos, para materiais dúcteis e para materiais frágeis. Os independentes do eixo hidrostático (materiais dúcteis) onde os incrementos nas compressões hidrostáticas $\left(\sigma_{1}=\sigma_{2}=\sigma_{3}\right)$ não modificam a superfície de ruptura (a superfície é 
paralela ao eixo hidrostático) e os dependentes (materiais frágeis) que os incrementos nas compressões hidrostáticas modificam a forma da superfície, normalmente cortam o eixo hidrostático em algum ponto (Paccola, 2004).

A solução do problema do concreto como material elástico e linear não corresponde á realidade, especialmente quando no concreto começa o processo de fissuração. É necessário considerar não linearidades físicas associadas ao problema mecânico e formular um critério de ruína quando o concreto está sujeito a vários estados de tensões. A modelagem do concreto com elementos sólidos fornece resultados mais realistas que se aproximam melhor dos resultados de laboratório, mas são pouco utilizados na prática.

A NLF do concreto armado provém principalmente dos efeitos da fissuração na interface pasta-agregado ocasionado por forças de tração, perda de aderência entre o concretoarmadura, retração e fluência do concreto, plastificação da armadura e plastificação do concreto comprimido. As matrizes lineares são penalizadas em virtude das perdas de rigidez quando ocorrem as plastificações e fissuras.

Sob tensões triaxiais o concreto mostra que tem uma superfície de ruptura razoavelmente bem definida em função das suas três tensões principais e suas superfícies representadas no espaço dessas tensões.

Uma ruína corresponde à capacidade última de resistência que um elemento de concreto armado pode suportar. Alguns critérios utilizados para definir ruína são: atingir a tensão de proporcionalidade ou ruptura início de fissuração, alcançar a capacidade máxima da seção e deformações excessivas. A ruptura do concreto tracionado é caracterizada pela sua fragilidade (formação de fissuras e perda de sua resistência à tração) e a ruptura do concreto comprimido é caracterizada pela sua pequena ductilidade (formação de muitas fissuras e o elemento nessa região perde sua resistência totalmente).

A Fig. 3.1 mostra um concreto convencional sujeito aos estados de tensão uniaxial, biaxial e triaxial. No comportamento do concreto, considerado como material isotrópico sujeito a estados de tensão triaxial, a curva interna corresponderia a um limite elástico (começo da propagação das fissuras estáveis), e a externa corresponde ao limite de ruptura (propagação das fissuras inestáveis), ocorre o encruamento do material (Fig. 3.1). A Fig. 7.2 mostra o encruamento para um material isotrópico num estado biaxial de tensões. 


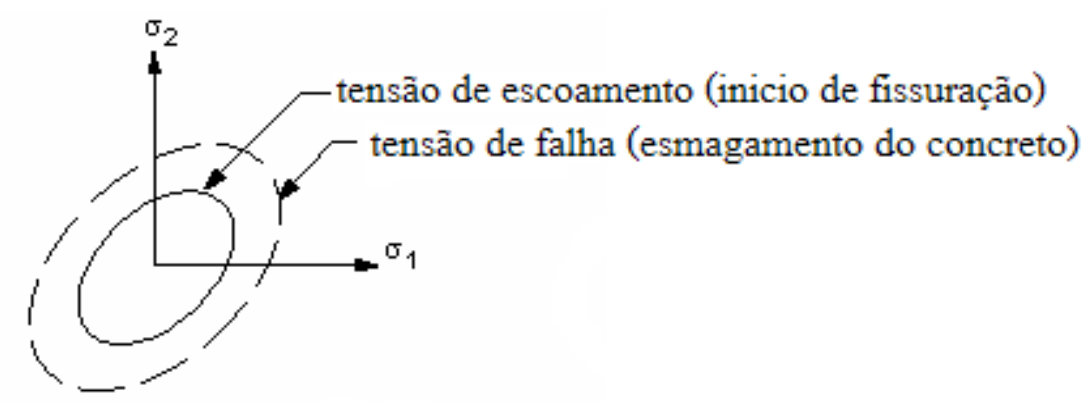

Fig. 7.2 - Encruamento para materiais isotrótropicos (ANSYS v. 11).

O critério mais simples de ruptura é de Rankine, que define uma variável independente como parâmetro de ruptura, segundo este critério a ruptura ocorre quando a tensão principal maior atinge um valor igual à resistência à tração simples do material, $\sigma_{\mathrm{t}}, \mathrm{o}$ critério é expresso na Eq. 7.2.

$$
\sigma_{1}<\sigma_{\mathrm{t}} ; \sigma_{2}<\sigma_{\mathrm{t}} ; \sigma_{3}<\sigma_{\mathrm{t}}
$$

A Fig. 7.3 mostra a representação gráfica desse critério no espaço. Esse critério pode ser adotado quando se quer verificar a ocorrência de fissuras. Fora da região os pontos não são admissíveis.

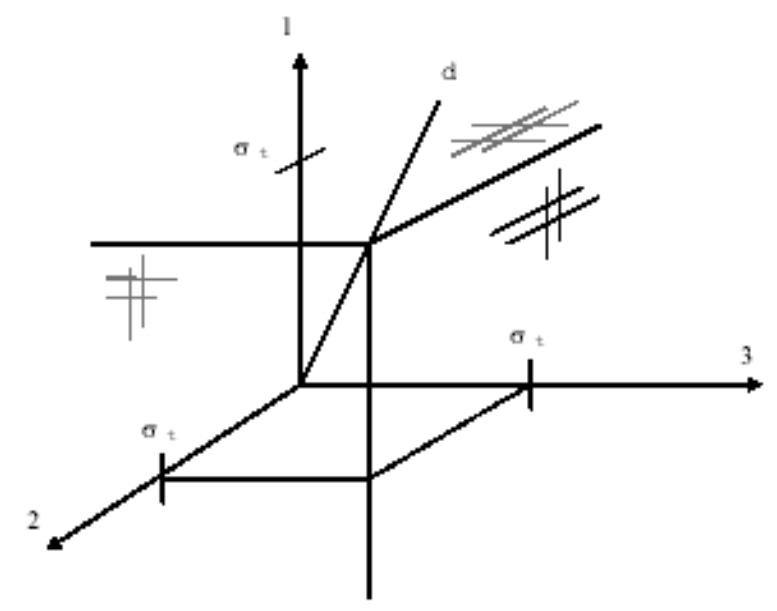

Fig. 7.3 - Critério de Rankine no espaço das tensões principais limitado por planos perpendiculares aos eixos, (Proença, 2004).

A Fig. 7.4 mostra o critério de Rankine no plano das tensões, para um caso particular de $\sigma_{2}=0$. 


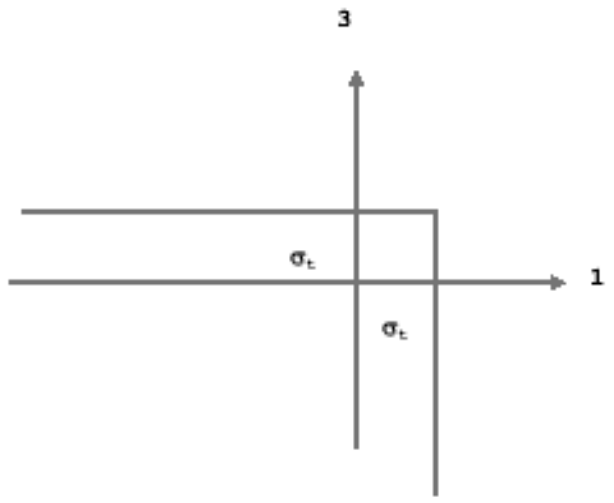

Fig. 7.4 - Representação gráfica do critério de Rankine no plano das tensões (Proença, 2004).

Os critérios de Tresca [ruptura ocorre localmente quando a tensão de cisalhamento $\tau_{\max }$ atinge um valor crítico característico do material $\left.\mathrm{k}=\left(\sigma_{1}-\sigma_{3}\right) / 2\right]$ e von-Misses (ruptura ocorre localmente quando a tensão octaédrica $\tau_{\text {oct }}$ atinge um valor crítico $\mathrm{k}^{\prime}=0,82 \mathrm{k}$ ) são independente da pressão hidrostática e aplica-se mais a materiais dúcteis (superfície de ruptura paralela ao eixo hidrostático). A Fig. 7.5 mostra as superfícies de ruptura para os dois critérios, no espaço das tensões e projetadas num plano desviatório. Outro aspecto a observar é que as superfícies de ruptura coincidem para $\theta=30^{\circ}$. Segundo estes critérios o valor de $\mathrm{k}$ pode ser obtido do ensaio de tração simples, para maiores detalhes ver Proença (2004). O critério de ruptura do aço corresponderia ao modelo de Tresca ou von-Misses.
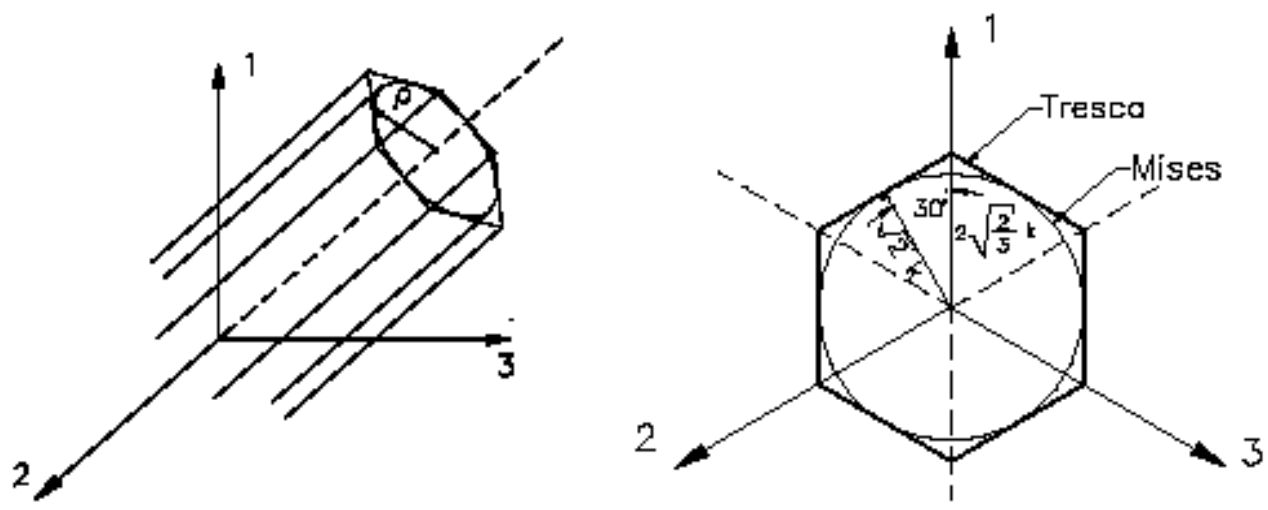

Fig. 7.5 - Superfícies de ruptura dos critérios de Tresca e von-Misses (Proença, 2004).

Na Fig. 7.6 para um comportamento biaxial tem-se a associação do critério de Rankine e von-Misses, para tentar de representar o concreto. 


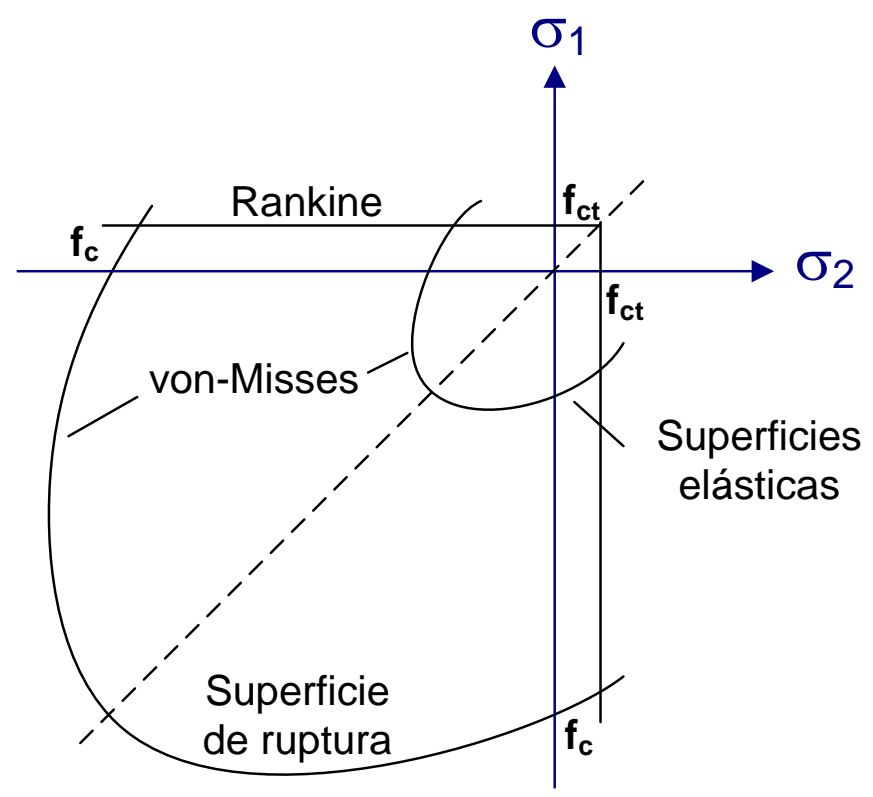

Fig. 7.6 - Comportamento biaxial do concreto no modelo Rankine e von-Misses (Proença 2004).

Outros critérios para materiais frágeis, também simples, utilizam 2 parâmetros, MörhCoulomb e Drucker-Prager, outro mais sofisticado utiliza 5 parâmetros, Willam-Warnke.

Na Fig. 7.7 mostram-se os critérios de Mörh-Coulomb e Drucker-Prager, o cone externo corresponde a Drucker-Prager. Os dois parâmetros da figura são o ângulo de atrito do concreto $\phi$ e a sua coesão c, para o critério de Mörh-Coulomb.

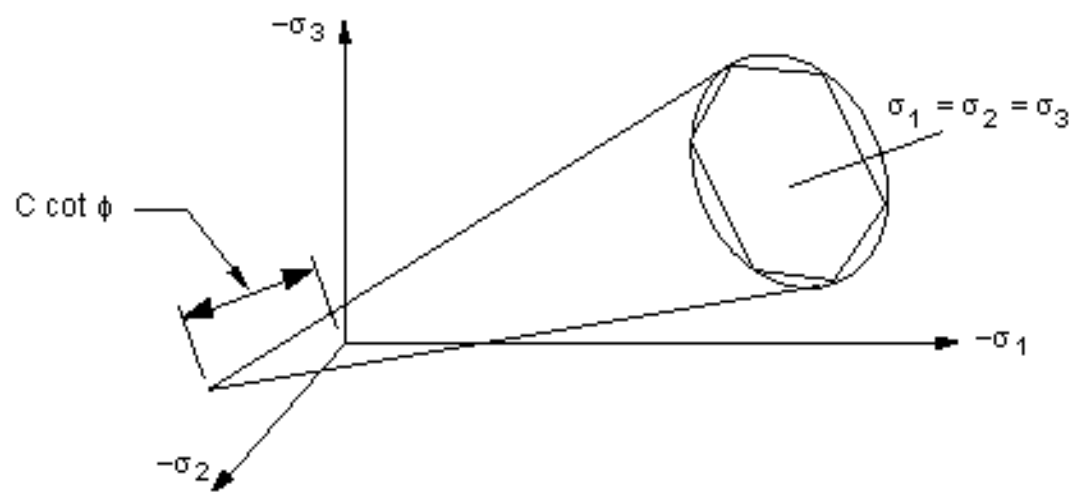

Fig. 7.7 - Superfície de ruptura de Mörh-Coulomb e Drucker-Prager (ANSYS, v. 11).

Como anteriormente mencionado, a superfície de ruptura no espaço tridimensional das tensões principais pode ser descrita pelas formas de sua seção transversal nos planos desviadores e pelas formas de seus meridianos, nos planos meridionais.

Os planos desviadores e meridianos dos critérios de Mörh-Coulomb e Drucker-Prager podem ser vistos na Fig. 7.8. 


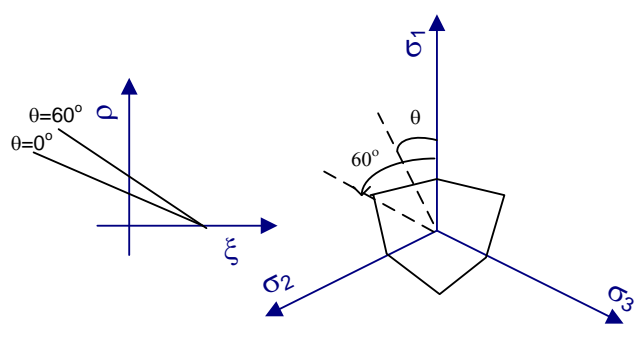

(a)

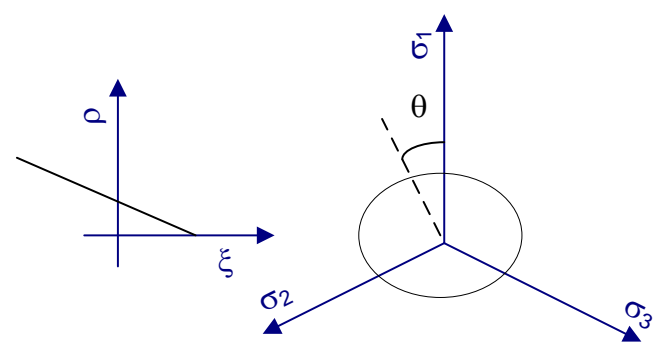

(b)

Fig. 7.8 - (a) Modelo de Mörh-Coulomb e (b) modelo de Drucker-Prager (Chen e Saleeb, 1994).

A Fig. 7.9, para Drucker-Prager, mostra o comportamento biaxial (semelhante ao recomendado pela norma FIB, 1999 da Fig. 7.12) e uniaxial de tensões.

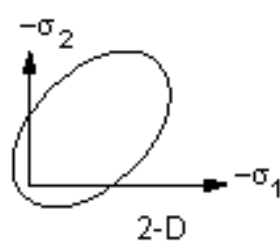

(a)

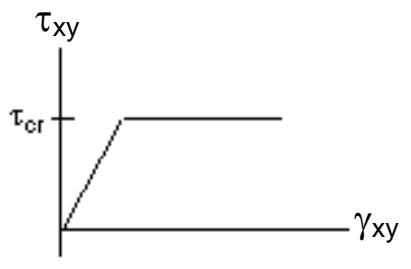

(b)

Fig. 7.9 - Modelo biaxial e uniaxial de Drucker- Prager (ANSYS, v.11).

O critério de Mörh-Coulomb define sua ruptura quando é atingido um valor limite da tensão de cisalhamento, que é influenciado pela tensão normal atuante no plano, caso a envoltória seja aproximada linearmente, a expressão é:

$$
\left|\tau_{\lim }\right|=c-\sigma \times \operatorname{tg} \phi
$$

Na Fig. 7.10, c é a coesão entre partículas, $\phi$ o ângulo de atrito interno das partículas do material, $f_{c}$ a resistência do concreto à compressão simples e $f_{c t}$ a resistência do concreto â tração simples. Estas duas últimas propriedades servem para definir os círculos de Mörh (Fig. 7.10). 


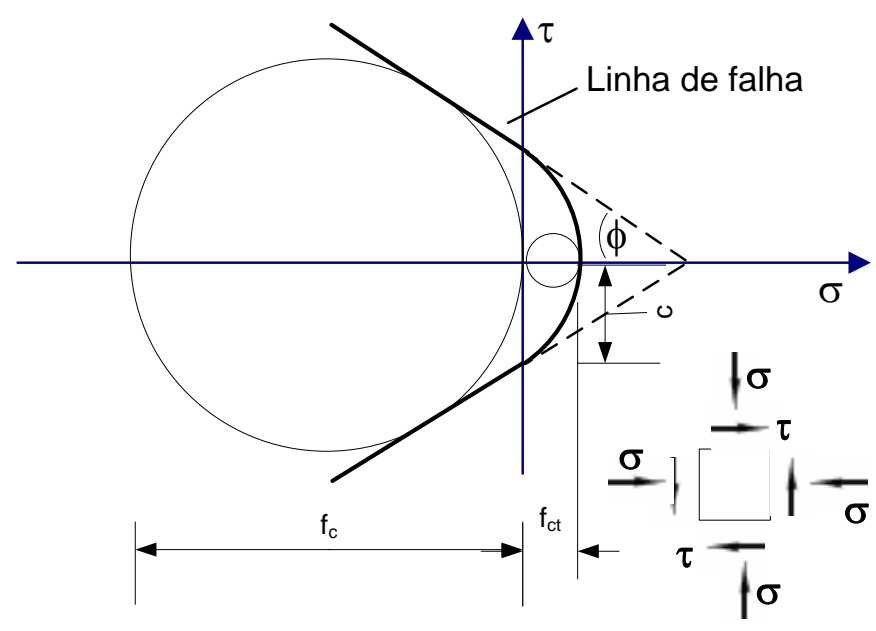

Fig. 7.10 - Resistência do concreto no critério de Mörh-Coulomb em um plano qualquer do material (Adaptado de Park e Paulay, 1996).

Da Fig. 3.4, pela semelhança de triângulos ABO e DEO a relação entre a coesão e a resistência do concreto é:

$$
c=\frac{1-\operatorname{sen} \phi}{2 \times \cos \phi} \times f_{c}
$$

Segundo Guray (2007) a coesão pode ser expressa por médio da Eq. 7.5 em função do diâmetro máximo do agregado $\mathrm{D}_{\max }$ e em função do módulo de deformação do concreto $\mathrm{E}_{\mathrm{c}}$.

$$
c=0,23 \times \ln \left(E_{c} \times D_{\max }^{2}\right)-0,6
$$

Segundo o mesmo autor anterior, o ângulo de atrito varia entre $30^{\circ}$ a $37^{\circ}$ e para o CAR o valor de $37^{\circ}$ é o adequado.

Para o modelo de Willam-Warnke, que contem 5 parâmetros, os meridianos são representados por parábolas e suas seções transversais por curvas elípticas. A Fig. 7.11 mostra estas características. As formas dos planos desviatórios são muito similares ao dos recomendados pela FIB (1999), sendo então um modelo muito adequado para representar o concreto. Sua envoltória é definida por ensaios de laboratório. 

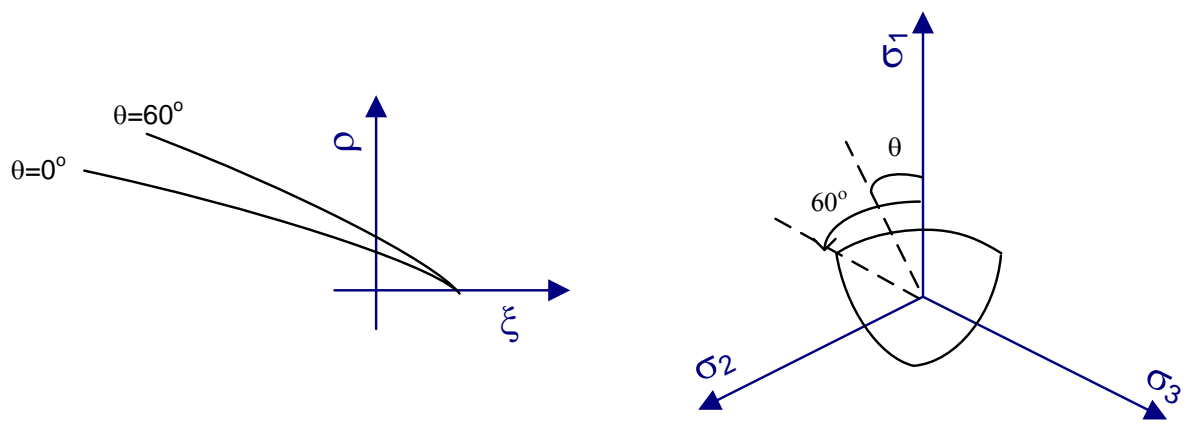

Fig. 7.11 - Seções dos meridianos e plano desviatório para o critério de Willam-Warnke (Chen e Saleeb, 1994).

Alguns modelos simples que incorporam poucos parâmetros foram modificados para serem utilizados na prática.

A norma FIB (1999) sugere um modelo para o concreto sujeito a um comportamento biaxial, onde dependendo do valor das tensões principais pode existir um ganho de resistência que pode chegar até $25 \%$ maior que a uniaxial, ver Fig. 7.12.

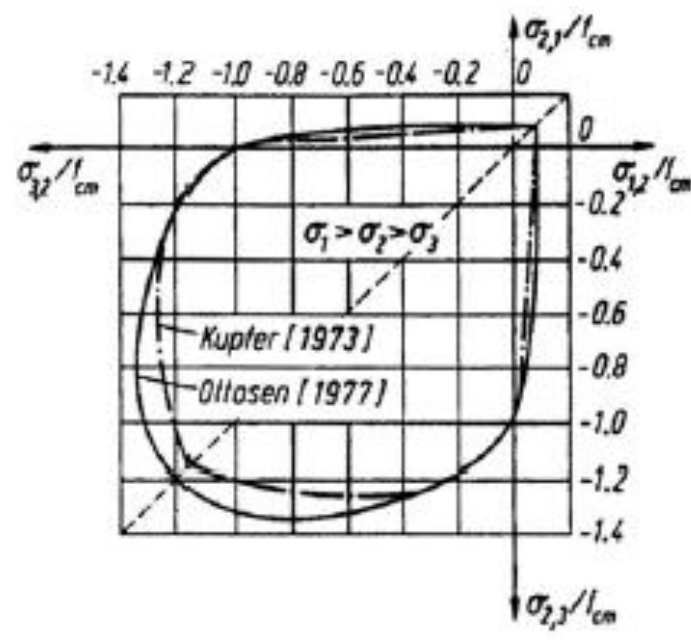

Fig. 7.12 - Curva de resistência biaxial do concreto. (FIB, 1999).

Para comportamentos triaxiais a mesma norma FIB (1999), sugere o modelo da Fig. 7.13. Este modelo indica que a ruptura é influenciada pelos valores das tensões hidrostáticas (a superfície corta o eixo hidrostático e no outro extremo se abre). Na mesma Fig. 7.13 um plano de corte (plano $\sigma_{1}-\sigma_{3}$ ), que sugere o comportamento biaxial do concreto, sendo que a superfície cortada tem o aspecto da curva da Fig. 7.12. 


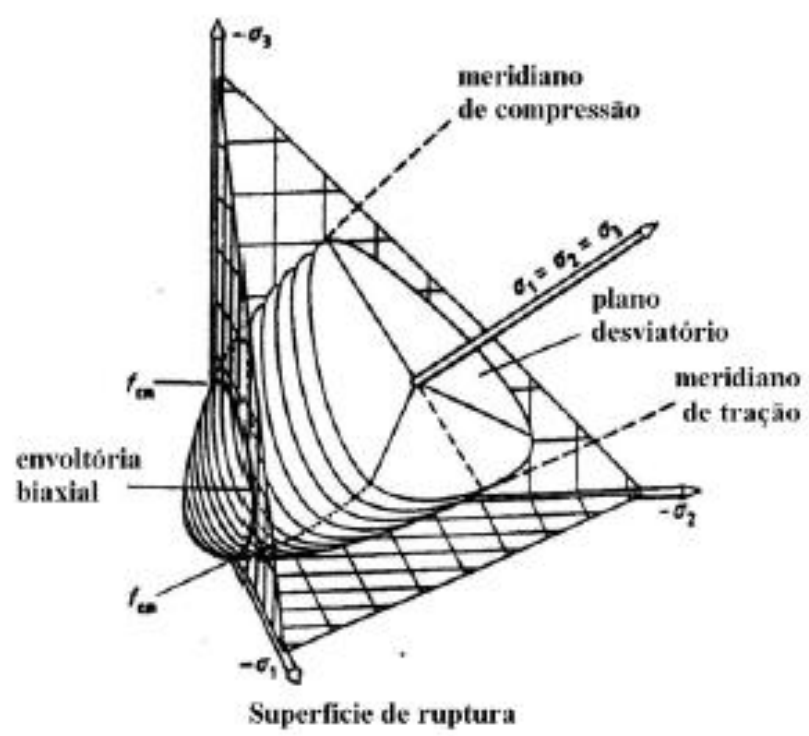

Fig. 7.13 - Superfície de ruptura sugerida pela norma FIB, 1999.

É possível verificar que para os critérios de ruptura para materiais frágeis, como o concreto, os incrementos nas compressões hidrostáticas modificam a forma da superfície, normalmente cortam o eixo hidrostático em algum ponto (Fig. 7.7, 7.13 e Fig. 7.14).

Segundo Chen e Saleeb (1994) o incremento da pressão hidrostática diminui a possibilidade de fissuras por aderência e o modo de ruptura passa de segmentação do agregado ou pasta a esmagamento da pasta de cimento.

No caso do concreto confinado sob tensões triaxiais no espaço de tensões principais, a resistência do concreto aumenta para incrementos na compressão da pressão hidrostática e a ruptura ocorre quando a tensão tangencial desviatória $\tau_{0}$ atinge seu valor máximo. A Fig. 7.14 mostra este plano desviatório.

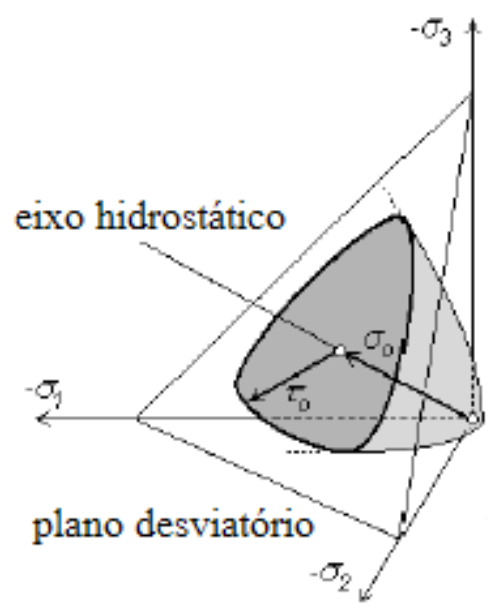

Fig. 7.14 - Plano desviatório para uma superfície de ruptura definida por $\tau_{0}$ (adaptada de Cervenka, 2002). 
Os modelos matemáticos que foram pesquisados para estudar a NLF do concreto, consideram a teoria da elasticidade, mesmo para comportamentos pós-críticos. Existem outros critérios para estudar e modelar as não linearidades físicas do concreto junto com uma teoria da elasticidade não linear empregada na teoria dos grandes deslocamentos, modelos muito complexos não são adequados para serem utilizados na prática. Somente as propriedades mais importantes do concreto deveriam ser incorporadas.

\subsubsection{Elementos finitos utilizados}

Para a modelagem do material concreto, inicialmente utilizou-se o elemento SOLID65. Este elemento possui oito nós com três graus de liberdade (GL) por nó. O elemento apresenta deformações plásticas, fissuração e ruptura em três direções ortogonais. No elemento SOLID65, a fissuração ocorre quando a tensão principal de tração em qualquer direção atinge a superfície de ruptura. Depois de fissuração, o módulo de elasticidade do concreto torna-se igual a zero na direção considerada. O esmagamento ocorre quando todas as tensões de compressão atingem a superfície de ruptura, subseqüentemente, o módulo de elasticidade torna-se igual a zero em todas as direções. A Fig. 7.15 apresenta o elemento SOLID65. Para modelar o concreto foi analisado também o elemento SOLID185, considera a NLG, mas não é adequado para o concreto porque seus modelos de ruptura são de materiais elasto-plásticos e não apresenta propriedades de fissuração e ruptura, a geometria e suas características mecânicas são as mesmas que o do SLID65 (Fig. 7.15).
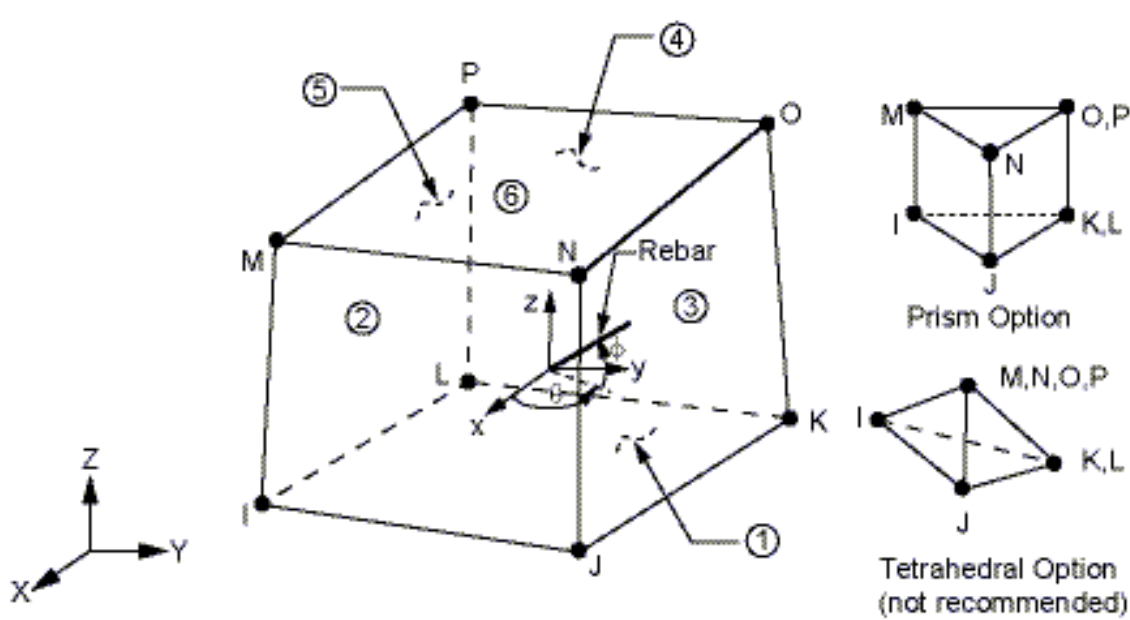

Tetrahedral Option (not recommended)

Fig. 7.15- Elemento SOLID65 (ANSYS, v. 11).

$\mathrm{Na}$ modelagem das barras de aço da armadura foi utilizado o elemento finito LINK8. Esse elemento tem dois nós, sendo que cada nó possui três graus de liberdade translações nas direções x, y e z. A Fig. 7.16 mostra esse elemento. 

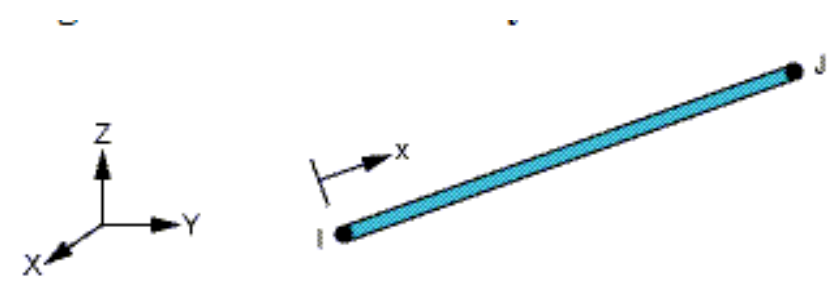

Fig. 7.16 - Elemento LINK8 (ANSYS, v. 11).

Para a modelagem do elemento de barra foram também avaliados outros elementos finitos (EF) com o objetivo de obter resultados que se aproximem dos resultados dos ensaios de laboratório, entre eles LINK180 que é o mesmo do LINK8, mas que consegue simular grandes deformações, ou seja, pode simular a não linearidade geométrica (NLG). O PIPE20 é um elemento de barra linear que considera forças axiais, momento fletor e momento torsor, possui 6 GL por nó, considera a plasticidade, foi trocado por não se adequado para seções sólidas. Também foi utilizado o elemento BEAM188 que incorpora a teoria de vigas de Timoshenko, para os casos usuais possui 6 GL por nó, inclui a NLG e suas matrizes incluem termos para analisar problemas de instabilidade, possui seções predefinidas entre elas as circulares e é possível discretizar uma malha de EF na sua seção transversal.

Nos modelos, foi considerada uma aderência perfeita entre as barras de aço e o concreto, pois os seus elementos finitos tinham seus nós comuns. Foram modelados tanto as armaduras longitudinais como as transversais, dessa maneira foi possível obter o confinamento do núcleo do concreto pelas armaduras transversais.

Para modelar o aparelho de apoio foi considerado elemento solido SOLID45. Este elemento possui oito nós com três graus de liberdade por nó. O elemento apresenta deformações plásticas e grandes deformações, tem as mesmas propriedades do SOLID65 (Fig. 7.15) mais não apresenta as propriedades de fissuração e ruptura e tampouco é possível introduzir armaduras difusas em taxas ("rebar", da Fig. 7.19).

\subsubsection{Critérios de ruptura empregados no ANSYS}

Como parte deste documento foi realizada uma análise numérica tridimensional com o ANSYS, v. 11, incorporando as NLF e NLG dos pilares curtos, é necessário conhecer os critérios de ruptura que esses programas incorporam para serem utilizados com propriedade.

O ANSYS tem um elemento 3D que é muito empregado para materiais frágeis como o concreto, é o SOLID 65, este elemento inclui a ruptura por fissuração e a ruptura à compressão e as fissuras podem acontecer nos três planos ortogonais, a fissura é tratada como uma faixa dispersa de fissuras e não como uma discreta. 
Apresenta pequena resistência à tração e elevada resistência à compressão, tem um comportamento elástico linear até a ruptura. Para o caso de um comportamento uniaxial, o diagrama $\sigma \mathrm{x} \varepsilon$ pode ser visto na Fig. 7.17.

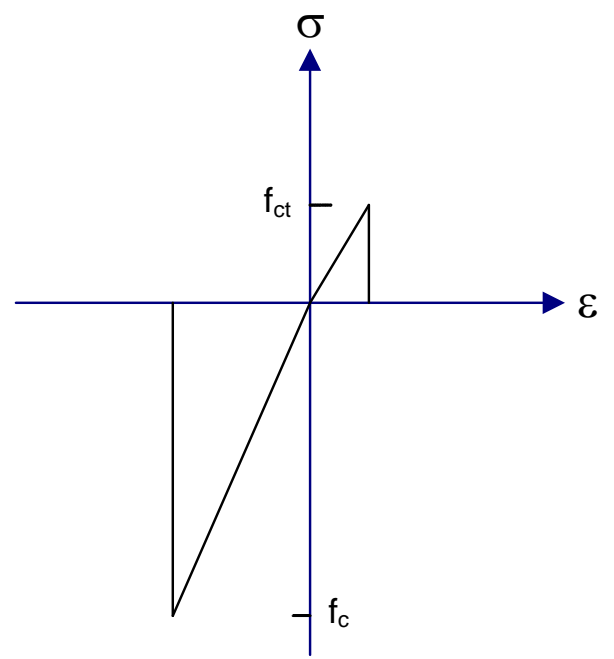

Fig. 7.17 - Comportamento uniaxial do concreto (adaptada do ANSYS, v. 11).

O SOLID65 é um elemento que pode ser empregado para modelar barras de aço difusas dentro do concreto. Segundo os manuais do ANSYS, o critério de ruptura relativo a um estado multiaxial de tensões é obtido da Eq. 7.6.

$$
\frac{F_{\sigma}}{f_{c}}-S \geq 0
$$

Nesta:

$F_{\sigma}$ é função do estado de tensões principais $\left(\sigma_{1}, \sigma_{2}, \sigma_{3}\right)$ num ponto;

$\mathrm{f}_{\mathrm{c}}$ é a resistência uniaxial à ruptura do concreto;

S é o estado de tensões principais na superfície de ruptura.

Satisfeita esta desigualdade ocorrerá a fissuração se alguma das tensões principais for de tração, o esmagamento se todas as tensões principais forem de compressão.

A superfície de ruptura é similar á da Fig. 7.18. 


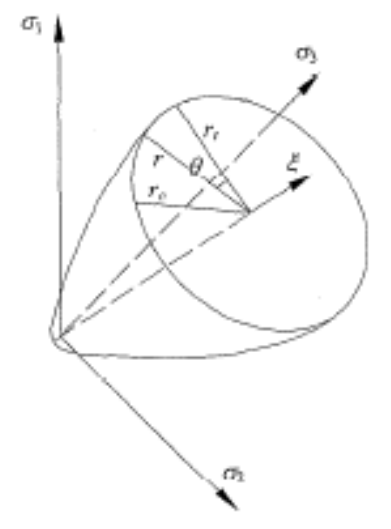

Fig. 7.18 - Superfície de ruptura em 3D (adaptada de ANSYS, v. 11).

O elemento SOLID65 provem do modelo de Willam-Warnke anteriormente descrito, uma vez atingida a ruptura na superficie, considera-se uma completa deterioração do material e o modelo perde a capacidade de absorver tensões (Fig. 7.17), não sendo capaz de caracterizar o fenômeno do amolecimento do concreto comprimido. Este modelo pode ser adequado para o CAR com resistências elevadas, mas não para o CAR confinado.

O modelo também não apresenta o pequeno amolecimento na tração que considera a transferência de tensão através do concreto entre fissuras.

Para suprir esta deficiência, o SOLID 65 tem a possibilidade de desabilitar a diminuição brusca da resistência durante a ruptura sendo possível combinar com outro modelo para simular os comportamentos do modelo de plasticidade dos materiais, assim é factível combinar com o modelo do Ducker-Prager ou do von-Misses. Para esta análise foi complementado com o de von-Misses, então o concreto comprimido foi admitido como um material elastoplástico perfeito.

O SOLID65 permite considerar a transferência do cisalhamento entre fissuras, e foi considerado $10 \%$ para as fissuras abertas que provem da tração e $30 \%$ para as que provem do esmagamento (Leonel et al., 1997).

O SOLID65 não consegue representar o escorregamento entre o concreto e as barras das armaduras, o efeito de pino e o amolecimento na tração.

Para a armadura foi adotado o modelo de plastificação de von-Misses, considerando o aço como um material elastoplástico perfeito. 


\subsection{IMPLEMENTAÇÃO COMPUTACIONAL DOS PILARES CURTOS}

A seção transversal do pilar foi considerada como composta de 2 materiais o concreto e o aço. Para as armaduras foram fornecidas as suas áreas, para ambos os materiais suas propriedades mecânicas elásticas como o módulo de elasticidade e coeficiente de Poisson e finalmente seus critérios de ruptura. Para o SOLID65 foi adotado o critério de ruptura de Willam-Warnke e por cima o von-Misses.

O concreto foi modelado com o elemento SOLID65, e a armadura com elemento de barra LINK 180, os nós dos elementos sólidos coincidem com os nós do elemento da barra. Uma das extremidades estava restringida em todos seus nós e na outra foi aplicada o deslocamento máximo obtido nos ensaios, em cada etapa do ensaio foi feita uma leitura dos resultados para acompanhar o comportamento do pilar curto até a ruína, o programa transforma os deslocamentos em forças equivalentes e aplica forças. A opção de análise foi a de "full Newton-Rapson".

A Fig. 7.19 mostra os dois modelos dos pilares curtos que foram analisados.

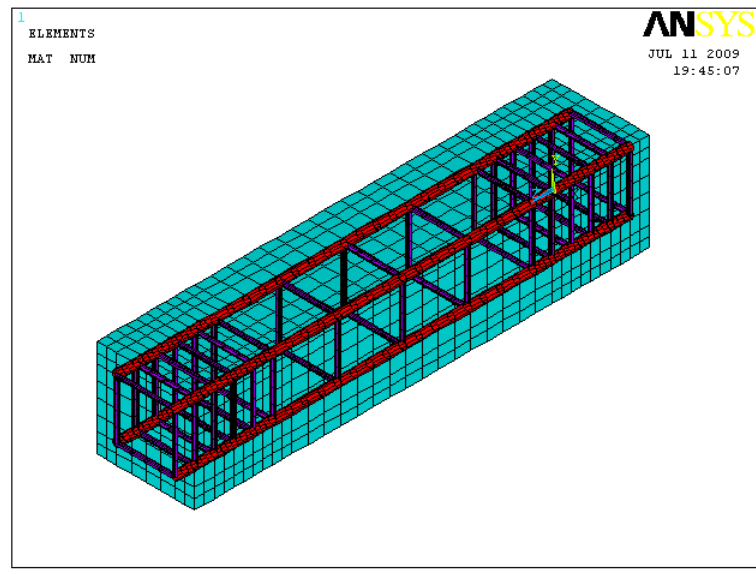

(a) espaçamento de $10 \mathrm{~cm}$.

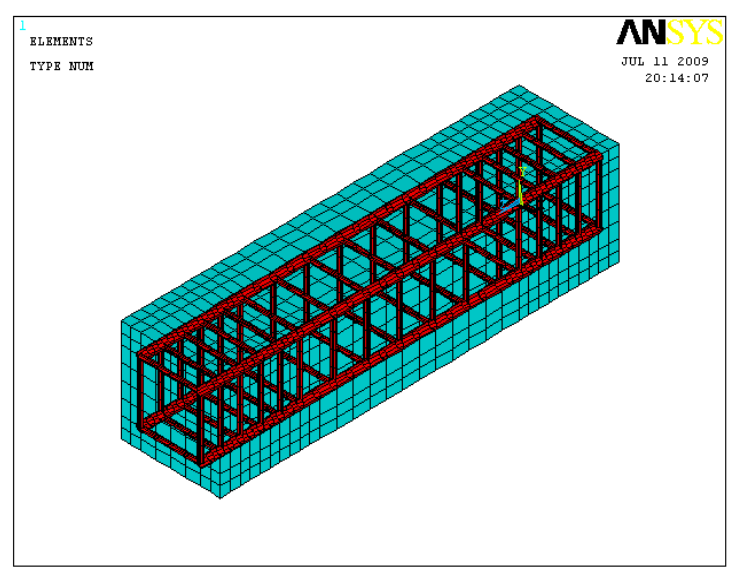

(b) espaçamento de $5 \mathrm{~cm}$.

Fig. 7.19 - Modelos dos pilares curtos (a) estribos a cada $10 \mathrm{~cm}$ e (b) estribos a cada $5 \mathrm{~cm}$.

Na Fig. 7.19 é possível observar que os modelos numéricos têm as mesmas propriedades dos ensaiados, nas extremidades os estribos estão espaçados a cada $2,5 \mathrm{~cm}$ que correspondem à armadura de fretagem. Numa extremidade, todos os nós foram fixados em relação aos deslocamentos nas três direções e na outra extremidade os nós estavam fixos nas direções do plano da seção transversal e livres na direção do eixo do pilar, sendo que, nesta direção foram aplicados os deslocamentos por etapas até o deslocamento máximo obtido dos ensaios para a força máxima. 
Foram obtidas respostas para cada etapa dos deslocamentos aplicados, as Fig. 7.20 até a Fig. 7.25 mostram os valores das tensões no concreto do núcleo confinado no final da etapa de carga (marcado nos comentários das figuras na parte superior esquerda como TIME $=1$, que significa o final da análise).

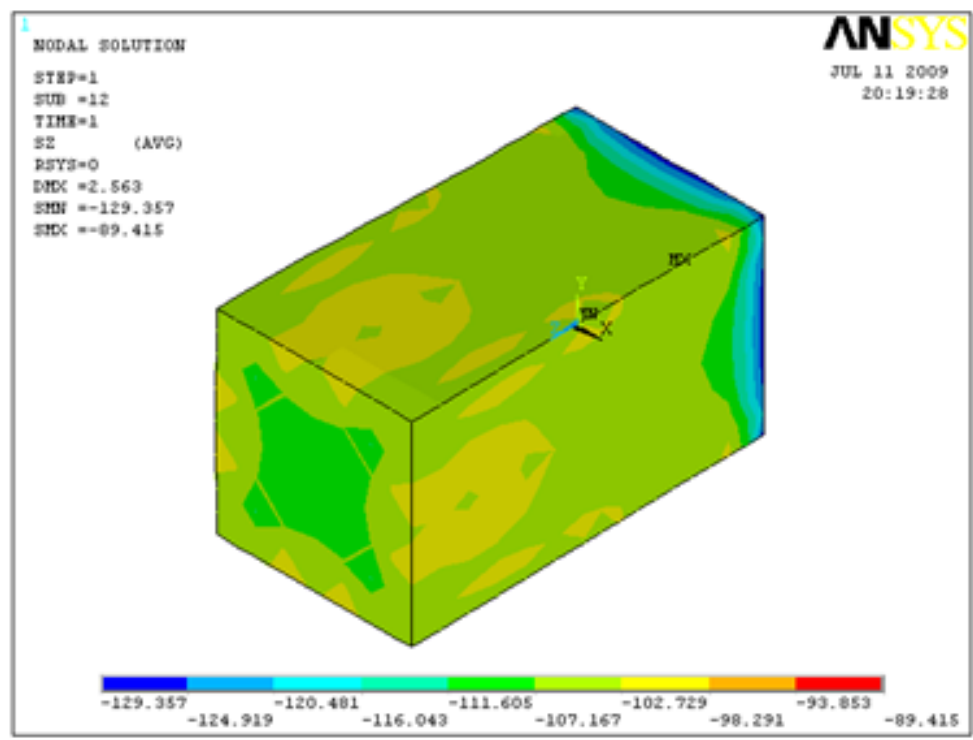

Fig. 7.20 - Incremento de tensões no núcleo devido ao confinamento para o pilar curto $50 \mathrm{H}$.

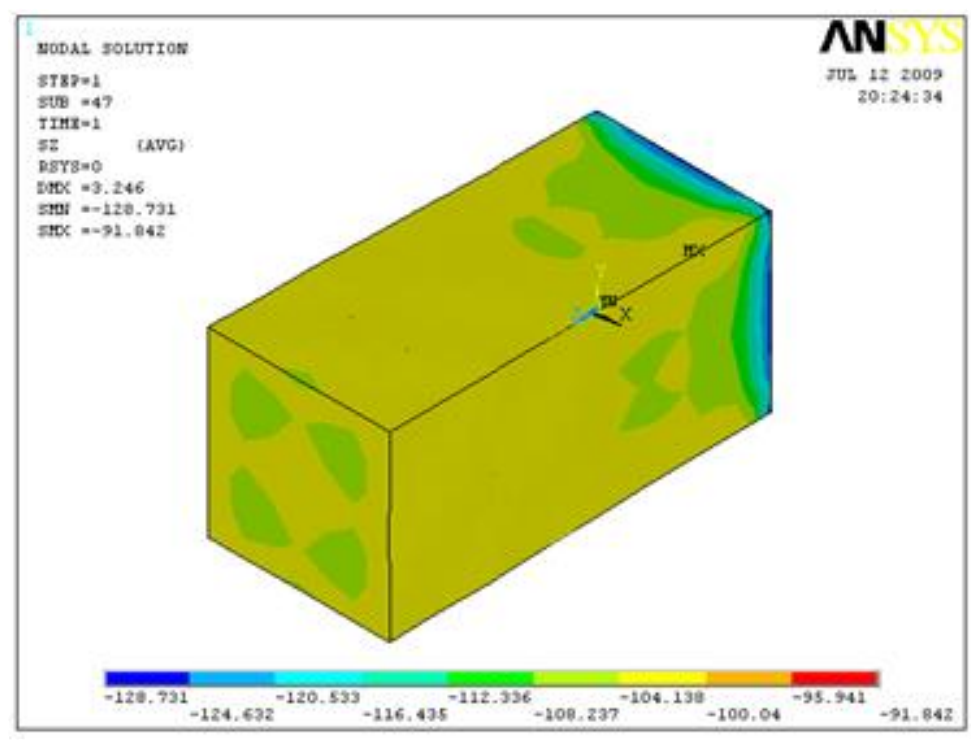

Fig. 7.21 - Incremento de tensões no núcleo devido ao confinamento para o pilar curto $100 \mathrm{H}$. 


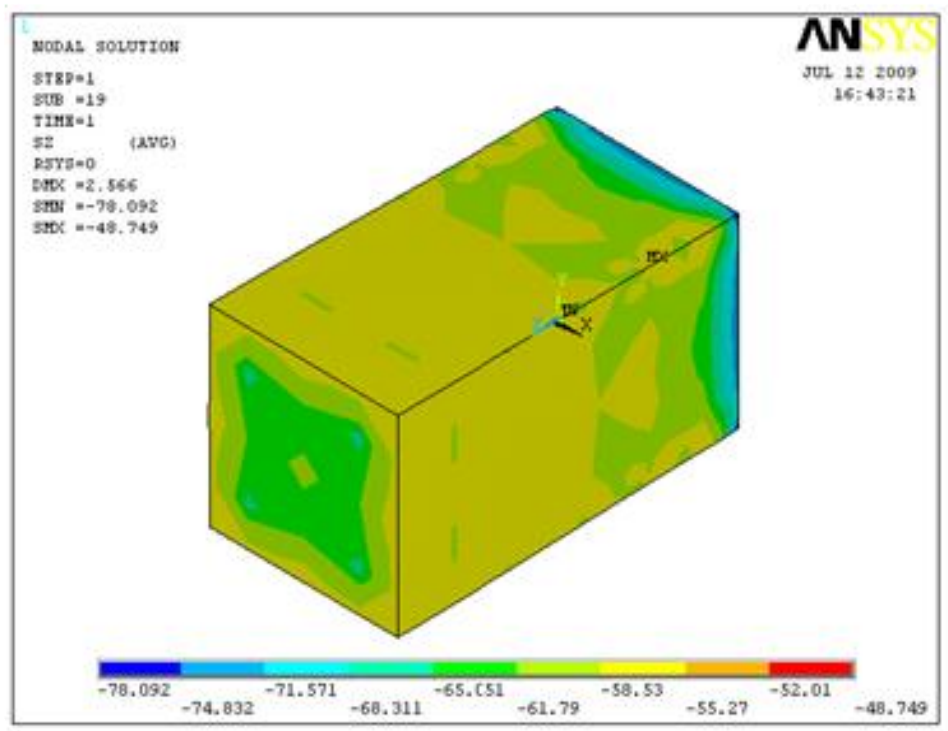

Fig. 7.22 - Incremento de tensões no núcleo devido ao confinamento para o pilar curto 50M.

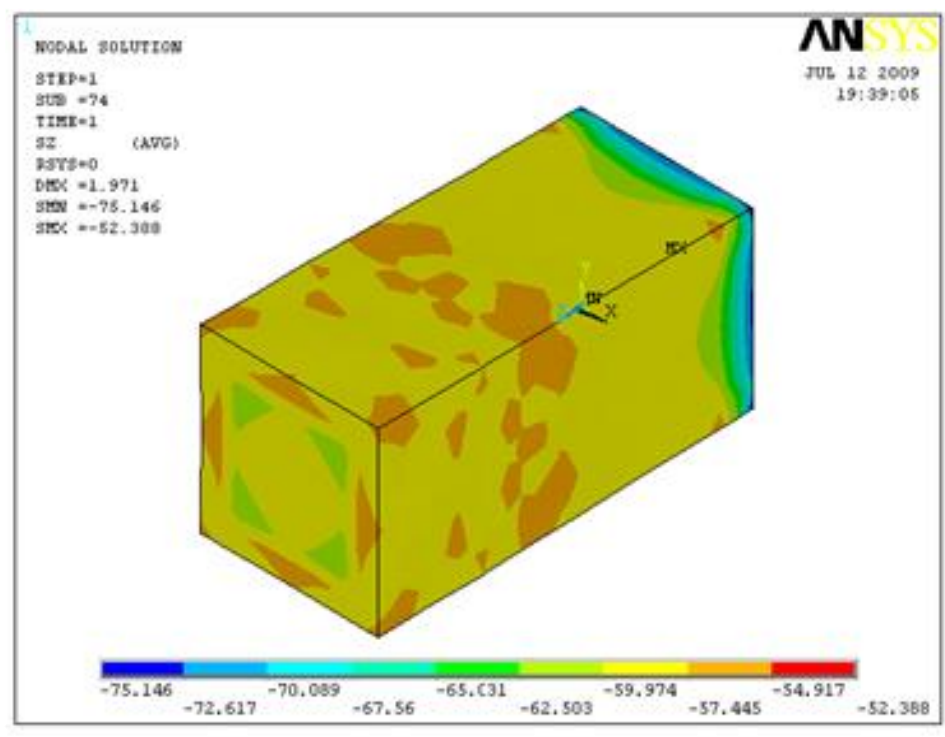

Fig. 7.23 - Incremento de tensões no núcleo devido ao confinamento para o pilar curto 100M. 


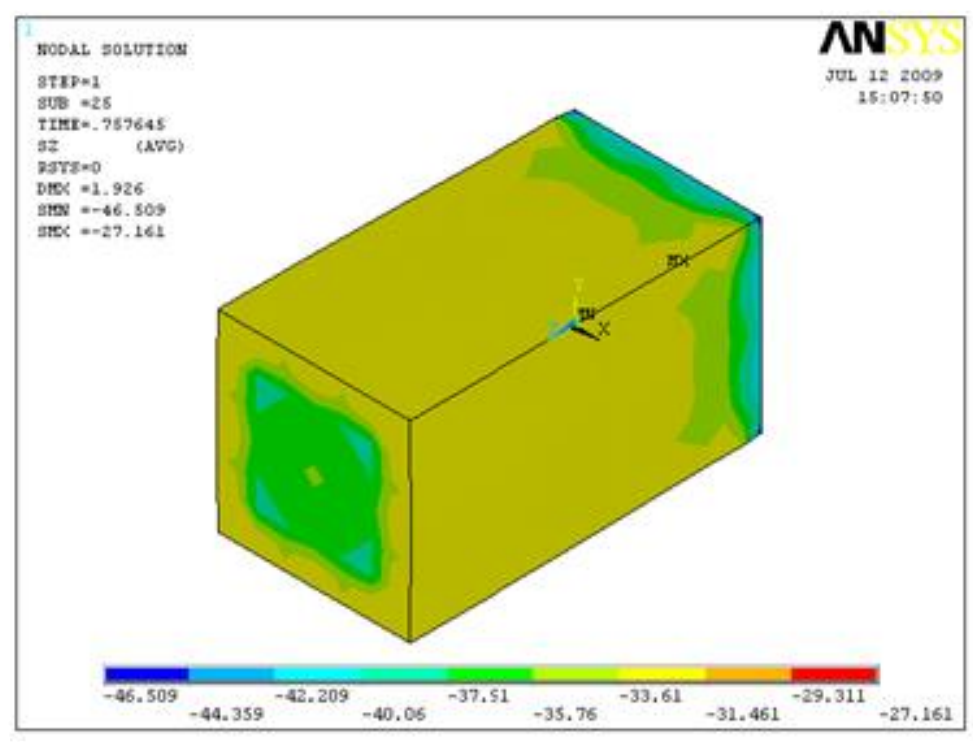

Fig. 7.24 - Incremento de tensões no núcleo devido ao confinamento para o pilar curto 50L.

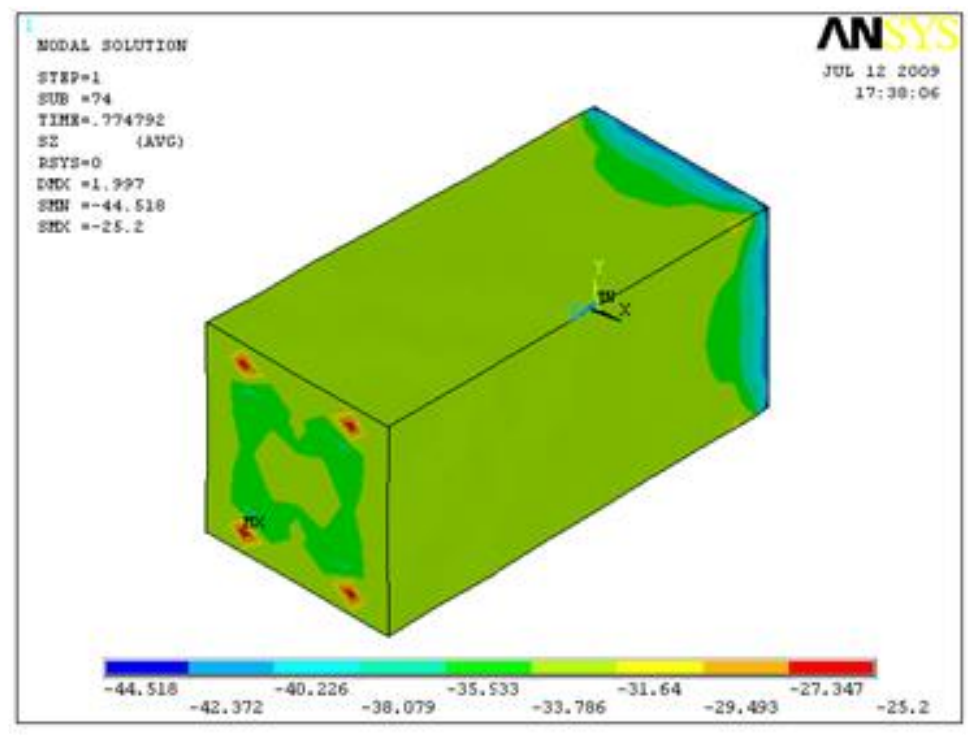

Fig. 7.25 - Incremento de tensões no núcleo devido ao confinamento para o pilar curto 100L.

Os valores destas tensões estão resumidos na Tabela 7.1, indicado como $\mathrm{f}_{\mathrm{cc}}$ na coluna da resistência do núcleo comfinado. Os elementos mostrados nas Fig. 7.20 até 7.25 correspondem à metade dos pilares curtos, a parte extrema não visível é a região que contêm a armadura de fretagem e a parte visível é a região do meio do pilar que mostra o efeito do confinamento que provem das armaduras transversais. Nestas figuras é possível observar que o concreto do núcleo está sujeito a um estado de tensão triaxial (por causa das pressões laterais e à força axial aplicada) e apresenta tensões maiores que a resistência uniaxial do concreto, significando que houve um encruamento do material, este é o efeito do confinamento. As Fig. 7.20 até Fig. 7.25 mostram que regiões do núcleo estão mais bem confinadas, os pilares curtos com espaçamento entre estribos de $5 \mathrm{~cm}$ apresenta um núcleo 
melhor confinado, a região externa da seção transversal correspondente ao cobrimento não apresenta confinamento. Para realizar a análise numérica nos diferentes pilares curtos, foram introduzidas as propriedades mecânicas dos materiais obtidas nos ensaios (Tabela 6.1 e Tabela 6.2).

Com este modelo de EF não foi possível introduzir o efeito do destacamento do cobrimento, que corresponderia a uma queda da resistência. Os valores das tensões estão em MPa. Para os pilares curtos 50L e 100L não foi possível atingir a força correspondente ao deslocamento máximo aplicado (nas Fig. 7.24 e 7.25 o TIME < 1), nestes pilares os materiais atingiram a superfície de ruptura antes.

Das análises dos pilares curtos foram verificados os valores das tensões das armaduras longitudinais e transversais para todas as etapas de carga. As Fig. 7.26 até Fig. 7.31 mostram os valores das tensões para a etapa final de carga.

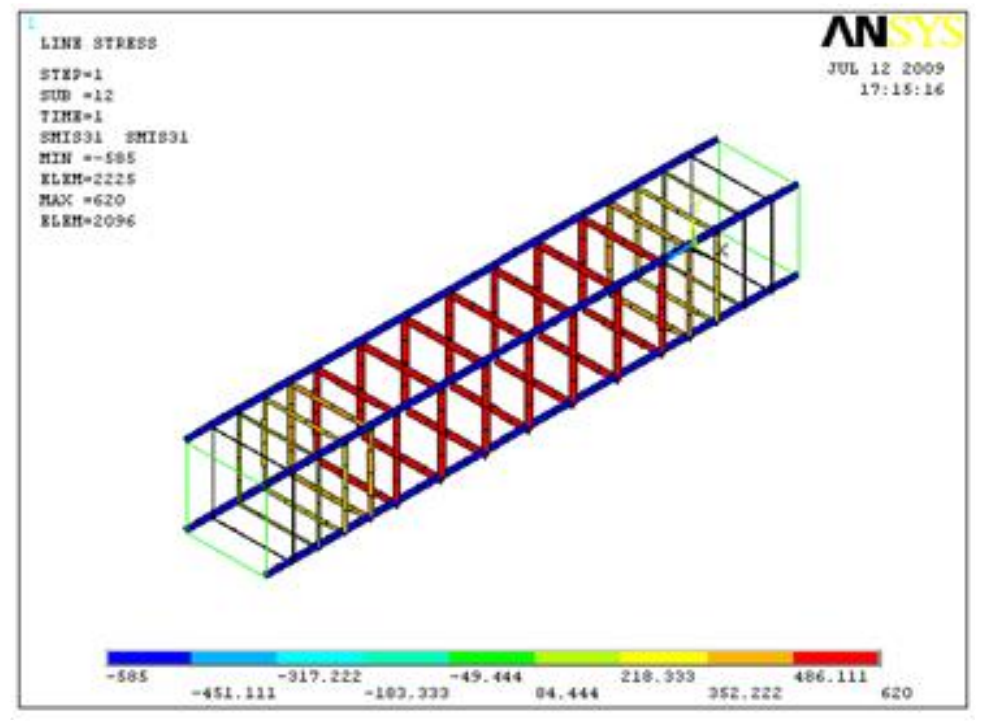

Fig. 7.26 - Valor das tensões nas armaduras na força última no pilar curto $50 \mathrm{H}$. 


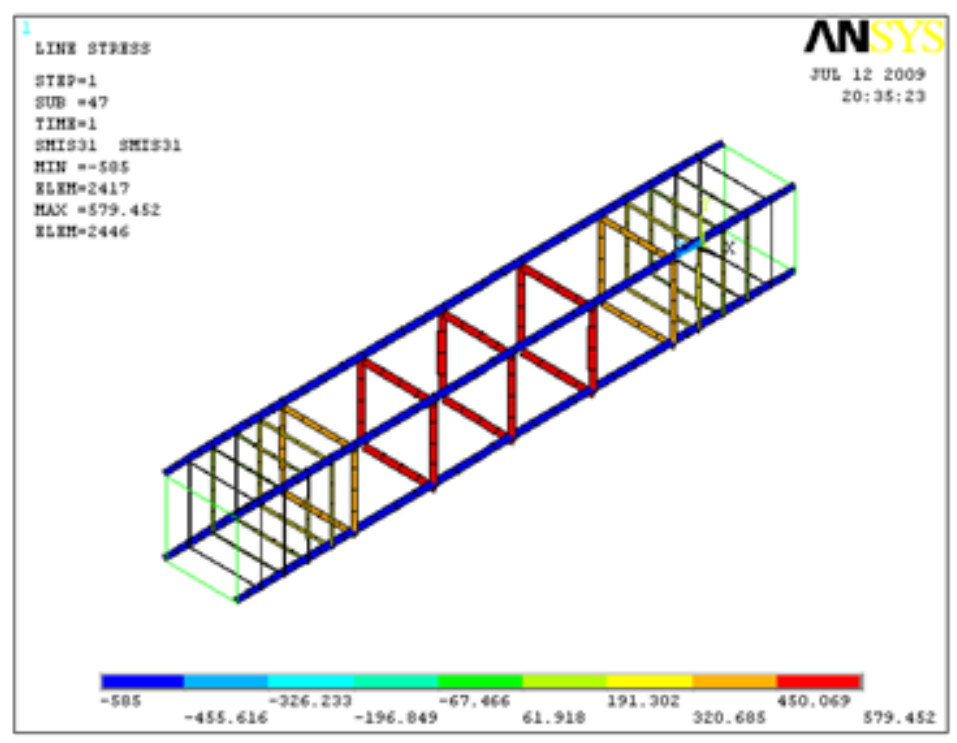

Fig. 7.27 - Valor das tensões nas armaduras na força última no pilar curto $100 \mathrm{H}$.

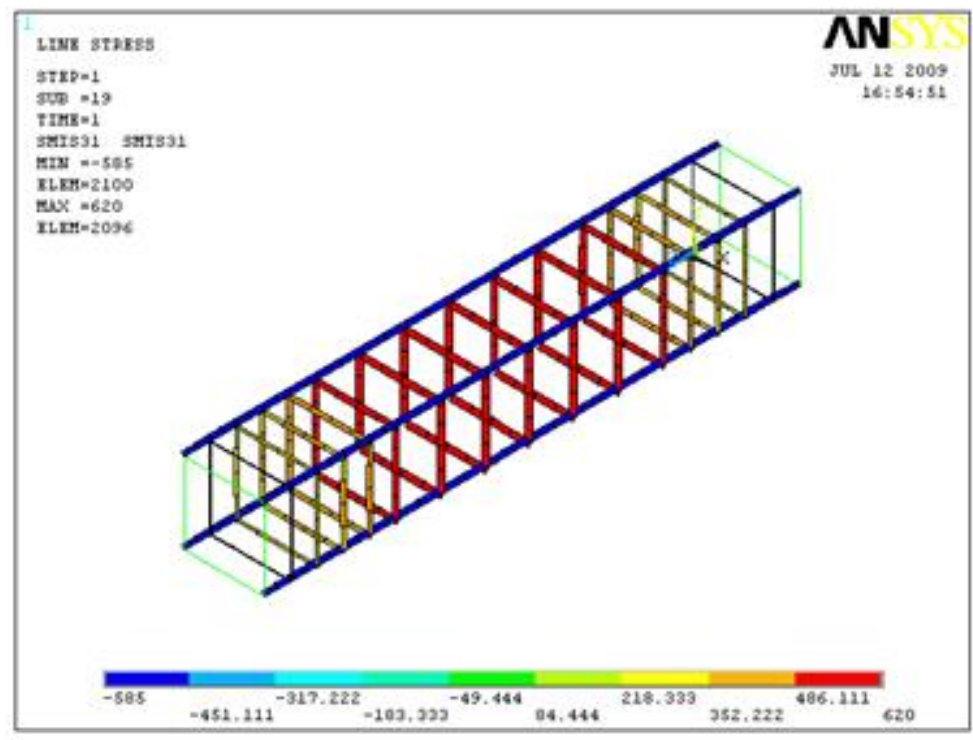

Fig. 7.28 - Valor das tensões nas armaduras na força última no pilar curto 50M. 


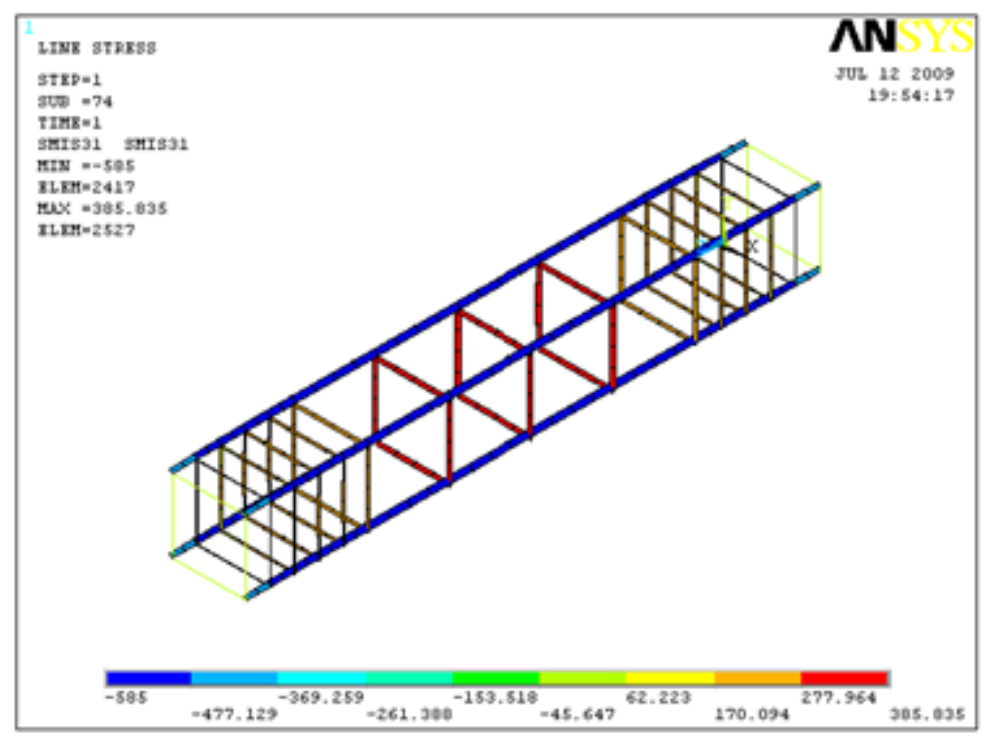

Fig. 7.29 - Valor das tensões nas armaduras na força última no pilar curto 100M.

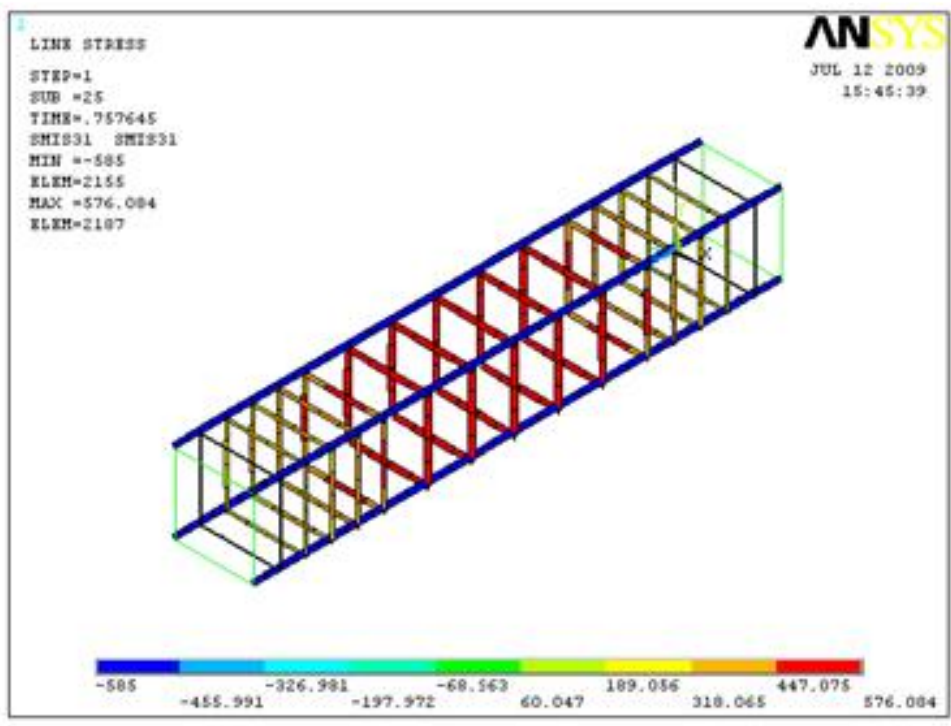

Fig. 7.30 - Valor das tensões nas armaduras na força última no pilar curto 50L. 


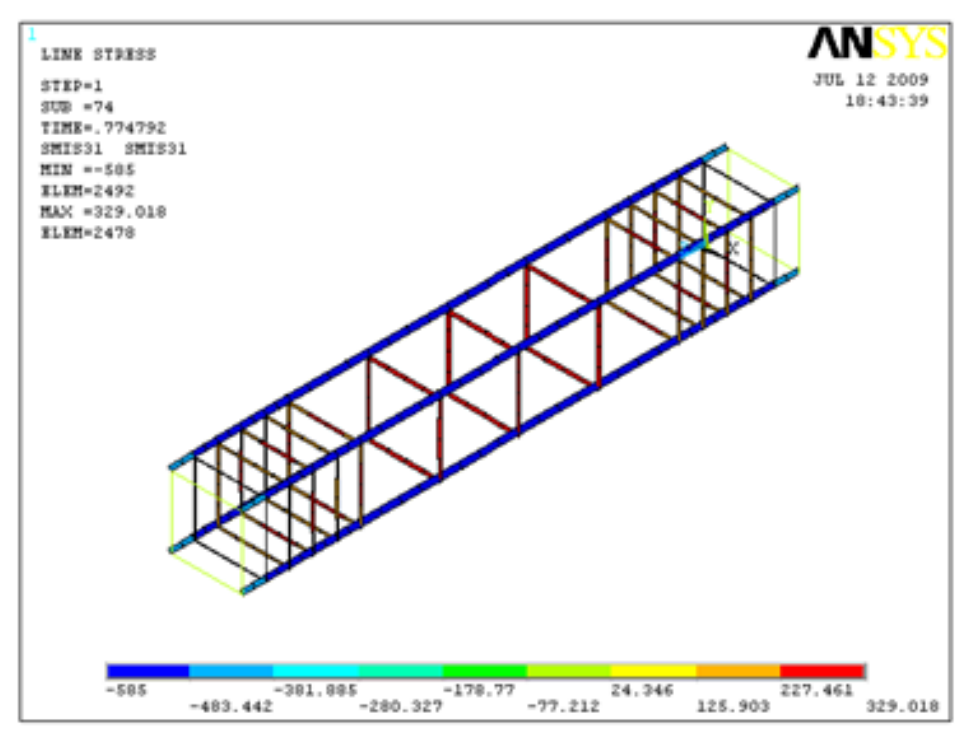

Fig. 7.31 - Valor das tensões nas armaduras na força última no pilar curto 100L.

Observando as Fig. 7.25 até 7.31 é possível constatar que para os pilares curtos com o espaçamento entre estribos de $5 \mathrm{~cm}$ as suas armaduras transversais atingiram o escoamento, o mesmo não aconteceu para os pilares com espaçamento entre estribos de $10 \mathrm{~cm}$. Isto mostra que, ao diminuir o espaçamento entre estribos, estes funcionam melhor como elementos confinantes, porque a tensão atuante no estribo está diretamente relacionada com o efeito do confinamento. Em todos os pilares curtos as armaduras longitudinais escoaram.

Os valores das tensões nas armaduras obtidas nas análises numéricas são diferentes aos obtidos nos ensaios de laboratório, a diferença é apreciável, um dos motivos é porque nas análises numéricas somente foram aplicadas forças centradas, possivelmente ao considerar excentricidade acidental os resultados se aproximem dos resultados obtidos nos ensaios, também foi idealizada uma aderência perfeita entre o aço e o concreto, alem disso os elementos finitos empregados para simular o concreto não descrevem todas suas características físicas, entre outros fatores.

Como parte do estudo comportamental dos pilares curtos foram obtidas as tensões laterais confinantes dos diferentes pilares curtos, um resumo dos seus valores estão na Tabela 7.1. Nas Fig. 7.32 e Fig. 7.33 podem ser observados os valores destas tensões para o pilar $50 \mathrm{M}$ para duas etapas diferentes da análise. 


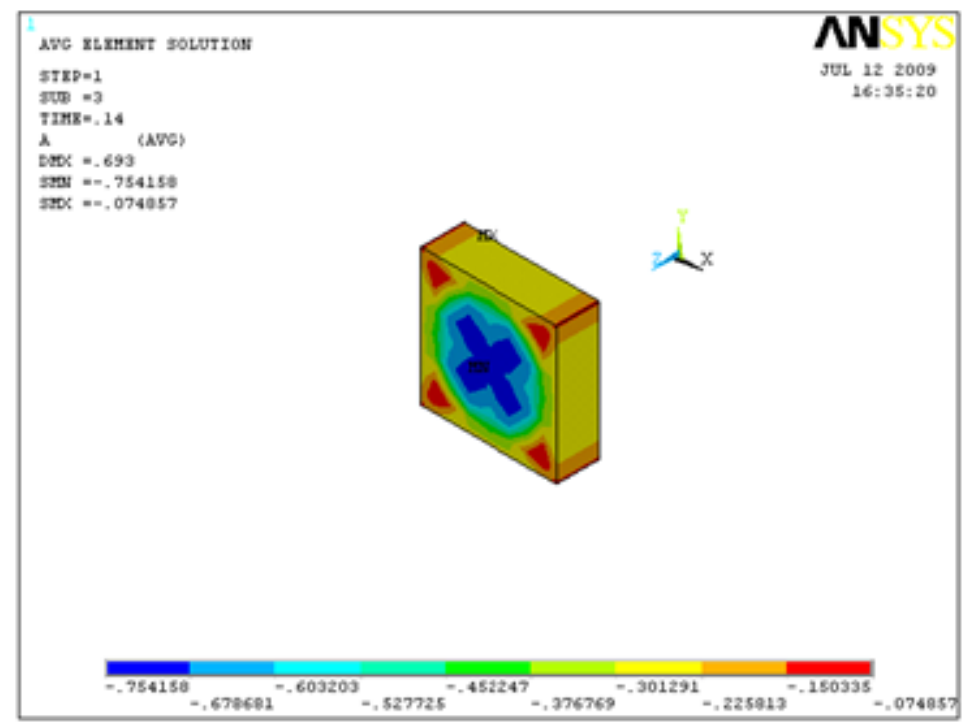

Fig. 7.32 - Tensões laterais de confinamento do pilar 50M para um 14\% da força última.

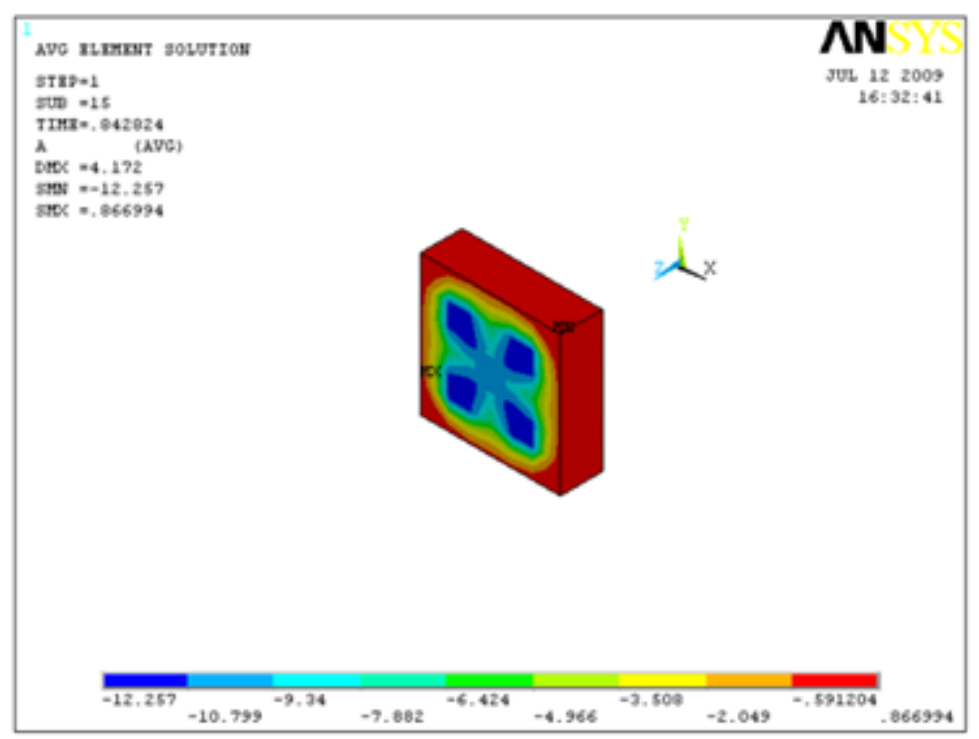

Fig. 7.33 - Tensões laterais de confinamento do pilar 50M para um 84\% da força última.

As Fig. 7.32 e 7.33 mostram um elemento do pilar curto entre 2 estribos com os valores das distribuições das pressões laterais confinantes. É possível verificar o incremento dos valores entre as duas etapas da analise. Se forma um arco horizontal no plano da seção transversal seus valores são diferentes nas diferentes regiões da seção transversal, estes arcos horizontais correspondem às regiões melhor confinadas, formato muito similar ao da Fig. 3.9. Estas distribuições variáveis provem do efeito da deformação lateral do concreto que se apóia na armadura transversal a qual provoca pressões laterais que introduzem no concreto um comportamento tridimensional; na região do cobrimento esta pressão é inexistente. A Fig. 7.32 corresponde ao início da aplicação da força e a Fig. 7.33 quase ao final da etapa da aplicação da força. 


\subsection{COMPARAÇÃO ENTRE OS VALORES OBTIDOS NUMERICAMENTE PELO MODELO DE LÉGERON E PAULTRE (2003) E OS EXPERIEMENTAIS}

Os resultados numéricos apresentados nas Fig. 7.20 até a Fig. 7.33 e outros não mostrados foram resumidos na Tabela 7.1.

Tabela 7.1 - Respostas dos modelos da análise numérica dos pilares curtos.

\begin{tabular}{|c|c|c|c|c|}
\hline \multirow{2}{*}{ Serie } & \multicolumn{4}{|c|}{ Analise Numérica } \\
\cline { 2 - 5 } & $\sigma_{\mathrm{LAT}}(\mathrm{MPa})$ & $\mathrm{f}_{\mathrm{cc}}(\mathrm{MPa})$ & $\varepsilon_{\mathrm{sw}}(\%)$ & $\sigma_{\mathrm{sw}}(\mathrm{MPa})$ \\
\hline \hline $100 \mathrm{H}$ & 1,97 & 108,2 & 2,70 & 579,40 \\
\hline $100 \mathrm{M}$ & 1,65 & 62,50 & 1,76 & 385,80 \\
\hline $100 \mathrm{~L}$ & 1,08 & 35,90 & 1,50 & 329,00 \\
\hline $50 \mathrm{H}$ & 2.01 & 111,6 & 5,60 & 620,00 \\
\hline $50 \mathrm{M}$ & 2,03 & 65,05 & 5,00 & 620,00 \\
\hline $50 \mathrm{~L}$ & 1,92 & 37,90 & 2,69 & 576,10 \\
\hline
\end{tabular}

Na Tabela $7.1 \sigma_{\text {LAT }}$ é a tensão lateral de confinamento, $\mathrm{f}_{\mathrm{cc}}$ é o valor da tensão do concreto confinado no núcleo da seção, $\varepsilon_{\mathrm{sw}}$ é a deformação específica da armadura transversal e $\sigma_{\text {sw }}$ é a tensão atuante na armadura transversal. Todos os valores da tabela correspondem à força última. É possível verificar que as tensões nas armaduras transversais para os pilares com espaçamento entre estribos de $5 \mathrm{~cm}$ atingiram o escoamento (exceto para o pilar 50L, que esteve muito próximo), para o caso dos pilares com espaçamento entre estribos de $10 \mathrm{~cm}$ os estribos não atingiram o escoamento, isto mostra que o confinamento melhora quando a tensão atuante nas armaduras transversais é maior. O valor da tensão confinante da Tabela 7.1 corresponde a uma seção transversal junto ao estribo, não é a tensão confinante efetiva (adotada no modelo de Légeron e Paultre, 2003) considerada numa seção entre duas separações consecutivas de estribos (ver Eq. 3.4). O valor da tensão no núcleo do concreto foi maior para os pilares com espaçamento de estribos de $5 \mathrm{~cm}$, isto mostra que a maior tensão confinante maior o incremento da resistência do núcleo em virtude do efeito do estado de tensões triaxiais.

Foi feita um analise dos pilares curtos considerando o modelo de Légeron e Paultre (2003), incluindo seus parâmetros principais. A Tabela 7.2 mostra estes resultados. 
Tabela 7.2 - Resultados da análise dos pilares com o modelo de Légeron e Paultre (2003).

\begin{tabular}{|c|c|c|c|c|c|c|c|c|c|}
\hline \multirow{2}{*}{ Serie } & \multirow{2}{*}{$\begin{array}{c}0,92 \mathrm{f}_{\mathrm{c}, \text { adot }}(\mathrm{MPa}) \\
\mathrm{CP} 10 \times 20\end{array}$} & \multirow{2}{*}{$\begin{array}{c}\varepsilon_{\mathrm{c} 1} \\
(\%)\end{array}$} & \multirow{2}{*}{$\begin{array}{l}\varepsilon_{\mathrm{cu} 1} \\
(\% 0)\end{array}$} & \multicolumn{6}{|c|}{ Légeron - Paultre (2003) - EUROCODE 2 (2004) } \\
\hline & & & & $\sigma_{\text {LAT_e }}(\mathrm{MPa})$ & $f_{\mathrm{cc}}(\mathrm{MPa})$ & $\varepsilon_{c c 1}(\%)$ & $\varepsilon_{\text {ccul } 1}(\%)$ & $\sigma_{\mathrm{sw}}(\mathrm{MPa})$ & $\mathrm{I}_{\mathrm{e}}(\%)$ \\
\hline $100 \mathrm{H}$ & 94,8 & 2,80 & 2,80 & 0,20 & 95,8 & 2,86 & 3,22 & 155,5 & 0,21 \\
\hline $100 \mathrm{M}$ & 54,3 & 2,42 & 3,50 & 0,18 & 55,2 & 2,50 & 4,16 & 140,0 & 0,33 \\
\hline $100 \mathrm{~L}$ & 31,3 & 2,04 & 3,50 & 0,17 & 32,1 & 2,15 & 4,56 & 130,0 & 0,53 \\
\hline $50 \mathrm{H}$ & 94,8 & 2,80 & 2,80 & 1,11 & 100,3 & 3,14 & 5,14 & 210,7 & 1,17 \\
\hline $50 \mathrm{M}$ & 54,3 & 2,42 & 3,50 & 1,25 & 60,6 & 3,00 & 8,12 & 238,1 & 2,31 \\
\hline $50 \mathrm{~L}$ & 31,3 & 2,04 & 3,50 & 2,04 & 40,3 & 3,38 & 16,51 & 386,6 & 6,50 \\
\hline
\end{tabular}

Os resultados da Tabela 7.2 mostram também resultados de parâmetros do concreto não confinado. Para o concreto não confinado: a segunda coluna da tabela corresponde à resistência do concreto do pilar, a terceira coluna da tabela é a deformação específica correspondente ao ponto de máximo da curva tensão-deformação específica do concreto e a quarta coluna a deformação específica limite no dimensionamento à flexão; estas duas últimas da norma EUROCODE 2 (2004), que são dados necessários para obter os valores dos parâmetros do concreto confinado (ver item 2.4.2).

Para o concreto confinado $\sigma_{\text {LAT_e }}$ é a tensão lateral confinante efetiva considerada entre dois espaçamentos de estribos (ver Eq. 3.44) este valor é necessário para calcular o índice de confinamento efetivo $\mathrm{I}_{\mathrm{e}}$ (Eq. 3.35). A resistência do concreto confinado no núcleo da seção $f_{c c}$ é dada pelo EUROCODE 2 (2004) como (Eq. 7.7 e Eq. 7.8):

$$
\begin{array}{rrr}
f_{c c}=f_{c} \times\left(1+5 \times I_{e}\right) & \text { para } & \sigma_{\text {LAT_e }_{-}} \leq 0,05 \mathrm{f}_{\mathrm{c}} \\
f_{c c}=f_{c} \times\left(1,125+2,5 \times I_{e}\right) & \text { para } & \sigma_{\text {LAT_e }_{\mathrm{e}}}>0,05 \mathrm{f}_{\mathrm{c}}
\end{array}
$$

A deformação específica correspondente ao pico da curva do concreto confinado é $\varepsilon_{\mathrm{cc} 1}$ e a deformação específica última do concreto confinado é $\varepsilon_{\text {ccul }}$, suas expressões são fornecidas pelo EUROCODE 2 (2004) como (Eq. 7.9 e Eq. 7.10):

$$
\begin{gathered}
\varepsilon_{c c 1}=\varepsilon_{c 1} \times\left(\frac{f_{c c}}{f_{c}}\right)^{2} \\
\varepsilon_{c c u l}=\varepsilon_{c u 1}+0,2 \times I_{e}
\end{gathered}
$$

$\mathrm{Na}$ mesma tabela anterior $\sigma_{\mathrm{sw}}$ é a tensão atuante na armadura transversal correspondente á tensão máxima do concreto confinado (Eq. 3.45 até Eq. 3.47) e $\mathrm{I}_{\mathrm{e}}$ é o índice de confinamento efetivo (Eq. 3.35), e segundo Légeron e Paultre (2003) tem-se pequeno grau de confinamento para $\mathrm{I}_{\mathrm{e}}<5 \%$, mediano grau de confinamento para $5 \%<\mathrm{I}_{\mathrm{e}}<20 \%$ e alto grau de confinamento para $I_{e}>20 \%$. Os valores das deformações específicas e a tensão no concreto confinado provem das expressões de norma EUROCODE 2 (op. cit.) que no seu 
conteúdo inclui o calculo de parâmetros realistas para concretos confinados, mas não fornece a expressão da tensão lateral de confinamento que nesta situação foi obtida do modelo de Légeron e Paultre (op. cit.), de este modelo é possível também obter os valores de $\mathrm{f}_{\mathrm{cc}}$ (Eq. 3.44) e de $\varepsilon_{\mathrm{cc} 1}$ (Eq. 3.43), mas preferiu-se adotar os valores obtidos da norma EUROCODE 2 (2004) para estar dentro da mesma normativa.

Analisando a Tabela 7.2 é possível verificar que as deformações específicas correspondentes aos concretos confinado $\left(\varepsilon_{\mathrm{cc} 1}\right)$ são maiores que a dos concretos sem confinamento $\left(\varepsilon_{\mathrm{c} 1}\right)$, a diferença é pequena para os pilares com espaçamento entre estribos de $10 \mathrm{~cm}$. Mesmo comentário para as deformações específicas últimas ( $\varepsilon_{\mathrm{ccu} 1}$ e $\left.\varepsilon_{\mathrm{cu} 1}\right)$. Pode ser constatado que o índice de confinamento dos pilares corresponde a um pequeno grau de confinamento, exceto para o pilar 50L, neste pilar o valor de $\mathrm{I}_{\mathrm{e}}$ corresponde a um mediano grau de confinamento. As tensões nas armaduras transversais correspondentes ao pico da curva tensão-deformação específica do concreto confinado estão com valores menores que o de escoamento, sendo que a do pilar 50L foi o de maior valor. $\mathrm{O}$ incremento da resistência do núcleo do concreto foi muito pequeno para os pilares com espaçamento entre estribos de 10 $\mathrm{cm}$, já para o pilar 50L o incremento foi de quase $30 \%$. Os mesmos efeitos do confinamento e suas expressões fazem parte do modelo do Método Geral.

A Tabela 7.3 mostra um resumo dos valores obtidos dos pilares curtos durante os ensaios.

Tabela 7.3 - Resumo dos resultados dos ensaios de laboratório para os pilares curtos.

\begin{tabular}{|c|c|c|c|c|}
\hline \multirow{2}{*}{ Serie } & \multicolumn{4}{|c|}{ Ensaios de laboratório } \\
\cline { 2 - 5 } & $\mathrm{f}_{\mathrm{cc}}(\mathrm{MPa})$ & $\varepsilon_{\mathrm{cc} 1}(\% \mathrm{o})$ & $\varepsilon_{\mathrm{sw}}(\% \mathrm{o})$ & $\sigma_{\mathrm{sw}}(\mathrm{MPa})$ \\
\hline \hline $100 \mathrm{H}$ & 84,2 & 2,79 & 0,89 & 177,56 \\
\hline $100 \mathrm{M}$ & 48,80 & 2,16 & 0,61 & 121,70 \\
\hline $100 \mathrm{~L}$ & 27,48 & 1,82 & 0,44 & 87,78 \\
\hline $50 \mathrm{H}$ & 104,7 & 2,89 & 0,92 & 183,54 \\
\hline $50 \mathrm{M}$ & 52,10 & 3,37 & 1,03 & 205,49 \\
\hline $50 \mathrm{~L}$ & 29,15 & 3,73 & 0,98 & 195,51 \\
\hline
\end{tabular}

Na Tabela 7.3 o valor de $\varepsilon_{\mathrm{cc} 1}$ é a deformação do pilar curto correspondente à força última e $\mathrm{f}_{\mathrm{cc}}$ é o valor da resistência do concreto confinado, é possível mostrar que os resultados dos ensaios se aproximam dos resultados do modelo de Légeron e Paultre (2003), melhor que do modelo numérico porque o modelo de Légeron e Paultre (op. cit.) foi obtido com resultados de ensaios que consideram todas as não linearidades presentes no concreto, os motivos das diferenças já foram apontadas no item 6.1.3. O padrão na melhora na ductilidade e do incremento da resistência do concreto foi mantido considerando o menor espaçamento 
entre estribos, assim como a tensão atuante nas armaduras transversais foi maior para os pilares com estribos menos espaçados.

\subsection{CONSIDERAÇÕES FINAIS}

Ressalva-se neste projeto de pesquisa que foi enfatizado a obtenção de dados experimentais, e portanto, na comparação dos resultados experimentais com os resultados teóricos, os valores numéricos não servirão para calibração de modelos teóricos, mas foram considerados na análise comportamental dos modelos estudados.

O modelo que melhor aproxima aos resultados de laboratório nos ensaios dos pilares curtos é o modelo de Légeron e Paultre (2003) porque o modelo destes pesquisadores é fruto do estudo de resultados de 200 pilares curtos, que consideram as não linearidades próprias do concreto e do aço, fornecendo resultados mais realistas. Com o método dos EF os resultados serviram para realizar uma análise comportamental dos modelos como mencionado anteriormente, porque os elementos finitos empregados para a análise e os modelos de ruptura não conseguem simular todas as não linearidades físicas do concreto, alem de outros fatores que foram mencionados no item anterior.

O modelo de Légeron e Paultre (2003) foi incorporado ao Método Geral para considerar o confinamento. Na realidade o que interessa é o diagrama $\sigma_{c} \times \varepsilon_{c}$ do concreto confinado para assim obter resultados mais realistas e comprar os resultados dos ensaios dos pilares esbeltos sob compressão excêntrica com os resultados teóricos empregando o modelo do Método Geral.

Foi verificado que o confinamento que provem da armadura transversal pode ser incluído e foi verificado que sim existe ductilidade que provem do confinamento. Para pilares com espaçamento entre estribos de $10 \mathrm{~cm}$ é inexistente, mas para pilares com espaçamento entre estribos de $5 \mathrm{~cm}$ o efeito da ductilidade esteve presente. Somente o pilar $50 \mathrm{H}$ teve um ganho de resistência do núcleo e os motivos foram apontados no item 6.1.3.

Considera-se importante a realização de ensaios prévios para evitar alguns erros que possam surgir nos ensaios definitivos. 


\section{Capítulo 8}

\section{ANÁLISE TEÓRICA DOS PILARES ESBELTOS}

Os resultados dos ensaios dos pilares esbeltos são analisados com base no Método Geral, considerando programas computacionais elaborados pelo autor no software de programação algébrico e simbólico MathCad v. 14.

Como mencionado anteriormente, o Método Geral (MG) é considerado um método exato, seus resultados são os que melhor se aproximam dos resultados dos ensaios de laboratório e, quando são incluídos seus fatores de ponderação, servem para se obter um dimensionamento seguro e econômico. Os métodos aproximados presentes nas normas podem não ser adequados para o CAR. Foram elaborados gráficos de dimensionamento com base no método, os quais se encontram no Anexo F.

A comparação é feita verificando os valores da força última e da excentricidade de segunda ordem obtida nos ensaios, com os obtidos pela análise da curva força aplicadadeslocamento lateral calculados com o modelo do MG. São feitas duas comparações uma considerando o confinamento e a outra sem considerar o confinamento.

Ressalva-se que esta pesquisa é enfatizada na obtenção de dados experimentais dos pilares esbeltos e sua análise teórica com os modelos propostos pelo Método Geral.

\subsection{CONSIDERAÇÕES NA ELABORAÇÃO DO PROGRAMA}

O Método Geral é o que se pode fazer de mais rigoroso para estudar o comportamento de uma estrutura de concreto armado: à medida que uma peça se deforma, procura-se verificar se o elemento tem uma configuração estável e se não é atingida a ruína (se não há ruptura do concreto e deformação plástica excessiva das barras longitudinais da armadura nem instabilidade). É o método mais adequado para pilares esbeltos, ou melhor, para pilares com 
qualquer esbeltez, e neste estudo foram incorporados os modelos constitutivos do CAR e do CAR confinado.

O MG faz somente duas pequenas aproximações, a primeira é admitir a expressão simplificada da curvatura (Eq. 4.5) e a segunda aproximação provem da consideração do modelo numérico das diferenças finitas, sendo que a precisão dos resultados é função do número de partes em que foi dividido o pilar (Fig. 4.18).

Para a elaboração do programa, a teoria básica do método se encontra no Capitulo 4, os critérios empregados com base na teoria foram resumidos no fluxograma da Fig. 8.1 (para definição de variáveis ver Fig. 4.13 até a Fig. 4.16).

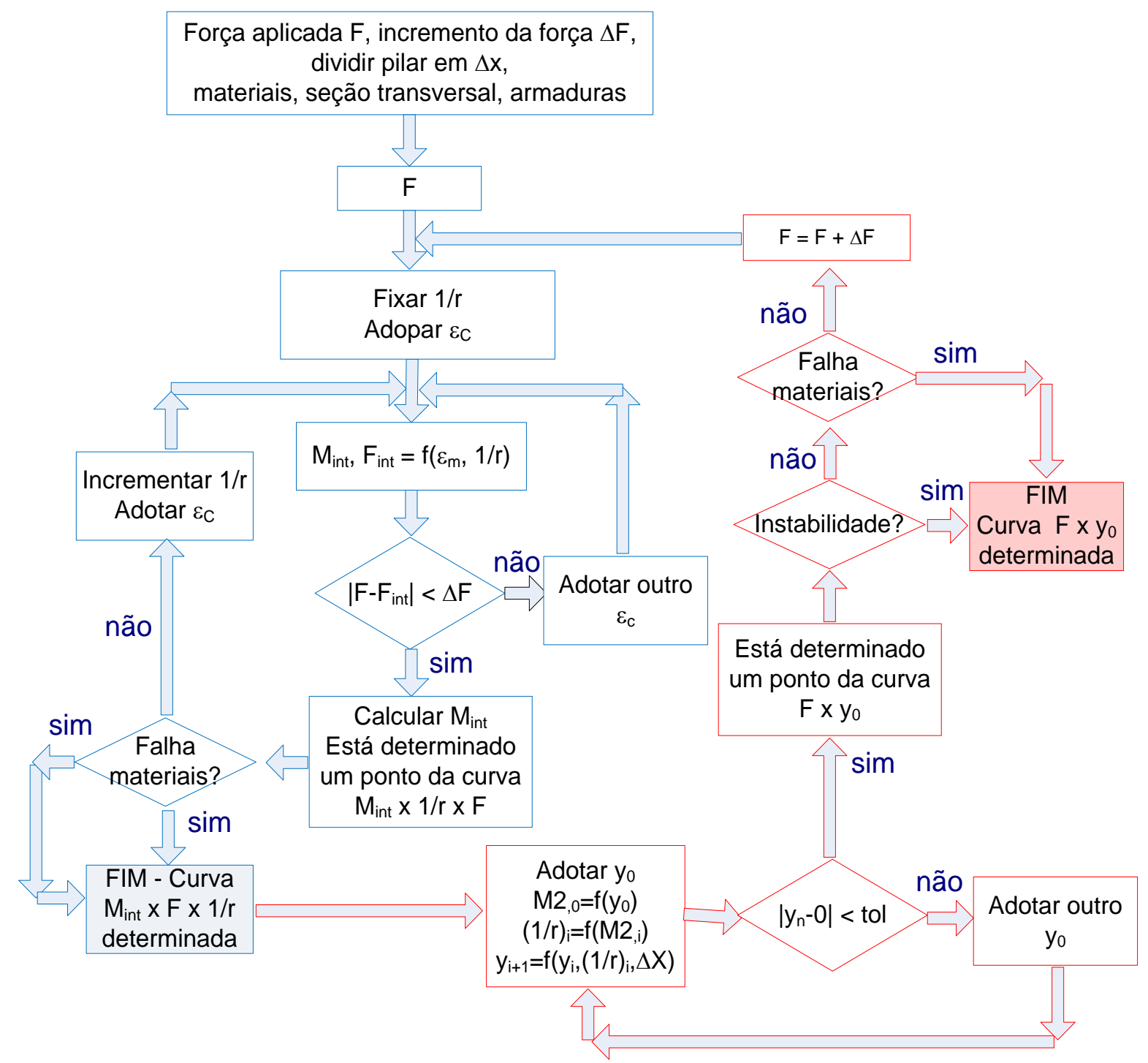

Fig. 8.1 - Fluxograma para a obtenção do gráfico Momento-Curvatura e do Método Geral com força axial incremental. 


\subsubsection{Diagramas momento-curvatura dos pilares esbeltos}

Para a obtenção da curva força axial-deslocamento lateral é necessário primeiro a obtenção do diagrama momento-curvatura para a configuração e geometria do pilar, isto está marcado em azul no fluxograma da Fig. 8.1.

A Fig. 8.2 mostra as curvaturas para o caso do pilar com concreto tipo L e um pilar com concreto tipo $\mathrm{H}$ para uma força axial reduzida $v$ de 0,3 . Nesta figura $\rho_{\mathrm{s}}$ é a taxa geométrica de armadura longitudinal correspondente a $4 \phi 12,5 \mathrm{~mm}$, cobrimento mecânico $\delta$ é 0,27. A obtenção dos gráficos foi considerando os modelos do EUROCODE 2 (2004) e Légeron e Paultre (2003) quando incluído o confinamento. Para a definição de variáveis ver item 4.5
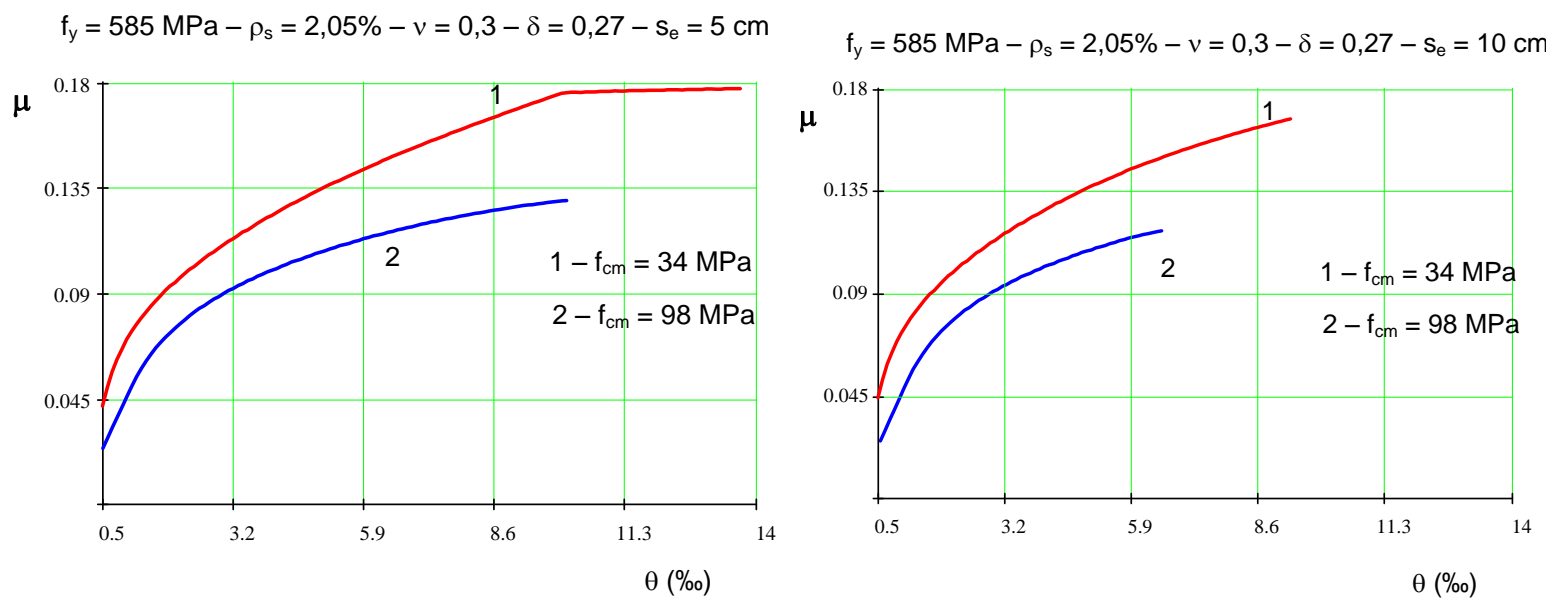

Fig. 8.2 - Diagrama momento-curvatura para os pilares esbeltos do ensaio para espaçamento entre estribos de $5 \mathrm{~cm}$ (esquerda) e $10 \mathrm{~cm}$ (direita).

Nesses diagramas pode-se observar que para um menor espaçamento entre estribos $s_{e} a$ curvatura última correspondente à ruína dos materiais é aumentada e o seu momento também é aumentado, isto significa uma melhoria na ductilidade se não ocorrer antes um ELU por instabilidade.

A Fig. 8.3 mostra um diagrama momento-curvatura para a mesma configuração dos diagramas anteriores, mas sem considerar o confinamento. 


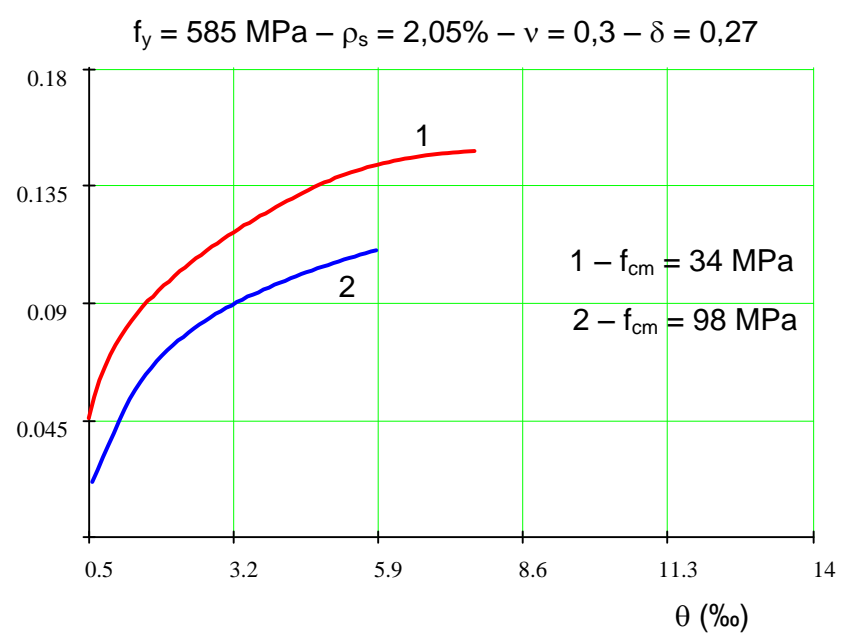

Fig. 8.3 - Diagrama momento-curvatura para os pilares esbeltos do ensaio sem confinamento.

Analisando as Fig. 8.2 e Fig. 8.3 é possível observar que o incremento na curvatura para o espaçamento entre os estribos de $10 \mathrm{~cm}$ é muito pequena em relação à situação sem estribos, isto mostra que o confinamento que produz o estribo com espaçamento de $10 \mathrm{~cm}$ é muito pequeno.

Foram obtidos diagramas momento-curvatura para todos os pilares dos ensaios para a força axial correspondente à força última. A Fig. 8.4 mostra para os pilares com concreto tipo H.
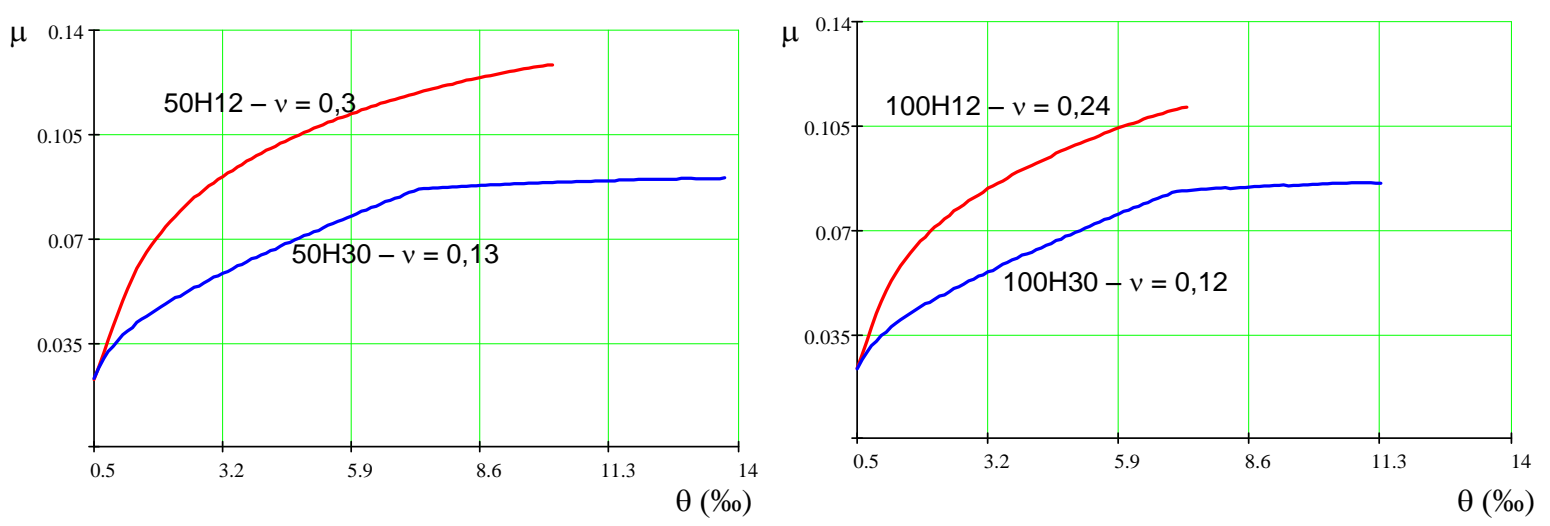

Fig. 8.4 - Diagramas momento-curvatura para os pilares com concreto tipo $\mathrm{H}$.

A Fig. 8.5 mostra os pilares com concreto tipo M. 

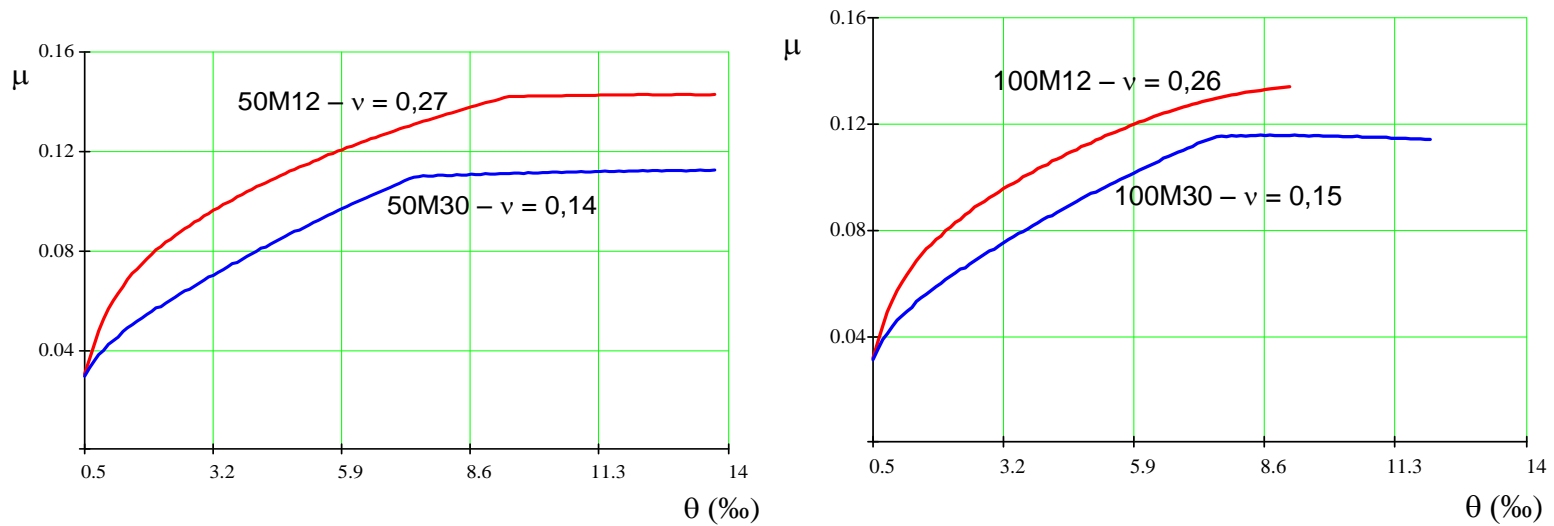

Fig. 8.5 - Diagramas momento-curvatura para os pilares com concreto tipo M.

A Fig. 8.6 mostra os pilares com concreto tipo L.
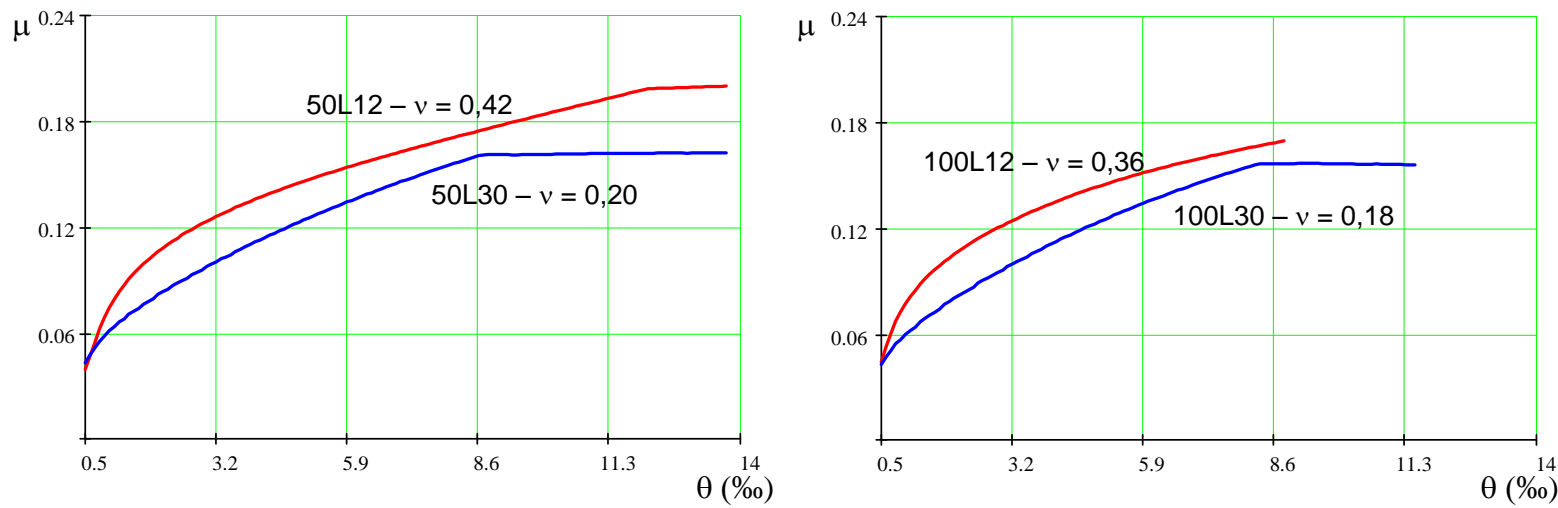

Fig. 8.6 - Diagrama momento-curvatura para os pilares com concreto tipo L.

É possível observar que, mesmo para forças últimas diferentes, aparentemente existe uma maior ductilidade para os pilares com espaçamento de estribos de $5 \mathrm{~cm}$ porque atingiram maior curvatura correspondente à ruína dos materiais, exceto para os pares 50M12 - 50M30 e 50L12 - 50L30, nos quais os pares atingiram a mesma curvatura última, isto mostra que a curvatura correspondente à ruína dos materiais (curvatura última) não é parâmetro para medir ductilidade, pois os pilares podem atingir antes a ruína por instabilidade.

Se a força axial for a mesma, para uma mesma geometria e mesmos materiais, mas excentricidades iniciais diferentes (momentos iniciais diferentes), a curvatura correspondente à ruína (seja por ruptura dos materiais ou instabilidade) é um parâmetro de ductilidade.

$\mathrm{O}$ parâmetro empregado para medir ductilidade de peças fletidas $D_{c}$ (trabalho realizado pela força $F$ numa deformação combinada, ver item 3.5.2 e item 6.2.8) resulta melhor que analisar o diagrama momento-curvatura.

Nas Fig. 8.4, Fig. 8.5 e Fig. 8.6 é possível observar que todos os pilares com excentricidade de $30 \mathrm{~mm}$ apresentam uma região de plastificação (ramo horizontal das curvas), e todos os pilares apresentam uma região de perda de rigidez (forma curva do 
diagrama momento-curvatura) devido à formação de fissuras, que corresponde a relações não lineares entre tensões e deformações específicas.

O diagrama momento-curvatura pode ser empregado para obter, em princípio, o valor do momento de $1^{\mathrm{a}}$ ordem que poderia ser aplicado a um pilar para este atingir a ruína; neste caso é necessário conhecer o momento de $2^{\mathrm{a}}$ ordem, que no caso dos pilares do ensaio são conhecidos.

Logo, para estes pilares o diagrama momento resistente-curvatura pode servir para analisar os resultados dos ensaios. Para o pilar 50H30 foi feito esta análise, conforme a Fig. 8.7 .

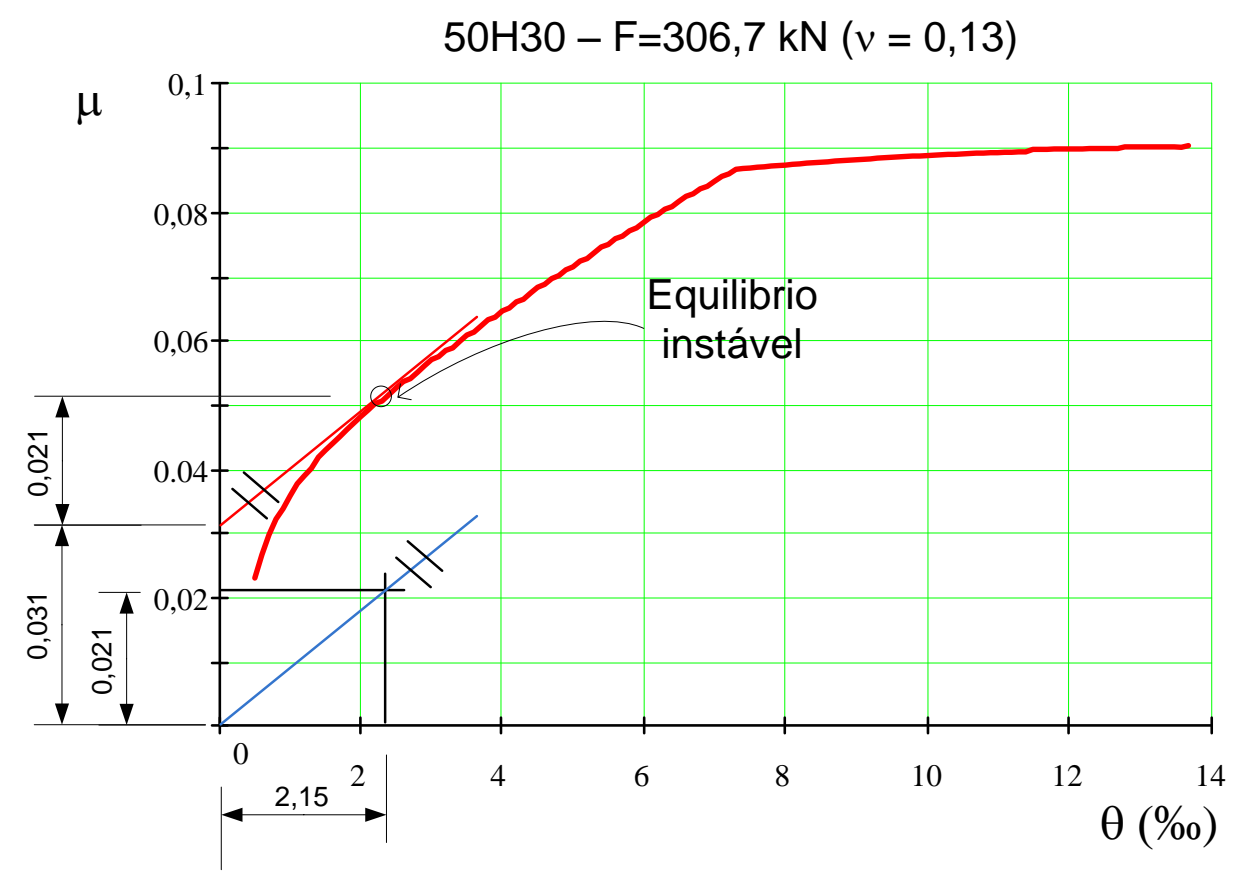

Fig. 8.7 - Diagrama momento-curvatura do pilar 50H30 e a validação do resultado do ensaio com os momentos de $1^{\mathrm{a}}$ e $2^{\mathrm{a}}$ ordem.

A Tabela 8.1 resume os dados necessários para a análise do pilar 50H30.

Tabela 8.1 - Resultados dos ensaios para o pilar $50 \mathrm{H} 30$.

\begin{tabular}{|c|c|c|c|c|c|c|}
\hline Serie & $\begin{array}{c}\text { Força última } \\
(\mathrm{kN})\end{array}$ & $\begin{array}{c}\text { Deforamaçao } \\
\text { LVDT comp. (\%) }\end{array}$ & $\begin{array}{c}\text { Deformação } \\
\text { LVDT trac. (\%) }\end{array}$ & $\begin{array}{c}\text { Distancia entre } \\
\text { LVDTs (m) }\end{array}$ & $\begin{array}{c}\text { Curvatura } \\
(1 / \mathrm{m})\end{array}$ & $\begin{array}{c}\text { Curvatura } \\
\text { adimensional }\end{array}$ \\
\hline \hline $50 \mathrm{H} 30$ & 306,730 & $-2,090$ & 2,394 & 0,250 & 0,018 & 2,152 \\
\hline
\end{tabular}

\begin{tabular}{|c|c|c|c|c|c|c|}
\hline Serie & $\begin{array}{c}\text { Excentricidade } \\
1^{\mathrm{a}} \text { ordem }(\mathrm{mm})\end{array}$ & $\begin{array}{c}\text { Excentricidade 2 }^{\mathrm{a}} \\
\text { ordem }(\mathrm{mm})\end{array}$ & $\begin{array}{c}\text { Momento 1 } \\
\text { ordem }(\mathrm{kN} . \mathrm{m})\end{array}$ & $\begin{array}{c}\text { Momento 2 } \\
\text { ordem }(\mathrm{kN} . \mathrm{m})\end{array}$ & $\begin{array}{c}\text { Mom.1a ordem } \\
\text { adimensional }\end{array}$ & $\begin{array}{c}\text { Mom. 2a ordem } \\
\text { adimensional }\end{array}$ \\
\hline \hline $50 \mathrm{H} 30$ & 30,000 & 19,876 & 9,202 & 6,097 & 0,031 & 0,021 \\
\hline
\end{tabular}

Considerando que o momento de $2^{\mathrm{a}}$ ordem varia linearmente com a curvatura (linha azul mostrada na Fig. 8.7). A reta que define esse momento é conseguida unindo a origem com a coordenada que corresponde à curvatura adimensional e o momento de $2^{\mathrm{a}}$ ordem 
correspondente à ruína [no caso do pilar $50 \mathrm{H} 30(2,15 ; 0,021)]$, mas poderia ser outra coordenada obtida dos ensaios, não necessariamente a última. Esses valores são obtidos das leituras da deformação lateral do pilar (transdutor LVDT3), das leituras dos transdutores LVDT6 e LVDT7 e a leitura da correspondente força aplicada.

Assim, para uma determinada força axial (no caso a força última), o máximo momento adimensional de $1^{\mathrm{a}}$ ordem suportável pelo pilar é o fornecido pela interseção, com o eixo dos momentos, da reta tangente (linha vermelha da Fig. 8.6) á curva momento-curvatura paralela à linha azul. Pela Fig. 8.6 é possível observar que a ordenada obtida pela reta que intersepta o eixo dos momentos aproxima o valor do momento de $1^{\text {a }}$ ordem obtido no ensaio. Todos os valores se encontram resumidos na Tabela 8.1.

O método simplificado do pilar padrão acoplado ao diagrama momento-curvatura da norma ABNT NBR 6118:2003, permite obter graficamente o valor do momento máximo de $1^{\text {a }}$ ordem para os pilares com esbeltez menor a 90. Considerando que os pilares dos ensaios tinham esbeltez de 92, muito perto do limite da norma, é verificada se é possível a validade dos valores do ensaio por este método simplificado.

O método do pilar padrão considera a elástica da curva como uma senóide, verificado experimentalmente no item 6.2.2 que é uma boa aproximação, com esta consideração o deslocamento lateral de $2^{\mathrm{a}}$ ordem pode ser calculado por:

$$
e_{2}=\frac{L_{e}^{2}}{\pi^{2}} \times \frac{1}{r}
$$

Considerando a Eq. 8.1 o momento de $2^{\mathrm{a}}$ ordem reduzido pode ser calculado mediante a Eq. 8.2.

$$
\mu_{2}=v \times \frac{e_{2}}{h}
$$

Ou em termos da curvatura adimensional:

$$
\mu_{2}=v \times \frac{L_{e}^{2}}{\pi^{2}} \times \frac{\theta / 1000}{h^{2}}
$$

Para obter a coordenada $(\theta, \mu)$ e introduzir no gráfico momento-curvatura é necessário adotar um valor da curvatura, que para empregar o mesmo gráfico vai ser adotado o mesmo valor da curvatura da Tabela 8.1, ou seja $\theta=2,15 \%$, substituindo este valor na Eq. 8.3 a força axial última reduzida é $v=0,13, \mathrm{~L}_{\mathrm{e}}=320 \mathrm{~cm}$ e h $=12 \mathrm{~cm}$, obtêm-se $\mu_{2}=0,0201$, valor próximo do resultado experimental. No gráfico obtém-se um valor muito perto do momento de $1^{\mathrm{a}}$ ordem máximo, obtido anteriormente, e que pode ser aplicado ao pilar. 


\subsubsection{Diagramas força axial-deslocamento lateral dos pilares esbeltos}

Já foi visto o procedimento da obtenção do diagrama momento-curvatura (é possível também construir uma tabela) necessário para o estudo do modelo do Método Geral. No MG é possível construir uma curva de força axial-deslocamento lateral (que corresponderia à mesma situação dos ensaios), da qual é possível obter a força última e seu correspondente deslocamento lateral.

A curva é desenhada ponto a ponto, normalmente é para uma força axial adotada (se começa por valores pequenos e vai-se incrementando, ver Fig. 4.15). Esta parte do programa está marcada em vermelho no fluxograma da Fig. 8.1. O procedimento para a obtenção dos outros pontos continua até o último ponto que corresponde à ruptura do concreto ou a deformação plástica excessiva das barras da armadura longitudinal ou por instabilidade do pilar, ou seja, até atingir a ruína do pilar. A curva é obtida ponto a ponto, como mostra a Fig. 8.8 , obtida para o pilar $50 \mathrm{H} 12$.

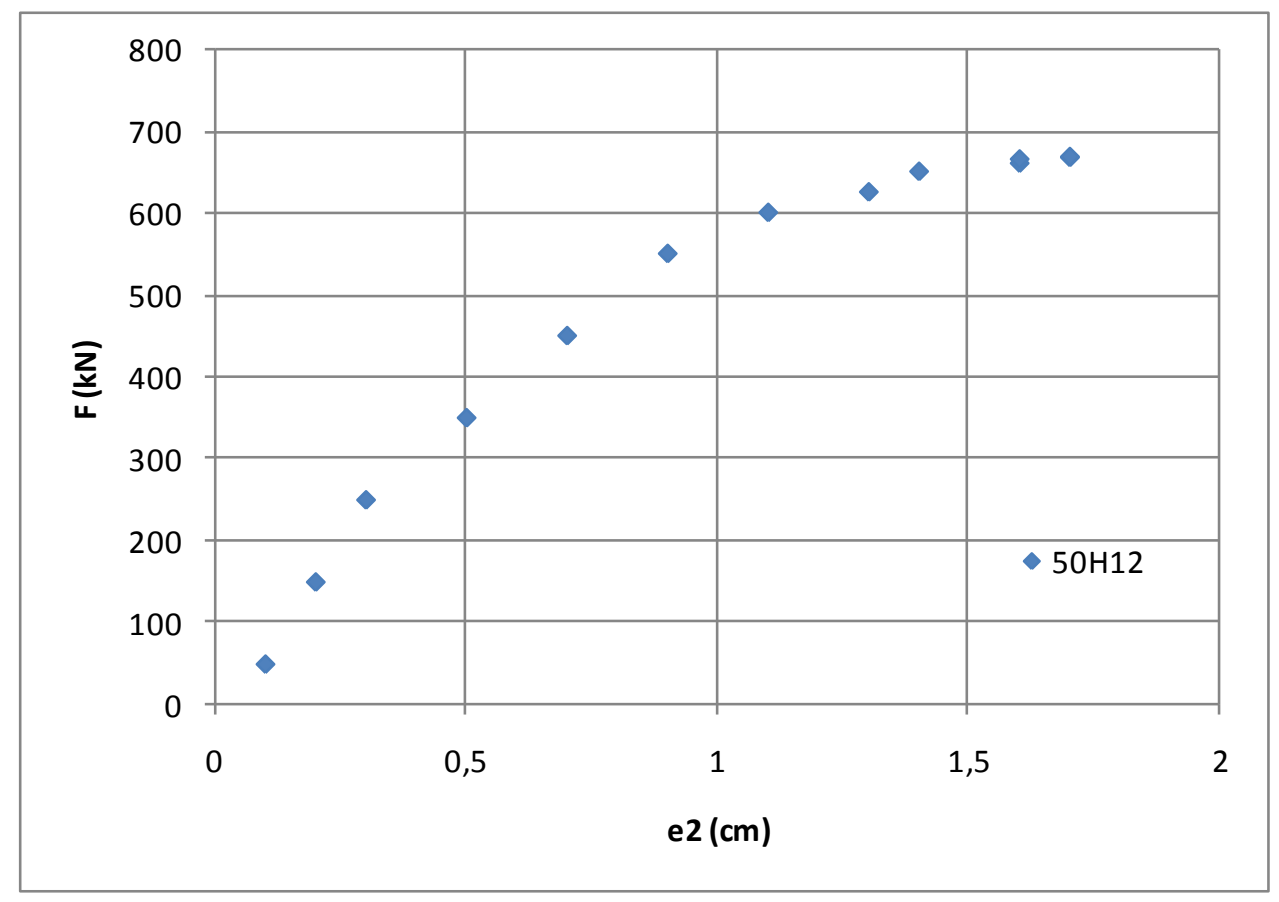

Fig. 8.8 - Resultado da aplicação do Método Geral para um pilar do ensaio.

Verifica-se que a ruína do pilar 50H12 foi por instabilidade, não houve ruptura dos materiais com relação a força última.

Com base nas premissas expostas no item 4.6.1, no próximo item são elaboradas as curvas para análise dos resultados experimentais. 


\subsection{COMPARAÇÃO DOS RESULTADOS EXPERIMENTAIS DOS PILARES POR MEIO DO MÉTODO GERAL}

Como parte do objetivo desta tese, foi feita uma verificação dos resultados obtidos nos ensaios, por meio dos programas com base no Método Geral que é considerado exato. Ao modelo foram incorporados os efeitos do confinamento. Como resultados foram obtidos a força última e o deslocamento lateral (excentricidade de $2^{\mathrm{a}}$ ordem).

A Fig. 8.9 mostra os resultados teóricos obtidos com o Método Geral dos pilares esbeltos com concreto tipo $\mathrm{H}$ considerando o confinamento que provem da armadura transversal.

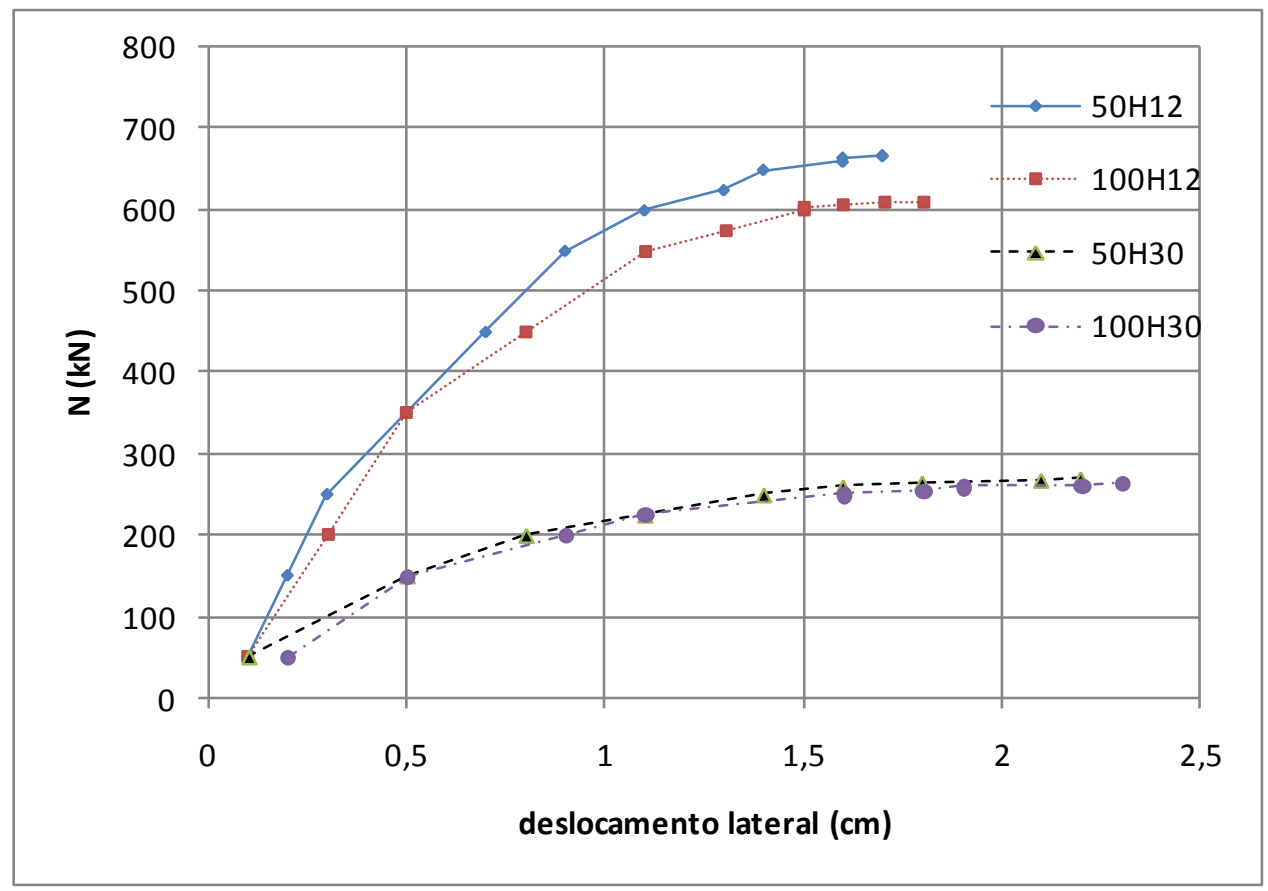

Fig. 8.9 - Diagrama força-excentricidade de $2^{\mathrm{a}}$ ordem para os pilares com concreto tipo $\mathrm{H}$.

A Fig. 8.10 mostra os resultados teóricos obtidos com o MG dos pilares esbeltos com concreto tipo M. 


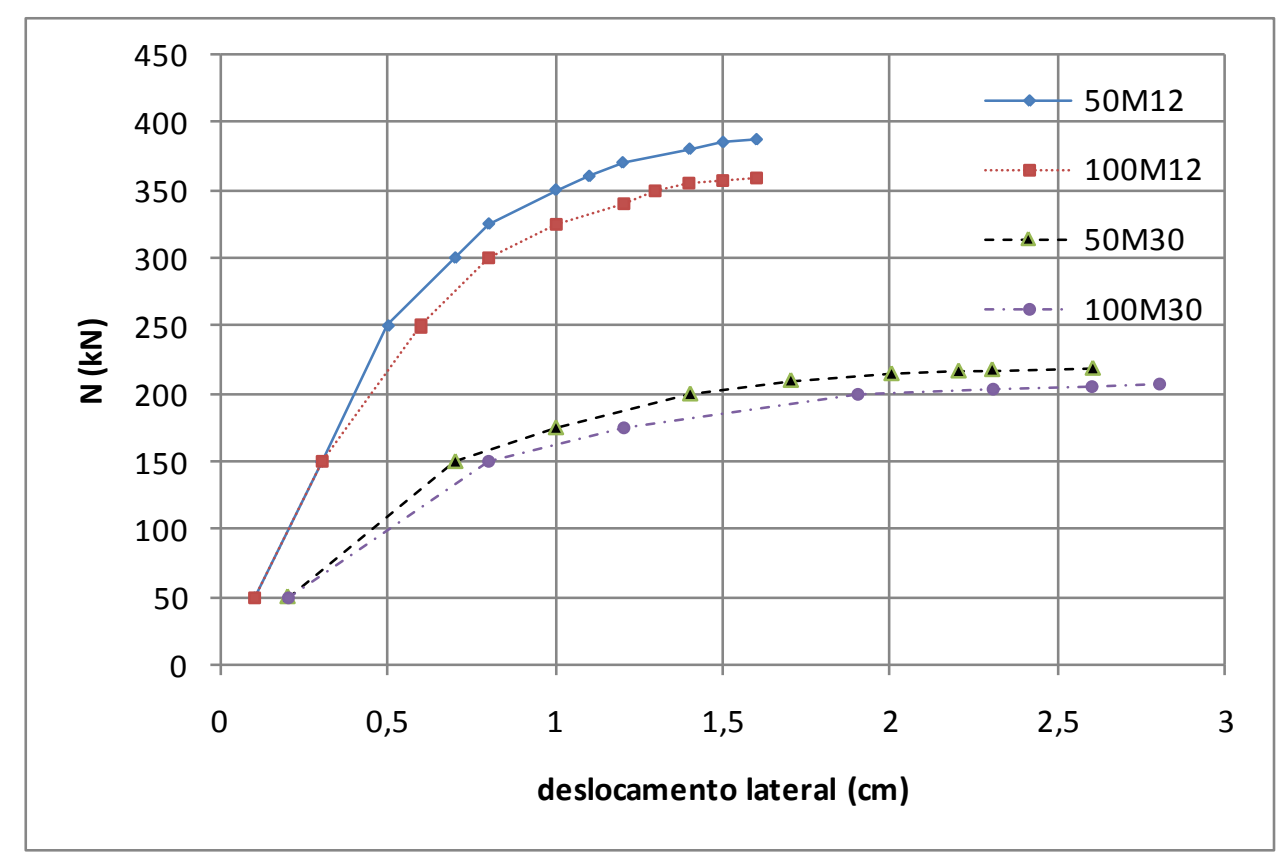

Fig. 8.10 - Diagrama força-excentricidade de $2^{\mathrm{a}}$ ordem para os pilares com concreto tipo $\mathrm{M}$.

A Fig. 8.11 mostra os resultados teóricos obtidos com o MG dos pilares esbeltos com concreto tipo L.

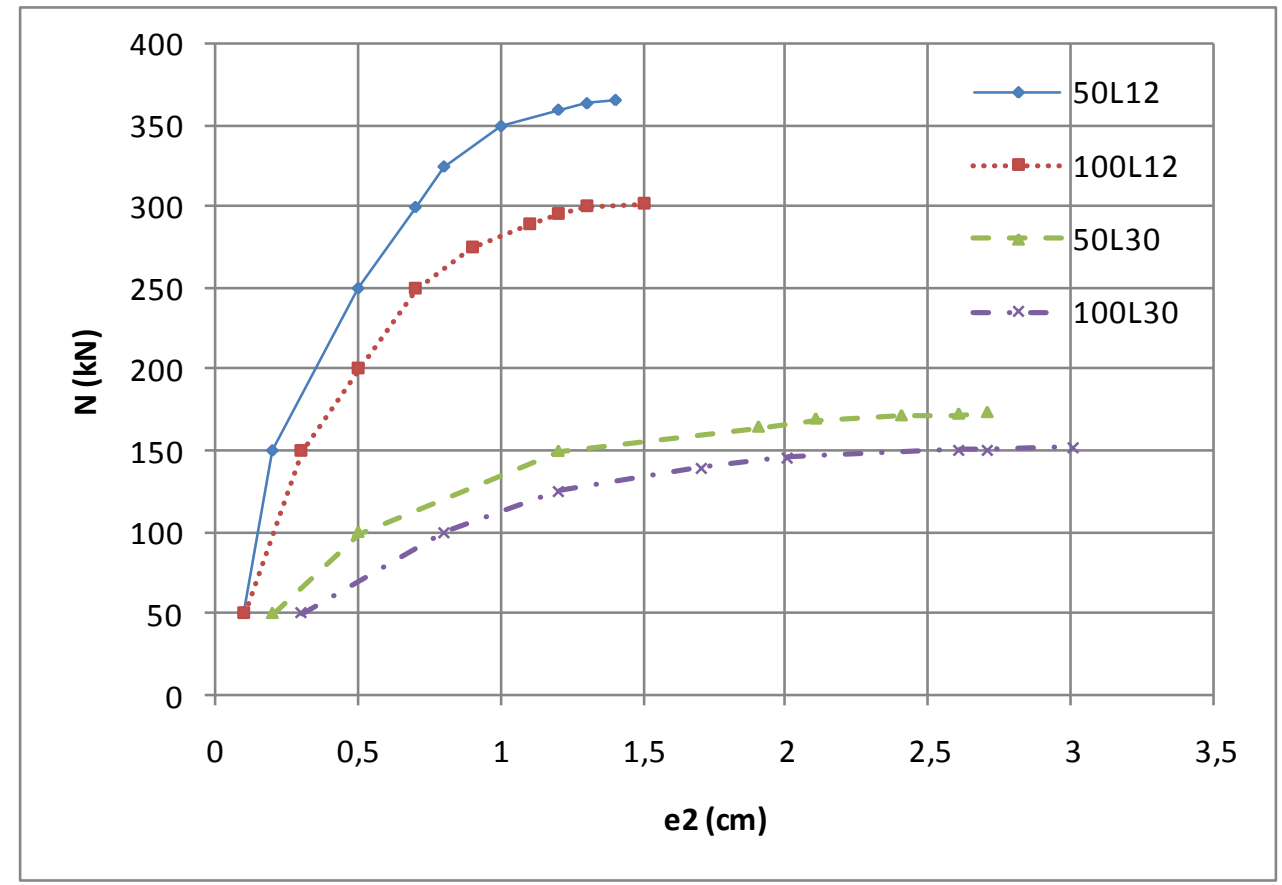

Fig. 8.11 - Diagrama força-excentricidade de $2^{\mathrm{a}}$ ordem para os pilares com concreto tipo L.

Nestes diagramas foram incorporados no método geral os modelos de confinamento de Légeron e Paulte (2003), por isso geralmente os pilares com menor espaçamento entre estribos apresentam uma maior força última. 
Analisando as Fig. 8.9 até Fig. 8.11 nota-se que todos os pilares com excentricidade de $30 \mathrm{~mm}$ têm maior predisposição à perda da estabilidade e seus deslocamentos laterais correspondentes à força última foram maiores.

Os pilares com excentricidade de força de $12 \mathrm{~mm}$ apresentam quase um mesmo deslocamento lateral independentemente do tipo de concreto e espaçamento entre as armaduras transversais.

O comprimento do pilar foi dividido em 20 partes, possivelmente refinando melhor a malha de elementos os resultados sejam mais precisos.

O módulo de deformação do concreto incorporado no programa foi do EUROCODE 2 (2004), isto para evitar variabilidade nas respostas, possivelmente considerando os valores obtidos nos ensaios os resultados apresentados pelo programa diminuiriam, pois os módulos obtidos nos ensaios foram menores aos do EUROCODE 2 (op. cit.).

Com o Método Geral não é possível obter resultados que mostrem o comportamento pós-pico dos pilares, somente vai até a ruína, seja por ruptura dos materiais ou instabilidade.

Os resultados obtidos para o índice de ductilidade no item 6.2.8 indicam que existe maior ductilidade para os pilares com excentricidades maiores de força, indicando maior ductilidade para os concretos de menor resistência à compressão. Os pilares com espaçamento entre estribos de $5 \mathrm{~cm}$ tiveram um pequeno incremento no parâmetro da ductilidade, houve dois pares de pilares que mostraram o contrario, os motivos destes resultados não esperados foram citados no item 6.2.8, porém nota-se um padrão de ductilidade.

Mesmo tendo sido concluído que o efeito do confinamento é muito pequeno para as taxas volumétricas de estribos adotadas, possivelmente, quando o efeito da força de compressão for mais importante que o efeito da flexão os resultados poderiam ser mais conclusivos (que não é o caso de pilares esbeltos).

Analisando os diagramas das Fig. 8.9 até Fig. 8.11 foi verificado que ao diminuir o espaçamento entre estribos houve um aumento nas resistências dos pilares. $\mathrm{O}$ incremento na resistência, ao diminuir o espaçamento dos estribos, para os pilares com $30 \mathrm{~mm}$ de excentricidade foi menor que para os que tinham excentricidade de $12 \mathrm{~mm}$. Considerando o espaçamento entre estribos, o ganho de resistência foi maior nos pilares com concreto de menor resistência, isto em virtude da maior deformabilidade lateral.

A Tabela 8.2 mostra um resumo dos valores das forças últimas teóricas e experimentais e de seus deslocamentos laterais máximos. 
Tabela 8.2 - Comparação de valores de forças últimas e deslocamentos laterais.

\begin{tabular}{|c|c|c|c|c|c|}
\hline Serie & $\begin{array}{l}\text { Fult,exp } \\
(\mathrm{kN})\end{array}$ & $\begin{array}{c}\text { Fult,Met.Geral } \\
(\mathrm{kN})\end{array}$ & $\begin{array}{c}\mathrm{F}_{\mathrm{ult}, \mathrm{MG}} / \mathrm{F}_{\mathrm{ult}, \exp } \\
(\mathrm{kN})\end{array}$ & $\begin{array}{l}e_{2, \exp } \\
(\mathrm{cm})\end{array}$ & $\begin{array}{l}e_{2, M G} \\
(\mathrm{~cm})\end{array}$ \\
\hline $100 \mathrm{H} 12$ & $\overline{586,5}$ & $\overline{6711,0}$ & 1,04 & 1,86 & 1,8 \\
\hline $50 \mathrm{H} 12$ & 706,9 & 668,0 & 0,94 & 2,07 & 1,7 \\
\hline $100 \mathrm{H} 30$ & 277,6 & 264,0 & 0,95 & 2,01 & 2,3 \\
\hline $50 \mathrm{H} 30$ & 306,7 & 270,0 & 0,88 & 1,99 & 2,2 \\
\hline $100 \mathrm{M} 12$ & 364,9 & 359,0 & 0,98 & 1,91 & 1,6 \\
\hline 50M12 & 385,6 & 387,0 & 1,00 & 1,89 & 1,6 \\
\hline $100 \mathrm{M} 30$ & 216,4 & 208,0 & 0,96 & 2,37 & 2,8 \\
\hline $50 \mathrm{M} 30$ & 191,1 & 219,0 & 1,15 & 3,08 & 2,6 \\
\hline 100L12 & 290,9 & 302,0 & 1,04 & 1,84 & 1,5 \\
\hline 50L12 & 338,9 & 366,0 & 1,08 & 1,72 & 1,4 \\
\hline 100L30 & 148,9 & 152,0 & 1,02 & 2,53 & 3,0 \\
\hline $50 \mathrm{~L} 30$ & 163,9 & 174,0 & 1,06 & 2,60 & 2,7 \\
\hline
\end{tabular}

$\mathrm{Na}$ Tabela 8.2 foram resumidos os valores das forças últimas e suas respectivas excentricidades de $2^{\mathrm{a}}$ ordem, obtidas experimentalmente e com o Método Geral. Existe uma boa aproximação entre os valores, a relação entre as forças mostra uma pequena segurança nos valores experimentais em relação aos teóricos, exceto nos pilares com concreto do tipo L, sendo que, possivelmente, o modelo de confinamento de Légeron e Paultre (2003), foi mais bem ajustado para o CAR. Em relação aos pilares 100M30 e 50M30 (ambos com a mesma excentricidade de força de $30 \mathrm{~mm}$ ), considerando os resultados experimentais, o pilar com espaçamento entre estribos de $5 \mathrm{~cm}$ mostrou menor força última (único caso) em virtude da presença de excentricidades acidentais.

O pilar 100H12 apresentou uma menor força experimental em relação à teórica, o motivo pode ter sido também a presença de excentricidade acidental adicional, que sempre está presente, embora com todos os cuidados no posicionamento do pilar na máquina de ensaio. Em média a relação entre os resultados experimentais e os teóricos é de 1,01 incluindo o valor experimental do pilar 50M30.

Considerando os resultados fornecidos pelo programa, em todos os casos, os pilares com menor espaçamento entre estribos apresentaram maior força última, que era o esperado considerando o efeito do confinamento, mesmo sendo pequeno este efeito ocorreu.

Em relação aos valores dos deslocamentos laterais as diferenças estão por volta de 15\%. Não pode ser estabelecido um parâmetro de ductilidade pelo valor do deslocamento lateral, pois as forças últimas são diferentes.

Outro fator que afetou os resultados dos ensaios foi que os pilares tiveram suas concretagens por etapas, além disto, existiu certa dificuldade no posicionamento dos pilares 
na máquina de ensaio INSTRON, provocando pequenas alterações nas excentricidades iniciais e imperfeições iniciais, especialmente nos primeiros pilares.

Como verificado que a configuração da seção transversal dos pilares produz um pequeno grau de confinamento, e nas verificações da ductilidade (com nos resultados dos ensaios) foi obtida uma regularidade, mas com algumas exceções no parâmetro que considera a ductilidade $\mathrm{D}_{\mathrm{c}}$ (item 6.2.8), foram elaborados outros gráficos sem considerar o efeito do confinamento.

A Fig. 8.12 mostra os pilares com concreto tipo $\mathrm{H}$ sem o efeito do confinamento e com excentricidade de força de $12 \mathrm{~mm}$ e $30 \mathrm{~mm}$.

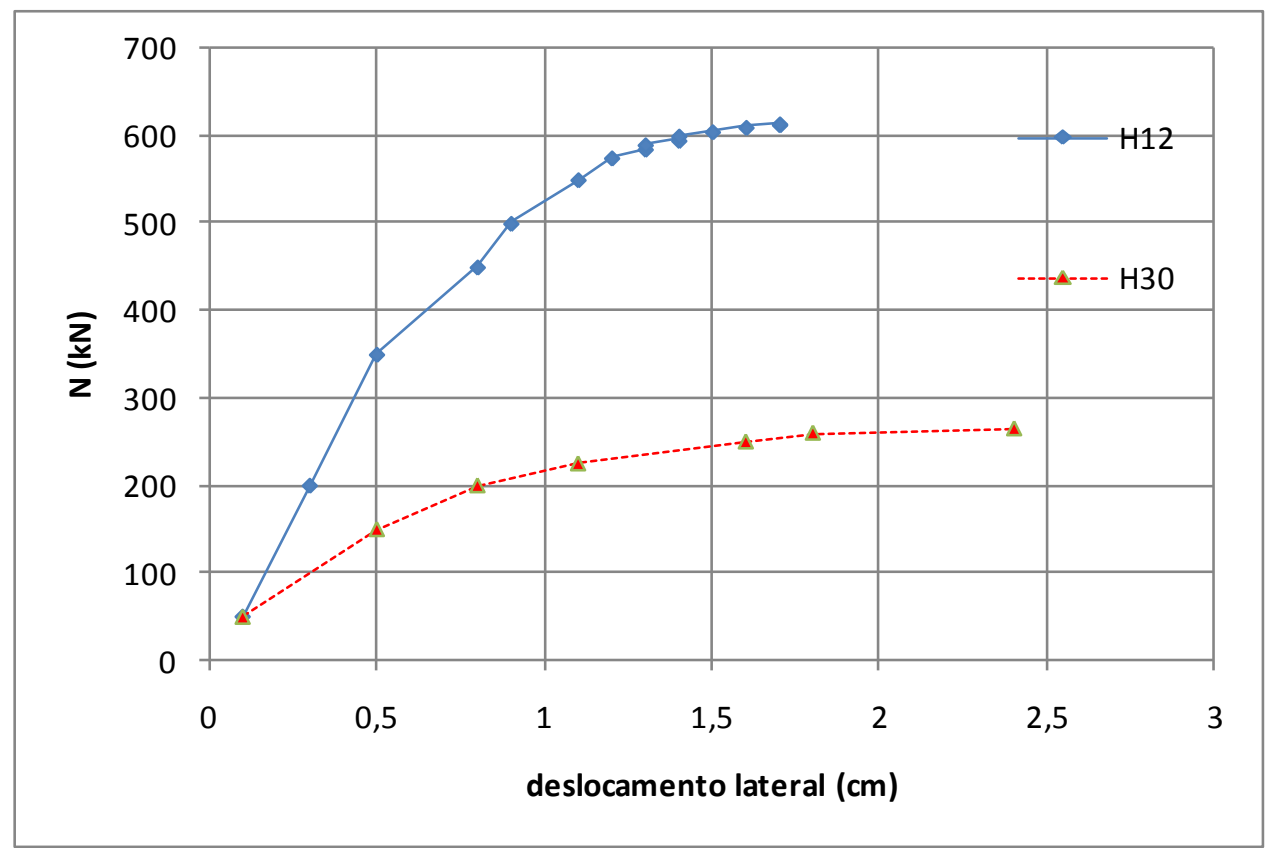

Fig. 8.12 - Pilares com concreto tipo H sem o efeito do confinamento.

A Fig. 8.13 mostra os pilares com concreto tipo M sem o efeito do confinamento. 


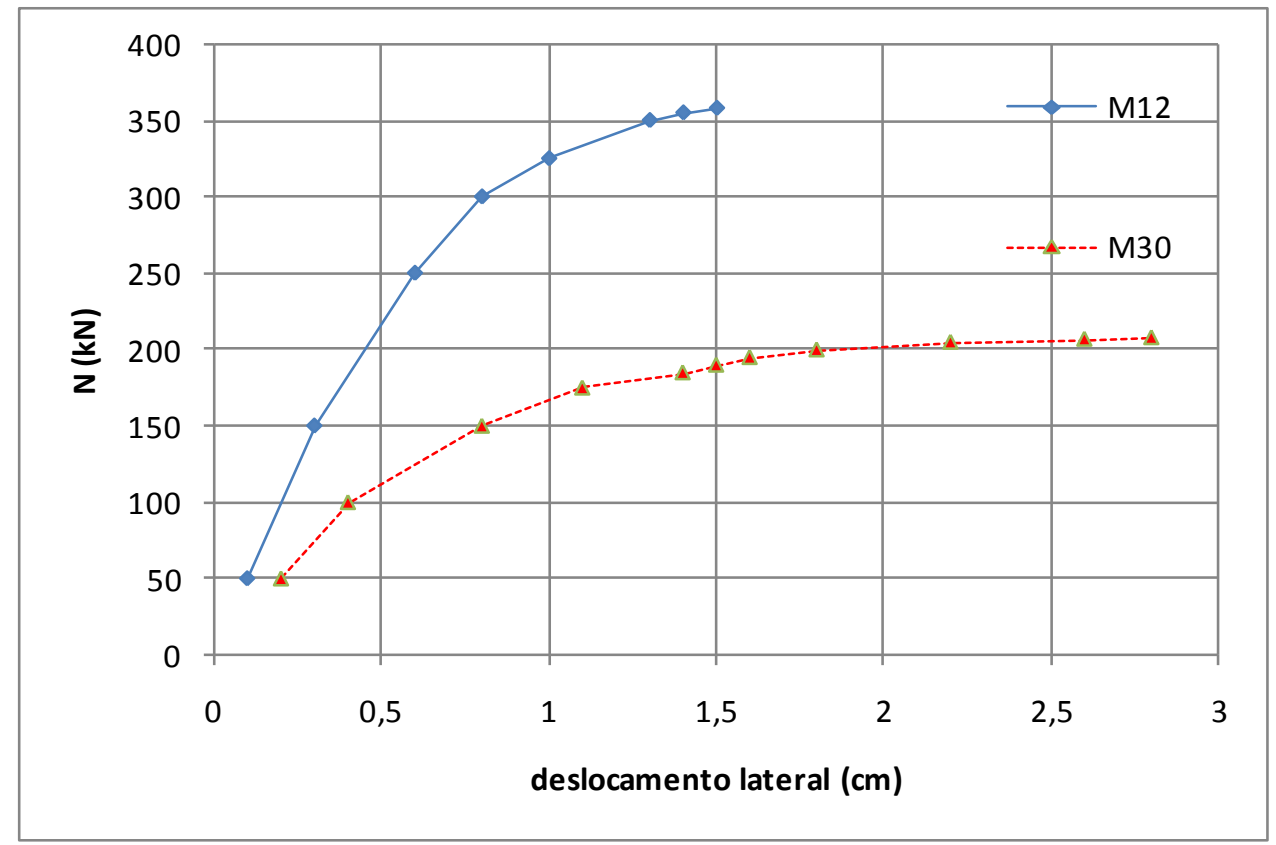

Fig. 8.13 - Pilares com concreto tipo M sem o efeito do confinamento.

A Fig. 8.14 mostra os pilares com concreto tipo L sem o efeito do confinamento.

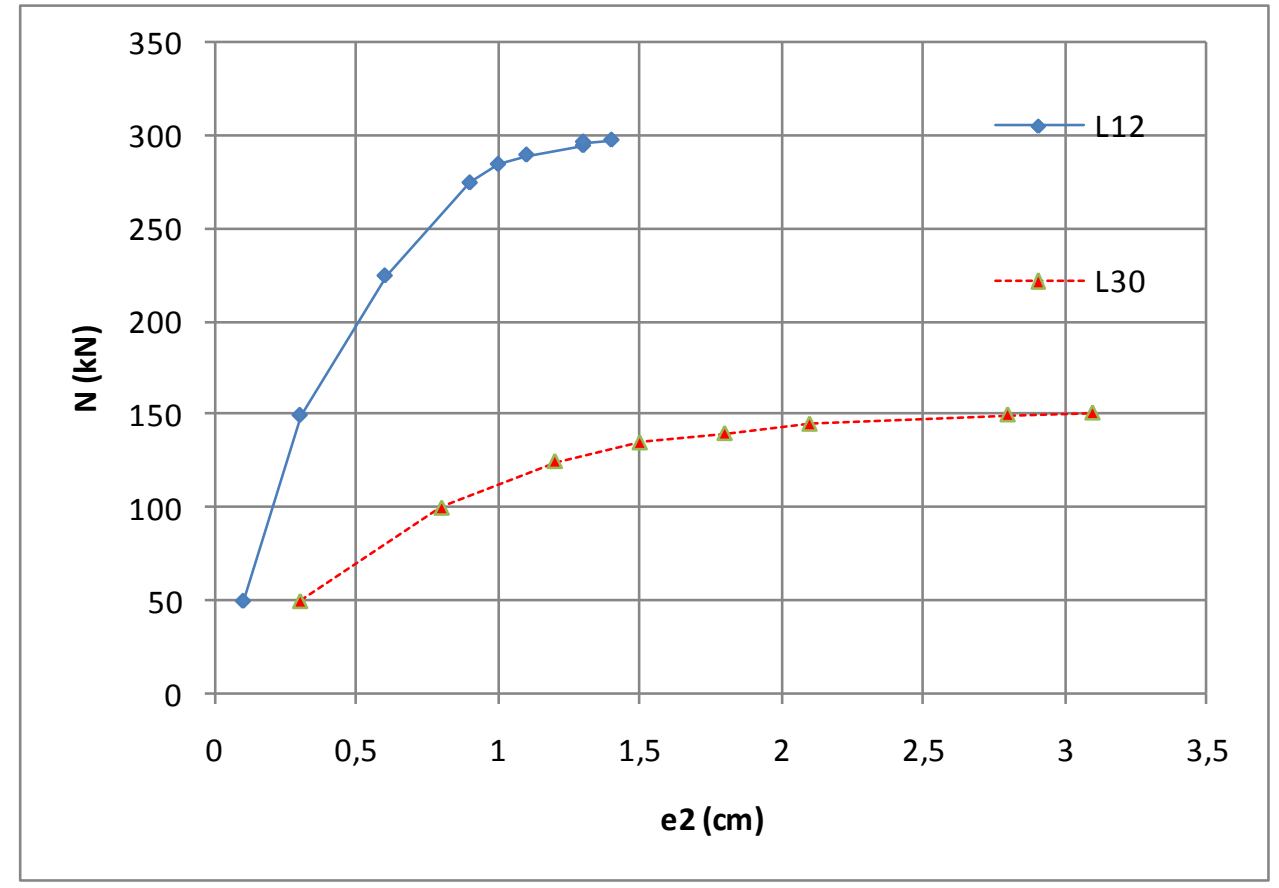

Fig. 8.14 - Pilares com concreto tipo L sem o efeito do confinamento.

Nas Fig. 8.12 até Fig. 8.14 é possível verificar que os gráficos se aproximam muito aos dos pilares com espaçamento entre estribos de $10 \mathrm{~cm}$, o que significa que o efeito do confinamento é realmente muito pequeno. 
As figuras seguintes apresentam uma comparação entre os resultados experimentais obtidos nos ensaios com os teóricos calculados com as hipóteses do Método Geral, considerando as curvas força-deslocamento lateral.

A Fig. 8.15 mostra as curvas dos pilares com concreto tipo $\mathrm{H}$.

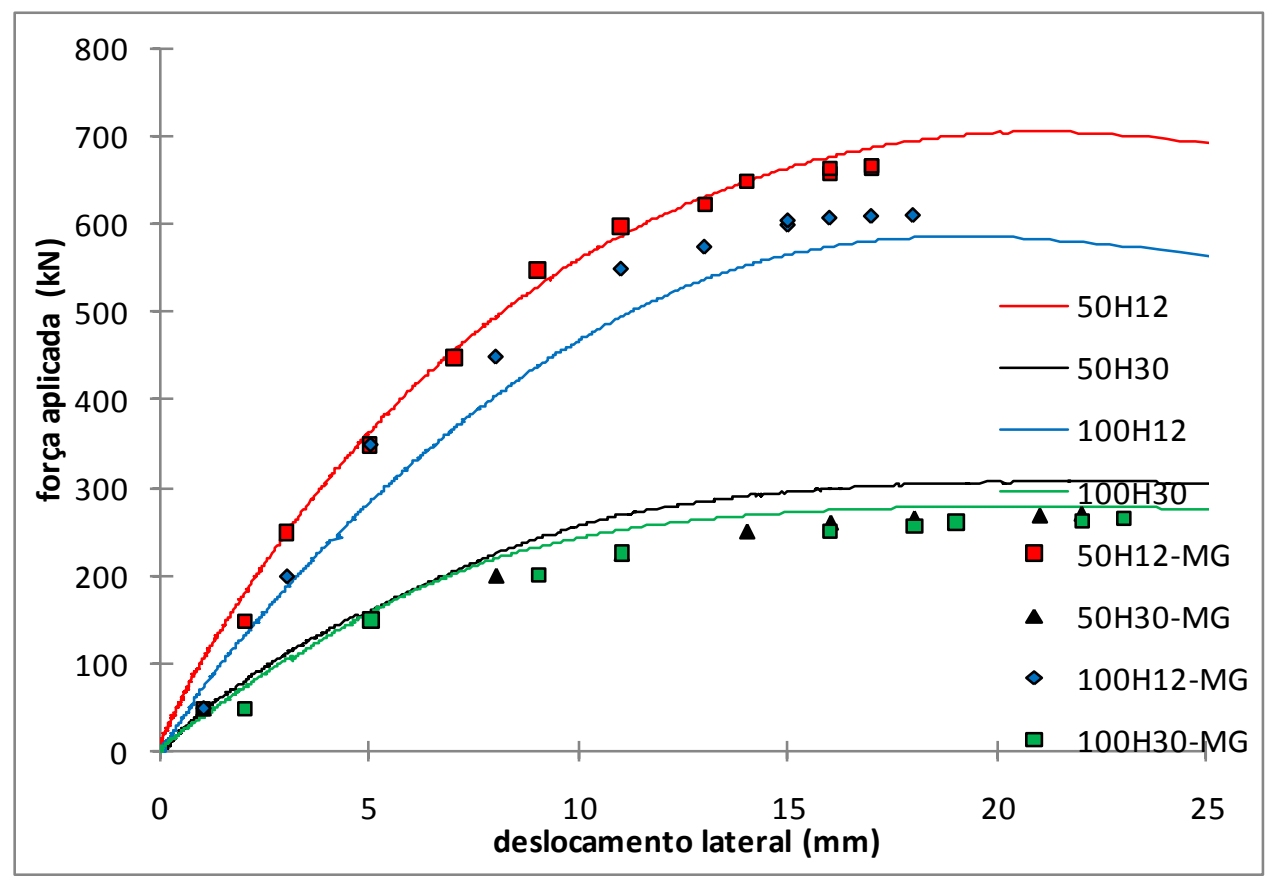

Fig. 8.15 - Resultados obtidos experimentalmente e com o Método Geral dos pilares com concreto tipo $\mathrm{H}$.

A Fig. 8.16 mostra as curvas dos pilares com concreto tipo M.

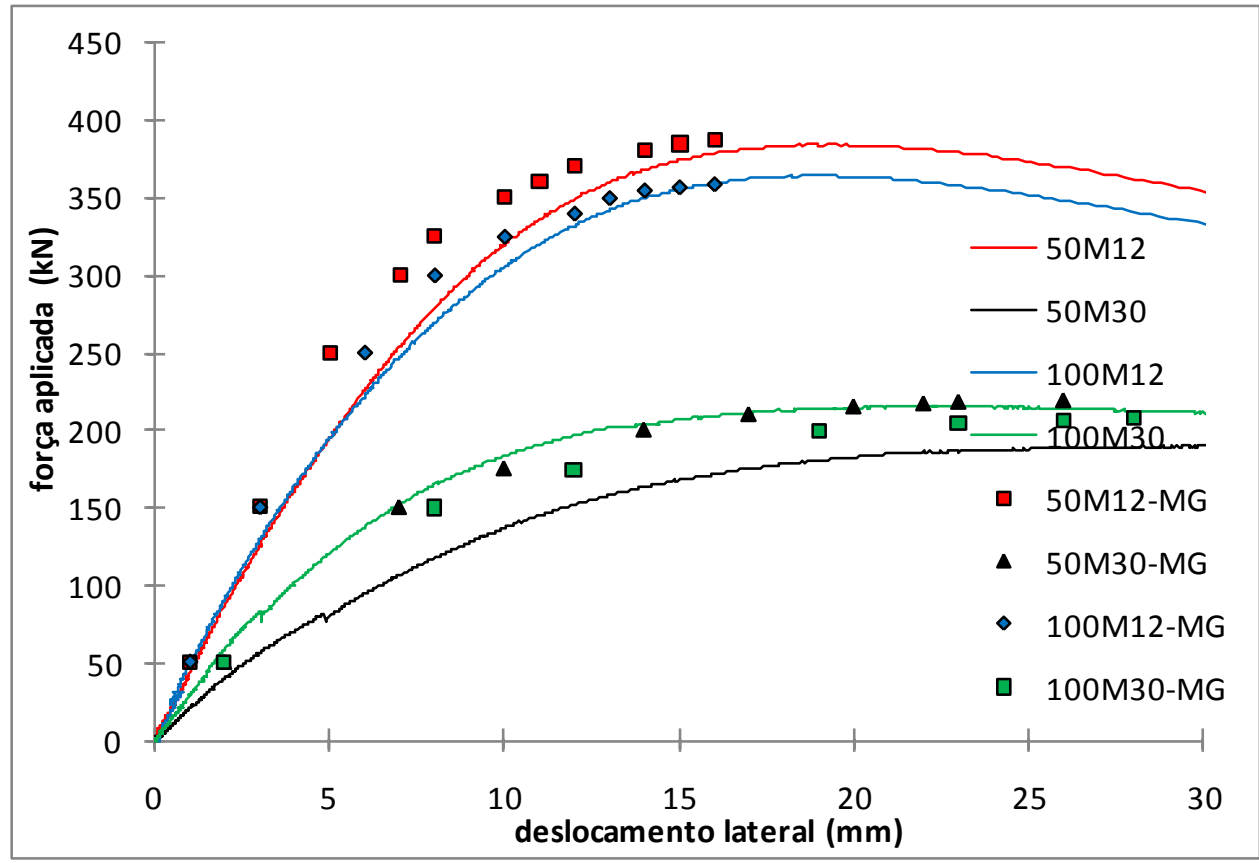

Fig. 8.16 - Resultados obtidos experimentalmente e com o Método Geral dos pilares com concreto tipo M. 
A Fig. 8.17 mostra as curvas dos pilares com concreto tipo L.

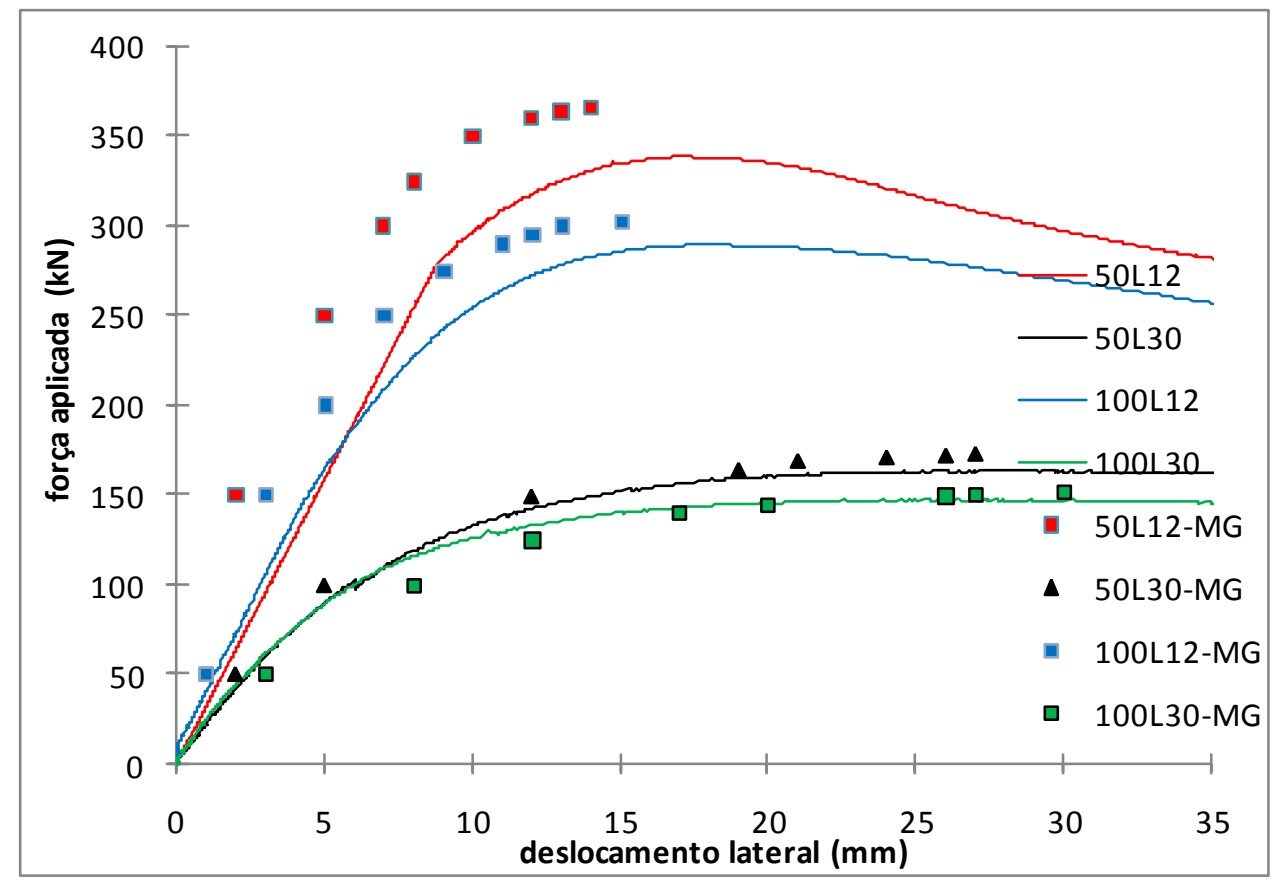

Fig. 8.17 - Resultados obtidos experimentalmente e com o Método Geral dos pilares com concreto tipo L.

Nas Fig. 8.15 até Fig. 8.17 é possível observar que ocorreu maior perda de rigidez de alguns pilares durante os ensaios; sendo que foram observadas excentricidades acidentais durante os ensaios, o que pode ter ocasionado este fato. Outros problemas mecânicos com relação às instalações dos pilares na máquina de ensaio.

Existiu maior diferença entre as curvas nos pilares que tinham excentricidade de 12 mm, especialmente nos pilares com concreto tipo L, é possível considerar que o modelo de confinamento de Légeron e Paultre (2003) está mais bem calibrado para os pilares de CAR.

Ocorreu aumento da capacidade resistente dos pilares, que pode ser observado em ambos os resultados (teóricos e experimentais), este padrão aconteceu em todos os pilares (exceto nos resultados experimentais dos pilares 50M30 e 100M30), mas é possível afirmar que o efeito do confinamento no incremento da resistência esteve presente.

Como não foi possível verificar a ductilidade dos pilares mediante o modelo do Método Geral e tampouco seria possível verificar com o método dos elementos finitos porque ambos os modelos não consideram o ramo pós-pico, os resultados experimentais foram os que mostraram o efeito do confinamento. Observou-se um padrão nos resultados, porém seria conveniente verificar a ductilidade empregando outros modelos, por exemplo, considerando a mecânica do dano continuo que considera a deterioração do material, com este modelo sim é possível considerar o comportamento pós-pico. 
Para projetos foram elaborados gráficos de dimensionamento, considerando o Método Geral, sem o confinamento dos pilares, porque os resultados que foram obtidos necessitam maiores pesquisas a respeito do tema com relação aos pilares esbeltos. Os gráficos são apresentados no Anexo F. No Anexo G, é apresentado um exemplo de dimensionamento de um pilar de CAR com o emprego dos gráficos de dimensionamento.

\subsection{CONSIDERAÇÕES FINAIS}

O modelo teórico adotado para a verificação dos resultados experimentais, o Método Geral, foi adequado e foi possível introduzir neste modelo o efeito do confinamento. Considerando a força última, os resultados obtidos com o Método Geral incluindo o confinamento e os obtidos nos ensaios experimentais foram muito similares. Existiu uma pequena variação a favor dos resultados experimentais, exceto para os pilares com concreto tipo L, a explicação foi que o modelo de Légeron e Paultre pode ser que tenha sido ajustado para o CAR.

As excentricidades de $2^{\mathrm{a}}$ ordem em ambos os resultados (teóricos e experimentais) são muito similares, não houve um padrão nos resultados considerando o espaçamento entre estribos, houve sim um maior deslocamento lateral para os pilares com excentricidades de força maior, que era o esperado.

Existiu um aumento na resistência dos pilares ao diminuir o espaçamento dos estribos tanto nos resultados dos ensaios de laboratório como nos resultados teóricos, o efeito do confinamento foi efetivo neste caso.

Com o Método Geral não foi possível verificar os resultados dos ensaios considerando a ductilidade pós-pico, foi sugerido outro modelo de verificação para tal efeito. Com os resultados obtidos dos ensaios foi calculado um parâmetro de ductilidade que mostrou certa regularidade considerando a taxa volumétrica dos estribos, mas com algumas exceções. Foi verificado que o diagrama momento-curvatura pode ser um procedimento para verificar a ductilidade, sempre que não ocorra uma ruína do pilar por instabilidade, e também é possível fazer uma verificação de resultados de ensaios usando os diagramas.

Considerando as dimensões da seção transversal dos pilares e seu comprimento, foi verificado que os pilares foram muito sensíveis a pequenas variações de excentricidade. Para ter uma melhor confiabilidade e evitar possíveis erros nos resultados de ensaios é recomendável ensaios prévios. 


\section{CONCLUSÃO}

Esta tese investigou o comportamento de pilares esbeltos de concreto de alta resistência confinados por estribos e submetidos à ação de força excêntrica, ou seja, pilares submetidos à flexo-compressão normal. Foram realizados 12 ensaios de pilares com esbeltez mecânica 92, nos quais foram estudados três parâmetros: a excentricidade da força, a taxa volumétrica de armadura transversal e a resistência do concreto. Para poder avaliar a ductilidade e analisar propostas de outros pesquisadores em relação ao confinamento ensaiouse seis pilares curtos de seção quadrada à compressão centrada.

São apresentadas neste capitulo as principais conclusões observadas na analises dos resultados dos ensaios nas analises teóricas. Foi investigado, por meio de resultados de ensaios de laboratório, o comportamento pós-pico dos pilares com diferentes propriedades. Foram obtidas conclusões importantes em relação à ductilidade e ao incremento da capacidade de força do pilar considerando o efeito do confinamento proveniente da armadura transversal constituída por estribos.

As conclusões são divididas em quatro partes, a primeira está relacionada ao método do ensaio e as principais observações encontradas nos procedimentos; na segunda parte são discutidas as conclusões das análises dos ensaios e dos modelos teóricos aplicados aos pilares curtos; na terceira parte discutem-se as conclusões obtidas nos ensaios dos pilares esbeltos; e, a quarta parte apresenta as recomendações para trabalhos futuros.

\section{Métodos aplicados aos ensaios}

- Como houve a necessidade do preparo do concreto no laboratório foi necessário realizar um estudo de dosagem o qual foi bem sucedido e as resistências ficaram muito 
próximas das estimadas; possivelmente o método de dosagem, com o emprego das curvas de dosagem, seja o melhor método para conseguir as resistências planejadas com os materiais da região, o trabalho de dosagem foi muito rigoroso. Os usos de aditivos e adições exigiu a realização de estudos de compatibilidade de materiais. Os valores das resistências foram acompanhados por ensaios de corpos-de-prova cilíndricos de $10 \mathrm{~cm}$ x $20 \mathrm{~cm}$ em todas as etapas.

- As armaduras foram também ensaiadas e as resistências obtidas tiveram resultados maiores que as fornecidas pelo fabricante.

- As excentricidades de força foram verificadas minuciosamente nos ensaios, e houve variação dos valores obedecendo $12 \mathrm{~mm} \pm 2 \mathrm{~mm}$ e $30 \mathrm{~mm} \pm 3 \mathrm{~mm}$, com estes valores foram feitas as análises teóricas e foram encontrados resultados diferentes em até $15 \%$. Isto significa que para os pilares esbeltos as excentricidades de projeto e as acidentais precisam ser bem avaliadas. Os modelos de pilares ensaiados foram muito sensíveis a pequenas variações nas medidas das excentricidades.

- As diferenças notadas nos resultados dos ensaios podem ser em virtude de: a) houve problemas na máquina de ensaio dos modelos e em alguns casos a resistência do concreto do pilar não correspondia ao dia do ensaio dos corpos-de-prova; b) considerando a concretagem dos pilares em duas etapas, a resistência média do concreto adotada pode não ter sido a do pilar ensaiado; c) excentricidades acidentais que provocaram aumento no valor do momento fletor; d) nos pilares esbeltos, presença de flexão na outra direção; e) erro ao posicionar as barras das armaduras dentro da fôrma; f) erro no paralelismo das faces laterais do pilar; g) os extremos dos pilares curtos não foram retificados, podendo ter ocorrido imperfeições nas faces extremas dos pilares em contato com os pratos da máquina de ensaios (INSTRON).

- Avaliando os itens do parágrafo anterior, os itens a) e b) não foram previsíveis; no item c) as excentricidades acidentais poderiam ser considerados nas verificações, mas não foram incorporados porque existiria muita variabilidade dos dados e resultados; nos itens d), e) e f) as diferenças entre resultados dos ensaios e resultados teóricos poderiam ter diminuído se nos pilares esbeltos no lugar do lançado lateral do concreto no sentido mais estreito das formas o lançado fosse adotado no sentido mais largo, e se nos pilares curtos no lugar do lançado lateral do concreto teria sido adotado o lançado com os pilares na posição vertical caso não tivesse armadura de fretagem; no item g) 
nos pilares curtos, para o lançado vertical do concreto nas formas a retífica ou o capeamento com enxofre dos extremos do pilar seria obrigatório.

- Foi possível estudar o comportamento pós-pico dos pilares curtos e pilares esbeltos e verificar a sua ductilidade, isto em virtude da máquina de ensaio que permite aplicar forças com controle de deslocamentos, na razão de $0,005 \mathrm{~mm} / \mathrm{m} . \mathrm{s}$ até atingir o $80 \%$ da força última no ramo pós-pico do ensaio, depois a razão foi de $0,01 \mathrm{~mm} / \mathrm{m}$.s e mantida assim até a etapa final do ensaio; com estas razões foi possível estudar o comportamento pós-pico de modo adequado.

- Para o ensaio dos pilares esbeltos foi adotado o aparelho de apoio que foi utilizado por Lima Jr. (2003), o qual permitiu rotações livres nas extremidades dos pilares e a aplicação precisa de forças excêntricas, houve confiabilidade no sistema de aplicação de forças.

— Os ensaios de pilares esbeltos permitiram estabelecer um método para a realização dos ensaios dos pilares de concreto armado sujeitos à força excêntrica.

\section{Pilares curtos}

- A partir dos ensaios dos pilares curtos à compressão centrada foi verificado que, mesmo para espaçamento entre estribos de $5 \mathrm{~cm}$, a seção resistente dos pilares de concreto de alta resistência e de resistência convencional corresponde a toda a seção transversal. Possivelmente para taxas volumétricas maiores de armadura transversal ou espaçamento entre estribos menores o cobrimento não faça parte da seção transversal do pilar, mas a perda do cobrimento precisa ser compensada por um confinamento eficiente.

- Houve uma diminuição repentina da resistência após a perda súbita do confinamento, isto aconteceu para os pilares com concreto do tipo $\mathrm{H}$ e $\mathrm{M}$ com espaçamento entre estribos de $5 \mathrm{~cm}$, não foi observado o segundo pico porque o confinamento não compensou a perda repentina do cobrimento, ambos os pilares estavam com uma taxa de estribos que corresponde a um pequeno grau de confinamento. $\mathrm{O}$ pilar com concreto do tipo L, e mesmo espaçamento entre estribos, não teve diminuição repentina de resistência, houve um segundo pico, porque o espaçamento entre estribos corresponde a um grau médio de confinamento. Nos três pilares houve a formação de um plano natural formado pelos estribos e as faces do pilar, não acontecendo o mesmo para os pilares com espaçamento entre estribos de $10 \mathrm{~cm}$, sendo que a diminuição da 
resistência correspondeu principalmente à flambagem das barras das armaduras longitudinais.

- Em função das observações do parágrafo anterior, para considerar o confinamento em concretos com resistência maior os espaçamentos entre estribos têm que ser menores ou o arranjo da armadura transversal e longitudinal precisa ser mais bem estudado. A maneira de ter confiabilidade nos resultados é por meio do índice de ductilidade, que serve para qualquer tipo de concreto.

- Não foi possível verificar o modelo Légeron e Paultre (2003), mas sim realizar uma aproximação gráfica. Numericamente, com os resultados dos ensaios: das forças últimas, das tensões no concreto do núcleo da seção transversal, das deformações específicas na armadura transversal, das tensões atuantes na armadura transversal e da deformação específica correspondentes ao pico na curva $\sigma_{\mathrm{c}} \times \varepsilon_{\mathrm{c}}$ do concreto confinado, se verificou um comportamento similar com os resultados do modelo de Légeron e Paultre (op. cit.).

- Foi verificado graficamente nos resultados dos ensaios que existe ductilidade que provem do confinamento. Para pilares com espaçamento entre estribos de $10 \mathrm{~cm}$ é inexistente, mas para pilares com espaçamento entre estribos de $5 \mathrm{~cm}$ o efeito da ductilidade esteve presente. Em relação ao ganho de resistência que provem do confinamento somente o pilar $50 \mathrm{H}$ teve um ganho de resistência do núcleo.

- Na análise numérica foram obtidos valores diferentes dos experimentais, mas os resultados serviram para distinguir uma análise comportamental. As diferenças foram em virtude dos elementos finitos empregados e aos modos de ruína (entre outros), que não conseguiram simular todas as não linearidades físicas do concreto.

- Dos resultados dos ensaios, verificou-se que as barras das armaduras transversais não atingiram o escoamento na força última, mas sim no ramo pós-pico, o modelo adotado de Légeron e Paultre (2003) mostrou o mesmo comportamento.

- Foi verificado que na ocorrência da flambagem de barras longitudinais há uma perda abrupta de resistência do pilar curto.

- Considerando a análise comportamental e os resultados obtidos dos ensaios e com o modelo de Légeron e Paultre (2003), foi possível prever, de modo bastante satisfatório, o comportamento de pilares de CAR e concreto convencional confinados, e, o modelo de Légeron e Paultre (2003) pode ser incorporado ao Método Geral para considerar o confinamento. Na realidade o que interessa é o diagrama $\sigma_{\mathrm{c}} \times \varepsilon_{\mathrm{c}}$ do 
concreto confinado para assim obter resultados mais realistas e comparar os resultados dos ensaios dos pilares esbeltos sob compressão excêntrica com os resultados teóricos empregando o modelo do Método Geral.

- As normas como a FIB (1999) e o EUROCODE (2004) permitem considerar o confinamento, introduzem o valor da tensão de confinamento nas expressões que propõem, mas não apresentam nenhuma equação para seu cálculo. Foi o modelo de Légeron e Paultre (2003) que forneceu os parâmetros necessários para a obtenção dos valores destas tensões laterais de confinamento.

\section{Pilares esbeltos}

- Foi verificado que em todos os pilares esbeltos as ruínas ocorreram por ter atingido o ponto limite de equilíbrio instável, em virtude da elevada esbeltez. Inicialmente estava programado ensaiar pilares sob compressão excêntrica, com esbeltez de 60, que atingissem a ruína por ruptura do concreto ou deformação plástica excessiva das barras da armadura longitudinal. Houve uma diminuição no número de modelos para adequar-se ao cronograma de trabalho do laboratório da estruturas da EESC.

- A ruína por instabilidade dos pilares gera uma curva força-deslocamento com um ramo pós-pico instável. Foi verificado que para os pilares com qualquer tipo concreto e com excentricidades de força fora do núcleo da seção transversal, a ruína não é súbita, mas nos pilares sob compressão simples ou com excentricidade de força dentro do núcleo da seção e de CAR, caso em que a compressão prevalece, a ruína normalmente é brusca.

— Todos os pilares (exceto o pilar 50H12) mostram uma segunda queda na resistência quando acontece a ruptura do concreto na face mais comprimida. Para os pilares com espaçamento de estribos de $5 \mathrm{~cm}$ esta segunda queda de resistência é súbita e provocada por um destacamento repentino do cobrimento, especialmente para os pilares de CAR

- Para o pilar 50H12 a força última que corresponde à instabilidade coincide com a força que provocou o destacamento do cobrimento, por este motivo este pilar não apresentou uma segunda queda na resistência, a ductilidade pós-pico relativa ao efeito do confinamento é inexistente, ocorreu um acúmulo de energia que provocou um incremento na capacidade resistente do pilar. A perda repentina do cobrimento pode ter antecipado a ruína por instabilidade. 
- O destacamento do cobrimento adquire importância, pois pode gerar uma ruína súbita, como a do pilar 50H12, no qual o confinamento não foi suficiente para compensar a perda do cobrimento. Esse fenômeno precisa ser mais bem pesquisado com outras taxas e arranjos de armadura longitudinal e transversal, considerando o valor do índice de confinamento com pelo menos grau médio de confinamento.

- Se considerarmos que o confinamento adquire importância após a perda do cobrimento, é possível concluir que para pilares esbeltos, a importância do confinamento corresponderia a pilares com pequena excentricidade de força, já que os pilares com excentricidades maiores geralmente tem comportamentos dúcteis mesmo no caso de maiores espaçamentos entre estribos.

- Para os pilares com concretos do tipo M e L com espaçamentos entre estribos de 10 cm não houve destacamento do cobrimento, porque os arranjos de armaduras longitudinais e transversais não formaram um plano natural de separação do cobrimento. Para o pilar com concreto do tipo H e mesmo espaçamento entre estribos, houve sim uma ruína repentina após a ruptura do concreto na face mais comprimida, mas em virtude da liberação da energia acumulada própria destes concretos, e não porque se formou um plano natural de separação do cobrimento.

- Como o confinamento é função da tensão atuante na armadura transversal, foram analisadas as deformações específicas nos ramos do estribo posicionado no meio do pilar; sendo que apenas o ramo do estribo paralelo à face mais comprimida teve incrementos na deformação por causa do aumento da força, porém sem atingir o escoamento, nenhum outro ramo do estribo apresentou uma regularidade no comportamento.

- Houve um incremento na capacidade de força proveniente do efeito do confinamento, mais não houve claramente um incremento na ductilidade, isto porque os pilares como eram esbeltos tinham esforços de flexão preponderantes.

- Foi verificado (teórica e experimentalmente) que ao diminuir o espaçamento entre estribos houve um ganho na resistência do pilar da seguinte maneira: para os pilares com excentricidade de força de $12 \mathrm{~mm}$ o ganho relativo foi maior que para os que tinham excentricidade de $30 \mathrm{~mm}$ e para os pilares com concreto de menor resistência o ganho relativo de resistência foi maior, por causa da maior deformabilidade lateral.

- Mesmo verificado o ganho de resistência dos pilares ao diminuir o espaçamento entre estribos, este incremento foi discreto em virtude da elevada esbeltez dos pilares. Para 
os pilares dos ensaios o ganho na resistência do pilar ao incrementar a resistência do concreto foi bem menor que o incremento na própria resistência do concreto considerando os dois espaçamentos de estribos. $\mathrm{O}$ incremento na capacidade resistente dos pilares teria sido menor ainda para pilares com maior esbeltez considerando incrementos na resistência do concreto e espaçamento entre estribos. Em função do exposto anteriormente neste parágrafo o confinamento (muito necessário para pilares com CAR) é pouco benéfico em pilares esbeltos, pois estes não apresentam ganhos de resistência com o aumento da resistência do concreto e por causa de sua elevada esbeltez estes já apresentam ductilidade na ruína, sempre que sua excentricidade de força esteja fora do núcleo da seção. Em pilares robustos (pouco esbeltos) à medida que cresce a resistência do concreto à compressão, há um incremento significativo (proporcional ao acréscimo de resistência do concreto) no valor da capacidade de força do pilar e se estiver adequadamente confinado um acréscimo na ductilidade.

- O Método Geral não mostra comportamento pós-críticos dos pilares, somente analisa a ruína, seja por ruptura dos materiais ou instabilidade.

- Com o Método Geral foi possível validar os incrementos de resistência que provem do confinamento, mas o incremento da ductilidade que provem do confinamento, para o caso de pilares esbeltos, não ficou muito esclarecido e não foi possível determinar um modelo para efeito de comparação. O Método Geral não considera comportamentos pós-críticos. Analisando os resultados dos ensaios por meio do modelo de Galeano e Vignoli (2008) foi possível estabelecer certa regularidade na ductilidade ao diminuir o espaçamento entre estribos, mas alguns pilares tiveram resultados contrários aos esperados.

- Como não foi possível analisar a ductilidade dos pilares mediante o modelo do Método Geral e tampouco foi possível analisar com o MEF, porque ambos os modelos não consideram o ramo pós-pico, os resultados experimentais foram os que mostraram o efeito do confinamento, sendo que houve certo padrão. O correto a fazer seria verificar a ductilidade empregando outros modelos, por exemplo, por meio das hipóteses da mecânica do dano continuo que considera a deterioração do material; com este modelo sim é possível considerar o comportamento pós-críticos.

- Foi verificado que o diagrama momento-curvatura pode ser um procedimento para verificar a ductilidade, sempre que não ocorra a ruína do pilar por instabilidade, e 
também é possível fazer uma verificação de resultados de ensaios considerando estes diagramas.

- O modelo baseado no Método Geral, adotado para a análise dos resultados experimentais, foi adequado e foi possível introduzir neste modelo o efeito do confinamento, o programa elaborado pelo autor conseguiu obter os mesmos resultados dos ensaios. Considerando a força última, os resultados obtidos com o Método Geral incluindo o confinamento e os obtidos nos ensaios foram muito similares. Existiu uma pequena variação a favor dos resultados experimentais, exceto para os pilares com concreto do tipo L, a explicação pode ser pelo fato que o modelo de Légeron e Paultre (2003) tenha sido ajustado para pilares com CAR.

- As excentricidades de $2^{\mathrm{a}}$ ordem em ambos os resultados (teóricos e experimentais) são muito similares, não houve um padrão nos resultados considerando o espaçamento entre estribos, houve sim um maior deslocamento lateral para os pilares com excentricidades de força maior, que é o esperado.

- Em todos os pilares nenhuma das armaduras longitudinais, em ambas as faces inicialmente mais comprimida ou menos comprimida atingiram o escoamento, com relação a força última, e os valores da deformação específica do concreto na face mais comprimida ficou menor que a deformação limite, correspondente ao pico da curva tensão-deformação específica do concreto confinado.

- Com base no exposto e considerando os comentários do parágrafo anterior é possível afirmar que as peças ensaiadas não atingiram seu limite por ruptura do concreto nem por deformação específica excessiva das armaduras longitudinais, porém houve a ruína por instabilidade das peças.

- Verificou-se que o efeito da ductilidade foi muito pequeno (ou quase inexistente) para as taxas de armadura transversal e para os tipos adotados de distribuição das armaduras longitudinais e transversais. Em pesquisas futuras é necessário pensar em um confinamento mais efetivo, porque com as taxas adotadas o grau de confinamento foi pequeno. É possível concluir que, para as taxas volumétricas de armadura transversal adotadas, não é indicado considerar no projeto o modelo de confinamento dos pilares, sugere-se considerar a seção transversal total como a resistente.

- Os diagramas momento axial reduzido-momento reduzido podem incorporar o confinamento da seção, mas seu desenho precisa ser empregado com cautela. 
Atualmente não existem trabalhos que considerem o comportamento pós-pico dos pilares construídos com CAR.

- Para os projetos estruturais foram elaborados gráficos de dimensionamento, considerando o Método Geral, sem o confinamento dos pilares, porque os resultados que foram obtidos necessitam maiores pesquisas do confinamento efetivo dos pilares esbeltos. Os gráficos estão no Anexo F. No Anexo G, é apresentado um exemplo de dimensionamento de um pilar de CAR com o emprego dos gráficos de dimensionamento.

- O Método Geral que era considerado como um método de verificação, com o emprego dos gráficos do anexo $\mathrm{F}$, passou a se um método de dimensionamento como se demonstra no exemplo do Anexo G.

\section{Recomendações para futuros trabalhos}

Diversos temas podem ser propostos para a continuidade desta pesquisa. Embora ela tenha enfocado o aspecto da esbeltez dos pilares de concreto de alta resistência confinados, o confinamento tem que ser mais bem estudado. Sugerem-se:

- Realizar um estudo mais abrangente considerando outras esbeltezes com maior número de pilares em mesma série.

- Avaliar o comportamento de pilares esbeltos compostos por outro tipo de concreto, por exemplo, concretos auto-adensáveis.

- Avaliar o comportamento de pilares sujeitos a outras excentricidades de força.

- Estudar pilares esbeltos melhor confinados, variando as taxas de armadura longitudinal e transversal.

- Verificar a ductilidade empregando outros modelos, por exemplo, considerando a Mecânica do Dano Continuo que considera a deterioração do material, para poder analisar os resultados nas etapas além da força última.

- Estudar pilares esbeltos com outras formas de seção transversal.

- Aplicar forças excêntricas que produzam momentos diferentes nas extremidades, considerando curvaturas simples e reversas. 


\section{REFERÊNCIAS BIBLIOGRÁFICAS}

AGUIAR, E. A. B. (2000). Projeto de pilares de concreto de alto desempenho. Dissertação de Mestrado - Escola de Engenharia de São Carlos, Universidade de São Paulo, São Carlos, 2000 .

AGUIAR, E. A. B. e PINHEIRO, L. M. (2000). Projeto de Pilares de Concreto de Alto Desempenho. In: IV SIMPÓSIO EPUSP SOBRE ESTRUTURAS DE CONCRETO, 2000, São Paulo (SP). Anais...São Paulo.

AGUIRRE, F.; BARBOSA, P. e GIONGO, J. S. (2006). Modelos de Resistência ao Esforço cortante pela Teoria do Campo da Compressão Modificada para Concretos de Alta Resistência. In: VI SIMPÓSIO EPUSP SOBRE ESTRUTURAS DE CONCRETO, 2006, São Paulo (SP). Anais...São Paulo.

AGUIRRE, F. e MONTEDOR, C. (2005). Hidratação do cimento e volume de vazios. Trabalho de aula da disciplina: Tecnologia dos Concretos Estruturais - Escola de Engenharia de São Carlos, Universidade de São Paulo, São Carlos, 2005, São Paulo.

AÏTCIN, P. C. and NEVILLE, A. (1993). High Performance concrete demystified. Concrete International, Vol. 15, No. 1, January, p. 21-26.

AÏTCIN, P. C. (2000). Concreto de alto desempenho. Tradução Geraldo G. Serra. São Paulo: Pini. 667 p.

AMARAL, Epamínondas Melo do. (1992). Concreto de alta resistência: Primeira parte. Revista Ibracon. São Paulo, Ano II, No. 4, abril, p. 40-49.

AMERICAN CONCRETE INSTITUTE. ACI Committee 318. Building Code Requirements for Structural Concrete (ACI 318-05) and Commentary (ACI 318R-05), Farmington Hills, 2005.

AMERICAN CONCRETE INSTITUTE. ACI Committee 363.R. State of-the-Art Report on High-Strength Concrete (ACI 363-91). ACI Manual of Concrete Practice, Detroit, 1991. 
AMERICAN CONCRETE INSTITUTE. ACI-ASCE, Joint Committee 441. State-of-the Art on High-Strength Concrete Columns (ACI 441-97). ACI Structural Journal, Vol. 94, No. 3, May-June p. 323-335.

AMERICAN INSTITUTE OF STEEL CONSTRUCTION. Specification for Structural Steel Buildings. AISC (2005). Chicago, 2005.

ANSARY, F. and LI, Q. (1998). High-strength concrete subjected to triaxial compression. ACI Materials Journal, Vol. 95, No. 6, November-December p. 747-755.

ANSYS Version 11. User’s Manual. ANSYS, Inc., 2007.

ASCE, Structural Engineering Institute Technical Committee on Load and Resistance Factor Design (1997). Effective length and notational load approaches for assessing frame stability: implications for American steel design. ASCE publications, $442 \mathrm{p}$.

ASSOCIAÇÃO BRASILEIRA DE CIMENTO PORTLAND (ABCP). Guia básico de utilização do cimento Portland, (ABCP BT-106) - 7a revisão. São Paulo, 2002.

ASSOCIAÇÃO BRASILEIRA DE NORMAS TÉCNICAS (ABNT). NBR 6118:2003. Projeto de Estruturas de Concreto, Rio de Janeiro, 2003.

. NBR 5732:1991. - Cimento Portland Comun - Especificação. Rio de Janeiro, 1991.

. NBR 5733:1991. - Cimento Portland de Alta Resistência Inicial - Especificação, Rio de Janeiro, 1991.

. NBR 5735-EB 208:1991. Cimento Portland de Alto Forno - Especificação, Rio de Janeiro, 1991.

. NBR 5736:1991. Cimento Portland Pozolânico - Especificação, Rio de Janeiro, 1991.

1994.

. NBR 5738:1994. Modelagem e Cura de Corpos-de-Prova Cilíndricos, Rio de Janeiro,

. NBR 5739:1994. Ensaio de Compressão de Corpos-de-Prova Cilíndricos de Concreto, Rio de Janeiro, 1994.

. NBR 7211:1983. Agregado para Concreto, Rio de Janeiro, 1983.

. NBR 7215:1996. - Cimento Portland - Determinação da resistência ã compressão Método de ensaio, Rio de Janeiro, 1996.

. NBR 7217:1987. Determinação da Composição Granulométrica, Rio de Janeiro, 1987.

. NBR 7222:1994. Argamassa e Concreto - Determinação da Resistência a Tração por Compressão Diametral de Corpos-de-prova Cilíndricos, Rio de Janeiro, 1994.

NBR 8953:1992. Concreto para Fins Estruturais - Classificação por Grupos de Resistência, Rio de Janeiro, 1992.

NBR 8800:2008. Projeto de Estruturas de Aço e de Estruturas Mistas de Aço e Concreto de Edifícios, Rio de Janeiro, 2008. 
NBR 11578:1991. Cimento Portland Composto - Especificação, Rio de Janeiro, 1991.

ARAÚJO de, J. M. (1984). Dimensionamento de pilares esbeltos de concreto armado. Dissertação de Mestrado - Universidade Federal de Rio Grande do Sul, Porto Alegre, 1984.

ATTARD, M. M. and SETUNGE, S. (1996). Stress-strain relationship of confined and unconfined concrete. ACI Materials Journal, Vol. 93, No. 5, September-October p. 432-442.

AUFIERO, L. (1977). Estabilidade de colunas isostáticas de concreto armado. Dissertação de Mestrado - Escola de Engenharia de São Carlos, Universidade de São Paulo, São Carlos, 1977.

BASF (The Chemical Company). Disponível em: <http://www.basf-cc.com.br/>. Acesso em: agosto de 2009.

BAZANT, Z. P.; CEDOLIN, L. and TABBARA M. R. (1991). New method of analysis for slender columns. ACI Structural Journal, Vol. 88, No 4, p. 391-401.

BAZANT, Z. P. and KWON, Y. W. (1994). Failure of slender and stocky reinforced concrete columns: test of size effect. Materials and Structures, Vol. 27, March, p. 79-90.

BORGES, L. A. C. (1999). Análise de pilares esbeltos de concreto armado solicitados a flexocompressão oblíqua. Dissertação de Mestrado - Escola de Engenharia de São Carlos, Universidade de São Paulo, São Carlos, 1999.

BUCHAIM, R. (1979). Efeitos de segunda ordem e estado limite último de instabilidade em pilares de concreto armado. Dissertação de Mestrado - Escola de Engenharia de São Carlos, Universidade de São Paulo, São Carlos, 1979.

CADAMURO Jr. I. W. (1997). Dimensionamento de pilares esbeltos de concreto armado com seção qualquer solicitados por flexão composta oblíqua. Dissertação de Mestrado - Escola de Engenharia de São Carlos, Universidade de São Paulo, São Carlos, 1997.

CÁMARA, E.; LIMA Jr., H. C.; WILLRICH, F. L.; FABRO, G. e GIONGO, J. S. (2002). Comportamento estrutural dos pilares dimensionados segundo o projeto de revisão da Norma NBR 6118:2001. Revista Brasileira do Concreto - Instituto Brasileiro do Concreto, São Paulo, V. out/dez, No. 31, p. 46-61.

CANADIAN STANDARD ASSOCIATION (2005). CAN3-A23.3.04. Design on Concrete Structures for Buildings, with update No. 2, Toronto, Canada, 2005.

CARRAZEDO, R. (2002). Mecanismos de confinamento e suas implicações no reforço de pilares de concreto por encamisamento com compósito de fibras de carbono. Dissertação de Mestrado - Escola de Engenharia de São Carlos, Universidade de São Paulo, São Carlos, 2002.

CARRAZEDO, R. (2005). Mecanismos de confinamento em pilares de concreto encamisados com polímeros reforçados com fibras submetidos à flexo-compressão. Tese de Doutorado Escola de Engenharia de São Carlos, Universidade de São Paulo, São Carlos, 2005. 
CASTRO, A. L. (2007). Aplicação de conceitos reológicos na tecnologia dos concretos de alto desempenho. Tese de Doutorado - Escola de Engenharia de São Carlos, Universidade de São Paulo, São Carlos, 2007.

CEB Bulletin d'Information 228. (1995). High Performance Concrete: Recommended Extensions to the CEB-FIB Model Code 1990. CEB Bulletin 228, Lausanne, Switzerland, 33 p., 1995.

CEB Bulletin d'Information 197. (1990). High Performance Concrete: State of the Art Report. CEB bulletin 197, London, United Kingdom, 61 p., 1990.

CEB-FIP Model Code for Concrete Structures. (1993). CEB-FIP MC 90. Comité EuroInternational du Béton, Tomas Telford Services Ltd., Switzerland, 1993.

CECCON, J. L. (2008). Análise dos efeitos de segunda ordem em pilares solicitados a flexão oblíqua composta. Tese de Doutorado - Escola Politécnica, Universidade de São Paulo, São Paulo, 2008.

CERVENKA, V. (2002). Computer Simulation of Failure of Concrete Structures for Practice. In: CONCRETE STRUCTURES IN THE 21ST CENTURY, 2002, Proceedings of the first Fib congress, JPCEA/JCI, Session 13, p. 289-304.

CHEN, W. F. and SALEEB, A. F. (1994). Constitutive equations for engineering materials. New York: Elsevier. 579 p.

CHEN, W. F. (1982). Plasticity in reinforced concrete. New York: McGraw-Hill. 474 p.

CHUANG, P. H. and KONG, K. K. (1997). Large-scale tests on slender, reinforced concrete columns. The Structural Engineer, Vol. 75, Nos. 23 - 24, December, p. 410-416.

CHUANG, P. H. and KONG, S. K. (1998). Strength of slender reinforced concrete columns. Journal of Structural Engineering, Vol. 124, No. 9, March, p. 992-998.

CHUANG, P. H.; KONG, S. K. and KONG, F. K. (2000). Slender columns in high strength concrete and normal strength concrete: BS 8110 and EC 2 compared. The Structural Engineer, Vol. 78, Nos. 23 - 24, December, p. 34-41.

CLAESON, C. and GYLLTOFT, K. (1998). Slender high-strength concrete columns subjected to eccentric loading. Journal of Structural Engineering, Vol. 124, No. 3, March, p. 233-240.

CLAESON, C. and GYLLTOFT, K. (2000). Slender concrete columns subjected to sustained and short-term eccentric loading. ACI Structural Journal, Vol. 97, No. 1, January-February, p. 45-52.

COLLINS, M.; MITCHELL, D. and MacGREGOR, J. G. (1993). Structural design considerations for high-strength concrete. Concrete International, Vol. 15, No 5, May, p. 2734.

COMISION PERMANENTE DEL HORMIGÓN. (2008). Instrucción Española de Hormigón Armado (EHE-2008). Ministerio de Fomento, Madrid, 2008. 
COUTINHO de, J. S. (2001). Durabilidade - Ataque por sulfatos. FEUP. Disponível em: $<$ http://paginas.fe.up.pt>. Acesso em: setembro de 2009.

CUSSON, D. and PAULTRE, P. (1994). High-strength concrete columns confined by rectangular ties. Journal of Structural Engineering. Vol. 120, No 3, February, p. 783-804.

CUSSON, D. and PAULTRE, P. (1995). Stress-strain model for confined high-strength concrete. Journal of Structural Engineering, Vol. 121, No. 3, March, p. 468-477.

DANTAS, B. A. (2006). Estudo de pilares de concreto armado submetidos à flexão-composta reta. Dissertação de Mestrado - Faculdade de Tecnologia, Universidade de Brasília. Brasília, 2006.

DELALIBERA, R. G. (2002). Análise teórica e experimental de vigas de concreto armado com armadura de compressão. Dissertação de Mestrado - Escola de Engenharia de São Carlos, Universidade de São Paulo, São Carlos, 2002.

DIN 1045-1 (2001). Tragwerke aus Beton, Stahlbeton und Sapannbeton - Teil 1:Bemessung und Konstruction Deutsches Institur fur Normung 2 V., Juli, 2001.

DINIZ, S. M. C. and FRANGOPOL, D. M. (1997). Strength and ductility simulation of highstrength concrete columns. Journal of Structural Engineering, Vol. 123, No. 10, October, p. 468-477.

EUROPEAN COMMITTEE FOR STANDARDIZATION, STANDARD EN 1992-1-1:2004, EUROCODE 2 (2004): Design of Concrete Structures - Part 1-1: General rules and rules for buildings. Brussels, 2004.

FIB Structural Concrete. Textbook on Behavior, Design and Performance. FIB (1999). Updated knowledge of the CEB-FIP MC90. Comité Euro-International du Béton. Vol. 1, 1999.

FOSTER, W. S. (1994). High-performance concrete - stretching the paradigm. Concrete International, Vol. 16, No. 10, October, p. 33, 34.

FOSTER, S. J. and ATTARD, M. M. (1997). Experimental tests on eccentrically loaded highstrength concrete columns. ACI Structural Journal, Vol. 94, No. 3, May-June p. 295-303.

FOSTER, S. J. and ATTARD, M. M. (2001). Strength and ductility of fiber-reinforced highstrength concrete columns. Journal of Structural Engineering, Vol. 127, No. 1, January, p. 2834.

FOSTER, S. J. (2001). On behavior of high-strength concrete columns: cover spalling, steel fibers, and ductility. ACI Structural Journal, Vol. 98, No. 4, July-August, p. 583-589.

FRANÇA, R. L. S. (1984). Relações momento-curvatura em peças de concreto armado submetidas à flexão-composta oblíqua. Dissertação de Mestrado - Escola Politécnica, Universidade de São Paulo, São Paulo, 1984.

FRANÇA, R. L. S. (1991). Contribuição ao estudo dos efeitos de segunda ordem em pilares de concreto armado. Teses de Doutorado - Escola Politécnica, Universidade de São Paulo, São Paulo, 1991. 
FUSCO, P.B. (1981). Estruturas de concreto. Rio de Janeiro, Guanabara Dois, 464 p.

FUSCO, P. B. (2008). Tecnologia do concreto estrutural. São Paulo, Pini, 179 p.

GALAMBOS, T. V. (1998). Guide to stability design criteria for metal structures. 2 ed. New York: John Wiley \& Sons, 911 p.

GALEANO, L and VIGNOLI, A. (2008). Strength and ductility of HSC and SCC slender columns subjected to short-term eccentric load. ACI Structural Journal, Vol. 105, No. 3, MayJune, p. 259-269.

GERMAIN, O. and ESPION, B. (2005). Slender high-strength RC columns under eccentric compression. Magazine of Concrete Research, Vol. 57, No. 6, August, p. 361-370.

GUIMARÃES, A. E. P. (1999). Análise de pilares de concreto de alta resistência com adição de fibras metálicas submetidos à compressão centrada. Dissertação de Mestrado - Escola de Engenharia de São Carlos, Universidade de São Paulo, São Carlos, 1999.

GURAY, A. (2007). Sensitivity study of the Drucker-Prager modeling parameters in the prediction of the nonlinear response of reinforced concrete structures. Materials and Design, Vol. 28, No. 12, p. 2596-2603.

HAN B.-S.; SHIN, S.-W and BAHN, B.-Y. (2003). A model of confined concrete in highstrength reinforced concrete tied columns. Magazine of Concrete Research, Vol. 55, No. 3, June, p. 203-214.

HELENE P. R. L. e TERZIAN, P. (1992). Manual de dosagem e controle do concreto. São Paulo: Pini, 319 p.

HELLAND, S. (1988). The Use of High Strength Concrete. Colóquio sobre Concreto de Alta Resistência. In: ANAIS DA $30^{\mathrm{a}}$ REUNIÃO DO INSTITUTO BRASILEIRO DE CONCRETO - REIBRAC, Rio de Janeiro (RJ). Anais...Rio de Janeiro.

HONG, K.-N.; AKIYAMA, S. T.; YI, S.T. and SUZUKI, M. (2006). Stress-strain behavior of high-strength concrete columns confined by low-volumetric ratio rectangular ties. Magazine of Concrete Research, Vol. 58, No. 2, March, p. 101-115.

IBRAHIM, H. H. H. and MacGREGOR, J. G. (1996-b). Flexural behavior of laterally reinforced high-strength concrete sections. ACI Structural Journal, Vol. 93, No. 6, NovemberDecember, p. 674-684.

JIMENEZ, M. P.; GARCÍA, M. Á. y MORÁN, C. F. (2000). Hormigón armado. 14 ed. Barcelona: Gustavo Gili, S.A., 844 p.

KIM J.-K. and YANG J.-K. (1995). Buckling behavior of slender high-strength concrete columns. Engineering Structural, Vol. 17 No 1, pp. 39-51.

KUNTIA, M. and GHOSH, S. K. (2004). Flexural stiffness of reinforced concrete columns and beams: Analytical approach. ACI Structural Journal, Vol. 101, No. 3, May-June, p. 351363. 
KUNTIA, M. and GHOSH, S. K. (2004-b). Flexural stiffness of reinforced concrete columns and beams: Experimental verification. ACI Structural Journal, Vol. 101, No. 3, May-June, p. 364-374.

KWAK, H.-G. and KIM, J.-K. (2004). Ultimate resisting capacity of slender RC columns. Computers \& Structures, Vol. 82, Nos. 11 and 12, May, p. 901-915.

KWAK, H.-G. and KIM, J.-K. (2006). Nonlinear behavior of slender RC columns (1) Numerical formulation. Construction and Building Materials, Vol. 20, No. 8, October, p. 527537.

KWAK, H.-G. and KIM, J.-K. (2006-b). Nonlinear behavior of slender RC columns (2) Introduction of design formula. Construction and Building Materials, Vol. 20, No. 8, October, p. 538-553.

KAWAK, H.-G. and FILIPPOU, F. C. (1990). Finite element analysis of reinforced concrete structures under monotonic loads. Structural Engineering, Mechanics and Materials University of California, Berkeley, Report No UCB/SEMM-90/1, 124 p.

LEE, J.-H. and SON H.-S. (2000). Failure and strength of high-strength concrete columns subjected to eccentric loads. ACI Structural Journal, Vol. 97, No. 1, January-February, p. 7585 .

LÉGERON, F. and PAULTRE, P. (2003). Uniaxial confinement model for normal- and highstrength concrete columns. Journal of Structural Engineering, Vol. 129, No. 2, February, p. 241-252.

LEONEL, E. D.; RIBERO, G. O. e PAULA de, F. A. A. (1997). Simulação Numérica de Estruturas de Concreto Armado por Meio do MEF/ANSYS. In: III SIMPÓSIO EPUSP SOBRE ESTRUTURAS DE CONCRETO, 1997, São Paulo (SP). Anais...São Paulo.

LI, B.; PARK, R. and TANAKA, H. (2001). Stress-strain behavior of high-strength concrete confined by ultra-high- and normal-strength transverse reinforcements. ACI Structural Journal, Vol. 98, No. 3, May-June, p. 395-406.

LIBORIO, J. B. L. (2005). Tecnologia dos concretos estruturais. Notas de aula. (Disciplina da pós-graduação) - Escola de Engenharia de São Carlos, Universidade de São Paulo, São Carlos, 2005.

LIBORIO, J. B. L; CASTRO, A. L.; SILVA da, F. G.; SILVA, V. M. (2005). Demystifying the production process of high performance and high strength concretes - Design considerations. In: IV HIGH PERFORMANCE CONCRETE STRUCTURES, 2005. Olinda/PE. Proceedings...CD-ROM.

LIMA Jr., H. C. e GIONGO, J. S. (2000). Fator de ductilidade para pilares de concreto de alta resistência. Revista Engenharia Estudo e Pesquisa. Ed. Interciência. Vol. 3, No. 2, p. 65-74.

LIMA Jr., H. C. e GIONGO, J. S. (2005). Metodologia para Ensaios de Pilares Submetidos à Flexo-Compressão Reta e/ou Oblíqua. In: $47^{\circ}$ CONGRESSO BRASILEIRO DO CONCRETO, 2005, Recife. Anais...Recife. 
LIMA Jr., H. C. (2003). Avaliação da ductilidade de pilares de concreto armado, submetidos à flexo-compressão reta com e sem adição de fibras metálicas. Tese de Doutorado - Escola de Engenharia de São Carlos, Universidade de São Paulo. 323p. São Carlos.

LIMA, S. M. DE. (2008). Concreto de alto desempenho aplicado a sistemas de processamento e armazenagem de alimentos em baixas temperaturas. Tese de Doutorado - Escola de Engenharia de São Carlos, Universidade de São Paulo. 232p. São Carlos.

LIMA, F. B. (1997). Pilares de concreto de alto desempenho: Fundamentos e experimentação. Teses de Doutorado - Escola de Engenharia de São Carlos, Universidade de São Paulo, São Carlos, 1997.

LLOYD, N. A. and RANGAN, B. V. (1996). Studies on high-strength concrete columns under eccentric compression. ACI Structural Journal, Vol. 93, No. 6, November- December, p. 631-638.

LU, X, and HSU, C-T. T. (2007). Stress-strain relation of high-strength concrete under triaxial compression. Journal of Materials in Civil Engineering, Vol. 19, No. 3, March, p. 261268.

MacGREGOR, J. G. (1993). Design of slender concrete columns - revised. ACI Structural Journal, Vol. 90, No. 3, May-June, p. 302-310.

MacGREGOR, G. J. (1997). Reinforced concrete. 3 ed. New Jersey: Prentice Hall, 939 p.

MACHADO, A. P de. (2002). Reforço de estruturas de concreto armado com fibras de carbono. São Paulo: Pini. 271 p.

MAJEWSKI, T; BOBINSKI, J. and TEJCHMAN, J. (2008). FE analysis of failure behavior of reinforced concrete columns under eccentric compression. Engineering Structures, No. 30 p. 300-317.

MENDIS, P. A. (2000). Behavior of slender high-strength concrete columns. ACI Structural Journal, Vol. 97, No. 6, November-December, p. 895-901.

METHA, P. K. e MONTEIRO, P. J. M. (1994). Concreto: estrutura, propriedades e materiais. Tradução Carmona Filho, A., Coitinho dal Molin, D. C. e Cincotto, M. A. 2 ed. São Paulo: Pini, $581 \mathrm{p}$.

MIRZA, S. A. (1990). Flexural stiffness of rectangular reinforced concrete columns. ACI Structural Journal, Vol. 87, No. 4, July-August, p. 425-436.

MONTOYA, E; VECCHIO, F. J. and SHEIKH, S. A. (2006). Compression field modeling of confined concrete: Constitutive models. Journal of Materials in Civil Engineering, Vol. 18, No. 4, August, p. 510-517.

MOREIRA, C. P. (2002). Resistência à compressão de elementos de concreto confinado. Dissertação de Mestrado - Programa de Engenharia Civil da COPPE, Universidade Federal do Rio de Janeiro, 2002. 
MOSTAFAEI, H.; VECCHIO, F. J. and KABEYASAWA, T. (2009). Deformation capacity for reinforced concrete columns. ACI Structural Journal, Vol. 106, No. 2, March-April, p. 187-195.

NARDIN de, S. (1999). Estudo teórico-experimental de pilares mistos compostos por tubos de aço preenchidos com concreto de alta resistência. Dissertação de Mestrado - Escola de Engenharia de São Carlos, Universidade de São Paulo, São Carlos, 1999.

NEMECEK, P. and BITTNAR, Z. (2004). Experimental investigation and numerical simulation of pos-peak behavior and size effect of reinforced concrete columns. Materials and Structures, Vol. 37, April, p. 161-169.

NEVILLE A. N. (1997). Propriedades do concreto. Tradução Salvador E. Giammusso. São Paulo: Pini. 828 p.

NORWEGIAN COUNCIL FOR BUILDING STANDARDIZATION (1992). (NS 3473-E 1992): Concrete structures: design rules. Oslo,1992.

OLIVEIRA, S. R. (2001). Análise de pavimentos de edifícios de concreto armado com a consideração da não linearidade física - modelagem e metodologia da aplicação a projetos. Tese de Doutorado - Escola de Engenharia de São Carlos, Universidade de São Paulo, São Carlos, 2001.

OLIVEIRA de, P. H. S. A. (2004). Processo aproximado para consideração da não linearidade física de pilares de concreto armado. Dissertação de Mestrado - Escola Politécnica, Universidade de São Paulo, São Paulo, 2004.

OLIVEIRA de, W. L. A. (2004-b). Análise teórico-experimental de pilares de concreto armado sob ação de força centrada com resistência média à compressão do concreto de 40 MPa. Dissertação de Mestrado - Escola de Engenharia de São Carlos, Universidade de São Paulo, São Carlos, 2004.

OLIVEIRA de, W. L. A. (2008). Análise teórico-experimental de pilares mistos preenchidos de seção circular. Tese de Doutorado - Escola de Engenharia de São Carlos, Universidade de São Paulo, São Carlos, 2008.

O’REILLY, D. V. A. (1990). Métodos para dosificar mezclas de hormigón. Ciudad de la Habana: Científico-Técnica, 102 p.

PAIVA, N. M. B. (1994). Pilares de concreto de alta resistência com seção transversal retangular solicitados â compressão simples. Dissertação de Mestrado - Faculdade de Engenharia Civil, Universidade Estadual de Campinas, Campinas, 1994.

PACCOLA, R. R. (2004). Análise não linear física de placas e cascas anisotrópicas laminadas acopladas ou não com meio continuo tridimensional visco elástico através da combinação entre MEC e MEF. Teses de Doutorado - Escola de Engenharia de São Carlos, Universidade de São Paulo, São Carlos, 2004.

PARK, R. e PAULAY, T. (1996). Estructuras de concreto reforzado. Traducción Sergio Fernández Éverest. México: Limusa. 796 p. 
PASQUEL, C. E. (1996). Tópicos de Tecnología del Concreto. $2^{a}$ ed. Cochabamba: Serrano. $380 \mathrm{p}$

PAULA, J. A. (1988). Algoritmos para o estudo de pilares esbeltos de concreto solicitados à flexão normal composta. Dissertação de Mestrado - Escola de Engenharia de São Carlos, Universidade de São Paulo, São Carlos, 1988.

PAULTRE, P. and LÉGERON, M. (2008). Confinement reinforcement design for reinforced concrete columns. Journal of Structural Engineering, Vol. 134, No. 5, May, p. 738-751.

PETRUCCI, E. G. R. (1982). Concreto de cimento Portland. 9 ed. Porto Alegre: Ed. Globo, $307 \mathrm{p}$.

PROENÇA, B. P. S. (1988). Sobre modelos matemáticos de comportamento não linear do concreto: Analise crítica e contribuições. Teses de Doutorado - Escola de Engenharia de São Carlos, Universidade de São Paulo, São Carlos, 1988.

PROENÇA, S. P. B. (2004). Formulação Variacional da mecânica dos sólidos e introdução aos métodos numéricos. Escola de Engenharia de São Carlos, Universidade de São Paulo, São Carlos, 98 p.

QUEIROGA, M. V. (1999). Análise experimental de pilares de concreto de alto desempenho submetidos à compressão simples. Dissertação de Mestrado - Escola de Engenharia de São Carlos, Universidade de São Paulo, São Carlos, 1999.

RAMOS, R. F. (2001). Análise experimental de pilares de concreto armado sob ação centrada com resistência do concreto de $25 \mathrm{MPa}$. Dissertação de Mestrado - Escola de Engenharia de São Carlos, Universidade de São Paulo, São Carlos, 2001.

RANGAN, B. V. (1990). Strength of reinforced concrete slender column. ACI Structural Journal, Vol. 87, No. 1, January-February, p. 32-38.

RAZVI, S. R. and SAATCIOGLU, M. (1998). Discussion and closure to strain localization in confined high-strength concrete (Vol. 122, No 9, 1996). Journal of Structural Engineering, Vol. 124, No. 9, September, p. 1090-1093.

RAZVI, S. R. and SAATCIOGLU, M. (1999). Confinement model for high strength concrete. Journal of Structural Engineering, Vol. 125, No. 3, March, p. 281-289.

RIGAZZO de, A. O. (2003). Reforço em pilares de concreto armado por cintamento externo com mantas flexíveis de fibras de carbono. Dissertação de Mestrado - Faculdade de Engenharia Civil, Universidade Estadual de Campinas, Campinas, 2003.

RUSSELL, H. G. (1999). ACI Defines high-performance concrete. Concrete International. U.S., Vol. 21, No. 2, February, p. 56-57.

SAATCIOGLU, M. and RAZVI, S. R. (1992). Strength and ductility of confined concrete. Journal of Structural Engineering, Vol. 118, No. 6, June, p. 1590-1607.

SAATCIOGLU, M.; SLAMAT, A. H. and RAZVI, S. R. (1995). Confinement columns under eccentric loading. Journal of Structural Division, Vol. 121, No. 11, November, p. 1547-1556. 
SAATCIOGLU, M. and RAZVI, S. R. (1998). High-strength concrete columns with square sections under concentric compression. Journal of Structural Engineering, Vol. 124, No. 12, December, p. 1438-1447.

SALMON, C. G. and JOHNSON, J. E. (1996). Steel structures. 4 ed. New York: Harper \& Row, 1024 p.

SANTOS, L. M. (1987). Estado limite último de instabilidade. Publicação M-03/87. Escola Politécnica - Departamento de Engenharia de Estruturas e Fundações, Universidade de São Paulo, São Paulo, 112 p.

SCADELAI, M. A. (2004). Dimensionamento de pilares de acordo com a NBR6118:2003. Dissertação de Mestrado - Escola de Engenharia de São Carlos, Universidade de São Paulo, São Carlos, 2004.

SHARMA, U.; BHARGAVA, P. and KAUSHIK, S. K. (2005). Comparative study of confinement models for high-strength concrete columns. Magazine of Concrete Research, Vol. 57, No. 4, May, p. 185-197.

SHEIKH, S. A. and UZUMERI, M. (1982). Analytical model for concrete confinement in tied columns. Journal of Structural Division, Vol. 108, No. ST12, December, p. 2703-2721.

SILVA V. M. (2007). Ação da carbonatação em vigas de concreto armado em serviço, construídas em escala natural. Tese de Doutorado - Escola de Engenharia de São Carlos, Universidade de São Paulo. 306p. São Carlos.

SUDANO, A. L. (2005). Influencia da forma da seção transversal no confinamento de pilares de concreto armado encamisados com PRFC (polímero Reforçado com fibra de carbono). Dissertação de Mestrado - Escola de Engenharia de São Carlos, Universidade de São Paulo, São Carlos, 2005.

SUMAJOUW, D. M. J.; HARDJITO, D.; WALLAH, S. E and RANGAN B. V. (2007). Fly ash-based geopolymer concrete: study of slender reinforced columns. Journal Material Science, No. 42, p. 3124-3130.

TAKEUTI, A. R. (1999). Reforço de pilares de concreto armado por meio de encamisamento com concreto de alto desempenho. Dissertação de Mestrado - Escola de Engenharia de São Carlos, Universidade de São Paulo, São Carlos, 1999.

TASNIMI, A. A. (2004). Mathematical model for complete stress-strain curve prediction of normal, light-weight and high-strength concretes. Magazine of Concrete Research, Vol. 56, No. 1, July-August, p. 23-34.

Tecnosil - Silica Ativa. Disponível em: 〈http://www.tecnosilbr.com.br/silica_ativa>. Acesso em: agosto de 2009.

TIBONI, R. (2007). A utilização da cinza da casca de arroz da termoelétricas como componente do aglomerante de compósitos à base de cimento Portland. Dissertação de Mestrado - Escola de Engenharia de São Carlos, Universidade de São Paulo. São Carlos, 2007. 
TIKKA, T. M. and MIRZA, S. A. (1999). Equivalent uniform moment diagram factor for reinforced concrete columns. ACI Structural Journal, Vol. 101, No. 4, July-August, p. 521532.

TIKKA, T. K. and MIRZA, S. A. (2005). Nonlinear EI equation for slender reinforced concrete columns. ACI Structural Journal, Vol. 102, No. 6, November-December, p. 839-848.

TIMOSHENKO, S. P. ;GOODIER, J. N. (1970). Theory of elasticity. 4 ed. Tokyo: McGrawHill, 567 p.

U.S. Department of Transportation - Federal Highway Administration. Disponível em: <http://www.fhwa.dot.gov/infraestruture>. Acesso em: agosto de 2009.

VANDERLEI, R. D. (1999). Análise experimental de pilares de concreto armado de alto desempenho sob flexo-compresssão reta. Dissertação de Mestrado - Escola de Engenharia de São Carlos, Universidade de São Paulo, São Carlos, 1999.

YALCIN, C. and SAATCIOGLU, M. (2000). Inelastic analysis of reinforced concrete columns. Computers \& Structures, Vol. 77, No. 5, July, p. 539-555.

YOUNG, Y. Y.; NOUR, M. and NAWY, E. G. (1989). Behavior of lateral confined HSC under axial loads. Journal of Structural Engineering, V.114, No 2, p. 332-350. 
AGUIRRE, F. e BARBOSA, P. (2002). High Strength Concrete Design According the Bulletim d'Information 228. In: III INTERNATIONAL CONFERENCE ON HIGHPERFORMANCE CONCRETE, AND PERFORMANCE AND QUALITY OF CONCRETE, 2002, Recife (PE). Supplementary Proceedings...Recife.

ASSOCIAÇÃO BRASILEIRA DE NORMAS TÉCNICAS (ABNT). NBR 8522:2003. Concreto - Curva Tensão Deformação, Rio de Janeiro, 2003. 2003.

NBR 8681:2003. Ações e Segurança nas Estruturas - Procedimento, Rio de Janeiro,

NBR 6152:1992. - Materiais Metálicos: Determinação das propriedades mecânicas à tração - Método de ensaio. Rio de Janeiro, 1992.

BOTTA, A. S. (1998). Cálculo de esforços e deslocamentos em estruturas reticuladas considerando-se a mecânica do dano para a modelagem do concreto armado. Dissertação de Mestrado - Escola de Engenharia de São Carlos, Universidade de São Paulo, São Carlos, 1998.

CAD/TQS Informática Ltda. v. 9. Sistemas Estruturais para Engenharia Civil. São Paulo, 2003.

CRISFIELD, M. A. (1997). Non-linear finite element analysis of solid and structures. London: Wiley. 345 p.

FOSTER, S. J.; LIU, J. and SHEIKH, S. A. (1998). Cover spalling in HSC columns loaded in concentric compression. Journal of Structural Engineering, Vol. 124, No. 12, December, p. $1431-1437$.

FRANCO, M. (1985). Problemas de estabilidade nos edifícios de concreto armado. Publicação Técnica do Instituto de Engenharia de São Paulo, São Paulo, 27 p.

FURLONG, R. W.; HSU, C.-T. T.and MIRZA, S. A. (2004). Analysis and design of concrete columns for biaxial bending-overview. ACI Structural Journal, Vol. 101, No. 3, May-June, p. 413-423. 
IBRAHIM, H. H. H. and MacGREGOR, J. G. (1996). Tests of eccentrically loaded highstrength concrete columns. ACI Structural Journal, Vol. 93, No. 5, September-October, p. 585-594.

LI, B.; PARK, R. (2004). Confining reinforcement for high-strength concrete columns. ACI Structural Journal, Vol. 101, No. 3, May-June, p. 314-324.

LEE, J.-H. and SON H.-S. (2000). Failure and strength of high-strength concrete columns subjected to eccentric loads. ACI Structural Journal, Vol. 97, No. 1, January-February, p. 7585 .

LEONHARDT, F. y MÖNNIG, E. (1982). Construções de concreto: Princípios básicos do dimensionamento de estruturas de concreto armado - Vol. 1. Tradução David Fridman. 1a edição 1977 - 2a reimpressão. Rio de Janeiro: Livraria Interciência. 305 p.

NEMECEK, P. P.; PATZAK, B. and BITTNAR, Z. (2005). Effect of transversal reinforcement in normal and high strength concrete columns. Materials and Structures, Vol. 38, August-September, p. 665-671.

NIELSEN, M. P. (1999). Limit analysis and concrete plasticity. 2 ed. New York: CRC Press, $908 \mathrm{p}$.

SÜSSEKIND, J. C. (1984). Curso de Concreto Armado. 4. ed. Rio de Janeiro: Ed. Globo, 2 v. $280 \mathrm{p}$.

VASCONCELOS de, A. C. e FRANÇA, R. L. S. (1997). Um método simplificado e muito preciso para avaliação dos momentos de segunda ordem em edifícios altos usuais. Publicação Técnica do Instituto de Engenharia de São Paulo, São Paulo, 19 p.

WEE, T. H.; CHIN, M. S. and MANSUR, M. A. (1996). Stress-strain relationship of highstrength concrete in compression. Journal of Materials in Civil Engineering, Vol. 8, No. 2, May, p. 70-76. 


\section{ANEXO A - ESTUDO DO TRAÇO PARA A ELABORAÇÃO DAS CURVAS DE DOSAGEM}

\section{CÁlCULO DO TEOR DE ARGAMASSA PARA O TRAÇO MÉDIO}

\section{Concreto sem aditivo}

\begin{tabular}{|c|c|c|c|c|c|c|c|c|c|}
\hline \multicolumn{10}{|c|}{ QUANTIDADE DE ARGAMASSA PARA CONCRETO SEM ADITIVOS - PARA UM TRAÇO MÉDIO (CONCRETAGEM EM 20-1-09) } \\
\hline \multirow{2}{*}{$\begin{array}{c}\text { Teor de } \\
\text { argamassa } \\
\%\end{array}$} & \multirow{2}{*}{$\begin{array}{l}\text { Traço unitário } \\
\text { individual em } \\
\text { massa (1:a:p) }\end{array}$} & \multicolumn{2}{|c|}{ Qtdade de areia $(\mathrm{kg})$} & \multicolumn{2}{|c|}{ Qtdade de cimento $(\mathrm{kg})$} & \multicolumn{2}{|c|}{ Qtdade de agua $(\mathrm{kg})$} & \multirow{2}{*}{$\begin{array}{l}\text { Relação } \\
\text { a/c final }\end{array}$} & \multirow{2}{*}{$\begin{array}{c}\text { Volume de } \\
\text { concreto } \\
\text { final (I) }\end{array}$} \\
\hline & & Massa total & $\begin{array}{c}\text { Acrécimo na } \\
\text { mistura }\end{array}$ & Massa total & $\begin{array}{l}\text { Acréscimo } \\
\text { na mistura }\end{array}$ & Massa total & $\begin{array}{l}\text { Acréscimo } \\
\text { na mistura }\end{array}$ & & \\
\hline $49 \%$ & $1: 1,94: 3,06$ & 15,850 & \multirow{2}{*}{0,817} & 8,170 & \multirow{2}{*}{0,163} & 4,493 & \multirow{2}{*}{0,150} & 0,550 & 21,91 \\
\hline $50 \%$ & $1: 2,00: 3,00$ & 16,667 & & 8,333 & & 4,643 & & 0,557 & 22,43 \\
\hline $51 \%$ & $1: 2,06: 2,94$ & 17,517 & 0,850 & 8,503 & 0,170 & 4,793 & \multirow{2}{*}{0,150} & 0,564 & 22,96 \\
\hline $52 \%$ & $1: 2,12: 2,88$ & 18,403 & 0,886 & 8,681 & 0,177 & 4,793 & & 0,552 & 23,35 \\
\hline
\end{tabular}

\section{Concreto com aditivo superplastificante}

\begin{tabular}{|c|c|c|c|c|c|c|c|c|c|c|c|}
\hline \multicolumn{12}{|c|}{ QUANTIDADE DE ARGAMASSA PARA CONCRETO COM ADITIVO SUPERPLASTIFICANTE - PARA UM TRAÇO MËDIO (CONCRETAGEM EM 17-2-09) } \\
\hline \multirow{2}{*}{$\begin{array}{c}\text { Teor de } \\
\text { argamassa } \\
\%\end{array}$} & \multirow{2}{*}{$\begin{array}{l}\text { Traço unitário individual em } \\
\text { massa (1:a:p1:p2) }\end{array}$} & \multicolumn{2}{|c|}{ Qtdade de areia (kg) } & \multicolumn{2}{|c|}{ Qtdade de cimento (kg) } & \multicolumn{2}{|c|}{$\begin{array}{l}\text { Qtdade de } \\
\text { superplastificante }(\mathrm{kg})\end{array}$} & \multicolumn{2}{|c|}{ Qtdade de agua (kg) } & \multirow{2}{*}{$\begin{array}{l}\text { Relação } \\
\text { a/c final }\end{array}$} & \multirow{2}{*}{$\begin{array}{c}\text { Volume de } \\
\text { concreto } \\
\text { final (I) }\end{array}$} \\
\hline & & Massa total & $\begin{array}{c}\text { Acrécimo na } \\
\text { mistura }\end{array}$ & Massa total & $\begin{array}{l}\text { Acréscimo } \\
\text { na mistura }\end{array}$ & Massa total & $\begin{array}{l}\text { Acréscimo } \\
\text { na mistura }\end{array}$ & Massa total & $\begin{array}{l}\text { Acréscimo } \\
\text { na mistura }\end{array}$ & & \\
\hline $50 \%$ & $1: 1,75: 1,10: 1,65$ & 15,909 & \multirow{2}{*}{0,835} & 9,091 & \multirow{2}{*}{0,186} & 0,0909 & \multirow{2}{*}{0,0019} & 3,182 & \multirow{2}{*}{0,050} & 0,350 & 20,92 \\
\hline $51 \%$ & $1: 1,81: 1,08: 1,62$ & 16,744 & & 9,276 & & 0,0928 & & 3,232 & & 0,348 & 21,35 \\
\hline $52 \%$ & $1: 1,86: 1,06: 1,58$ & 17,614 & 0,870 & 9,470 & 0,193 & 0,0947 & 0,0019 & 3,332 & 0,100 & 0,352 & 21,84 \\
\hline $53 \%$ & $1: 1,92: 1,03: 1,55$ & 18,520 & 0,907 & 9,671 & 0,201 & 0,0967 & 0,0020 & 3,482 & \multirow{2}{*}{0,150} & 0,360 & 22,41 \\
\hline $54 \%$ & $1: 1,97: 1,01: 1,52$ & 19,466 & 0,946 & 9,881 & 0,210 & 0,0988 & 0,0021 & 3,482 & & 0,35 & 22,83 \\
\hline
\end{tabular}

\section{Concreto com aditivo superplastificante e sílica ativa}

\begin{tabular}{|c|c|c|c|c|c|c|c|c|c|c|c|c|c|}
\hline & & & & & & & & & & & & & \\
\hline \multirow{2}{*}{$\begin{array}{c}\text { Teor de } \\
\text { argamassa } \\
\%\end{array}$} & \multirow{2}{*}{$\begin{array}{c}\text { Traço unitário individual em massa } \\
\text { (1:SA:a:p1:p2) }\end{array}$} & \multicolumn{2}{|c|}{ Qtdade de areia (kg) } & \multicolumn{2}{|c|}{ Qtdade de cimento (kg) } & \multicolumn{2}{|c|}{ Qtdade de sílica ativa $(\mathrm{kg})$} & \multicolumn{2}{|c|}{$\begin{array}{l}\text { Qtdade de } \\
\text { superplastificante (kg) }\end{array}$} & \multicolumn{2}{|c|}{ Qtdade de agua (kg) } & \multirow{2}{*}{$\begin{array}{c}\text { Relação } \\
\text { a/agl } \\
\text { final }\end{array}$} & \multirow{2}{*}{$\begin{array}{l}\text { Volume de } \\
\text { concreto } \\
\text { final (I) }\end{array}$} \\
\hline & & Massa total & $\begin{array}{c}\text { Acrécimo na } \\
\text { mistura }\end{array}$ & Massa total & $\begin{array}{l}\text { Acréscimo } \\
\text { na mistura }\end{array}$ & Massa total & $\begin{array}{l}\text { Acréscimo } \\
\text { na mistura }\end{array}$ & Massa total & $\begin{array}{l}\text { Acréscimo } \\
\text { na mistura }\end{array}$ & Massa total & \begin{tabular}{|l|} 
Acréscimo \\
na mistura
\end{tabular} & & \\
\hline $51 \%$ & $0,93: 0,07: 1,55: 0,98: 1,47$ & 15,816 & \multirow{2}{*}{0,8503} & 9,454 & \multirow{2}{*}{0,1970} & 0,750 & \multirow{2}{*}{0,0156} & 0,0756 & \multirow{2}{*}{0,0016} & 3,061 & \multirow{2}{*}{0,250} & 0,300 & 21,23 \\
\hline $52 \%$ & $0,93: 0,07: 1,60: 0,96: 1,44$ & 16,667 & & 9,651 & & 0,766 & & 0,0772 & & 3,311 & & 0,318 & 21,87 \\
\hline $53 \%$ & $0,93: 0,07: 1,65: 0,94: 1,41$ & 17,553 & 0,8865 & 9,856 & 0,2053 & 0,782 & 0,0163 & 0,0788 & 0,0016 & 3,511 & \multirow{2}{*}{0,200} & 0,330 & 22,48 \\
\hline $54 \%$ & $0,93: 0,07: 1,70: 0,92: 1,38$ & 18,478 & 0,9251 & 10,070 & 0,2143 & 0,799 & 0,0170 & 0,0806 & 0,0017 & 3,511 & & 0,323 & 22,91 \\
\hline
\end{tabular}


PROPRIEDADES DO CONCRETO FRESCO (TRAÇO ADOTADO)

Concreto sem aditivos

\begin{tabular}{|l|c|c|c|c|c|}
\hline \multicolumn{6}{|c|}{ RESUMO DO CONCRETO FRESCO } \\
\hline \hline traço & $\begin{array}{c}\text { Slump } \\
(\mathbf{m m})\end{array}$ & $\begin{array}{c}\text { massa } \\
\mathbf{( k g )}\end{array}$ & $\begin{array}{c}\text { volume } \\
\text { balde (I) })\end{array}$ & $\begin{array}{c}\text { massa } \\
\text { unitária } \\
(\mathbf{k g} / \mathbf{m 3})\end{array}$ & $\begin{array}{c}\text { horário } \\
\text { concretagem }\end{array}$ \\
\hline forte & $120 \pm 5$ & 35,20 & 14,4 & 2444 & $08: 30$ \\
\hline medio & $125 \pm 2$ & 34,90 & 14,4 & 2424 & $09: 30$ \\
\hline fraco & $120 \pm 2$ & 34,75 & 14,4 & 2413 & $10: 30$ \\
\hline
\end{tabular}

Concreto com superplastificante

\begin{tabular}{|l|c|c|c|c|c|}
\hline \multicolumn{6}{|c|}{ RESUMO DO CONCRETO FRESCO } \\
\hline \hline traço & $\begin{array}{c}\text { Slump } \\
(\mathbf{m m})\end{array}$ & $\begin{array}{c}\text { massa } \\
\mathbf{( k g )}\end{array}$ & $\begin{array}{c}\text { volume } \\
\text { balde }(\mathbf{l})\end{array}$ & $\begin{array}{c}\text { massa } \\
\text { unitária } \\
(\mathbf{k g} / \mathbf{m 3})\end{array}$ & $\begin{array}{c}\text { horário } \\
\text { concretagem }\end{array}$ \\
\hline forte & $220 \pm 30$ & 35,60 & 14,4 & 2472 & $08: 30$ \\
\hline medio & $215 \pm 25$ & 35,40 & 14,4 & 2458 & $09: 30$ \\
\hline fraco & $210 \pm 10$ & 35,1 & 14,4 & 2438 & $10: 30$ \\
\hline
\end{tabular}

Concreto com superplastificante e sílica ativa

\begin{tabular}{|l|c|c|c|c|c|}
\hline \multicolumn{6}{|c|}{ RESUMO DO CONCRETO FRESCO } \\
\hline \hline traço & $\begin{array}{c}\text { Slump } \\
(\mathbf{m m})\end{array}$ & $\begin{array}{c}\text { massa } \\
(\mathbf{k g})\end{array}$ & $\begin{array}{c}\text { volume } \\
\text { balde (I) }\end{array}$ & $\begin{array}{c}\text { massa } \\
\text { unitária } \\
(\mathbf{k g} / \mathbf{m 3})\end{array}$ & $\begin{array}{c}\text { horário } \\
\text { concretagem }\end{array}$ \\
\hline forte & $220 \pm 20$ & 35,50 & 14,4 & 2465 & $08: 30$ \\
\hline medio & $200 \pm 25$ & 35,35 & 14,4 & 2455 & $09: 30$ \\
\hline fraco & $200 \pm 15$ & 35,15 & 14,4 & 2441 & $10: 30$ \\
\hline
\end{tabular}


RESULTADOS DOS ENSAIOS À COMPRESSÃO DOS CORPOS-DEPROVA PARA O CONCRETO SEM ADITIVOS (TRAÇO ADOTADO)

\begin{tabular}{|c|c|c|c|c|c|c|c|c|c|c|c|}
\hline \multicolumn{12}{|c|}{ ESTUDO DE DOSAGEM PARA CONCRETO SEM ADITIVOS - CONCRETAGEM EM 23-1-09 } \\
\hline \multicolumn{12}{|c|}{ ENSAIO À COMPRESSÃO SIMPLES - MEDIDAS } \\
\hline \multirow[t]{2}{*}{ TRAÇOS } & CP & D1 (cm) & $\mathrm{D} 2(\mathrm{~cm})$ & D3 $(\mathrm{cm})$ & D4 (cm) & $\mathrm{DM}(\mathrm{cm})$ & h1 (cm) & h2 (cm) & $\mathrm{hm}(\mathrm{cm})$ & $\begin{array}{c}\text { massa } \\
\text { (g) }\end{array}$ & \begin{tabular}{|c}
$\begin{array}{c}\text { F ruptura } \\
\text { (KN) }\end{array}$ \\
\end{tabular} \\
\hline & \multicolumn{11}{|c|}{ CP COM 3 DIAS (26-1-09-15:00) } \\
\hline \multirow{3}{*}{$\begin{array}{l}\text { TRAÇO } \\
\text { FORTE }\end{array}$} & 1 & 10,00 & 10,00 & 10,00 & 10,00 & 10,00 & 20,00 & 20,00 & 20,00 & & 309,5 \\
\hline & 2 & 10,00 & 10,00 & 10,00 & 10,00 & 10,00 & 20,00 & 20,00 & 20,00 & & 206,8 \\
\hline & 3 & 10,00 & 10,00 & 10,00 & 10,00 & 10,00 & 20,00 & 20,00 & 20,00 & & 298,6 \\
\hline \multirow{3}{*}{$\begin{array}{l}\text { TRAÇO } \\
\text { MÉDIO }\end{array}$} & 4 & 10,00 & 10,00 & 10,00 & 10,00 & 10,00 & 20,00 & 20,00 & 20,00 & & 247,7 \\
\hline & 5 & 10,00 & 10,00 & 10,00 & 10,00 & 10,00 & 20,00 & 20,00 & 20,00 & & 244,3 \\
\hline & 6 & 10,00 & 10,00 & 10,00 & 10,00 & 10,00 & 20,00 & 20,00 & 20,00 & & 240,8 \\
\hline \multirow{3}{*}{$\begin{array}{l}\text { TRAÇO } \\
\text { FRACO }\end{array}$} & 7 & 10,00 & 10,00 & 10,00 & 10,00 & 10,00 & 20,00 & 20,00 & 20,00 & & 134,9 \\
\hline & 8 & 10,00 & 10,00 & 10,00 & 10,00 & 10,00 & 20,00 & 20,00 & 20,00 & & 134,3 \\
\hline & 9 & 10,00 & 10,00 & 10,00 & 10,00 & 10,00 & 20,00 & 20,00 & 20,00 & & 114,5 \\
\hline & \multicolumn{11}{|c|}{ CP COM 7 DIAS (30-1-09-15:30) } \\
\hline \multirow{3}{*}{$\begin{array}{l}\text { TRAÇO } \\
\text { FORTE }\end{array}$} & 1 & 10,01 & 10,13 & 10,14 & 10,15 & 10,11 & 19,69 & 19,65 & 19,67 & 3877,9 & 376,0 \\
\hline & 2 & 10,12 & 10,05 & 10,04 & 10,12 & 10,08 & 19,65 & 19,71 & 19,68 & 3855,6 & 379,6 \\
\hline & 3 & 10,03 & 10,08 & 10,09 & 10,07 & 10,07 & 19,61 & 19,55 & 19,58 & 3822,8 & 360,0 \\
\hline \multirow{3}{*}{$\begin{array}{l}\text { TRAÇO } \\
\text { MÉDIO }\end{array}$} & 4 & 10,04 & 9,99 & 10,00 & 9,99 & 10,01 & 19,87 & 19,83 & 19,85 & 3832,5 & 264,0 \\
\hline & 5 & 10,09 & 10,03 & 10,03 & 10,06 & 10,05 & 19,61 & 19,62 & 19,62 & 3812,4 & 290,4 \\
\hline & 6 & 10,11 & 10,04 & 10,11 & 10,07 & 10,08 & 19,70 & 19,65 & 19,68 & 3842,3 & 275,5 \\
\hline \multirow{3}{*}{$\begin{array}{l}\text { TRAÇO } \\
\text { FRACO }\end{array}$} & 7 & 10,11 & 10,01 & 10,15 & 10,01 & 10,07 & 19,71 & 19,71 & 19,71 & 3794,6 & 159,6 \\
\hline & 8 & 10,06 & 10,16 & 10,15 & 10,10 & 10,12 & 19,51 & 19,51 & 19,51 & 3791,2 & 157,0 \\
\hline & 9 & 10,11 & 10,01 & 10,00 & 10,03 & 10,04 & 19,68 & 19,72 & 19,70 & 3808,0 & 160,9 \\
\hline & \multicolumn{11}{|c|}{ CP COM 14 DIAS (6-2-09-14:15) } \\
\hline \multirow{3}{*}{$\begin{array}{l}\text { TRAÇO } \\
\text { FORTE }\end{array}$} & 1 & 10,15 & 10,05 & 10,02 & 10,10 & 10,08 & 19,71 & & 19,71 & 3903,2 & 398,1 \\
\hline & 2 & 10,10 & 10,14 & 10,18 & 10,12 & 10,14 & 19,68 & & 19,68 & 3872,6 & 404,9 \\
\hline & 3 & 10,00 & 10,12 & 10,09 & 10,05 & 10,07 & 19,64 & & 19,64 & 3818,2 & 394,9 \\
\hline \multirow{3}{*}{$\begin{array}{l}\text { TRAÇO } \\
\text { MÉDIO }\end{array}$} & 4 & 10,01 & 10,14 & 10,15 & 9,97 & 10,07 & 19,66 & & 19,66 & 3845,9 & 300,6 \\
\hline & 5 & 10,08 & 10,13 & 10,06 & 10,11 & 10,10 & 19,64 & & 19,64 & 3850,0 & 303,7 \\
\hline & 6 & 10,10 & 10,09 & 10,09 & 10,09 & 10,09 & 19,65 & & 19,65 & 3835,1 & 287,2 \\
\hline \multirow{3}{*}{$\begin{array}{l}\text { TRAÇO } \\
\text { FRACO }\end{array}$} & 7 & 10,03 & 10,14 & 10,07 & 10,09 & 10,08 & 19,58 & & 19,58 & 3795,2 & 186,1 \\
\hline & 8 & 10,20 & 10,00 & 10,07 & 10,14 & 10,10 & 19,50 & & 19,50 & 3837,0 & \\
\hline & 9 & 10,10 & 10,08 & 10,07 & 10,12 & 10,09 & 19,50 & & 19,50 & 3783,9 & 155,2 \\
\hline & \multicolumn{11}{|c|}{ CP COM 28 DIAS (20-2-09-16:00) } \\
\hline \multirow{3}{*}{$\begin{array}{l}\text { TRAÇO } \\
\text { FORTE }\end{array}$} & 1 & 10,05 & 10,05 & 10,03 & 10,01 & 10,04 & 19,69 & 19,65 & 19,67 & 3835,3 & 419,7 \\
\hline & 2 & 10,05 & 10,09 & 10,10 & 10,09 & 10,08 & 19,62 & 19,58 & 19,60 & 3830,1 & \\
\hline & 3 & 10,03 & 10,05 & 10,03 & 10,00 & 10,03 & 19,65 & 19,68 & 19,67 & 3811,2 & 443,0 \\
\hline \multirow{3}{*}{$\begin{array}{l}\text { TRAÇO } \\
\text { MÉDIO }\end{array}$} & 4 & 10,12 & 10,01 & 10,05 & 10,09 & 10,07 & 19,63 & 19,69 & 19,66 & 3843,0 & 330,2 \\
\hline & 5 & 10,15 & 10,00 & 10,08 & 10,08 & 10,08 & 19,70 & 19,64 & 19,67 & 3830,3 & 328,9 \\
\hline & 6 & 10,10 & 10,05 & 10,07 & 10,09 & 10,08 & 19,55 & 19,60 & 19,58 & 3838,1 & 329,9 \\
\hline \multirow{3}{*}{$\begin{array}{l}\text { TRAÇO } \\
\text { FRACO }\end{array}$} & 7 & 10,10 & 10,12 & 10,02 & 10,05 & 10,07 & 19,54 & 19,62 & 19,58 & 3780,9 & 185,0 \\
\hline & 8 & 10,05 & 10,03 & 10,04 & 10,09 & 10,05 & 19,58 & 19,59 & 19,59 & 3776,7 & 197,0 \\
\hline & 9 & 10,09 & 10,03 & 10,02 & 10,04 & 10,05 & 19,59 & 19,55 & 19,57 & 3758,3 & 188,6 \\
\hline
\end{tabular}




\section{Resumo dos resultados anteriores}

\begin{tabular}{|c|c|c|c|c|c|c|c|c|c|c|}
\hline \multicolumn{11}{|c|}{ ESTUDO DE DOSAGEM PARA CONCRETO SEM ADITIVOS - CONCRETAGEM EM 23-1-09 } \\
\hline \multicolumn{11}{|c|}{ RESUMO DO ENSAIO À COMPRESSÃO SIMPLES } \\
\hline \multirow[t]{2}{*}{ TRAÇOS } & CP & $\begin{array}{c}\text { diâmetro } \\
(\mathrm{cm})\end{array}$ & $\begin{array}{c}\text { altura } \\
(\mathrm{cm})\end{array}$ & $\begin{array}{c}\text { seção } \\
\text { CP } \\
(\mathrm{cm} 2)\end{array}$ & $\begin{array}{l}\text { Força } \\
\text { ruptura } \\
\text { (KN) }\end{array}$ & $\begin{array}{c}\text { tensão } \\
\text { ruptura } \\
\text { (MPa) }\end{array}$ & $\begin{array}{l}\text { tensão } \\
\text { média } \\
\text { (MPa) }\end{array}$ & $\begin{array}{c}\text { massa } \\
(\mathrm{kg})\end{array}$ & $\begin{array}{c}\text { massa } \\
\text { unitária } \\
(\mathrm{kg} / \mathrm{m} 3)\end{array}$ & $\begin{array}{c}\text { massa } \\
\text { média } \\
(\mathrm{kg} / \mathrm{m} 3)\end{array}$ \\
\hline & \multicolumn{10}{|c|}{$3 \mathrm{~d}$} \\
\hline \multirow{3}{*}{$\begin{array}{l}\text { TRAÇO } \\
\text { FORTE }\end{array}$} & 1 & 10,00 & 20,00 & 78,54 & 309,50 & 39,41 & \multirow{3}{*}{38,7} & 0,00 & 0,00 & \multirow{3}{*}{0} \\
\hline & 2 & 10,00 & 20,00 & 78,54 & 206,80 & 26,33 & & 0,00 & 0,00 & \\
\hline & 3 & 10,00 & 20,00 & 78,5 & 298,6 & 38,0 & & 0,00 & 0,00 & \\
\hline \multirow{3}{*}{$\begin{array}{l}\text { TRAÇO } \\
\text { MÉDIO }\end{array}$} & 4 & 10,00 & 20,00 & 78,54 & 247,70 & 31,54 & \multirow{3}{*}{31,1} & 0,00 & 0,00 & \multirow{3}{*}{0} \\
\hline & 5 & 10,00 & 20,00 & 78,54 & 244,30 & 31,11 & & 0,00 & 0,00 & \\
\hline & 6 & 10,00 & 20,00 & 78,5 & 240,8 & 30,7 & & 0,00 & 0,00 & \\
\hline \multirow{3}{*}{$\begin{array}{l}\text { TRAÇO } \\
\text { FRACO }\end{array}$} & 7 & 10,00 & 20,00 & 78,54 & 134,90 & 17,18 & \multirow{3}{*}{16,3} & 0,00 & 0,00 & \multirow{3}{*}{0} \\
\hline & 8 & 10,00 & 20,00 & 78,54 & 134,30 & 17,10 & & 0,00 & 0,00 & \\
\hline & 9 & 10,00 & 20,00 & 78,5 & 114,5 & 14,6 & & 0,00 & 0,00 & \\
\hline & \multicolumn{10}{|c|}{$7 d$} \\
\hline \multirow{3}{*}{$\begin{array}{l}\text { TRAÇO } \\
\text { FORTE }\end{array}$} & 1 & 10,11 & 19,67 & 80,2 & 376,0 & 46,9 & \multirow{3}{*}{46,5} & 3,88 & 2457 & \multirow{3}{*}{2455} \\
\hline & 2 & 10,08 & 19,68 & 79,8 & 379,6 & 47,5 & & 3,86 & 2454 & \\
\hline & 3 & 10,07 & 19,58 & 79,6 & 360,0 & 45,2 & & 3,82 & 2453 & \\
\hline \multirow{3}{*}{$\begin{array}{l}\text { TRAÇO } \\
\text { MÉDIO }\end{array}$} & 4 & 10,01 & 19,85 & 78,6 & 264,0 & 33,6 & \multirow{3}{*}{34,9} & 3,83 & 2456 & \multirow{3}{*}{2450} \\
\hline & 5 & 10,05 & 19,62 & 79,4 & 290,4 & 36,6 & & 3,81 & 2449 & \\
\hline & 6 & 10,08 & 19,68 & 79,8 & 275,5 & 34,5 & & 3,84 & 2446 & \\
\hline \multirow{3}{*}{$\begin{array}{l}\text { TRAÇO } \\
\text { FRACO }\end{array}$} & 7 & 10,07 & 19,71 & 79,6 & 159,6 & 20,0 & \multirow{3}{*}{20,0} & 3,79 & 2417 & \\
\hline & 8 & 10,12 & 19,51 & 80,4 & 157,0 & 19,5 & & 3,79 & 2417 & 2426 \\
\hline & 9 & 10,04 & 19,70 & 79,1 & 160,9 & 20,3 & & 3,81 & 2443 & \\
\hline & & & & & & $4 \mathrm{~d}$ & & & & \\
\hline & 1 & 10,08 & 19,71 & 79,8 & 398,1 & 49,9 & & 3,90 & 2482 & \\
\hline & 2 & 10,14 & 19,68 & 80,7 & 404,9 & 50,2 & 49,9 & 3,87 & 2439 & 2455 \\
\hline & 3 & 10,07 & 19,64 & 79,6 & 394,9 & 49,6 & & 3,82 & 2443 & \\
\hline & 4 & 10,07 & 19,66 & 79,6 & 300,6 & 37,8 & & 3,85 & 2457 & \\
\hline MÉDI & 5 & 10,10 & 19,64 & 80,0 & 303,7 & 37,9 & 37,2 & 3,85 & 2449 & 2449 \\
\hline & 6 & 10,09 & 19,65 & 80,0 & 287,2 & 35,9 & & 3,84 & 2440 & \\
\hline & 7 & 10,08 & 19,58 & 79,8 & 186,1 & 23,3 & & 3,80 & 2428 & \\
\hline & 8 & 10,10 & 19,50 & 80,2 & 0,0 & 0,0 & 21,4 & 3,84 & 2455 & 2436 \\
\hline & 9 & 10,09 & 19,50 & 80,0 & 155,2 & 19,4 & & 3,78 & 2426 & \\
\hline & & & & & & $8 \mathrm{~d}$ & & & & \\
\hline & 1 & 10,04 & 19,67 & 79,1 & 419,7 & 53,1 & & 3,84 & 2465 & \\
\hline & 2 & 10,08 & 19,60 & 79,8 & 0,0 & 0,0 & 54,6 & 3,83 & 2448 & 2456 \\
\hline & 3 & 10,03 & 19,67 & 79,0 & 443,0 & 56,1 & & 3,81 & 2454 & \\
\hline & 4 & 10,07 & 19,66 & 79,6 & 330,2 & 41,5 & & 3,84 & 2456 & \\
\hline MÉDIO & 5 & 10,08 & 19,67 & 79,8 & 328,9 & 41,2 & 41,4 & 3,83 & 2441 & 2452 \\
\hline & 6 & 10,08 & 19,58 & 79,8 & 329,9 & 41,4 & & 3,84 & 2458 & \\
\hline & 7 & 10,07 & 19,58 & 79,7 & 185,0 & 23,2 & & 3,78 & 2423 & \\
\hline ERAÇ & 8 & 10,05 & 19,59 & 79,4 & 197,0 & 24,8 & 23,9 & 3,78 & 2430 & 2425 \\
\hline & 9 & 10,05 & 19,57 & 79,2 & 188,6 & 23,8 & & 3,76 & 2423 & \\
\hline
\end{tabular}


RESULTADOS DOS ENSAIOS À COMPRESSÃO DOS CORPOS-DEPROVA PARA O CONCRETO COM SUPERPLASTIFICANTE (TRAÇO ADOTADO)

\begin{tabular}{|c|c|c|c|c|c|c|c|c|c|c|c|}
\hline \multicolumn{12}{|c|}{ ESTUDO DE DOSAGEM PARA CONCRETO COM SUPERPLASTIFICANTE - CONCRETAGEM EM 18-2-09 } \\
\hline & & & & 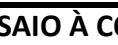 & MPRESS & AO SIMPLE & S - MEDIL & & & & \\
\hline \multirow[t]{2}{*}{ TRAÇOS } & CP & D1 (cm) & D2 (cm) & D3 (cm) & D4 (cm) & $\mathrm{DM}(\mathrm{cm})$ & h1 (cm) & h2 (cm) & $\mathrm{hm}(\mathrm{cm})$ & $\begin{array}{c}\text { massa } \\
\text { (g) }\end{array}$ & $\begin{array}{l}\text { F ruptura } \\
\text { (KN) }\end{array}$ \\
\hline & \multicolumn{11}{|c|}{ CP COM 8 DIAS (26-2-09-15:00) } \\
\hline \multirow{3}{*}{$\begin{array}{l}\text { TRAÇO } \\
\text { FORTE }\end{array}$} & 1 & 10,03 & 9,99 & 10,01 & 10,01 & 10,01 & 19,89 & 19,96 & 19,93 & 3988,1 & 651,1 \\
\hline & 2 & 10,10 & 10,04 & 9,91 & 10,11 & 10,04 & 19,83 & 19,81 & 19,82 & 3966,2 & 647,8 \\
\hline & 3 & 10,10 & 10,10 & 10,10 & 10,14 & 10,11 & 19,77 & 19,73 & 19,75 & 4013,2 & 615,7 \\
\hline \multirow{3}{*}{$\begin{array}{l}\text { TRAÇO } \\
\text { MÉDIO }\end{array}$} & 4 & 10,01 & 10,10 & 10,06 & 10,05 & 10,06 & 19,83 & 19,85 & 19,84 & 3956,3 & 541,8 \\
\hline & 5 & 10,08 & 10,01 & 10,09 & 10,11 & 10,07 & 19,74 & 19,68 & 19,71 & 3933,7 & 553,8 \\
\hline & 6 & 10,09 & 10,06 & 10,13 & 10,04 & 10,08 & 19,87 & 19,89 & 19,88 & 3968,2 & 550,5 \\
\hline \multirow{3}{*}{$\begin{array}{l}\text { TRAÇO } \\
\text { FRACO }\end{array}$} & 7 & 9,99 & 10,01 & 10,05 & 9,90 & 9,99 & 19,90 & 19,90 & 19,90 & 3856,8 & 387,1 \\
\hline & 8 & 9,93 & 10,15 & 10,04 & 10,04 & 10,04 & 19,77 & 19,78 & 19,78 & 3873,2 & 364,2 \\
\hline & 9 & 10,11 & 10,03 & 10,05 & 10,05 & 10,06 & 19,90 & 19,85 & 19,88 & 3917,8 & 392,0 \\
\hline & \multicolumn{11}{|c|}{ CP COM 14 DIAS (4-3-09-15:15) } \\
\hline \multirow{3}{*}{$\begin{array}{l}\text { TRAÇO } \\
\text { FORTE }\end{array}$} & 1 & 10,09 & 10,11 & 10,13 & 10,09 & 10,11 & 19,95 & 19,97 & 19,96 & 4026,5 & 710,3 \\
\hline & 2 & 10,13 & 10,04 & 10,15 & 10,05 & 10,09 & 19,92 & 19,96 & 19,94 & 4023,7 & 701,6 \\
\hline & 3 & 10,06 & 10,02 & 10,08 & 9,99 & 10,04 & 19,97 & 19,94 & 19,96 & 3982,7 & 692,5 \\
\hline \multirow{3}{*}{$\begin{array}{l}\text { TRAÇO } \\
\text { MÉDIO }\end{array}$} & 4 & 10,15 & 10,12 & 10,09 & 10,20 & 10,14 & 19,71 & 19,72 & 19,72 & 3968,5 & 555,8 \\
\hline & 5 & 10,11 & 10,05 & 10,10 & 10,03 & 10,07 & 19,75 & 19,75 & 19,75 & 3927,7 & 559,5 \\
\hline & 6 & 10,00 & 10,06 & 10,08 & 9,98 & 10,03 & 19,83 & 19,90 & 19,87 & 3928,7 & 576,4 \\
\hline \multirow{3}{*}{$\begin{array}{l}\text { TRAÇO } \\
\text { FRACO }\end{array}$} & 7 & 10,04 & 10,02 & 10,05 & 9,89 & 10,00 & 19,90 & 19,85 & 19,88 & 3874,9 & 420,6 \\
\hline & 8 & 10,03 & 10,08 & 10,05 & 10,10 & 10,07 & 19,70 & 19,65 & 19,68 & 3892,8 & 431,1 \\
\hline & 9 & 10,05 & 10,00 & 10,04 & 9,97 & 10,02 & 19,90 & 19,87 & 19,89 & 3870,2 & 418,3 \\
\hline & \multicolumn{11}{|c|}{ CP COM 28 DIAS (18-3-09-15:30) } \\
\hline \multirow{3}{*}{$\begin{array}{l}\text { TRAÇO } \\
\text { FORTE }\end{array}$} & 1 & 9,99 & 10,08 & 10,05 & 10,03 & 10,04 & 19,96 & 20,00 & 19,98 & 3981,0 & 756,2 \\
\hline & 2 & 10,00 & 9,99 & 10,01 & 9,97 & 9,99 & 20,04 & 20,08 & 20,06 & 3992,8 & 770,1 \\
\hline & 3 & 10,09 & 10,03 & 10,10 & 10,05 & 10,07 & 19,90 & 19,91 & 19,91 & 4004,0 & 769,8 \\
\hline \multirow{3}{*}{$\begin{array}{l}\text { TRAÇO } \\
\text { MÉDIO }\end{array}$} & 4 & 10,00 & 10,11 & 10,02 & 10,10 & 10,06 & 19,73 & 19,75 & 19,74 & 3924,4 & 593,1 \\
\hline & 5 & 10,13 & 9,88 & 10,14 & 9,95 & 10,03 & 19,93 & 19,93 & 19,93 & 3959,9 & 619,1 \\
\hline & 6 & 10,03 & 10,05 & 10,05 & 10,05 & 10,05 & 19,89 & 19,90 & 19,90 & 3955,3 & 607,4 \\
\hline \multirow{3}{*}{$\begin{array}{l}\text { TRAÇO } \\
\text { FRACO }\end{array}$} & 7 & 10,10 & 10,10 & 10,05 & 10,03 & 10,07 & 19,72 & 19,62 & 19,67 & 3885,9 & 456,4 \\
\hline & 8 & 10,08 & 10,00 & 10,06 & 10,02 & 10,04 & 19,80 & 19,79 & 19,80 & 3862,4 & 459,5 \\
\hline & 9 & 10,07 & 10,10 & 10,08 & 10,03 & 10,07 & 19,75 & 19,75 & 19,75 & 3883,0 & 453,4 \\
\hline
\end{tabular}




\section{Resumo dos resultados anteriores}

\begin{tabular}{|c|c|c|c|c|c|c|c|c|c|c|}
\hline \multicolumn{11}{|c|}{ ESTUDO DE DOSAGEM PARA CONCRETO COM SUPERPLASTIFICANTE - CONCRETAGEM EM 18-2-09 } \\
\hline \multicolumn{11}{|c|}{ RESUMO DO ENSAIO À COMPRESSÃO SIMPLES } \\
\hline \multirow[t]{2}{*}{ TRAÇOS } & $\mathbf{C P}$ & $\begin{array}{c}\text { diâmetro } \\
\text { (cm) }\end{array}$ & $\begin{array}{l}\text { altura } \\
(\mathrm{cm})\end{array}$ & $\begin{array}{c}\text { seção } \\
\text { CP } \\
(\mathrm{cm} 2)\end{array}$ & $\begin{array}{l}\text { Força } \\
\text { ruptura } \\
\text { (KN) }\end{array}$ & $\begin{array}{c}\text { tensão } \\
\text { ruptura } \\
\text { (MPa) }\end{array}$ & $\begin{array}{l}\text { tensão } \\
\text { média } \\
\text { (MPa) }\end{array}$ & $\begin{array}{c}\text { massa } \\
(\mathrm{kg})\end{array}$ & $\begin{array}{c}\text { massa } \\
\text { unitária } \\
(\mathrm{kg} / \mathrm{m} 3)\end{array}$ & $\begin{array}{c}\text { massa } \\
\text { média } \\
(\mathrm{kg} / \mathrm{m} 3)\end{array}$ \\
\hline & \multicolumn{10}{|c|}{$8 \mathrm{~d}$} \\
\hline \multirow{3}{*}{$\begin{array}{l}\text { TRAÇO } \\
\text { FORTE }\end{array}$} & 1 & 10,01 & 19,93 & 78,7 & 651,1 & 82,7 & \multirow{3}{*}{80,4} & 3,99 & 2543 & \multirow{3}{*}{2534} \\
\hline & 2 & 10,04 & 19,82 & 79,2 & 647,8 & 81,8 & & 3,97 & 2528 & \\
\hline & 3 & 10,11 & 19,75 & 80,3 & 615,7 & 76,7 & & 4,01 & 2531 & \\
\hline \multirow{3}{*}{$\begin{array}{l}\text { TRAÇO } \\
\text { MÉDIO }\end{array}$} & 4 & 10,06 & 19,84 & 79,4 & 541,8 & 68,2 & \multirow{3}{*}{68,9} & 3,96 & 2511 & \multirow{3}{*}{2506} \\
\hline & 5 & 10,07 & 19,71 & 79,7 & 553,8 & 69,5 & & 3,93 & 2505 & \\
\hline & 6 & 10,08 & 19,88 & 79,8 & 550,5 & 69,0 & & 3,97 & 2501 & \\
\hline \multirow{3}{*}{$\begin{array}{l}\text { TRAÇO } \\
\text { FRACO }\end{array}$} & 7 & 9,99 & 19,90 & 78,3 & 387,1 & 49,4 & \multirow{3}{*}{48,2} & 3,86 & 2474 & \multirow{3}{*}{2476} \\
\hline & 8 & 10,04 & 19,78 & 79,2 & 364,2 & 46,0 & & 3,87 & 2474 & \\
\hline & 9 & 10,06 & 19,88 & 79,5 & 392,0 & 49,3 & & 3,92 & 2480 & \\
\hline & \multicolumn{10}{|c|}{$14 \mathrm{~d}$} \\
\hline \multirow{3}{*}{$\begin{array}{l}\text { TRAÇO } \\
\text { FORTE }\end{array}$} & 1 & 10,11 & 19,96 & 80,2 & 710,3 & 88,6 & \multirow{3}{*}{87,9} & 4,03 & 2515 & \multirow{3}{*}{2520} \\
\hline & 2 & 10,09 & 19,94 & 80,0 & 701,6 & 87,7 & & 4,02 & 2522 & \\
\hline & 3 & 10,04 & 19,96 & 79,1 & 692,5 & 87,5 & & 3,98 & 2522 & \\
\hline \multirow{3}{*}{$\begin{array}{l}\text { TRAÇO } \\
\text { MÉDIO }\end{array}$} & 4 & 10,14 & 19,72 & 80,8 & 555,8 & 68,8 & \multirow{3}{*}{70,7} & 3,97 & 2493 & \multirow{3}{*}{2497} \\
\hline & 5 & 10,07 & 19,75 & 79,7 & 559,5 & 70,2 & & 3,93 & 2496 & \\
\hline & 6 & 10,03 & 19,87 & 79,0 & 576,4 & 73,0 & & 3,93 & 2503 & \\
\hline \multirow{3}{*}{$\begin{array}{l}\text { TRAÇO } \\
\text { FRACO }\end{array}$} & 7 & 10,00 & 19,88 & 78,5 & 420,6 & 53,6 & \multirow{3}{*}{53,6} & 3,87 & 2482 & \multirow{3}{*}{2480} \\
\hline & 8 & 10,07 & 19,68 & 79,6 & 431,1 & 54,2 & & 3,89 & 2487 & \\
\hline & 9 & 10,02 & 19,89 & 78,8 & 418,3 & 53,1 & & 3,87 & 2471 & \\
\hline & \multicolumn{10}{|c|}{$28 d$} \\
\hline \multirow{3}{*}{$\begin{array}{l}\text { TRAÇO } \\
\text { FORTE }\end{array}$} & 1 & 10,04 & 19,98 & 79,1 & 756,2 & 95,6 & \multirow{3}{*}{96,8} & 3,98 & 2518 & \multirow{3}{*}{2528} \\
\hline & 2 & 9,99 & 20,06 & 78,4 & 770,1 & 98,2 & & 3,99 & 2538 & \\
\hline & 3 & 10,07 & 19,91 & 79,6 & 769,8 & 96,7 & & 4,00 & 2527 & \\
\hline & 4 & 10,06 & 19,74 & 79,4 & 593,1 & 74,7 & & 3,92 & 2502 & \\
\hline RAÇO & 5 & 10,03 & 19,93 & 78,9 & 619,1 & 78,4 & 76,6 & 3,96 & 2517 & 2509 \\
\hline & 6 & 10,05 & 19,90 & 79,2 & 607,4 & 76,6 & & 3,96 & 2509 & \\
\hline & 7 & 10,07 & 19,67 & 79,6 & 456,4 & 57,3 & & 3,89 & 2480 & \\
\hline$A C ̧ U$ & 8 & 10,04 & 19,80 & 79,2 & 459,5 & 58,0 & 57,4 & 3,86 & 2465 & 2471 \\
\hline FRACU & 9 & 10,07 & 19,75 & 79,6 & 453,4 & 56,9 & & 3,88 & 2469 & \\
\hline
\end{tabular}


RESULTADO DOS ENSAIOS À COMPRESSÃO DOS CORPOS-DEPROVA PARA O CONCRETO COM SUPERPLASTIFICANTE E SÍLICA ATIVA (TRAÇO ADOTADO)

\begin{tabular}{|c|c|c|c|c|c|c|c|c|c|c|c|}
\hline \multicolumn{12}{|c|}{ ESTUDO DE DOSAGEM PARA CONCRETO COM SUPERPLASTIFICANTE E SA - CONCRETAGEM EM 20-2-09 } \\
\hline \multicolumn{12}{|c|}{ ENSAIO À COMPRESSÃO SIMPLES - MEDIDAS } \\
\hline \multirow[t]{2}{*}{ TRAÇOS } & CP & D1 (cm) & D2 (cm) & D3 (cm) & D4 (cm) & $\mathrm{DM}(\mathrm{cm})$ & h1 (cm) & h2 (cm) & $\mathrm{hm}(\mathrm{cm})$ & $\begin{array}{c}\text { massa } \\
\text { (g) }\end{array}$ & $\begin{array}{c}\text { F ruptura } \\
\text { (KN) }\end{array}$ \\
\hline & \multicolumn{11}{|c|}{ CP COM 7 DIAS (27-2-09-15:30) } \\
\hline \multirow{3}{*}{$\begin{array}{l}\text { TRAÇO } \\
\text { FORTE }\end{array}$} & 1 & 10,05 & 10,00 & 10,07 & 9,94 & 10,02 & 19,92 & 19,90 & 19,91 & 3909,0 & 632,4 \\
\hline & 2 & 10,04 & 10,04 & 10,05 & 10,05 & 10,05 & 19,83 & 19,87 & 19,85 & 3919,5 & 656,0 \\
\hline & 3 & 10,00 & 9,98 & 10,01 & 9,95 & 9,99 & 20,09 & 20,03 & 20,06 & 3929,8 & 656,8 \\
\hline \multirow{3}{*}{$\begin{array}{l}\text { TRAÇO } \\
\text { MÉDIO }\end{array}$} & 4 & 10,16 & 9,99 & 10,10 & 10,10 & 10,09 & 20,00 & 20,00 & 20,00 & 3939,9 & 584,6 \\
\hline & 5 & 10,05 & 10,10 & 10,05 & 10,05 & 10,06 & 19,85 & 19,90 & 19,88 & 3895,6 & 571,9 \\
\hline & 6 & 10,00 & 10,01 & 10,10 & 10,04 & 10,04 & 20,00 & 19,92 & 19,96 & 3882,8 & 582,2 \\
\hline \multirow{3}{*}{$\begin{array}{l}\text { TRAÇO } \\
\text { FRACO }\end{array}$} & 7 & 10,10 & 10,08 & 10,10 & 10,05 & 10,08 & 19,97 & 19,90 & 19,94 & 3880,9 & 479,9 \\
\hline & 8 & 10,06 & 10,05 & 10,01 & 10,01 & 10,03 & 20,09 & 20,09 & 20,09 & 3884,2 & 476,4 \\
\hline & 9 & 10,05 & 10,09 & 10,12 & 10,02 & 10,07 & 19,86 & 19,95 & 19,91 & 3875,1 & 482,1 \\
\hline & \multicolumn{11}{|c|}{ CP COM 14 DIAS (6-3-09-14:15) } \\
\hline \multirow{3}{*}{$\begin{array}{l}\text { TRAÇO } \\
\text { FORTE }\end{array}$} & 1 & 10,02 & 10,10 & 10,05 & 10,05 & 10,06 & 19,88 & 19,91 & 19,90 & 3951,1 & 716,9 \\
\hline & 2 & 10,04 & 10,05 & 10,08 & 10,00 & 10,04 & 20,21 & 20,20 & 20,21 & 4007,2 & 701,2 \\
\hline & 3 & 10,06 & 10,07 & 10,05 & 10,17 & 10,09 & 19,96 & 20,00 & 19,98 & 3993,3 & 733,8 \\
\hline \multirow{3}{*}{$\begin{array}{l}\text { TRAÇO } \\
\text { MÉDIO }\end{array}$} & 4 & 10,08 & 10,14 & 10,09 & 10,08 & 10,10 & 19,95 & 19,94 & 19,95 & 3926,6 & 656,6 \\
\hline & 5 & 10,05 & 10,14 & 10,05 & 10,09 & 10,08 & 19,96 & 19,98 & 19,97 & 3920,4 & 645,6 \\
\hline & 6 & 10,10 & 10,01 & 10,08 & 10,03 & 10,06 & 19,92 & 19,98 & 19,95 & 3918,5 & 666,4 \\
\hline \multirow{3}{*}{$\begin{array}{l}\text { TRAÇO } \\
\text { FRACO }\end{array}$} & 7 & 10,06 & 9,97 & 10,05 & 10,00 & 10,02 & 20,00 & 19,99 & 20,00 & 3848,5 & 530,3 \\
\hline & 8 & 10,02 & 10,08 & 10,10 & 10,00 & 10,05 & 19,92 & 19,86 & 19,89 & 3867,8 & 553,3 \\
\hline & 9 & 10,11 & 10,00 & 10,06 & 10,15 & 10,08 & 19,89 & 19,89 & 19,89 & 3867,7 & 541,0 \\
\hline & \multicolumn{11}{|c|}{ CP COM 28 DIAS (20-3-2009-16:00) } \\
\hline \multirow{3}{*}{$\begin{array}{l}\text { TRAÇO } \\
\text { FORTE }\end{array}$} & 1 & 9,98 & 10,00 & 9,93 & 10,05 & 9,99 & 20,00 & 20,05 & 20,03 & 3947,6 & 784,4 \\
\hline & 2 & 10,04 & 10,08 & 10,10 & 10,09 & 10,08 & 19,83 & 19,84 & 19,84 & 3945,9 & 779,1 \\
\hline & 3 & 10,04 & 10,00 & 10,08 & 9,93 & 10,01 & 19,91 & 19,93 & 19,92 & 3928,9 & 756,9 \\
\hline \multirow{3}{*}{$\begin{array}{l}\text { TRAÇO } \\
\text { MÉDIO }\end{array}$} & 4 & 10,00 & 10,10 & 10,03 & 10,00 & 10,03 & 19,96 & 20,03 & 20,00 & 3916,0 & 693,5 \\
\hline & 5 & 10,07 & 10,00 & 10,04 & 10,02 & 10,03 & 20,10 & 20,08 & 20,09 & 3937,9 & 705,8 \\
\hline & 6 & 10,05 & 10,06 & 10,02 & 10,08 & 10,05 & 19,90 & 19,90 & 19,90 & 3890,8 & 699,3 \\
\hline \multirow{3}{*}{$\begin{array}{l}\text { TRAÇO } \\
\text { FRACO }\end{array}$} & 7 & 10,03 & 10,12 & 10,07 & 10,09 & 10,08 & 19,83 & 19,78 & 19,81 & 3852,1 & 615,2 \\
\hline & 8 & 10,00 & 10,00 & 10,05 & 9,98 & 10,01 & 19,96 & 19,93 & 19,95 & 3830,4 & 615,7 \\
\hline & 9 & 10,05 & 10,03 & 10,00 & 10,05 & 10,03 & 19,97 & 20,00 & 19,99 & 3901,2 & 632,8 \\
\hline
\end{tabular}




\section{Resumo dos resultados anteriores}

\begin{tabular}{|c|c|c|c|c|c|c|c|c|c|c|}
\hline \multicolumn{11}{|c|}{ ESTUDO DE DOSAGEM PARA CONCRETO COM SUPERPLASTIFICANTE E SA - CONCRETAGEM EM 20-2-09 } \\
\hline \multicolumn{11}{|c|}{ RESUMO DO ENSAIO À COMPRESSÃO SIMPLES } \\
\hline \multirow[t]{2}{*}{ TRAÇOS } & CP & $\begin{array}{c}\text { diâmetro } \\
\text { (cm) }\end{array}$ & $\begin{array}{c}\text { altura } \\
(\mathrm{cm})\end{array}$ & $\begin{array}{c}\text { seção } \\
\text { CP } \\
(\mathrm{cm} 2)\end{array}$ & $\begin{array}{l}\text { Força } \\
\text { ruptura } \\
\text { (KN) }\end{array}$ & $\begin{array}{c}\text { tensão } \\
\text { ruptura } \\
\text { (MPa) }\end{array}$ & $\begin{array}{l}\text { tensão } \\
\text { média } \\
(\mathrm{MPa})\end{array}$ & $\begin{array}{c}\text { massa } \\
(\mathrm{kg})\end{array}$ & $\begin{array}{c}\text { massa } \\
\text { unitária } \\
\text { (kg/m3) }\end{array}$ & $\begin{array}{c}\text { massa } \\
\text { média } \\
(\mathrm{kg} / \mathrm{m} 3)\end{array}$ \\
\hline & \multicolumn{10}{|c|}{$7 \mathrm{~d}$} \\
\hline \multirow{3}{*}{$\begin{array}{l}\text { TRAÇO } \\
\text { FORTE }\end{array}$} & 1 & 10,02 & 19,91 & 78,8 & 632,4 & 80,3 & \multirow{3}{*}{82,3} & 3,91 & 2492 & \multirow{3}{*}{2495} \\
\hline & 2 & 10,05 & 19,85 & 79,2 & 656,0 & 82,8 & & 3,92 & 2492 & \\
\hline & 3 & 9,99 & 20,06 & 78,3 & 656,8 & 83,9 & & 3,93 & 2502 & \\
\hline \multirow{3}{*}{$\begin{array}{l}\text { TRAÇO } \\
\text { MÉDIO }\end{array}$} & 4 & 10,09 & 20,00 & 79,9 & 584,6 & 73,1 & \multirow{3}{*}{72,9} & 3,94 & 2465 & \multirow{3}{*}{2463} \\
\hline & 5 & 10,06 & 19,88 & 79,5 & 571,9 & 71,9 & & 3,90 & 2465 & \\
\hline & 6 & 10,04 & 19,96 & 79,1 & 582,2 & 73,6 & & 3,88 & 2458 & \\
\hline \multirow{3}{*}{$\begin{array}{l}\text { TRAÇO } \\
\text { FRACO }\end{array}$} & 7 & 10,08 & 19,94 & 79,8 & 479,9 & 60,1 & \multirow{3}{*}{60,3} & 3,88 & 2438 & \multirow{3}{*}{2443} \\
\hline & 8 & 10,03 & 20,09 & 79,1 & 476,4 & 60,3 & & 3,88 & 2446 & \\
\hline & 9 & 10,07 & 19,91 & 79,6 & 482,1 & 60,5 & & 3,88 & 2444 & \\
\hline & \multicolumn{10}{|c|}{$14 \mathrm{~d}$} \\
\hline \multirow{3}{*}{$\begin{array}{l}\text { TRAÇO } \\
\text { FORTE }\end{array}$} & 1 & 10,06 & 19,90 & 79,4 & 716,9 & 90,3 & \multirow{3}{*}{90,2} & 3,95 & 2501 & \multirow{3}{*}{2502} \\
\hline & 2 & 10,04 & 20,21 & 79,2 & 701,2 & 88,5 & & 4,01 & 2504 & \\
\hline & 3 & 10,09 & 19,98 & 79,9 & 733,8 & 91,8 & & 3,99 & 2501 & \\
\hline \multirow{3}{*}{$\begin{array}{l}\text { TRAÇO } \\
\text { MÉDIO }\end{array}$} & 4 & 10,10 & 19,95 & 80,1 & 656,6 & 82,0 & \multirow{3}{*}{82,3} & 3,93 & 2458 & \multirow{3}{*}{2464} \\
\hline & 5 & 10,08 & 19,97 & 79,8 & 645,6 & 80,9 & & 3,92 & 2459 & \\
\hline & 6 & 10,06 & 19,95 & 79,4 & 666,4 & 83,9 & & 3,92 & 2474 & \\
\hline \multirow{3}{*}{$\begin{array}{l}\text { TRAÇO } \\
\text { FRACO }\end{array}$} & 7 & 10,02 & 20,00 & 78,9 & 530,3 & 67,3 & \multirow{3}{*}{68,3} & 3,85 & 2441 & \multirow{3}{*}{2443} \\
\hline & 8 & 10,05 & 19,89 & 79,3 & 553,3 & 69,7 & & 3,87 & 2451 & \\
\hline & 9 & 10,08 & 19,89 & 79,8 & 541,0 & 67,8 & & 3,87 & 2437 & \\
\hline & \multicolumn{10}{|c|}{$28 d$} \\
\hline \multirow{3}{*}{$\begin{array}{l}\text { TRAÇO } \\
\text { FORTE }\end{array}$} & 1 & 9,99 & 20,03 & 78,4 & 784,4 & 100,1 & \multirow{3}{*}{98,0} & 3,95 & 2515 & \multirow{3}{*}{2505} \\
\hline & 2 & 10,08 & 19,84 & 79,8 & 779,1 & 97,7 & & 3,95 & 2494 & \\
\hline & 3 & 10,01 & 19,92 & 78,7 & 756,9 & 96,1 & & 3,93 & 2505 & \\
\hline & 4 & 10,03 & 20,00 & 79,1 & 693,5 & 87,7 & & 3,92 & 2477 & \\
\hline I KAÇU & 5 & 10,03 & 20,09 & 79,1 & 705,8 & 89,3 & 88,4 & 3,94 & 2480 & 2474 \\
\hline & 6 & 10,05 & 19,90 & 79,4 & 699,3 & 88,1 & & 3,89 & 2463 & \\
\hline & 7 & 10,08 & 19,81 & 79,8 & 615,2 & 77,1 & & 3,85 & 2439 & \\
\hline TRAÇO & 8 & 10,01 & 19,95 & 78,7 & 615,7 & 78,3 & 78,5 & 3,83 & 2442 & 2450 \\
\hline FRACU & 9 & 10,03 & 19,99 & 79,1 & 632,8 & 80,0 & & 3,90 & 2469 & \\
\hline
\end{tabular}




\section{RESUMO DOS VALORES MÉDIOS DAS RESISTÊNCIAS À COMPRESSÃO DO CONCRETO A SER EMPREGADO NA ELABORAÇÃO DAS CURVAS DE DOSAGEM}

\section{Concreto sem aditivos}

\begin{tabular}{|c|c|c|c|c|c|c|c|c|}
\hline \multirow{2}{*}{ traço } & \multirow{2}{*}{$a / c$} & \multirow{2}{*}{$\begin{array}{c}\text { cimento } \\
(\mathrm{kg})\end{array}$} & \multirow{2}{*}{$\begin{array}{l}\text { traço } \\
\text { agreg. }\end{array}$} & \multirow{2}{*}{$\begin{array}{l}\text { teor de } \\
\text { argam. }\end{array}$} & $3 \mathrm{~d}$ & $7 d$ & $14 \mathrm{~d}$ & $28 \mathrm{~d}$ \\
\hline & & & & & $f_{c_{c} \text { médio }}$ & $f_{c_{-} \text {médio }}$ & $f_{c_{c \_ \text {médio }}}$ & $f_{c_{c} \text { médio }}$ \\
\hline forte & 0,45 & $\overline{4478,99}$ & $1: 3,5$ & $\overline{51 \%}$ & 38,71 & 446,54 & 499,90 & 254,58 \\
\hline médio & 0,56 & 361,94 & $1: 5,0$ & $51 \%$ & 31,10 & 34,89 & 37,20 & 41,36 \\
\hline fraco & 0,71 & 287,52 & $1: 6,5$ & $51 \%$ & 16,28 & 19,97 & 21,35 & 23,95 \\
\hline
\end{tabular}

\section{Concreto com aditivo superplatificante}

\begin{tabular}{|l|c|c|c|c|c|c|c|c|}
\hline \multirow{2}{*}{ traço } & \multirow{2}{*}{ a/c } & cimento & traço & teor de & \% & $\mathbf{8} \mathbf{d}$ & $\mathbf{1 4} \mathbf{d}$ & $\mathbf{2 8} \mathbf{d}$ \\
\cline { 7 - 9 } & & $\mathbf{k g})$ & agreg. & argam. & superpl. & $\mathbf{f}_{\text {c_médio }}$ & $\mathbf{f}_{\mathbf{c}_{\text {__médio }}}$ & $\mathbf{f}_{\text {c_médio }}$ \\
\hline \hline forte & 0,24 & 606,8 & $1: 3,0$ & $53 \%$ & $1 \%$ & 80,42 & 87,93 & 96,82 \\
\hline médio & 0,36 & 431,7 & $1: 4,5$ & $53 \%$ & $1 \%$ & 68,91 & 70,66 & 76,58 \\
\hline fraco & 0,5 & 332,7 & $1: 6,0$ & $53 \%$ & $1 \%$ & 48,24 & 53,61 & 57,42 \\
\hline
\end{tabular}

Concreto com aditivo superplatificante e sílica ativa

\begin{tabular}{|c|c|c|c|c|c|c|c|c|c|}
\hline \multirow{2}{*}{ traço } & \multirow{2}{*}{$a / c$} & \multirow{2}{*}{$\begin{array}{c}\text { cimento } \\
\text { (kg) }\end{array}$} & \multirow{2}{*}{$\begin{array}{l}\text { traço } \\
\text { agreg. }\end{array}$} & \multirow{2}{*}{$\begin{array}{l}\text { teor de } \\
\text { argam. }\end{array}$} & \multirow{2}{*}{$\begin{array}{c}\% \\
\text { superpl. }\end{array}$} & \multirow{2}{*}{$\begin{array}{c}\text { \% SA em } \\
\text { subst. }\end{array}$} & \multirow{2}{*}{$\frac{7 \mathrm{~d}}{\mathrm{f}_{\mathrm{c} \_ \text {médio }}}$} & \multirow{2}{*}{$\frac{14 \mathrm{~d}}{\mathrm{f}_{\mathrm{c} \_ \text {médio }}}$} & \multirow{2}{*}{$\frac{28 \mathrm{~d}}{\mathrm{f}_{\mathrm{c} \_ \text {médio }}}$} \\
\hline & & & & & & & & & \\
\hline forte & & 549,5 & $1: 3,0$ & $53 \%$ & $0,8 \%$ & $10 \%$ & & 90,21 & 97,96 \\
\hline médio & & & & & & & 8 & 82, & 88,38 \\
\hline fraco & 0,41 & 360,6 & $1: 5,0$ & $53 \%$ & $0,8 \%$ & $10 \%$ & 60,30 & 68,26 & 78,48 \\
\hline
\end{tabular}


ANEXO B - RESULTADOS DA RESISTÊNCIA À COMPRESSÃO DO CONCRETO PARA OS PILARES (DOS TRAÇOS FINAIS OBTIDOS DAS CURVAS DE DOSAGEM) PROPRIEDADES DO CONCRETO FRESCO

Concreto sem aditivos $1^{\mathrm{a}}$ concretagem (pilares esbeltos e pilares curtos)

\begin{tabular}{|c|c|c|c|c|c|c|c|}
\hline \multicolumn{7}{|c|}{ RESUMO DE DADOS E RESULTADOS DO CONCRETO FRESCO } \\
\hline \hline concreto & $\begin{array}{c}\text { Slump } \\
(\mathbf{m m})\end{array}$ & $\begin{array}{c}\text { massa } \\
(\mathbf{k g})\end{array}$ & $\begin{array}{c}\text { volume } \\
\text { balde } \\
(\mathbf{I})\end{array}$ & $\begin{array}{c}\text { massa } \\
\text { unitária } \\
(\mathbf{k g} / \mathbf{m} 3)\end{array}$ & $\begin{array}{c}\text { horário } \\
\text { concretagem }\end{array}$ & $\begin{array}{c}\text { temperatura } \\
\text { ambiente } \\
{ }^{\circ} \mathbf{C}\end{array}$ & $\begin{array}{c}\text { umidade } \\
\text { ambiente } \\
\%\end{array}$ \\
\hline $30 \mathrm{MPa}$ & $100 \pm 5$ & 34,85 & 14,4 & 2420 & $09: 30$ & & \\
\hline
\end{tabular}

Concreto sem aditivos $2^{\text {a }}$ concretagem (pilares esbeltos)

\begin{tabular}{|c|c|c|c|c|c|c|c|}
\hline \multicolumn{7}{|c|}{ RESUMO DE DADOS E RESULTADOS DO CONCRETO FRESCO } \\
\hline \hline concreto & $\begin{array}{c}\text { Slump } \\
(\mathbf{m m})\end{array}$ & $\begin{array}{c}\text { massa } \\
(\mathbf{k g})\end{array}$ & $\begin{array}{c}\text { volume } \\
\text { balde } \\
(\mathbf{l})\end{array}$ & $\begin{array}{c}\text { massa } \\
\text { unitária } \\
(\mathrm{kg} / \mathrm{m} 3)\end{array}$ & $\begin{array}{c}\text { horário } \\
\text { concretagem }\end{array}$ & $\begin{array}{c}\text { temperatura } \\
\text { ambiente } \\
{ }^{\circ} \mathrm{C}\end{array}$ & $\begin{array}{c}\text { umidade } \\
\text { ambiente } \\
\%\end{array}$ \\
\hline $30 \mathrm{MPa}$ & $130 \pm 15$ & 34,8 & 14,4 & 2417 & $08: 45$ & & \\
\hline
\end{tabular}

Concreto com aditivo superplastificante $1^{\text {a }}$ concretagem (pilares esbeltos e pilares curtos)

\begin{tabular}{|c|c|c|c|c|c|c|c|}
\hline \multicolumn{7}{|c|}{ RESUMO DE DADOS E RESULTADOS DO CONCRETO FRESCO } \\
\hline \hline concreto & $\begin{array}{c}\text { Slump } \\
(\mathrm{mm})\end{array}$ & $\begin{array}{c}\text { massa } \\
(\mathbf{k g})\end{array}$ & $\begin{array}{c}\text { volume } \\
\text { balde } \\
(\mathbf{l})\end{array}$ & $\begin{array}{c}\text { massa } \\
\text { unitária } \\
(\mathbf{k g} / \mathrm{m3})\end{array}$ & $\begin{array}{c}\text { horário } \\
\text { concretagem }\end{array}$ & $\begin{array}{c}\text { temperatura } \\
\text { ambiente } \\
{ }^{\circ} \mathrm{C}\end{array}$ & $\begin{array}{c}\text { umidade } \\
\text { ambiente } \\
\%\end{array}$ \\
\hline $60 \mathrm{MPa}$ & $205 \pm 5$ & 35,1 & 14,4 & 2438 & $09: 30$ & 25 & 75 \\
\hline
\end{tabular}

Concreto com aditivo superplastificante $2^{\text {a }}$ concretagem (pilares esbeltos)

\begin{tabular}{|c|c|c|c|c|c|c|c|}
\hline \multicolumn{7}{|c|}{ RESUMO DE DADOS E RESULTADOS DO CONCRETO FRESCO } \\
\hline \hline concreto & $\begin{array}{c}\text { Slump } \\
(\mathbf{m m})\end{array}$ & $\begin{array}{c}\text { massa } \\
(\mathbf{k g})\end{array}$ & $\begin{array}{c}\text { volume } \\
\text { balde } \\
(\mathbf{I})\end{array}$ & $\begin{array}{c}\text { massa } \\
\text { unitária } \\
(\mathbf{k g} / \mathbf{m 3})\end{array}$ & $\begin{array}{c}\text { horário } \\
\text { concretagem }\end{array}$ & $\begin{array}{c}\text { temperatura } \\
\text { ambiente } \\
{ }^{\circ} \mathrm{C}\end{array}$ & $\begin{array}{c}\text { umidade } \\
\text { ambiente } \\
\%\end{array}$ \\
\hline $60 \mathrm{MPa}$ & $235 \pm 25$ & 35,05 & 14,4 & 2434 & $09: 30$ & 23 & 75 \\
\hline
\end{tabular}


Concreto com aditivo superplastificante e sílica ativa $1^{\text {a }}$ concretagem (pilares esbeltos e pilares curtos)

\begin{tabular}{|c|c|c|c|c|c|c|c|}
\hline \multicolumn{7}{|c|}{ RESUMO DE DADOS E RESULTADOS DO CONCRETO FRESCO } \\
\hline \hline concreto & $\begin{array}{c}\text { Slump } \\
(\mathbf{m m})\end{array}$ & $\begin{array}{c}\text { massa } \\
(\mathbf{k g})\end{array}$ & $\begin{array}{c}\text { volume } \\
\text { balde } \\
(\mathbf{l})\end{array}$ & $\begin{array}{c}\text { massa } \\
\text { unitária } \\
(\mathbf{k g} / \mathbf{m} 3)\end{array}$ & $\begin{array}{c}\text { horário } \\
\text { concretagem }\end{array}$ & $\begin{array}{c}\text { temperatura } \\
\text { ambiente } \\
{ }^{\circ} \mathbf{C}\end{array}$ & $\begin{array}{c}\text { umidade } \\
\text { ambiente } \\
\%\end{array}$ \\
\hline $100 \mathrm{MPa}$ & $195 \pm 15$ & 35,7 & 14,4 & 2479 & $09: 30$ & 28 & 65 \\
\hline
\end{tabular}

Concreto com aditivo superplastificante e sílica ativa $2^{\text {a }}$ concretagem (pilares esbeltos)

\begin{tabular}{|c|c|c|c|c|c|c|c|}
\hline \multicolumn{7}{|c|}{ RESUMO DE DADOS E RESULTADOS DO CONCRETO FRESCO } \\
\hline \hline concreto & $\begin{array}{c}\text { Slump } \\
(\mathbf{m m})\end{array}$ & $\begin{array}{c}\text { massa } \\
(\mathbf{k g})\end{array}$ & $\begin{array}{c}\text { volume } \\
\text { balde } \\
(\mathbf{l})\end{array}$ & $\begin{array}{c}\text { massa } \\
\text { unitária } \\
(\mathrm{kg} / \mathrm{m3})\end{array}$ & $\begin{array}{c}\text { horário } \\
\text { concretagem }\end{array}$ & $\begin{array}{c}\text { temperatura } \\
\text { ambiente } \\
{ }^{\circ} \mathrm{C}\end{array}$ & $\begin{array}{c}\text { umidade } \\
\text { ambiente } \\
\%\end{array}$ \\
\hline $100 \mathrm{MPa}$ & $215 \pm 5$ & 35,45 & 14,4 & 2462 & $09: 30$ & 27 & 75 \\
\hline
\end{tabular}




\section{RESULTADOS DOS ENSAIOS À COMPRESSÃO DOS CORPOS-DE- PROVA PARA CONCRETO SEM ADITIVOS}

\section{$1^{\text {a }}$ concretagem (pilares esbeltos e pilares curtos)}

\begin{tabular}{|c|c|c|c|c|c|c|c|c|c|c|}
\hline \multicolumn{11}{|c|}{ CONCRETO DE 30 MPa - CONCRETAGEM EM 9-3 } \\
\hline \multicolumn{11}{|c|}{ ENSAIO À COMPRESSÃO SIMPLES - MEDIDAS } \\
\hline $\mathbf{C P}$ & D1 $(\mathrm{cm})$ & $\mathrm{D} 2(\mathrm{~cm})$ & D3 (cm) & D4 (cm) & $\mathrm{DM}(\mathrm{cm})$ & h1 (cm) & $\mathrm{h} 2(\mathrm{~cm})$ & $\mathrm{hm}(\mathrm{cm})$ & massa (g) & F ruptura(KN) \\
\hline \multicolumn{11}{|c|}{ CP COM 3 DIAS (12-3-09-16:00) } \\
\hline 1 & 10,00 & 10,00 & 10,00 & 10,00 & 10,00 & 20,00 & 20,00 & 20,00 & & 209,1 \\
\hline 2 & 10,00 & 10,00 & 10,00 & 10,00 & 10,00 & 20,00 & 20,00 & 20,00 & & 211,3 \\
\hline \multicolumn{11}{|c|}{ CP COM 9 DIAS (18-3-15:30) } \\
\hline 1 & 10,09 & 10,04 & 10,11 & 9,99 & 10,06 & 19,92 & 19,92 & 19,92 & 3882,6 & 261,9 \\
\hline 2 & 10,05 & 10,08 & 10,05 & 10,09 & 10,07 & 19,79 & 19,70 & 19,75 & 3868,8 & 250,1 \\
\hline \multicolumn{11}{|c|}{ CP COM 15 DIAS (24-3-10:45) } \\
\hline 1 & 9,97 & 10,11 & 10,00 & 10,05 & 10,03 & 19,89 & 19,96 & 19,93 & 3841,9 & 268,1 \\
\hline 2 & 10,06 & 9,94 & 10,06 & 10,00 & 10,02 & 19,73 & 19,73 & 19,73 & 3824,7 & 264,9 \\
\hline \multicolumn{11}{|c|}{ CP COM 30 DIAS (8-4-10:30) - ME nos CP 3 e 4} \\
\hline 1 & 10,00 & 10,07 & 10,06 & 10,00 & 10,03 & 19,77 & 19,70 & 19,74 & 3800,7 & 289,9 \\
\hline 2 & 10,03 & 10,12 & 10,04 & 10,02 & 10,05 & 19,77 & 19,77 & 19,77 & 3861,5 & 308,3 \\
\hline 3 & 10,10 & 10,00 & 10,04 & 10,00 & 10,04 & 19,78 & 19,78 & 19,78 & 3825,6 & 275,0 \\
\hline 4 & 9,95 & 10,08 & 9,90 & 10,10 & 10,01 & 19,85 & 19,80 & 19,83 & 3848,5 & 263,0 \\
\hline \multicolumn{11}{|c|}{ CP COM 30 DIAS -curados junto aos pilares (8-4-09-10:30) - ME no CP3 } \\
\hline 1 & 9,96 & 10,00 & 9,94 & 10,00 & \begin{tabular}{|l|}
9,98 \\
\end{tabular} & 19,78 & 19,82 & 19,80 & 3759,8 & 267,9 \\
\hline 2 & 10,00 & 10,02 & 10,00 & 10,04 & 10,02 & 19,83 & 19,84 & 19,84 & 3794,7 & 263,3 \\
\hline 3 & 10,00 & 10,14 & 10,00 & 10,10 & 10,06 & 19,83 & 19,83 & 19,83 & 3819,9 & 281,0 \\
\hline
\end{tabular}

\section{$2^{\mathrm{a}}$ concretagem (pilares esbeltos)}

\begin{tabular}{|c|c|c|c|c|c|c|c|c|c|c|}
\hline \multicolumn{11}{|c|}{ CONCRETO DE 30 MPa - CONCRETAGEM EM 12-3 } \\
\hline \multicolumn{11}{|c|}{ ENSAIO À COMPRESSÃO SIMPLES - MEDIDAS } \\
\hline $\mathbf{C P}$ & D1 (cm) & $\mathrm{D} 2(\mathrm{~cm})$ & D3 (cm) & D4 (cm) & $\mathrm{DM}(\mathrm{cm})$ & $\mathrm{h} 1(\mathrm{~cm})$ & $\mathrm{h} 2(\mathrm{~cm})$ & $\mathrm{hm}(\mathrm{cm})$ & massa $(\mathrm{g})$ & F ruptura(KN) \\
\hline \multicolumn{11}{|c|}{ CP COM 4 DIAS (16-3-09-14:30)- até esta data ficarom nas formas } \\
\hline 1 & 10,00 & 10,00 & 10,00 & 10,00 & 10,00 & 20,00 & 20,00 & 20,00 & & 175,2 \\
\hline 2 & 10,00 & 10,00 & 10,00 & 10,00 & 10,00 & 20,00 & 20,00 & 20,00 & & 173,4 \\
\hline \multicolumn{11}{|c|}{ CP COM 7 DIAS (19-3-09-15:30) } \\
\hline 1 & 10,10 & 10,05 & 10,13 & 10,05 & 10,08 & 19,89 & 19,81 & 19,85 & 3857,7 & 190,4 \\
\hline 2 & 10,04 & 10,05 & 10,02 & 10,02 & 10,03 & 19,94 & 19,90 & 19,92 & 3822,7 & 198,7 \\
\hline \multicolumn{11}{|c|}{ CP COM 14 DIAS (26-3-09-16:15) } \\
\hline 1 & 10,09 & 10,05 & 10,10 & 10,05 & 10,07 & 19,79 & 19,77 & 19,78 & 3824,7 & 199,7 \\
\hline 2 & 10,01 & 10,00 & 10,12 & 10,02 & 10,04 & 19,87 & 19,81 & 19,84 & 3830,9 & 213,6 \\
\hline \multicolumn{11}{|c|}{ CP COM 36 DIAS (17-4-15:00) - ME no CP3 } \\
\hline 1 & 9,96 & 10,07 & 9,99 & 10,06 & 10,02 & 19,70 & 19,70 & 19,70 & 3810,8 & 221,4 \\
\hline 2 & 10,05 & 10,00 & 10,04 & 10,04 & 10,03 & 19,98 & 19,99 & 19,99 & 3890,0 & 234,1 \\
\hline 3 & 10,12 & 10,07 & 10,09 & 10,09 & 10,09 & 19,80 & 19,80 & 19,80 & 3856,6 & 242,0 \\
\hline \multicolumn{11}{|c|}{ CP COM 36 DIAS -curados junto aos pilares (17-4-15:00) } \\
\hline 1 & 9,99 & 10,00 & 9,95 & 10,00 & 9,99 & 19,90 & 19,94 & 19,92 & 3738,3 & 244,2 \\
\hline 2 & 10,00 & 10,14 & 10,00 & 10,00 & 10,04 & 19,75 & 19,85 & 19,80 & 3781,7 & 230,0 \\
\hline
\end{tabular}


RESULTADO DOS ENSAIOS À COMPRESSÃO DOS CORPOS-DEPROVA PARA CONCRETO COM ADITIVO SUPERPLASTIFICANTE

\section{$1^{\text {a }}$ concretagem (pilares esbeltos e pilares curtos)}

\begin{tabular}{|c|c|c|c|c|c|c|c|c|c|c|}
\hline \multicolumn{11}{|c|}{ CONCRETO DE $60 \mathrm{MPa}$ - CONCRETAGEM EM 23-3 } \\
\hline \multicolumn{11}{|c|}{ ENSAIO À COMPRESSÃO SIMPLES - MEDIDAS } \\
\hline $\mathbf{C P}$ & D1 (cm) & $\mathrm{D} 2(\mathrm{~cm})$ & $\mathrm{D} 3(\mathrm{~cm})$ & $\mathrm{D} 4(\mathrm{~cm})$ & $\mathrm{DM}(\mathrm{cm})$ & h1 (cm) & h2 (cm) & $\mathrm{hm}(\mathrm{cm})$ & massa (g) & F ruptura(KN) \\
\hline \multicolumn{11}{|c|}{ CP COM 14 DIAS (06-4-09-16:00) } \\
\hline 1 & 10,01 & 10,01 & 10,00 & 10,04 & 10,02 & 19,81 & 19,78 & 19,80 & 3874,0 & 431,3 \\
\hline 2 & 10,04 & 10,10 & 10,04 & 10,07 & 10,06 & 19,76 & 19,76 & 19,76 & 3876,8 & 419,3 \\
\hline \multicolumn{11}{|c|}{ CP COM 25 DIAS (17-4-15:00) - ME } \\
\hline 1 & 10,03 & 10,00 & 10,04 & 10,00 & 10,02 & 19,95 & 19,95 & 19,95 & 3912,0 & 443,0 \\
\hline 2 & 10,03 & 10,03 & 9,97 & 10,04 & \begin{tabular}{|l|}
10,02 \\
\end{tabular} & 19,75 & 19,75 & 19,75 & 3861,9 & 447,0 \\
\hline \multicolumn{11}{|c|}{ CP COM 36 DIAS (28-4) - ME } \\
\hline 1 & 10,02 & 10,13 & 10,05 & 10,03 & 10,06 & 19,91 & 19,90 & 19,91 & 3918,0 & 518,4 \\
\hline 2 & 10,22 & 10,20 & 10,15 & 10,05 & 10,16 & 19,81 & 19,80 & 19,81 & 3915,5 & 502,9 \\
\hline 3 & 10,08 & 10,11 & 10,03 & 10,13 & 10,09 & 19,90 & 19,92 & 19,91 & 3897,0 & 480,9 \\
\hline \multicolumn{11}{|c|}{ CP COM 32 DIAS - cura junto aos pilares (24-4-16:00) - ME } \\
\hline 1 & 10,00 & 10,03 & 10,04 & 10,03 & 10,03 & 19,65 & 19,65 & 19,65 & 3836,0 & 507,3 \\
\hline 2 & 10,08 & 10,04 & 10,08 & 10,06 & 10,07 & 19,76 & 19,78 & 19,77 & 3728,5 & 504,7 \\
\hline
\end{tabular}

\section{$2^{\text {a }}$ concretagem (pilares esbeltos)}

\begin{tabular}{|c|c|c|c|c|c|c|c|c|c|c|}
\hline \multicolumn{11}{|c|}{ CONCRETO DE 60 MPa - CONCRETAGEM EM 24-3 } \\
\hline \multicolumn{11}{|c|}{ ENSAIO À COMPRESSÃO SIMPLES - MEDIDAS } \\
\hline $\mathbf{C P}$ & $\mathrm{D} 1(\mathrm{~cm})$ & $\mathrm{D} 2(\mathrm{~cm})$ & D3 (cm) & D4 (cm) & $\mathrm{DM}(\mathrm{cm})$ & $\mathrm{h} 1(\mathrm{~cm})$ & h2 (cm) & $\mathrm{hm}(\mathrm{cm})$ & massa (g) & F ruptura(KN) \\
\hline \multicolumn{11}{|c|}{ CP COM 9 DIAS (2-4-09-16:00) } \\
\hline 1 & 10,06 & 10,00 & 10,07 & 10,01 & 10,04 & 19,77 & 19,74 & 19,76 & 3748,0 & 370,3 \\
\hline 2 & 10,06 & 10,00 & 10,02 & 10,01 & 10,02 & 19,89 & 19,90 & 19,90 & 3899,3 & 349,7 \\
\hline \multicolumn{11}{|c|}{ CP COM 15 DIAS (8-4-09-10:45) } \\
\hline 1 & 9,95 & 10,10 & 10,05 & 10,10 & 10,05 & 19,72 & 19,70 & 19,71 & 3869,3 & 382,1 \\
\hline 2 & 10,08 & 9,98 & 10,09 & 10,05 & 10,05 & 19,83 & 19,80 & 19,82 & 3757,4 & 386,2 \\
\hline \multicolumn{11}{|c|}{ CP COM 24 DIAS (17-4-09-15:00) } \\
\hline 1 & 10,02 & 10,09 & 10,10 & 10,03 & 10,06 & 19,82 & 19,85 & 19,84 & 3935,8 & 417,0 \\
\hline 2 & 10,10 & 9,91 & 10,11 & 9,97 & 10,02 & 19,70 & 19,72 & 19,71 & 3737,5 & 404,3 \\
\hline \multicolumn{11}{|c|}{ CP COM 34 DIAS (27-4-16:00) - ME no CP1 } \\
\hline 1 & 10,07 & 10,02 & 10,08 & 10,00 & 10,04 & 19,77 & 19,80 & 19,79 & & 426,6 \\
\hline 2 & 10,07 & 10,00 & 10,05 & 10,03 & 10,04 & 19,75 & 19,80 & 19,78 & & 455,3 \\
\hline \multicolumn{11}{|c|}{ CP COM 31 DIAS - cura junto aos pilares (24-4-15:00) - ME } \\
\hline 1 & 9,96 & 10,10 & 9,83 & 10,10 & 10,00 & 19,79 & 19,80 & 19,80 & 3686,4 & 418,8 \\
\hline 2 & 10,06 & 10,10 & 10,00 & 10,10 & 10,07 & 19,72 & 19,65 & 19,69 & 3700,5 & 479,3 \\
\hline
\end{tabular}


RESULTADO DOS ENSAIOS À COMPRESSÃO DOS CORPOS-DE-

PROVA PARA CONCRETO COM ADITIVO SUPERPLASTIFICANTE

E SÍLICA ATIVA

$1^{\text {a }}$ concretagem (pilares esbeltos e pilares curtos)

\begin{tabular}{|c|c|c|c|c|c|c|c|c|c|c|}
\hline \multicolumn{11}{|c|}{ CONCRETO DE $100 \mathrm{MPa}$ - CONCRETAGEM EM 27-3 } \\
\hline \multicolumn{11}{|c|}{ ENSAIO À COMPRESSÃO SIMPLES - MEDIDAS } \\
\hline CP & D1 $(\mathrm{cm})$ & D2 (cm) & D3 (cm) & D4 (cm) & DM (cm) & h1 (cm) & h2 (cm) & $\mathrm{hm}(\mathrm{cm})$ & massa (g) & F ruptura(KN) \\
\hline \multicolumn{11}{|c|}{ CP COM 10 DIAS (6-4-09-16:00) } \\
\hline 1 & 9,95 & 10,00 & 9,94 & 10,01 & 9,98 & 19,90 & 19,94 & 19,92 & 3889,7 & 711,3 \\
\hline 2 & 10,07 & 10,00 & 10,07 & 10,03 & 10,04 & 20,00 & 19,99 & 20,00 & 3959,8 & 748,0 \\
\hline \multicolumn{11}{|c|}{ CP COM 27 DIAS (23-4-16:00) - ME } \\
\hline 1 & 10,07 & 10,00 & 10,12 & 10,12 & 10,08 & 19,97 & 19,92 & 19,95 & 3943,5 & 823,5 \\
\hline 2 & 10,10 & 10,00 & 10,08 & 10,02 & 10,05 & 19,84 & 19,84 & 19,84 & 3931,6 & 828,6 \\
\hline 3 & 10,06 & 10,09 & 10,03 & 10,04 & 10,06 & 19,80 & 19,80 & 19,80 & 3918,7 & 839,7 \\
\hline \multicolumn{11}{|c|}{ CP COM 33 DIAS (29-4) - ME } \\
\hline 1 & 10,08 & 10,05 & 10,05 & 10,04 & 10,06 & 19,97 & 19,92 & 19,95 & 3953,0 & 813,1 \\
\hline 2 & 10,05 & 10,08 & 10,05 & 10,08 & 10,07 & 19,80 & 19,82 & 19,81 & 3935,0 & 837,1 \\
\hline \multicolumn{11}{|c|}{ CP COM 28 DIAS - cura junto aos pilares (24-4)-ME } \\
\hline 1 & 10,16 & 9,90 & 10,13 & 9,93 & 10,03 & 19,87 & 19,89 & 19,88 & 3919,5 & 809,7 \\
\hline 2 & 10,05 & 10,10 & 10,09 & 10,06 & 10,08 & 19,82 & 19,84 & 19,83 & 3933,8 & 764,1 \\
\hline
\end{tabular}

\section{$2^{\mathrm{a}}$ concretagem (pilares esbeltos)}

CONCRETO DE $100 \mathrm{MPa}$ - CONCRETAGEM EM 31-3

ENSAIO À COMPRESSÃO SIMPLES - MEDIDAS

\begin{tabular}{|c|c|c|c|c|c|c|c|c|c|c|}
\hline CP & D1 (cm) & D2 (cm) & D3 (cm) & D4 (cm) & $\mathrm{DM}(\mathrm{cm})$ & h1 (cm) & $\mathrm{h} 2(\mathrm{~cm})$ & $\mathrm{hm}(\mathrm{cm})$ & massa (g) & F ruptura(KN) \\
\hline \multicolumn{11}{|c|}{ CP COM 8 DIAS (8-4-09-10:30) } \\
\hline 1 & 10,04 & 10,04 & 10,04 & 10,10 & 10,06 & 19,88 & 19,86 & 19,87 & 3899,1 & 647,7 \\
\hline 2 & 10,00 & 10,00 & 10,04 & 10,00 & 10,01 & 20,10 & 20,10 & 20,10 & 3962,9 & 682,6 \\
\hline \multicolumn{11}{|c|}{ CP COM 17 DIAS (17-4-09-15:00) } \\
\hline 1 & 10,09 & 10,06 & 10,08 & 9,99 & 10,06 & 19,90 & 19,98 & 19,94 & 3953,0 & 787,9 \\
\hline 2 & 10,01 & 9,93 & 10,00 & 10,00 & 9,99 & 19,94 & 20,00 & 19,97 & 3927,8 & 771,6 \\
\hline \multicolumn{11}{|c|}{ CP COM 24 DIAS (24-4)-ME } \\
\hline 1 & 10,02 & 10,00 & 10,01 & 10,02 & 10,01 & 19,92 & 19,90 & 19,91 & 3907,5 & 819,7 \\
\hline 2 & 10,03 & 10,00 & 10,05 & 10,03 & 10,03 & 20,01 & 19,98 & 20,00 & 3864,2 & 789,9 \\
\hline 3 & 10,04 & 9,95 & 10,03 & 10,00 & 10,01 & 19,96 & 20,00 & 19,98 & 3930,0 & 804,8 \\
\hline \multicolumn{11}{|c|}{ CP COM 28 DIAS (27-4)-ME } \\
\hline 1 & 10,00 & 10,00 & 10,00 & 10,00 & 10,00 & 20,00 & 20,00 & 20,00 & & 815,5 \\
\hline 2 & 10,00 & 10,00 & 10,00 & 10,00 & 10,00 & 20,00 & 20,00 & 20,00 & & 822,2 \\
\hline \multicolumn{11}{|c|}{ CP COM 28 DIAS - curados junto aos pilares (27-4)-ME } \\
\hline 1 & 10,00 & 10,00 & 10,00 & 10,00 & 10,00 & 20,00 & 20,00 & 20,00 & & 799,8 \\
\hline
\end{tabular}


RESUMO DOS VALORES MÉDIOS DA RESISTÊNCIA À COMPRESSÃO DO CONCRETO ENDURECIDO

\section{$1^{\text {a }}$ concretagem (pilares esbeltos e pilares curtos)}

\begin{tabular}{|c|c|c|c|c|c|c|c|c|c|}
\hline \multicolumn{10}{|c|}{ RESUMO DO TRAÇO E RESULTADOS DE COMPRESSÃO SIMPLE } \\
\hline \multirow{2}{*}{ concreto } & \multirow{2}{*}{$a / c$} & \multirow{2}{*}{$\begin{array}{l}\text { cimento } \\
(\mathrm{kg} / \mathrm{m} 3)\end{array}$} & \multirow{2}{*}{$\begin{array}{l}\text { traço } \\
\text { agreg. }\end{array}$} & \multirow{2}{*}{$\begin{array}{l}\text { teor de } \\
\text { argam. }\end{array}$} & $3 \mathrm{~d}$ & 9d & $15 \mathrm{~d}$ & $30 \mathrm{~d}$ & $30 \mathrm{~d}-\mathrm{j}$ \\
\hline & & & & & $f_{c \_ \text {médio }}$ & $f_{c_{c} \text { médio }}$ & $f_{c \_ \text {médio }}$ & $f_{c_{c} \text { médio }}$ & $f_{c_{c} \text { médio }}$ \\
\hline $30 \mathrm{Mpa}$ & 0,65 & 317,3 & $1: 6$ & $51 \%$ & 26,76 & 32,19 & 33,77 & 35,93 & 34,35 \\
\hline
\end{tabular}

$2^{\mathrm{a}}$ concretagem (pilares esbeltos)

\begin{tabular}{|c|c|c|c|c|c|c|c|c|c|}
\hline \multicolumn{10}{|c|}{ RESUMO DO TRAÇO E RESULTADOS DE COMPRESSÃO SIMPLE } \\
\hline \multirow{2}{*}{ concreto } & \multirow{2}{*}{$a / c$} & \multirow{2}{*}{$\begin{array}{l}\text { cimento } \\
(\mathrm{kg} / \mathrm{m} 3)\end{array}$} & \multirow{2}{*}{$\begin{array}{l}\text { traço } \\
\text { agreg. }\end{array}$} & \multirow{2}{*}{$\begin{array}{l}\text { teor de } \\
\text { argam. }\end{array}$} & $4 \mathrm{~d}$ & $7 d$ & $14 \mathrm{~d}$ & $36 \mathrm{~d}$ & $36 \mathrm{~d}-\mathrm{j}$ \\
\hline & & & & & $f_{c \_ \text {médio }}$ & $f_{c \_ \text {médio }}$ & $f_{c_{c \_ \text {médio }}}$ & $\mathbf{f}_{\mathrm{c} \_ \text {médio }}$ & $f_{c \_ \text {médio }}$ \\
\hline $30 \mathrm{Mpa}$ & 0,65 & 317,3 & $1: 6$ & $51 \%$ & 22,19 & 24,49 & 26,03 & 29,31 & 30,13 \\
\hline
\end{tabular}

\section{$1^{\text {a }}$ concretagem (pilares esbeltos e pilares curtos)}

\begin{tabular}{|c|c|c|c|c|c|c|c|c|c|}
\hline \multicolumn{10}{|c|}{ RESUMO DO TRAÇO E RESULTADOS DE COMPRESSÃO SIMPLE } \\
\hline \multirow{2}{*}{ concreto } & \multirow{2}{*}{$a / c$} & \multirow{2}{*}{$\begin{array}{l}\text { cimento } \\
(\mathrm{kg} / \mathrm{m} 3)\end{array}$} & \multirow{2}{*}{$\begin{array}{l}\text { traço } \\
\text { agreg. }\end{array}$} & \multirow{2}{*}{$\begin{array}{l}\text { teor de } \\
\text { argam. }\end{array}$} & \multirow{2}{*}{$\begin{array}{c}\% \\
\text { superpl. }\end{array}$} & $14 \mathrm{~d}$ & $25 \mathrm{~d}$ & $36 \mathrm{~d}$ & $32 \mathrm{~d}-\mathrm{j}$ \\
\hline & & & & & & $f_{\text {c_médio }}$ & $f_{c \_ \text {médio }}$ & $\mathbf{f}_{c_{c} \text { médio }}$ & $\mathbf{f}_{\mathrm{c}_{\text {cmmédio }}}$ \\
\hline $60 \mathrm{Mpa}$ & 0,48 & 343,4 & $1: 5,8$ & $53 \%$ & $1 \%$ & 53,74 & 56,46 & 62,51 & 63,85 \\
\hline
\end{tabular}

\section{$2^{\mathrm{a}}$ concretagem (pilares esbeltos)}

\begin{tabular}{|c|c|c|c|c|c|c|c|c|c|c|}
\hline \multicolumn{11}{|c|}{ RESUMO DO TRAÇO E RESULTADOS DE COMPRESSÃO SIMPLE } \\
\hline \multirow{2}{*}{ concreto } & \multirow{2}{*}{$\mathrm{a} / \mathrm{c}$} & \multirow{2}{*}{$\begin{array}{l}\text { cimento } \\
(\mathrm{kg} / \mathrm{m} 3)\end{array}$} & \multirow{2}{*}{$\begin{array}{l}\text { traço } \\
\text { agreg. }\end{array}$} & \multirow{2}{*}{$\begin{array}{l}\text { teor de } \\
\text { argam. }\end{array}$} & \multirow{2}{*}{$\begin{array}{c}\% \% \\
\text { superpl. }\end{array}$} & 9d & $15 \mathrm{~d}$ & $24 \mathrm{~d}$ & $34 \mathrm{~d}$ & $31 \mathrm{~d}-\mathrm{j}$ \\
\hline & & & & & & $f_{c_{-} \text {médio }}$ & $f_{c \_ \text {médio }}$ & $f_{c \_ \text {médio }}$ & $f_{c_{-} \text {médio }}$ & $\mathbf{f}_{c_{-} \text {médio }}$ \\
\hline $60 \mathrm{Mpa}$ & 0,48 & 343,4 & $1: 5,8$ & $53 \%$ & $1 \%$ & 45,57 & 48,42 & 51,85 & 55,70 & 56,79 \\
\hline
\end{tabular}

\section{$1^{\text {a }}$ concretagem (pilares esbeltos e pilares curtos)}

\begin{tabular}{|c|c|c|c|c|c|c|c|c|c|c|}
\hline \multicolumn{11}{|c|}{ RESUMO DO TRAÇO E RESULTADOS DE COMPRESSÃO SIMPLE } \\
\hline \multirow{2}{*}{ concreto } & \multirow{2}{*}{$\mathrm{a} / \mathrm{c}$} & \multirow{2}{*}{$\begin{array}{l}\text { cimento } \\
(\mathrm{kg} / \mathrm{m} 3)\end{array}$} & \multirow{2}{*}{$\begin{array}{l}\text { traço } \\
\text { agreg. }\end{array}$} & \multirow{2}{*}{$\begin{array}{l}\text { teor de } \\
\text { argam. }\end{array}$} & \multirow{2}{*}{$\begin{array}{c}\% \\
\text { superpl. }\end{array}$} & \multirow{2}{*}{$\begin{array}{c}\text { \% SA em } \\
\text { subst.cim. }\end{array}$} & $10 \mathrm{~d}$ & $27 \mathrm{~d}$ & $33 \mathrm{~d}$ & $28 \mathrm{~d}-\mathrm{j}$ \\
\hline & & & & & & & $f_{c \_ \text {médio }}$ & $f_{\text {c_médio }}$ & $f_{c_{-} \text {médio }}$ & $\mathbf{f}_{\mathrm{c}_{\text {_médio }}}$ \\
\hline $100 \mathrm{Mpa}$ & 0,26 & 561,9 & $1: 3$ & $53 \%$ & $0,8 \%$ & $8 \%$ & 92,73 & 104,48 & 103,80 & 99,16 \\
\hline
\end{tabular}

\section{$2^{\mathrm{a}}$ concretagem (pilares esbeltos)}

\begin{tabular}{|c|c|c|c|c|c|c|c|c|c|c|c|}
\hline \multicolumn{12}{|c|}{ RESUMO DO TRAÇO E RESULTADOS DE COMPRESSÃO SIMPLE } \\
\hline \multirow{2}{*}{ concreto } & \multirow{2}{*}{$a / c$} & \multirow{2}{*}{$\begin{array}{l}\text { cimento } \\
\text { (kg/m3) }\end{array}$} & \multirow{2}{*}{$\begin{array}{l}\text { traço } \\
\text { agreg. }\end{array}$} & \multirow{2}{*}{$\begin{array}{l}\text { teor de } \\
\text { argam. }\end{array}$} & \multirow{2}{*}{$\begin{array}{c}\% \\
\text { superpl. }\end{array}$} & \multirow{2}{*}{$\begin{array}{c}\% \text { SA em } \\
\text { subst.cim. }\end{array}$} & $8 \mathrm{~d}$ & $17 \mathrm{~d}$ & $24 \mathrm{~d}$ & $28 \mathrm{~d}$ & $28 \mathrm{~d}-\mathrm{j}$ \\
\hline & & & & & & & $f_{c_{c} \text { médio }}$ & $f_{c_{c} \text { médio }}$ & $f_{c_{c \_ \text {médio }}}$ & $f_{c \_ \text {médio }}$ & $f_{c_{c} \text { médio }}$ \\
\hline $100 \mathrm{Mpa}$ & 0,26 & 561,9 & $1: 3$ & $53 \%$ & $0,8 \%$ & $8 \%$ & 84,15 & 98,88 & 102,17 & 104,26 & 101,83 \\
\hline
\end{tabular}




\section{ANEXO C - RESULTADO DA RESISTÊNCIA À COMPRESSÃO DIAMETRAL (DOS TRAÇOS FINAIS)}

\begin{tabular}{|c|c|c|c|c|c|c|c|c|c|c|}
\hline \multicolumn{11}{|c|}{ ENSAIO DE COMPRESSÃO DIAMETRAL - MEDIDAS } \\
\hline CP & D1 (cm) & D2 (cm) & D3 (cm) & D4 (cm) & $\mathrm{DM}(\mathrm{cm})$ & $\mathrm{h} 1(\mathrm{~cm})$ & $\mathrm{h} 2(\mathrm{~cm})$ & $\mathrm{hm}(\mathrm{cm})$ & massa (g) & F ruptura(KN) \\
\hline \multicolumn{11}{|c|}{ CONCRETO DE 30 MPa - CONCRETAGEM EM 9-3 } \\
\hline \multicolumn{11}{|c|}{ CP COM 9 DIAS (18-3-09-15:30) } \\
\hline 1 & 10,04 & 10,06 & 9,99 & 10,10 & 10,05 & 19,73 & 19,73 & 19,73 & 3830,0 & 99,3 \\
\hline 2 & 10,09 & 10,05 & 10,09 & 10,05 & 10,07 & 19,78 & 19,78 & 19,78 & 3826,0 & 84,4 \\
\hline \multicolumn{11}{|c|}{ CP COM 30 DIAS (8-4-09-10:30) } \\
\hline 1 & 10,04 & 10,07 & 10,04 & 10,11 & 10,07 & 20,00 & 19,95 & 19,98 & 3875,5 & 104,0 \\
\hline 2 & 10,10 & 10,05 & 10,10 & 10,05 & 10,08 & 19,77 & 19,67 & 19,72 & 3866,1 & 97,0 \\
\hline
\end{tabular}

\begin{tabular}{|l|c|c|c|c|c|c|c|c|c|c|}
\hline \multicolumn{10}{|c|}{ CPNCRETO DE 30 MPa - CONCRETAGEM EM 12-3 } \\
\hline \multicolumn{10}{|c|}{ COM 7 DIAS (19-3-09-15:30) } \\
\hline 1 & 10,02 & 10,00 & 10,00 & 10,04 & 10,02 & 19,91 & 19,91 & 19,91 & 3821,5 & 82,2 \\
\hline 2 & 10,00 & 10,04 & 10,02 & 10,06 & 10,03 & 19,87 & 19,89 & 19,88 & 3816,2 & 75,1 \\
\hline \multicolumn{10}{|c|}{ CP COM 36 DIAS (17-4-15:00) } \\
\hline 1 & 10,09 & 10,05 & 10,07 & 10,06 & 10,07 & 19,80 & 19,80 & 19,80 & 3828,8 & 88,6 \\
\hline 2 & 10,15 & 10,04 & 10,06 & 10,09 & 10,09 & 19,79 & 19,80 & 19,80 & 3863,2 & 103,3 \\
\hline
\end{tabular}

\begin{tabular}{|l|c|c|c|c|c|c|c|c|c|c|}
\hline \multicolumn{10}{|c|}{ CONCRETO DE 60 MPa - CONCRETAGEM EM 23-3 } \\
\hline \multicolumn{10}{|c|}{ CP COM 14 DIAS (06-4-09-16:00) } \\
\hline 1 & 10,07 & 10,09 & 10,05 & 10,09 & 10,08 & 19,74 & 19,76 & 19,75 & 3904,5 & 115,4 \\
\hline 2 & 10,05 & 10,08 & 10,06 & 10,09 & 10,07 & 19,88 & 19,83 & 19,86 & 3904,8 & 106,3 \\
\hline \multicolumn{10}{|c|}{ CP COM 25 DIAS (17-4-15:00) } \\
\hline 1 & 10,00 & 10,00 & 9,95 & 10,02 & 9,99 & 19,93 & 19,90 & 19,92 & 3900,4 & 141,3 \\
\hline 2 & 10,00 & 10,10 & 9,99 & 10,10 & 10,05 & 19,62 & 19,60 & 19,61 & 3860,9 & 141,0 \\
\hline
\end{tabular}

\begin{tabular}{|c|c|c|c|c|c|c|c|c|c|c|}
\hline \multicolumn{10}{|c|}{ CP COM 9 DIAS (18-3-09-15:30) } \\
\hline \multicolumn{10}{|c|}{} \\
\hline 1 & 10,04 & 10,06 & 9,99 & 10,10 & 10,05 & 19,73 & 19,73 & 19,73 & 3830,0 & 99,3 \\
\hline 2 & 10,09 & 10,05 & 10,09 & 10,05 & 10,07 & 19,78 & 19,78 & 19,78 & 3826,0 & 84,4 \\
\hline \multicolumn{10}{|c|}{ CP COM 34 DIAS $(27-4-16: 00)$} \\
\hline 1 & 10,08 & 10,05 & 10,10 & 10,09 & 10,08 & 19,70 & 19,73 & 19,72 & & 125,0 \\
\hline 2 & 10,00 & 10,03 & 10,06 & 10,00 & 10,02 & 19,95 & 20,00 & 19,98 & & 125,3 \\
\hline
\end{tabular}

\begin{tabular}{|c|c|c|c|c|c|c|c|c|c|c|}
\hline \multicolumn{10}{|c|}{ CONCRETO DE 100 MPa - CONCRETAGEM EM 27-3 } \\
\hline \multicolumn{10}{|c|}{ CP COM 10 DIAS (6-4-09-16:00) } \\
\hline 1 & 10,06 & 10,07 & 10,05 & 10,09 & 10,07 & 19,89 & 19,87 & 19,88 & 3939,8 & 148,7 \\
\hline 2 & 10,02 & 10,06 & 10,08 & 10,04 & 10,05 & 19,90 & 19,90 & 19,90 & 3947,1 & 194,2 \\
\hline \multicolumn{10}{|c|}{ CP COM 26 DIAS $(22-4-16: 00)$} \\
\hline 1 & 10,10 & 10,08 & 10,03 & 10,14 & 10,09 & 19,87 & 19,88 & 19,88 & 3973,2 & 220,7 \\
\hline 2 & 10,04 & 10,10 & 10,04 & 10,10 & 10,07 & 19,84 & 19,88 & 19,86 & 3940,1 & 210,4 \\
\hline
\end{tabular}

\begin{tabular}{|c|c|c|c|c|c|c|c|c|c|c|}
\hline \multicolumn{10}{|c|}{ CONCRETO DE 100 MPa - CONCRETAGEM EM 31-3 } \\
\hline \multicolumn{10}{|c|}{ CP COM 23 DIAS (23-4-16:00) } \\
\hline 1 & 10,06 & 10,06 & 10,06 & 9,99 & 10,04 & 19,92 & 19,90 & 19,91 & 3881,0 & 213,6 \\
\hline 2 & 10,08 & 9,96 & 10,04 & 9,94 & 10,01 & 19,88 & 19,90 & 19,89 & 3926,0 & 207,5 \\
\hline
\end{tabular}




\section{Resumo dos resultados anteriores}

\begin{tabular}{|c|c|c|c|c|c|c|c|c|c|c|}
\hline \multicolumn{11}{|c|}{ RESUMO DO ENSAIO À COMPRESSÃO DIAMETRAL } \\
\hline $\begin{array}{c}\text { Idade dos } \\
\text { CP }\end{array}$ & $\begin{array}{c}\text { diâmetro } \\
(\mathrm{cm})\end{array}$ & $\begin{array}{l}\text { altura } \\
(\mathrm{cm})\end{array}$ & $\begin{array}{c}\text { seção } \\
\text { CP } \\
(\mathrm{cm} 2)\end{array}$ & $\begin{array}{l}\text { Força } \\
\text { ruptura } \\
\text { (KN) }\end{array}$ & $\begin{array}{l}\text { tensão de } \\
\text { tração por } \\
\text { CD (MPa) }\end{array}$ & $\begin{array}{c}\text { tensão de } \\
\text { tração por CD } \\
\text { (média -MPa) }\end{array}$ & $\begin{array}{l}\text { tração } \\
\text { direta } \\
(\mathrm{MPa})\end{array}$ & $\begin{array}{c}\text { massa } \\
(\mathbf{k g})\end{array}$ & $\begin{array}{c}\text { massa } \\
\text { unitária } \\
(\mathrm{kg} / \mathrm{m} 3)\end{array}$ & $\begin{array}{c}\text { massa (valor } \\
\text { médio - } \\
\mathrm{kg} / \mathrm{m} 3 \text { ) }\end{array}$ \\
\hline \multicolumn{11}{|c|}{ CONCRETO DE $30 \mathrm{MPa}$ - CONCRETAGEM EM 9-3 } \\
\hline \multicolumn{11}{|l|}{$9 \mathrm{~d}$} \\
\hline 1 & 10,05 & 19,73 & 79,3 & 99,3 & 3,2 & \multirow{2}{*}{2,9} & \multirow{2}{*}{2,6} & 3,83 & 2448 & \multirow{2}{*}{2438} \\
\hline 2 & 10,07 & 19,78 & 79,6 & 84,4 & 2,7 & & & 3,83 & 2429 & \\
\hline \multicolumn{11}{|l|}{$30 \mathrm{~d}$} \\
\hline 1 & 10,07 & 19,98 & 79,6 & 104,0 & 3,3 & \multirow{2}{*}{3,2} & \multirow{2}{*}{2,9} & 3,88 & 2439 & \multirow{2}{*}{2449} \\
\hline 2 & 10,08 & 19,72 & 79,7 & 97,0 & 3,1 & & & 3,87 & 2459 & \\
\hline \multicolumn{11}{|c|}{ CONCRETO DE $30 \mathrm{MPa}$ - CONCRETAGEM EM 12-3 } \\
\hline \multicolumn{11}{|l|}{$9 \mathrm{~d}$} \\
\hline 1 & 10,02 & 19,91 & 78,8 & 82,2 & 2,6 & \multirow{2}{*}{2,5} & \multirow{2}{*}{2,3} & 3,82 & 2437 & \multirow{2}{*}{2433} \\
\hline 2 & 10,03 & 19,88 & 79,0 & 75,1 & 2,4 & & & 3,82 & 2430 & \\
\hline \multicolumn{11}{|l|}{$30 \mathrm{~d}$} \\
\hline 1 & 10,07 & 19,80 & 79,6 & 88,6 & 2,8 & \multirow{2}{*}{3,1} & \multirow{2}{*}{2,8} & 3,83 & 2429 & \multirow{2}{*}{2436} \\
\hline 2 & 10,09 & 19,80 & 79,9 & 103,3 & 3,3 & & & 3,86 & 2443 & \\
\hline
\end{tabular}

\begin{tabular}{|c|c|c|c|c|c|c|c|c|c|c|}
\hline \multicolumn{11}{|c|}{ CONCRETO DE $60 \mathrm{MPa}$ - CONCRETAGEM EM 23-3 } \\
\hline $9 \mathrm{~d}$ & & & & & & & & & & \\
\hline 1 & 10,08 & 19,75 & 79,7 & 115,4 & 3,7 & \multirow{2}{*}{3,5} & \multirow{2}{*}{3,2} & 3,90 & 2480 & \multirow{2}{*}{2475} \\
\hline 2 & 10,07 & 19,86 & 79,6 & 106,3 & 3,4 & & & 3,90 & 2469 & \\
\hline \multicolumn{11}{|l|}{$30 \mathrm{~d}$} \\
\hline 1 & 9,99 & 19,92 & 78,4 & 141,3 & 4,5 & \multirow{2}{*}{4,5} & \multirow{2}{*}{4,1} & 3,90 & 2497 & \multirow{2}{*}{2490} \\
\hline 2 & 10,05 & 19,61 & 79,3 & 141,0 & 4,6 & & & 3,86 & 2483 & \\
\hline
\end{tabular}

\begin{tabular}{|c|c|c|c|c|c|c|c|c|c|c|}
\hline \multicolumn{11}{|c|}{ CONCRETO DE $60 \mathrm{MPa}$ - CONCRETAGEM EM 24-3 } \\
\hline \multicolumn{11}{|l|}{$9 d$} \\
\hline 1 & 10,10 & 19,73 & 80,1 & 99,3 & 3,2 & \multirow{2}{*}{2,9} & \multirow{2}{*}{2,6} & 3,83 & 2423 & \multirow{2}{*}{2431} \\
\hline 2 & 10,05 & 19,78 & 79,3 & 84,4 & 2,7 & & & 3,83 & 2438 & \\
\hline \multicolumn{11}{|l|}{$34 \mathrm{~d}$} \\
\hline 1 & 10,09 & 19,72 & 80,0 & 125,0 & 4,0 & \multirow{2}{*}{4,0} & \multirow{2}{*}{3,6} & 0,00 & 0 & \multirow{2}{*}{0} \\
\hline 2 & 10,00 & 19,98 & 78,5 & 125,3 & 4,0 & & & 0,00 & 0 & \\
\hline
\end{tabular}

\begin{tabular}{|c|c|c|c|c|c|c|c|c|c|c|}
\hline \multicolumn{11}{|c|}{ CONCRETO DE $100 \mathrm{MPa}$ - CONCRETAGEM EM 27-3 } \\
\hline \multicolumn{11}{|l|}{$10 \mathrm{~d}$} \\
\hline 1 & 10,07 & 19,88 & 79,6 & 148,7 & 4,7 & \multirow{2}{*}{5,5} & \multirow{2}{*}{4,9} & 3,94 & 2490 & \multirow{2}{*}{2495} \\
\hline 2 & 10,05 & 19,90 & 79,3 & 194,2 & 6,2 & & & 3,95 & 2500 & \\
\hline \multicolumn{11}{|l|}{$26 \mathrm{~d}$} \\
\hline 1 & 10,09 & 19,88 & 79,9 & 220,7 & 7,0 & \multirow{2}{*}{6,9} & \multirow{2}{*}{6,2} & 3,97 & 2501 & \multirow{2}{*}{2496} \\
\hline 2 & 10,07 & 19,86 & 79,6 & 210,4 & 6,7 & & & 3,94 & 2491 & \\
\hline
\end{tabular}

\begin{tabular}{|c|c|c|c|c|c|c|c|c|c|c|}
\hline \multicolumn{11}{|c|}{ CONCRETO DE $100 \mathrm{MPa}$ - CONCRETAGEM EM 31-3 } \\
\hline $23 \mathrm{~d}$ & & & & & & & & & & \\
\hline 1 & 10,04 & 19,91 & 79,2 & 213,6 & 6,8 & \multirow{2}{*}{6,7} & \multirow{2}{*}{6,0} & 3,88 & 2461 & \multirow{2}{*}{2486} \\
\hline 2 & 10,01 & 19,89 & 78,6 & 207,5 & 6,6 & & & 3,93 & 2511 & \\
\hline
\end{tabular}




\section{ANEXO D - DIAGRAMAS AXIAL-MOMENTO PARA O ESTADO LIMITE ÚLTIMO PELO EUROCODE 2 (2004) SEM CONFINAMENTO}

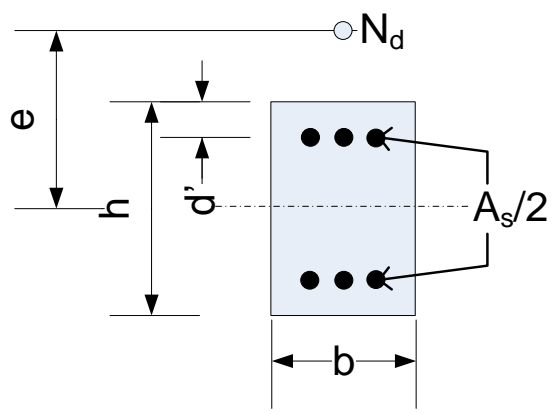

EUROCODE 2 (2004) - EN 1992-1-1

$$
\begin{gathered}
v=\frac{N_{d}}{A_{c} \times \sigma_{c d}} \quad \mu=\frac{N_{d} \times e}{A_{c} \times h \times \sigma_{c d}} \quad \omega=\frac{A_{s} \times f_{y d}}{A_{c} \times \sigma_{c d}} \\
\sigma_{c d}=0,85 \times f_{c d} \quad A_{c}=b \times h \\
\gamma_{c}=1,5 \quad \gamma_{s}=1,15 \quad \frac{d^{\prime}}{h}=0,1
\end{gathered}
$$

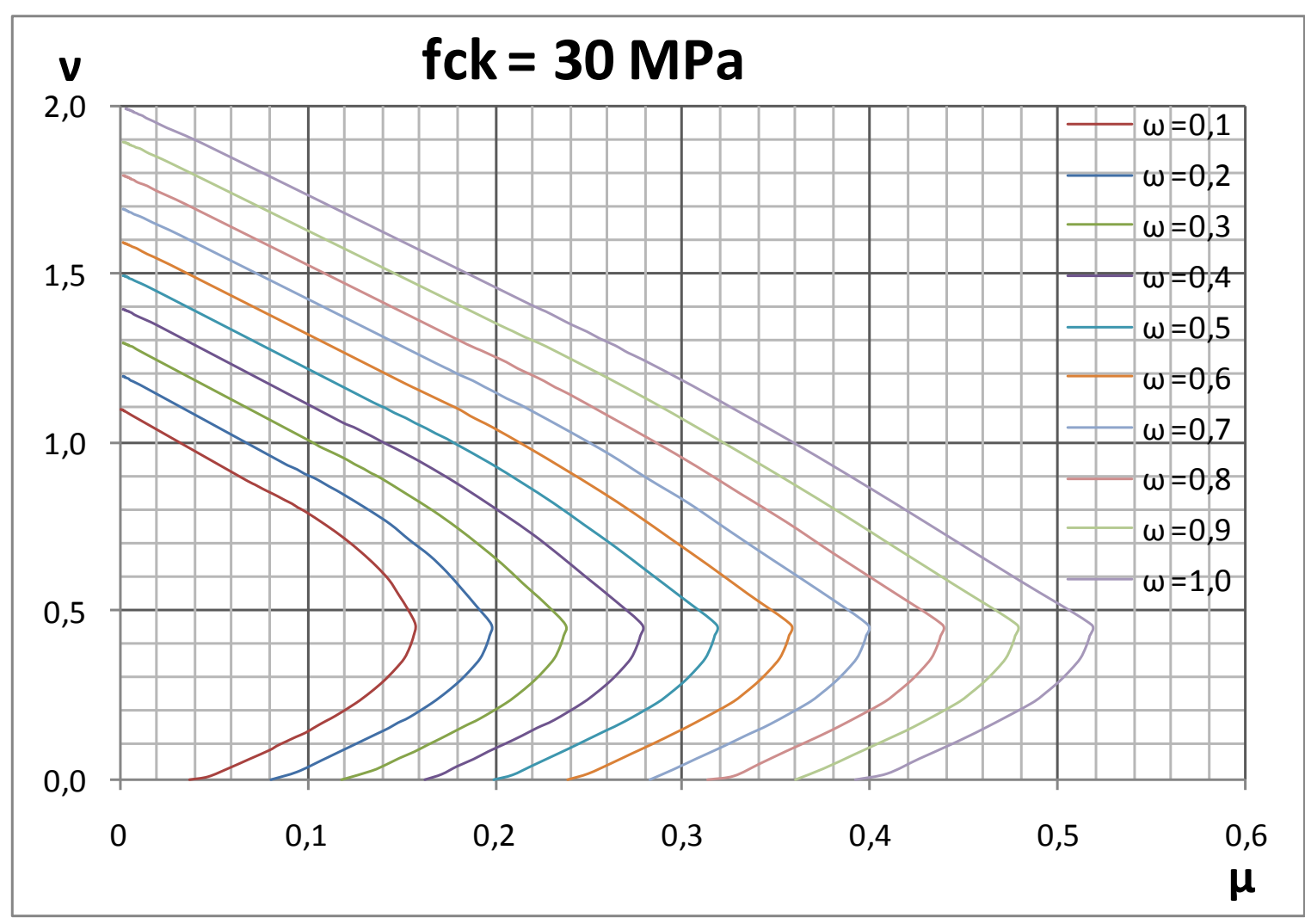



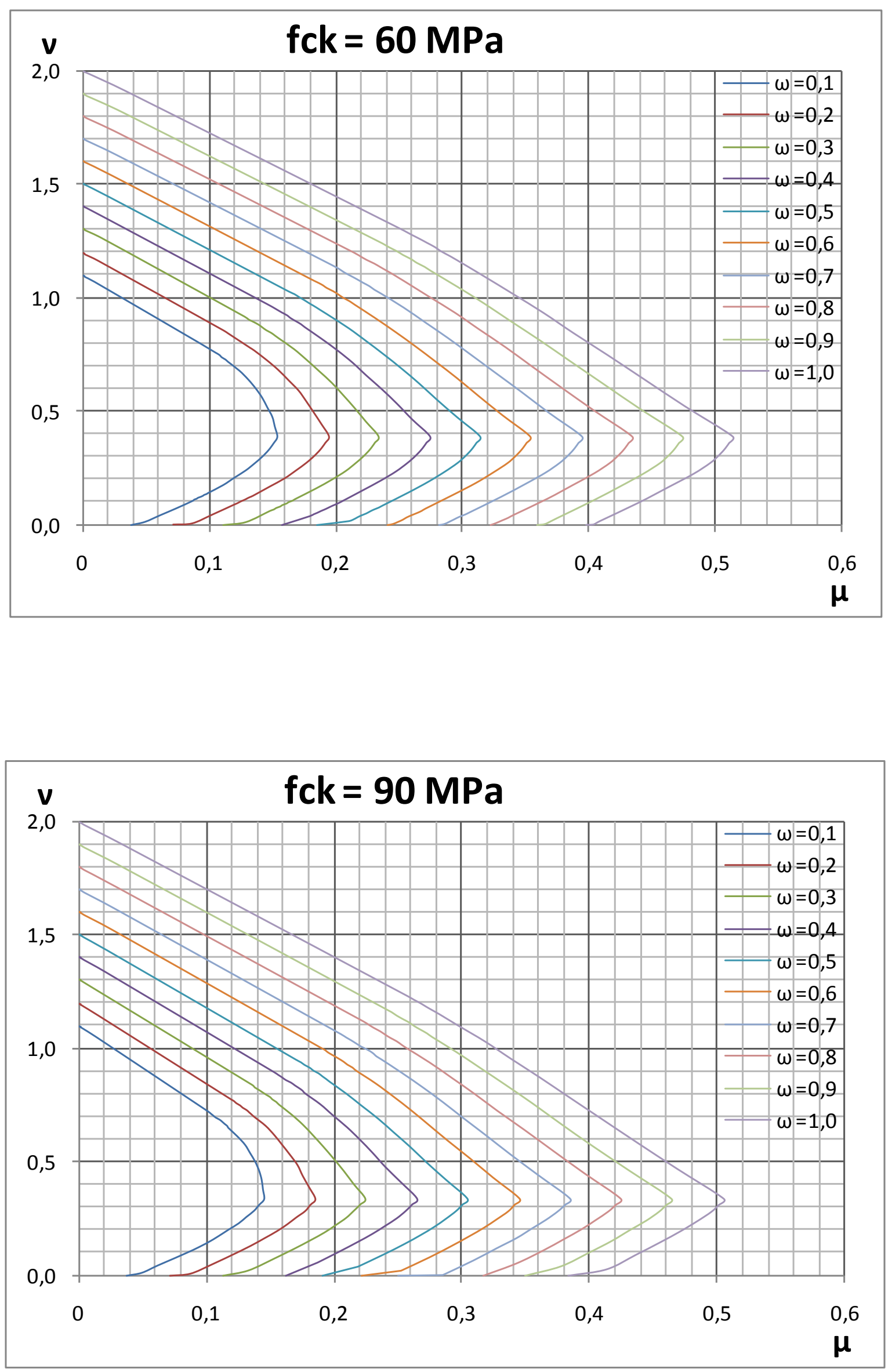


\section{ANEXO E - DIAGRAMAS MOMENTO-CURVATURA PARA O DIMENSIONAMENTO}

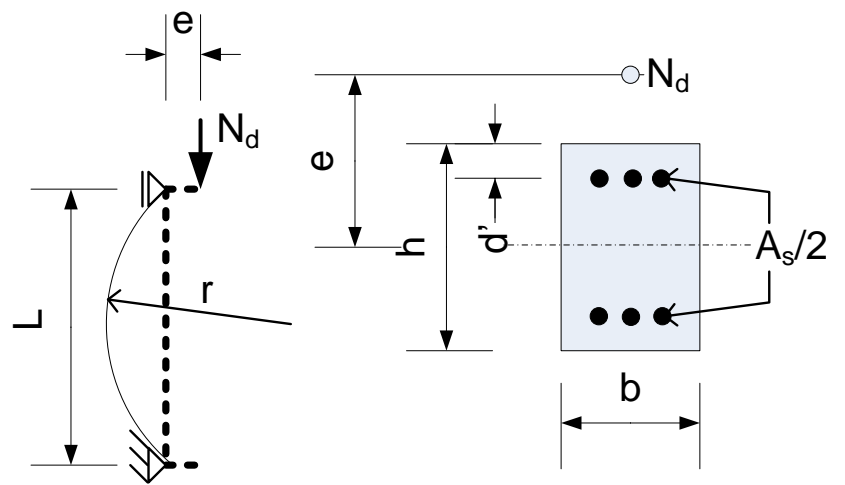

EUROCODE 2 (2004) - EN 1992-1-1

$$
\begin{gathered}
v=\frac{N_{d}}{A_{c} \times \sigma_{c d}} \quad \mu=\frac{N_{d} \times e}{A_{c} \times h \times \sigma_{c d}} \quad \omega=\frac{A_{s} \times f_{y d}}{A_{c} \times \sigma_{c d}} \\
\sigma_{c d}=0,85 \times f_{c d} \quad A_{c}=b \times h \\
\gamma_{c}=1,5 \quad \gamma_{s}=1,15 \quad \frac{d^{\prime}}{h}=0,1 \quad \theta=\frac{h}{r}
\end{gathered}
$$

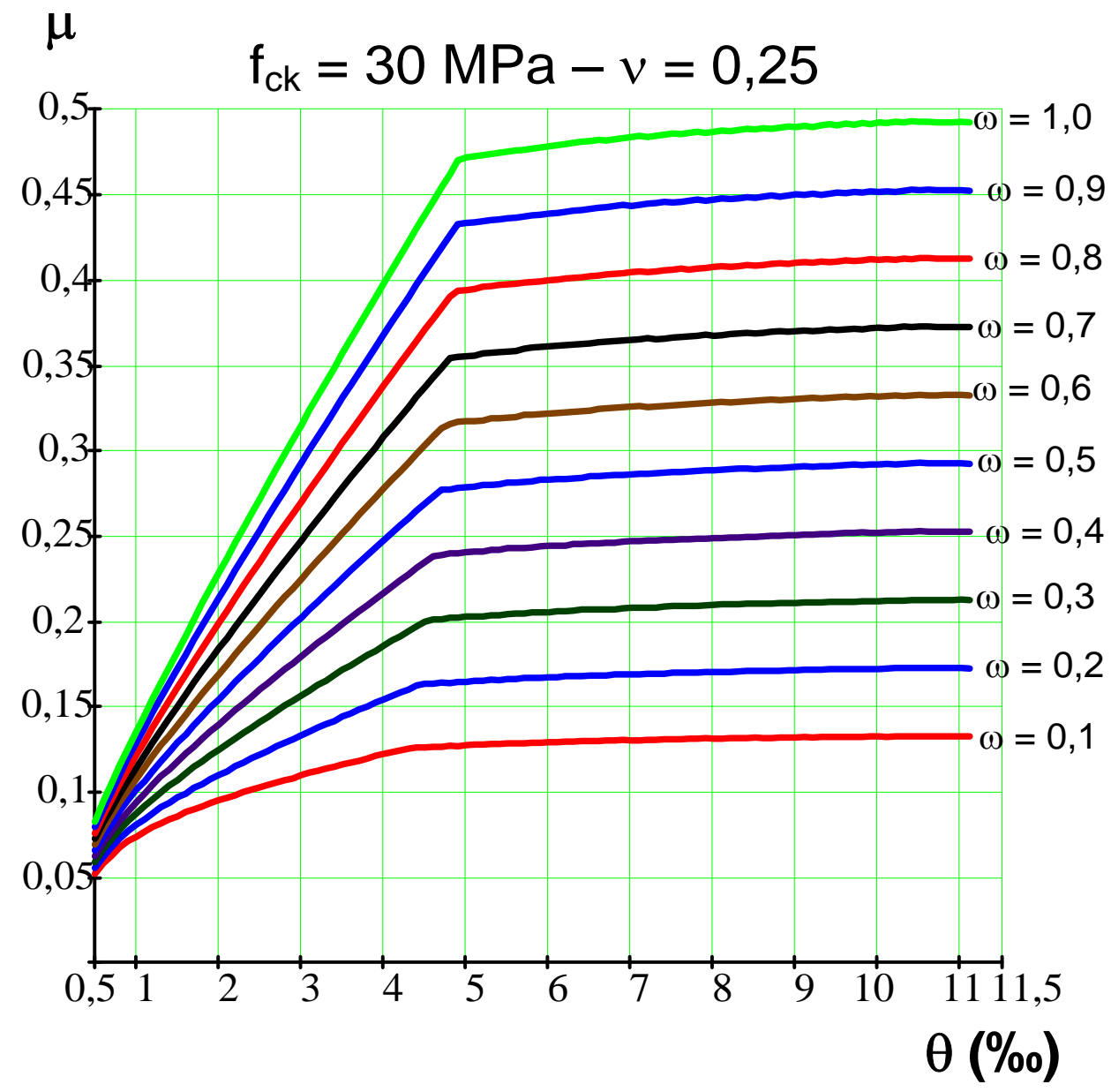



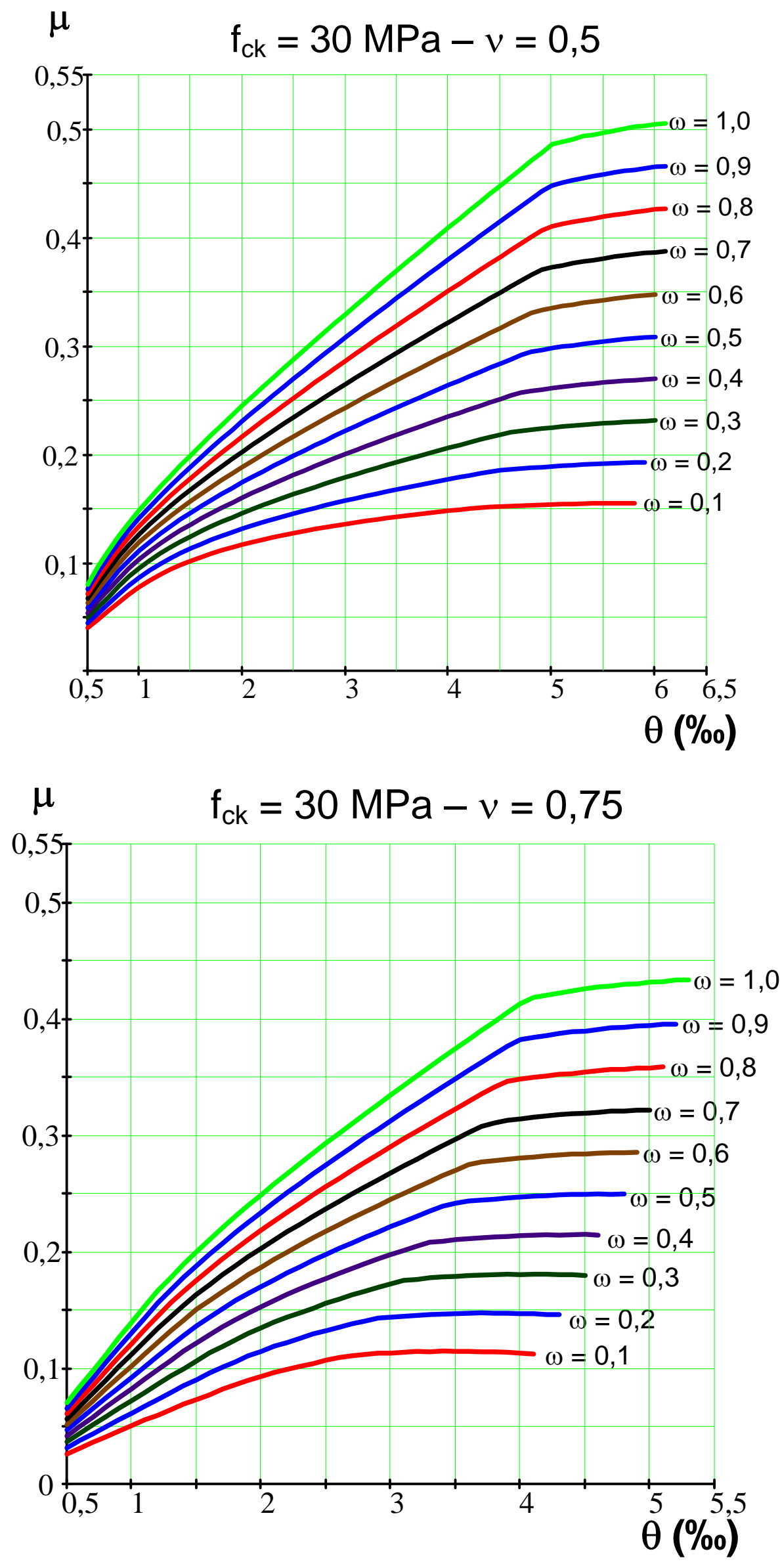

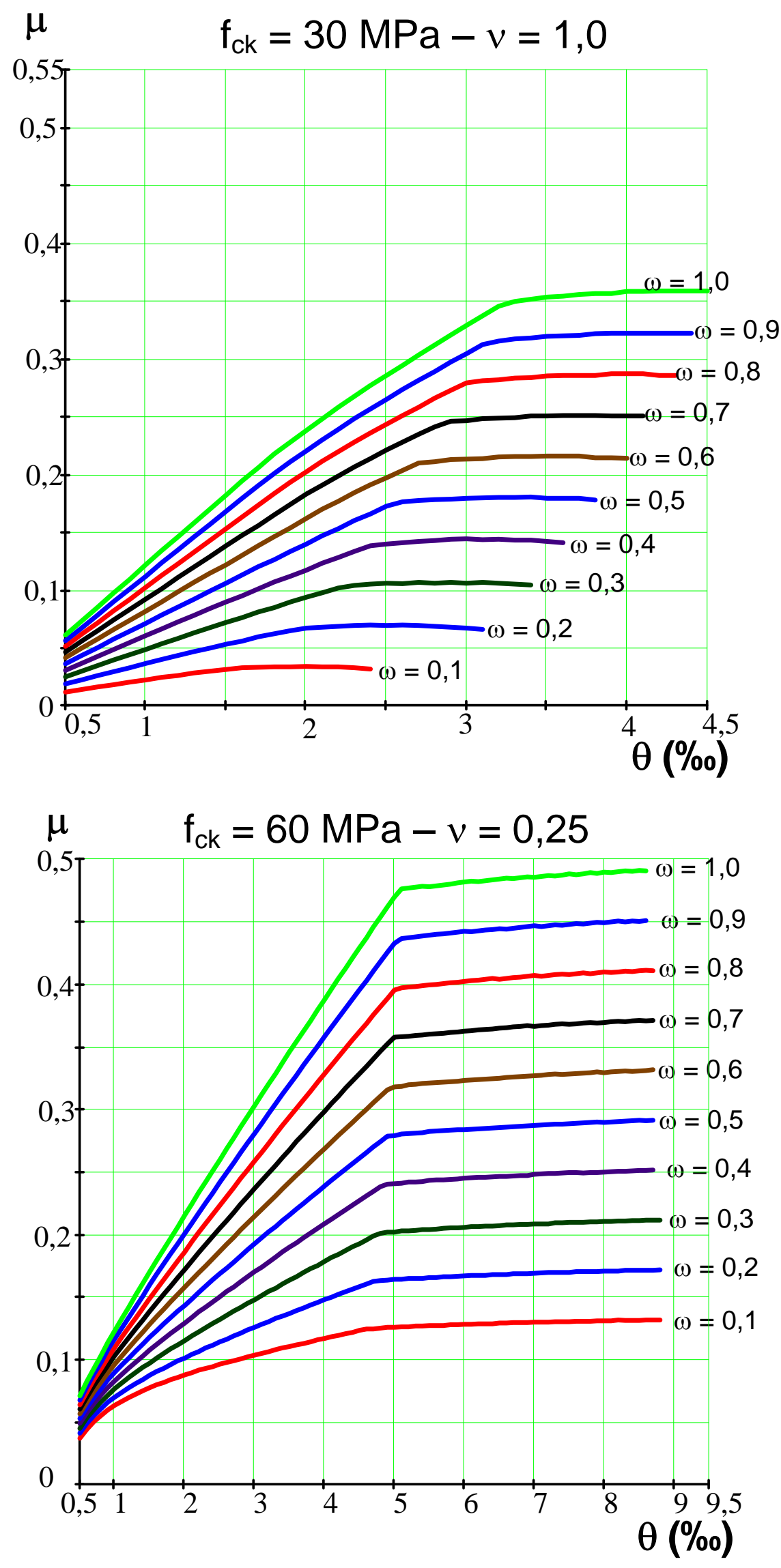

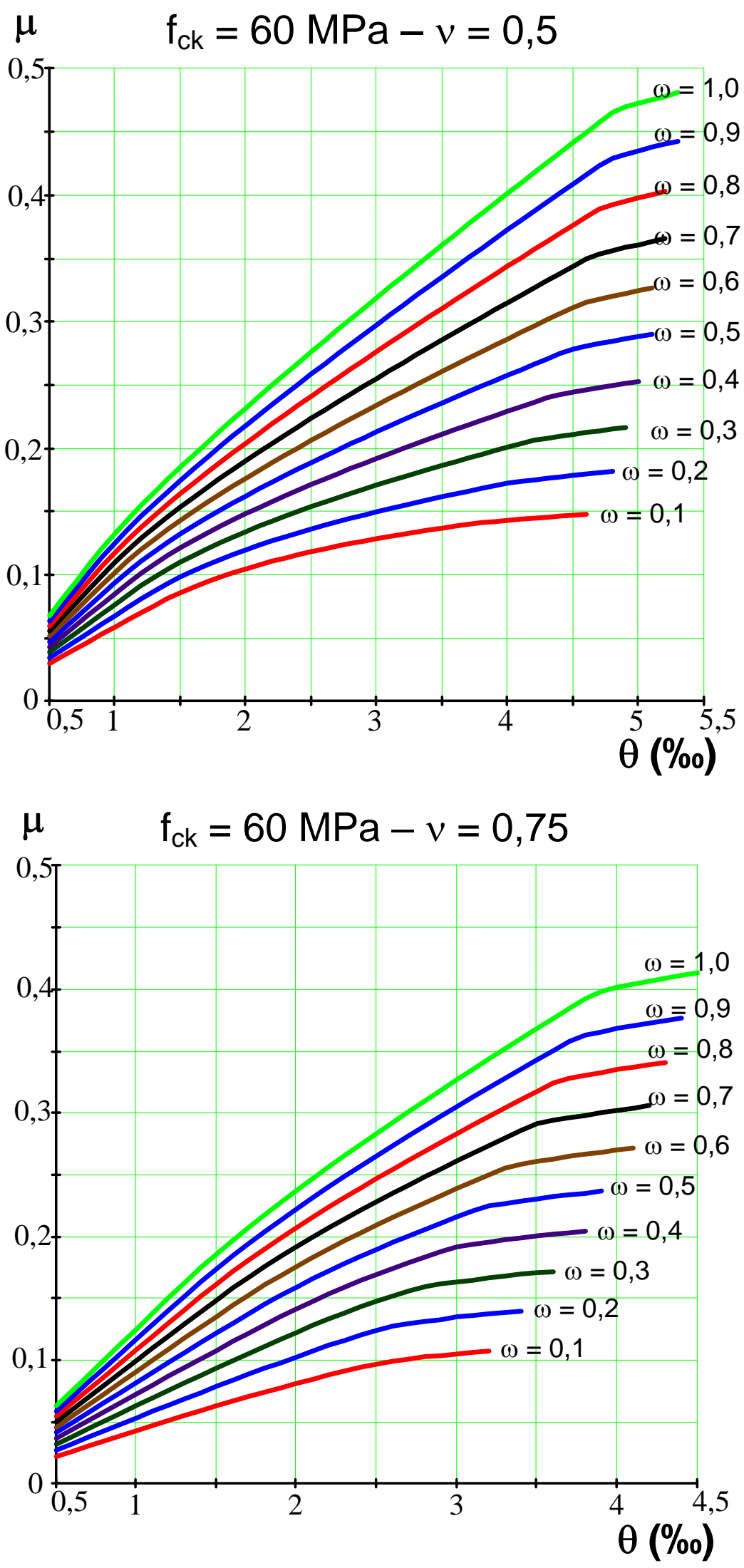

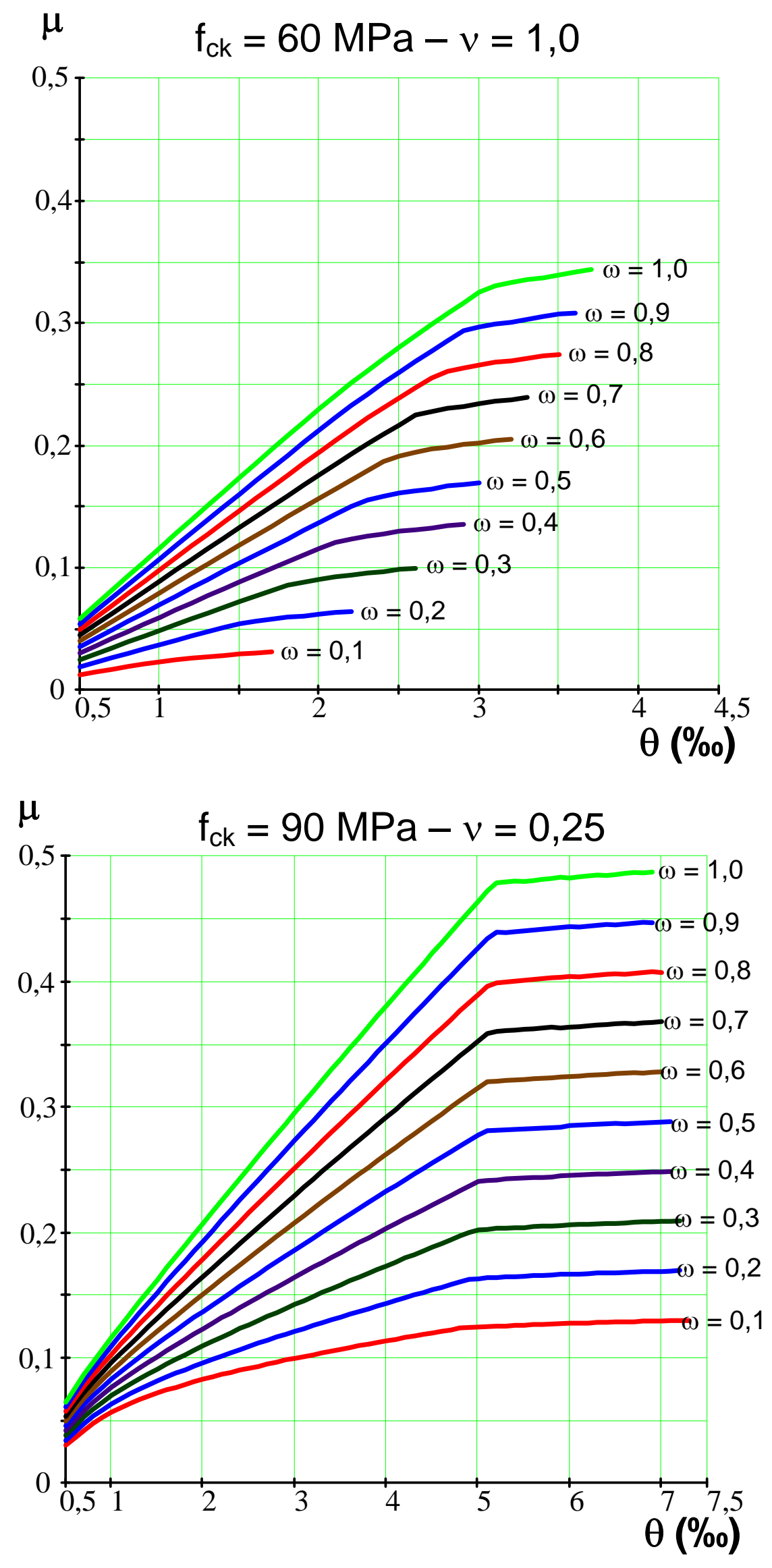

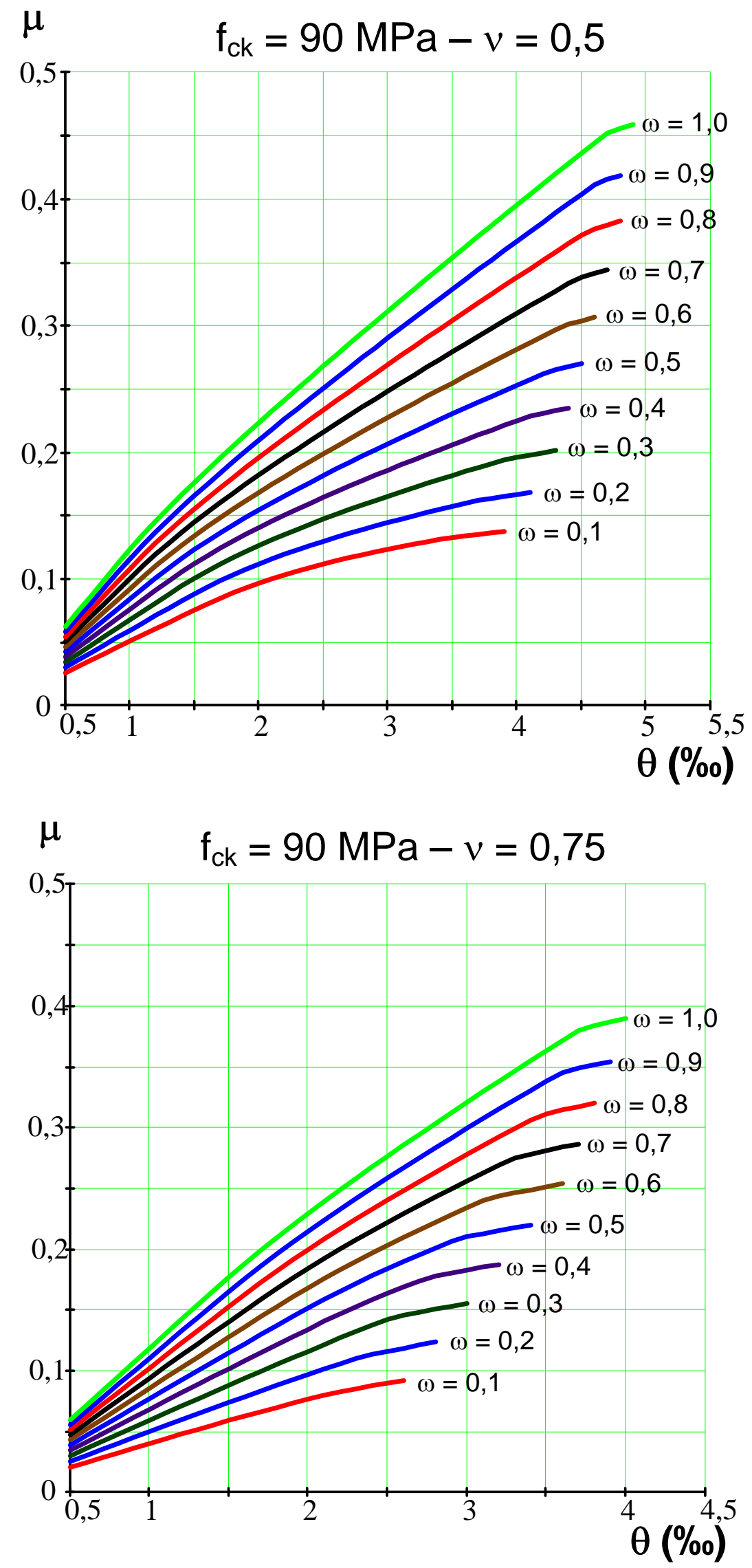


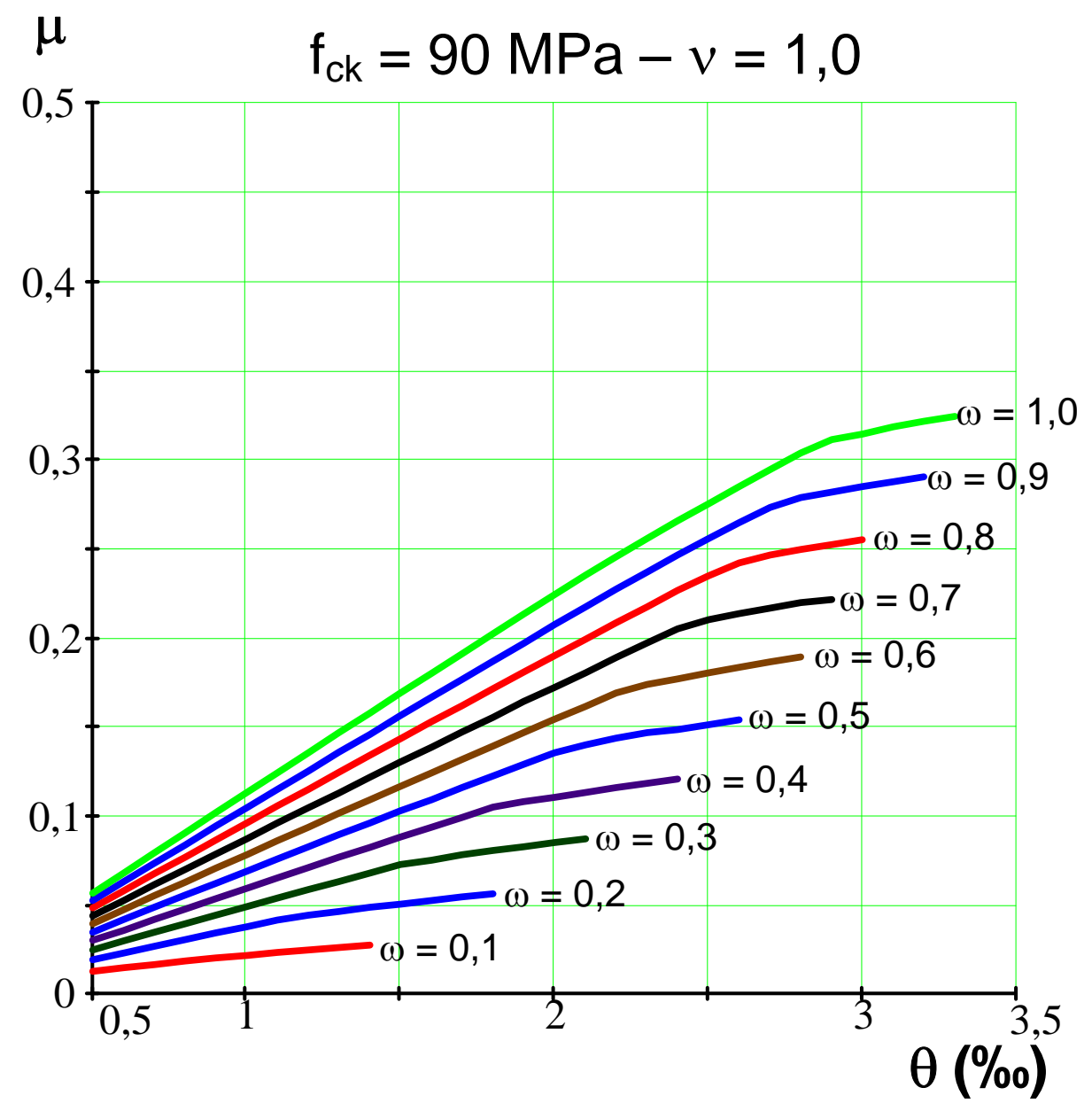




\section{ANEXO F - DIAGRAMAS FORÇA AXIAL-MOMENTO DE DIMENSIONAMENTO PARA VÁRIAS ESBELTEZES COM O MÉTODO GERAL}
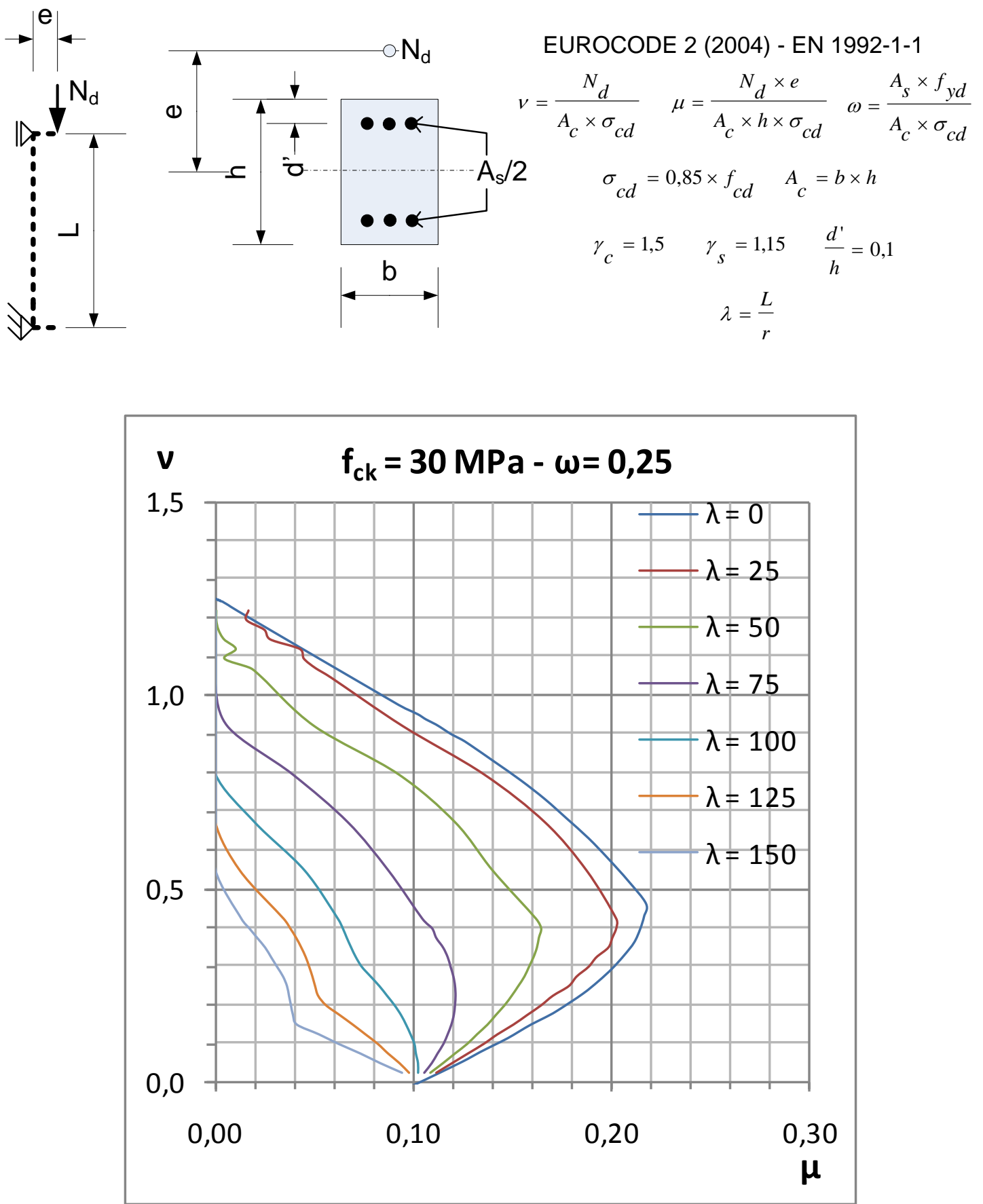

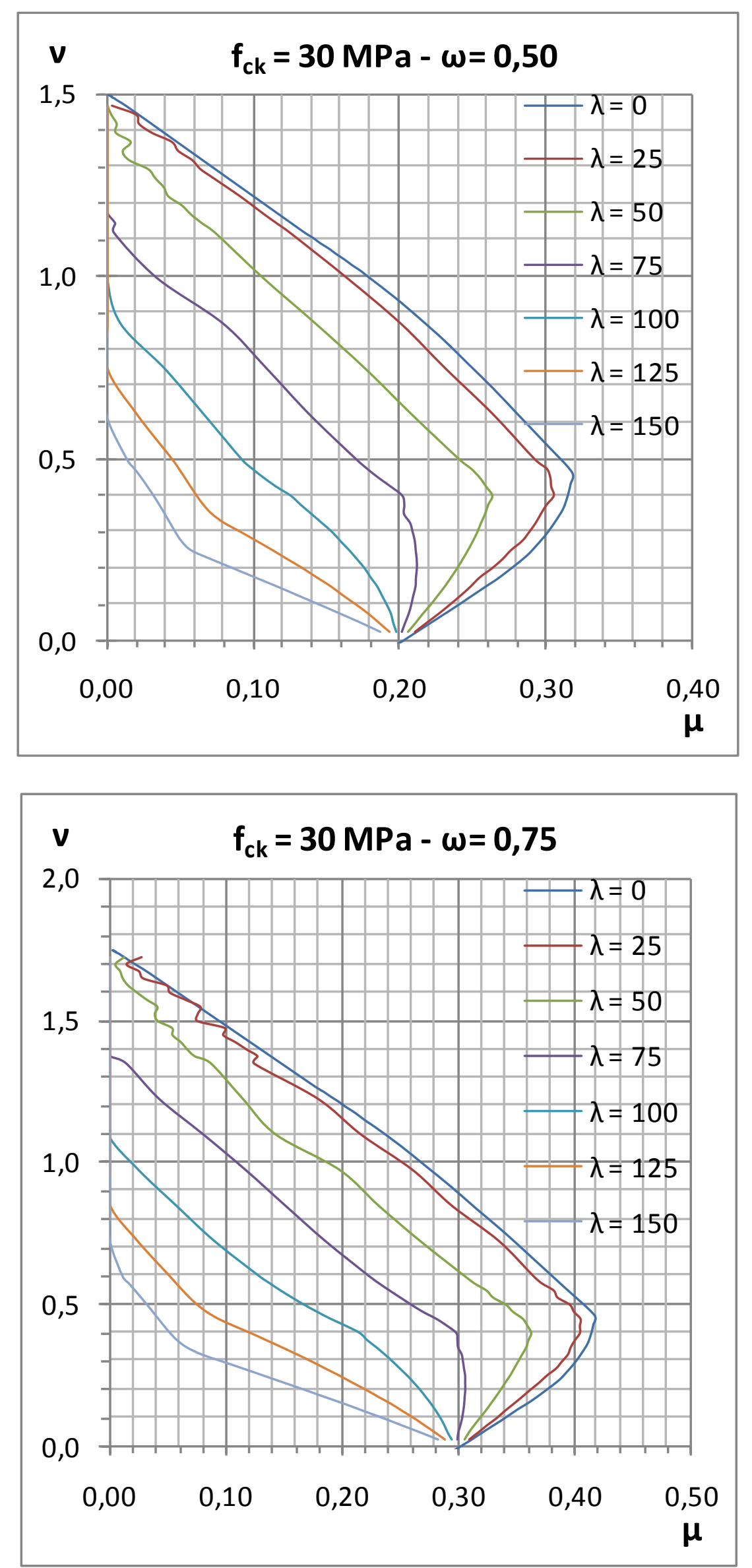

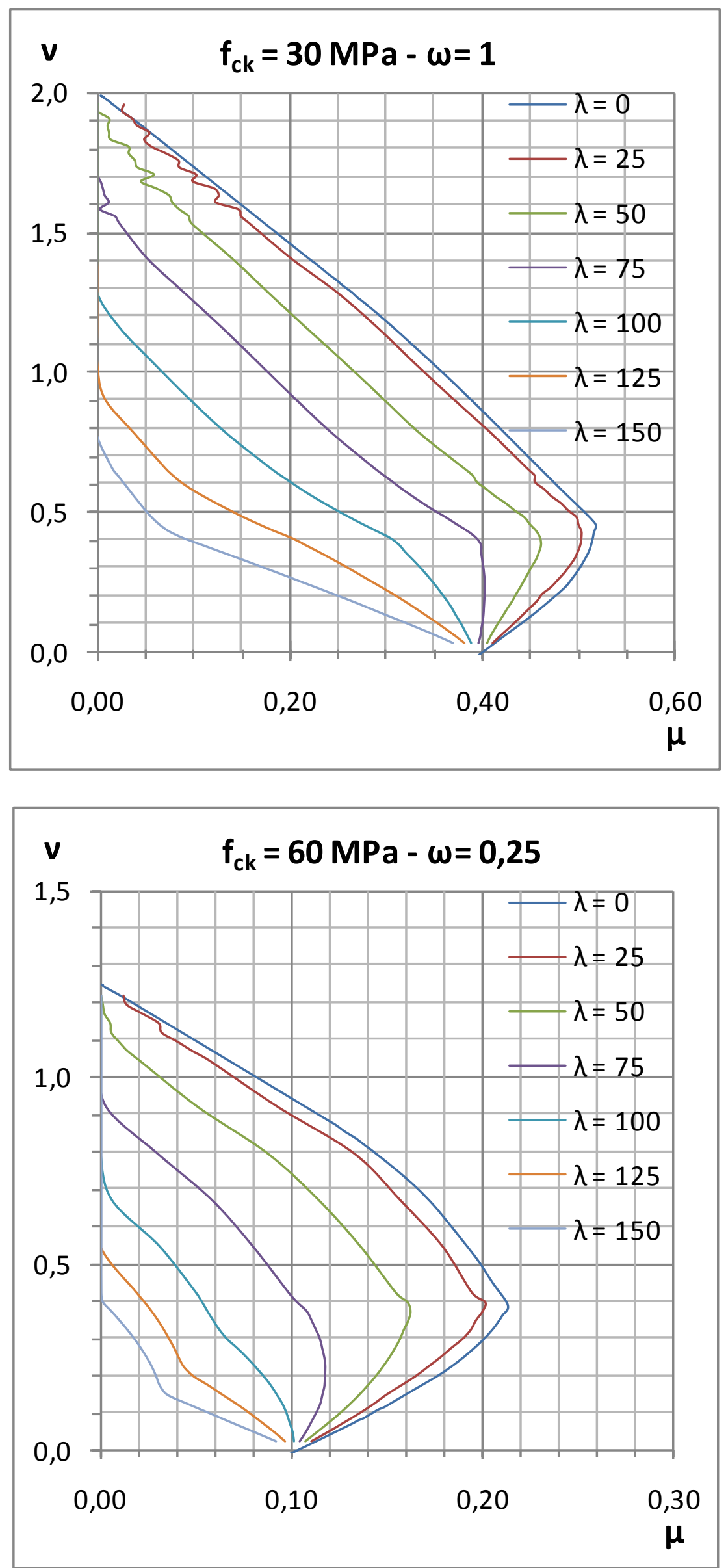

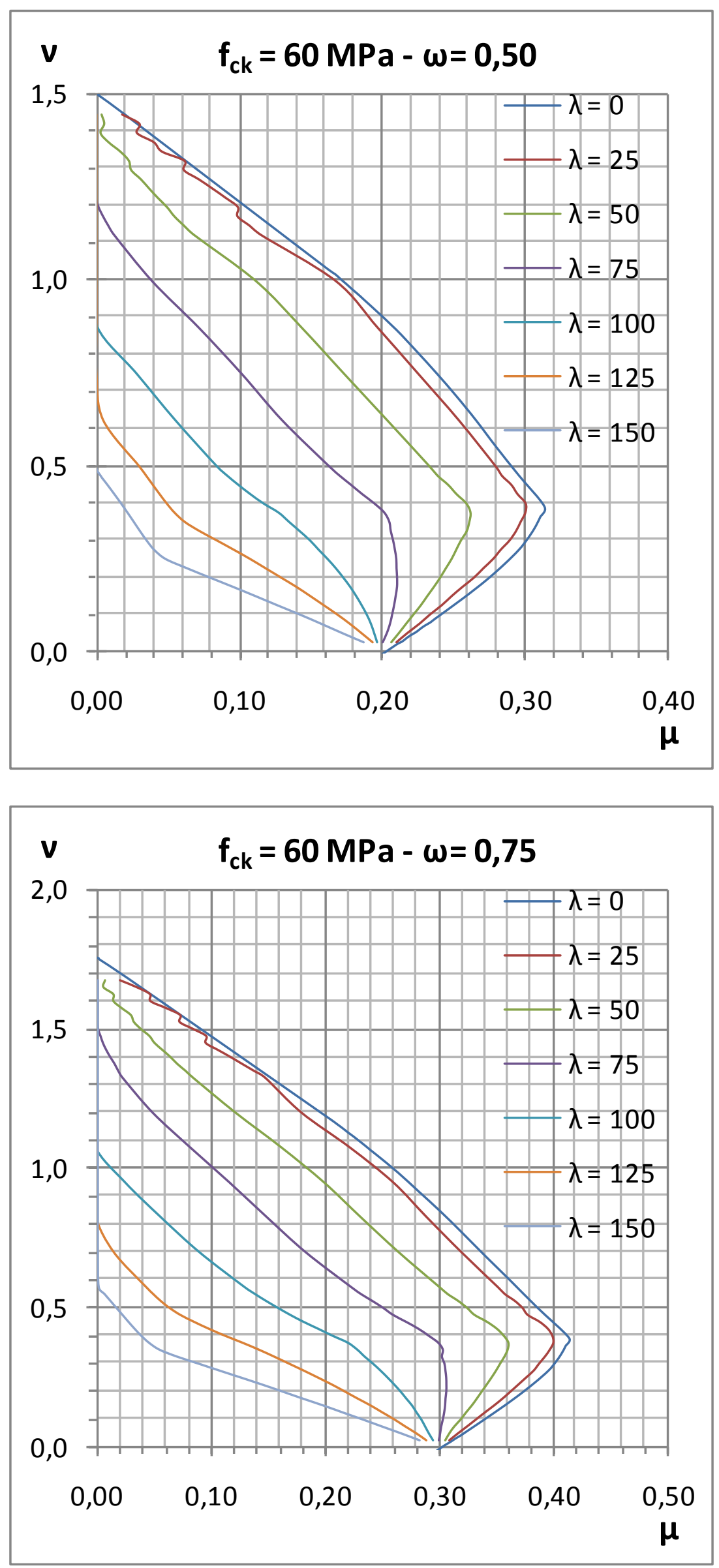

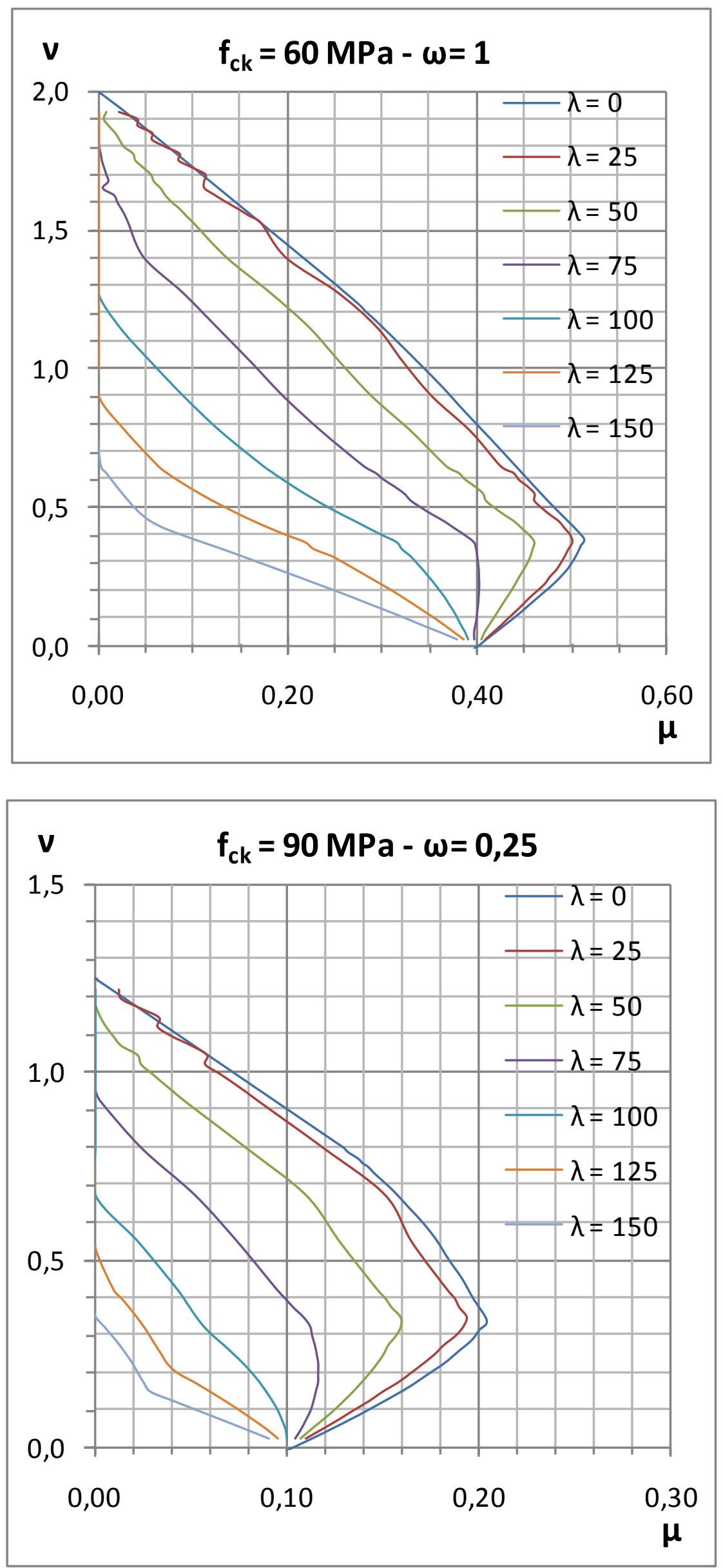

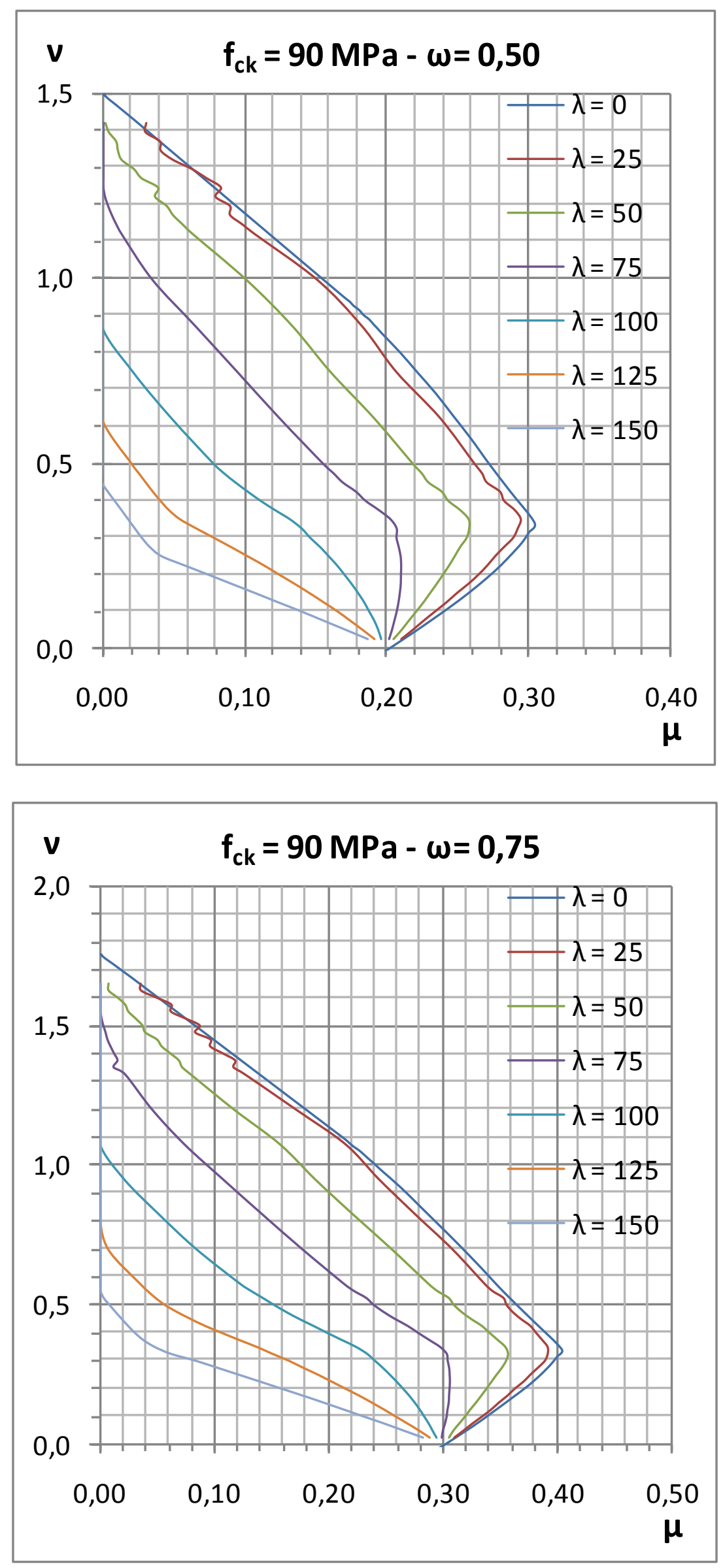


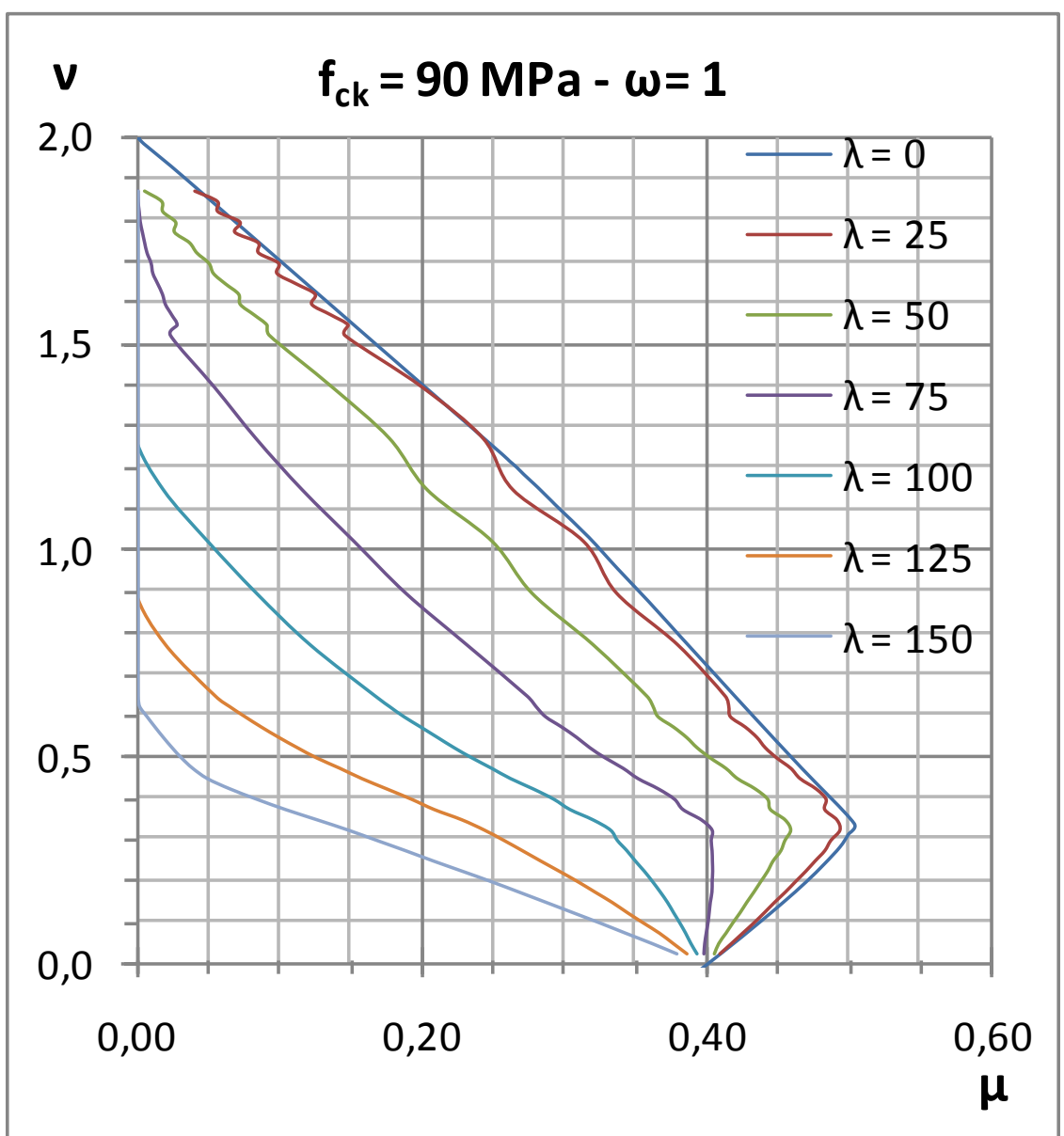




\section{ANEXO G - APLICAÇÃO DOS DIAGRAMAS MOMENTO- CURVATURA E FORÇA AXIAL-MOMENTO A UM EXEMPLO DE DIMENSIONAMENTO}

$\mathrm{N}_{\mathrm{d}}=1900 \mathrm{kN}$

$\mathrm{M}_{\mathrm{d}}=100 \mathrm{kN} \cdot \mathrm{m}$

$\mathrm{L}_{\mathrm{e}}=550 \mathrm{~cm}$

$\mathrm{f}_{\mathrm{ck}}=60 \mathrm{MPa}$

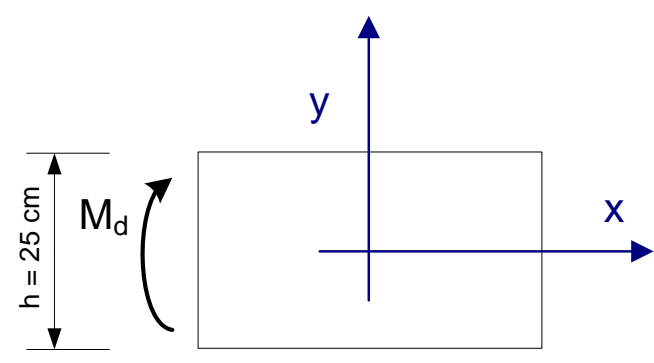

$\mathrm{f}_{\mathrm{yk}}=500 \mathrm{MPa}$

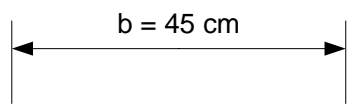

Cobrimento $=2,0 \mathrm{~cm}$ (classe de agressividade I com controle rigoroso do projeto e execução)

Cobrimento mecânico $\left(\mathrm{d}^{\prime}\right) \approx 4 \mathrm{~cm}$

Cobrimento mecânico reduzido $\left(\delta=\frac{d^{\prime}}{h}\right) \quad \delta \approx 0,15$

Supondo que o momento $\mathrm{M}_{\mathrm{d}}$ e a força axial $\mathrm{N}_{\mathrm{d}}$ correspondem à situação mais crítica de projeto e de cálculo

- Esbeltez em relação ao eixo x (na direção da flexão)

$$
\begin{aligned}
& \lambda_{x}=\frac{L_{e}}{0,29 \times h} \\
& \lambda_{\mathrm{x}} \approx 75
\end{aligned}
$$

- Esforços solicitantes reduzidos (momento de $1^{\mathrm{a}}$ ordem e força axial).

$$
\begin{array}{ccc}
\mu=\frac{M_{d}}{\sigma_{c d} \times b \times h^{2}} \quad \mu=0,105 & \nu=\frac{N_{d}}{\sigma_{c d} \times b \times h} \quad v \approx 0,5 \\
\sigma_{c d}=0,85 \times \frac{f_{c k}}{\gamma_{c}} & \sigma_{c d}=34 . M P a & f_{y d}=\frac{f_{y k}}{\gamma_{s}} \quad f_{y d}=434,8 . M P a
\end{array}
$$

1) Método simplificado do pilar padrão acoplado ao diagrama momento-curvatura (é possível empregar este método porque a esbeltez é menor do que 90).

O momento de $2^{\mathrm{a}}$ ordem reduzido pode ser calculado por: 
$\mu_{2}=v \times \frac{L_{e}{ }^{2}}{\pi^{2}} \times \frac{\theta / 1000}{h^{2}}$

Adotando a curvatura $\theta$ como $4 \%$.

$\mu_{2}=0,098$

Foi necessário construir um novo gráfico momento-curvatura para um cobrimento mecânico reduzido $\delta=0,15$ (porque os do Anexo E correspondem a um $\delta=0,1$ ), uma força axial reduzida de $v=0,5$, e uma resistência característica do concreto $\mathrm{f}_{\mathrm{ck}}=60 \mathrm{MPa}$. Considerado o valor da curvatura adotada $\theta=4 \%$ e com o valor de $\mu_{2}=0,098$, foi procurado o valor de $\omega$.

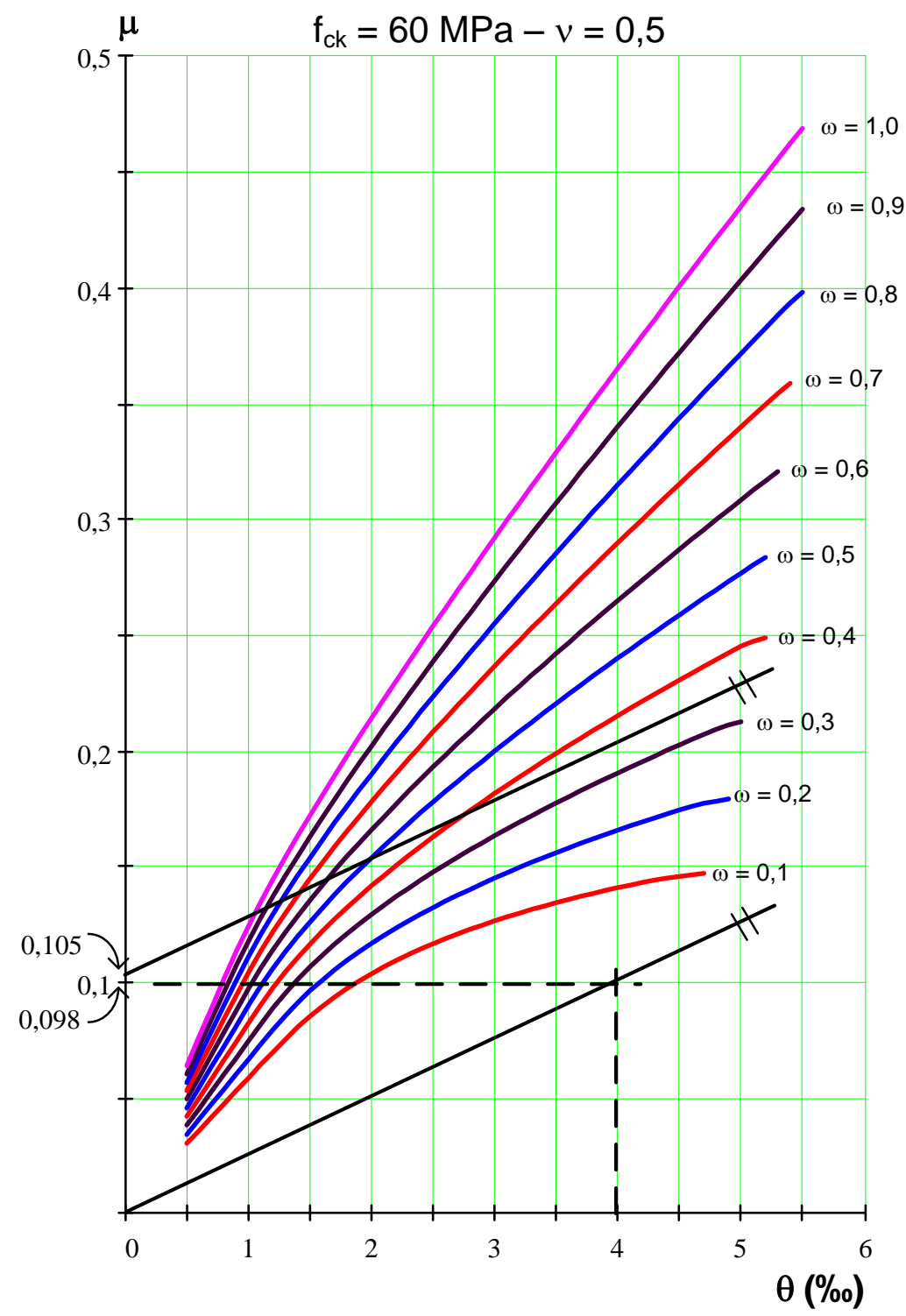

Pelo gráfico momento-curvatura, o valor encontrado para a taxa mecânica $\omega$ da armadura longitudinal varia entre 0,30 a 0,40. Para encontrar o valor mais realista será 
construído um gráfico de esforço axial-momento fletor com o modelo do Método Geral, considerando a esbeltez do problema $(\lambda=75)$ e um cobrimento mecânico $\delta=0,15$.

2) Método exato empregando o diagrama força axial-momento considerando o modelo do

\section{Método Geral.}

Considerando a esbeltez $\lambda=75$, resistência característica do concreto fck $=60 \mathrm{MPa} e$ cobrimento mecânico reduzido $\delta=0,15$, foi elaborado um gráfico para distintas taxas mecânicas e foram interpolados os esforços solicitantes reduzidos $v=0,5$ e $\mu=0,105$.

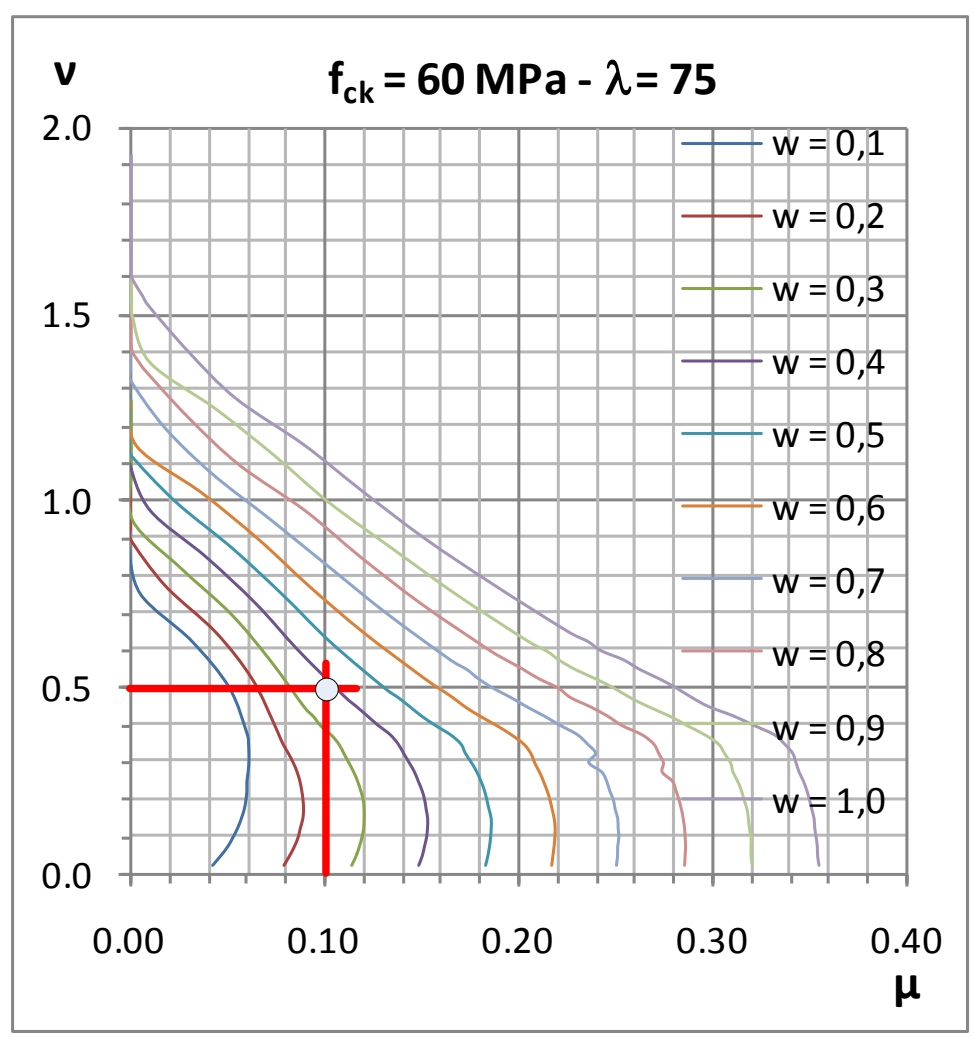

Pela figura anterior é possível verificar que a taxa mecânica $\omega$ está mais perto de 0,4 . Foi elaborado outro gráfico para a taxa mecânica de $\omega=0,38$ e para diferentes esbeltezes. 


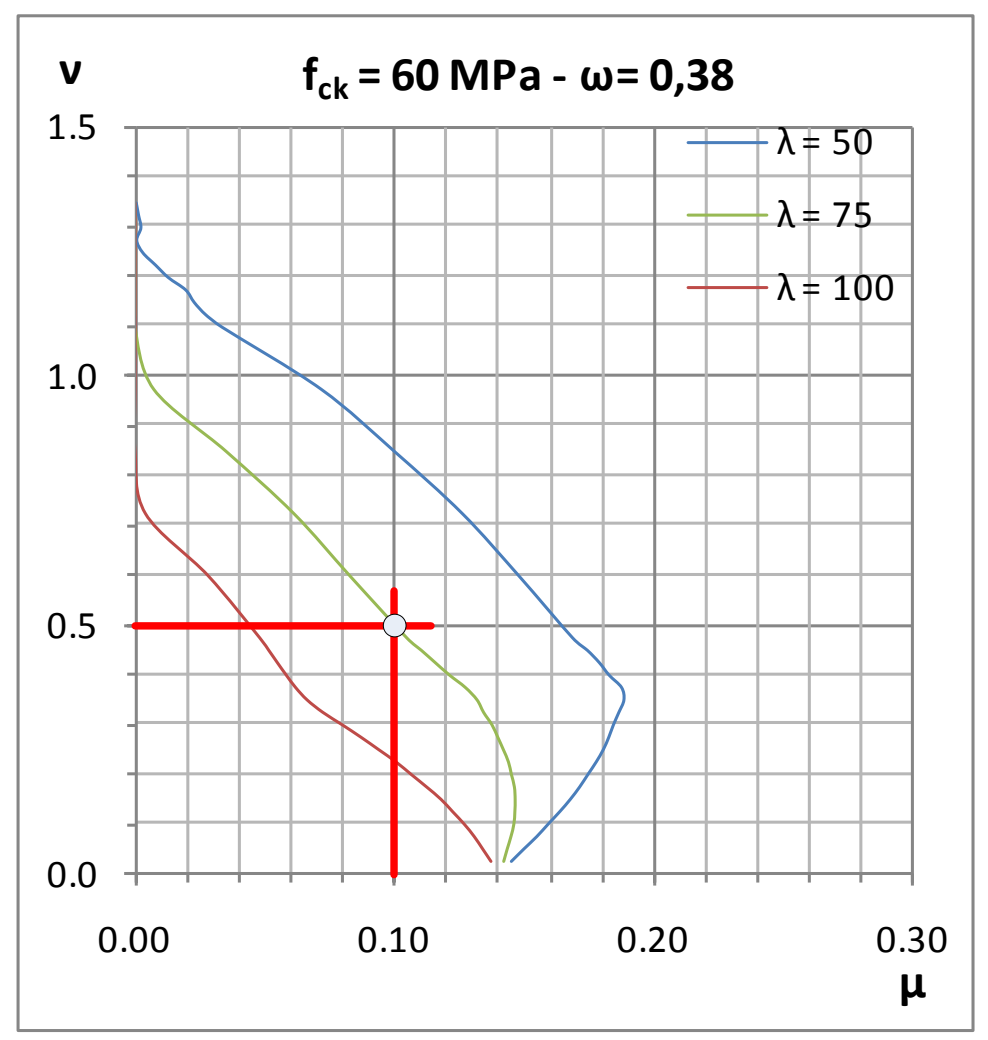

Com o gráfico da figura anterior foi verificado que para a esbeltez mecânica $\lambda=75 \mathrm{a}$ taxa mecânica de $\omega=0,38$ é satisfatória, sendo que o dimensionamento (não é verificação) com o MG foi imediato e seguro e inclui os modelos realistas do diagrama $\sigma_{\mathrm{c}} \mathrm{x} \varepsilon_{\mathrm{c}}$ do concreto. $\mathrm{O}$ valor achado se encontra dentro dos valores do método simplificado. Considerando a taxa mecânica obtida, a área da armadura longitudinal correspondente é calculada por:

$$
A_{s}=\frac{\omega \times b \times h \times \sigma_{c d}}{f_{y d}}
$$

$\mathrm{A}_{\mathrm{s}}=33,43 \mathrm{~cm}^{2}$, que pode ser coberta por $8 \Phi 25 \mathrm{~mm}$. Com esta área a taxa geométrica de armadura longitudinal corresponde a 3,5\%.

O esquema do armado corresponde ao da figura a seguir, sem considerar outras disposições construtivas e normativas. 
$8 \Phi 25 \mathrm{~mm}$
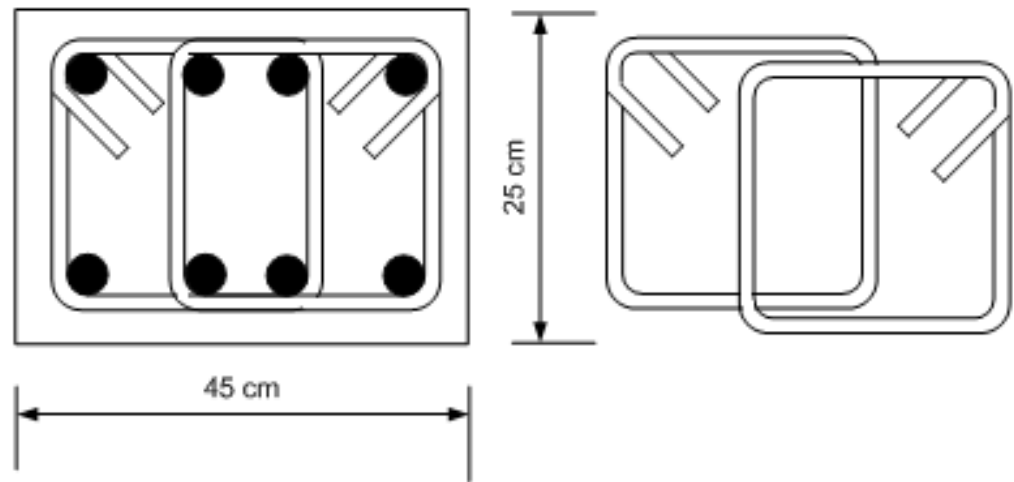

$A_{\mathrm{s}}$ transversal - $\Phi 8 @ 20 \mathrm{~cm}$

Neste exemplo, os gráficos de dimensionamento momento-curvatura e esforço axialmomento foram obtidos sem considerar o confinamento. Para efeitos de comparação será analisado o confinamento que provem da armadura transversal do pilar detalhado na figura anterior, neste pilar: o espaçamento da armadura transversal é $\mathrm{s}_{\mathrm{e}}=20 \mathrm{~cm}$, a área de armadura transversal na direção x e y correspondem a $A_{s w x}=1,39 \mathrm{~cm}^{2}$ e $A_{s w y}=2,0 \mathrm{~cm}^{2}$ e a taxa volumétrica de armadura transversal é $\rho_{\mathrm{sw}}=0,59 \%$. Com estes dados foi calculado o índice de confinamento efetivo (Eq. 3.35) como $\mathrm{I}_{\mathrm{e}}=0,49 \%$, que corresponde a um baixo grau de confinamento (para espaçamento entre estribos $s_{e}=10 \mathrm{~cm} \mathrm{o} I_{e}=3,23 \%$, e continua com um baixo grau de confinamento). Como anteriormente concluído, para situações com baixo grau de confinamento, a influencia deste na ductilidade e no incremento da resistência do pilar é muito pequeno, e considera-se prudente não incluir o efeito do confinamento no dimensionamento. 


\section{ANEXO H - PROGRAMA PILCON_MG: CALCULA UM PONTO DO GRÁFICO FORÇA-DESLOCAMENTO \\ LATERAL, ELABORADO COM O MATH-CAD V.14}

CONSTRUÇÄO DE UM PONTO DO GRÁFICO FORÇA AXIAL-DESLOCAMENTO LATERAL DO MÉTODO GERAL - REALISTA - EUROCODE - CONFINADO

\section{MATERIAIS}

CONCRETO $c=$ cobrimento da armadura transversa, a direçẫo $\times$ será da base do pilar

$\mathrm{f}_{\mathrm{c}}:=94.8 \cdot \mathrm{MPa}$

$$
\mathrm{h}_{\mathrm{x}}:=20 \cdot \mathrm{cm} \quad \mathrm{h}_{\mathrm{y}}:=12 \cdot \mathrm{cm} \quad \mathrm{A}_{\mathrm{c}}:=\mathrm{h}_{\mathrm{x}} \cdot \mathrm{h}_{\mathrm{y}} \quad \mathrm{c}:=2 \cdot \mathrm{cm} \quad \mathrm{A}_{\mathrm{c}}=240 \cdot \mathrm{cm}^{2}
$$

ARMADURA LONGITUDINAL

$$
\begin{array}{ccc}
\mathrm{f}_{\mathrm{y}}:=585 \cdot \mathrm{MPa} & \mathrm{A}_{\mathrm{s}}:=4.9 \cdot \mathrm{cm}^{2} \quad \mathrm{E}_{\mathrm{s}}:=200000 \cdot \mathrm{MPa} & \varepsilon_{\mathrm{y}}:=\frac{\mathrm{f}_{\mathrm{y}}}{\mathrm{E}_{\mathrm{s}}} \\
\varepsilon_{\mathrm{y}}=2.925 \cdot \frac{\mathrm{mm}}{\mathrm{m}} & \omega:=\frac{\mathrm{A}_{\mathrm{s}} \cdot \mathrm{f}_{\mathrm{y}}}{\mathrm{A}_{\mathrm{c}} \cdot \mathrm{f}_{\mathrm{c}}} & \omega=0.126
\end{array}
$$

SOMA DOS QUADRADOS DOS ESPAÇOS LIVRES

ENTRE DUAS ARMADURAS LONGITUDINAIS

$\Sigma \omega 2:=320 \cdot \mathrm{cm}^{2}$

ARMADURA TRANSVERSAL

$$
\begin{array}{ccc}
\phi_{\mathrm{e}}:=6.3 \cdot \mathrm{mm} & \mathrm{s}_{\mathrm{e}}:=5 \cdot \mathrm{cm} \quad \mathrm{A}_{\mathrm{swx}}:=0.62 \cdot \mathrm{cm}^{2} \quad A_{\mathrm{swy}}:=0.62 \cdot \mathrm{cm}^{2} \\
\mathrm{f}_{\mathrm{yw}}:=620 \cdot \mathrm{MPa} & \varepsilon_{\mathrm{yw}}:=\frac{\mathrm{f}_{\mathrm{yw}}}{\mathrm{E}_{\mathrm{s}}} \quad \varepsilon_{\mathrm{yw}}=3.1 \cdot \frac{\mathrm{mm}}{\mathrm{m}} \quad \begin{array}{l}
\text { Aswé a armadura } \\
\text { transveral total nas } \\
\text { direçôes } \mathrm{x} \text { ou } \mathrm{y}
\end{array}
\end{array}
$$

DIMENSỖES DO NUCLEO DO PILAR (entre eixos do estribo)

$\mathrm{nc}_{\mathrm{x}}:=\mathrm{h}_{\mathrm{x}}-\phi_{\mathrm{e}}-2 \cdot \mathrm{c} \quad \mathrm{nc}_{\mathrm{y}}:=\mathrm{h}_{\mathrm{y}}-\phi_{\mathrm{e}}-2 \cdot \mathrm{c} \quad \mathrm{nc}_{\mathrm{x}}=15.37 \cdot \mathrm{cm} \quad \mathrm{nc}_{\mathrm{y}}=7.37 \cdot \mathrm{cm}$

TAXA DE ARMADURA TRANSVERSAL

$\rho_{w x}:=\frac{A_{s w x}}{s_{e} \cdot n c_{y}} \quad \rho_{w y}:=\frac{A_{s w y}}{s_{e} \cdot n c_{x}} \quad \rho_{w x}=1.682 \% \quad \rho_{w y}=0.807 . \%$

TAXA DE ARMADURA LONGITUDINAL EM RELAÇÃO AO NÚCLEO DO PILAR

$\rho_{\text {snc }}:=\frac{\mathrm{A}_{\mathrm{s}}}{\mathrm{nc}_{\mathrm{x}} \cdot \mathrm{nc}_{\mathrm{y}}} \quad \rho_{\text {snc }}=4.326 \%$ 
COEFICIENTE DE CONFINAMENTO EFETIVO

$$
\mathrm{K}_{\mathrm{e}}:=\frac{\left(1-\frac{\Sigma \omega 2}{6 \cdot \mathrm{nc}_{\mathrm{x}} \cdot \mathrm{nc}_{\mathrm{y}}}\right) \cdot\left(1-\frac{\mathrm{s}_{\mathrm{e}}-\phi_{\mathrm{e}}}{2 \cdot \mathrm{nc}_{\mathrm{x}}}\right) \cdot\left(1-\frac{\mathrm{s}_{\mathrm{e}}-\phi_{\mathrm{e}}}{2 \cdot \mathrm{nc}_{\mathrm{y}}}\right)}{1-\rho_{\text {snc }}} \quad \mathrm{K}_{\mathrm{e}}=0.334
$$

PARÂMETROS DAS EQUAÇÖES DO BULLETIM $228(58<\mathrm{fc}<108)$ E Do FIB-99 $(25<\mathrm{fc}<90$ - no programa para 25 e $58 \mathrm{MPa})$

\section{OBTENÇÄO DA DEFORMAÇÄO PÓS-PICO CORRESPONDENTE AO $50 \%$ DA TENSÄO MÁXIMA}

$$
t:=\mid \begin{aligned}
& 0.807 \cdot \frac{\mathrm{mm}}{\mathrm{m}} \text { if } \mathrm{f}_{\mathrm{c}}=58 \cdot \mathrm{MPa} \\
& 0.579 \cdot \frac{\mathrm{mm}}{\mathrm{m}} \text { if } \mathrm{f}_{\mathrm{c}}=68 \cdot \mathrm{MPa} \\
& 0.338 \cdot \frac{\mathrm{mm}}{\mathrm{m}} \text { if } \mathrm{f}_{\mathrm{c}}=78 \cdot \mathrm{MPa} \\
& 0.221 \cdot \frac{\mathrm{mm}}{\mathrm{m}} \text { if } \mathrm{f}_{\mathrm{c}}=88 \cdot \mathrm{MPa} \\
& 0.070 \cdot \frac{\mathrm{mm}}{\mathrm{m}} \text { if } \mathrm{f}_{\mathrm{c}}=98 \cdot \mathrm{MPa} \\
& 0.070 \cdot \frac{\mathrm{mm}}{\mathrm{m}} \text { if } \mathrm{f}_{\mathrm{c}}=98 \cdot \mathrm{MPa} \\
& 0.015 \cdot \frac{\mathrm{mm}}{\mathrm{m}} \text { if } \mathrm{f}_{\mathrm{c}}=108 \cdot \mathrm{MPa} \\
& {\left[\begin{array}{l}
\left.2.45-38 \cdot 10^{-3} \cdot \frac{\mathrm{f}_{\mathrm{c}}-8}{\mathrm{MPa}}+7.083 \cdot 10^{-5} \cdot\left(\frac{\mathrm{f}_{\mathrm{c}}-8}{\mathrm{MPa}}\right)^{2}+6.574 \cdot 10^{-7} \cdot\left(\frac{\mathrm{f}_{\mathrm{c}}-8}{\mathrm{MPa}}\right)^{3}\right] \cdot \frac{\mathrm{mm}}{\mathrm{m}} \text { otherwise }
\end{array}\right.}
\end{aligned}
$$

agregado := $3 \quad \begin{aligned} & 1 \text { agregado de quartzo, } 2 \text { agregado de pedra calcária, } \\ & 3 \text { agregado basaltico e } 4 \text { para agregado de arenito }\end{aligned}$

$\alpha_{\mathrm{a}}:=\mid \begin{aligned} & 1 \text { if agregado }=1 \\ & 0.9 \text { if agregado }=2 \\ & 1.2 \text { if agregado }=3 \\ & 0.7 \text { if agregado }=4\end{aligned}$ 


$$
\begin{aligned}
& \text { Par_B228_FIB(n) }:=\mid \text { if } f_{c} \geq 58 \mathrm{MPa} \\
& \mid \begin{array}{l}
\mathrm{E}_{\mathrm{ci}} \leftarrow \alpha_{\mathrm{a}} \cdot 22000 \cdot\left(\frac{\mathrm{f}_{\mathrm{c}}}{\mathrm{MPa}}\right)^{0.3} \cdot \mathrm{MPa} \\
\varepsilon_{\mathrm{c} 1} \leftarrow 0.0007 \cdot\left(\frac{\mathrm{f}_{\mathrm{c}}}{\mathrm{MPa}}\right)^{0.31}
\end{array} \\
& \begin{array}{l}
\text { if } \mathrm{f}_{\mathrm{c}}<58 \cdot \mathrm{MPa} \\
\mathrm{E}_{\mathrm{ci}} \leftarrow \alpha_{\mathrm{a}} \cdot 21500 \cdot\left(\frac{\frac{\mathrm{f}_{\mathrm{c}}}{\mathrm{MPa}}}{10}\right)^{\frac{1}{3}} \cdot \mathrm{MPa} \\
\varepsilon_{\mathrm{c} 1} \leftarrow 0.0017+0.001 \cdot \frac{\mathrm{f}_{\mathrm{c}}}{70 \cdot \mathrm{MPa}}
\end{array} \\
& E_{\mathrm{c} 1} \leftarrow \frac{\left(\frac{f_{c}}{M P a}\right) \cdot M P a}{\varepsilon_{c 1}}
\end{aligned}
$$

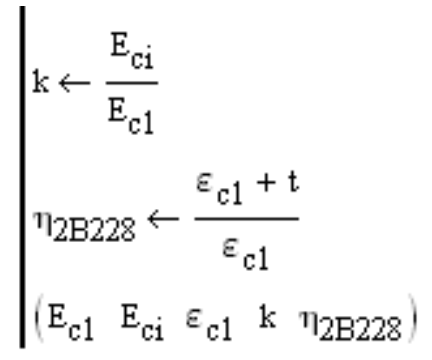

graf $:=$ Par_B228_FIB(O)

$$
\begin{array}{ccll}
\mathrm{E}_{\mathrm{c} 1}:=\mathrm{graf}_{0,0} \quad \mathrm{E}_{\mathrm{ci}}:=\mathrm{graf}_{0,1} \quad \varepsilon_{\mathrm{c} 1}:=\mathrm{graf}_{0,2} & \mathrm{k}:=\mathrm{graf}_{0,3} & \eta_{2}:=\mathrm{graf}_{0,4} \\
\mathrm{E}_{\mathrm{c} 1}=33029.33 \cdot \mathrm{MPa} & \mathrm{E}_{\mathrm{ci}}=51837.78 \cdot \mathrm{MPa} & \varepsilon_{\mathrm{c} 1}=2.8702 \cdot \frac{\mathrm{mm}}{\mathrm{m}} & \mathrm{k}=1.569
\end{array}
$$


EQUAÇÖES $\sigma_{\odot} \times z_{\odot}$ DO CONCRETO NÄO CONFINADO

(A PRIMEIRA DO TRAMO DESCENDENTE É DO B228 E A SEGUNDA DO FIB)

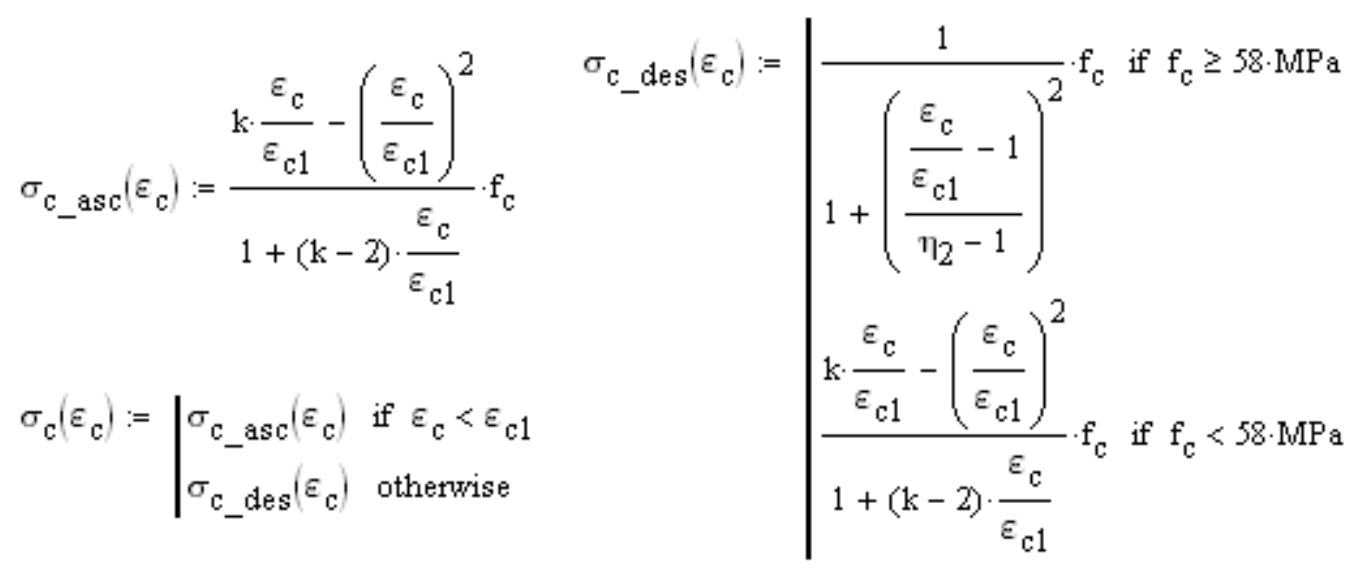

CÁlCULO DA DEFORMAÇÄO PÓS PICO CORRESPONDENTE AO 50\% DA TENSÄO PICO

$$
\begin{aligned}
& \operatorname{aux}:=\mathrm{k}-\frac{0.5 \cdot \sigma_{\mathrm{c}}\left(\varepsilon_{\mathrm{c} 1}\right)}{\mathrm{f}_{\mathrm{c}}} \cdot(\mathrm{k}-2)
\end{aligned}
$$

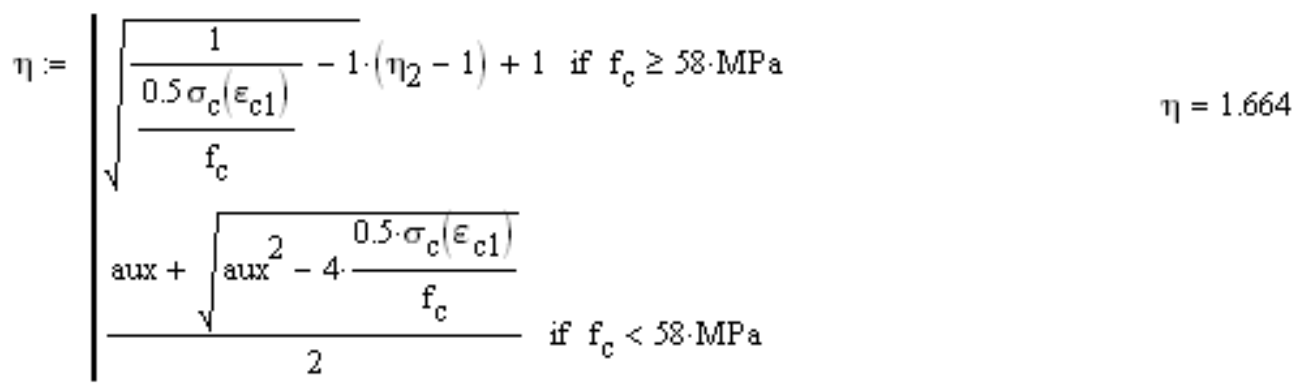

$$
\begin{aligned}
& \varepsilon_{\mathrm{c}_{-} 50}:=\eta \cdot \varepsilon_{\mathrm{c} 1} \quad \varepsilon_{\mathrm{c}_{-} 50}=4.775 \cdot \frac{\mathrm{mm}}{\mathrm{m}}
\end{aligned}
$$


PARÂMETROS DO MODELO DE LÉGERON-PAULTRE (2003)

ii $:=0$

$$
\begin{aligned}
& \text { Par_LP(ii) }:=\mid \text { for } i \in 0 . \text { ii } \\
& \mid \begin{array}{l}
\rho_{w_{-} e} \leftarrow K_{e} \cdot\left(\rho_{w x}+\rho_{w y}\right. \\
\kappa \leftarrow \frac{f_{c}}{\rho_{w_{-}} e^{\cdot E_{s} \cdot \varepsilon_{c 1}}} \\
\sigma_{s w} \leftarrow f_{y w} \text { if } k \leq 10
\end{array} \\
& \text { if } \kappa>10 \\
& \mid \sigma_{\text {SW_aux }} \leftarrow \frac{0.25 \cdot \frac{f_{c}}{M P a}}{P_{W_{-}} e^{\cdot(k-10)}} \cdot M P a \\
& \begin{array}{l}
\sigma_{\text {sw }} \leftarrow \mathrm{f}_{\mathrm{yw}} \text { if } \sigma_{\text {sw_aux }} \geq \mathrm{f}_{\mathrm{yw}} \\
\sigma_{\text {sw }} \leftarrow \sigma_{\text {sw aux }} \text { otherwise }
\end{array} \\
& \sigma_{\text {con_e }} \leftarrow \rho_{w_{-}} \cdot \sigma_{s w} \\
& \mathrm{I}_{\mathrm{e}} \leftarrow \frac{\sigma_{\text {con_e }}}{\mathrm{f}_{\mathrm{c}}} \\
& \mathrm{f}_{\mathrm{cc}} \leftarrow \mathrm{f}_{\mathrm{c}} \cdot\left(1+2.4 \cdot \mathrm{I}_{\mathrm{e}}^{0.7}\right)
\end{aligned}
$$

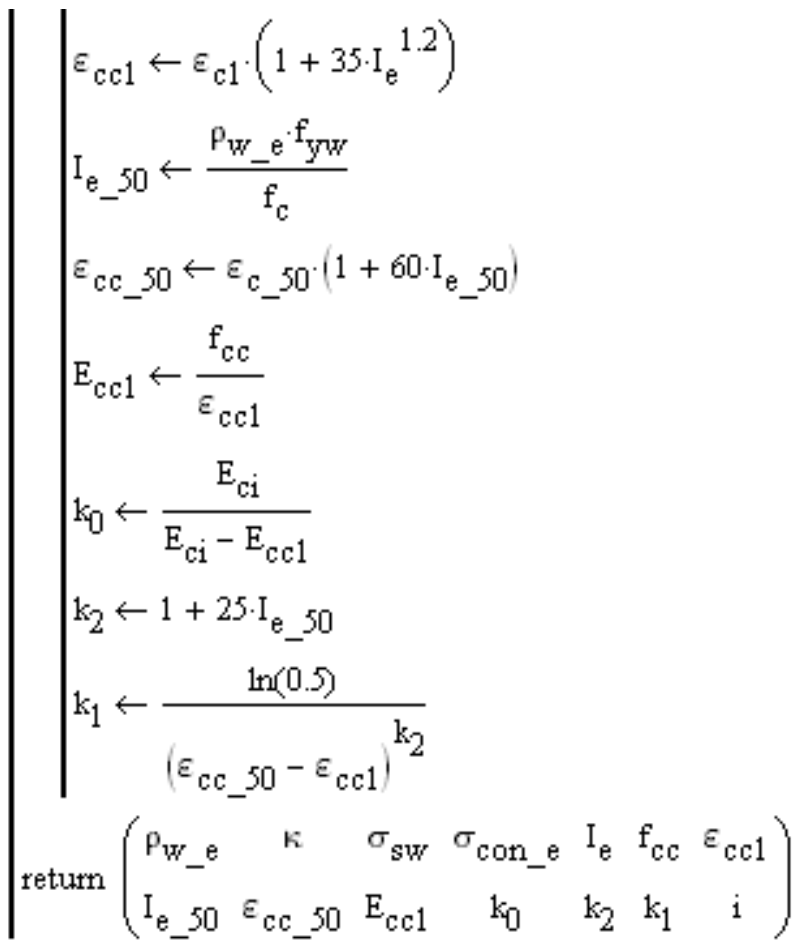




$$
\begin{aligned}
& L P:=P a{ }_{-} L P(i i) \\
& \rho_{W_{-} \mathrm{e}}:=\mathrm{LP}_{0,0} \quad \kappa:=\mathrm{LP}_{0,1} \quad \sigma_{\mathrm{sw}}:=\mathrm{LP}_{0,2} \quad \sigma_{\text {con_e }}:=\mathrm{LP}_{0,3} \quad \mathrm{I}_{\mathrm{e}}:=\mathrm{LP}_{0,4} \\
& \mathrm{f}_{\mathrm{cc}}:=\mathrm{LP}_{0,5} \quad \varepsilon_{\mathrm{cc} 1}:=\mathrm{LP}_{0,6} \quad \mathrm{I}_{\mathrm{e}_{-} 50}:=\mathrm{LP}_{1,0} \quad \varepsilon_{\mathrm{cc}_{-} 50}:=\mathrm{LP}_{1,1} \quad \mathrm{E}_{\mathrm{cc} 1}:=\mathrm{LP}_{1,2} \\
& k_{0}:=\mathrm{LP}_{1,3} \quad \mathrm{k}_{2}:=\mathrm{LP}_{1,4} \quad \mathrm{k}_{1}:=\mathrm{LP}_{1,5} \quad \text { armados }:=\mathrm{LP}_{1,6} \\
& \rho_{W_{-} e}=0.4155 \% \quad \kappa=39.75 \quad \sigma_{s W}=191.747 \cdot \mathrm{MPa} \quad \sigma_{\text {con_e }}=0.797 \cdot \mathrm{MPa} \quad I_{\mathrm{e}}=0.84 \% \\
& \mathrm{f}_{\mathrm{cc}}=102.82 \mathrm{MPa} \quad \varepsilon_{\mathrm{cc} 1}=3.19 \cdot \frac{\mathrm{mm}}{\mathrm{m}} \quad \mathrm{I}_{\mathrm{e}_{-} 50}=2.72 \% \quad \varepsilon_{\mathrm{cc}_{-} 50}=12.56 \cdot \frac{\mathrm{mm}}{\mathrm{m}} \\
& \mathrm{E}_{\mathrm{cc} 1}=32183.768 \mathrm{MPa} \quad \mathrm{k}_{0}=2.638 \quad \mathrm{k}_{2}=1.679 \quad \mathrm{k}_{1}=-1766.76
\end{aligned}
$$

\section{LIMITES DO CONCRETO PELO EUROCODE}

$$
\begin{aligned}
& \varepsilon_{\text {culE }}:=\mid 3.5 \cdot \frac{\mathrm{mm}}{\mathrm{m}} \text { if } 20 \cdot \mathrm{MPa} \leq \mathrm{f}_{\mathrm{c}}<58 \cdot \mathrm{MPa} \quad \varepsilon_{\mathrm{culE}}=2.8 \cdot \frac{\mathrm{mm}}{\mathrm{m}}
\end{aligned}
$$

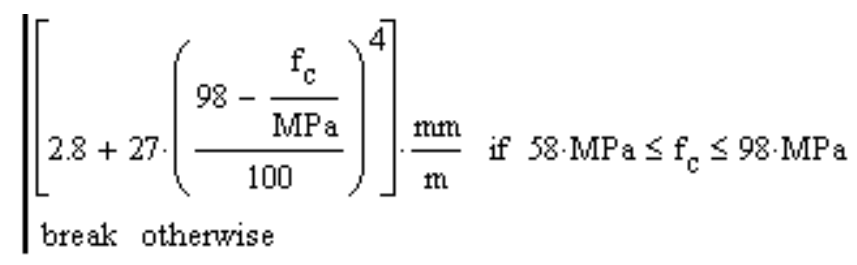

$$
\begin{aligned}
& \varepsilon_{\mathrm{c} 1 \mathrm{E}}:=\mid \begin{array}{l}
0.7 \cdot\left(\frac{\mathrm{f}_{\mathrm{c}}}{\mathrm{MPa}}\right)^{0.31} \cdot \frac{\mathrm{mm}}{\mathrm{m}} \text { if } \mathrm{f}_{\mathrm{c}}<87.5 \cdot \mathrm{MPa} \\
2.8 \cdot \frac{\mathrm{mm}}{\mathrm{m}} \text { otherwise }
\end{array} \quad \varepsilon_{\mathrm{c} 1 \mathrm{E}}=2.8 \cdot \frac{\mathrm{mm}}{\mathrm{m}}
\end{aligned}
$$

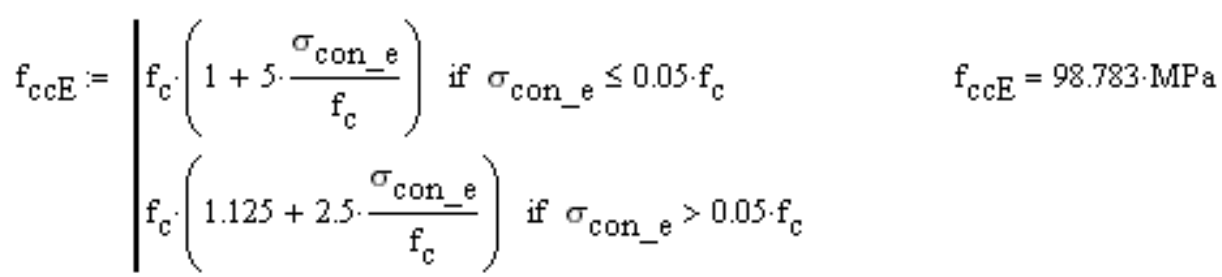$$
\varepsilon_{\mathrm{cc} 1 \mathrm{E}}:=\varepsilon_{\mathrm{c} 1 \mathrm{E}} \cdot\left(\frac{\mathrm{f}_{\mathrm{ccE}}}{\mathrm{f}_{\mathrm{c}}}\right)^{2} \quad \varepsilon_{\mathrm{cc} 1 \mathrm{E}}=3.04 \cdot \frac{\mathrm{mm}}{\mathrm{m}} \quad \varepsilon_{\mathrm{malh}}:=\varepsilon_{\mathrm{cc} 1 \mathrm{E}}
$$$$
\varepsilon_{\mathrm{ccu} 1 \mathrm{E}}:=\varepsilon_{\mathrm{culE}}+0.2 \frac{\sigma_{\text {con_e }}}{\mathrm{f}_{\mathrm{c}}} \quad \varepsilon_{\mathrm{ccu} 1 \mathrm{E}}=4.481 \cdot \frac{\mathrm{mm}}{\mathrm{m}} \quad \varepsilon_{\text {cul }}:=\varepsilon_{\mathrm{ccu} 1 \mathrm{E}}
$$ 
DADOS PARA A OBTENÇÄO DOS PARÂMETROS DA CURVA

FORÇA-DESLOCAMENTO LATERAL COM O MÉTODO GERAL

As1 e As2 são as áreas de aço de cada camada, contando de baixo para cima

$$
\begin{array}{llll}
\mathrm{A}_{\mathrm{s} 1}:=2.45 \cdot \mathrm{cm}^{2} & \rho_{1}:=\frac{\mathrm{A}_{\mathrm{s} 1}}{\mathrm{~A}_{\mathrm{c}}} \quad \rho_{1}=1.021 \% & \mathrm{~d}_{\mathrm{s} 1}:=8.6 \cdot \mathrm{cm} \\
\mathrm{A}_{\mathrm{s} 2}:=2.45 \cdot \mathrm{cm}^{2} & \rho_{2}:=\frac{\mathrm{A}_{\mathrm{s} 2}}{\mathrm{~A}_{\mathrm{c}}} \quad \rho_{2}=1.021 \% & \mathrm{~d}_{\mathrm{s} 2}:=3.4 \cdot \mathrm{cm} \\
\beta_{\mathrm{s} 1}:=\frac{\mathrm{d}_{\mathrm{s} 1}}{\mathrm{~h}_{\mathrm{y}}} & \beta_{\mathrm{s} 1}=0.717 \\
\beta_{\mathrm{s} 2}:=\frac{\mathrm{d}_{\mathrm{s} 2}}{\mathrm{~h}_{\mathrm{y}}} & \beta_{\mathrm{s} 2}=0.283
\end{array}
$$

DIMENSỖES E OUTRAS CARACTERÍSTICAS DO PILAR

$$
\begin{array}{cccc}
\mathrm{L}:=320 \cdot \mathrm{cm} & \text { div }:=20 & \mathrm{n}:=\frac{\mathrm{div}}{2} & \Delta \mathrm{L}:=\frac{\mathrm{L}}{\mathrm{div}} \\
\text { toler }:=0.5 \cdot \mathrm{mm} & \mathrm{e}_{0}:=3 \cdot \mathrm{cm} & \mathrm{e}_{2} \text { ini }:=0.1 \cdot \mathrm{cm} & \Delta \mathrm{e}_{2}:=1 \cdot \mathrm{cm}
\end{array}
$$

FORÇA MÁXIMA A COMPRESSAO SIMPLE

$$
\mathrm{N}_{\max }:=\mathrm{f}_{\mathrm{c}} \cdot\left(\mathrm{A}_{\mathrm{c}}-\mathrm{A}_{\mathrm{s} 1}-\mathrm{A}_{\mathrm{s} 2}\right)+\mathrm{f}_{\mathrm{y}} \cdot\left(\mathrm{A}_{\mathrm{s} 1}+\mathrm{A}_{\mathrm{s} 2}\right) \quad \mathrm{N}_{\max }=2515.4 \cdot \mathrm{kN}
$$

FORÇA INICIAL APLICADA

$$
\mathrm{N}_{\text {ini }}:=151 \cdot \mathrm{kN} \quad v_{\text {ini }}:=\frac{\mathrm{N}_{\text {ini }}}{\mathrm{A}_{\mathrm{c}} \cdot \mathrm{f}_{\mathrm{ccE}}} \quad v_{\text {ini }}=0.06369
$$

$\delta$ é a distancia da fibra extrema da seçẫo ao centroide das armaduras extremas, reduzida

$\delta:=0.27$

\section{PARÂMETROS DA CURVATURA E DEFORMAÇÄO MÁXIMA DO CONCRETO E AÇO}

$$
\begin{aligned}
& \varepsilon_{c_{-} \max \_ \text {ini }}:=0.01 \cdot \frac{\mathrm{mm}}{\mathrm{m}} \quad \mathrm{r}_{\text {ini }}:=\frac{1}{0.00000008} \cdot \mathrm{cm} \quad \theta_{\text {ini }}:=\frac{\mathrm{h}_{\mathrm{y}}}{\mathrm{r}_{\text {ini }}} \quad \theta_{\text {ini }}=0.001 \cdot \frac{\mathrm{mm}}{\mathrm{m}} \\
& \varepsilon s 1_{-} \text {ult }:=10 \cdot \frac{\mathrm{mmm}}{\mathrm{m}} \quad \theta_{\text {ult }}:=\frac{\varepsilon_{\mathrm{cul}}+\varepsilon s 1_{-} \text {ult }}{1-\delta} \quad \theta_{\text {ult }}=19.837 \cdot \frac{\mathrm{mm}}{\mathrm{m}}
\end{aligned}
$$


INÍCIO DAS INTERAÇÖES PARA A OBTENÇÄO DO GRÁFICO MOMENTO-CURVATURA E UM PONTO DO GRÁFICO FORÇA AXIAL-DESLOCAMENTO LATERAL DO MÉTODO GERAL

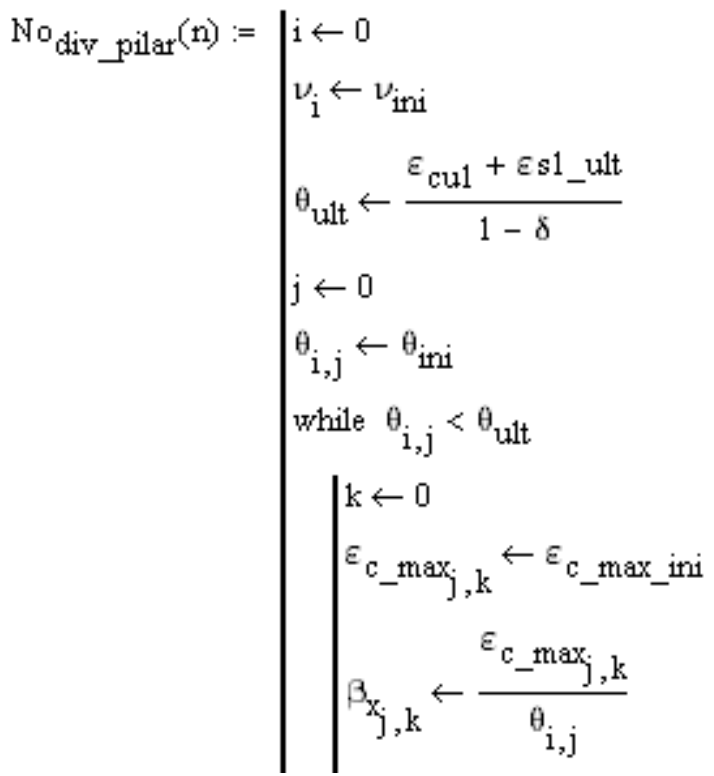

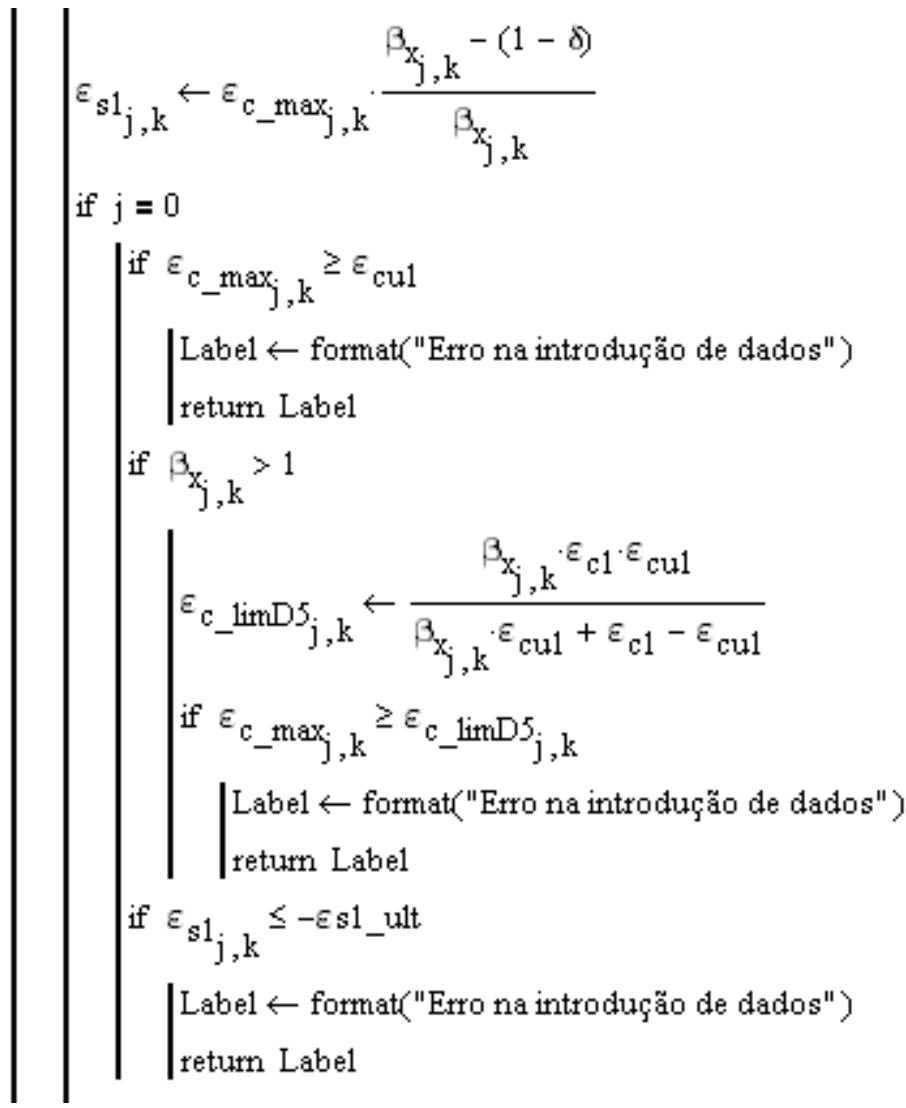


Anexos

305

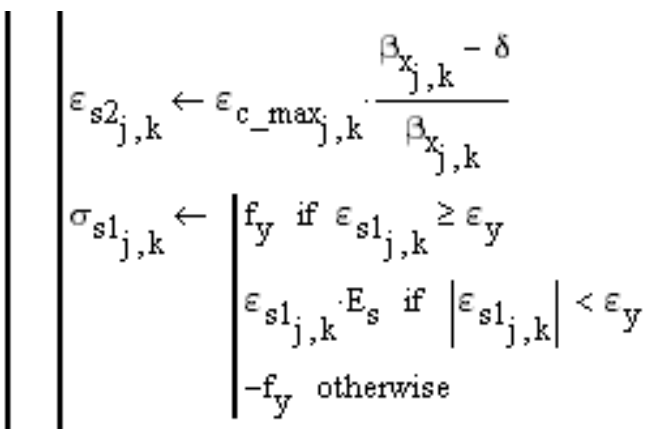

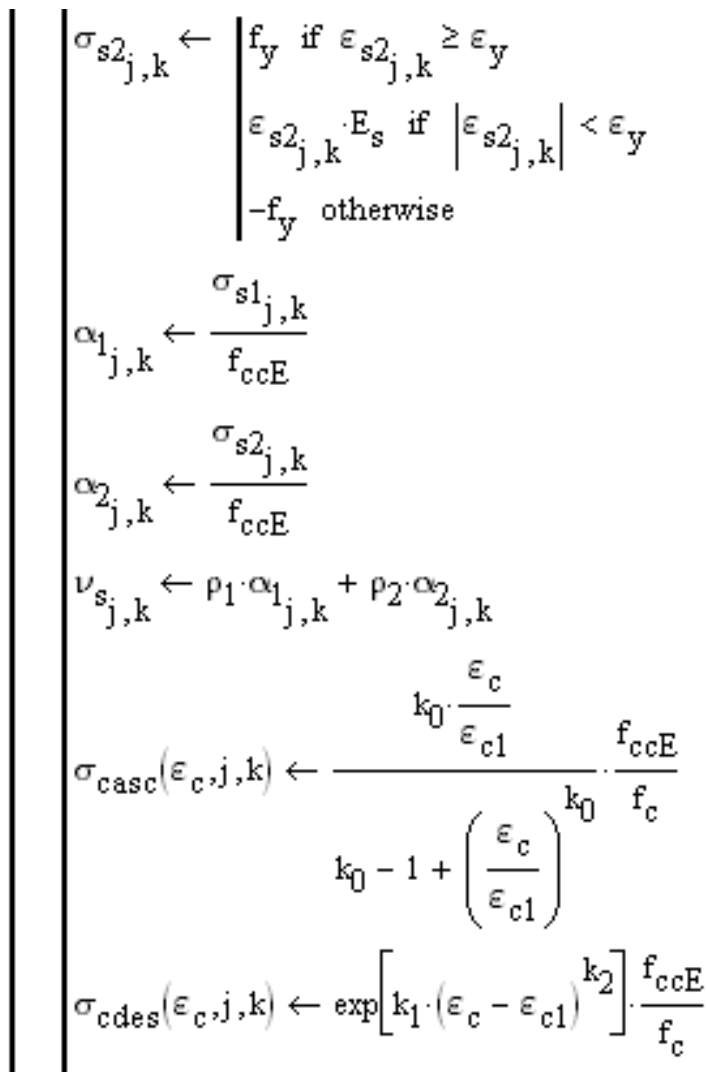




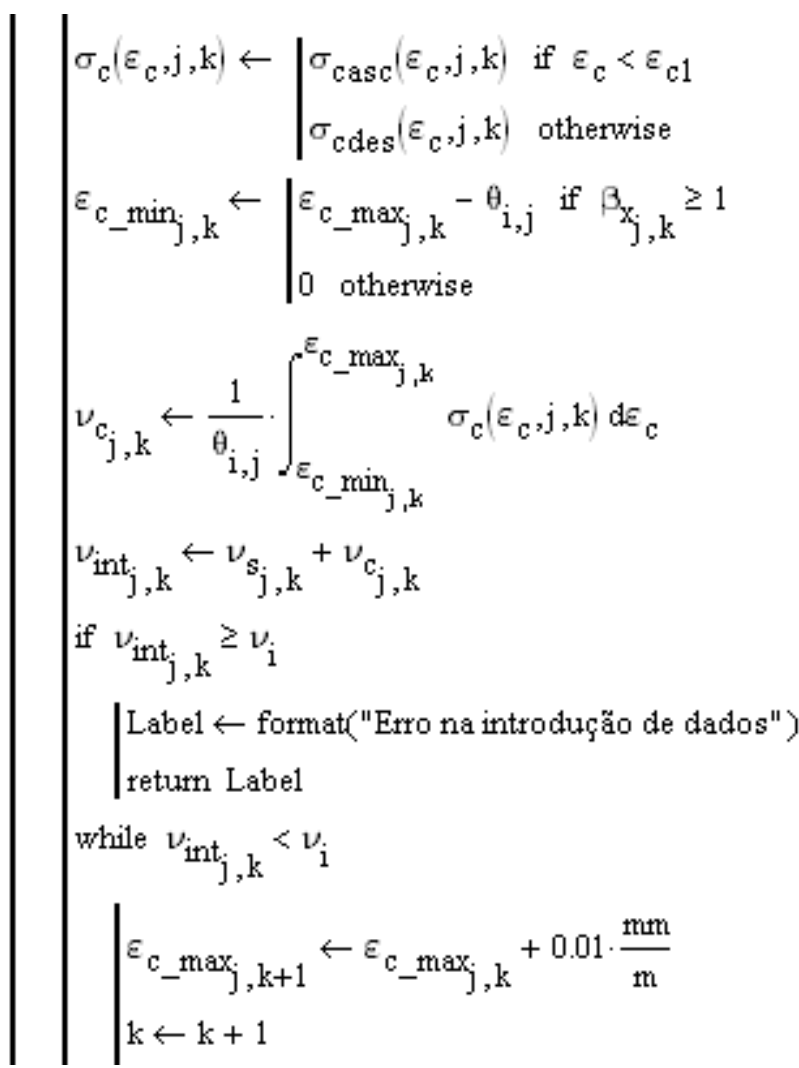

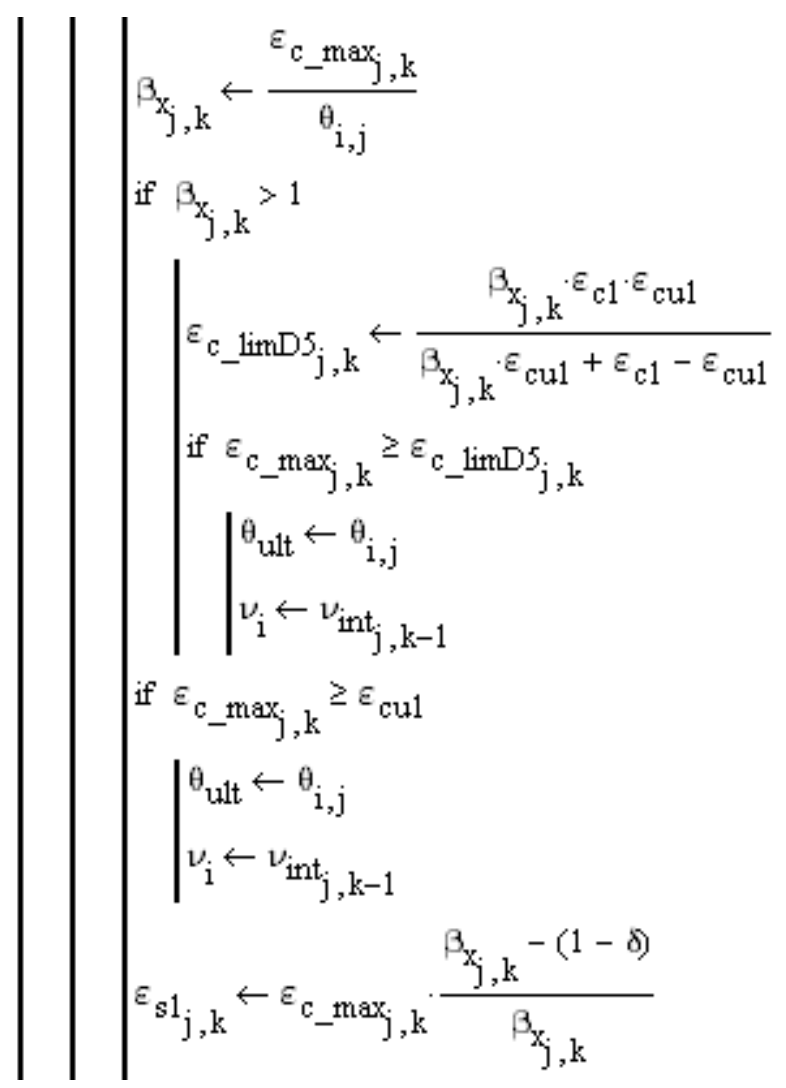




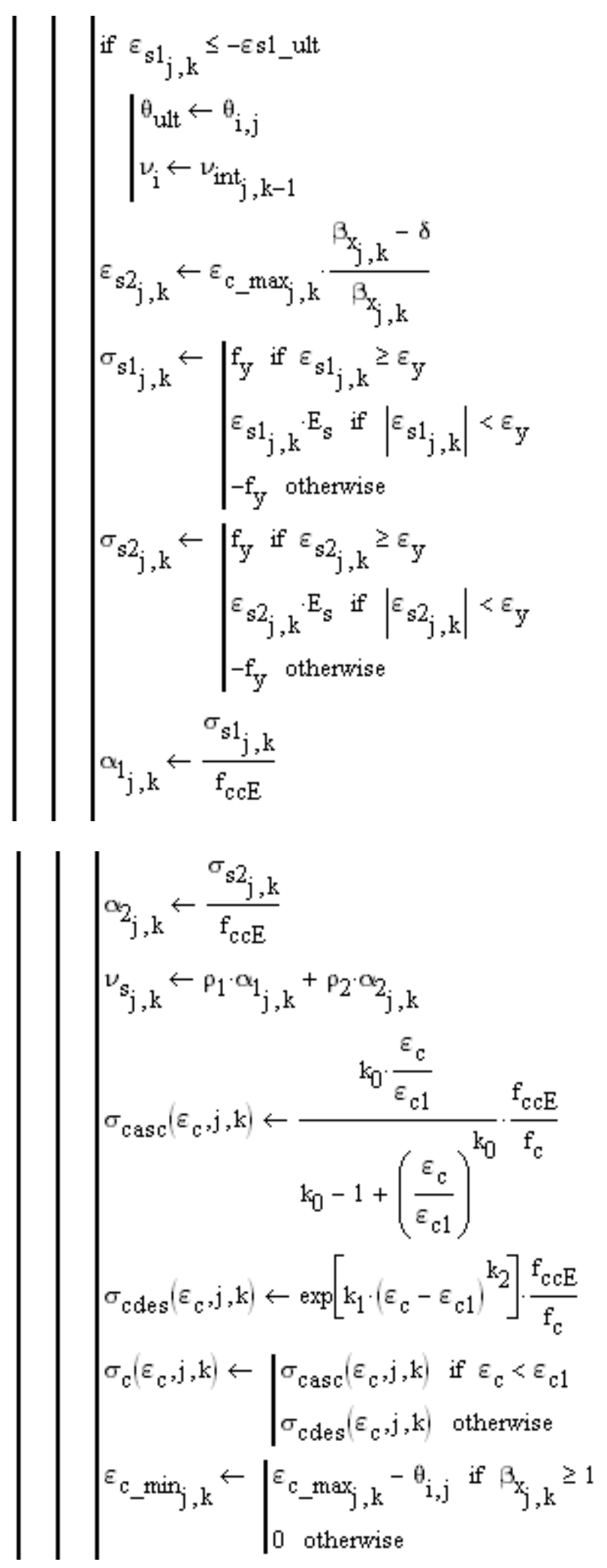




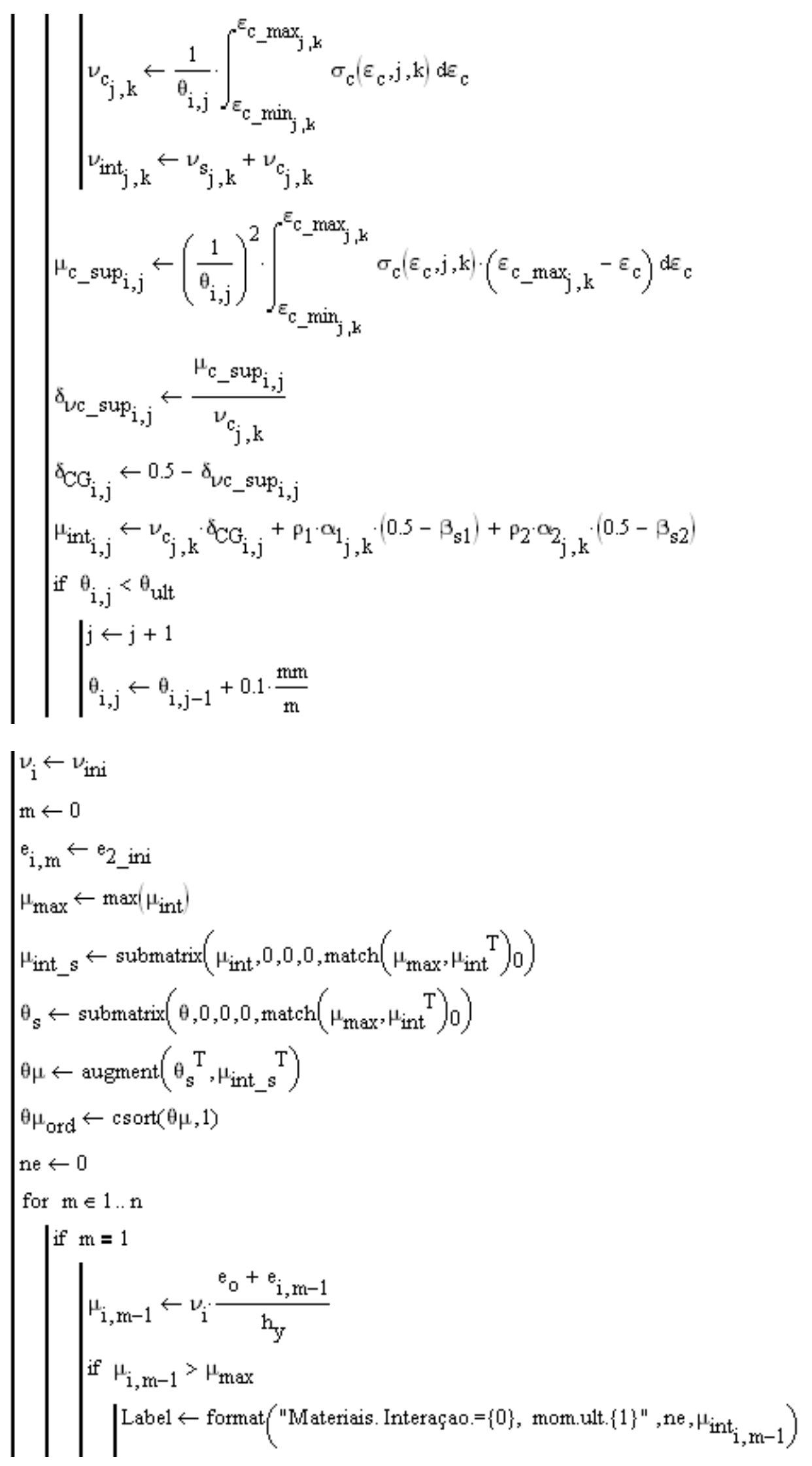




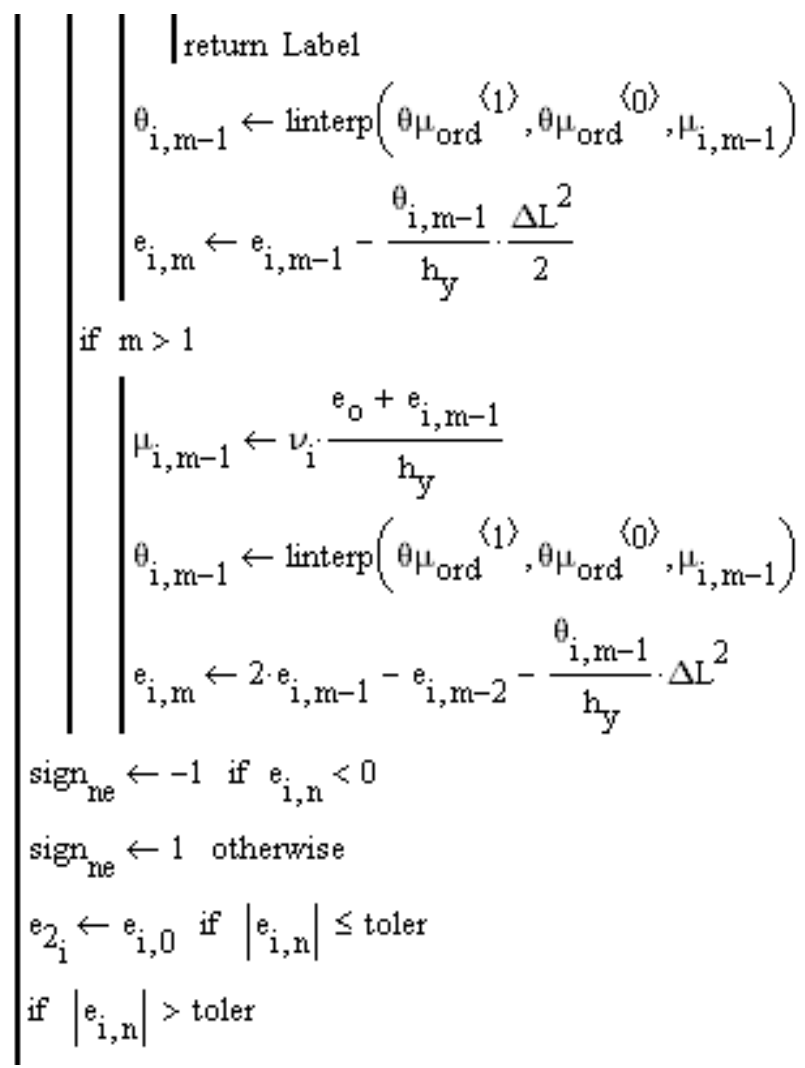

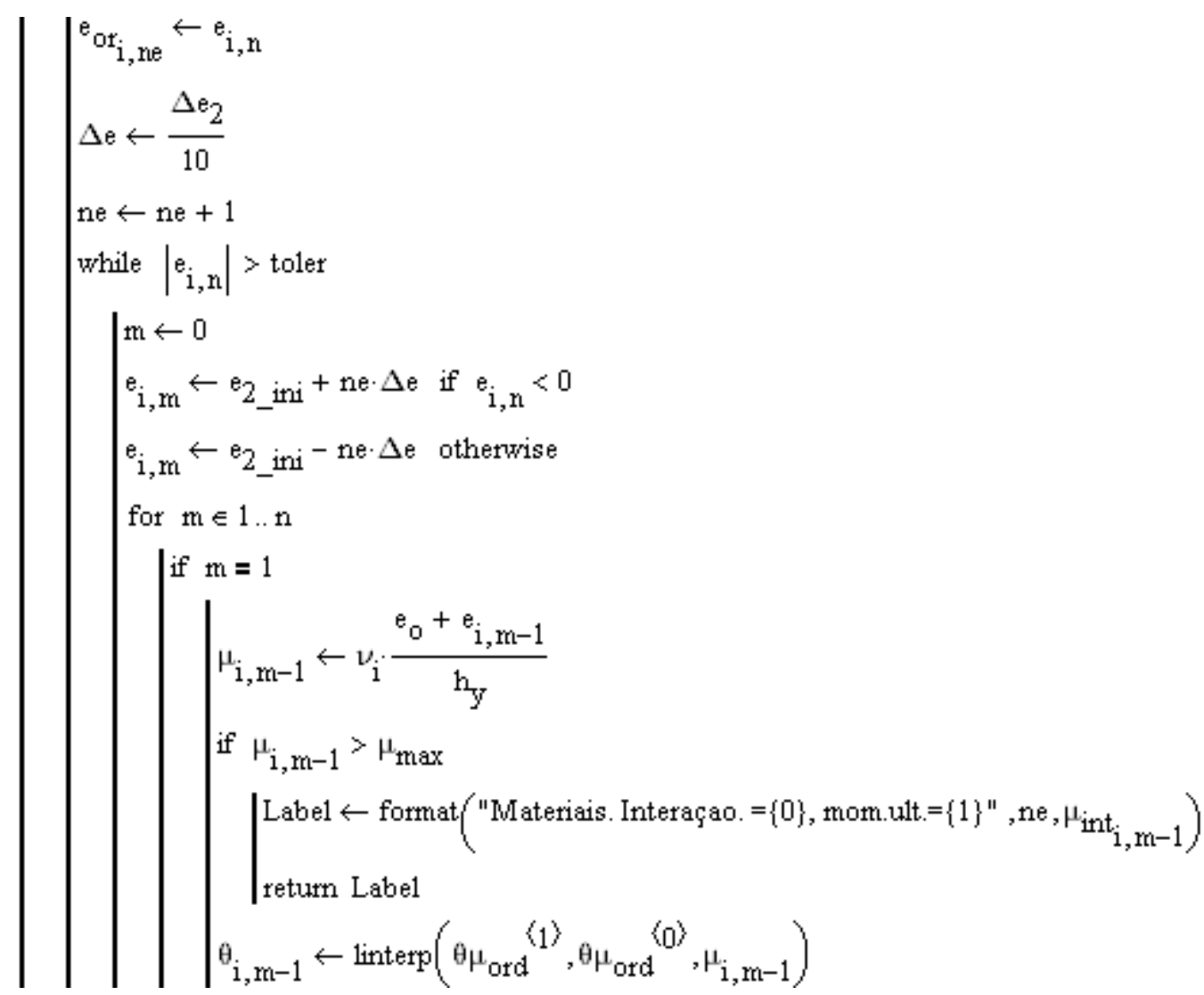




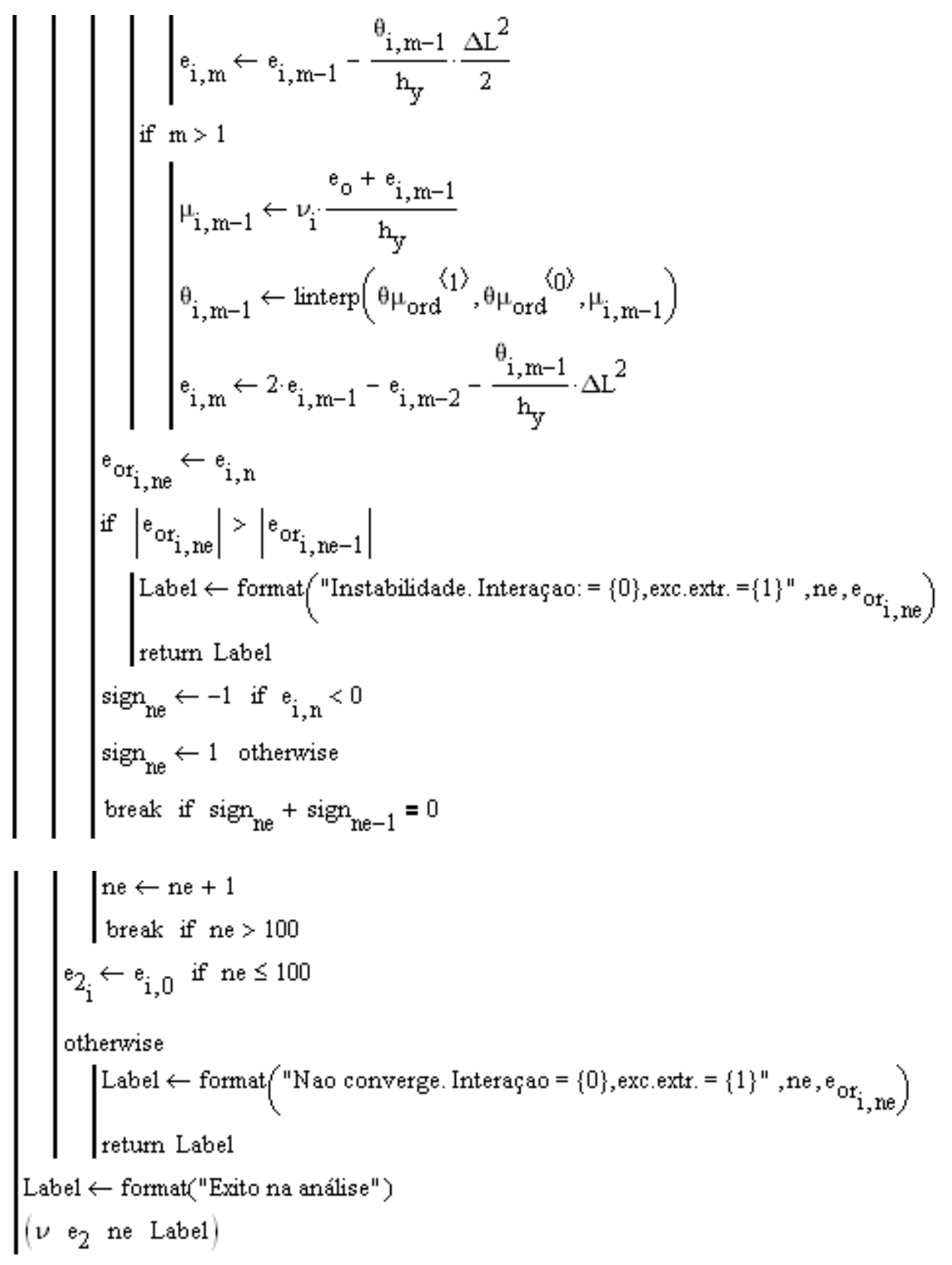




\section{RESULTADOS DA ANALISE}

$$
\begin{aligned}
& \text { tab }:=\mathrm{No}_{\text {div_pilar }}(\mathrm{n}) \\
& \nu:=\operatorname{tab}_{0,0} \quad \mathrm{e}_{2}:=\mathrm{tab}_{0,1} \quad \text { interaçao }:=\mathrm{tab}_{0,2} \quad \text { comentario }:=\mathrm{tab}_{0,3} \\
& \nu=(0.064) \quad \quad \mathrm{e}_{2}=(0.5) \quad \text { interaçao }=5 \quad \text { comentario = "Exito na análise" } \\
& \text { No div_pilar }^{(\mathrm{n})}=[(0.064)(0.5) 5 \text { "Exito na análise" }]
\end{aligned}
$$

ESTE PONTO É DO DIAGRAMA FORÇA DESLOCAMENTO LATERAL DO PILAR 50H30, CONSIDERANDO O ESPAÇAMENTO ENTRE ESTRIBOS $\mathrm{s}_{\mathrm{e}}=50 \mathrm{~mm}$

E A EXCENTRICIDADE DE FORÇA $e_{0}=30 \mathrm{~mm}$

TABELA $:=\left(\frac{s_{e}}{m m} \frac{f_{c}}{M P a} \frac{e_{0}}{m m} \frac{h_{x}}{c m} \frac{h_{y}}{c m} \frac{\phi_{e}}{m m} \frac{A_{s}}{c^{2}} K_{e} \frac{\sigma_{c o n} e}{M P a} \frac{f_{c c E}}{M P a} \frac{\nu_{0} \cdot A_{c} \cdot f_{c c E}}{k v} \frac{e_{2}}{c m} \frac{e_{0}+e_{2}}{c m}\right)$

TABELA $=\left(\begin{array}{lllllllllllll}50 & 94.8 & 30 & 20 & 12 & 6.3 & 4.9 & 0.334 & 0.797 & 98.783 & 151 & 0.5 & 3.5\end{array}\right)$

A SIMBOLOGÍA do PROGRAMA COINCIDE COM O RESTO DA TESE 